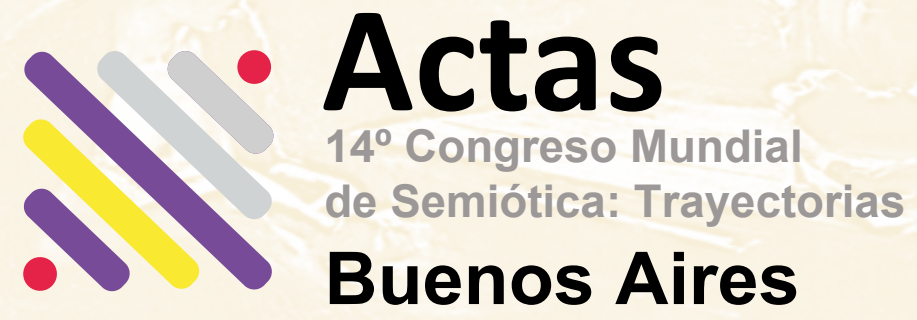

Septiembre 2019

International Association for Semiotic Studies (IASS/AIS)

\title{
Tomo 8
}

\section{Conferencias}

plenarias

Coordinadores

Oscar Steimberg,

Oscar Traversa y

Gastón Cingolani

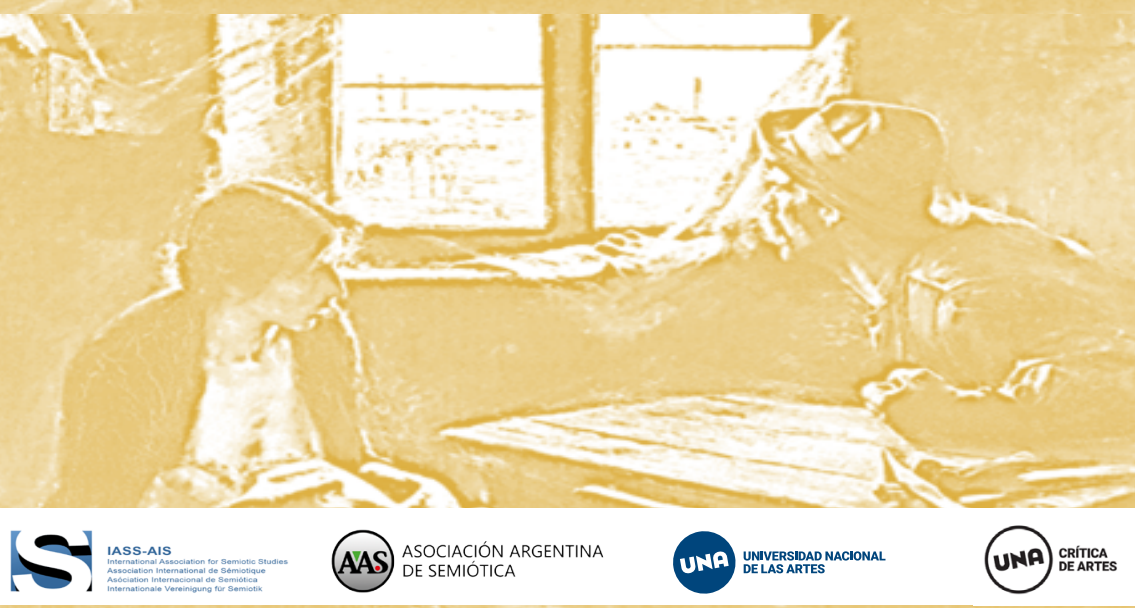

Proceedings of the 14th World Congress of the International Association for Semiotic Studies (IASS/AIS) 



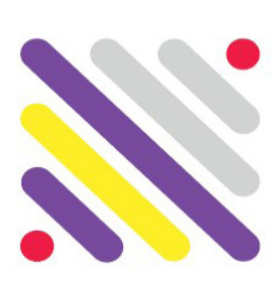

Actas

$14^{\circ}$ Congreso Mundial

de Semiótica: Trayectorias

\section{Buenos Aires}

Septiembre 2019

International Association for Semiotic Studies (IASS/AIS)

\section{Tomo 8}

\section{Conferencias plenarias}

\section{Coordinadores}

Oscar Steimberg, Oscar Traversa y

Gastón Cingolani 
Área Transdepartamental de Crítica de Artes

Actas Buenos Aires. 14을 Congreso Mundial de Semiótica : trayectorias : Proceedings of the 14th World

Congress of the International Association for Semiotic Studies-IASS/AIS : tomo 8 : conferencias plenarias /

editado por Rolando Martínez Mendoza ; José Luis Petris ; prólogo de Gastón Cingolani ; Oscar Steimberg

; Oscar Traversa. - 1a ed edición multilingüe. - Ciudad Autónoma de Buenos Aires : Libros de Crítica. Área

Transdepartamental de Crítica de Artes, 2020.

Libro digital, PDF

Edición multilingüe: $\quad$ Alemán ; Español ; Francés; Inglés.

Archivo Digital: descarga y online

ISBN 978-987-47805-7-7

1. Semiología. 2. Semiótica. 3. Epistemología. I. Martínez Mendoza, Rolando, ed. II. Petris, José Luis, ed. III. Cingolani, Gastón, prolog. IV. Steimberg, Oscar, prolog. V. Traversa, Oscar, prolog. VI. Título.

CDD 401.41

Actas Buenos Aires. 14 Congreso Mundial de Semiótica:

Trayectorias. Trajectories. Trajectoires. Flugbahnen.

Asociación Argentina de Semiótica y Área Transdepartamental de Crítica de Artes de la Universidad Nacional de las Artes, Buenos Aires, Argentina.

Proceedings of the 14th World Congress of the International Association for Semiotic Studies (IASS/AIS)

Buenos Aires, 9 al 13 de septiembre de 2019.

\section{Tomo 8}

ISSN 2414-6862

e-ISBN de la obra completa: 978-987-47805-0-8

e-ISBN del Tomo 8: 978-987-47805-7-7

DOI: 10.24308/IASS-2019-8

(C) IASS Publications \& Libros de Crítica, noviembre 2020

Editores Generales José Luis Petris y Rolando Martínez Mendoza

Editores Marina Locatelli y Julián Tonelli

Diseño Andrea Moratti

Todos los derechos reservados. Ninguna parte de esta publicación debe ser reproducida, almacenada en un sistema de recuperación ni transmitida bajo ninguna forma ni por ningún medio, ya sea electrónico, mecánico, de fotocopiado, grabación o cualquier otro medio, sin el permiso de los editores.

Los editores rechazan cualquier responsabilidad en caso de declaraciones falsas o erróneas de los autores, contenido plagiado y uso no autorizado de material con derechos de autor. 


\section{Trayectorias}

Se elegió para la propuesta temática del congreso esta palabra: 'trayectorias', a causa de la extraordinaria pluralidad de sentidos que surge de sus usos contemporáneos.

El ejemplo más claro podemos encontrarlo en la trayectoria de definiciones de la misma palabra semiótica.

En este recorrido se despliegan las múltiples historias de su adopción como nombre de un campo de indagaciones analíticas y de publicaciones.

Sin embargo, el término Trayectorias, en plural, sugiere también que ese recorrido no es ni único ni lineal.

No oculta, en suma, la condición diversa de los caminos recorridos para la percepción de problemáticas intrínsecamente plurales y móviles.

A la vez, la variedad de trayectorias encuentra su razón en la multiplicidad de soportes mediáticos, dispositivos, medios y lenguajes que, en la contemporaneidad, se reclaman, se interpelan y se disputan tiempos y espacios.

Trayectorias, entonces, no se aplica aquí sólo a los desarrollos conceptuales de la disciplina semiótica sino, también, a los recorridos del cambiante conjunto de objetos (mediáticos, comunicacionales, de diseño, biológicos, arquitectónicos) en los que ella fija su mirada.

Las Trayectorias son, de este modo, las memorias, las materialidades y los compromisos que guían las definiciones, las escrituras y las búsquedas por los itinerarios del sentido.

Es por esto que se ha entendido que con el nombre Trayectorias se elegía un modo de reconocimiento de la condición insoslayable de despliegue y recomienzo que configura constantemente el quehacer de la investigación semiótica. 

Entre los días 9 y 13 de septiembre de 2019 se realizó en Buenos Aires, República Argentina, el $14^{\circ}$ Congreso Internacional de Semiótica. Fue organizado por la Asociación Argentina de Semiótica y la Universidad Nacional de las Artes de Buenos Aires (UNA) a través de su Área Transdepartamental de Crítica de Artes. El Congreso convocó a más de 700 expositores de 45 países. El intercambio en los Plenarios, las Mesas y los espacios de socialización fue de gran riqueza y humanamente imposible in situ de abarcar en su totalidad. Por este motivo es que la publicación de sus Actas se propone no sólo como registro del acontecimiento sino como una continuación y complemento del intercambio de ideas y trabajos semióticos que tuvo lugar, por primera vez, en América del Sur. La decisión de hacerlo en 8 tomos temáticos busca facilitar la profundización del diálogo en las áreas comunes de interés. 

Tomo 8

Conferencias plenarias 


\section{ÍNDICE}

Presentación. Oscar Steimberg, Oscar Traversa y

Gastón Cingolani

Paolo Fabbri (1939-...). Tiziana Migliore

(traducción al español de Claudio Guerri) 15

\section{TRAYECTORIAS EPISTEMOLÓGICAS Y METODOLÓGICAS}

Metalogues Meet Interview: It Takes Three to Tango.

Myrdene Anderson

Matrices ideológicas y componente retórico en la discursividad política: las emociones en Mauricio Macri y Cristina Fernández de Kirchner, agosto de 2019.

Elvira Narvaja de Arnoux

A Gradualist Perspective for the Approach to Visual Images. José Luis Caivano

Trayectoria y continuidad de la teoría textual de Umberto Eco en las nuevas narrativas y sus estrategias textuales. Alfredo Tenoch Cid Jurado

Luis Prieto. La recuperación de una teoría muy pertinente. María Teresa Dalmasso

Epistemología para una semiótica del espacio:

César Jannello. Lucrecia Escudero Chauvel 89

Cursos semióticos: caminos y trayectorias antrópicas. Jacques Fontanille

Applying Peirce. From the Three Categories to the Semiotic

Nonagon. Claudio F. Guerri

Trajectoires de la sémio-linguistique. Anne Hénault 133

A Non-Anthropocentric Semiotics of the Writing in the 
¿Por qué hay sentido y no más bien nada? Experiencia, cognición, sentido. Jean-Marie Klinkenberg

Presentación del proyecto semiótico: actualidad de René Thom. Isabel Marcos

The Semiotic Method. Tiziana Migliore 185

Trajectories of Meaning in Space and Value Systems.

Pierre Pellegrino 199

Transdisciplinary Trajectories: The Audacity of Design and the Resilience of Signs. Farouk Y. Seif

Reading Trajectories: Semiosis, Graphic Design and Ideology. Evripides Zantides

\section{TRAYECTORIAS DE LOS OBJETOS}

Semiótica de un proceso utópico y otro distópico en América Latina: dos senderos antitéticos hacia la autenticidad. Fernando Andacht

Territorios artísticos en disputa. La obra de Eduardo Kac. Pampa Arán

Semiosis of the Body in Arab Sexological Literature.

Mohamed Bernoussi

Trayectoria de la semiótica de las mediatizaciones hacia las plataformas mediáticas. José Luis Fernández 299

Le web 2.0 : une nouvelle trajectoire pour la sémiologie audiovisuelle?. François Jost

Vecindades digitales. Hacia qué objetos apuntan los índices. María del Valle Ledesma 
Rostros gigantes: tamaño versus proporción en la semiótica del poder. Massimo Leone

Semiosis de las artes performativas: a partir del cuerpo de las envolturas. Rocco Mangieri

Del espacio a la ciudad. Trayectorias semióticas.

Isabella Pezzini

Presencia, identidad y afectividad en Los heraldos negros, de César Vallejo. Apuntes de hermenéutica semiótica. Óscar Quezada Macchiavello

Continuidades y rupturas en la narrativa de la historieta costumbrista. Oscar Steimberg

Salomé y Judit: dos milenios de recurrencia discursiva. Oscar Traversa

Los lugares de la memoria en un marco semiótico.

La experiencia de SPEME. Patrizia Violi 419

From Buffy to Discovery of Witches. Semiotic Considerations on Vampires, Witches, \& Preternatural Phenomena in Literature and Television. Gloria Withalm 429 


\section{Presentación}

DOI: 10.24308/IASS-2019-8-001

Los organizadores del 140 Congreso de la IASS-AIS se propusieron prestar y generar atención a la diversidad que caracteriza al actual momento internacional de la disciplina. Se entendió que esa diversidad puede considerarse promisoria en un campo de búsqueda y producción de conocimiento cuya juventud constituye uno de los rasgos propios de los estudios semióticos en su conjunto.

Y consideramos al respecto que el propósito de los organizadores fue bien recibido por los expositores que, a partir de diferentes perspectivas y entradas analíticas, dieron pertinentemente cuenta de esa condición presente en el objeto a compartir: se advertirá que las intervenciones de carácter más general no dejan de lado la apelación al caso y a la ejemplificación y que, a la inversa, los de focalización más centralizada refieren también a proposiciones o novedades de carácter global.

En cuanto a esa diversidad alcanzada y compartida, y más allá de la confluencia de los expositores en su búsqueda o aceptación, cabe señalar que constituyó una característica del conjunto de las intervenciones singulares, síntoma entonces de que el movimiento general de la disciplina apunta en esa dirección. Y del hecho de que esta tendencia confirma el carácter indefectiblemente multidisciplinario al que debe aspirar una "ciencia general de los signos".

Pero es asimismo de interés recordar que ese objetivo está surcado también por peligros y obstáculos: en relación con los primeros puede señalarse el de caer en una hibridez privada entonces de sustancia, inútil para el desenvolvimiento de los saberes con que se asocien. $Y$ en cuanto a los segundos, opuestos a los genéricamente abarcativos, 
el riesgo contrario: que se carezca de pluralidades de avances, de manera igualmente improductiva, asumiéndose una condición de juez de los desarrollos de sus partenaires.

Podría acordarse que, en esta nueva instancia de formulaciones y procesamientos, está desplegándose un tal vez importante capítulo de futuras tareas: el que podría abrirse a la reflexión sobre los aportes que desde la semiótica se propongan para la construcción de una ligazón productiva con el conjunto de las ciencias y, de manera aún más comprehensiva, con otras prácticas cruciales de la vida social, como las estéticas y las que atienden a los ejercicios del cuerpo.

Ya sea como consecuencia inconsciente o como puro efecto del tiempo social, la coincidencia del $14^{\circ}$ Congreso con el $50^{\circ}$ aniversario de la creación de la IASS-AIS trae una lectura temporalizada, expresada además en el lema que encabezó el evento: "Trayectorias". La semiótica se despliega aquí apreciando su propia historia, sus recorridos y renovadas tradiciones, al mismo tiempo que avizora líneas futuras, proyectando la reflexión sobre lo que está llegando y sobre cómo comprender y debatir las anticipaciones.

Oscar Steimberg, Oscar Traversa y Gastón Cingolani 


\section{Paolo Fabbri (1939.---)}

DOI: 10.24308/IASS-2019-8-002

Tiziana Migliore

Grandi studiosi scomparsi di recente, da Umberto Eco a Michel Serres, da Tzvetan Todorov a Remo Bodei, da Marcel Detienne a Zygmunt Bauman, sono stati intellettuali raffinatissimi e anche ottimi maestri. Ma in ambito gnoseologico e pedagogico il ruolo svolto da Paolo Fabbri in cinquant'anni di attività teorica ed empirica va oltre.

\section{Tramandare e diramare}

II 21 dicembre 2019, giorno in cui ha ritirato il Sigismondo d'oro, premio prestigioso del Comune di Rimini, il semiologo ha concluso il suo discorso con l'elogio del Ficus macrophylla e delle sue radici aeree colonnari, con i rami che si allungano, toccano terra e formano altre radici, metafora degli allievi di oggi e di domani. Fabbri non era solo un pensatore argutissimo nel dissipare le nebbie dei fenomeni sociali, prodigo di riflessioni lucide e calzanti. Le voci della rubrica "Parole, parole, parole" che teneva per L'Unità, poi raccolte nel volume Segni del tempo. Lessico e dialoghi politicamente scorretti (2004), ben rispecchiano la sua militanza, lo sviluppo di una critica dell'esperienza "clinica", come diceva citando Deleuze (1993), curativa della società. Già il non essersi allineato con nessuno per piaggeria e l'aver percorso con coerenza un tragitto in cui ha creduto è raro di questi tempi. E tuttavia il suo apporto è essenziale per un altro aspetto. Fabbri, uomo vissuto a cavallo fra XX e XXI secolo, ha costantemente ricordato che la conoscenza ha valore se è tramandata. Conoscenza in termini di comprensione, non di mero passaggio di dati o nozioni. Se l' "informazione" richiede il minimo di tempo e il massimo di spazio, la "formazione" può avvenire in uno spazio minimo, ma necessita del massimo di tempo. Per Fabbri non c'è comprensione senza formazione e rinvio ai posteri, ponte gettato fra più generazioni, oltre l'arco delle esistenze individuali. "Ci segue come guida", era la formula con cui commemorava gli autori più amati: Greimas, Lévi-Strauss, Barthes, Deleuze, Guattari, Marin, Eco...

Non a caso Fabbri andava così tanto orgoglioso della Ray Cat Solution, la soluzione escogitata con la chimica Françoise Bastide nel 1981, su commissione della Human Interference Task Force del Department of Energy and Bechtel Corp degli Stati Uniti, per avvisare le generazioni future della presenza di 
scorie radioattive. I gatti cambiano colore se esposti a radiazioni e quindi un loro improvviso mutamento è il segnale di luoghi pericolosi da abbandonare e con rifiuti da smaltire. Di recente un laboratorio di Montreal, brico.bio, sta sviluppando questa idea, formalizzata da Fabbri e Bastide nel 1984 in un articolo scientifico della rivista Zeitschrift für Semiotik. E ne è nato un documentario diretto da Benjamin Huguet e selezionato al Pariscience 2015-International Science Film Festival.

\section{Semiotica progetto di vita}

Inattuale rispetto al presentismo dominante e all'effimero per cui letterati, artisti, musicisti, filosofi, architetti, si accontentano oggi del successo immediato, incapaci di vedere al di là del proprio naso, Fabbri ha fatto propria la mentalità degli antichi di spiegare e produrre aere perennius. In questo sta la sua "semiotica", sinonimo di insegnamento: cogliere segni, nelle esperienze sociali e personali che facciamo, e lasciarne.

Nel tempo e nello spazio, da una generazione all'altra e da un Paese all'altro, attraverso la costruzione di una rete internazionale, Fabbri ha ribadito che i segni non sono atomi da classificare, elementi scissi da noi. Sono invece processi con cui significhiamo il mondo e diamo significato al nostro esistere. Leggerli non è facile, perché, mentre li riceviamo e ne produciamo, vediamo solo la parte emersa dell'iceberg del loro senso. C'è allora chi si adatta e finisce col dire che il mondo è "liquido" e chi invece vorrebbe vederci chiaro. A tutti, studiosi e non, a Bologna come a Parigi, a Madrid, Istanbul o Lima, a Buenos Aires, a Mosca, a San Diego..., Fabbri si è rivolto ogni giorno, senza scarti fra lavoro e svago in nome di una sua Gaia scienza, per mettere il senso in condizione di significare e aiutare a praticare l'intelligenza. Si è battuto contro la piattezza del pensiero e dal Centro di Semiotica di Urbino, che ha fondato con Carlo Bo e Pino Paioni nel 1970 e diretto fino alla fine, ha invitato al metodo strutturale, al pensiero "per differenze": non limitarsi a visioni univoche, ma guardare le cose per mezzo dei loro contrari, complementari e contraddittori, rovesciandole e smontandole.

"Com'è che non ci avevo pensato prima?" - è allora la domanda più frequente dopo aver incontrato Fabbri, fautore di quella Svolta semiotica (1994) frutto di una serie di seminari a Palermo e che ha avuto l'effetto di trasformare una disciplina e una professione in un progetto di vita. Umberto Eco si è ispirato a lui ne forgiare il personaggio di Paolo da Rimini de I/ nome della rosa, l'Abbas Agraphicus fondatore della biblioteca, perché Fabbri non amava concludere le sue ricerche, mettere punti, e per questo ha trasmesso il sapere oralmente più che in forma scritta. Allo stesso tempo gli scritti che lascia sono illuminazioni dense: distinguono e rischiarano, ma non smettono di aprire brecce su altre letture possibili. 


\subsection{I quattro livelli e gli anelli mancanti}

Elève titulaire dell'Ecole Pratique des Hautes Etudes a Parigi dopo una laurea in Legge e Scienze Politiche a Firenze nel 1962, Fabbri ha studiato con Lucien Goldmann, il sociologo specialista di Pascal e Racine, ed è entrato a contatto con gli ambienti più avanzati della ricerca strutturale in linguistica, antropologia e semiotica, in particolare con Algirdas Julien Greimas, padre della semiotica strutturale, e con Roland Barthes. Era l'epoca della "guerriglia semiotica", della critica dei discorsi ideologici. Si trattava di "sbiancare" i messaggi che i poteri dominanti in politica e nei media spacciavano per ovvii e innocenti. Dietro la comunicazione ci sono tattiche e strategie enunciative, credenze, simulacri offerti all'altro. Di lì in avanti Fabbri avrebbe cominciato ad occuparsi di retorica, passioni, miti, segreti, guerra, efficacia simbolica, segreti, spionaggio, rumors, fare scientifico, camouflage, profezie, tatuaggi... In uno dei passi più rilevanti de L'efficacia semiotica (2017), il libro a cura di Gianfranco Marrone che raccoglie le principali interviste con lui e punto di riferimento per comprendere la sua opera immensa e labirintica, Fabbri ha perfino spronato a sviluppare un' "antiepistemologia”, come analisi dei modi in cui si nasconde la conoscenza.

L'efficacia della sua semiotica, rispetto ad altri approcci vaghi e dove tutto fa brodo, sta nell'essere marcata, caratterizzata dall'andirivieni fra quattro livelli: descrittivo, metodologico, teorico ed epistemologico. È cioè una teoria che, per funzionare, deve avere pochi presupposti epistemologici, partire da casi-studio scelti secondo criteri di empiria e pertinenza, ed essere coerente con il metodo, che è una "cassetta di attrezzi" in divenire, concetti e strumenti estratti direttamente dai casi-studio: "programma narrativo" (da miti e fiabe!), "modalità", "enunciazione", "punto di vista", "aspettualità", "pregnanza e salienza", "estesia"... Un metalinguaggio descrittivo molto meno tecnico del gergo calcistico, come piaceva dire a Fabbri per respingere le accuse mosse alla semiotica, e interdisciplinare, mutuabile da chiunque voglia capire meglio le dinamiche del senso. L'ultimo suo libro, Vedere ad arte. Iconico e icastico (2019), mostra il posto della pittura, della scultura, del disegno, della fotografia, del video, dell'installazione e la performance, non secondario al linguaggio verbale, nel modellizzare il reale, interpretando e rifigurando i rapporti sociali. Per Fabbri, che è stato presidente del DAMS di Bologna dal 1998 al 2001, le opere d'arte sono "retine esterne": trapiantano negli spettatori nuovi sensi, lasciando intravedere immagini potenziali e sollecitando pensieri ancora impensati.

\subsection{Abitare il "tra"}

Nel riconoscere indizi di teoria nell'esperienza Fabbri ha sempre valorizzato l'attività della traduzione, intesa come spostamento, eterotopia (Foucault 1967), détournement (Jullien 1995) che permette di interrogare 
la nostra cultura, le nostre abitudini, a partire dall'alterità. Così una buona traduzione è quella che arricchisce la lingua di partenza e la lingua di arrivo; quando si traduce un'altra lingua, si è obbligati a ripensare la propria. Fabbri citava spesso la difficoltà di tradurre negli Stati Uniti, dove non esiste, come non esiste in italiano, in spagnolo o in francese, l'aggettivo /vincibile/ dal trattato cinese L'arte della guerra di Sun Tzu. L'Occidente ha dovuto introdurre nel suo lessico il termine e quindi il concetto di /vincibility/, /vincibilità/, a cui non era abituato.

Ecco, il semiologo strutturalista è prima di tutto un traduttore, un "intercessore" fra lingue, popoli, pratiche artistiche (Deleuze 1962), come chi percorre il Bosforo su un battello turco che fa Anadolu-Avrupa, AvrupaAnadolu, dall'Anatolia all'Europa e ritorno. Abita il "tra" e traduce una cultura nell'altra (Fabbri, Migliore, a cura di, 2011). Nella concezione filogenetica della conoscenza abbracciata da Fabbri, gli allievi traducono i maestri e i maestri, con le tracce che lasciano, intercedono presso gli allievi. Anche vita e (non) morte si comprendono mutuamente.

\section{Riferimenti bibliografici}

Bastide F., Fabbri P., "Lebende Detektoren und komplementäre Zeichen: Katzen, Augen und Sirenen" ["Living detectors and complimentary signs: Cats, eyes and sirens"], Zeitschrift für Semiotik, Tübingen, Stauffenburg Verlag, 6 (3), 1984, pp. 257-264.

Deleuze G., Critique et clinique, Minuit, Paris 1993 ; trad. it. Critica e clinica, Cortina, Milano 1996.

- Nietzsche et la philosophie, PUF, Paris 1962; trad. it., Nietzsche e la filosofia, Einaudi, Torino 2002.

Fabbri P., Vedere ad arte. Iconico e icastico, a cura di T. Migliore, Mimesis, Milano 2019.

- L'efficacia semiotica, Risposte e repliche, a cura di G. Marrone, Mimesis, Milano 2017.

- Segni del tempo. Lessico e dialoghi politicamente scorretti, Meltemi, Roma 2004.

- La svolta semiotica, Laterza, Bari-Roma 1994.

Fabbri P., Migliore T., a cura di, "The in between". Introduzione a The Architecture of Babel. Creation, Extinctions and Intercessions in the Languages of the Global World, Olschki, Firenze 2011, XI-XXII. 
Foucault M., “Des espaces autres”, conférence au Cercle d'études architecturales, 14 marzo 1967. In Architecture, Mouvement, Continuité, 5, octobre 1984, pp. 4649 ; trad. it., "Eterotopia", in Michel Foucault. Eterotopia. Luoghi e non-luoghi metropolitani, Associazione culturale Mimesis, Milano 1994, pp. 11-20.

Jullien F., Le détour et l'accès. Stratégies du sens en Chine, en Grèce, Grasset \& Fasquelle, Paris 1995 ; trad. it., Strategie del senso in Cina e in Grecia, Meltemi, Roma 2004.

\section{Paolo Fabbri (1939.---)}

(traducción al español de Claudio Guerri)

Tiziana Migliore

Los grandes eruditos fallecidos recientemente, desde Umberto Eco a Michel Serres, desde Tzvetan Todorov a Remo Bodei, desde Marcel Detienne a Zygmunt Bauman, eran intelectuales muy refinados y también excelentes maestros. Pero en el campo gnoseológico y pedagógico el papel desempeñado por Paolo Fabbri en cincuenta años de actividad teórica y empírica va más allá.

\section{Transmitir en el tiempo y ramificar}

El 21 de diciembre de 2019, día en que recibió el Sigismondo d'oro, un prestigioso premio del Municipio de Rímini, el semiólogo concluyó su discurso con un elogio del Ficus macrophylla y de sus raíces aéreas, como columnas, con las ramas que se estiran, tocan el suelo y forman otras raíces, una metáfora para los estudiantes de hoy y de mañana. Fabbri no sólo era un pensador muy ingenioso para disipar las neblinas de los fenómenos sociales, sino también pródigo en reflexiones lúcidas y adecuadas. Las entradas de la columna "Parole, parole, parole" que escribía para el diario L'Unità, luego recogidas en el volumen Segni del tempo. Lessico e dialoghi politicamente scorretti (2004), reflejan bien su militancia y el desarrollo de una crítica de la experiencia "clínica" -como dijo citando a Deleuze (1993)-, beneficiosa para la sociedad. Ya el no haberse alineado con nadie por puro compromiso y el haber recorrido constantemente un camino en el que él creía son algo raro en estos tiempos. Y, sin embargo, su contribución es esencial por otra razón. Fabbri, un hombre que vivió el cruce de los siglos XX y XXI, nos ha recordado constantemente que el conocimiento tiene valor si se transmite. Conocimiento en términos de comprensión, no simplemente el traspaso de datos o nociones. Si la "información" requiere un mínimo de tiempo y un máximo de espacio, deberá entenderse que la "formación" puede tener lugar en un espacio mínimo, pero necesita el máximo 
de tiempo. Para Fabbri no hay comprensión sin capacitación y remisión a la posteridad, un puente lanzado entre varias generaciones, más allá del arco de las vidas individuales. "Nos per-sigue como guía" fue la fórmula con la que conmemoró a los autores más queridos: Greimas, Lévi-Strauss, Barthes, Deleuze, Guattari, Marin, Eco...

No es una simple coincidencia que Fabbri estuviera tan orgulloso con la Ray Cat Solution, la solución ideada con la química Françoise Bastide en 1981, encargada por la Fuerza de Tareas de Interferencia Humana del Departamento de Energía de EE.UU. y la Bechtel Corp., para advertir acerca de la presencia de residuos radiactivos a las generaciones futuras. Los gatos cambian de color cuando se exponen a la radiación; por lo tanto, un cambio repentino de color es un signo de lugares peligrosos que hay que abandonar y con residuos que hay que eliminar. Últimamente, un laboratorio de Montreal, Brico.bio, está desarrollando esta idea, formalizada por Fabbri y Bastide en 1984 en un artículo científico de la revista Zeitschrift für Semiotik. El resultado es un documental dirigido por Benjamin Huguet y seleccionado para el Festival Internacional de Cine Científico Pariscience 2015.

\section{Semiótica, un proyecto de vida}

Inactual en comparación con el presentismo dominante y con lo efímero sostenido por los hombres de letras, artistas, músicos, filósofos, arquitectos que hoy en día se contentan con un éxito inmediato, incapaces de ver más allá de sus narices. Fabbri hizo propia la mentalidad de los antiguos para explicar y producir aere perennius. En esto radica su "semiótica", sinónimo de enseñanza: captar los signos, en nuestras experiencias sociales y personales y dejarnos algo.

En el tiempo y en el espacio, de una generación a otra y de un país a otro, a través de la construcción de una red internacional, Fabbri ha insistido en que los signos no son átomos a clasificar, elementos escindidos de nosotros. Por el contrario, son procesos mediante los cuales significamos el mundo y damos sentido a nuestra existencia. Leerlos no es fácil, porque mientras los recibimos y los producimos sólo vemos la parte emergente del iceberg de su significado. Hay quien se adapta y termina diciendo que el mundo es "líquido" y quien, inversamente, quiere verlo claro. Para todos, eruditos o no, tanto en Bolonia como en París, en Madrid, Estambul o Lima, en Buenos Aires, en Moscú, en San Diego..., Fabbri se ha volcado cada día, sin diferencia entre trabajo y ocio en nombre de su Gaya Ciencia, para poner el sentido en posición de significar y ayudar a practicar la inteligencia. Luchó contra la chatura del pensamiento y desde el Centro de Semiótica de Urbino, que fundó con Carlo Bo y Pino Paioni en 1970 y dirigió hasta el final, invitó al método estructural, a pensar "por las diferencias": no limitarse a visiones unívocas, sino mirar las cosas a través de sus opuestos, complementarios y contradictorios, derribándolos y desmantelándolos. 
“¿Cómo es que no lo pensé antes?” es la pregunta más frecuente después de haberse encontrado con Fabbri, autor de El giro semiótico (1994), que fue el resultado de una serie de seminarios en Palermo y tuvo el efecto de transformar una disciplina y una profesión en un proyecto de vida.

Umberto Eco se inspiró en Fabbri para forjar el personaje de Paolo da Rimini en El nombre de la rosa, el Abbas Agraphicus fundador de la biblioteca, porque a él no le gustaba concluir sus investigaciones, poner puntos finales, y por eso transmitió su conocimiento de forma oral más que escrita. Al mismo tiempo, los escritos que deja son densas iluminaciones: distinguen y aclaran, pero no dejan de abrir brechas para otras posibles lecturas.

\subsection{Los cuatro niveles y los eslabones perdidos}

Élève titulaire en la École Pratique des Hautes Études de París tras licenciarse en Derecho y Ciencias Políticas en Florencia en 1962, Fabbri estudió con Lucien Goldmann, el sociólogo especializado en Pascal y Racine, y entró en contacto con los entornos más avanzados de la investigación estructural en lingüística, antropología y semiótica, en particular con Algirdas Julien Greimas, el padre de la semiótica estructural, y Roland Barthes. Era la época de la "guerra de guerrillas semiótica", de la crítica del discurso ideológico. Se trataba de poner en evidencia los mensajes que los poderes dominantes en la política y en los medios de comunicación despachaban como obvios e inocentes. Detrás de la comunicación hay tácticas y estrategias de enunciación, creencias, simulacros ofrecidos al otro. A partir de entonces, Fabbri comenzaría a ocuparse de la retórica, las pasiones, los mitos, la guerra, la eficacia simbólica, los secretos, el espionaje, los rumores, la ciencia, el camuflaje, las profecías, los tatuajes... En uno de los pasajes más relevantes de L'efficacia semiotica (2017), el libro editado por Gianfranco Marrone que recoge las principales entrevistas con él y que es un punto de referencia para comprender su inmensa y laberíntica obra, Fabbri ha impulsado incluso el desarrollo de una "anti-epistemología", como un análisis de las formas mediante las que se oculta el conocimiento.

La eficacia de su semiótica, comparada con otros enfoques vagos donde todo es sopa, radica en ser marcada, caracterizada por el ir y venir entre cuatro niveles: descriptivo, metodológico, teórico y epistemológico. Se trata de una teoría que, para funcionar, debe tener pocos supuestos epistemológicos, a partir de estudios de casos elegidos según criterios de empirismo y pertinencia, y ser coherente con el método, que es una "caja de herramientas" en devenir, conceptos y herramientas extraídos directamente de los estudios de casos: "programa narrativo" (ide los mitos y cuentos de hadas!), "modalidad", "enunciación", "punto de vista", "aspectualidad", "pregnancia y prominencia", "estesis"... Un metalenguaje descriptivo mucho menos técnico que la jerga futbolística, como le gustaba decir a Fabbri para rechazar las acusaciones que se 
hacían contra la semiótica, que puede tomar prestado de todo aquel que quiera entender mejor la dinámica del significado. Su último libro, Vedere ad arte. Iconico e icastico (2019), muestra el lugar de la pintura, la escultura, el dibujo, la fotografía, el vídeo, la instalación y la actuación, sin sujetarse al lenguaje verbal, en el modelado de lo real, interpretando y refigurando las relaciones sociales. Para Fabbri, que fue presidente del DAMS en Bolonia de 1998 a 2001, las obras de arte son "retinas externas": trasplantan nuevos sentidos a los espectadores, dejándoles vislumbrar imágenes potenciales y solicitándoles pensamientos aún impensados.

\subsection{Vivir el "entre"}

Al reconocer indicios de teoría en la experiencia, Fabbri siempre ha valorado la actividad de la traducción, entendida como desplazamiento, como una heterotopía (Foucault 1967), como un détournement (Jullien 1995), que permite cuestionar nuestra cultura, nuestros hábitos, a partir de la alteridad. Así que una buena traducción es la que enriquece el idioma de origen y el idioma de destino; cuando se traduce otro idioma, se está obligado a repensar el propio. Fabbri mencionó a menudo la dificultad de traducir en los Estados Unidos, donde el adjetivo/vencible/ del tratado chino El arte de la guerra de Sun Tzu no existe, como no existe en italiano, español o francés. Occidente tuvo que introducir en su léxico el término y por lo tanto el concepto de /vencibilidad/, / vincibility/, al que no estaba acostumbrado.

He aquí, el semiólogo estructuralista es ante todo un traductor, un "intercesor" entre las lenguas, los pueblos, las prácticas artísticas (Deleuze 1962), como el que recorre el Bósforo en un barco turco haciendo AnadoluAvrupa, Avrupa-Anadolu, de Anatolia a Europa y viceversa. Habita el "entre" y traduce una cultura en otra (Fabbri, Migliore, eds., 2011). En la concepción filogenética del conocimiento abrazada por Fabbri, los estudiantes traducen a los maestros y los maestros, con las huellas que dejan, interceden ante los estudiantes. Incluso la vida y (no) la muerte se comprenden mutuamente.

\section{Referencias bibliográficas}

Bastide F., Fabbri P., "Lebende Detektoren und komplementäre Zeichen: Katzen, Augen und Sirenen" ["Living detectors and complimentary signs: Cats, eyes and sirens"], Zeitschrift für Semiotik, Tübingen, Stauffenburg Verlag, 6 (3), 1984, pp. 257-264.

Deleuze G., Critique et clinique, Minuit, Paris 1993 ; trad. it. Critica e clinica, Cortina, Milano 1996. 
- Nietzsche et la philosophie, PUF, Paris 1962; trad. it., Nietzsche e la filosofia, Einaudi, Torino 2002.

Fabbri P., Vedere ad arte. Iconico e icastico, a cura di T. Migliore, Mimesis, Milano 2019.

- L'efficacia semiotica, Risposte e repliche, a cura di G. Marrone, Mimesis, Milano 2017.

- Segni del tempo. Lessico e dialoghi politicamente scorretti, Meltemi, Roma 2004.

- La svolta semiotica, Laterza, Bari-Roma 1994.

Fabbri P., Migliore T., a cura di, "The in between". Introduzione a The Architecture of Babel. Creation, Extinctions and Intercessions in the Languages of the Global World, Olschki, Firenze 2011, XI-XXII.

Foucault M., "Des espaces autres", conférence au Cercle d'études architecturales, 14 marzo 1967. In Architecture, Mouvement, Continuité, 5, octobre 1984, pp. 4649 ; trad. it., "Eterotopia”, in Michel Foucault. Eterotopia. Luoghi e non-luoghi metropolitani, Associazione culturale Mimesis, Milano 1994, pp. 11-20.

Jullien F., Le détour et l'accès. Stratégies du sens en Chine, en Grèce, Grasset \& Fasquelle, Paris 1995 ; trad. it., Strategie del senso in Cina e in Grecia, Meltemi, Roma 2004. 


\section{TRAYECTORIAS EPISTEMOLÓGICAS Y METODOLÓGICAS}





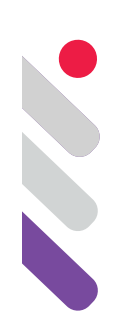

\section{Metalogue Meets Interview: It Takes Three to Tango}

DOI: 10.24308/IASS-2019-8-003

Myrdene Anderson

Purdue University, Indiana, USA

myanders@purdue.edu

\section{Abstract}

Anthropologist Gregory Bateson (1904-1980) dangled an invitation to dance (why not tango!) while introducing his "metalogues" in the book, Steps to an Ecology of Mind: Collected Essays in Anthropology, Psychiatry, Evolution, and Epistemology (1972). The first section in that volume consists in metalogues recounting proto-quasi-scientific conversations Bateson had had with his daughter, Mary Catherine Bateson (also the daughter of anthropologist Margaret Mead), then about ten years of age.

Metalogue as form of inquiry is later revisited through Bateson's ongoing collaboration with this now adult daughter, anthropologist Mary Catherine Bateson-in the posthumously published Angels Fear: Towards an Epistemology of the Sacred (1987). The critical, nuanced, magically productive interplay of surprise and suspense embodied in the metalogues of the two Batesons transcends that in any ordinary two-way conversation, and has inspired others to explore metalogue.

Embracing metalogue as a methodology in sociocultural research affords the semiotician a release from the vaulted interview, that itself has already become the standard interaction format in commercial media. I will challenge the utility of interview across the variety of settings, and even suggest it perpetuates a compromising colonial form of discourse.

\section{Introduction to metalogue}

The type specimens of metalogue remain the seven conversational performances that launch Gregory Bateson's 1972 book, often just called Steps ([1972]2000: 1-40). Those seven metalogues have titles drawn from the child's urgent probes: 


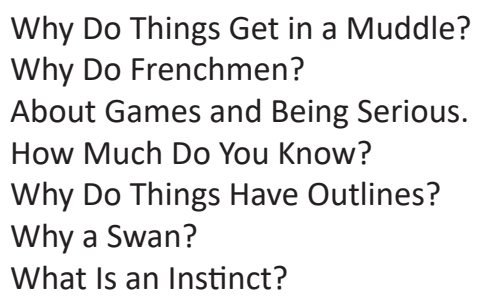

In the first metalogue about "muddles", I find myself drawn into the drama of entropy at every scale (G. Bateson 1972: 3-8), as there the conversation was itself muddled, not just about being muddled! Without taking the steam out of the daughter's inquiry, the father captures a teachable moment to steer toward the fundamentals of entropy, context, relationship, and relativity, each integral to all semiotic explorations, whether literary, biological, cognitive, or cosmic.

But first, Bateson realized he had to explain what he meant as metalogue. Metalogue is "a conversation about some problematic subject. This conversation should be such that not only do the participants discuss the problem but the structure of the conversation as a whole is also relevant to the same subject" (Bateson 1972: 1).

Here the metalogues become abductive reasonings where the daughter intuits the father's arguments, rather than the reverse, as it was now, she who was tasked with gathering up her father's manuscripts for a book he left unfinished. These metalogues dart into and out of focus, approaching the exaggerated, suggestive, hardly just nuanced, positions of tango. The conversants, or partners, both discuss (dance) the subject (relationship) and allow the puzzling structure of the interlocution in motion to solve the jigsaw of the entire problem. The syncope, as the transcending third-as-abduction, interjects - in the gap opened by the breathless deletion of space and time- to stimulate and simulate both resolution and on-going challenge, just as in tango.

\section{Invitation to dance}

Since dance comes from a highly motivated body/mind, and in itself generates a surplus of meaning, some have wondered whether dance could be analogous to language (Könczei 1994). Dance as metaphor has inspired many musings in semiotics, because semiotics takes as its subject matters those open, complex systems far from equilibrium, where constituents seek their relational others within a simultaneously-imagined-and-actualized Umwelt. In actualizing those relations, a dance manifests, fusing the constituents with the whole system, such that-as William Butler Yeats has said a century ago-one can't separate the dancers from the dance-the final lines in his poem, "Among school children" ([1933,1962]1989: 217-219). ("Bole" in the second line means "trunk".) 
O chestnut tree, great rooted blossomer,

Are you the leaf, the blossom or the bole?

$\mathrm{O}$ body swayed to music, $\mathrm{O}$ brightening glance,

How can we know the dancer from the dance?

Whether the dance involves one, or two, or more individuals, matters not. Whether they be of our species, matters not. Whether they be alive, matters not, although dance as metaphor functions best when movement, or its absence, is to a degree both volitional and contagious and responsive. The grains in a collapsing sand castle may then not qualify as dancing! A particular dance in a culture may be labeled, codified, and fused with other genres, such as music and song-Argentinian tango has been so labeled, codified, and exported (cf. Thompson 2005), even to Finland, in the far north of Europe, just south of where I do ethnographic research with the Saami, or Laplanders-who do not tango, or even dance, beyond the movements accompanying their chanting, juoigos 'yoik' (Anderson 1978: 305-314).

\subsection{Saami, the people "without dance"?}

The Saami reindeer-herding people of Saapmi whom I've just mentioned, were described in the obscure literatures of a century ago as unique, supposedly being the only cultural group without dance. This assertion struck me as unreasonable, for how can one separate dance from all the other habits of movement of any culture, any more than one can separate the dancer from the dance? Perhaps in Saapmi there was no dance so regular that it had its own label, or maybe dance might be unmarked and associated with something else that was marked, named, noticed, like music.

The Saami do practice a vocal art close to chant, called yoik. In the southern subarctic regions where there has been the most contact with Fennoscandinavian cultures and their tradition of song, traditional Saami chanting may include words, but farther north, and more traditionally, worded language would be superfluous. While yoiking, the individual rocks back and forth, balancing on one foot and the other; this is particularly crucial for balance if one has been drinking, as sometimes might be the case. There may be a swinging gesture with one arm. Surely that is dance! Small children imitate "dancing" while yoiking by first swirling around and around (usually counterclockwise) until they are quite dizzy; only then do they feel confident in pulling off both the vocal and the stumbling bodily elements of this performative genre.

\subsection{Tensho, a "dancing religion"!}

A decade before my still continuing research with the Saami, I carried out a year of ethnography with a Japanese "dancing religion" for my bachelor's 
thesis in anthropology at the University of Hawaii (Anderson 1968). This sect, of Tensho-Kotai-Jingu-Kyo, emerged in Japan during the stress of the second world war. Ogamisama, the foundress, also called the "dancing goddess", developed a standing form of prayer for outdoor practice, complementing the more common indoor kneeling form. Those standing in outdoor prayer would keep their eyes closed while stepping about on alternating feet, much as the Saami yoikers. Instead of yoiking, the Japanese sect members repeat the six-syllabled chant nam-myoho-renge-kyo common in other Buddhistic settings. Chanting's prehistory may extend far beyond the circumpolar region.

Oddly, or not, the footwork in this Japanese sect and that accompanying Saami yoiking are quite similar. There is a reason. The human body has two feet for support, when it often needs a third foot, for a tripod. Recall R. Buckminster Fuller's (1895-1983) passion for the number three, as found in the stable triangle and thence his geodesic dome (Fuller and Lopez-Perez 2019). This number three also recalls semiotics, but I've no evidence that Fuller had had any exposure to the three's of Charles Sanders Peirce (1839-1914) (Brent 1993).

The tripod as a construction independent of a body represents a major engineering accomplishment. While having no moving parts, the tripod figures right up there with the greatest of inventions such as the bicycle and the typewriter. The tripod had an antecedent: consider the body-plus a stick, a cane, a staff, a sword. These combos afford the stability of a tripod when standing, but also facilitate movement because walking with two feet is more precarious than running with two feet, although stumbling while running will be more disastrous. This is true of other systems as well, such as humanity's postmodern condition, only able to remain for now far-from-equilibrium because of our metaphoric jettisoned rocket fuel; eventually such systems, such runners, will stumble.

\section{Ethnography as "participant observation"}

My research has largely been ethnographic, like that of Gregory Bateson and his first wife, Margaret Mead. Ethnography is a performative methodology especially particular to sociocultural and linguistic anthropology, where "participant observation" is practiced in order "to make the familiar strange, and to make the strange familiar", recursively (Anderson and Gorlée 2011). The ethnographer starts by intuiting the thick points and thin joints in the patterns and rhythms in the stream of experiences in daily life. The ethnographer proceeds by being open to the surprise of discovery, not by seeking answers to questions. Who knows enough to ask!

The point of ethnography is to learn about the systems of living and learning of any group such that they can be "translated" with value-added to both insiders and outsiders. The ethnographer will never uncover, or model, or 
describe, or understand "everything", whether in her own society or a distant one, but stunning insights are more apt to occur in an unfamiliar setting. We are blinded by habit of expectation in our own too-familiar society. Gregory Bateson also unpacked styles of learning, calling attention to "deutero-learning", or learning to learn (1972: 159-176), which may have no better platform than metalogue.

Half a century since then, Bateson's second and final daughter, Nora Bateson (2016), coined "symmathesy" - any entity or process consisting in learning together through contextual mutual interaction. Symmathesy labels the process and consequence of metaloguing beyond that transpiring only through languaging. Body, mind, family, friendship, ecosystem - anything involving living systems, are generated through symmathesy, through the fluidities of dance.

Continuing insights from research on embodied cognition confirm that learning, communication, and movement (dance) are braided together through the interplay of collective inquiry and individual reflection.

\section{Reservations about interview, and recovery through metalogue}

It happens that in all these six decades of my ethnographic and other research-in Saapmi, Hawaii, and elsewhere-I have not relied on interviewing. I aim to convince everyone that the informal and open forms of learning that humans have traditionally practiced are still valid, even in science. Humans learn from others as a byproduct (if not the motivation) of all their activities, with or without categorizing these as, say, just being together, or casual conversing, in more motivated discussion, co-generative dialoguing, and finally metaloguing. Interviewing, however vaulted in qualitative research and in contemporary mass media communication, is fraught with handicaps, all the more dangerous because they fly beneath the radar of our critical attention in the west.

Interview presumes interviewer and interviewee, though either or both may be singular or plural. The imperial interviewer holds the reins as to topic, tempo, and terminus. The asymmetry-unto-hierarchy is pronounced. In this emerging era of postcolonialism, whether that be reactionary or transcending, interview stands out as a Trojan horse, allowed-even invited-to continue domesticating our discourse and reinfecting our minds.

Interview has colonized public discourse partly because so much around the globe has been transacted in various Englishes, and the model English has been found to be a "hearer-oriented" language, following the Danish semiotician and linguist Per Durst-Andersen $(2011,2018)$. His theory reflects analysis of English's grammatical structures of tense, aspect, and mood that contrast with those for speaker-oriented and context-oriented languages. All language families contain languages characterized by these three grammars. Within the Indo-European language family, for instance, while English is "hearer-oriented", 
Spanish is "speaker-oriented", and Russian is "context-oriented" (or "realityoriented"), at this time. These grammatical habits (no doubt with psychological persuasions) cycle, so like everything else, will constantly trend, but over perhaps more than a millennium. Actually, some of the Englishes spoken as second languages may not be hearer-oriented, but instead follow the model of the native tongues of new speakers (Durst-Andersen 2018).

Increasingly, whether they are deliberate or not, researchers resort to metaloguing in their investigations as well as in applied pedagogical settings, for example, in the teaching of science and math (Roth and Tobin 2004). In these ventures, the foregrounded process is learning-cum-teaching. In fact, learning and teaching co-occur, in the best synergistic practices among all parties, as learning is mutual and nonlinear-not the transfer of boxes of information from one mind to others-and teaching cannot be limited to the intentional process. A stage of "cogenerative dialoguing", grounded in the back-and-forth of shared memory and understanding, may build up to genuine metaloguing. Both of these stages of intercourse transcend in utility the oft-vaulted methodology of "interviewing". Respecting and retaining "voice" fuels the approach to metalogue as methodology, while "interviewing" fixes the tone of the context and dictates its direction. Alas, interviewing may come more naturally to speakers of English and of other "hearer-oriented" languages (Andersen 2010).

In contrast to co-generative dialogue and full-blown metalogue, which both seethe with abductive potential, the interview in western science, social science, and the media proceeds linearly and surgically and efficiently-to hunt more than gather, to get from cause to effect, or effect to cause, or just to take up time or space.

\section{Returning to tango}

In tango, the prescribed number of dancers is two; it is very difficult to imagine a solo tango or a trio. In English, even bereft of speakers having danced or seen tango, one may assert, "It takes two to tango", referring to any system where two participants can be held mutually responsible for an outcome, even when one might be lacking. But any semiotician will agree that it takes three to tango: the two dancers are intersubjectively sense-perceptible, while their relationship is suprasubjective, following John Deely's coinage (2014: 96).

However, I was even more amazed to find that my subtitle, "It takes three to tango", had already colonized several discourses on the web. One animates a mission in an online gaming quest, another is a series of children's books, another concerns political systems, and still another labels polyamorous relationships! 


\subsection{Subjectivity and suprasubjectivity}

The dance as sets of relations among its punctuatedly-moving constituents, exists in itself, and those relations are not perceptible apart from the process ensnaring the enactors. A dancer's entire body is in motion, from molecule to toe, and also in relation to another or plural other dancers within a context, forming an ecology. Though the relations are never perceptible, they will be felt, by the semiosic participants, and may be inferred by those within and beyond the dance itself, thanks especially to mirror neurons. This whole is the suprasubjective, transcending third party. To communicate this "dance-quadance" with the words of any natural language is beyond challenging. However, professional choreographers can both visualize and feel the dance in writing or reading dance notation, such as Rudolf Laban's Labanotation, and Irmgard Bartenieff's "space-effort-body-shape".

Besides being a dancer and student of Rudolf Laban, and founder of the Dance Notation Bureau in Manhattan, Bartenieff (1900-1981) was also a physical therapist and movement analyst who developed, with Laban, a qualitative, analogue notation system (Bartenieff 1979). We are assured that movement is essential for our minds as well as our bodies (Bowman 2014, Tversky 2019), but documenting graphically the fluidity of movement in both space and time has posed difficulties for alloanimal ethologists, for linguists of sign-language for the deaf, as well as for dance theorists and choreographers. Bartenieff brought to the explicit structure of her notation system, along with marking space and time, the ephemeral effort motivating each move. I'm sure Bartenieff would be active in semiotics were she alive today. Semiotics has always been a home for dance and dancers (cf. Martha Davis (1971), Maxine Sheets-Johnstone ([1999]2011).

Alan Lomax (1914-2002) and his father John Lomax (1867-1948) worked throughout the $20^{\text {th }}$ century with the technologies of their times, concentrating on documenting, not describing, song and dance, especially of the circumCaribbean region with its rich African heritage. Filmic documentation in Alan Lomax's Dance and Human History demonstrates how dance relates to the rest of culture, being most tightly related to climate, subsistence activities, and social relations (Lomax and Paulay 1974).

\subsection{Lurching forth and back}

Lurching from tango back into dance, more than one scientist has noted that, "Brains sculpt each other; why study them in isolation?" (Sanders 2019). Indeed, not only do brains sculpt each other-minds, emotions, and bodies do as well, most congenially through motion, dance inclusive (Tversky 2019). The $19^{\text {th }}$ century French neurologist Guillaume-Benjamin-Amand Duchenne (de Boulogne) (1806-1875) could demonstrate that bodies construct emotions from the outside, the social side, inwards! This seems not to have seeped in for western science until rediscovered by semiotician Paul Ekman (1990). 
Western scientists have also never acknowledged that natural selection [selection-out] or even artificial selection [selection-in] presumes a unit of analysis that can be either removed or retained in the population. Yet, bodies should not be singled out as candidates for selection, as bodies are not hermetically sealed, nor are brains or minds, should one distinguish these. The body and brain/mind dance not only with each other, even as they coconstruct each other, but dance as well with other bodies and brain/minds. Life is promiscuous and contagious. Pet rocks exhibit behavior! On the brink of the 2020 pandemic, one can read that infection by Streptococcus can trigger a faulty immune reaction in the brain that resembles obsessive-compulsive disorder (Zamzow 2019). At the molecular level, a St. Vitus' dance is more the rule than the exception!

In contemporary science, of course genes still count, but they're not all our individual genes: some are experiential records, epigenes, giving us environmental in-formation from recent generations, not heredity, while genes of hundreds of other species live in our guts, in our microbiome. Both of these categories of genes participate in the functioning of both bodies and brain/ minds, of all macroscopic creatures. We, our semiosic selves, may be mere epiphenomena of a swirling nanoworld.

Contemporary science also documents how conditions in our own personal "environment", or better, the significant surround in the Umwelt, extends the perimeter of our (mutual) exposure to "the world", shaping our cognitive and bodily lived experience, as dancers, dances, and their contexts each and all learn, reflexively and collaboratively. We take in the exhaled breath of conspecifics and others, along with supposedly inert chemicals constituting "air" all of which have been continuously recycled from stardust and dinosaur piss. (A biosemiotician has commented, though, that dinosaurs, as birds, would not be urinating.)

\subsection{Syncope and recovery and close}

Now, one more brief and abrupt turn, this time not to find another purchase on tango, or to allow tango to illuminate other processes in human narrativity, but to slide to a close.

The dance-communication of metalogue has implicitly become our semiotic model for process.

The metaphor of dance itself illuminates many dynamical processes we confront in literary semiotics, semiotics of culture, cognitive semiotics, and biosemiotics, not to mention biology and the human sciences generally.

Ratcheting "dance" up to the meta-metaphor of tango raises the ante in the collaborative venture called metalogue, animating the writer(s), the silent and oral reader(s), and all listeners and thinkerslearners allwho become invested in the verge toward abductive release. 
This paper quite unintentionally has assumed the shape of a monometalogue-infected by the twists and lurches of tango.

A final confession: I am actually incapable of interviewing.

\section{References}

ANDERSEN, Mette Skovgaard. 2010. Cultural fingerprints in national weather forecasts. Eds, Per Durst-Andersen and Elsebeth F. Lange, Mentality and Thought: North, South, East, and West, 171-186.

ANDERSON, Myrdene. 1968. Impact of the death of a charismatic leader; Incorporating an ethnography of Tensho-Kotai-Jingu-Kyo. Honolulu, Hawaii: University of Hawaii B.A. thesis.

ANDERSON, Myrdene. 1978. Saami ethnoecology: Resource management in Norwegian Lapland. New Haven, Connecticut: Yale University Ph.D. dissertation.

ANDERSON, Myrdene, and Dinda L. GORLÉE. 2011. Duologue in the familiar and the strange: Translatability, translating, translation. Eds. Karen Haworth, Jason Hogue, and Leonard G. Brocchi, Semiotics 2010, 221-232. Ontario: Legas Publishing.

BARTENIEFF, Irmgard. 1979. Body movement: Coping with the environment. New York: Routledge.

BATESON, Gregory. 1972. Steps to an Ecology of Mind: Collected Essays in Anthropology, Psychiatry, Evolution, and Epistemology. San Francisco, California: Chandler.

BATESON, Gregory, and Mary Catherine BATESON. 1987. Angels fear: Towards an epistemology of the sacred. New York: Macmillan.

BATESON, Nora. 2016. Small arcs of larger circles: Framing through other patterns. Charmouth, Dorset, UK: Triarchy Press.

BOWMAN, Katy. 2014. Move your DNA: Restore your health through natural movement. Sequim, Washington: Propriometrics Press.

BRENT, Joseph. 1993. Charles Sanders Peirce: A life. Bloomington: Indiana University Press.

DAVIS, Martha. 1971. Understanding body movement: An annotated bibliography. New York: Ayer Company Publishers.

DEELY, John. [1990]2014. Basics of Semiotics. 5th edition. (Tartu Semiotics Library 4.2.] Tartu: University of Tartu Press. 
DURST-ANDERSEN, Per. 2011. Linguistic supertypes: A cognitive -semiotic theory of human communication. Berlin: Mouton.

EKMAN, Paul. 1990. Duchenne and facial expression. In R. Andrew Cuthbertson, editor and translator, The mechanism of human facial expression, by G.-B. Duchenne de Boulogne. Cambridge: Cambridge University Press.

FULLER, R. Buckminster, and Daniel LOPEZ-PEREZ. 2019. Buckminster Fuller: Pattern-thinking. Baden, Switzerland: Lars Müller.

KÖNCZEI, Csilla. 1994. Dance and meaning: What are abstract dances about? Semiotische Berichte 1994(1-4), 95-104.

LABAN, Rudolf, and F.C. LAWRENCE. [1947]1974. Effort: Economy in body movement. Boston: Plays, Inc.

LOMAX, Alan, and Forrestine PAULAY. 1974. Rhythms of the earth. DVD produced by John Bishop, including documentaries such as Dance and Human History. Watertown, Massachusetts: Documentary Educational Resources.

ROTH, Wolff-Michael, and Kenneth TOBIN (2004) Co-generative dialoguing and metaloguing: Reflexivity of processes and genres. Forum: Qualitative Social Research 5.3, article 7.

SANDERS, Laura. 2019. Brains sculpt each other; Why study them in isolation?

Science News (11 May 2019), 4).

SHEETS-JOHNSTONE, Maxine. [1999]2011. The primacy of movement. $2^{\text {nd }}$ expanded edition (Advances in Consciousness Research). Philadelphia: John Benjamins Publishing Company.

THOMPSON, Robert Farris. 2005. Tango: The art history of love. New York: Vintage.

TVERSKY, Barbara. 2019. Mind in motion: How action shapes thought. New York: Basic Books.

YEATS, W. B. [1933/1961]1989. Among school children. From The Poems of W. B. Yeats: A New Edition, edited by Richard J. Finneran. Copyright 1933 by Macmillan Publishing Company, renewed (C) 1961 by Georgie Yeats. Reprinted with the permission of A. P. Watt, Ltd. on behalf of Michael Yeats. The Collected Poems of W. B. Yeats (1989). London and New York: Palgrave.

ZAMZOW, Rachel. 2019. When strep plays mind games. Science News (31 August 2019), 22-26. 


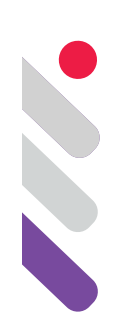

\title{
Matrices ideológicas y componente retórico en la discursividad política: las emociones en Mauricio Macri y Cristina Fernández de Kirchner, agosto de 2019
}

DOI: 10.24308/IASS-2019-8-004

\author{
Elvira Narvaja de Arnoux \\ Universidad de Buenos Aires, Argentina \\ elviraarnoux@gmail.com
}

\section{Introducción}

Émile Benveniste fue el primer presidente de la Asociación Internacional de Semiótica, creada en 1969. En el primer Simposio Internacional de Semiótica de Varsovia de 1968, que también había presidido, expone los lineamientos generales de la teoría de la enunciación que dan lugar a dos artículos fundamentales: "Semiología de la lengua" ([1969] 1974), en el que identifica los modos de significar, semiótico y semántico, que constituye el "núcleo de la noción de enunciación" (Fenoglio 2013: 45) y "El aparato formal de la enunciación" ([1970] 1974). En este último incluye además de los deícticos, entre otros, las modalidades, las formas que establecen la relación con el alocutario, y las que exponen valoraciones de los objetos o emociones del sujeto. En estos trabajos retoma y sistematiza sus reflexiones sobre la subjetividad en el lenguaje y afirma una lingüística del discurso "basada en la alocución y el diálogo, abriendo el enunciado hacia el proceso de enunciación, la subjetividad y la intersubjetividad" (Kristeva 2012: 19).

El reconocimiento de las huellas discursivas de la actividad de un sujeto sirvió rápidamente para identificar regularidades que, más allá de las individualidades en juego, remitían a posicionamientos en campos diversos. El análisis del discurso político se inicia en ese marco, apoyándose también en el psicoanálisis y el marxismo. De esos cruces surge la utilización de la categoría de formaciones discursivas como una entrada analítica (Haroche, Henry y Pêcheux 1971), que articula las perspectivas de Foucault ([1969] 1970) y Althusser (1968) y estimula variados desarrollos. 
Diversos aspectos han sido abordados en los estudios que contrastan discursividades específicas. Entre ellos, sobre todo cuando se retoman los aportes de la tradición retórica y de la estilística, los modos cómo las emociones se exponen en los discursos (Charaudeau 2008, 2011; Arnoux 2019a). Micheli (2014) considera así tres formas de semiotizar las emociones atendiendo a materiales verbales: por un lado, las emociones dichas, que se ponen en relación con una marca o expresión que remite a aquel que la experimenta y con, habitualmente, un objeto al que se aplica. Por el otro, las mostradas a través de marcas o índices diversos (cambios de registro, alteraciones en el orden esperado de la frase, cortes expresivos, repeticiones, amplificaciones, estilos en un sentido amplio) de las que se infiere abductivamente la emoción que experimenta el locutor o, en caso de disyunción enunciativa, el enunciador. Y, finalmente, las que están apuntaladas por la representación de situaciones asociadas culturalmente a determinadas emociones. La esquematización discursiva permite derivarlas porque se comparte la evaluación que la sostiene; por ejemplo, el cuadro de un anciano desvalido puede generar la compasión o, incluso, la indignación en una sociedad en la que se considera que el anciano debe ser protegido y se evalúa negativamente lo que lo cuestiona.

La fuerte presencia de las emociones en la discursividad política contemporánea ha llevado a hablar de un "giro afectivo" que incide en los regímenes de verdad y está en la base del ejercicio de la "posverdad". En ella lo que pesa es la experiencia subjetiva de la realidad y las emociones y creencias personales que el sujeto expone como "prueba" de la verdad de lo que dice. Sin embargo, en muchos discursos políticos, las emociones siguen los lineamientos de la tradición retórica: así, el ethos y el pathos acompañan, modalizan o sostienen el despliegue del logos y este penetra también en las otras dos instancias (Amossy 2008). De este modo, las emociones intervienen en la persuasión pero acompañando el discurso razonado (Plantin 2011, 2016). Esto ocurre, incluso, en los géneros epidícticos en los que dominan las operaciones de amplificación que exponen y generan emociones (Arnoux y di Stefano 2018; Arnoux 2019b). Consideramos que estas diferencias respecto del lugar de las emociones en el discurso pueden asociarse con formaciones discursivas, entendidas estas en el sentido amplio de regularidades sostenidas en posicionamientos sociales: en el caso que analizaremos, una ligada a la discursividad empresarial y a sus programas de comportamiento guionados y objeto de entrenamiento; y otra próxima a los discursos políticos de la modernidad que responden a las regulaciones de la tradición retórica.

Así, de las regularidades discursivas que identificamos podemos inferir matrices ideológicas de discursividad que incluyen componentes retóricos, en los cuales el tratamiento de las emociones es un aspecto. Ilustraremos con los discursos de Mauricio Macri y de Cristina Fernández de Kirchner posteriores a las PASO (Primarias Abiertas, Simultáneas y Obligatorias) del 11 de agosto de 
2019 y cuando los dos candidatos tienen respecto de ellas una distancia que les permite cierta evaluación de lo acontecido.

\section{En torno a las PASO en la Argentina}

Los resultados de las PASO en la Argentina pusieron en cuestionamiento algunas de las estrategias en política electoral desplegadas por expertos ligados, en muchos casos, a las propuestas del marketing en el ámbito empresarial. Los diagnósticos derivados de encuestas y las intervenciones en las redes sociales $y$ en los medios audiovisuales resultaron insuficientes o fueron apreciadas diferentemente por distintos sectores de la población. Esto llevó, incluso, a que algunos periodistas reconocieran públicamente que no habían evaluado correctamente la situación e hicieran una autocrítica (un conocido conductor de programas políticos, Luis Majul, por ejemplo, el 13 de agosto, en su emisión televisiva, señaló que no había dimensionado bien la situación, que se había dejado llevar por los datos que aparecían en las encuestas y, posiblemente, por el machacar en las redes sociales).

Lo que se suministraba como explicación del éxito de los ganadores era que "la gente había votado con el bolsillo". Evidentemente, la situación económica tenía su incidencia pero, podemos hipotetizar, que esta se combinaba con otros aspectos: los regímenes de verdad a los que se adscribían los votantes y las valoraciones asociadas con ellos que influían y activaban determinados gestos capaces de intervenir en circunstancias críticas en las decisiones electorales. Para algunos, del sector oficialista, la verdad se asentaba, más que en razonamientos, en sentimientos y creencias, en el hablar desde el corazón y decir lo que se creía verdadero. Para otros, de los que se impusieron en la contienda, la verdad de lo que se decía debía comprobarse en el hacer e implicaba cierta atención a un razonamiento sostenido por datos o armado de tal manera que resultara convincente.

Los discursos de los políticos argentinos que abordaremos exponen los polos de lo que se llamó en el gobierno anterior "la grieta", es decir la división de la sociedad en torno a dos posiciones antagónicas entre las cuales el diálogo parecía imposible. Ambos explotan las estrategias que les han resultado más efectivas frente a públicos amplios, aunque en Cristina Fernández con una mayor adaptación a la situación del país y la propia. Las emociones ocupan un lugar importante, pero en el primero son, fundamentalmente, dichas $y$, en la otra, mostradas y analizadas. En el primer caso se reduce la actividad inferencial del auditorio, en el segundo se activa y obligan a una escucha reflexiva. Ambos construyen un ethos en el que se conjugan la sinceridad y la responsabilidad, necesario para ubicarse como capaces de enfrentar la situación crítica del país y confiables, lo que impone la campaña electoral, pero, en un caso surge de lo dicho y reiterado y, en el otro, se deriva de escenas o alusiones. 


\section{Mauricio Macri: discursividad empresarial y posverdad}

El macrismo desarrolló, en sus expresiones públicas más habituales, las emociones afables, el trato respetuoso y amable, la mirada optimista, la confiada creencia, la apelación a los sentimientos y la mostración de los propios, siempre positivos, la capacidad de reconocer el error y pedir disculpas. Hasta que a mediados de 2018, con el avance de la crisis, los asesores percibieron que estos rasgos no eran suficientes ni siquiera para mantener la propia tropa y se desplazaron a modos más combativos. El "estoy enojado" o el "carajo" del presidente en el cierre de la campaña de agosto de 2019 lo exponían, aunque los vaivenes entre "paz y amor" y cierta violencia verbal mostraban el desmadre. Por ejemplo, en el discurso de apertura de las sesiones legislativas del mismo año (1/3/2019), las expresiones faciales, la mirada y la gestualidad desencajadas no correspondían al equilibrado texto leído. Sin embargo, en ciertas situaciones, como la que analizamos, el guionado de base -construido por los asesores- persiste.

El 29 de agosto de 2019, después del "reperfilamiento" de la deuda o "default selectivo" que generó aumento del dólar y del riesgo país, en medio de un remarcamiento de precios que aumentó el índice inflacionario ya de por sí agobiante, Macri pronuncia un discurso (no leído y que respondía sin desvíos al guión establecido) en ocasión de la finalización del arreglo de un buque para el transporte de arena. Lo hace cuando considera que no solo debe mantener la gobernabilidad hasta el fin de su mandato sino que también debe hacer gestos para continuar en la contienda electoral. Fue caracterizado por los medios como sorpresivo ya que la que se esperaba era una alocución propia de inauguraciones, puestas en marcha de emprendimientos o retome de obras, situaciones que el expresidente privilegiaba y le permitía insistir en "lo concreto" de los logros. Profirió, sin embargo, un discurso político que explotaba el guión que, en relación con otros acontecimientos, lo mostraban como un alma sensible. Es una pieza en la que se muestra la importancia del componente emocional en la formación discursiva del PRO y de muchos de los de la alianza Cambiemos en la etapa en que gobernaron. Los problemas objetivos y la explicación del sentido y alcance de las medidas que se van a implementar se reemplazan abundantemente por las emociones que supuestamente el locutor experimenta y las que supone en el otro. La captatio benevolentiae, que en la tradición retórica ocupaba en general la zona del exordio, se desparrama por el texto. El presidente, que a la vez es candidato, se presenta como sincero y atento al sufrimiento del otro.

Inicia a partir de un enunciado generalizador que no contempla la diferencia de situaciones entre los que especulan financieramente o los que no depositan las retenciones de las exportaciones y los que no llegan a fin de mes sin endeudarse y los que sufren hambre. El resultado electoral se ubica como la 
causa de emociones negativas que afectan a todos, entre los que el locutor se incluye, por igual: "Los argentinos estamos realmente a partir del resultado de las PASO en un clima de preocupación y angustia". El inicio de la preocupación y la angustia en el resultado electoral puede atribuirse al sector gobernante y a los que lo apoyan pero no al resto de la población que si esas emociones experimenta lo hace desde mucho antes, desde que el descalabro económico ha limitado sus posibilidades cotidianas de asegurar su sustento y el de su familia. Sin embargo, se insiste en que las PASO "han tenido la capacidad de desencadenar una crisis como la que estamos viviendo". La responsabilidad de lo que ocurre está en aquellos que han contribuido con su voto a los resultados, la víctima ocupa el lugar de victimario, lo que aparecía con mayor virulencia en los discursos más próximos a los resultados. Se minimiza, además, el sentido político de esa instancia electoral "no son más que una encuesta, una encuesta que debe ser la más cara de todas".

La incertidumbre se presenta como la emoción dominante y responsable de los avatares económicos. En esto se proyecta lo que se asocia habitualmente con los cambios en los mercados: "Se ha generado una incertidumbre política con estas PASO y que ha tenido lamentablemente consecuencias económicas". El mercado reacciona negativamente cuando experimenta la incertidumbre, en este caso generada por los votos. En otros enunciados, la incertidumbre no se destaca explícitamente como causa ya que se la ubica al mismo nivel que los problemas gracias al conector aditivo pero en la medida en que está en primer lugar se interpreta como lo que hay que "reducir" para "resolver los problemas". Por cierto que lo que descarta es la responsabilidad gubernamental en lo acaecido: "estoy tomando las medidas e implementando todas las herramientas que hacen falta para reducir la incertidumbre y resolver los problemas que afectan el día a día, que impactan en los precios, en los salarios, en la capacidad de llegar a fin de mes". La inflación como los resultados electorales son responsables de la incertidumbre generadora de efectos económicos: "estamos focalizados en lograr reducir el impacto de la inflación y la incertidumbre que afecta el bolsillo de los argentinos".

La superación de la incertidumbre implica generar certezas y esto va a ser logrado por la calma que se alcance: "Tengo la responsabilidad de liderar este país hasta que se logre la calma y podamos tener las certezas que hoy no tenemos en esta coyuntura".

La crisis se ubica en el plano emocional, no genera situaciones concretas de carencia y mayor vulnerabilidad sino que afecta el estado anímico. Lo subjetivo está en el frente de la escena: hay que ocuparse de la crisis "para que no haga sufrir más a los argentinos". El expresidente se presenta como aquel capaz de incidir en las emociones de la población. No despliega un programa de acciones para superar la crisis sino que privilegia la buena voluntad, el deseo de 
generar emociones positivas, la creencia en que se tiene el poder de lograrlo: "Está en nuestras manos contribuir a esa tranquilidad. Sin generar miedo ni desconcierto sino un clima de paz y de encuentro". La sinceridad, la buena fe, el afecto que se desean compartidos, aunque se los atribuya al grupo gobernante, van a resolver la situación: "cuanto más grande sea nuestra voluntad para lograr acuerdos, más calma y serenidad vamos a llevar a los argentinos. Si actuamos de buena fe, si ponemos la voluntad, si ponemos la mirada y sobre todo el corazón en lo único que importa, que son los argentinos, podemos lograr eso y mucho más".

La comprensión de las emociones del otro muestra la sensibilidad y benevolencia del locutor pero al mismo tiempo pone al votante en el lugar de un sujeto que no toma decisiones racionales sino emocionales. El que tiene la posibilidad de entender es el propio locutor que afectuosamente dice:

Quiero otra vez reiterar que entiendo el desahogo y el enojo de muchos argentinos. Muchos argentinos que me expresaron en la PASO, a través de su voto, el cansancio de nadar contra la corriente desde hace mucho tiempo y especialmente, muy especialmente, el último año y medio, que fue muy duro, muy duro para todos.

Sé que no siempre es fácil, que hay desconfianza, que a veces hay enojos.

Desahogo, enojo, desconfianza, cansancio son las emociones que atribuye al otro. Las opciones léxicas son significativas, construyen la representación de sujetos pasivos que solo dan salida a estados de ánimo pero que son incapaces de gestos combativos. El colectivo afectado emocionalmente es amplio: antes, los argentinos, ahora, todos: "fue muy duro, fue muy duro para todos".

De esa totalidad se destaca el presidente, cuyo ethos el discurso construye. Por un lado, es alguien que asume con responsabilidad su función y que conoce sus obligaciones: "Como presidente me hago cargo de los que está ocurriendo. Por eso estoy acá. Porque mi misión, mi único objetivo es poder llevarles tranquilidad"; "Tengo la responsabilidad de liderar este país"; "tenemos 59 días por delante hasta llegar a las elecciones y que transcurran de la mejor manera posible es mi responsabilidad como presidente"; "sabemos muy bien qué hacer para incidir en que ese presente y ese futuro sean lo más tranquilo y ordenado posible". Por otro lado enuncia sus virtudes: "Mis intenciones no son egoístas, jamás lo han sido. Son pensadas más allá de cualquier especulación personal, buscando lo mejor para todos". Reitera "jamás he especulado". La reiteración es significativa porque justamente se lo considera responsable de la especulación financiera que ha implicado la fuga de dólares y acrecentado la riqueza de los financistas cercanos al poder. Se muestra, por otra parte, como defensor del diálogo: "De mi parte está todo el compromiso en dialogar y cooperar en todo lo 
que haga falta"; "está en nuestras manos generar ese diálogo y esa cooperación que necesitamos para vivir mejor".

En la peroratio, al interpelar a los otros para que "no aflojen", las emociones ocupan también el frente de la escena y tienden a la construcción de un ethos optimista, confiado en un futuro venturoso, en el que el "nosotros inclusivo" sostiene la identificación. Dominan sintagmas que se reiteran en otros discursos, tan amplios que no anclan en la realidad y parecen girar en un vacío voluntarista: "seguir dando pelea por ese futuro que nos merecemos"; "vamos argentinos, estemos seguros, con mucha fuerza, démosle para adelante"; "no vamos y no podemos aflojar"; "los argentinos decidimos cambiar porque estamos seguros de que podemos ser mejores"; "Basta de resignación. No dejemos que la resignación le gane a la esperanza. Si llegamos hasta acá es porque elegimos el futuro y la paz y ese sentimiento tiene que crecer. Tiene que crecer y reafirmarse en el corazón de cada uno de nosotros".

El despliegue de lo emocional es común en este grupo en el que el guionado de los discursos es marcado y los sintagmas se reiteran en distintas situaciones. Se evidencia en las semejanzas entre discursos de un mismo locutor y de locutores diferentes, lo que demuestra cierto entrenamiento grupal en gestos y expresiones (Arnoux 2019a, 2020). La matriz ideológica tiene como componente retórico el discurso guionado en el entramado de la posverdad. Las formulaciones se repiten en la superficie de los discursos aunque estos se profieran en situaciones distintas generando los rasgos de homogeneización y trivialización que se destacan en muchos discursos políticos del sector. Apelan al aceptar gozoso de la emotiva sinceridad del locutor, cuya reiteración la vuelve verdadera. Estos guiones armados siguiendo las estrategias de marketing son, en muchos casos, como dijimos, objeto de entrenamiento, y atenúan inseguridades del locutor frente a situaciones nuevas. Pero presentan debilidades cuando es necesaria una lucha ideológica más compleja. Esto explicaría la autocrítica de la presidenta del PRO, Patricia Bullrich, el 17 de febrero de 2020, en un programa televisivo del conductor Eduardo Feinmann, en el que al solicitársela respondió reiteradamente que tendrán que "trabajar mucho en el mundo de las ideas [...] la Argentina necesita cambios más de fondo y esto hay que explicitarlo, explicitarlo más [...] trabajar claramente en un mundo de ideas, que en muchos casos no lo hicimos".

La matriz ideológica del kirchnerismo, en cambio, tiene un componente retórico propio de la discursividad política moderna (incluso si se explotan géneros actuales en los que operan ciertas restricciones de formato), en el cual las emociones ligadas a la construcción del ethos o al pathos acompañan al discurso razonado. Si bien el componente retórico suministra las orientaciones de base, exige la adaptación a la situación y al tema tratado. Por otra parte, 
al privilegiar las emociones mostradas estimula la actividad inferencial del auditorio que es el que debe interpretar lo que le ocurre al locutor.

En el primer caso, el discurso mejor es el que se adecua al guion y ha sido objeto de variados entrenamientos. En el segundo, el que hace gala de juegos discursivos que resultan de la percepción de la situación aunque permanezcan los formatos ya internalizados. Al respecto es interesante señalar que el actual presidente, Alberto Fernández, para marcar las diferencias, insiste explícitamente en su rechazo al "coaching", que tendería a lo guionado.

\section{Cristina Fernández de Kirchner: emociones y discursividad política}

Del otro lado de lo que se llamó, como dijimos, la grieta, Cristina Kirchner, en una fecha próxima al discurso de Macri, el 31 de agosto, en la Facultad de Periodismo y Comunicación Social de la ciudad de La Plata, enuncia un discurso en el que las emociones mostradas abren y cierran una nueva presentación de su libro Sinceramente. El espacio y la situación difieren de los elegidos por aquel pero también la discursividad política se despliega en el entramado de otra escenografía: presentación de libro frente a inauguración de obras. Cristina se apoya en un libro, es decir, en un objeto de la modernidad, y en un género que implica el uso de estrategias valorativas hacia el autor, lo que se adapta a la situación preelectoral. El ámbito es un espacio universitario que impone despliegues razonados pero en el juego conversacional propio de la modalidad genérica adoptada.

El tono emocional se acentúa en el inicio y el cierre, las zonas privilegiadas para esa expansión en la tradición retórica. Las lágrimas se desencadenan en esos momentos. Las palabras del presentador las estimulan. Al comienzo este le pregunta "¿Qué es La Plata para vos?". Ella le responde que La Plata le despierta "cosas muy fuertes", instalando la respuesta en el campo emocional que se refuerza con el uso de apreciativos "es el lugar donde me pasaron las cosas más lindas y las cosas más feas". Lo despliega y en relación con lo primero dice "es el lugar donde nos conocimos", respecto de lo segundo "me recuerda gente que no está". Las dos referencias remiten al marido muerto, a Néstor Kirchner, presidente de la nación en el tramo anterior al suyo. Se emociona y pide cambiar de tema. Las emociones mostradas ocupan el frente de la escena y conmueven al auditorio no solo porque se muestran como difíciles de evitar sino porque lo que genera las lágrimas es la ausencia del antiguo líder político, cuya figura se infiere fácilmente. El ejercicio de la actividad inferencial, facilitada por el cuadro 'recuerdo de la muerte de alguien familiarmente próximo' acerca al orador y a la audiencia. Que las emociones se expongan en el espacio público frente no solo a los asistentes al auditorio sino también a los que seguían la presentación afuera y los que la miraban por televisión genera el efecto de irrefrenable, a la vez que la escenografía con su dinámica dialógica autoriza su expansión. Por 
otra parte, lo vivido se presenta con sus dos caras, lo que evidencia un gesto analítico y reflexivo, que se reitera en otras ocasiones.

Cuando se le pregunta cómo vivió el domingo de las elecciones responde que "la sensación que aún hoy tengo es ambivalente" y lo explica. Las emociones son dichas pero en el espacio de una distancia reflexiva y de una vuelta analítica sobre sus propias emociones:

[...] por un lado sentí alegría de poder concretar la esperanza de tanta gente de poder cambiar esto tan feo que estamos viviendo. Pero al mismo tiempo, y eso es muy particular - si no lo dijera sería muy hipócrita-, siento como que con todo esto que estamos viviendo, esta realidad tan terrible, me pregunto por qué perdimos estos cuatro años.

Así como el mismo hecho puede generar emociones distintas también una misma emoción puede dar lugar a diferentes respuestas. La expresidenta analiza:

El dolor humaniza, puede convertirte en una bestia herida [...] o convertirte en alguien distinto. Antes de que pasara lo de Néstor, no tenía tanta cercanía con la gente [...] y después de lo de él es como que empecé a sacar fuerza de la gente que se me acercaba, me daba rosarios.

Incluso critica su discursividad de universitaria, engolada y con palabras difíciles propias de los que quieren mostrarse como más inteligentes y rescata la sencillez.

En los gestos emocionales, que pueden ser generalizados, señala la causa que los provoca y que, en cierta medida, los justifica. Al referirse al "periodismo de guerra" plantea que el ataque insistente "genera crispación, enojo, porque estás siendo atacado", la necesidad de defenderse permanentemente lleva a que el sujeto "cuando puede, contrataca". Si bien se mueve en el plano de lo general, lo dicho es una respuesta a las críticas acerca de lo combativo de su discurso. En relación con la violencia social -otro de los temas que aparece en la interacción-, aunque generalice, abre su corazón. Dice así: "Uno viene con sus historias, con sus cosas de familia, con sus creencias, con sus prejuicios, con sus miedos, tenemos miedo también, muchas veces lo exteriorizamos atacando al otro porque lo creemos diferente y le tenemos miedo".

Las emociones que experimenta y que busca desencadenar en el auditorio se apuntalan con referencias a situaciones particulares vividas por ella o por otro. Respecto de la primera recuerda su presentación en Comodoro Py, cuatro meses después del final de su mandato. Se refiere al "acto bajo la lluvia" (asociado a emociones políticas en la iconografía de la Revolución de Mayo), que ilustra lo general: "me sigue conmoviendo el amor de la gente". Este se muestra en toda su fuerza por la inclemencia del tiempo y la edad de muchos 
asistentes: "ese día llovía de una forma impresionante y multitudes, personas mayores... se movilizaron".

En otro momento retoma la muerte de un hombre de 68 años en la puerta de un supermercado porque había robado, recuerda reconstruyendo el cuadro y orientándolo emocionalmente: "medio kilo de queso, medio litro de aceite y dos chocolatines", "Es demasiado", "me impresionó muchísimo", "hay que ponerles un límite", "no se puede vivir en una sociedad en la que pasan esas cosas". El cierre evaluativo completa la esquematización y refuerza las emociones ligadas al cuadro del anciano desvalido.

Se refiere a la conferencia de Macri del 12 de agosto después de las PASO e interpreta las palabras presidenciales a partir del hecho de que permitiera la devaluación del peso y culpara a los votantes por su decisión en las elecciones. Construye una escena interpelante, que lo ridiculiza y deslegitima como presidente: "lo votaste a fulanito, ahora vas a ver. Te voy a subir el dólar, te voy a subir tal otra". Al cuestionarlo se ubica, más que en la dimensión política, en la moral:

No, eso no se hace. Esas cosas no se le hacen a la sociedad, no se le hacen a la gente, no es de buen ser humano. Va más allá de ser mal presidente o dirigente, es de mal ser humano hacer esas cosas, no se hacen esas cosas. Hay que tener responsabilidad en la vida, cuando la gente te confiere el honor de que las represente hay que tener mucha responsabilidad.

Compara esa conducta con la de Kirchner cuando perdió las elecciones en el 2009: "al otro día siguió trabajando sin echarle la culpa a nadie, y menos agarrársela con la gente y provocar medidas que le hacen daño a la gente". La escena referida de Macri genera rechazo, lo que se refuerza con las apreciaciones negativas propias de la polémica en la que la descalificación del otro es una herramienta (Bonhomme 2015): "no es de buen ser humano" reiterado por "es de mal ser humano", la acusación indirecta de irresponsable y la desvalorización que surge del contraste con Kirchner.

Se cierra la presentación con lágrimas como al comienzo. En este caso lo que las motiva no es el recuerdo del marido sino la referencia a la hija: "Lo de Florencia también fue una cosa muy dura, es muy dura para mí todavía porque además no está él y yo me siento responsable". El despliegue emocional humaniza a Cristina Kirchner, sobre todo porque la instala en el ámbito familiar, cuyas alegrías y pesares son comprendidos fácilmente por el auditorio. Asimismo, interviene en la construcción de un ethos alejado del que cultivaba como presidenta y tiende a erosionar, como señalamos, algunas de las críticas que recibiera. Sinceridad, sencillez, responsabilidad, sensibilidad, equilibrio se destacan en diferentes momentos. El presentador va a decir que siempre la vio notablemente calma a diferencia de la inestabilidad del 
"machirulo que tenemos de presidente ahora". Esa calma se completa con el "despojarse": "Todos tenemos que saber el lugar que tenemos que ocupar para ayudar a cambiar esto y que no sea el péndulo permanente"; "Me postulé a vicepresidenta para ayudar a conformar esta nueva mayoría popular. Pero yo ya estoy, ahora es lo que viene, es tiempo de las nuevas generaciones". Se entrevé el renunciamiento, gesto asociado con Evita y caro al peronismo.

El marcado peso de las emociones en la presentación estimulada en los momentos más intensos por el que interactúa con ella no dejan de lado los aspectos tradicionales del discurso político.

Por un lado, la dimensión polémica en el que el blanco es la alianza gobernante a la que define como "un gobierno de empresarios conducido por un empresario".

Por otro lado, el aspecto programático: habla así de "un acuerdo estratégico para armar un modelo de sociedad que necesariamente, tiene que ser de perfil industrial, que es el gran generador de trabajo, que también tiene que ser ciencia y tecnología".

Finalmente, el gesto pedagógico que la lleva a historizar la relación con el FMI y a proponer alguna de las razones que llevaron al fracaso de Macri: aceptar las demandas de los diferentes sectores económicos y no articularlos con los intereses de las mayorías.

\section{Reflexiones finales}

Como dijimos, muy tempranamente la teoría de la enunciación fue adoptada para analizar el contraste entre discursos anclados en diferentes lugares sociales y posiciones políticas. Es lo que hemos hecho analizando la dimensión emocional en dos discursos posteriores a las PASO, cercanos en su fecha de producción y enunciados por los dos principales exponentes de las posiciones políticas que iban a disputar en las elecciones.

Las situaciones en que fueron pronunciados difieren pero el que las hayan elegido no es secundario ya que en ellas resuenan aspectos, en tanto asociados con el género inauguración de obras o presentación de libro, que uno $\mathrm{u}$ otro locutor valoran. Macri se afirmaba habitualmente en su gobierno en las construcciones y se refiere a sí en su condición de ingeniero. Cristina valora lo intelectual y se ubica, en el discurso analizado, en la categoría de universitaria que comparte con un sector del auditorio.

Las regularidades en el primero surgen de un guion que atiende a la superficie discursiva, de allí la necesidad de que las emociones sean dichas y cubran gran parte del discurso para que en su reiteración, en este y en otros discursos, genere un efecto persuasivo. La verdad se presenta como derivada de una convicción personal y asentada en emociones dichas enfáticamente. En la segunda, las regularidades remiten al componente retórico propio de 
la discursividad política moderna e inscripta en una vasta tradición, en la que las emociones no están ausentes de la elocuencia pero que acompañan y se vinculan de diversas maneras con el razonamiento que necesariamente como el logos en la tripartición ethos, logos y pathos- debe exponerse. De lo verdadero se suministran pruebas y lo verosímil es producto de un discurrir racionalmente adecuado que apela a principios compartidos. Por otra parte, se estimula la actividad inferencial del auditorio al apelar a una interpretación indicial y al reconocimiento de cuadros que se sostienen en evaluaciones y se asocian culturalmente con determinadas emociones.

Estas diferencias son significativas porque muestran, por un lado, la proyección de los modos actuales de regulación de la discursividad en los discursos políticos con fuerte impacto del ámbito empresarial y, por el otro, los ligados al ejercicio de la palabra pública en relación con las formas de representación surgidas con posterioridad a las revoluciones democráticas. Como los dos locutores conforman frentes, las diferencias partidarias no se marcan en estos discursos sino que se acentúan las posiciones más generales que hemos señalado y que permiten alcanzar a un número mayor de votantes.

En Macri, lo empresarial se muestra también, además de las referencias a la incertidumbre como generador de desestabilizaciones económicas, en la insistencia en el rol de liderazgo, en el clima de paz y encuentro, en la vocación al diálogo, y se amplía a lo político con la fórmula "institucionalidad democrática". Tiende a generalizar con colectivos amplios. En Cristina, en cambio, la terminología política es abundante y no deja de lado los componentes propios de esa discursividad: lo polémico, lo programático y lo didáctico. Por otra parte, se refiere a sectores concretos que viven experiencias socialmente dolorosas.

El triunfo de la segunda posición en las PASO y, luego, en las elecciones definitivas, nos permite conjeturar que más allá de los éxitos circunstanciales que apelan a perfiles de receptores y a las estrategias discursivas de las redes sociales, un discurso con los rasgos propios de la discursividad política moderna sigue movilizando en sociedades muy golpeadas por los efectos de la libertad de mercado, el endeudamiento descontrolado, el aumento de la brecha entre los que más tienen y los más carenciados y la vulnerabilidad que acecha a cada vez más sectores.

\section{Bibliografía}

ALTHUSSER, Louis. 1968. La revolución teórica de Marx. Buenos Aires: Siglo XXI.

AMOSSY, Ruth. 2008. Dimension rationnelle et dimension affective de l'ethos. In Michael RINN (ed.), Émotions et discours. L'usage des passions dans la langue, 113-125. Rennes : Presses Universitaires de Rennes. 
AMOSSY, Ruth. 2010. La présentation de soi. Ethos et identité verbale. París: PUF.

ARNOUX, Elvira Narvaja de. 2019a. La crisis política en la Argentina: memoria discursiva y componente emocional en el debate sobre la Reforma Previsional. Guadalajara: CALAS (Centro María Sibylla Merian de Estudios Latinoamericanos Avanzados en Humanidades y Ciencias Sociales).

ARNOUX, Elvira Narvaja de. 2019b. Hugo Chávez: los modos discursivos de conmover, movilizar y encauzar en el último tramo de su gobierno. In Sybille GROßE, Claudia SCHLAAK \& Verena WEILAND, Contrôle et escalades verbales / Control y escaladas de tensión políticas. Politique et régulation au moyen de la langue / Política y control a través de la lengua, 17-29. Heidelberg: Universitätsverlag WINTER.

ARNOUX, Elvira Narvaja de. 2020a. Verdad y dimensión emocional de la discursividad política: su tratamiento en retóricas del siglo XIX en el ámbito hispánico y sus diferencias con el régimen de la posverdad. In Luzmara CURCINO, Vanice SARGENTINI \& Carlos PIOVEZANI (eds.), Discurso e (pós)verdade: efeitos de real e sentidos da convicção. São Carlos: EdUFSCar, en prensa.

ARNOUX, Elvira Narvaja de. 2020b. Los discursos de la política. In Angela SCHROTT y Óscar LOUREDA (eds.) Manual de lingüística del hablar, colección Manuals of Romance Linguistics (MLR). Nueva York / Berlín: De Gruyter, en prensa.

ARNOUX, Elvira Narvaja de \& Mariana DI STEFANO. 2018. La dimensión emocional de los discursos. In Elvira ARNOUX y Mariana DI STEFANO (eds.), Identidades discursivas: enfoques retórico-argumentativos, 11-38. Buenos Aires: Cabiria.

BENVENISTE, Émile. 1974. Problèmes de linguistique générale II. París: Gallimard.

BONHOMME, Marc. 2015. Autour du discours polémique. In Johannes ANGERMULLER \& Gilles PHILIPPE (eds.), Analyse du discours et dispositifs d'énonciation, Autour des travaux de Dominique Maingueneau, 239-248. Limoges: Lambert-Lucas.

CHARAUDEAU, Patrick. 2011. Las emociones como efectos de discurso. Versión, 26, La experiencia emocional y sus razones, 97-118. http://www.patrick-charaud. au.com/Las-emociones-como-efectos-de.html (consultado el 22 de noviembre de 2018).

CHARAUDEAU, Patrick. 2008. Pathos et discours politique. In Michael RINN (ed.), Émotions et discours. L'usage des passions dans la langue, 49-58. Rennes: Presses Universitaires de Rennes.

FENOGLIO, Irène. 2013. Éléments pour une genèse de la notion d'énonciation chez Benveniste. Ce que dévoilent les manuscrits. In Lionel DUFAYE \& Lucie GOURNAY (eds.), Benveniste après un demi-siècle. Regards sur l'énonciation aujourd'hui, 41-83. París: Ophrys. 
FOUCAULT, Michel ([1969] 1970). La arqueología del saber, Buenos Aires: Siglo $\mathrm{XXI}$.

HAROCHE Claudine, Paul HENRY \& Michel PÊCHEUX. 1971. La sémantique et la coupure saussurienne. Langages 24, 93-106.

KRISTEVA, Julia. 2012. Émile Benveniste, un linguiste qui ne dit ni ne cache, mais signifie. In Émile BENVENISTE, Dernières Leçons, 13-40. París: Seuil, Gallimard

MICHELI, Raphaël. 2014. Les émotions dans les discours. Modèle d'analyse, perspectives empiriques. Bruselas: De Boeck, Duculot.

PLANTIN, Christian. 2011. Les bonnes raisons des émotions. Berna: Peter Lang.

PLANTIN, Christian. 2016. Émotion: la construction argumentative de l'émotion, Ethos (I), (II) y (III), Pathos: de preuve à fallacie. In Christian PLANTIN, Dictionnaire de l'argumentation. Lyon: ENS Éditions. 


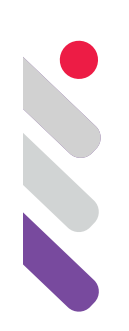

\title{
A Gradualist Perspective for the Semiotic Approach to Visual Images
}

DOI: 10.24308/IASS-2019-8-005

\author{
José Luis Caivano \\ Universidad de Buenos Aires and National \\ Council for Research (Conicet) \\ Buenos Aires, Argentina \\ caivano@fadu.uba.ar
}

\section{Introduction}

Among other features, the visual world is essentially continuous, without oppositions or abrupt jumps. The basic elements or signs that build it for our cognition have usually gradual variations. Colors admit gradual changes of hue, lightness and saturation, and those variations can be almost unnoticeable. A couple of examples of this are the numberless tonal variations that can be observed in human skins or in a collection of leaves taken from a tree in different seasons. This also applies to spatial shapes, or morphology, in general. Processes of metamorphosis (gradual changes of shape, or transformations) are very common in nature and biology. For instance, there are countless different shapes of human bodies between fat and thin, tall and low, etc. Another example: One can follow, day by day the small and unnoticeable changes suffered by a frog, from eggs to adult, passing through embryo and tadpoles. There are only four or five words to designate the different steps in this metamorphosis, but a photographic series of it may show hundreds of instances.

Visual textures and cesias (transitions between transparency, translucency, opacity and gloss) may also change in a continuous and indistinguishable way. In Figure 1a, three visual states are described by words (transparent, translucent, matte), but among them there is a continuous visual variation, where it is difficult to establish boundaries. Almost nothing is more continuous than the visual perception of movement. Muybridge photographic series, and later the cinematographic process, have been able to simulate motion from a succession of static frames that capture changes in shape, position, lighting, 
etc. at small intervals. The result is a fluid continuity (Figure $1 \mathrm{~b}$ ). Visual acuity tests performed by ophthalmologists have characters or shapes with a gradual decrease in size. Tests devised to detect deficiencies in color vision (Ishihara, Munsell-Farnsworth, etc.) use variations with degrees of tonal difference between elements (Figure 1c). Contrast vision tests use linear patterns with slight changes in orientation, size, separation and degree of sharpness or contrast of the lines (Figure 1d). All this accounts for that the sense of vision can essentially detect small modifications of shapes, sizes, colors and textures.

Vision is very effective in detecting small differences. And this is enhanced by the possibility of comparing objects and situations simultaneously. The development in simultaneity is a typical quality of most visual languages, something that auditory and verbal languages do not share, because successivity predominates in them. Sensorial assessment in simultaneity does not require the participation of memory, while in successive events, memory is essential to detect differences. Vision can take advantage of this condition, as long as the visual elements appear close, but occupying a different portion of the space, not in exact overlap.

In the history of visual semiotics, theoretical proposals have generally developed models by projecting categories formulated in verbal language. These developments verbalize the analysis and description of the visual world, and reduce and simplify it in terms of oppositions or tight categories: light-dark, straight-curved, large-small, etc. It is a logic of binary type, which shares the opposing criteria of affirmation-negation, truth-falsehood... But the world is not like that, let alone the visual world. It is certainly useful to verbalize what we see for the purposes of communication, or to modelize a certain understanding - simplified - of what surrounds us.

However, the human brain does not need to verbalize visual situations to understand them and make decisions. When we cross a street, we unconsciously calculate in milliseconds an infinite number of changing data: distances, speeds, sizes, shapes and colors, attitudes and gazes of drivers of nearby vehicles, as well as our own motor skills. And eventually we are able to reach the opposite sidewalk safely. If all this had to be verbalized to be processed by the brain, it would be impossible to perform such action.

Of course one can never dispense with the use of signs, both to model or produce some representation of the world, or for communicative purposes. But sign systems that allow to account for gradual evolutions, changes, cumulative differences and variations would offer a much richer knowledge of the visual world. 


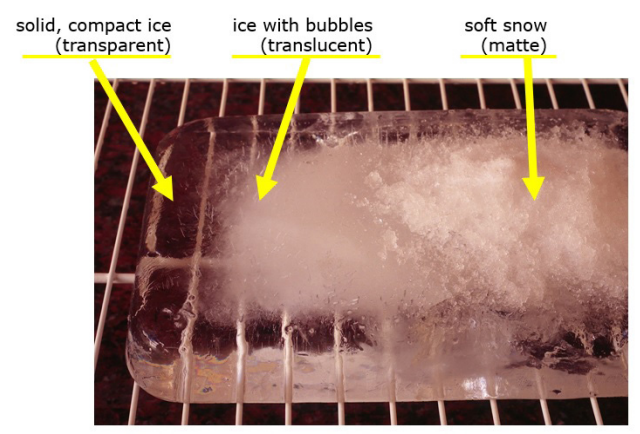

a)

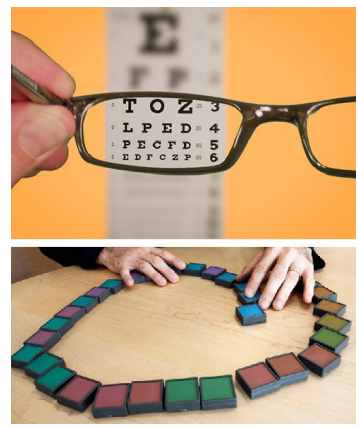

b)

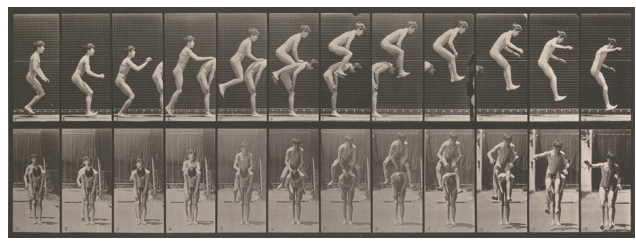

c)

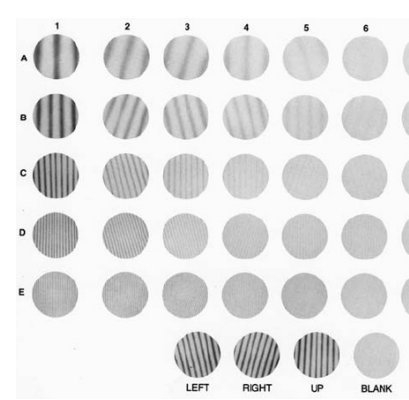

d)

Figure 1: a) Continuous variations of cesia in a fragment of ice, between transparent to matte).

b) One of Muybridge photographic series. c) Ophtalmological test for visual acuity and Munsell-Farnsworth test for color blindness. d) Test to evaluate the vision of contrast.

\section{Grammars of visual language}

In 1967, Jacques Bertin develops and systematizes, with the name of graphic semiology, the elements that allow cartography to display its full potential and expand its methods towards other fields and genres of the production, processing and graphic communication of information, with great influence in what has been more recently called infographics or info design, among many other fields of application. Bertin exposes the elementary graphic signs that, with the possibility of a graduated variation, allow to represent and communicate a large number of concepts, data and types of information of diverse complexity and various levels of relationability. Qualitative aspects can be adequately represented by shapes and colors, quantitative data, by means of figure sizes and lightness values, textures are suitable for both, and orientations allows to refer to spatial situations. In turn, each of these graphic variables can be materialized in terms of points, lines or surfaces, with which the repertoire of available combinations increases considerably (Figure 2 ). If we 
also consider that each of these categories admits gradual variations, we have practically a language with almost infinite combinatorial possibilities, which can be semantically associated with a huge number of concepts or classes of information.

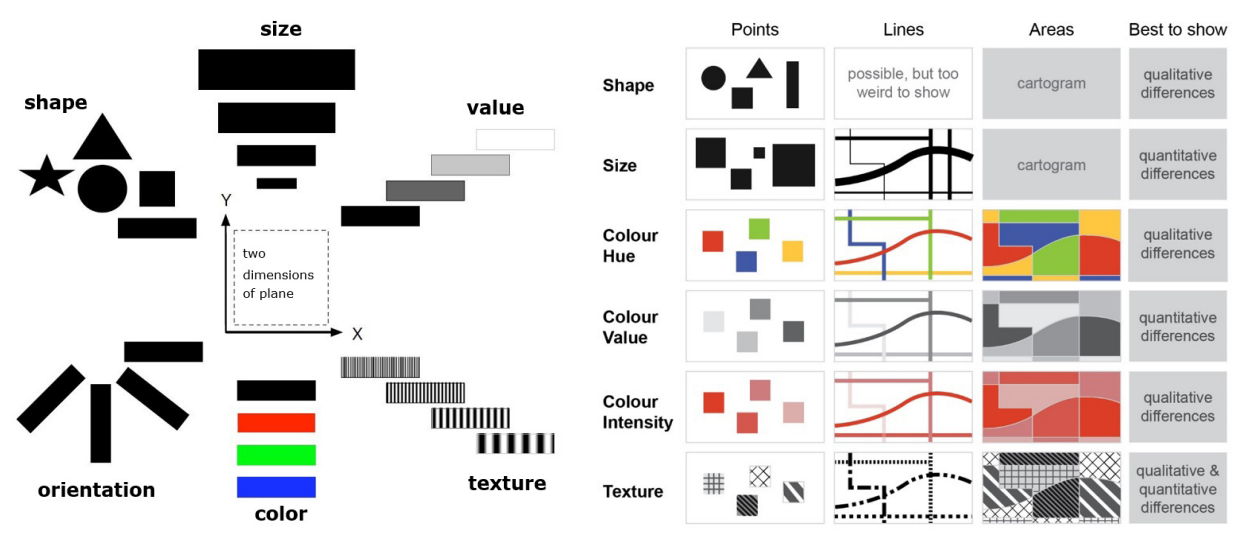

Figure 2: The graphic variables according to Bertin (left), with possible materializations, combinatory and uses (right). From Bertin (1967), and Burkhard \& Kruse (2017: 64).

There are models that organize and identify thousands of colors in terms of a gradation of three dimensions, for instance, the Natural Color System, with the variables of hue, blackness, and chromaticness (Figure 3a).

César Jannello (1984) devised a model that organizes the variation of shapes, also in terms of three variables: form-matrix, size, and saturation (Figure $3 b$ ). These allow for the gradual transformation of two-dimensional figures (see also Guerri 2012). Other models have been developed or amplified in a similar way, to account for the gradual transformation of three-dimensional shapes, for instance, the one that can be seen on Figure 3c, by Mason Dambrot (2017).

Jannello (1961) also proposed a cubic model to organize visual textures. The variables are: directionality, size, and density (Figure 3d). Using the same variables, I proposed a slightly different way of organizing textures, an example of which can be seen in Figure 3e (Caivano 1990, 1994).

There are also models that organize and identify visual sensations of gloss, transparency, translucency, matte appearance, etc. The name "cesia" was given by Jannello to this kind of visual sensations, and I developed a model with three variables: permeability, darkness, and diffusivity (Caivano 1991). It can account for gradual changes between dark and transparent, between transparent and opaque, and many other situations that we see in daily life (Figure 3f).

Finally, I can mention my proposal to organize a model for the gradual description of movements, in terms of visual signs (Caivano 1999). 


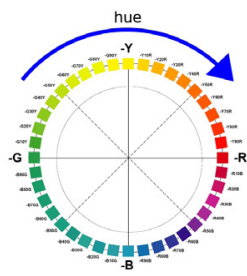

a)

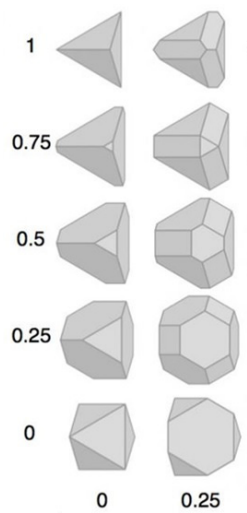

c)
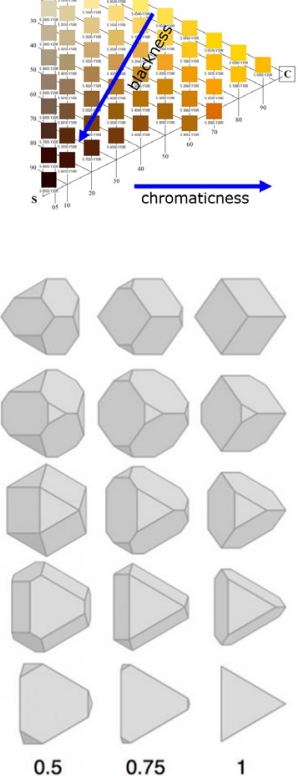

0.75

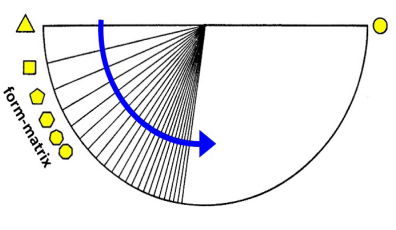

b)
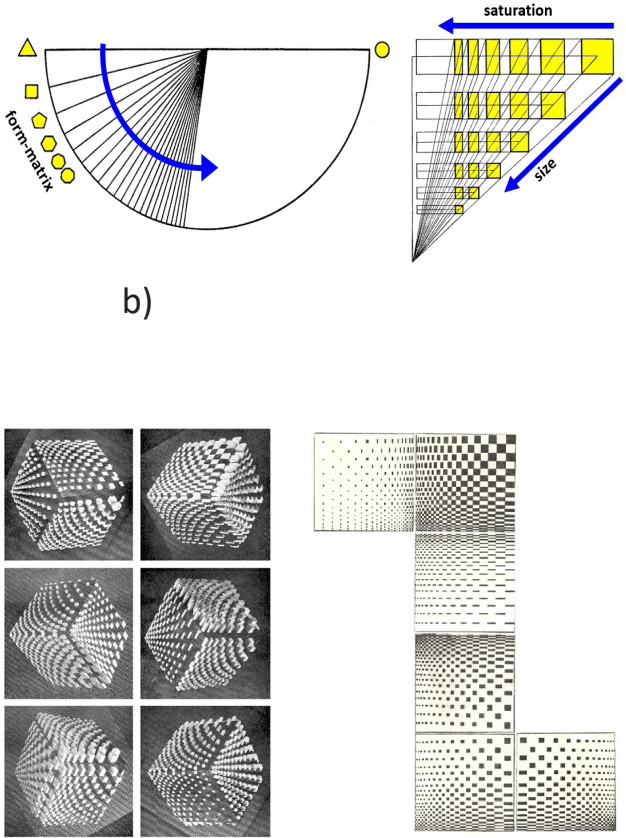

d)
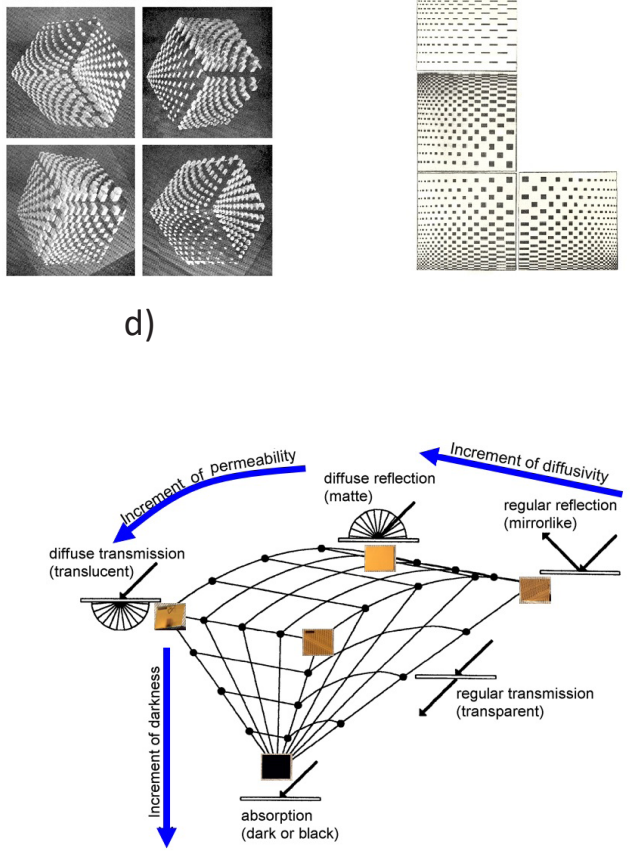

f)

Figure 3: a) Natural Color System. b) Jannello's system for 2D shapes. c) Gradual variation of 3D shapes. d) Jannello's model for visual textures. e) Another model for visual textures by Caivano. f) The system for cesias by Caivano (transparency, translucency, gloss, matte appearance, etc.).

Verbal signs are limited to explain visual variations. The mathematical language allows quantifying gradations and specifying variables, although it only serves for quantifiable aspects, or where quantification is relevant. Each 
language has its limitations. A combination of different languages or different kinds of representations can be an overcoming instance to address a more thorough analysis of a certain object.

\section{A gradualist view of semiosis}

The argument here is that a semiotic perspective based on a gradualist conception allows to handle adequate complexities for visual studies. There are antecedents in biology, geology and other natural sciences, as well as in human sciences, history, economics, etc. In natural sciences, the gradualist hypothesis may adopt the forms of uniformitarianism (advocated by James Hutton by 1785 and Charles Lyell by 1830, among others) or evolutionism (from Darwin 1859, The origin of species), in front of the opposite idea of catastrophism (favored by Georges Cuvier by 1822). In politics and society, we can find processes of sudden change trough revolutions versus processes that evolve through gradual transformations. In economy, shock policies or gradual policies may be applied, for instance.

In addition, I maintain that developments based on Peircean semiotics, are better suited for visual studies than dualistic structures anchored in linguistics. The Greimasian semiotic square, based on the operations of assertion and negation, with the relations of contrariety, contradiction and complementarity, participates in the binarist conception of semiosis (Figure 4a). It is certainly useful for many cases, but proves to be inoperative when it is necessary to account for more complex, non-binary types of semiosis, as is usually the case with visual semiosis. However, if the connections are understood as intermediate cases or transitions, the same binarist model could be transformed in a gradualist one (Figure 4b).

From a Greimasian perspective, Jacques Fontanille (1998) develops a model or tensive space, applied in this example to the semiotics of light, that, even when based upon oppositions, takes into account transitions and intermediate cases (Figure 4c). Note that for the intermediate cases, no names (or just a couple, at most) are available, either in French or any other language. In another diagram, Fontanille shows the way from the semiotic square to the tensive space (Figure 4d). 


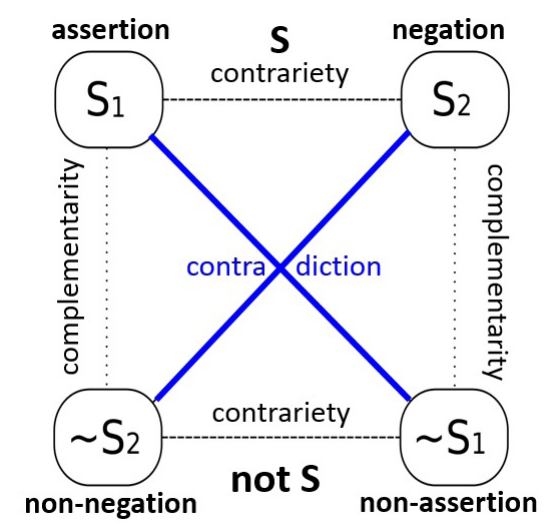

a)

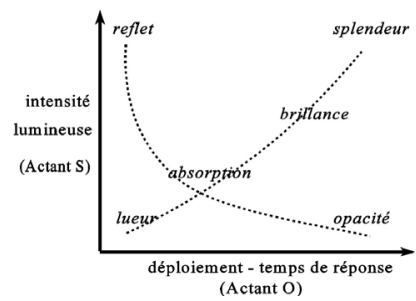

c)

C)

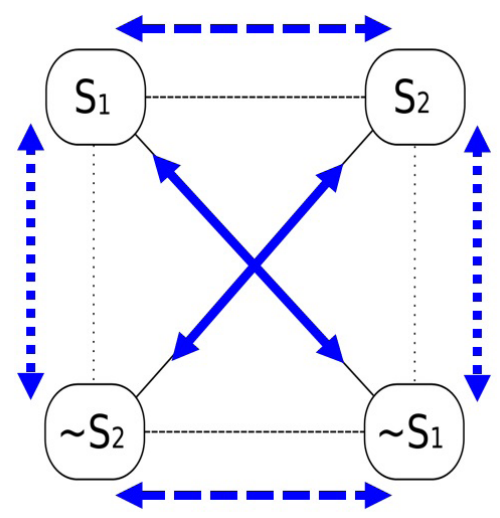

b)
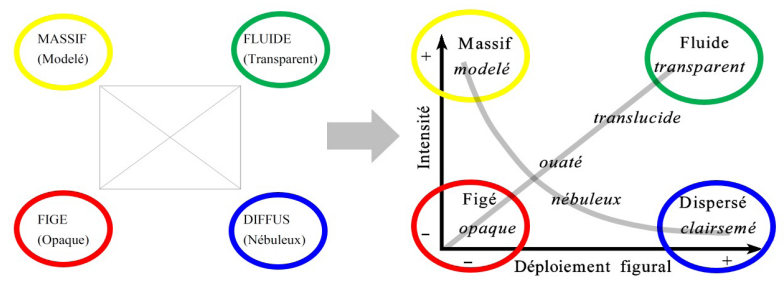

Figure 4: a) Greimas' semiotic square (from Hébert 2006). b) The same square, but with transitions between the binary oppositions. c) Fontanille's model or tensive space applied to the semiotics of light. d) Fontanille: from the semiotic square to the tensive space.

\section{The concept of scale}

Scale is one of the attributes of visual images, specifically in the field of spatiality, although languages that do not have visual or spatial development, but temporal, such as sound, admit scalar variations (Figure 5a). And scale is just a category of gradual nature. Images within another image that are repeated to infinity are known as mise en abyme. As examples of them, the can of Royal baking powder and the series of images reflected in facing mirrors can be mentioned. They have attributes of self-similarity, homothecy, and a fractal nature, and are gradualist procedures, with jumps of scale with greater or lesser degree of proximity between the steps or intervals. These jumps or intervals can be made as small as desired. What regulates this is the ratio of sizes or the scale between the first and second images, since the other images will repeat that initial interval indefinitely (Figure 5b). 
One of the requirements for a scale to be useful is that it has regularity in its units and intervals; i.e. it has to be modulated. Dardo Bardier (2007: $36 \mathrm{ff})$ represents this property comparing two stairs. The one on the left is well modulated: any difference in height between the steps serves as a module. The one on the right, however, is poorly modulated: no difference in height between steps is repeated (Figure $5 c$ ).

The feature of continuity would appear to be altered with changes in scale. Bardier points out how an object, phenomenon or event observed on two different scales seems to have dissimilar nature. A pencil stroke looks continuous to the naked eye and appears as a fragmented series of dots when viewed with a magnifying glass (Figure $5 \mathrm{~d}$ ). But between the small and the large scale of observation there are intermediate scales, where that opposition or difference is diluted, clearly becoming a gradation.

We always observe, measure, and represent something on a given scale. "If we were able to describe a fact on all its scales, we would have a full description of the fact" (Bardier 2007: 232, my translation). But describing something on all its scales gives as a result that such object appears different on each scale, even if its transformation from one extreme to the other is gradual. Here, we may refer to the video Powers of ten, by Charles and Ray Eames (1977), made at IBM (available on YouTube).

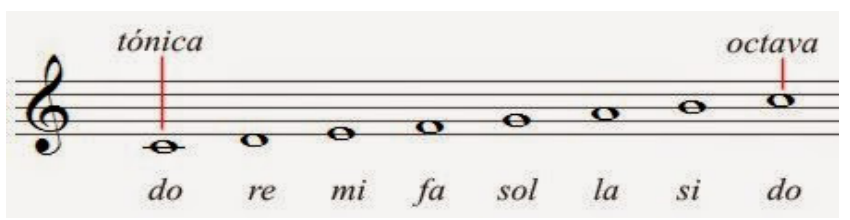

a)

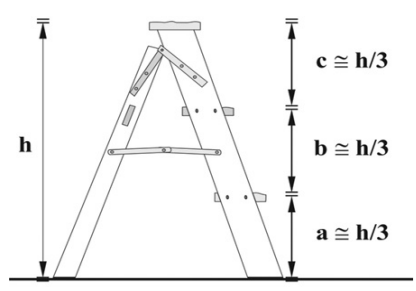

c)

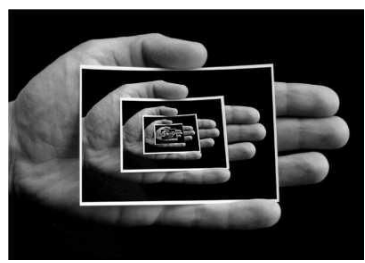

b)

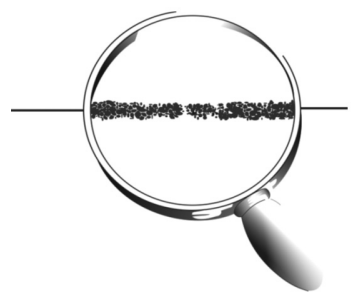

d)

Figure 5: a) A musical scale. b) An image reflected in facing mirrors. c) A well modulated scale (left), and a poorly modulated one (right), from Bardier 2007: 36). d) The same object looks continuous at one scale and discontinuous at another (from Bardier 2007: 70). 
The concept of edge is also relevant. Bardier describes two types of edges: net (or sharp) edge, with an abrupt change, and diffuse (or nebulous) edge, with a progressive change (Figure 6 , above). But what appears on a scale with a net edge, turns out to have a diffuse edge on another scale. Let's see an example. A city at the sea shore has a limit, represented on a map by a line or an abrupt color change dividing land from water. But when we see the "real" sea shore, such an edge does not exist: waves come and go and the limit is changing continuously (not even mentioning the changes produced by tides). And even if it is possible to eliminate waves and tides, the boundary between wet and dry sand is also quite diffuse. Thus, there are countless intermediate scales, where the edge is not as net or diffuse (Figure 6, below).
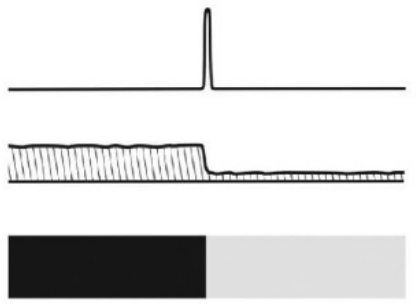

net (or sharp) edge abrupt change

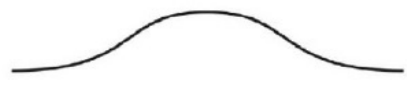

CONCEPT OF EDGE

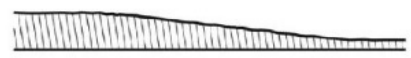

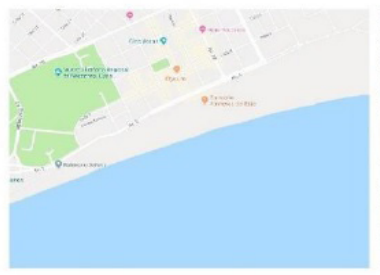

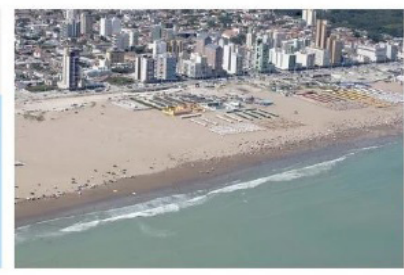

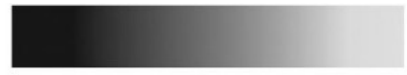

diffuse (or nebulous) edge progressive change

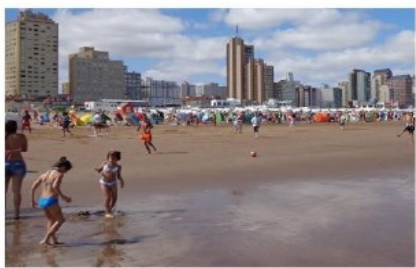

Figure 6:

Sharp and diffuse edges.

The two schemes on top are reproduced from Bardier (2007: 228)

Since visual images are basically composed of shapes, colors, textures, cesias, and eventually movement, they acquire the gradual features of these elementary visual signs. This allows visual images to communicate a type of information or build a particular kind of knowledge, made of continuities, gradual transitions, scales, nuances, transformations, and in this sense, they can share or take advantage of some properties of numerical languages. To study these problems in depth, visual semiotics should build more gradualist models, instead of binary ones. 


\section{Transformation of an oppositional scheme into a gradualist one}

Is it possible to escape from the dualistic enclosure that verbal language proposes? Let's see a case. Tables or schemas of variables with positive and negative values usually applied in social sciences work in the manner of net edges; i.e., through an abrupt division they make a dualistic simplification that, although useful to classify certain information, in practice hides the more complex nature that the phenomena under study generally have (Figure 7, left). If we want to have more precise and nuanced information at the same time, recording situations that are not simply "white" or "black", the same scheme could be used, but affecting the variables by a gradual scale, even if it is simply adding a single transition. Obviously, between the "precarious" and "non-precarious" opposites there may be intermediate cases, i.e., degrees of precariousness. This allows recording cases that cannot be so easily sort out by means of opposites (Figure 7, right).
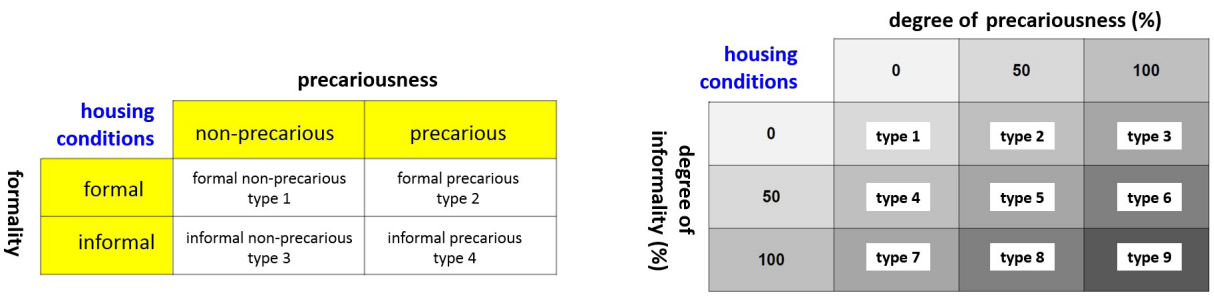

Figure 7: a) A binarist classification (adapted from the doctoral dissertation by Mariela Díaz, Hábitat popular y mercado laboral durante el proceso de urbanización El Alto - La Paz (Bolivia), 1985-201", Fac. Cs. Sociales, UBA, 2013). b) The same classification, but transformed into a gradualist one.

\section{Peirce, linguistic categorization and gradualism}

Peircean diagrams of semiosis are dynamic by definition, because semiosis is understood as a relational process that admits many situations. From the triadic sign relationship of representamen, object, and interpretant, nine classes of sign can be derived: qualisign, sinsign, legisign $\left(1^{\text {st }}\right)$; icon, index, symbol $\left(2^{\text {nd }}\right)$; rheme, dicising, argument $\left(3^{\text {rd }}\right)$. And by connecting these signs, it is possible to obtain ten sign relationships (Figure 8a). 


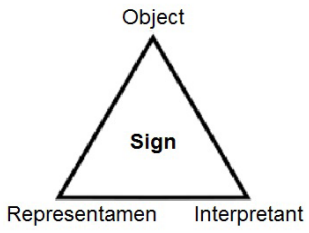

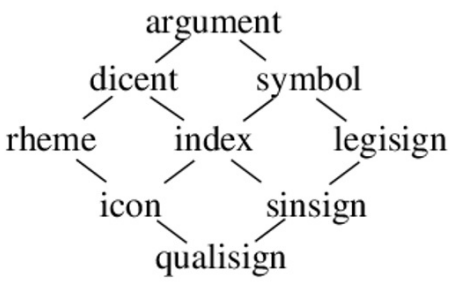

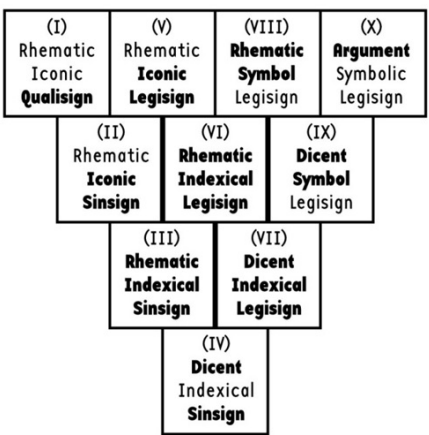

a)

\begin{tabular}{|c|c|c|c|}
\hline ARCHITEC Uै & Abduction & Deduction & Induction \\
\hline $\begin{array}{l}\text { Abduction } \\
\text { DESIGN }\end{array}$ & $\begin{array}{l}\text { F oxF } \\
\text { Abduction } \\
\text { Deduction } \\
\text { Induction }\end{array}$ & $\begin{array}{l}\mathbf{2} \\
\mathbf{E} \text { of } \mathbf{F} \\
\text { Abduction } \\
\text { Deduction } \\
\text { Induction }\end{array}$ & $\begin{array}{l}3 \\
\mathbf{V} \text { of } \mathbf{F} \\
\text { Abduction } \\
\text { Deduction } \\
\text { Induction }\end{array}$ \\
\hline $\begin{array}{l}\text { Deduction } \\
\text { CONSTRUCTION }\end{array}$ & $\begin{array}{l}\mathbf{F} \\
\text { F of E } \\
\text { Abduction } \\
\text { Deduction } \\
\text { Induction }\end{array}$ & $\begin{array}{l}\text { E onE } \\
\text { Abduction } \\
\text { Deduction } \\
\text { Induction }\end{array}$ & $\begin{array}{l}6 \\
\text { V of E } \\
\text { Abduction } \\
\text { Deduction } \\
\text { Induction }\end{array}$ \\
\hline Induction & $\begin{array}{l}7 \\
\text { F of V } \\
\text { Abduction } \\
\text { Deduction } \\
\text { Induction }\end{array}$ & $\begin{array}{l}\mathbf{8} \\
\text { E of V } \\
\text { Abduction } \\
\text { Deduction } \\
\text { Induction }\end{array}$ & $\begin{array}{l}\text { V } \\
\text { V oxv } \\
\text { Abduction } \\
\text { Deduction } \\
\text { Induction }\end{array}$ \\
\hline
\end{tabular}

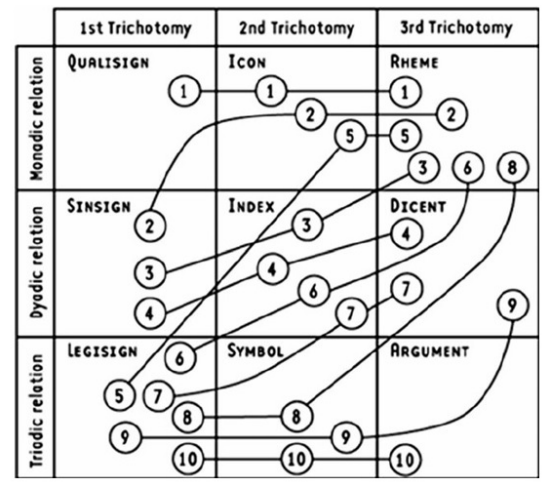

b)

Figure 8: a) Peirce's triadic model, 9 classes of sign, and 10 classes of sign relationships. b) Guerri's semiotic nonagon, and 10 classes of signs as a cross-relational system, by Queiroz

The relational nature of semiosis is well represented in various interpretations of Peircean schemes, or developments stemming from his conceptions, for instance Claudio Guerri's semiotic nonagon (see Guerri et al. 2014), or the 10 classes of signs as a system of cross-relational classes by Joao Queiroz (2012), after Floyd Merrel (Figure 8b).

Symbols grow. They come into being by development out of other signs, particularly from icons, or from mixed signs partaking of the nature of icons and symbols. We think only in signs. These mental signs are of mixed nature (...) A symbol, once in being, spreads among the peoples. In use and in experience, its meaning grows. Such words as force, law, wealth, marriage, bear for us very different meanings from those they bore to our barbarous ancestors.

(Peirce: Collected Papers 2.302)

It is clear that in this process there is a gradual transformation, with intermediate stages, i.e. it is a dynamic process. The color purple illustrates a 
case of an index transformed into symbol. In the past, when purple was very difficult and expensive to obtain, it was the color of royalty. In the Roman Empire, only senators, victorious generals, and the emperor himself could be able to use purple. Today, this indexical connection has disappeared, but purple still conveys meanings of magnificence, pomp, dignity, nobility, and elevated position. In other words, a sign that in a certain context begins to be taken as an index (because of a physical connection between it and its object), with time and reiterative use becomes a symbol, because habit causes the relationship to be preserved in an arbitrary way, independently of the original connection.

In this transformation, there must be intermediate stages, where sometimes these signs behave in one way, sometimes in another, and sometimes ambiguously. It would be a process similar to Robert McLaury's vantage theory (1997), when a semantic relationship of coextension appears in the process in which a language is making a passage from a semantic relationship of inclusion or quasi-synonymy to one of complementarity.

If using an ordered set of colors, you ask people to mark the colors designated by basic names, for instance in English, you will get something like Figure 9a. If you perform the same survey with speakers of a different language, for instance Spanish, you will realize that they segment the color continuum in a different way (Figure 9b). Note also that the semantic extensions of each term are very well defined and mostly do not overlap (Berlin and Kay 1969: 119, 126).

McLaury (1997: 111-115) found some intriguing cases. For instance, in the Uspantec language in Guatemala, speakers designated much of the same samples with two different names ( $q^{\prime} e n$, orange, and kyaq, red), according to the category from which they started. There was a big semantic overlapping, however the terms were far from being near-synonyms. MacLaury understood that the situation could not be explained by the habitual semantic categories of inclusion, synonymy, or complementation. He named it coextension (Figure 9c).

It is easy to see that among the four categories ?inclusion, synonymy, coextension, and complementation? (Figure 10a) a gradual variation can be established by enlarging or moving the semantic extensions. Figure $10 \mathrm{~b}$ shows a gradual sequence of this process. This allows to explain the evolution of basic color names and to account for intermediate stages. Coextension (and sometimes also inclusion) act as intermediate stages between near-synonymy and complementation. This accounts for when a language is evolving to produce new separate cognitive categories. Symbols grow! (see Short 1988) This is a dynamic process. Some intermediate signs would appear when a sign is evolving to become a symbol.

Methods that employ a gradualist conception are more suitable for studying visual phenomena than those approaches based on typical binary oppositions or categorial classifications, strongly anchored in verbal language. 
Gradualist methods have a greater affinity with visual phenomena, which are intrinsically continuous.

a)

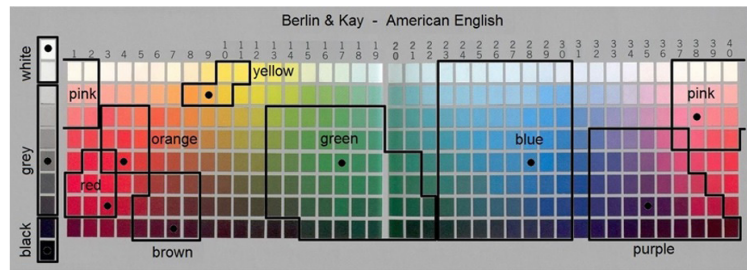

b)

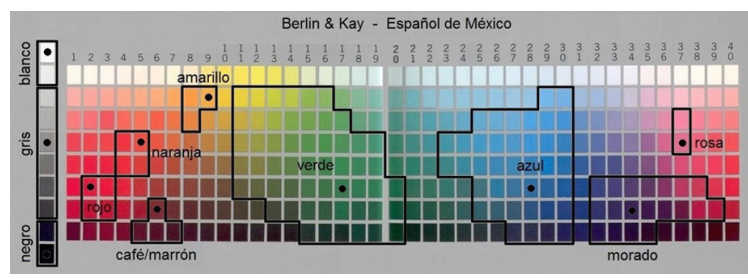

c)

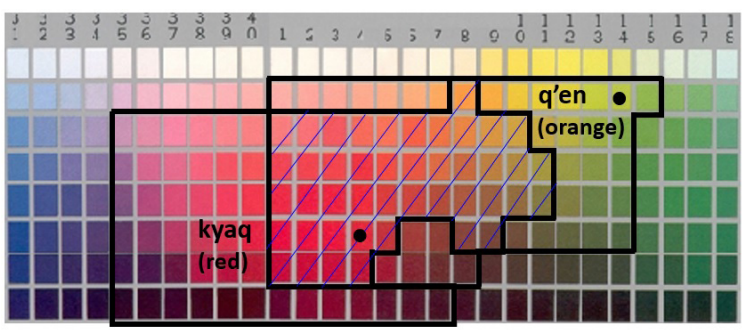

Figure 9: a) Linguistic color categorization by American English speakers. b) The same survey performed with Mexican Spanish speakers (adapted from Berlin and Kay 1969: 119, 126). c) McLaury finding of a new semantic category: coextension (adapted from McLaury 1997: 114).
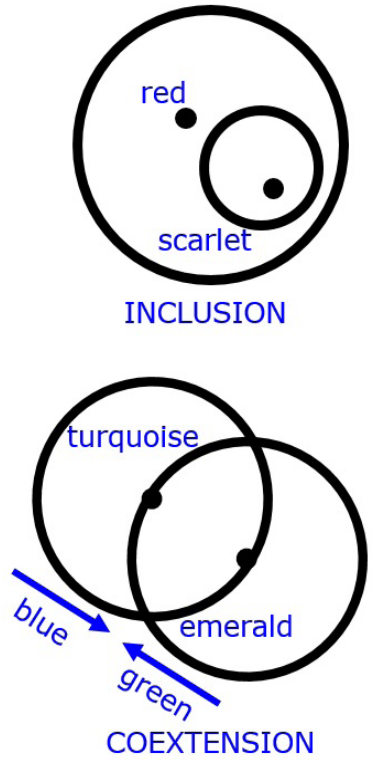

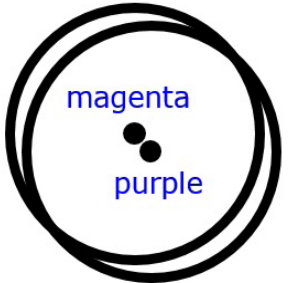

NEAR SYNONYMY

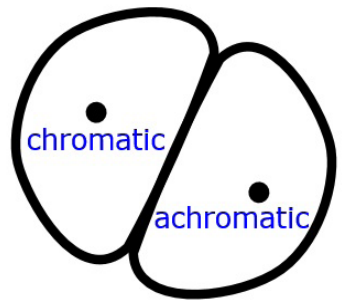

COMPLEMENTATION
Figure 10: a) An example of four semantic relationships: inclusion, synonymy, coextension, and complementation. b) Among them, a gradual sequence can be established that accounts for when a semantic relationship is being transformed into another. 


\section{References}

BARDIER, Dardo. 2007. Escalas de la realidad. Montevideo: Libros en red.

BERTIN, Jacques. 1967. Semiologie graphique, les diagrams, les réseaux, les chartes. Paris: Gauthiers-Villars de Mouton.

BERLIN, Brent, and Paul KAY. 1969. Basic color terms: Their universality and evolution. Berkeley, California: University of California Press.

BURKHARD, Benjamin, and Marion KRUSE. 2017. Map semantics and syntactics. In B. Burkhard and J. Maes (eds.), Mapping ecosystem services. Sofia: Pensoft, 63-69.

CAIVANO, José Luis. 1990. Visual texture as a semiotic system. Semiotica 80 (3/4): 239-252.

- - 1991. Cesia: A system of visual signs complementing color. Color Research and Application 16 (4): 258-268.

- - $\quad$ 1994. Towards an order system for visual texture. Languages of Design 2: 59-84.

- - 1999. La representación visual del movimiento: del caos al orden a través de la semiosis. In: Caos e ordem na mídia, cultura e sociedade, ed. Santaella \& Machado, special ed. Journal FACE. Sao Paulo: PUC, FAPESP, 56-64.

EAMES, Charles, and Ray EAMES. 1977. Powers of ten, video made at IBM. Available online: https://www.youtube.com/watch?v=0fKBhvDjuy0 (access: 1 September 2019).

FONTANILLE, Jacques. 1998. Reflets, transparences et nuages. Les figures du visible. In: Semiotica da arte, Teorizaçoes, análises e ensino, Publicaçoes do IV Congresso da Associaçao Internacional de Semiótica Visual, ed. de Oliveira \& Fechine. Sao Paulo: Hacker.

GUERRI, Claudio. 2012. Lenguaje gráfico TDE. Más allá de la perspectiva. Buenos Aires: Eudeba.

GUERRI, Claudio, et al. 2014. Nonágono semiótico: Un modelo operativo para la investigación cualitativa. Buenos Aires: Eudeba.

HEBERT, Louis. 2006. Le carré sémiotique. Online: www.signosemio.com (access: 1 September 2019).

JANNELLO, César. 1961. Textura. Buenos Aires: FAU-UBA. English version, Texture as a visual phenomenon. Architectural Design 33, 1963: 394-396. 
- - $\quad$ 1984. Fundamentos de teoría de la delimitación. Buenos Aires: FAU-UBA. French version, Fondements pour une semiotique scientifique de la conformation delimitante des objets du monde naturel. In: Semiotic theory and practice: Proceedings of the 3rd International Congress of the IASS, eds. M. Herzfeld and L. Melazzo. Berlin: Mouton de Gruyter, 1988, vol. I, 483-496.

MacLAURY, Robert. 1997. Color and cognition in Mesoamerica: Constructing categories as vantages. Austin: University of Texas Press.

MASON DAMBROT, Stuart. 2017. Modeling morphology: Solid-solid phase transitions based on colloidal particle shape changes. Phys.Org. Online: https:// phys.org/news/2017-06-morphology-solid-solid-phase-transitions-based.html (access: 1 September 2019).

PEIRCE, Charles S. 1860-1908. Collected papers. Cambridge, Massachusetts: Harvard University Press, 1931-1958.

QUEIROZ, Joao. 2012. Peirce's ten classes of signs: Modeling biosemiotic processes and systems. In Biosemiotics turning wild. Essays in honour of Kalevi Kull. Tartu University Press.

SHORT, Thomas. 1988. The growth of symbols. Cruzeiro Semiotico 8, January 1988, 81-87. 


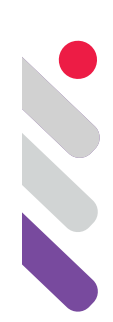

\title{
Trayectoria y continuidad de la teoría textual de Umberto Eco en las nuevas narrativas y sus estrategias textuales
}

DOI: 10.24308/IASS-2019-8-006

\author{
Alfredo Tenoch Cid Jurado \\ Universidad Autónoma Metropolitana Xochimilco, México \\ alfredo.cid.jurado@hotmail.com
}

\section{La Trayectoria como legado}

Hablar de legado de la semiótica interpretativa requiere de una observación meticulosa para identificar las fases en la trayectoria trazada a partir de los trabajos de Umberto Eco con la tarea de abordar las principales contribuciones a la teoría del texto y poder valorar su aportación en la descripción de los comportamientos con respecto al lector trasmutado en receptor (Traini [2006] 2014, Paolucci 2007). Las transformaciones formales del texto narrativo son el resultado de la modificación de base de la expresión material y de los cambios en el plano vehicular donde los relatos son semiotizados. Asimismo, la incorporación de recursos en los vehículos expresivos de nueva generación utilizados por internet y su continua evolución traen como resultado la adecuación de la semiótica narrativa hacia horizontes más allá del literario (Eco 2017). Dichos cambios afectan la noción de circuito comunicativo canónico y muestran comportamientos interpretativos emergentes e incluso cambios en los roles protagonistas originales. A la luz de la condición de cambio es necesario revisar las descripciones y la identificación de los requerimientos para el funcionamiento de los dispositivos tomados como lengua objeto en su resultado interpretativo.

Desde una perspectiva trazada a manera de trayectoria, algunos conceptos presentes en la teoría del texto de la semiótica equiana $(1962,1964,1979,1984$, 1990, 2002, 2011) resultan útiles para dos fines: i) establecer una metodología semiótica en la observación del comportamiento de las nuevas narrativas y de su adecuación a la respuesta a sus materialidades; ii) individuar los recursos para la actualización de la vocación pedagógica presente en una semiótica de 
orientación pragmática, sin perder de vista su tarea fundamental al comunicar los resultados, o sea, la transmisión por enseñanza del funcionamiento de los dispositivos. Los recursos accesibles en la fase de recepción de la fábula narrativa, entendida como baluarte de algún valor trascendental, hace posible distinguir el funcionamiento de los conceptos tradicionales: uso e interpretación, competencia enciclopédica, principio de interpretancia y la forma como manifestación del comportamiento cultural (Gritti 1991; Pisanty 1993, 1998; Pisanty \& Pellerey 2004; Traini [2006] 2014, Lorusso 2008, Paolucci 2016). Los recursos individuados permiten reconocer fases y comportamientos de la maquinaria textual narrativa en sus varias confecciones, elementos útiles a una tarea pedagógica con la cual comprender los componentes del mecanismo narrativo, explicarlo y propiciar el uso creativo y propositivo en la producción de nuevas formas de narrativa.

La presente reflexión toma los trabajos con vocación divulgadora presentes en la teoría textual de Umberto Eco, provenientes de diversos objetos de estudio, privilegiando los estudios sobre la literatura y la televisión. La trayectoria se explicita por medio de la continuidad en la pertinencia de los conceptos modelados, utilizados por el semiólogo italiano para explicar la llamada comunicación de masas.

\subsection{El legado en los estudios sobre la literatura}

Inicialmente, se identifica el rol de la semiótica en su función pedagógica y didáctica del recurso narrativo en la cognición humana. Un recuento de las aportaciones en el campo de la literatura debe superar ciertos límites en la construcción del objeto de estudio (Capozzi 1997, Salvatore Schiffer 1998). La obra literaria rebasa sus propios confines en el juego de sus códigos; de ahí su cualidad de "semiótica específica" proyectada hacia una general. Otras formas textuales y otras intenciones comunicativas se transversalizan en ese juego infinito de códigos. Los textos dedicados a la obra literaria no llevan como único objetivo la tarea de extender el conocimiento sobre la literatura, pues algunos buscan fincar opciones diversas del sistema literario previsto al interior de una red sociosemiótica e impactan en la recepción. En esa red, la aproximación teórica y metodológica se vuelve extensible a otros objetos de estudio. Diversos trabajos abordan las principales contribuciones del semiólogo italiano al estudio de la obra literaria, algunas centrándola como objeto de estudio, como motivo de ejemplo o también como posibilidad aplicativa de un análisis (Bernoussi 2017).

Una aproximación sistemática al estudio de la obra literaria se observa ya en Opera Aperta (1962) en el estudio de las formas expresivas, en el lenguaje utilizado, en el ordo rethoricus con la capacidad de describir la ruptura de un orden en la obra de James Joyce: "la distruzione dei rapporti oggettivi sanciti 
da una tradizione millenaria" (1964: 61). El acercamiento será a través de la atenta observación en el comportamiento de las poéticas con las cuales se compone una obra literaria (Gritti 1991). Si bien Lector in fabula (1979) abre las posibilidades disciplinarias hacia una semiótica basada en las relaciones y en las conexiones lógicas, la base reconocible de un método ubica su inspiración en una semiótica interpretativa. La cooperación textual resultante de las conexiones permite reconocer la competencia intertextual, "(estrema periferia di una enciclopedia), [la quale] comprende tutti i sistema semiotici familiari al lettore" (1979: 81). La noción de enciclopedia, precedida a su observación en la literatura por la reflexión en el comportamiento del lenguaje, supone igualmente el reconocimiento de procedimientos, de situaciones tipo establecidas como resultado de una semiosis social, denominadas por Eco como frames, sceneggiature, es decir guiones o marcos. La traducción al castellano las llama cuadros (1979 [1993: 113]) y pueden ser de distinta dimensión: desde los fabulae prefabbricate, y por su dimensión corresponder a las reglas de un género, hasta llegar a los comportamientos de mayor simplicidad como motivos, situaciones, topoi retóricos, en suma, "regole per l'azione pratica" (Eco 1979: 8185). La acuñación de conceptos rebasó casi inmediatamente el espacio literario de cada noción. De ese modo, autor y lector modelo, ideal, empírico, etc., pasaron rápidamente a formar parte de un léxico especializado con la capacidad de extenderse para hablar de equivalentes en el espectador ideal o modelo para la televisión (Casetti \& Di Chio 2001). Algunos otros conceptos se desprenden además del reconocimiento de los límites de la interpretación, entre ellos la deriva ermetica o la semiosi illimitata de donde destacan en contraposición el criterio de economía, el criterio de interpretancia (Eco 1984).

En el marco de hallar una intención al texto, la interpretación adquiere un valor con calidad de parámetro para mesurar el grado de respuesta al tejido lógico contenido en la obra literaria, en el texto, "alla natura del senso e alle possibilità e ai limiti dell'interpretazione" (Collini in Eco 1992 [1995: 13]). El lector y su radio de acción se extienden con respecto a la intención primera del texto, la intentio operis y el juego con las otras intentio, la lectoris y la autoris (Eco 1990: 110). El producto de una interacción negociada posibilitará la distinción entre uso e interpretación (Eco 1979: 59, Eco 1992 [1995]) y permitirá reconocer interpretaciones aceptables dentro de las mismas estrategias propuestas en origen por el texto.

Existen funciones identificadas en la literatura que la rebasan como sistema semiótico privilegiado en cuanto objeto de estudio por algunas escuelas de la disciplina. Sulla Letteratura (2002) y Confessions of a Young Novelist (2011) son dos textos que agrupan las reflexiones sobre una teoría empírica, en las dos actividades desarrolladas por el semiólogo y escritor italiano: la traducción y la escritura literaria materializadas como productos textuales, con 
su correspondiente reflexión teórica y filosófica. La literatura posee una tarea, descrita in extenso al momento de ser estudiada como sistema semiótico, la cual consiste en preservar y transmitir la memoria colectiva (Eco 1975) con el fin de mostrar su accionar proyectado sobre sus elementos componentes. El primero es el código: su conservación, su modificación y sus efectos, individuales y hacia los grupos sociales, pues en él reside la función metalingüística descrita por Jakobson (1990); el modelo de lengua da a conocer su comportamiento en tanto código y la base de construcción de los lenguajes (Eco 1993). La segunda noción es el texto: su intencionalidad genera la relación interpretativa con el receptor estableciendo lo relevante y los límites de lo que no se puede interpretar libremente, para derivar en una serie de consecuencias interpretativas hacia un relato (Eco 1979). Si se procede a distinguir y tipificar esas consecuencias, se ubican de inmediato el contexto y la circunstancia como los generadores necesarios para retratar en su implementación la acción de proponer nuevamente propuestas ya existentes, pero sobre todo en la implantación de modelos. Los modelos son de vario tipo: el de verdad a partir de la relevancia del dato, las verdades hermenéuticas derivadas, la confirmación de la verdad y la realidad cultural; los modelos de vida y las entidades construidas como realidades posibles (Eco 2002: 7-22).

Los relatos presentes en la literatura ofrecen elementos necesarios a considerar por su importancia. Por ejemplo, la hipertextualidad. El concepto es reconocido como expresión de la competencia intertextual e intersemiótica y su opuesto es visible en la doble cualidad transtextual de los personajes y sus situaciones: "la narrativa ipertestuale ci può educare alla libertà e alla creatività" (2002: 22). Su imposible modificabilidad abre opciones interpretativas y de desarrollo para las macrohistorias y, a su vez: "I racconti 'già fatti' ci insegano anche a morire" (2002: 22). El resultado es el efecto de la lección represiva por su capacidad de ser conclusiva: habitúa cierto respeto al final de una historia y a la consecuente prohibición que precede la ausencia de cambios. Un relato trae consigo el entendido de base con el cual una estructura narrativa comprende un inicio y una conclusión, la cual termina al momento del final del relato, el envase que ha permitido su transmisión, su comprensión y su interpretación. Destaca el valor del personaje en su capacidad de migración, individui fluttuanti (2002: 16), donde el novelista posee la prerrogativa de "crear personajes que matan a los de los historiadores" (Eco 2011: 77). Un personaje nace del relato y lo trasciende con las condiciones expresadas en su epifanía, las cuales no se modifican en su transmigración a otros sistemas semióticos que los hospedan, los acogen momentáneamente, en muchos casos hasta elegir un nuevo destino de llegada en su peregrinación. 


\subsection{Televisión, código, lenguaje y formas comunicativas}

La primera extensión de una teoría procedente de la comunicación literaria se lleva a cabo en un sistema semiótico emergente: la televisión. Ahí se evidencia la primera similitud metodológica entre una semiótica de los campos tradicionales y clásicos hacia un movimiento dirigido a las nuevas formas de comunicación masificada. Los estudios pioneros de Eco parten de su trabajo en la Radio e Televisione italiana, RAI, a partir de 1952 (Eco 1962, Pansa \& Vinci 1990: 32). Una aproximación fenomenológica y estética fue el resultado de las primeras armas a disposición para explicar el comportamiento en la construcción de significado en el proceso de comunicación. La actuación del sistema reflejaba las preocupaciones iniciales de una disciplina que veía en las formas nacientes y en los alcances de la comunicación de masas, problemas y preguntas por resolver desde la mirada semiótica. El traslado metodológico de la narratividad literaria suponía dos trayectorias: el recurso narrativo como organización del significado, y el uso de los códigos a través de su producción y en el reconocimiento aún fuera de los confines del texto literario (García Jiménez 2003). La aproximación a la observación del comportamiento directo del sistema de organización y de la estructuración de la organización narrativa va a facilitar la identificación de regularidades en el acto de narrar y en la adecuación a los recursos disponibles de las historias para ser narradas (Bertetti 2012).

Los límites textuales para definir el tipo de aproximación analítica de una tipología textual se delimitan en dos fuentes para observar las transformaciones operativas: i) la diversidad textual tomada como objeto de estudio en los trabajos realizados para la televisión a partir de sus acercamientos: descripción, definición, tipología, es decir la diferencia necesaria entre casos, géneros y formatos; ii) el concepto de texto proveniente de la noción canónica en su esencia literaria: el relato, el drama, el melodrama y la comedia en la suma de sus recursos explicativos de las formas de consumo patémico en cada forma asumida por el texto literario. Las formas comunicativas son el resultado de las adecuaciones de los contenidos de los mensajes a las posibilidades expresivas estructurales de cada uno de los géneros, los formatos y el uso del discurso televisivo.

El criterio de clasificación de las aproximaciones al estudio de la televisión se ha regido de acuerdo con el mapa conceptual desprendido del circuito de la comunicación. Grosso modo, las formas textuales se definen a través de tres instancias: la emisión, el mensaje y la recepción. La tipología de objetos es variada, como se observa al centrar la atención en el mensaje: los presentadores, los formatos y los tipos de mensajes, los códigos y los subcódigos, las reglas estéticas, la relación entre palabra e imagen (Pozzato 2004) y los aspectos técnicos como las tomas, el montaje, la técnica utilizada y el servicio social. En la recepción resulta fundamental el público, las condiciones de la recepción y los 
efectos a distintos niveles: ontológicos, éticos y estéticos. El recorrido mostró consecuencias metodológicas varias: la interacción de los estudiosos semióticos con las empresas productoras de televisión, la asunción de la semiótica como recurso para el diseño y la producción textual televisiva.

\subsection{El texto como trayectoria explicativa}

El texto es el punto focal en Umberto Eco para observar el binomio semiótica-televisión y sus peculiaridades. Dicha noción constituye un instrumento fundamental en el desarrollo de la semiótica; sin embargo, ha requerido su adecuación a la comunicación audiovisual, obedeciendo al inicio los parámetros de la televisión. El trabajo creativo en la RAI permitió su aguda mirada del comportamiento del medio y del impacto en el público a partir de criterios fijados por una perspectiva trazada desde la estética (Pansa \& Vinci 1990). La estancia en la RAI culminó con la aportación de la tipología de las observaciones -apocalípticas o integradas- en sus efectos masivos (Eco 1968).

Entonces, la propagación del modelo del circuito de la comunicación mostraba su realidad explicativa omnipresente en las formas de la comunicación de masas y los efectos de la evolución continua en la comunicación televisiva. La preocupación por efectuar un inventario de recursos a disposición era indispensable. Eco recordaba cuando en 1965, junto a Cesare Segre, Maria Corti, Gianfranco Bettetini, en un trabajo coordinado, "si cominciava ad applicare ai problemi della ricezione televisiva le nozioni jakobsoniane, con la idea che i codici dei ricettori erano diversi da quelli degli emittenti" (Bertetti 1999: 201).

Los principales artículos sobre televisión aparecieron diseminados en sus libros: Opera aperta (1962), Diario Mínimo (1963). Más adelante reunió ensayos en Il costume di casa (1973), Apocalittici e integrati (1977) y Dalla periferia dell'impero (1977). Las décadas siguientes vieron las compilaciones reunidas en Sugli specchi e altri saggi (1985) y Cinque scritti morali (1997). Más recientemente aparecieron en A passo di gambero (2006) y Pepe Satan Aleppe (2016). El denominador común de las compilaciones encuentra las varias procedencias: conferencias, pláticas, artículos divulgativos y periodísticos donde la televisión es protagonista o incluso actor de comparsa.

El criterio de acercamiento filosófico utilizado en su autoría se acentúa en la compilación de los escritos en Sulla televisione (2018), el cual muestra la lógica de su recolección al colocar a la televisión como problema de enunciación, como gestor de formas emergentes tanto de las competencias de producción como aquellas del reconocimiento, y como incubadora de modelos de comportamiento. Las formas textuales televisivas han mostrado una amplia tipología de mensajes que reflejan las necesidades comunicativas de sus receptores y los problemas cotidianos insertos en el fluir continuo de un medio informativo, de entretenimiento y de reflexión. 


\subsection{El texto televisivo como continuidad}

El texto televisivo muestra la perspectiva de observación, las dimensiones y los contrastes en los acercamientos para explicar efectos, la estética y el funcionamiento como sistema estructurado. Las aproximaciones como circuito comunicativo han revelado la necesidad de contar con un mapa conceptual para diferenciar los diversos elementos de un proceso; momentos, fases y componentes permiten abordajes con objetivos específicos para el análisis: por ejemplo, la atención y la focalización a la fase de la ideación, la puesta en discurso y la recepción de los mensajes televisivos. Se establecen instancias en cada fase del circuito y se individúan usos, necesidades y formatos (Charaudeau 1997, Casetti \& Di Chio 2001, Lacalle 2003). Las instancias son parte componente de la red social; la red establece conexiones de signos. La televisión representa un espacio participativo, donde los signos circulan gracias a los continuos reenvíos y a las prácticas sociales. Una importante contribución reside en detallar su condición de instancias, lugares desarrollados y coexistentes en el mundo de la producción y el consumo televisivo. Cada instancia es el lugar de diversas tareas y capacidades: i) el funcionamiento de las condiciones de producción en la organización y realización de mensajes, ii) la construcción de los discursos en sus formas estructurales y al perfilar sus posibles efectos; iii) el lugar de la interpretación como tarea individual y social al mismo tiempo. Las tres instancias actúan de manera coordinada en la intencionalidad y en la construcción del sentido; garantizan el retorno de las imágenes de uno de los polos, la producción a su opuesto en la fase de interpretación (Charaudeau 1997: 16). La consecuencia facilita el reconocimiento de dos de sus componentes fundamentales: el "qué cosa" y el "cómo". El texto revela la conformación de sentido y la producción de efectos sociales en el trabajo de distinción de los enfoques, concibiéndose desde dentro y desde fuera. Es posible identificar figuras concretas y figuras abstractas presentes en las dicotomías del destinador y el destinatario, el autor implícito y el espectador implícito, el narrador y el narratario, pues en términos generales explican procesos similares en la emisión. El llamado pacto comunicativo es otro recurso emergente de la televisión pensada por Eco como resultado de su propio desarrollo: la neotelevisión (Casetti \& Di Chio 2001: 240-249).

El trayecto iniciado por Eco es una constante si se piensa en una semiótica descriptiva de un proceso comunicativo y como continuidad en el análisis de textos no circunscritos a un solo sistema. Determina paralelismos entre dos objetos de estudio utilizados como punto de partida para el análisis textual: el sistema semiótico literario y el semiótico televisivo. En ambos casos, las aproximaciones se delinean de acuerdo a la motivación para realizar el enfoque analítico y sus herramientas a utilizar. La dimensión del texto recortado del continuum varía de acuerdo al sistema y al efecto social identificado como objeto descriptivo y de análisis. Conceptos provenientes de la semiótica 
cognitiva involucran procesos de relación como la semiosis ilimitada (Eco 1984), las conceptualizaciones y la activación de esquemas cognitivos, type o tipos (Eco 1997), etc. La obra abierta literaria es fuente de procesos creativos en el resultado interpretativo,

Le opere letterarie ci invitano alla libertà dell'interpretazione, perché ci propongono un discorso dai molti piani di lettura e ci pongono di fronte alle ambiguità del linguaggio e della vita. (Eco 2002)

El relato concebido como máquina para generar interpretaciones (1979, 2002) realza la primera disparidad con el texto televisivo. El funcionamiento de la maquinaria interpretativa actúa de manera distinta. El texto literario existe en dos modalidades: abierto y cerrado, mientras que, en la semiosis del texto televisivo, en un consumo diverso, las posibilidades interpretativas componen un complejo abanico de opciones. María Pía Pozzato $(2004,2013)$ distingue a propósito la pertinencia de la semiótica en los estudios del texto en su formato literario y en el estudio de los medios emergentes; su atención a la televisión subraya las cercanías y las diferencias entre ambos. El resultado general $a$ posteriori ha sido una semiótica del texto de mayor envergadura, no circunscrita a un solo sistema semiótico, pues la mirada centró su atención en fenómenos propios del sistema televisivo: la toma en directa, la serialidad, la construcción de verdad, la presencia inmediata, los efectos de respuesta inmediata (Marrone 2018).

La distinción de perspectivas de observación del texto televisivo como objeto de estudio se agrupan según sus problemáticas: la dimensión macro o micro del texto; la duración de la emisión televisiva; el lenguaje específico en las tomas, encuadres, movimientos de cámara; la aplicación de una rejilla de análisis; la relación con la construcción ficcional de verosimilitud o el reflejo de algún tipo de verdad; los elementos paratextuales; la continuidad y la fragmentación; la fluidez de la programación y la elección del emisor (Pozzato 2004: 269-271). Otros problemas derivados del acercamiento al plano expresivo del sistema televisivo se localizan en aspectos técnicos de la estética televisiva en su propio lenguaje como la toma en directa (Carlón 2004: 19), la constitución de situaciones de recepción por franjas etarias, regionales y coyunturales (Lacalle 2013), la selección de los corpus y la accesibilidad de la televisión en su fase de producción (Carlón 2004: 83). La suma de los factores anteriores muestra la vitalidad prolongada de los trabajos iniciales del semiólogo italiano dirigidos a la televisión. La continuidad y la línea de coherencia hacen visible la delimitación de los corpus de análisis, su accesibilidad, sus efectos en los cuerpos sociales y en la diferenciación del consumo.

El texto televisivo desde la perspectiva equiana se evidencia en las tres instancias reconocidas en la comunicación mediática: la producción, la emisión y la recepción. Cada una destaca el comportamiento semiótico sobre el cual se 
observa un extenso abanico de posibilidades para vislumbrar una noción de texto ampliada, más allá de las limitaciones del ámbito televisivo. Los problemas de comunión metodológica desprendidos de la observación del texto literario han sufrido adecuaciones, que han demostrado en su propia identidad mediática las posibilidades de una semiótica mediática, una metodología semiótica de análisis para textos no estrictamente literarios y, sobre todo, una capacidad de la disciplina semiótica para enfrentar formas textuales emergentes en otros medios. El texto resultante se convierte en una noción ampliada, resultado del intento de extrapolar las principales contribuciones semióticas desarrolladas estratégicamente para aplicar la semiótica a un medio, y resalta una trayectoria de orden metodológico al poder extenderse a otros sistemas e incluso campos.

\subsection{Los individui fluttuanti o el personaje como recurso neonarrativo}

Un concepto apto para caracterizar por medio de un doble comportamiento mediático la extensión explicativa, descriptiva y demostrativa de una metodología de inspiración semiótica, se finca en la idea del personaje neonarrativo, a partir de su conformación como existente al interior de un relato. Por una parte, es necesario observar su construcción como elemento constitutivo de un relato y, por lo tanto, intrínseco a las formas narrativas; mientras que, por otro lado, precisa de distinguir su comportamiento en el marco de la narratividad transtextual. En ambos, las contribuciones de orden metodológico de Umberto Eco adquieren un rol protagónico, situando dicho personaje como un actor semiótico y como un zoon semiotikon.

El individuo fluctuante aparece en la obra del semiólogo italiano como concepto de abstracción literaria en un contexto específico. Una de las constantes en el autor es ofrecer de manera divulgativa ensayos con los cuales conocer los resultados de mayor relevancia de la teoría textual. La reflexión sobre el comportamiento de los personajes literarios obedece a dos necesidades de base: explicar la competencia hipertextual de los consumidores de relatos y la transcendencia histórica inmutable de los personajes literarios. Dos textos exploran variantes de un mismo concepto: Sulla letteratura (2002) y Confections of a Young Novelist (2011). La conexión debe partir de la premisa entre una necesaria relación de dependencia y de contraste entre la historia y la ficción, a través de una transmigración que cobra mayor pertinencia para el análisis en el plano de la expresión.

Un individuo fluctuante se encastra en las condiciones de estructuración textual y de interpretación en el comportamiento hipertextual al momento de la recepción. El desarrollo de un individuo fluctuante activa una serie de condiciones presentes en reflexión filosófica sobre la textualidad en la narrativa transmedia. Las condiciones de verdad, de conexión lógica entre mundos y la posible transmigración intersemiótica son realidades presentes 
en la orquestación de los medios. La condición fluctuante de un personaje exige la cooperación interpretativa del receptor, sin importar el tipo de acceso necesario, tal y como es requerido por el sistema semiótico vehículo del relato: lectura, escucha, audiovisualidad, interactividad. La pertinencia del personaje transtextual adquiere relevancia para poder explicar la relación entre ficción e historia a partir de su conformación como concepto aplicado al estudio de la obra literaria en su proyección hacia la transmigración. En consecuencia, la condición neonarrativa debe buscarse en el resultado de una semiosis textual: en la dimensión hipertextual de su recurrencia, el reconocimiento de los valores y la coherencia de sus formas expresivas en relación con los valores vehiculados.

\section{Bibliografía}

BERNOUSSI, Mohamed. 2017. Umberto Eco sémioticien et romancier. Paris : Éditions Mimésis Philosophie.

BERTETTI, Paolo. 1999. La semiotica: venticinque anni dopo. Turín: Edizioni dell'Orso.

2012. Il racconto audiovisivo. Teoríe e strumenti semiotici. Torino:

Cartman.

BUDASSI, Sonia. 2010. Apache. En busca de Carlos Tevez. Buenos Aires: Tamarisco.

CAPOZZI, Rocco. 1997. Reading Eco. An Anthology. Bloomington: Indiana University Press.

CARLON, Mario, 2004. Sobre lo televisivo. Buenos Aires: La Crujía.

CASETTI, Francesco \& DI CHIO, Federico. 2001. Analisi della televisione. Stumenti Bompiani, Milán: Bompiani.

COLLINI, Stefan.1995. “Interpretazione terminabile e internabile." En Eco, Umberto, Interpretazione e sovrainterpretazione. Milán: Bompiani.

CHARAUDEAU, Patrick. 1997. Le discours d'information médiatique. La construction du miroir social. París: NATHAN.

ECO, Umberto. 1962.Opera Aperta. Milán: Bompiani.

1964. Le poetiche di Joyce. Milán: Bompiani.

1979. Lector in fabula. Milán: Bompiani.

1979. Lector in fabula. (Trad. Esp. Lector in fábula. Barcelona: Lumen 1993) 
1984. Semiotica e filosofia del linguaggio. Turín: Einaudi.

[1992] 1995. Interpretazione e sovrainterpretazione. Milán Bompiani.

1993. La ricerca della lingua perfetta. Bari: Laterza.

1997. Kant e l’ornitorinco. Milán: Bompiani.

2002. Sulla letteratura, Milán: Bompiani.

2011. Confesiones de un joven novelista. México: Lumen, 2011.

2017. Victor Hugo y el vértigo de la narración. Antequera, España: Confluencias.

2018 Sulla televisione. Scritti 1956-2015. (A cura di Gianfranco Marrone), Milán: La nave di Teseo.

GARCÍA JIMÉNEZ, Jesús. 2003. Narrativa audiovisual. Madrid: Cátedra.

GRITTI, Jules. 1991. Umberto Eco. Paris: Editions Universitaires.

JAKOBSON, Roman. 1990. On Language. (Edited by Linda W. Wuagh and MoniqueMonville-Burston) Cambridge Mass, London: Harvard University Press.

LACALLE, Charo. 2003. El espectador televisivo. Barcelona: Paidós.

2013. Jóvenes y ficción televisiva. Barcelona: UOC (Universitat Oberta De Catalunya)

LORUSSO, Anna Maria. 2008. Umberto Eco, Temi, problema e percorsi semiotici. Roma: Carocci.

2010. Semiotica della cultura. Bari: Laterza.

PANSA, Francesca \& Vinci, Anna. 1990. Effetto Eco. Roma: Edizioni del Gallo.

PAOLUCCI, Claudio. 2007. Studi di semiotica interpretativa. Milán: Bompiani. 2016. Umberto Eco. Milán: Feltrinelli.

PELLEREY, Roberto; PISANTY, Valentina. 2004. Semiotica e interpretazione. Milán: Bompiani.

PISANTY, Valentina. 1993. Cómo se lee un cuento popular. Barcelona: Paidós.

POZZATO, Maria Pía. 2004. Semiotica del testo. Metodi, autori, esempi. Roma: Carocci. 
2013. Capire la semiotica. Roma Carocci, Studi Superiori.

SALVATORE SCHIFFER, Daniel.1998. Umberto Eco. Le Labyrinthe du Monde, Paris : Ramsay,

TRAINI, Stefano. [2006] 2014. Le due vie della semiotica. Teorie strutturali e interpretative. Milán: Bompiani. 


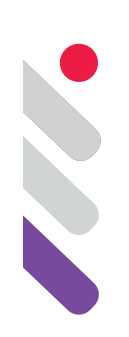

\title{
Luis Prieto. La recuperación de una teoría muy pertinente
}

DOI: 10.24308/IASS-2019-8-007

\author{
María Teresa Dalmasso \\ Universidad Nacional de Córdoba (Argentina) \\ maritedalmasso@gmail.com
}

1.

Al releer las lecciones de Prieto, en las que plantea que lo que él llama Semiología debe entenderse como una Teoría de la razón de ser del conocimiento de la realidad material, no podemos dejar de interrogarnos sobre la vigencia de un pensamiento que, dominante entre los años 60 y 70, permite orientar ciertas búsquedas en torno a creencias, valores y juegos de poder o, dicho en otras palabras, en torno a la dimensión ideológica que entreteje la trama discursiva propia de determinadas circunstancias socio-históricas.

En ese sentido, al revisitar la propuesta de Prieto, se desencadenan una serie de reflexiones, incentivadas por los desafíos que nos ofrece la complejidad discursiva en la que estamos inmersos en nuestros días. Si nos inquieta la presunción de que la discursividad imperante en los años que corren se caracteriza por cierta exaltación de la tensión constitutiva de la vida mental entre lo que Schaeffer (2009:289) ${ }^{1}$ denomina la visión de mundo y los saberes de la experiencia; y si queremos profundizar en las razones de lo que percibimos como una suerte de desequilibrio en la producción semiótica, provocado por el privilegio de una argumentación (cuando la hay) orientada más hacia la justificación de visiones de mundo o creencias que hacia la demostración de saberes de la experiencia, los conceptos fundamentales que sostienen la teoría

${ }^{1}$ Para Schaeffer (2009:286), el ideal del cristianismo en el sentido de que la visión de mundo funcione como un fundamento teórético de los saberes empíricos acarrearía las siguientes consecuencias: "no solo es responsable en parte de la virulencia de la crisis debida al desarrollo de las ciencias, sino que también es una causa de nuestra desorientación actual, porque dejamos de cultivar la función propia de las visiones del mundo, que no es la de competir con el campo de los saberes, sino dotarnos de una identidad individual y humana gracias a la cual nos resulta posible adaptarnos a lo que los saberes empíricos nos enseñan en relación con la realidad en la cual esa identidad se constituyó y terminará por deshacerse" 
la razón de ser del conocimiento de la realidad material devienen herramientas esenciales.

Llevados por este convencimiento, así como por la certeza de que dichos conceptos, y muy especialmente el de pertinencia, pueden articularse de manera fecunda con un marco conceptual de orientación sociosemiótica, nos proponemos recuperar sus ejes fundamentales.

Los conceptos nodales de la teoría, tales como los de pertinencia, sujeto, práctica y capacidad de decisión, no sólo facilitan la comprensión de las peculiaridades sociohistóricas de la producción semiótica, sino que habilitan articulaciones interdisciplinarias con saberes como la antropología, la biología, las ciencias cognitivas, entre otras (Schaeffer 2009:207), (Verón 2013:114-116).

2.

Umberto Eco, ya en el volumen número 60 de los Cahiers Ferdinand de Saussure $^{2}$ (2007:35-36) destaca la pertinencia o, más bien las pertinencias de los trabajos de Luis Prieto para las investigaciones contemporáneas. Justifica el uso del plural por tratarse de una obra multiforme que ahonda en diversidad de problemas y anticipa productivos enfoques.

Las rigurosas investigaciones de Prieto han tenido como objetivo explorar la realidad histórica constituida por el conocimiento de la realidad material y reflexionar sobre su razón de ser. La cientificidad de sus trabajos conlleva la construcción de un destinatario dotado de una disciplinada disposición hacia la lectura de encadenamientos argumentativos rigurosamente lógicos. Dicho destinatario debe estar munido de una competencia tal que le permita advertir que aquello que por momentos pueda aparecer como vicio de redundancia, no es más que la consecuencia necesaria de un afán del autor por formular definiciones precisas y coherentemente articuladas entre sí. De modo que su trabajo, centrado en problemáticas claramente delimitadas y enfocadas con intención científica, se vigoriza con una profundidad y solidez poco frecuentes. A este respecto, Eco (2007:37) destaca que Prieto ha demostrado, al menos en el caso de sistemas simples, la posibilidad de realizar una descripción científica exhaustiva, con métodos superadores de las simples exploraciones. Lo considera, por ello, el iniciador de lo que se denomina semióticas particulares.

En "Una semiología: problemas y resultados" (1993:22-31), Prieto, al definir la semiología que él ha desarrollado a lo largo de su obra como una Teoría de la razón de ser del conocimiento de la realidad material, se apresura a aclarar que no se trata de una teoría del conocimiento, sino que su objeto está constituido específicamente por la razón de ser del conocimiento $y$, más exactamente aún, por la razón de ser del conocimiento de la realidad

\footnotetext{
${ }^{2}$ Los contenidos de este volumen surgen del encuentro convocado por el décimo aniversario del fallecimiento de Luis Prieto.
} 
material. Planteada de este modo la definición del objeto de la teoría, se pone de manifiesto que, en el enfoque de los fenómenos cognitivos, la dimensión social cumple una función dominante. Esta toma de posición se ofrece como testimonio de su inscripción en un proyecto que, en contacto con la teoría de la ideología, confía en las posibilidades de objetividad de un estudio que, inspirado en el modelo lingüístico-estructural (particularmente el proporcionado por la fonología), permita dar cuenta de la dimensión ideológica inherente a toda forma de conocimiento. En ese sentido, aunque su modalidad de trabajo lo llevaba a profundizar de manera autónoma en la exploración de los temas tal como él lo subrayaba con la intención de demarcarse metodológicamente de investigadores contemporáneos, en especial europeos continentales-, su pensamiento conductor no se sustraía a las corrientes que impregnaban el campo de las ciencias sociales y humanas de la época. Concomitantemente -lo que nos permite captar aspectos esenciales de su posicionamiento científico-, Prieto estaba persuadido de que las ciencias del hombre no podían menos que conducir a una concientización política. Tal convicción constituía uno de los fundamentos de su concienzuda búsqueda.

Como correlato de esta concepción respecto del objeto de su teoría semiológica, el núcleo duro de la misma está constituido por la noción de pertinencia. Este concepto, caro a la fonología, presupone la capacidad de decisión del hombre, puesto que la pertinencia de un conocimiento se desprende de la relación entre ese conocimiento y el sujeto que lo construye y lo utiliza en el contexto de una práctica. Una concepción tal permite presuponer una dimensión ética en el proceso mismo de construcción del conocimiento.

3.

Por su parte, Umberto Eco (2007:35), además de destacar la relevancia y productividad de los aportes teóricos de Prieto, a los que califica de pioneros, le asigna un papel decisivo al concepto de pertinencia ${ }^{3}$. El propio Prieto, en el marco de su teoría, subraya la centralidad de esta noción a la hora de comprender por qué el hombre, según las particulares condiciones sociohistóricas en que está inserto, conoce el mundo de determinada manera. De esto se desprende que uno de los aspectos sustanciales de su propuesta teórica consiste en considerar que la validez de un conocimiento de la realidad material depende, fundamentalmente, de su pertinencia. Ahora bien, como esta pertinencia puede ser definida como la relación entre el conocimiento y el sujeto que lo construye y utiliza, propone caracterizar más precisamente a la semiología como "el estudio de los conocimientos de la realidad material

${ }^{3}$ Entre las virtudes que Eco (2007:35-36) atribuye a la noción de pertinencia postulada por Prieto, destaca su capacidad de limitar los deconstructivismos experimentales. 
que toma en cuenta al sujeto y que los considera por consiguiente en lo que implican de histórico-social." (Prieto 1993:22).

Como se puede apreciar, la inclusión del sujeto se funda en que la pertinencia de un conocimiento, y por ende la pertinencia de las estructuras semióticas que lo manifiestan, está supeditada a los intereses histórica y socialmente condicionados del sujeto ${ }^{4}$. Es decir que, según Prieto (1975:143165 ), la identidad bajo la cual un sujeto conoce un objeto material no encuentra su fundamento en el objeto mismo, sino que depende de la manera en que lo concibe. Por tanto, la identidad bajo la cual un sujeto conoce un objeto material y la manera en que lo concibe son siempre significativas, puesto que a través de ellas se palpa la dimensión ideológica ${ }^{5}$ de todo conocimiento. Una formulación semejante lo induce a diferenciar significatividad del conocimiento, de la semantización (Prieto 1975:147). Así es que, mientras que el primer término hace referencia al hecho de que las maneras de entender la realidad material no devienen significativas, sino que lo son en su misma gestación, el alcance del segundo aparece claramente explicitado por Barthes (1974:34) cuando sostiene que "por el hecho de que existe sociedad, cualquier uso se convierte en signo de este uso". Se trataría, entonces, de dos momentos diferenciados, de dos instancias en el proceso de la semiosis.

Prieto, por otra parte, le asigna un papel decisivo a la praxis en la definición de la pertinencia. Esto es así porque, como toda praxis implica el conocimiento de la realidad sobre la cual se ejerce, conocimiento y praxis son inseparables (1975:151-152). Ahora bien, la noción de conocimiento pertinente determinado por la praxis ${ }^{6}$, que presupone la existencia de conocimientos parciales del objeto ${ }^{7}$, cada uno de los cuales puede reclamarse legítimamente como verdadero ${ }^{8}$, lleva a Emanuele Fadda (2001:392-395) a reflexionar sobre posibles puntos de contacto entre los pensamientos de Prieto y de Peirce.

\footnotetext{
4 Idea que puede ser puesta en relación con la noción de objeto inmediato postulada por Peirce. 5 La definición de "ideología" formulada por Prieto (1975:160) supone, de algún modo, cierta relación con la noción de manipulación: "Llamaremos 'ideología' a todo discurso referido a un conocimiento de la realidad material que se orienta a 'naturalizar' ese conocimiento, es decir a explicarlo o a hacerlo aparecer como consecuencia necesaria de lo que su objeto es."

6 "(...) toda praxis implica el conocimiento de la realidad sobre la que se ejerce, conocimiento y praxis son inseparables y, en consecuencia, así como se dice que las ciencias del hombre tienen por objeto las diversas maneras de conocer la realidad material, se puede decir que ellas tienen por objeto las diversas formas de praxis ejercida sobre la realidad material" (Prieto 1975:151-152) [La traducción es nuestra]

7 "Un objeto material es (...) susceptible de ser conocido bajo un número indefinido de identidades, es decir de recibir un número indefinido de 'determinaciones'. La síntesis de todas las identidades bajo las cuales es posible conocerlo nos proporciona sólo otra identidad de la que no se podrá afirmar en ningún caso que constituye su identidad absoluta y que nos da acceso a eso que el objeto es 'en sí mismo'” Prieto (1975:154) [La traducción es nuestra]

${ }^{8}$ Un conocimiento parcial no es necesariamente ni pertinente ni verdadero; tampoco lo contrario.
} 
Esto es así porque la variedad de puntos de vista desde los cuales se puede conocer el objeto según las prácticas sugiere, tal como plantea Fadda, una cierta proximidad con la noción de semiosis ilimitada del semiólogo norteamericano. Sin embargo, como también lo señala este autor, no se puede soslayar que para Prieto (1991:193, 2018:146 y ss), toda práctica se asocia a una norma que circunscribe una comunidad de sujetos ${ }^{9}$ y que, en el marco de su concepción teórica, la dimensión social reviste un carácter más operativo que en Peirce.

Cabe señalar que la noción de pertinencia manifiesta toda su potencialidad al ahondar en la dimensión ideológica de los discursos (Prieto 1975:145). Ahora bien, si se considera, en primer lugar, que "El punto de vista del que resulta la pertinencia de la manera en que se concibe un objeto es siempre aportado por un sujeto que forma parte de un grupo social" $y$, en segundo término, que en los grupos sociales -siguiendo a Bourdieu y Passeron- opera un poder simbólico que confiere cierta legitimidad a determinados puntos de vista (Prieto 1975:148,149), sólo se puede concluir que no hay conocimiento de la realidad material que sea objetivo, puesto que nunca puede ser socialmente neutro. En consecuencia, todo conocimiento es ideológico, en particular el conocimiento naturalizado de la realidad material, es decir que se pretende impuesto por el objeto mismo (Prieto 1975:159).

\section{4.}

En el marco de la Teoría de la razón de ser del conocimiento de la realidad material, resulta imposible disociar las nociones de pertinencia, sujeto, práctica y capacidad de decisión, cuya articulación conduce a Prieto al desarrollo de una verdadera teoría del sujeto.

Un ejemplo de esta indisoluble asociación lo representa el hecho de que el punto de vista del que resulta la pertinencia de la manera en que se concibe un objeto es siempre aportada por un sujeto ${ }^{10}$ (siempre social). De allí, el papel fundamental que la capacidad de decisión propia del hombre cumple en la producción de conocimiento o, dicho, en otros términos, en la construcción de lo real. Por consiguiente, es esa capacidad de decisión la que hace posible la existencia de una historia distinta de la historia natural. Historia de cuya configuración -de acuerdo a una lectura que deja abierta el planteo del

\footnotetext{
${ }^{9}$ Prieto define norma como un conjunto de comportamientos que dos o más sujetos distinguen, sin ninguna relación con el instinto, de otros comportamientos igualmente eficaces para alcanzar los mismos fines y que los sujetos en cuestión eligen antes que otros comportamientos para alcanzar tales fines. (Prieto 1991: 191 ss.) y operante como el conjunto de medios eficaces para alcanzar un fin (Prieto 1991:192 ss.) (ver Fadda (2001:393). Ahora bien, cabe aclarar que cada sujeto pertenece a una serie de comunidades, cada una de ellas corresponde a una norma adoptada en cada práctica Fadda (2007:73-84).

10 En "Discurso y Sujeto" (Prieto, 2018:131) define un sujeto como "(...) un fragmento de la realidad material -el cuerpo del sujeto- que tiene conciencia de su identidad numérica, es decir que se reconoce a sí mismo como uno (...)". [La traducción es nuestra]
} 
autor- no estaría ausente la dimensión ética y, podríamos atrevernos a decir, tampoco la estética. Cabe aclarar, no obstante, que Prieto (2018:149-150) se refiere explícitamente a la dimensión estética al abordar la problemática de la obra de arte. Al hacerlo, la describe como producto de un proceso mediante el cual, una vez internalizada la norma de la comunidad en la que se integra el sujeto y satisfecha así la necesidad de encontrar un otro simétrico, ese sujeto, en el marco de esa norma, realiza autónomamente distinciones y elecciones, que expresan su gusto.

Esta explicación refiere a lo que, según hemos visto, se consideraría un segundo momento en el proceso de producción social del sentido. Recordemos que, en el marco de la teoría, se podían distinguir dos instancias, una correspondiente al plano de lo que ha denominado la significatividad y que refiere a la etapa de constitución de la norma -parafraseando a Kristeva (1972:66), podríamos decir que atañe al proceso de producción de sentido anterior al sentido-, y un segundo momento, el de la integración a la norma ya constituida. Es en este último nivel donde lo estético se manifiesta como un fenómeno del orden de la connotación.

Sintetizando el razonamiento de Prieto, mediante el cual articula los cuatro conceptos nodales a los que acabamos de hacer referencia, podemos decir que la razón de ser de todo conocimiento cuyo objeto forma parte de la realidad material reside en una práctica; que una práctica es siempre la práctica de un sujeto y que un sujeto sólo es tal en la medida en que está en condiciones de ejercer prácticas. Todo este proceso se hace posible gracias a "la facultad de decisión de que está dotado el ser humano, que le permite evadirse de la causalidad natural y convertirse así en el productor de la historia". (1993:30).

En este punto, es importante destacar el papel decisivo que Prieto asigna a la dimensión biológica respecto de la facultad de decisión, ya que esta última sería una consecuencia de su sistema nervioso. En ese sentido concluye: "el hombre, puede decirse, está biológicamente 'programado' para ser capaz de producir una realidad que no obedece a la 'programación' biológica”"11. (1993:31). Esta afirmación, que permite el ingreso a una zona de discusión de candente actualidad y que toca, en algún aspecto, el debate entre antropocentrismo y no antropocentrismo (Schaeffer 2009), (Carlón 2016), abre un terreno importante de reflexión y reclama la ampliación de una interacción disciplinar que excede las ciencias sociales y humanas.

11 Fadda, E. (1991) "Le lieu théorique de la sémiologie de L. Prieto". In Cahiers Ferdinand de Saussure, v.54, 393 "A decir verdad, (...) Prieto (...) no niega a priori la existencia de una consciencia cuasi-subjetiva en los animales superiores". [La traducción es nuestra] 
5.

Tal como lo hemos venido planteando, la Teoría de la Razón de Ser del conocimiento de la Realidad Material sostiene que los conocimientos que el hombre construye sobre la realidad material conforman una realidad segunda e histórica. Esta realidad histórica constituida por los conocimientos de la realidad material deviene el objeto de las distintas ciencias del hombre. Dicho en términos de Prieto, el objeto de estudio de las ciencias del hombre son las estructuras semióticas que otorgan sentido a esa realidad. (Prieto 1975:149-165). Esto lo obliga a advertir que una semiología que estudie todas las estructuras semióticas, cualquiera que sea su función, corre el riesgo de confundirse con las ciencias del hombre en su conjunto.

Dejando abierto el problema, concluye que lo esencial es que "semiología o ciencia del hombre, el estudio de las estructuras semióticas no es el estudio de los conocimientos in abstracto, sino de los conocimientos reales que grupos humanos han construido y de los que se sirven y, al mismo tiempo, de las formas que ha tomado la praxis de los hombres (...)" (1975:11-2).

Como ya lo hemos señalado, su propósito de desarrollar una aproximación objetiva de los fenómenos semióticos es desplegado con originalidad y una lógica impecable. Coincidente con el proyecto althusseriano y con el apoyo del modelo científico de la lingüística, en particular de la fonología, Prieto sostiene la posibilidad de las ciencias del hombre de dar cuenta objetivamente ${ }^{12}$ de los conocimientos histórico-sociales sobre la realidad material. Concibe la semiología como una suerte de epistemología de un conocimiento no científico de la realidad material y, al mismo tiempo como su propia epistemología $(1975: 157)^{13}$. Fundamenta su posición en el hecho de que, a diferencia del objeto material, que puede ser conocido bajo un número indefinido de identidades, el objeto de las ciencias del hombre, que es un objeto de pensamiento, un concepto, es finito ${ }^{14}$. Es decir que, como en el caso del fonema, presenta un número definido de características, que pueden ser reconocidas en su totalidad (1975:154).

\footnotetext{
12 Prieto sostiene que “(...) las ciencias del hombre, a diferencia de las ciencias de la naturaleza, pueden ser objetivas, en el sentido de que pueden reflejar su objeto tal como es, y "neutras" también, porque el sujeto no aporta ningún componente a la construcción del conocimiento que las constituye" Prieto (1975:157). Respecto de qué puede considererse un conocimiento científico, aclara que, al menos, se lo puede identificar por su capacidad de explicitar los conceptos con los que opera. (1975:150, nota 8).

${ }_{13}$ Prieto, L. Pertinence et pratique (1975:157, nota 18). “La epistemología de una epistemología se confunde con ella. Una ciencia del hombre, al ser de cierto modo la epistemología de un conocimiento no científico de la realidad material, es al mismo tiempo su propia epistemología" [La traducción es nuestra].

14 Prieto, L. Pertinence et pratique (1975:155). "No hay en el concepto nada que no sea pertinente. Como esa pertinencia es producto de la actividad humana, es necesariamente finita". [La traducción es nuestra].
} 
Prieto (1975:157-161) previene posibles objeciones aclarando que si bien las ciencias del hombre no se encuentran a resguardo de las pasiones sociales y que, por el contrario, frecuentemente están en medio de ellas, en razón de las características de su objeto, esta situación no pone en riesgo su objetividad (1975:164).

Una de las cualidades más relevantes que este semiólogo atribuye a las ciencias del hombre es su capacidad de praxis transformadora (1975:164-165). Característica que se pondría en evidencia cuando parte de los miembros de una sociedad se rebelan contra la supuesta pertinencia de un conocimiento de la realidad material, impuesto por los intereses de un sector de esa misma sociedad. Propone como ejemplo de esta aptitud el trabajo llevado a cabo por Karl Marx en El Capital. Esta facultad transformadora de las ciencias del hombre (Prieto 1975:162) obedecería a su posibilidad de analizar un conocimiento de la realidad material desde el objeto mismo (o sea desde el conocimiento de la realidad material que examina) y prescindiendo de un punto de vista.

6.

Estas consideraciones de Prieto respecto de que el contexto sociohistórico que incide sobre el conocimiento de la realidad material, con sus luchas políticas y sociales, no perturbaría la objetividad de las ciencias del hombre (Prieto 1975:161-162) resultan, desde una mirada actual, al menos, controvertibles.

El paradigma estructuralista, plasmado en la lingüística, en virtud de su fuerte formalización, permitía proyectar unas ciencias del hombre impermeables a lo ideológico. Como contraparte y según lo observaba Barthes (1974:11), un procedimiento semejante se arriesgaba a cierta banalización de los resultados. Hipótesis que Prieto se afanaba en invalidar mediante una rigurosa fundamentación de sus propuestas.

En contraste, en el estado actual del arte y no sin fundado criterio, domina una tendencia a eludir las formalizaciones estrictas, así como a desestimar, en términos generales, las pretensiones de objetividad. En este contexto y en alguna medida, los análisis corren el riesgo de tornarse más vulnerables a la interferencia de la opinión y a los deslizamientos genéricos. Puede entenderse este movimiento como una aspiración del discurso del saber a no renunciar a su propia historicidad. Sin embargo, si se descuida mencionar el lugar desde el que se toma la palabra -el punto de vista, en términos de Prieto (1975:158)- podría presumirse una débil voluntad de asumir la dimensión ideológica del propio discurso especializado (Verón 1997:11-37).

Esta somera e insuficientemente fundamentada referencia a ciertas transformaciones operadas en el campo de lo que Prieto denominaba ciencias del hombre, nos lleva a pensar en la oportunidad de hacer un alto en el camino, examinar con mirada crítica el itinerario trazado por la semiótica, y analizar el 
punto en que estamos a fin de poder proyectar las continuidades y los avances posibles. Todo ello, en primer lugar, sobre la base de la recuperación y/o reelaboración de los aportes disciplinares aún vigentes y productivos, así como de la apertura a una interacción más amplia con saberes de otros campos. En segundo lugar, mediante la inmersión en el estudio de los procesos actuales de construcción de lo real, condicionados socio-históricamente y facilitados por los dispositivos dominantes en la complejidad discursiva de nuestros tiempos.

El propósito de este congreso sobre "Trayectorias", en uno de sus sentidos, es rescatar los hitos que han ido jalonando el devenir disciplinar. Sin embargo, la finalidad de este recorrido no puede agotarse en un mero ejercicio descriptivo, sino que, a fin de asegurar su fecundidad, se debe a la tarea de examinar con mirada crítica las derivas, las continuidades y los desvíos, pero sobre todo los avances. De allí la importancia de recuperar aquellos pasos que han ido contribuyendo a la consolidación de las bases teóricas y metodológicas, así como de sus fundamentos epistemológicos. Es en este marco que se impone el rescate de saberes tan sólidos como la Teoría de la razón de ser del conocimiento de la realidad material que nos legara el semiólogo argentino Luis Prieto.

\section{Bibliografía citada}

ANGENOT, Marc. (1989) 1889. Un État du discours social, Québec, Éditions du Préambule.

BARTHES, Roland. 1974. "Presentación", en La Semiología (AAVV), 11-14, Buenos Aires, Editorial Tiempo contemporáneo.

CARLÓN, Mario. 2016. Después del fin, Buenos Aires, La Crujía Ediciones.

ECO, Umberto. 2007. "La pertinence de Luis Prieto". In Cahiers Ferdinand de Saussure, v. 60, 35-40, Genève, Librairie Droz S.A.

FADDA, Emanuele. 2001. “Le lieu théorique de la sémiologie de L. J. Prieto. Note sur la présence de Saussure dans la sémiologie actuelle". In Cahiers Ferdinand de Saussure, v. 54, 385-404, Genève, Librairie Droz S.A.

FADDA, Emanuele. 2007. “L'identité symbolique. Notes sur le sujet de la sémiose chez Prieto". In Cahiers Ferdinand de Saussure, v. 60, 73-84, Genève, Librairie Droz S.A.,

KRISTEVA, Julia. 1972. "La semiótica, ciencia crítica y/o crítica de la ciencia". In Semiótica y Praxis, AA.VV., 51-70. La Habana: Casa de las Américas.

PRIETO, Luis. 1975. Pertinence et pratique. Essai de sémiologie. Paris: Les Éditions de Minuit. 
PRIETO, Luis. 1991. Saggi di semiotica, vol. II, Sull'arte e sul soggetto. Parma: Pratiche.

PRIETO, Luis. 1993. "Una semiología: problemas y resultados”. In Revista Estudios, $n^{\circ}$ 2, 22-31. Córdoba: Centro de Estudios Avanzados, Universidad Nacional de Córdoba.

PRIETO, Luis. 2018. “Decisione e soggetto". In Prieto, L., L'Atto di comunicazione, A cura di Paolo Fabbri e Ugo M. Olivieri, 121-152. Milano-Udine: Mimesis Edizioni SRL

SCHAEFFER, Jean-Marie. 2009. El fin de la excepción humana. Buenos Aires: Fondo de Cultura Económica de Argentina.

VERÓN, Eliseo. 2013. La semiosis social 2. Ideas, momentos, interpretantes. Buenos Aires: Editorial Paidós

VERÓN, Eliseo. 1997. "Semiosis de lo ideológico y el poder". In Cursos y conferencias, 11-37. Buenos Aires: Oficina de publicaciones del CBC, Universidad de Buenos Aires. 


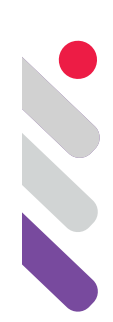

\title{
Epistemología para una semiótica del espacio: Cesar Jannello
}

DOI: 10.24308/IASS-2019-8-008

\author{
Lucrecia Escudero Chauvel \\ UNR CIM - LAPRECO - EHESS CERMA MOAM \\ lescuderochauvel@gmail.com; \\ lucrecia.escudero@ehess.fr
}

\section{Introducción}

César Jannello (Buenos Aires, 1918 - Buenos Aires, 1985) fue un arquitecto y diseñador argentino de vanguardia. Como profesor de la Cátedra de Sistemas Visuales I, II y III en la Facultad de Arquitectura, Diseño y Urbanismo de la Universidad de Buenos Aires (FADU-UBA) desarrolló una intensa y dedicada carrera de profesor en la práctica del diseño puro y aplicado y fue declarado Profesor Emérito luego de veinticinco años de enseñanza. Durante los años Sesenta del siglo XX, impulsado por el pensamiento estructuralista, crea la primera Cátedra de Semiología Arquitectónica de la Universidad de Buenos Aires inaugurando la metáfora de "la arquitectura como lenguaje". Su obra más famosa es la Silla $W$, diseñada a partir de los recursos básicos disponibles en el momento, una sola barra de acero plegada conforma la estructura sobre la que se sujetan el respaldo y asiento, ambos de madera, anticipándose al minimalismo. La silla sería utilizada por Le_Corbusier para amueblar la Casa Curuchet en La Plata. Influenciado por la Semiotica formal de Louis Hjelmslev y por la Semiotica plástica y figurativa de A.J. Greimas, produce la Teoria de la Delimitación Espacial (TDE) que él entendía como una poética del espacio. Presenta en 1979 la TDE en el Seminario del profesor A.J. Greimas en la Ecole des Hautes Etudes en Ciencias Sociales (EHESS) en París. De este período data su relación epistolar con el semiólogo francés, que se continuó hasta la muerte del arquitecto en 1985.

Desde los sesenta Jannello centra su reflexión sobre las relaciones entre Estética, Semiotica y diseño y profundiza en temas fundamentales de visión como color, textura, brillo y "cesia", un neologismo para explicar la combinación de estos elementos. En 1983 la TDE fue presentada en la X Conferencia de 
Escuelas y Facultades de América Latina en la Universidad de Sao Paulo, Brasil y en 1984 poco tiempo antes de morir, la Facultad de Arquitectura y Diseño de la Universidad Nacional Autónoma de México le otorga como reconocimiento, la Catedra Federico Mariscal ${ }^{1}$. El doctor Arquitecto y profesor Claudio Guerri revisa, en su programa de investigación Semiótica del Espacio - Teoría del Diseño, los postulados de Jannello proponiendo la ampliación de su teoría de la Delimitación Espacial (Guerri 2012).
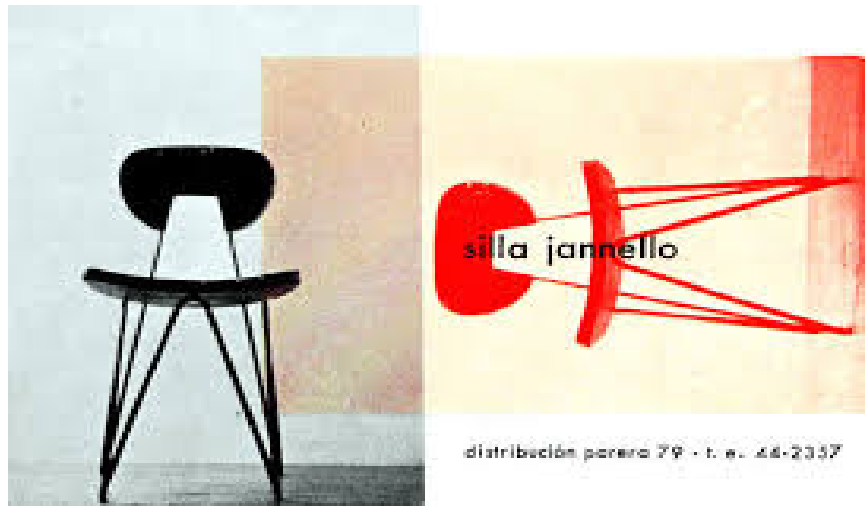

Figura 1 Silla Janello

\section{Recorridos y trayectorias}

La influencia de la teoría estructuralista de base lingüística se desarrolló en la Argentina en el ámbito del Diseño y de la Arquitectura a partir de la obra y la reflexión teórica del Arquitecto Cesar Jannello (Sebeok, T.-Umiker Sebeok, J 1988: 389-419). Es conocido el peso decisivo de la obra de A.J. Greimas -particularmente su Semántica Estructural publicada por Gredos en español en 1966 - en la constitución del paradigma generativo de la Semiótica latinoamericana, Janello se escribía regularmente con el semiótico francés, haciéndole partícipe de sus hipótesis y descubrimientos, pero la influencia mayor

\footnotetext{
${ }^{1}$ Durante el primer trimestre de 1984 en la Escuela de Postgrado Facultad de Arquitectura y Diseño de la UNAM el Arquitecto German Carvajal y la autora, representando al arquitecto, presentamos los resultados de los trabajos de las diferentes cátedras Sistemas Visuales I,II y III. Ese mismo año Jannello presentó la TDE en el III Congreso de la AIS/IASS en Palermo. Fue su última presentación en público. Janello dejo poca obra publicada, pero cientos de fichas manuscritas. El archivo con los manuscritos de Janello, cuya primera clasificación y ordenamiento lo realizamos con Carvajal en 1986, se pueden consultar actualmente en la Fundación IDA (www.fundacionida.org). Posteriormente Carvajal recopilo parte de sus escritos y los edito en un volumen que requirió un notable trabajo de curaduría con la colaboración de la Arquitecta María Graciela Brugnoli y los diseños del Arquitecto Rubén Gramon y José Luis Caivano, todos integrantes del equipo de las cátedras Sistemas Visuales I,II y III y financiado por la generosidad de su viuda, Monique Jannello, la Graham Foundation for Advances Studies in the Arts (Chicago, USA) y el Fondo Nacional de las Artes, auspiciado por la Academia Nacional de Bellas Artes de la República Argentina dirigida entonces por Rosa María Ravera (Carvajal 2005). Para una reseña bio-bibliográfica, así como la influencia del pensamiento de Jannello en Argentina y en América Latina cfr. Guerri (Guerri 1988:389-419).
} 
en la constitución de una Semiótica del espacio en general y de una Teoría del diseño en particular fueron el fonólogo Nicolai Trubetzkoy, el lingüista Román Jakobson y el semiólogo danés Louis Hjelmslev. La búsqueda teórica de Janello era la de un puro formalista.

Como en toda elaboración de hipótesis, la investigación de Jannello fue transformándose hacia posiciones cada vez más complejas y abarcativas, a medida que se iba dando cuenta que la construcción de una Semiótica del espacio excedía el marco de la arquitectura en tanto espacio construido, para acercarse a problemas epistemológicos, de estética o de filosofía, como los que representan la constitución de una poética del espacio donde la influencia de Jakobson es notoria, de la estética en la lectura que hace del semiólogo italiano Emilio Garroni (deSigniS n¹1 2005) o en la célebre partición del plano de la expresión y plano del contenido que realiza Hjelmslev para delimitar una función semiótica. En todo caso su reflexión iba deslizándose hacia una preocupación epistemológica mayor: cuales son los aspectos perceptivos que se encuentran a la base de los procesos de asignación de sentido del espacio circundante.

La originalidad de esta reflexión lo colocan en un punto de origen - las semióticas del espacio de naturaleza formal y estructural - pero también de inflexión para proyectarlo hacia la fundación de un campo teórico más abarcativo y completamente inédito para la época, como es el de tratar de responder a los criterios desde donde pensar el espacio como una operación cognitiva. Jannello se dio cuenta al final de su recorrido académico, que el verdadero problema de una Semiótica espacial es no solo un problema de segmentación - y por ende de descripción-, ni siquiera un problema de producción - las técnicas de diseño - sino sobre todo un problema cognitivo: que procesos de percepción, memoria y selección estética, se encuentran en esa particular actividad humana que la cultura ha designado como la proyección espacial².

Jannello funda una Semiótica General específica del espacio, que pone las categorías generales desde donde pensar el sentido del espacio como producto cultural; el espacio, a diferencia de Greimas, no es una Semiótica del mundo natural. Dice el semiólogo francés: "L'objet-espace s'identifie alors en partie avec celui de la sémiotique du monde naturel (qui traite non seulement les significations du monde, mais aussi de celles qui se rapportent aux comportements somatiques de l'homme) (Greimas, A. J.- Courtés, J 1979 :133). Jannello concibe al espacio como formando parte de una Semiótica general, de la que los proyectos de diseño serían sus semióticas aplicadas; crea una semiótica que presupone una serie de categorías generales desde donde pensar al espacio y compararlo con otros dominios de la cultura humana, como propios de la práctica social humana. En ese sentido su preocupación es "lo Espacial” de

${ }^{2}$ El arquitecto Claudio Guerri desarrollará luego un modelo de producción sígnica que recoge estas dimensiones basándose en el modelo de Charles S. Peirce (Guerri 2014). 
allí el nombre de su teoría: Teoría de la Delimitación Espacial. Si la(s) poesías son a la Poética lo que lo(s) diseño(s) a una teoría de la espacialidad, su trayectoria teórica se desliza hacia posiciones cada vez más abstractas y sofisticadas de conceptualización sobre desde donde analizar lo espacial.

El arquitecto muere viendo delante suyo un proyecto, del cual deja sólidamente asentado su base, de una poética del espacio como una Semiotica independiente de una semiótica de las lenguas naturales y formula las hipótesis y las condiciones bajo las cuales se podrán afrontar fenómenos discontinuos desde una perspectiva unitaria (Escudero Chauvel 1985:20-21).

Quisiera presentar someramente aquí la forma en que Jannello encaró el problema teórico de la constitución de una Semiótica del espacio y los puntos de convergencia y divergencia con las semióticas del mundo natural.

\section{La metáfora de la arquitectura como lenguaje y el proyecto de diseño}

La paradoja de la teoría de Janello es que, partiendo de la metáfora de la "Arquitectura como lenguaje" se va alejando de esta concepción tan desarrollada en las décadas 60 y 70 del siglo pasado que presuponía la ida de la arquitectura como un lenguaje compuesto por unidades formales articulables en diferentes secuencias que el semiólogo podía "leer", para adentrarse en una problemática también estructuralista pero de matriz fonológica, que pondrá el acento en aquellas operaciones necesarias para volver distintivo un espacio percibido como discontinuo.

Se trata entonces de un problema de índole cognitivo, el de la segmentación espacial resultado de una operación de naturaleza formal-como en la segmentación fonológica - que proyecta el eje de lo discreto y discontinuo sobre la aparente discontinuidad especial y las operaciones paradigmáticas de proyección, el paradigma táctico. Y en este sentido Jannello encontrará su espacio teórico inicial en las clásicas oposiciones estructuralistas de selección y combinación.

Sin embargo, la metáfora de la Arquitectura como lenguaje y de su lectura "textual" permitió la emergencia de una operación interpretativa que no resulta desdeñable: la del proyecto de diseño - como una instancia de mediación - como una primera instrucción de lectura, es decir, como un soporte donde un recorrido interpretativo - o varios - son posibles. En la reflexión de Janello es el proyecto de diseño el lugar primario de la segmentación espacial y el objeto diseñado el resultado de una elección especifica entre un conjunto de operaciones posibles.

El proyecto de diseño es entonces un a priori, un pre- texto, una representación intermediaria y no una intervención directa sobre el espacio (Jannello 1980).

La Arquitectura sería una práctica de producción de objetos que permite 
a su vez un primer itinerario perceptual, donde el problema no residiría tanto en la pura visibilidad exterior -la búsqueda de los "signos" visuales- adscribible a una teoría de los motivos y los estilos arquitectónicos, cuanto a ese primer dispositivo de producción de sentido que es la operación de la delimitación espacial. Arquitectura entonces como objeto de lectura cultural que permite a su vez colocar el acento en un conjunto de prácticas socio-simbólicas que afectan a un sujeto (Escudero Chauvel 1983: 63-69).

Es en esta perspectiva que los recorridos greimasianos y el de las hipótesis de Jannello se tocan en ese lugar neurálgico que es la puesta en valor de ciertos recorridos cognitivos - ver, tocar, recorrer- a los que la teoría acordara un lugar fundamental. Para inmediatamente diferenciarse de las semióticas del mundo natural: Janello consideraba que la constitución de una semiótica de la Arquitectura, o del "hecho" arquitectural, sería un objeto teórico a posteriori, una semiótica específica, el resultado de un sincretismo de semióticas aplicadas diferenciadas. Pero que su teoría debería ocuparse de aquellos sistemas como los sistemas de color, de textura, de brillo - las cesias -, sistemas considerados como suprasegmentales pero que se volverán una parte composicional en su reflexión epistemológica (Janello [1961] 1973:394-396).

\section{Semiótica del Espacio y semióticas de la Arquitectura}

¿Es posible una Semiótica del Espacio de naturaleza general y bajo qué condiciones? se preguntaba el arquitecto. La respuesta que daba el Diccionario de Semiótica coloca a la voz Espacio, como constituyente de las semióticas del mundo natural. Para los autores, espacio es la materia en que se manifiestan todos los objetos del mundo natural y, por lo tanto, en cuanto espacio significante, es un espacio semiótico (Greimas, A.J.-Courtés, J 1979:132-134). Es indudable el adelanto que ha significado en el estudio de los sistemas visuales la introducción del concepto en ámbito greimasiano, de semi-simbólico y semisimbolismo. Enunciado como una respuesta a la teoría de Louis Hjelmslev sobre las semióticas mono-planares, la noción de semi- simbolismo presupone la idea de un significante plástico constitutivo de una semiótica mono- plana (Greimas, A.J 1984).

Es decir, si lo que está en juego no es más el isomorfismo - conformidadentre los planos sino la correlación entre las categorías, la perspectiva "relacional" y no meramente lexical es la que adquiere vigencia.

Jannello opone un punto de vista original: retiene de la perspectiva hjelmsleviana la caracterización de una semiótica -objeto como un sistema de jerarquías, pero articula su teoría en función de dimensiones que organizaran los grandes recorridos topológicos del proyecto de diseño. Aun aceptando que el espacio es objeto de una semiótica del mundo natural, es el recorte que efectúa el diseño lo que lo vuelve pertinente y perceptible.

El sistema de la Arquitectura-o el dispositivo arquitectural, en los términos 
greimasianos - es para Jannello la resultante de las prácticas sociales que se han institucionalizado como segmentadoras de ese espacio y cuya representación primaria es el proyecto de diseño. Janello rápidamente deslindó el problema de la Arquitectura como existente construido históricamente, de la actividad proyectual $^{3}$

Una Semiótica del Espacio es de naturaleza diferente de una semiótica de la Arquitectura: es posible distinguir entre el nivel de la obra arquitectónica en cuanto existente histórico y un tipo especial de objeto, el proyecto de diseño, cuyo estatuto teórico, formas de codificación y producción es posible describir y prever como lugar privilegiado de enunciación de una legislación espacial intrínseca y pre- existente.

La reflexión de Jannello encuentra su lugar teórico en este ámbito, el del diseño como un conjunto ordenado de representaciones. En esta jerarquía es posible distinguir un nivel ulterior, el del Diseño propiamente dicho, como un sistema normativo abstracto y general que hace posible la aparición histórica de la Arquitectura (Jannello 1978,1980,1983; Carvajal 2005). De hecho, en la recopilación de sus escritos por Carvajal, la primera parte se refiere a lo "esencial" en arquitectura: su origen y su esencia, "el habitar". Pero inmediatamente introduce su verdadera preocupación teórica: el sentido de la forma, el paso de la geometría al diseño. En términos de Hjelmslev, el diseño es también una semiótica-objeto.

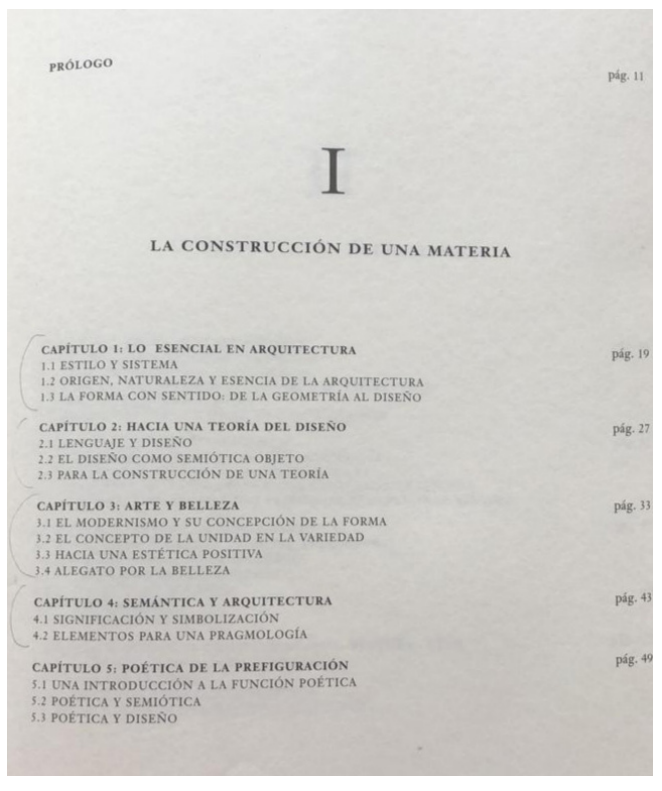

Figura 2. Índice de la primera parte de los escritos de Jannello recopilados por G. Carvajal Aproximaciones teóricas al problema

El conjunto de problemas

\footnotetext{
${ }^{3}$ Al respecto ver los desarrollos del Arquitecto Claudio Guerri en la caracterización de estos sucesivos momentos (Guerri 2012, 2014) que el espacio de esta reflexión no me permite abordar en profundidad.
} 
que plantea la interpretación de este espacio como conclusión de un proceso inter-semiótico de relaciones entre el existente -la obra-, el texto -el proyecto- y el sistema -el Diseño-, evidencian el punto de vista de una estrategia prescrita precisamente por la elección de una forma de y no otra. Lo que permitirá a Jannello determinar a posteriori todo un circuito de programas elementales de uso, apropiación, transformaciones del espacio, hasta la localización de verdaderas "isotopías espaciales" (Escudero Chauvel - Carvajal, 1988).

El espacio es, a diferencia del lenguaje, escasamente prescriptivo, está cargado de una inercia social y la síntesis espacial - el "orden" - no prevé enunciados agramaticales, salvo en su acepción funcional. La tesis del Funcionalismo "La Forma sigue a la Función" es elocuente de una voluntad que pone en suspenso el criterio de la norma. Janello será fuertemente crítico a esta aparente perversión construccionista del Movimiento Moderno.

Y esta tradición arquitectural moderna también puede ser analizada a partir de una serie de constantes y recurrencias formales que señalarían aquello que se ha querido negar a nivel de la enunciación teórica: existen recorridos de sentido privilegiados, hay una puesta de relieve de ciertos artificios proyectuales en detrimento de otros. Los estilos pertenecerían a esta categoría.

\section{El proyecto de diseño como semiótica especifica}

El punto de inflexión y la originalidad de la teoría de Jannello, lo que la diferencia de otras reflexiones acerca de la naturaleza semiótica del existente arquitectónico, es la propuesta de una interpretación del espacio a partir de un protocolo metodológico de distancias, transformaciones, aspectualizaciones, modelizaciones en el texto bidimensional del proyecto de diseño como en el tridimensional del existente construido.

Todas estas dimensiones presuponen teóricamente un momento anterior: el establecimiento de un sistema categorial desde el cual pensar el problema del continuum espacial. El antiguo y central problema saussureano de como volver discontinuo un objeto percibido como continuo, es decir de volverlo pertinente, distintivo y analizable, de construirlo como "objeto". Problema epistemológico que en el plano fonológico se había planteado Trubetzkoy y Jakobson.

Este sistema categorial es por cierto una construcción metodológicointerpretativa de naturaleza taxonómica y operacional que trata de poner en evidencia la organización contrastiva del texto visual ${ }^{4}$. El proyecto de diseño se vuelve un artificio y el acto de diseño puede transformarse en una poética en el sentido jakobsoniano (Jannello, 1979,1980); aparece entonces como un conjunto de enunciados descriptivos de una forma particular de segmentar el espacio a partir de la individualización de dimensiones espaciales.

La autonomía de este nivel se justifica no solo por la especificidad de una

${ }^{4} \mathrm{Al}$ respecto ver los resultados heurísticos del "nonágono" propuesto por el Arquitecto Claudio Guerri (Guerri 2014) 
práctica - la práctica proyectual-, con sus protocolos inherentes, sino por el tipo de análisis que requiere: una conceptualización propia del orden del espacio y no de la lengua. "El diseño hace posible un orden en el espacio. Opera con elementos morfo- sintácticos, a través de un sistema de códigos digitales, que genera una lógica de sentido relacional" (Jannello 1980:5).

\subsection{Las dimensiones}

Las dimensiones son categorías: las numerales, las mórficas y tácticas, que asumen el valor de invariantes en el análisis del espacio. Este término se utiliza en la teoría para designar un plano, grado o dirección en que se puede realizar una acción o efectuar una operación de transformación de diseño. Las dimensiones son determinaciones fundantes según Jannello de la naturaleza relacional de la forma del espacio, se proponen como premisas a priori para un sistema puro de percepción, carente de motivaciones referenciales (Jannello 1983).

En la definición que da el diccionario de Greimas-Courtés el término "dimensión", en cuanto termino figurativo, ha sido tomado prestado precisamente de la geometría y designara "cada una de las relaciones binarias constitutivas del cuadrado semiótico" (Greimas-Courtés 1979:100).

Para Janello las dimensiones son entidades relativas - en el sentido de relacionales - pues permiten imponer instrucciones al continuo de los objetos del mundo natural y por lo tanto constituyen metodológicamente hablando, la base de un sistema de diseño en todos sus aspectos y aplicaciones. A su vez conciernen a la competencia cognitiva respecto a la similitud o alteridad en la producción de objetos propios al diseñador (Jannello 1988).

Forman un paradigma -el paradigma de las relaciones mórficas y tácticas cuya representación geométrica es reproducible proyectualmente y establecen entre sí disyunciones.

\section{La Teoría de la Delimitación Espacial (TDE)}

Una teoría de la Delimitación Espacial (TDE), como la denomino, presenta al menos dos objetivos que contribuyen a la discusión y a la actualidad de la naturaleza de una Semiótica del Espacio y a su posible objeto: ¿cuáles son las categorías que posibilitan la articulación del espacio como una Semiótica General? ¿Cuál es la forma que ha de tener una teoría del proyecto de diseño como semiótica específica? La Segunda Parte de sus escritos nos muestran los interrogantes y el orden de problemas que se formulaba.

LA TDE es una teoría formal que elige a la configuración espacial simple - una unidad molar espacial, especie de "enunciado canónico" greimasiano - como una suerte de organización interna, adscribible a una tipología de paradigmas de las diferentes dimensiones- que posibilitan la construcción de 
diseños más complejos. Esta configuración espacial simple, - suerte de unidad molar indivisible - refiere a ciertas invariantes formales estructuradas en una red de relaciones y dotadas de un modo de existencia paradigmático.

Lo que llamamos una Semiótica del Espacio es el conjunto de posibilidades formales -llamado paradigma de las relaciones mórficas y tácticas - que el sistema otorga al diseñador permitiendo un análisis inmanente en un primer momento - los trazados - y contrastivo posteriormente, con una economía operativa considerable.

Por último, la TDE articula simultáneamente una gramática de producción del proyecto de diseño y una analítica de los productos de diseño, como una voluntad de formalización del continuum espacial. Es por lo que la TDE fija un nivel de descripción que considera pertinente el Sistema de diseño y la producción del proyecto deslindando los problemas vinculados a su actualización.

Veamos su proyecto de arquitectura teórica que desarrolla en la Segunda parte de la recopilación de sus escritos.

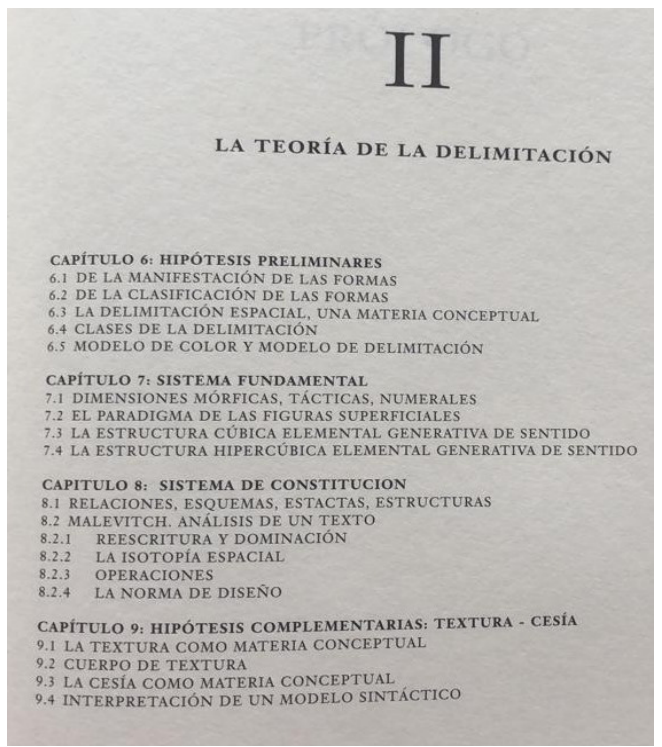

Figura 3. Índice de la Teoría de la Delimitación; jerarquía de problemas

\section{Conclusiones}

Me parece importante destacar que la reflexión de Jannello apunta a describir la competencia proyectual del ser humano, al margen de las performances que el usuario puede realizar, y de hecho realiza, en este espacio.

Era consciente que trabajaba en la elaboración de una teoría general de la delimitación espacial que superaba una teoría del diseño en el sentido clásico del término. Y que esta teoría debía ser sistemática y coherente en todos sus niveles porque estaba tratando con un objeto de alta complejidad del que 
debía dar cuenta. De allí su extremada rigurosidad en la redacción de su aparato conceptual. Su escritura era como su persona, austera y magra. Elegante en la economía extrema de la expresión

Fue sin duda fascinante verlo cada semana frente al pizarrón negro del aula escribir con tiza los conceptos sobre los que iba reflexionando en ese mismo momento. Sus asistentes, sentados en primera fila, discutíamos con él y aportábamos nuestras ideas. Era un working progress y estábamos todos muy conscientes de la unicidad de ese instante en que comenzaban a tomar forma sus hipótesis.

Sus propuestas iniciales sobre la segmentación del espacio a partir de un delimitante y un delimitado -suerte de la doble cara de la moneda saussureanahasta la compleja arquitectura final de su obra, lo vuelven no solo un pionero en la construcción de una Semiótica General del Espacio y de una semiótica específica del diseño, sino un visionario acerca del valor de la semiosis en la interpretación de los mecanismos del pensamiento humano como proceso de asignación de inteligibilidad del mundo circundante.

\section{BIBLIOGRAFIA}

CARVAJAL, German. 2005. Diseño como poética: el pensamiento de César Jannello. Buenos Aires: FNA. 122P.

CARVAJAL, German - ESCUDERO-CHAUVEL, Lucrecia. 1988. "The concept of isotopy in the context of a semiotic Theory of Spatial Delimitation". HERZFELD, M-MELAZZO, I (eds) Proceedings of the III International Congress of the IASS/AIS. Berlin-New York-Amsterdam: Mouton de Gruyter. PP117-121.

ESCUDERO-CHAUVEL, Lucrecia. 1983. "Los aportes de la semiótica al estudio de la Arquitectura". X CLEFA, Vol1. Sao Paulo: USP. PP 63-69.

ESCUDERO-CHAUVEL, Lucrecia. 1985. "Cesar Jannello: Arquitectura pensada desde la poética". Summa, 217. 20-21.

JANNELLO, César. 1961. "Texture as visual phenomenon ". Architectural Design 33 (8): 394-396.

JANNELLO, César. 1973. Modelo cuantizado de Color. UBA-FADU. Mimeo

JANNELLO, César. 1979. "Para una poética de la prefiguración". Sumarios 9/10. 24-28

JANNELLO, César. 1980. Diseño, lenguaje y Arquitectura. UBA-FADU. Off-print. 
JANNELLO, César. 1983. Proyecto de fundamentos para una Teoria de la Delimitación. UBA-FADU. Off-print.

JANNELLO, César. 1988. "Fondements pour une Théorie de la Delimitation " HERZFELD, M-MELAZZO, I (eds) Proceedings of the III International Congress of the IASS/AIS. Berlin-New York-Amsterdam: Mouton de Gruyter. PP. 483-419.

GREIMAS, Algirdas J. - Courtés, Joseph. 1979. Sémiotique. Dictionnaire raisonné de la théorie du langage. Paris : Hachette.

GREIMAS, Algirdas J. 1984. "Sémiotique figurative et sémiotique plastique ". Actes Sémiotiques 60, Vol.VI

GUERRI, Claudio. 1987. Acerca de la Teoria de la Delimitación Espacial. Buenos Aires: Ceading-UBA. Mimeo

GUERRI, Claudio. 1988. "Architecture, Design and Space Semiotics in Argentina”. SEBEOK, T.-UMIKER-SEBEOK (eds) The Semiotic Web 1987. Berlin-New YorkAmsterdam: Mouton de Gruyter. PP.389-419.

GUERRI, Claudio. 2012. Lenguaje Gráfico de la TDE. Mas allá de la Perspectiva. Buenos Aires: EUDEBA.

GUERRI, Claudio et al. 2014. Nonágono Semiótico. Un modelo operativo para la investigación cualitativa. GUERRI, C. y ACEBAL, M. (eds.). Buenos Aires: EUDEBA y Ediciones UNL. 2da edición 2016. 


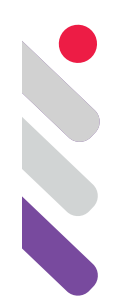

\title{
Cursos semióticos: caminos y trayectorias antrópicas
}

DOI: 10.24308/IASS-2019-8-009

\author{
JACQUES FONTANILLE \\ Centre de Recherches Sémiotiques (CeReS) \\ Universidad de Limoges \\ Instituto Universitario de Francia \\ jacques.fontanille@unilim.fr
}

\section{Introducción}

El tema general de este congreso ofrece la oportunidad de discutir algunos conceptos metodológicos y teóricos de la semiótica general, en particular su versión greimasiana. Para describir una serie de fases, los conceptos más utilizados son "ruta», "curso», "recorrido», "trayectoria». La transición de un idioma a otro, por supuesto, difumina los mapas semánticos: en español curso enfoca en la serie de etapas, recorrido insiste en el cruce de un conjunto de posibles obstáculos, y trayectoria objetiva al actante en movimiento, especialmente si es un objeto. Español duda entre camino y trayectoria por francés «trajectoire». De manera similar, el inglés, por "curso», tiene la opción entre course y path, y por "trayectoria», entre path y trajectory (esta última con el mismo efecto objetivante). En francés, parcours indica una serie de pasos, chemin significa una traza irregular de un curso de ritmo lento, y trajectoire es la forma general del movimiento de un objeto específico. Etcétera...

Cada idioma ofrece, en la misma configuración semántica, diferentes organizaciones conceptuales, y este es un argumento básico a favor del multilingüismo científico. De hecho, si las propiedades semánticas se distribuyen de manera diferente, es más fácil identificar aquellas que son relevantes y discriminatorias. Por ejemplo, "parcours ", " curso " y " course " se centran en el conteo de fases o etapas; " chemin ", " camino " o " path " convergen para ralentizar la toma del desplazamiento, y para evocar posibles elecciones y alternativas. A primera vista, estas propiedades semánticas relevantes y discriminantes serían: 
- La orientación y la relación entre el punto de inicio y el punto de llegada (diferencia, distancia, etc.). Variante teleológica: el punto de partida es un origen, y el punto de llegada, un objetivo.

- La disposición sintagmática de los constituyentes del desplazamiento (las fases del desplazamiento y los pasos entre cada fase). Variante mereológica: la disposición es una sucesión, una serie, con o sin nodos y aglomerados, etc. Variante polémica: los constituyentes también pueden ser obstáculos, resistencias, y dificultades para superar.

- La dirección y la orientación del desplazamiento se confunden (o no) con la intencionalidad de un actante: objetivación o subjetivación. Variación del punto de vista: desde un punto de vista global, se puede superponer la dirección y la orientación; desde un punto de vista sumergido e inmanente, podemos disociar la dirección y la orientación (podemos tomar una orientación sin conocer la dirección general)

- La toma de tempo rápido o tempo lento: neutralización o énfasis de la velocidad, neutralización o discriminación de los constituyentes, neutralización o resaltado y deliberación de alternativas y opciones. Variante modal (cognitiva, epistémica): consideramos, o no, alternativas y elecciones.

\section{El camino}

\subsection{Los caminos familiares}

Jacob Von Uexküll ([1933] 2016) examinó los constituyentes del camino en una perspectiva etosemiótica. En su estudio sobre los mundos humano y animal, Von Uexküll estaba interesado en la dimensión espacial del Umwelt, y comienza examinando los caminos familiares que lo estructuran, mediante los cuales los seres vivos se apropian de cualquier espacio físico para convertirlo en territorio. El camino familiar estructura el espacio en zonas de poder hacer y no poder hacer, prohibidas y permisos, posibilidades e imposibilidades. El conjunto de caminos familiares constituye el espacio familiar. La casa (o vivienda) es un punto de origen para todos los caminos del espacio familiar, lo que lo convierte en el centro de referencia subjetal del dominio. El territorio es una extensión más o menos disociada de la casa. Es el sitio de las prácticas diarias que no pueden llevarse a la casa-vivienda y, sin embargo, son esenciales para la vida y la supervivencia. Por lo tanto, para convertirse en un territorio, el espacio familiar debe estar protegido contra intrusos y competidores: se agregan otras prohibiciones y permisos, posibilidades e imposibilidades a los anteriores.

Este dispositivo elemental se complementa en el estudio de Von Uexküll por una zona neutral que se interpone entre la casa y el territorio: en esta zona neutral, la descendencia y los congéneres del depredador pueden moverse sin riesgo de ser tomados por error para presas o agresores, pero también otras especies, que son presas potenciales, también pueden instalar su hogar a salvo 
del ataque. En esta zona neutral, las modalidades se redistribuyen y los signos se invierten en beneficio de los seres más vulnerables. La casa-vivienda, la zona neutral y el territorio constituyen la topología esquemática mínima de un Umwelt.

Pero Von Uexküll muestra a continuación que los animales y los humanos también pueden proyectar en su entorno un cuarto tipo de espacio, que califica de " mágico ", donde tienen lugar interacciones imaginarias, ficticias o simbólicas, y que, más en general, obedecer otras condiciones existenciales, distintas a las de la casa y del territorio. Estas interacciones imaginarias escapan del simple acoplamiento entre percepción y acción; producen esquemas prácticos relativamente autónomos, que pertenecen a otro modo de existencia, bajo la presión de imposiciones biológicas y bajo una orientación subjetiva. Es probable que estos esquemas prácticos imaginarios y simbólicos se proyecten e influyan en la acción práctica en las otras tres zonas.

Desde un punto de vista etológico y antropológico, la concepción semiótica de los caminos (particularmente familiares) no puede liberarse de la estructuración básica del Umwelt: casa-vivienda, zona neutral, territorio, al que debe agregarse una zona imaginaria (para todas las interacciones que no deben nada a la percepción directa). Existe, pues, una estructura semiótica elemental capaz de dar una forma interpretable del camino: casa-vivienda, zona neutral, territorio, zona imaginaria. La siguiente pregunta será epistemológica y metodológica: cuando se incorporen como un concepto teórico, ¿̇los caminos, las vías y las trayectorias conservarán esta estructura semiótica?

\subsection{Los placeres semióticos del camino}

Tengo que asistir a una conferencia y viajo en coche. Al salir, tomo la carretera principal, la autopista, porque la hora de apertura de la conferencia está en el primer plano de mi atención: hago un trayecto (mi vehículo no es lo suficientemente rápido para hablar de una trayectoria). Cuando regreso, decido caminar por el país, el campo y las aldeas, tomando pequeños caminos, y mi desplazamiento sigue un camino. Durante este camino, los detalles de la práctica, sus aventuras y sus puntos de bifurcación o de desaceleración tienen prioridad sobre el logro del objetivo. Las cualidades del proceso, en lugar de su resultado final, proporcionan los valores del camino. En resumen, un curso de existencia cuya multiplicación de riesgos (paradas, desviaciones, aleas, etc.) haría que todo el valor emocional.

El camino implica riesgos específicos y esperados, ya que da rienda suelta a los eventos que no se imputan necesariamente a un obstáculo o un antactante, sino simplemente a otro actante. El trayecto conoce un solo actante (el viajero) y una multitud de obstáculos para neutralizar. El camino, con el sabor del riesgo, está lleno otros actantes disponibles para todas interacciones posibles. 
Esta cultura de riesgo y alea, y de caminos cruzados, en lugar de neutralizar los obstáculos y los antactantes mediante una optimización controlada del trayecto, da nuevamente una latitud de manifestación a todo tipo de otros actantes, y alienta a probar interacciones con ellos. El camino, en resumen, potencialmente destaca los roles actanciales del paisaje y de sus ocupantes, para permitir un curso más libre al evento e interacciones con el viajero.

Podemos hacer un desvío por la Búsqueda de Tiempo Perdido de Marcel Proust ([1913] 2007). En el episodio de los tres campanarios de Martinville, él organiza esta actanciación del paisaje en tres etapas: (1) evoca experiencias previas memorizadas pero inutilizables, (2) presenta la experiencia de la caminata actual, y (3) finalmente, realiza la narrativa a posteriori de la caminata.

- Las sensaciones memorizadas (la forma de un objeto, un reflejo de la luz, un olor) constituyen una envoltura, un contenedor que contiene un contenido inaccesible. El " placer especial » provisto por estas propiedades sensoriales es solo una indicación de la presencia de un contenido que no puede descubrirse.

- La experiencia actual, una caminata alrededor de los tres campanarios, captura movimientos relativos: el carro avanza, acelera, gira, frena, se detiene; los campanarios se acercan, se separan, avanzan, retroceden. Una red de expresiones hace esperar un contenido, pero esta vez, el contenido no se escapa, porque los movimientos relativos han proyectado roles actanciales sobre los elementos del paisaje, y el observador ha recibido varios afectos: asombro, esperando, embriaguez, etc. La envoltura del contenedor se abre (" Pronto, sus líneas y sus superficies soleadas, como si hubieran sido una especie de corteza, se rompieron, me apareció un poco de lo que estaba escondido en ellas ") y el observador puede capturar el contenido. Pero en esta primera versión de la caminata, iniciativa pertenece exclusivamente al observador en movimiento.

- La narrativa final le da toda la iniciativa a los campanarios: solo ellos avanzan, giran, se alejan, desaparecen y reaparecen, se lanzan al frente del carruaje, buscan su camino, tropiezan, aprietan, se desvanecen. Las interacciones proporcionadas por el camino, entre el observador y el paisaje, son iniciadas por el paisaje mismo, considerado como un actante en sí mismo: el medio toma el control. El significado del camino surge de las interacciones de las cuales el otro actante (el paisaje) ha tomado iniciativa.

El camino es, por lo tanto, un tipo de experiencia que, al dar rienda suelta a las posibles interacciones, al arriesgarse a apariciones y desapariciones inesperadas, sensaciones enigmáticas, sorpresas y decepciones, expectativas y accidentes, permite el paso a un otro modo de existencia: una forma de vida donde se animarán todos los existentes, se podrán tomar iniciativas, cuestionar al observador, provocarle, desestabilizarle, hacerle sentir de hecho todo el rango de los valores del camino. 
Peirce propone en un artículo titulado Argumento desatendido para la realidad de Dios (Pierce, en Deledalle 1990: 172-192) un concepto que puede facilitar el tratamiento de tal situación: el concepto de musement (diversión). El musement peirciano deja espacio para los vagabundeos de un pensamiento libre y flotante, una forma incontrolada de imaginación que, sin embargo, puede dar acceso a representaciones de importancia primordial, incluso de vital importancia. Según Peirce, de hecho, hay «temas de vital importancia», como el mismo Dios, cuya realidad se "percibe directamente» sin la mediación de una inferencia. Experiencia directa es, entonces, la única manera que abre el acceso a su significado.

La situación más favorable para diversión es precisamente el camino, sin inferencias y explicaciones funcionales y teleológicas. Al igual que Proust, quien, para descubrir el significado del «placer especial» que le dan grupos de sensaciones particulares, debe abandonar primero la exploración sistemática de ellos, para que puedan acceder a su atención que se ha vuelto fluida y difusa. Musement-diversión peirceano da acceso a una experiencia de profundos valores de la vida. El camino que conduce a los valores, toca los fundamentos existenciales de la vida misma. Proust no dijo nada más, en conclusión de la experiencia de los tres campanarios: "Fue porque creía en las cosas, en los seres, mientras las atravesaba [...]. Son los únicos que todavía tomo en serio y que todavía me dan alegría.» (Proust, Del lado de Swann, [1913] 2007: 184) (subrayado por nosotros).

\section{La trayectoria}

Una trayectoria es la forma esquemática del conjunto de posiciones sucesivas ocupadas por cualquier entidad en el espacio o el tiempo, que requiere al menos un referencial espacio-temporal, donde se identifican las posiciones alineadas, proporcionando esta alineación una forma reconocible de la trayectoria. Una trayectoria es, por lo tanto, la forma específica de una alineación de estados sucesivos.

La forma de una trayectoria le da cierta previsibilidad: la trayectoria de una pelota de tenis o de fútbol permite al receptor (el portero) predecir su punto de llegada, pero esto no prohíbe al remitente engañar a la vigilancia y a la capacidad de anticipación del receptor. Para un sociólogo, la trayectoria de un actor solo puede establecerse después del hecho, como una observación retrospectiva, sin ninguna previsibilidad. Parecería que, para la semiótica narrativa, es lo mismo, ya que el curso narrativo de un actante, de acuerdo con el uso más extendido en el análisis narrativo, solo puede reconstruirse desde el final, retrospectivamente.

Sin embargo, la forma general de la teoría greimasiana es la de una trayectoria generativa, que conocemos el número de posiciones sucesivas (los 
niveles de análisis), el principio y el final (es decir: la profundidad y la superficie), así como la orientación. Entonces sería necesario suponer que solo la teoría tendría una trayectoria en el sentido estricto, con una cierta previsibilidad, pero que, durante el análisis concreto, el método tropezaría para reconocer trayectorias, y que los actantes y actores solo podrían seguir cursos encontrados a posteriori y sin previsibilidad.

Además, en muchas obras del campo biosemiótico, predomina la explicación por el telos. Utilizada para dar sentido a los procesos en el mundo viviente, la explicación teleológica consiste en asignarles un propósito: la vida tiene un propósito, de modo que la vida tiene un significado. Luego, se señala en los trabajos en cuestión que el "propósito » invocado no es, estrictamente hablando, una determinación explícita de una posición terminal del curso. De hecho, el "propósito» resulta solo de la conversión de la acción observable de una entidad viviente (la función de un órgano, o el papel de un gen) en una finalidad de esta entidad. Asignar una finalidad a un proceso no es anticipar y predecir, solo se trata de ocultar el hecho de que el método de análisis no puede asignar un significado a la acción observada.

Extrañamente, la aporía es de la misma naturaleza en ambos casos: el método semiótico no logra alcanzar una forma-trayectoria equipada con una capacidad de predicción, y es, por lo tanto, la teoría la que tiene una trayectoria, pero en una perspectiva especulativa y no demostrable. Ya hemos sacado a la luz, con respecto al camino, la homología entre las propiedades de los caminos observados y los del análisis en sí mismo: al camino que toma un actante de movimiento lento, responde el camino metodológico lento y aleatorio del analista. En ambos casos, el del actante narrativo y el del analista, la elección del curso sin condiciones vinculantes y sin propósito es sin embargo la forma más segura de acceder a los valores existenciales fundamentales.

Recuerde las propiedades del camino: (1) una organización subjetal, con un observador inmerso en el curso y en el ambiente, (2) una aceptación o incluso una expectativa de lo inesperado y de los aleas y riesgos, (3) una actanciación del medio ambiente que le da una capacidad de iniciativa en las interacciones, y (4) un objetivo particular por los valores existenciales.

En contraste, la trayectoria, ya sea la de un actante observado, o la del analista sometido al camino generativo, implica: (1) un punto de vista externo y global, fuera del curso y fuera del medio ambiente, entonces sin influencia en la trayectoria; (2) la resistencia o el rechazo de aleas y riesgos, obstáculos para neutralizar o eludir; (3) una objetivación del medio ambiente y todo lo que lo ocupa: solo los participantes del curso puedan tomar la iniciativa de las interacciones; (4) un enfoque en los valores asociados con los objetivos prácticos asignados al curso, y a la semantización específica del sujeto del curso. 


\section{Cuatro propiedades de los cursos semióticos}

Ahora, los cuatro tipos de propiedades pueden analizarse por separado y construirse de manera diferencial.

\subsection{Subjetalidad y posición de observación}

La primera propiedad, relativa a la posición del observador, puede presentarse en forma de una topología de posiciones antrópicas. Primero establezcamos un dominio de referencia y experiencia, estructurado por tres zonas concéntricas (zona endotópica en el centro, AQUI, zona peritópica (los alrededores), HAY, zona paratópica LEJOS), y una zona externa, la zona utópica en un OTRO LUGAR imaginario, o al menos perteneciendo a otro modo de existencia.

El camino oscila entre las posiciones Aquí y Hay, y la trayectoria vacila entre los modos Lejos y Otro lugar. Por lo tanto, habría dos tipos de caminos: un camino subjetivo - Aquí, y un camino más vagamente pluripersonal - Hay; y dos tipos de trayectorias: una trayectoria inmanente y objetiva - Lejos, ancladas en la experiencia, y una trayectoria trascendente - Otro lugar, liberada de las condiciones de experiencia. Podemos sintetizar estas proposiciones en el siguiente diagrama, que describe nuestra topología antrópica.

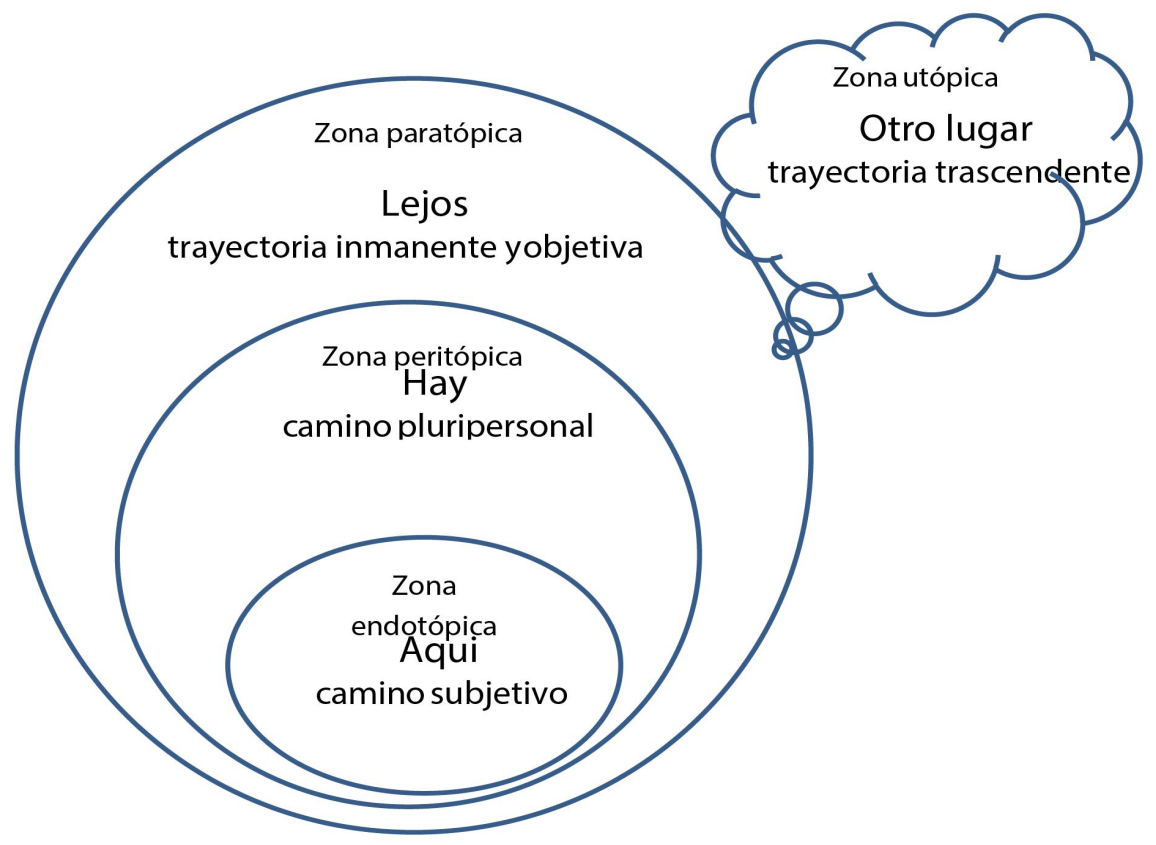

Figura 1: topología antrópica y tipología de cursos 


\subsection{La aversión al riesgo y el sabor del alea}

La segunda propiedad se refiere al tratamiento de aleas, riesgos y accidentes, más generalmente: como un obstáculo, como una desviación, como una ocasión, como una oportunidad, como una invención, etc. Para estructurar la categoría, se pueden adoptar varios puntos de vista. El primero de ellos es el de la modalidad bajo la cual se trata el riesgo: querer, saber, deber o poder. El segundo se centra en los actos cognitivos y apasionados por los cuales se capta el riesgo: se niega o se acepta, se busca o se sufre ; y según Eric Landowski ([2005] 2017), en varios modos de interacción, basado en la oposición entre programación y ajuste: la programación no admite riesgos ni aleas, y alienta eliminarlos o reducirlos; el ajuste, por el contrario, se alimenta de eles y, en consecuencia, les da la bienvenida para integrarlos en el camino de las interacciones.

Pero, en lugar de programación y ajuste radicalmente opuestos, consideramos que, desde el punto de vista de las prácticas, todos involucran una dosis de programación y una dosis de ajuste. Es la variación del equilibrio entre los dos lo que produce la diversidad de tratamientos. Por lo tanto, correlacionemos la intensidad del compromiso con la práctica, que está a favor del ajuste, y la extensidad de la programación de la práctica, a favor de la programación. El resultado es una tipología de prácticas y de los tipos de cursos correspondientes, en esta representación esquemática:

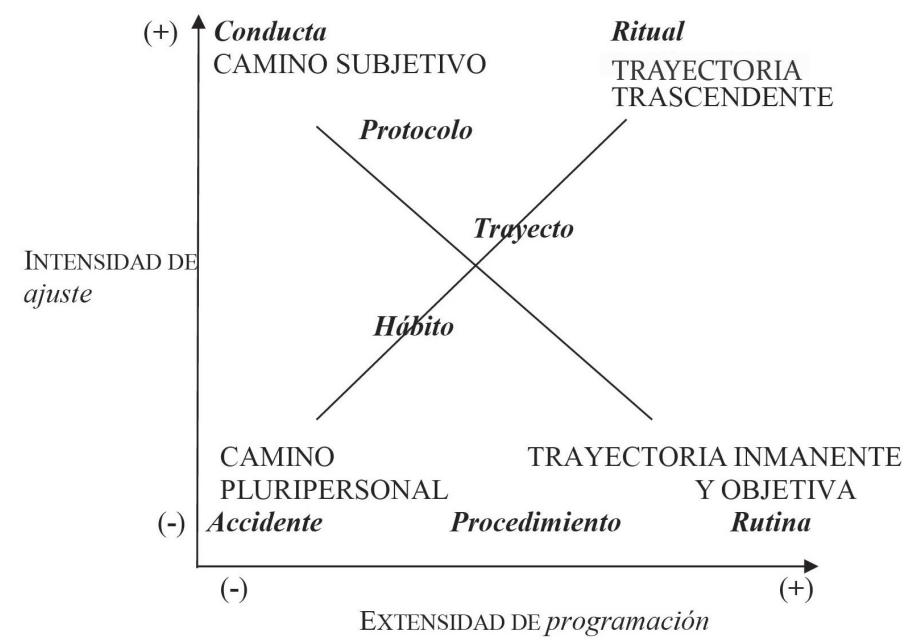

Figura 2: tipología práctica de cursos 
Si consideramos, por ejemplo, los diversos usos del curso generativo de Greimas (Greimas y Courtés [1979] 1982), nos damos cuenta de que la práctica del análisis semiótico está sujeta a grandes fluctuaciones. Dado que el propio Greimas ha definido el curso generativo como el marco de un procedimiento de análisis, este curso implica una trayectoria inmanente y objetiva. Pero este procedimiento encuentro accidentes de todo tipo: el primero de ellos es la interrupción del curso generativo, lo que explica que los contenidos abstractos y genéricos pueden directamente manifestarse, así como los contenidos figurativos, superficiales y concretos. Otro tipo de accidente se produce cuando la dimensión somática de la semiosis, requerida en el nivel profundo de la polarización tímica de los contenidos (euforia y disforia), que prefigura la axiología, se manifiesta directamente en la superficie del discurso o cualquier otro tipo semiótico: ies el cuerpo que habla!

Estos accidentes en el curso generativo hacen que pierda su carácter de trayectoria inmanente y objetiva, apelando, según el caso, a una instancia trascendente ( $\mathrm{y}$ a una trayectoria trascendente), o a la reconstitución de un centro subjetivo y sensible que asume la enunciación de estos contenidos manifestados accidentalmente. El mismo Greimas terminaría con tres usos diferentes del curso generativo: como una trayectoria inmanente objetiva (el procedimiento), como un curso subjetivizado, casi un camino subjetivo (une conducta entre los accidentes de manifestación) y como un camino pluripersonal (la instancia somática que se impone y produce un accidente en el curso generativo).

Otros usos ritualizan el análisis (un ritual analítico), haciendo del camino generativo un plan, un marco de descripción completamente programado. Para poder hablar de ritual analítico, la intensidad del compromiso en el ajuste también debe ser máxima: entonces, la práctica del análisis se esfuerza en todo momento por reducir todas las variaciones observadas en los componentes del curso generativo, con una sistemática que es la firma de un estilo de análisis: entonces estamos tratando de una trayectoria trascendente, la trascendencia aquí es la del modelo de análisis.

\subsection{Actanciación}

La tercera propiedad apareció en el estudio de los roles del paisaje y sus monumentos, durante el viaje en carruaje evocado por Proust: la actanciación del medio ambiente depende directamente de la posición del centro de referencia, de interacción y de iniciativa, dentro de la topología de las zonas antrópicas.

En la zona endotópica, el camino subjetivo solo da lugar a una experiencia sensible centrada en los estímulos sensoriales del centro subjetal, y las figuras del medio son entonces solo fragmentos de cualidades sensibles. 
En la zona peritópica, la del camino pluripersonal, la situación apenas evoluciona, pero el centro de referencia del sujeto se difunde y multiplica, la experiencia sensorial se puede compartir, incluso con las figuras del medio. Es precisamente el momento y el lugar donde se multiplican las interacciones bilaterales e incluso multilaterales entre actores humanos y figuras locales: la actanciación generaliza, sin especialización de roles, y en esta zona solo se puede reconocer «interactantes».

En la zona paratópica, se impone la trayectoria objetiva e inmanente, el centro subjetivo ya no es el centro de referencia de las interacciones, se despliega la iniciativa de los actantes del medio ambiente. Es el momento y el lugar donde las figuras del medio, incluidos los actores humanos y no humanos, siguen trayectorias autónomas y objetivadas.

En la zona utópica, la trayectoria trascendente da acceso a otro mundo semiótico donde todos los elementos del medio se tratan como animados: en el texto de Proust, es la metáfora hilada la que opera, especialmente cuando los monumentos en movimiento, convertirse en los equivalentes de grandes flores de tallo alto, finalmente se transforman en " chicas legendarias ".

Podemos referir directamente estas diferentes fases de actialización a la tipología de las cuatro zonas.

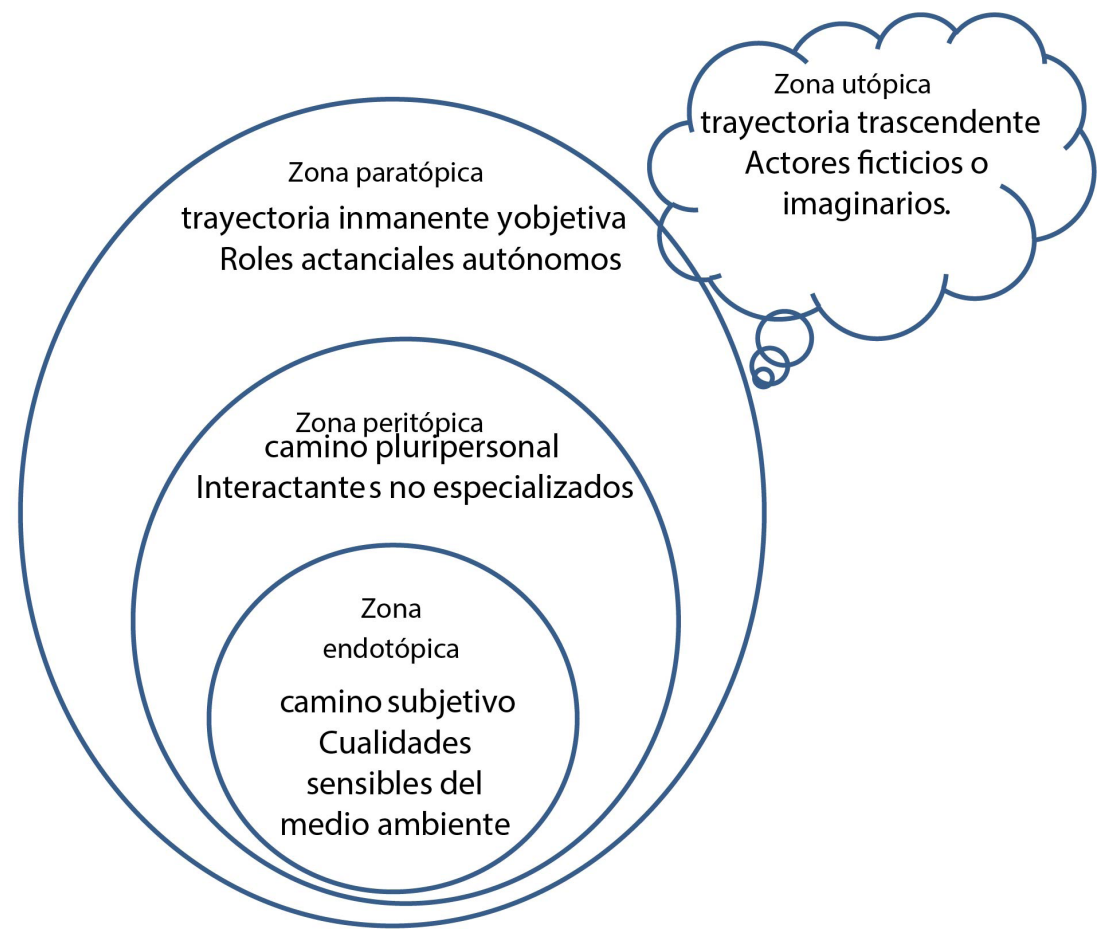

Figura 3: topología antrópica y tipología actancial 


\subsection{El curso de acceso a los valores}

La cuarta propiedad está disponible desde la oposición inicial entre los valores característicos de los objetivos del curso y los valores existenciales, profundas y amplias, que caracterizan aún el significado mismo del acto de recorrer, actuar, incluso vivir.

Esta versión se ha sugerido indirectamente por Jean-Marie Floch (Floch [1990] 1993: 131-152), sobre el mundo de los valores de consumo, estrategias de mercado, posicionamiento de marca y campañas de publicidad. Floch distinguidos valoraciones "prácticas, lúdicas, utópicas, y críticas». Cada uno de estos métodos de valoración produce valores típicos: los valores respectivamente «utilitarios, no utilitarios, existenciales, no existenciales».

Inmediatamente notamos que los valores fundamentales, los "valores existenciales», sólo son visibles si nos proyectamos en otro mundo, en otro modo de existencia, en la zona utópica. Tenga en cuenta también que en el cuadrado semiótico que organiza esta tipología, los valores existenciales presuponen valoración lúdica, que prepara así la salida hacia otro modo de existencia. Y, finalmente, la valoración crítica rechaza valores fundamentales y existenciales, adopta las determinaciones específicas del dominio de referencia y de la práctica básica, y más particularmente, de manera difusa y extensa, los efectos indirectos de la práctica. Esta característica es especialmente buscada, por ejemplo, acerca de la responsabilidad social y ambiental de las empresas: más allá del corazón de su negocio, de sus propios objetivos como empresas, deben también tener en cuenta sus efectos indirectos, alrededor sus prácticas básicas. Estamos entonces en la zona peritópica.

Podríamos estar tentados a localizar cada uno de los valores típicos en cada una de las áreas antrópicas. Pero eso sería olvidar que la valoración es una operación (sintagmática), y dicho de otro modo un proceso que sigue un curso. Hemos mostrado por ejemplo cómo el juego libre del musement (posición «lúdica», la negación de la posición "práctica») proporciona acceso a los valores existenciales (posición «mítica»). Podríamos mostrar igualmente por qué volver a las determinaciones e implicaciones concretas (posición «crítica», negando la posición «mítica») da acceso a los valores de la experiencia práctica finalizada por objetivos (posición «práctica»). En otras palabras, el acceso a los valores toma cursos, es decir caminos o trayectorias. Vamos a proveer la presentación gráfica de algunos (pero no de todos los posibles) cursos de acceso a los valores:

(1) Desde la zona endotópica a la zona utópica, la operación trasciende las condiciones prácticas, y el camino subjetivo da acceso a los valores existenciales por una revelación (como la ruta de Damasco para San Pablo).

(2) Desde la zona endotópica a la zona paratópica, hay una reificación y objetivación de los valores. 
(3) Desde la zona endotópica a la zona peritópica, la expansión a partes interesadas, al medio ambiente y a las consideraciones ecológicas inducen la empoderación axiológica.

(4) Desde la zona paratópica, objetiva e inmanente, a la zona utópica, la dimensión práctica es trascendida por la mitificación.

(5) Desde la zona paratópica a la zona peritópica, la trayectoria objetiva se disuelve, y la consideración de determinaciones adyacentes y periféricas provoca una diversión axiológica.

(6) Desde la zona paratópica a la zona endotópica, el camino se vuelve subjetivo y hay una reapropiación subjectal de los valores.

(7) Desde la zona peritópica (pluripersonal) a la zona endotópica, la reducción subjetal induce una singularización de los valores.

(8) Desde la zona utópica a la zona peritópica, el retorno a las consideraciones ambientales (esto es, de hecho, los alrededores y, por lo tanto, el entorno) induce una trivialización de los valores.

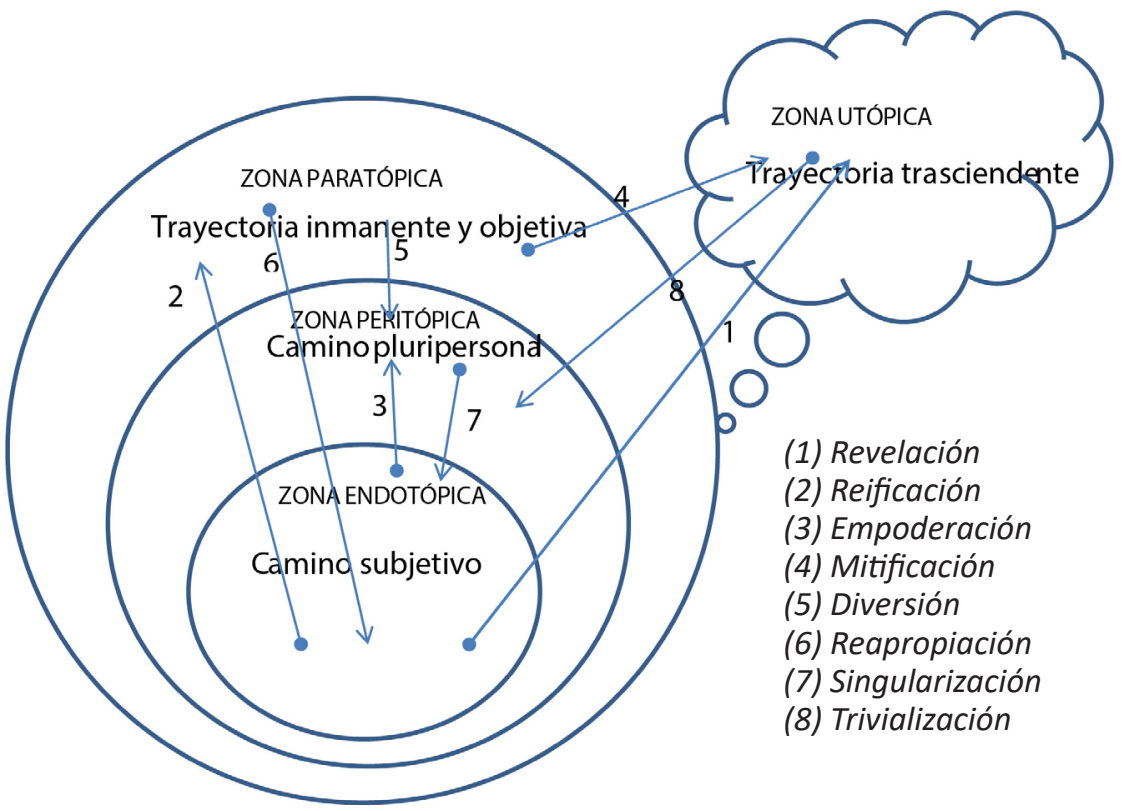

Figura 4: topología antrópica y cursos de acceso a los valores

\section{Para concluir}

Ahora podemos confirmar que la categoría del curso semiótico, incluidos caminos, trayectos y trayectorias, se puede analizar, distinguir y articular examinando cuatro propiedades: subjetalidad y posición de observación, aversión al riesgo y sabor del alea, actanciación, cursos de acceso a los valores. Estas cuatro propiedades semióticas son concebibles solo en el marco de 
una semiótica de las prácticas y en una perspectiva antropológica. En estas condiciones, representan también actantes narrativos y discursivos, como también los cursos del análisis semiótico.

\section{Referencias}

DELEDALLE, Gérard. 1990. Lire Peirce aujourd'hui. Bruxelles : De Boeck, (« Le point philosophique »).

FLOCH, Jean-Marie. [1990] 1993. Semiótica, marketing y comunicación. Barcelona: Paidós.

GREIMAS, Algirdas Julien, y COURTÈS, Joseph. [1979] 1982. Semiótica. Diccionario razonado de la teoría del lenguaje. Madrid: Gredos. Trad. Enrique Ballon Aguirre.

LANDOWSKI, Eric. [2005] 2017. Interacciones arriesgadas. Lima: Fondo editorial Universidad de Lima. Trad. Desiderio Blanco.

PROUST, Marcel. [1913] 2007. Por el camino de Swann, en A la busca del tiempo perdido. Madrid: Valdemar. Trad. Mauro Armiño.

UEXKÜLL, Jakob Johann, von. [1933] 2016. Andanzas por los mundos circundantes de los animales y los hombres. Buenos Aires: Editorial Cactus. 


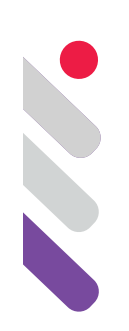

\title{
Applying Peirce. From the Three Categories to the Semiotic Nonagon
}

DOI: 10.24308/IASS-2019-8-010

\author{
Claudio F. Guerri \\ Universidad de Buenos Aires; Universidad \\ Nacional de Tres de Febrero, Argentina \\ claudioguerri@gmail.com
}

\section{Introduction}

The Semiotic Nonagon (SN) is presented as a case of applied semiotics. Although a relationship of logic and semiotic coherence is maintained with the Peircean proposal, a purely theoretical exegesis is not emphasized, but the possibility of action of the theory itself. Moving from Peirce's logicalphilosophical proposal to an operative model means becoming aware of a hardening-a stiffening - of what conceptually an infinite semiosis implies. On the other hand, in this way, an operability is achieved that Peirce's philosophical proposal has not considered explicitly. The nine sub-signs in the SN should not be taken as a mere classification of entities grouped into classes of objectsas a mere taxonomy-but as a diagram, that organizes the relationships of a semiotic process. It is, in Peirce's terms, the way in which the SN as an Immediate Object organizes the dynamic experience of the Dynamic Object. Once the limitation implied by any operative model is allowed for, its practical possibilities can also be valued.

Semiotics is fundamentally a practical discipline, a "scientific methodology" according to Juan Magariños de Morentin (2008: 26). In turn, since the production of meaning is a transversal necessity to all disciplines, it is also true that each one needs from Semiotics a specific, contextual, and effective response. In the case of Design disciplines-understood in a broad sense: Architecture, Graphic and Industrial Design, Fashion, Movies, Motion Graphics, Music, Products, Market Research, all kinds of Communication strategies, etcetera-, the task of producing an effective outcome is always very complex. The same difficulty is found in the reverse process, always prior to designing: analyzing. This means that understanding the specificity and the 
expected response in any of these activities is also a very complex intellectual job. In this sense, the triadic-Peircean-logic-based Semiotics offers a solid and coherent tool to try to approach reality, as much as possible in the limits of our knowledge and the context of our time.

However, despite being considered worldwide the founder of Semiotics, Charles Sanders Peirce never proposed or performed a complete semiotic analysis of any sign. Being interested mainly in the logic-philosophical point of view-building at that time an epistemological rupture difficult to be assimilated even by colleagues like William James-, led him to exemplify-very superficially - only with partial aspects of a sign. Peirce writes, "A weathercock is an index of the direction of the wind" (CP 2.286, 1893) ${ }^{1}$ [emphasis mine] without considering none of the other eight aspects of his own classification of the weathercock considered as a sign. This led to the general understandingactually, a real misunderstanding - of a very simplified meaning of the sign like "A weathercock is an Index", and so also La Gioconda "is an Icon", and the Washington or Buenos Aires obelisk "is a Symbol". By doing so, the verbal expression emphasizes the positivist reductionism that that interpretational operation implies, and forgets the most important interrelational aspects of the Peircean sign.

Therefore, the Semiotic Nonagon (SN) aims to guide a coherent and as complete as possible analysis, and thus avoid reductionism and the mere taxonomic division into partial aspects involved in semiosis, and in the production of meaning. Consequently, the $\mathrm{SN}$, by means of the geometric diagramthe Peircean three categories and the classification of the nine sub-signs-, reconstructs visually and conceptually the interrelation and interdependence of the different aspects of the sign.

The SN-name that differentiates it from the well-known Semiotic Square by Greimas-Courtés (1979: 29-33) is a graphic representation-a diagrammaticicon-that displays the intersection of Correlates and Trichotomies, and producing the nine boxes that represent the nine aspects of the classification of signs proposed by Peirce (CP 2.227-2.253, 1897-1903).

\section{Some critical representation of the Peircean sign}

As stated before, Peirce never related his nine aspects classification with a graphic representation. Nevertheless, there is a sketch of the nine sub-signs (Figure 1) that he drafted to visualize and think about the ten classes of signs (Figure 1) derived from the three Correlates (CP 2.235-2.237, 1903) and the three Trichotomies (CP2.238-2.253, 1903).

\footnotetext{
${ }^{1}$ We shall follow the practice of citing from the Collected Papers of Charles Sanders Peirce by CP, volume and paragraph number; the Essential Peirce by EP, volume and page number. References to the microfilm edition of Peirce's papers (Harvard University) will be indicated by MS, followed by the manuscript number.
} 


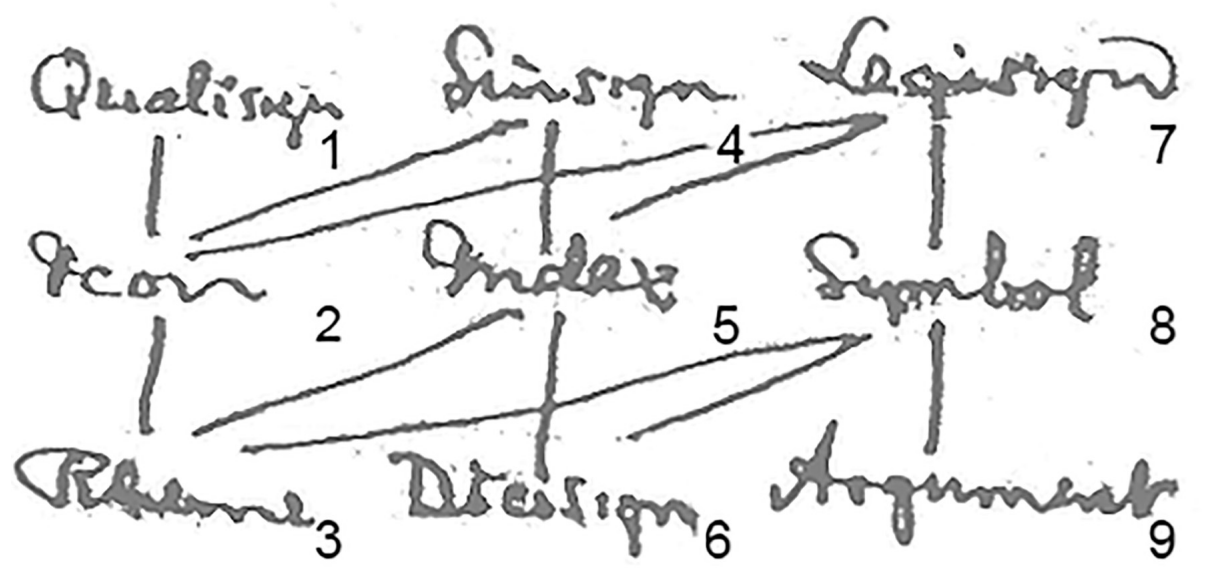

Figure 1: Draft by Peirce-from the manuscripts (MS 339, 1904)-of the relationships between the nine sub-signs, to assemble the diagram of the ten classes of signs (Figure 4). It is the only known 'graphic set', where Peirce has the nine aspects of the sign, with the correlates vertically, and the trichotomies horizontally. He did so with the only purpose of marking the relations needed to construct the triangular diagram of ten classes of signs, as can be verified with the lines that unite the nine aspects. I have added the numbers to facilitate recognizing the ten classes, and to show the relation with the SN (Figure $6)$.

It is very probably that this sketch (Figure 1 ) mislead several authors to repeat the same position of the nine aspects of the sign, like in Bense-Walters text (Figure 2) or, much worse, to add a diagram like Sheriff-a grid-around the nine words (Figure 3 ) without any further semiotic purpose.
1.1 = cualisigno;
1.2 = sinsigno;
1.3 = legisigno;
2.1 = icono;
2.2 = index;
2.3 = símbolo
$3.1=$ rema;
3.2 = dicent;
$3.3=$ argumento

Figure 2: Spanish version by Max Bense and Elizabeth Walter (1973 [1975]: 176) of the nine aspects of the sign in La Semiótica. Guía alfabética. It is worth noting that those authors add a numbering that indicates the interrelation - or intersection? - between Trichotomieshorizontally-and Correlates-vertically. Could it be this the clue that led Magariños de Morentin to formulate his Cuadro de Peirce as an antecedent of the Semiotic Nonagon? 


\begin{tabular}{|c|c|c|c|c|}
\hline \multirow{2}{*}{\multicolumn{2}{|c|}{$\begin{array}{l}\text { Phenomenological } \\
\text { or formal } \\
\text { categories }\end{array}$}} & \multicolumn{3}{|c|}{ Ontological or material categories } \\
\hline & & Firstness & Secondness & Thirdness \\
\hline Firstness & A sign is: & $\begin{array}{l}\text { a "mere } \\
\text { quality" } \\
\text { QUALISIGN }\end{array}$ & $\begin{array}{l}\text { an "actual } \\
\text { existent" } \\
\text { SINSIGN }\end{array}$ & $\begin{array}{l}\text { a "general } \\
\text { law" } \\
\text { LEGISIGN }\end{array}$ \\
\hline Secondness & $\begin{array}{l}\text { A sign } \\
\text { relates to } \\
\text { its object } \\
\text { in having: }\end{array}$ & $\begin{array}{l}\text { "some } \\
\text { character } \\
\text { in itself" } \\
\text { ICON }\end{array}$ & $\begin{array}{l}\text { "some } \\
\text { existential } \\
\text { relation to } \\
\text { that object" } \\
\text { INDEX }\end{array}$ & $\begin{array}{l}\text { "some } \\
\text { relation to } \\
\text { the } \\
\text { interpretant" } \\
\text { SYMBOL }\end{array}$ \\
\hline Thirdness & $\begin{array}{l}\text { A sign's } \\
\text { interpretant } \\
\text { represents } \\
\text { it (sign) } \\
\text { as a sign of: }\end{array}$ & $\begin{array}{l}\text { "possibility" } \\
\text { RHEME }\end{array}$ & $\begin{array}{l}\text { "fact" } \\
\text { DICENT } \\
\text { SIGN }\end{array}$ & $\begin{array}{l}\text { "reason" } \\
\text { ARGUMENT }\end{array}$ \\
\hline
\end{tabular}

Figure 3: this "graph" by John K. Sheriff (1994: 41) shows the same disposition of the aspects of the sign like in Peirce's draft (Figure 1). However, Sheriff adds-only for descriptive purposes-an irregular grid without any graphic emphasis. In the last 40 years, numerous authors repeated this error, not considering the semiotic value of the grid, despite the writings on Math, Geometry, and the Existential Graphs by Peirce.

Contrary to the distortions that occurred-without any specific objective-with the scheme of the nine sub-signs, it will be Peirce himself who draws the diagram of the ten classes of signs. As we will see later, these two systems - both the $\mathrm{SN}$ and the ten-classes diagram - allow the construction of differential-but complementary-cognitive information for any qualitative research. 


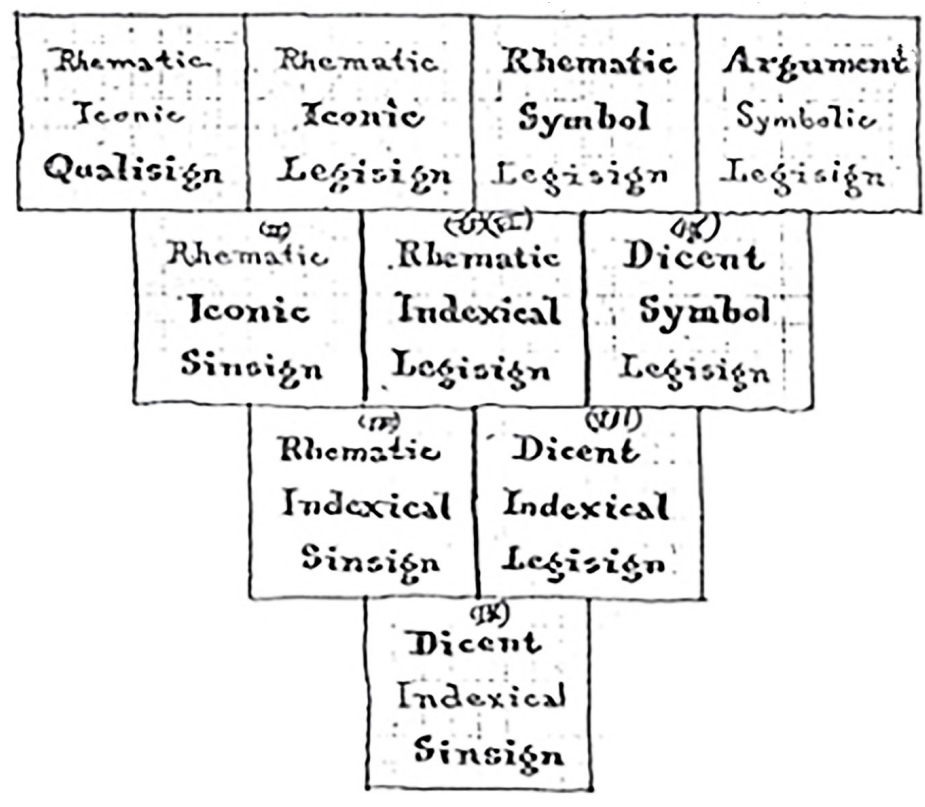

Figure 4: original draft of the diagram of the ten classes of signs by Peirce (MS 540:17, 1903).

\section{Signs, sub-signs and classes of signs}

"A sign, (...) is something which stands to somebody for something in some respect or capacity" (CP 2.228, 1897). This well-known definition (Figure 5 ) does not follow the logical sequence beginning from Firstness but Peirce's statement that "Symbols grow" (CP 2.302, 1895; 1.420, 1896). The sociocultural needs and laws - the political strategies - of a community are, at any time, always the starting point for the production of objects or the enforcement of behaviors. This definition shows that a sign is a whole-a single set-which may eventually be explained or described analytically in its three aspects or sub-signs. It shows at the same time, that there is not only one theory and practice-diadic approach-but two theoretical aspects, a theoretical-theoryFirstness-and a political-theory-Thirdness-, and one practice-Secondness.

Therefore, the weathercock will be considered an Index ${ }^{2}$ only if we are interested in that aspect of this object, e.g.: to know from which direction the wind is circumstantially blowing. By doing so, the other aspects of the weather vane are completely discarded from a semiotic point of view, although this is valid in common speech. In that context, all other aspects of that sign like

\footnotetext{
2 We can also state, to be really picky with the father of Semiotics, that the weathercock, when considering the direction of the wind, is actually a Indexical-Dicisign-a Dicent-IndexicalLegisign - because to be able to say that, we actually need to have: in 1ness. some knowledge of the historical-cultural context, Legisign, in 2ness. a concrete weathercock on the roof, Index, and in 3ness. the knowledge about the physical context-a quali-quantitative acknowledgement outside of the sign itself-that there are winds that have a name like Zonda or Pampero, and a consequent value for weather or agriculture.
} 
the quality of the material and skillfulness of the artisan that did the objectSinsign and Dicisign - , or the beauty or ugliness of the same object-Rhemaare simply not considered.

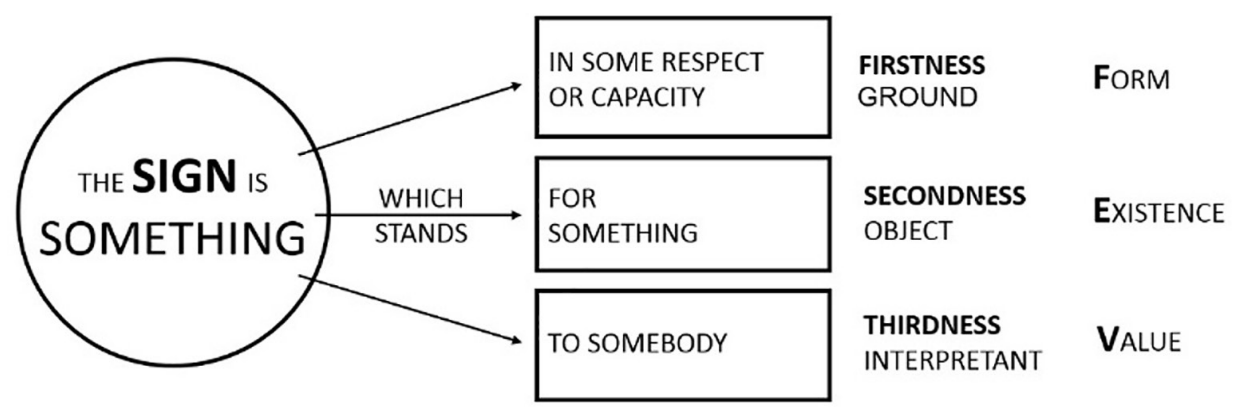

Figure 5: Diagram (Guerri 2012: 7) of the definition of sign by Peirce (CP 2.228, 1897) that shows a sign as a whole in relation to its three aspects or sub-signs. In bold the three Categories and on the right side, the terminology proposed for the Semiotic Nonagon to emphasize the crossing interrelation between Correlates and Trichotomies.

In general, for Peirce, everything can be considered or analyzed as a sign. In the context of Peircean semiotics, this means-as we will see-the possibility of recognizing three constitutive aspects in every sign (Figure 5), as well as analyzing each of these aspects again as signs, that is, with three new sub-signs or aspects (Figure 6), and so on, "ad infinitum" ${ }^{3}$ (CP 2.92, 1902) [emphasis in the original].

Therefore-according to Peirce-, for the next recursive partition of the sign we have to consider its division through Correlates and Trichotomies in relation to the three Categories. A short summary of quotations can help to understand this aspect of the Peircean proposal:

\footnotetext{
3 Consequently, given this level of recursiveness, there would be no way to represent this simultaneity of these coexisting different aspects or sub-signs in hyperspace-in an affordable and graphically manageable way-even with the help of today's digital media. "Even without Kant's categories, the recurrence of triads in logic was quite marked, and must be the croppings out of some fundamental conceptions. I now undertook to ascertain what the conceptions were. This search resulted in what I call my categories" (CP 4.3, 1898) [emphasis mine].
} 


\section{Correlates $^{4}$}

"The principles and analogies of Phenomenology enable us to describe, in a distant way, what the divisions of triadic relations must be".

"We must distinguish between the First, Second, and Third Correlate of any triadic relation. The First Correlate is that one of the three which is regarded as of the simplest nature, being a mere possibility".

"The Third Correlate is that one of the three which is regarded as of the most complex nature, being a law".

"The Second Correlate is that one of the three which is regarded as of middling complexity (...) the Second Correlate is an actual existence" (CP 2.233, 2.235, 2.236, 2.237, 1903) [emphasis mine].

Trichotomies

"Triadic relations are in three ways divisible by trichotomy, according as the First, the Second, or the Third Correlate, respectively, is a mere possibility, an actual existence, or a law. These three trichotomies, taken together, divide all triadic relations into ten classes [Figure 4 and 7]. These ten classes will have certain subdivisions according as the existent correlates are individual subjects or individual facts, and according as the correlates that are laws are general subjects, general modes of fact, or general modes of law" (CP 2.238, 1903).

"Signs are divisible by three trichotomies; first, according as the sign in itself is a mere quality, is an actual existent, or is a general law; secondly, according as the relation of the sign to its object consists in the sign's having some character in itself, or in some existential relation to that object, or in its relation to an interpretant; thirdly, according as its Interpretant represents it as a sign of possibility or as a sign of fact or a sign of reason" (CP 2.244, 1903).

"According to the first division, a Sign may be termed a Qualisign, a Sinsign, or a Legisign" (CP 2.244).

"According to the second trichotomy, a Sign may be termed an Icon, an Index, or a Symbol" (CP 2.247).

"According to the third trichotomy, a Sign may be termed a Rheme, a Dicisign (...) or an Argument" (CP 2.250, 1903) (emphasis in the original).

\footnotetext{
${ }^{4}$ To verify the correspondence and coherence of the three Correlates in relation to a concrete case, see mi article "Trayectorias de un Modelo Operativo: Nonágono Semiótico" in this Proceedings. In that article, the three Correlates of the sign Architecture are proposed as: 1. Design-as a mere possibility of Architecture-, 2. Construction-as the existence of a concrete case-, and 3. Habitability-as a necessity or law of a determinate community and time. For a wider development of the sign Architecture, Design, and Graphic Languages, see Guerri 2012: 35-43 or 2014 [2016]: 31-37.
} 


\subsection{The Semiotic Nonagon and the ten classes of signs}

Considering the former quotation from the Collected Papers, it can be easily verified that for the construction of the diagram of the ten classes of signs (Figure 4), Peirce-implicitly-proposes that the Correlates and the Trichotomies have to share the same appellation for the nine sub-signs. Subsequently, the nine sub-signs are actually a consequence of the intersection of Correlates and Trichotomies. The Qualisign-as an aspect of a sign-is the intersection of the first Correlate - as a phenomenological aspect of the sub-sign - with the first Trichotomy-as a ontological aspect of the sub-sign. In the same way, the Index is the intersection of the second Correlate with the second Trichotomy of any sign; etcetera.

By considering the concept of intersection, the SN (Figure 6) is presented as an empty grid of three columns and three rows-a double-entry tablecapable of becoming the sieve that, once agitated, allows to understand the system of relations that semiotically supports works or objects, disciplines, theories or concepts.

\begin{tabular}{|c|c|c|c|}
\hline SIGN & $\begin{array}{l}\text { 1st. Trichotomy } \\
\text { F FORM } \\
\text { possibility }\end{array}$ & $\begin{array}{l}\text { 2nd. Trichotomy } \\
\mathbf{E} \text { EXISTENCE } \\
\text { actualization }\end{array}$ & $\begin{array}{l}\text { 3rd. Trichotomy } \\
\mathbf{V} \text { VALUE } \\
\text { necessity or law }\end{array}$ \\
\hline $\begin{array}{l}\text { 1st. Correlate } \\
\text { F FORM } \\
\text { possibility }\end{array}$ & $\begin{array}{lr}\text { Form of } \mathbf{F}_{\text {orm }} & 1 \\
\text { Difference } & \text { Qualisign }\end{array}$ & $\begin{array}{rr}\text { Existence of } \mathbf{F}_{\text {orm }} & 2 \\
& \text { Icon }\end{array}$ & $\begin{array}{r}3 \\
\text { Rheme }\end{array}$ \\
\hline $\begin{array}{l}\text { 2nd. Correlate } \\
\text { E EXISTENCE } \\
\text { actualization }\end{array}$ & 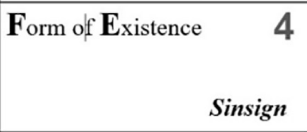 & $\begin{array}{l}\text { Existence of } \mathbf{E x i s t e n c e} \mathbf{5} \\
\text { Different } \quad \text { Index }\end{array}$ & $\begin{array}{r}\text { Value of Existence } 6 \\
\text { Dicisign }\end{array}$ \\
\hline $\begin{array}{l}\text { 3rd. Correlate } \\
\mathbf{V} \quad \text { VALUE } \\
\text { necessity or law }\end{array}$ & $\begin{array}{rr}\text { Form of } V_{\text {alue }} & 7 \\
& \text { Legisign }\end{array}$ & $\begin{array}{rr}\text { Existence of } \mathbf{V} \text { alue } & 8 \\
& \text { Symbol }\end{array}$ & $\begin{array}{l}\text { Value of } \mathbf{V} \text { alue } \\
\text { Differentiation Argument }\end{array}$ \\
\hline
\end{tabular}

Figure 6: Diagram of the Semiotic Nonagon with its nine sub-signs or aspects of the sign. In italics the original terminology by Peirce, and in regular the terminology proposed by Magariños de Morentin (1983: 91; 1984: 195) to differentiate the practical application of the categories and sub-signs in the semiotic nonagon from the original logic-philosophical proposal by Peirce, and in this way establishing an epistemological difference. The diagonal difference-differentdifferentiation was proposed by Martin Krampen. The VE-the Dicisign, as a quantitative proposition-is the connection, the way out of the $\mathrm{SN}$, between the sign and the world. 
Thus, the SN acts in two senses: it provides a taxonomy-a phenomenological description of the object to be analyzed-and at the same time; it allows an approach from the internal cognitive processes that the grid itself shows as interdependent relationships. The $\mathrm{SN}$ is based on maintaining the central concepts of the Peircean sign theory, but operating a cut in the Gordian knot of the sign for a practical purpose. Anyway, I am aware that the $\mathrm{SN}$ is a graphic representation that Peirce never imagined because it visually contradicts his conception of the sign that according to his philosophical proposal should be represented in the impossible hyperspace ${ }^{5}$.

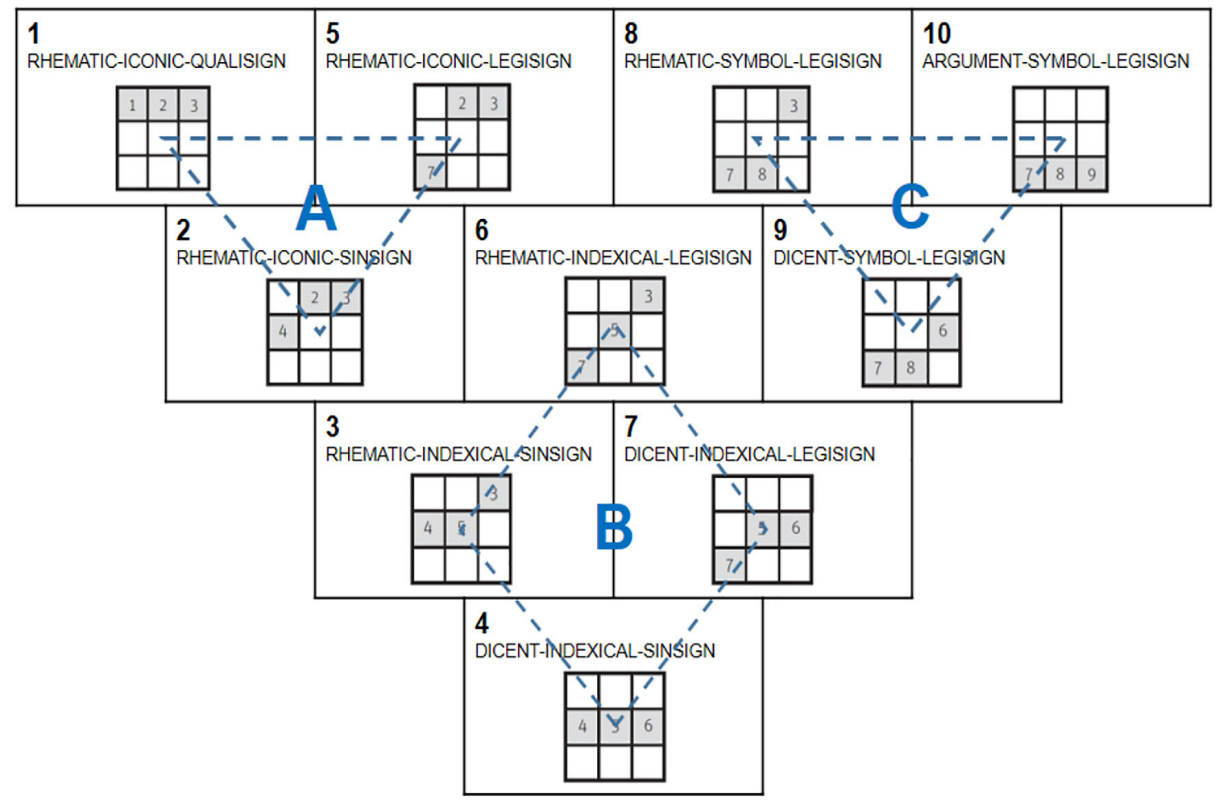

Figure 7: Diagram of the ten classes of signs (Guerri 2014 [2016]: 25; 27). We have added in each of the ten classes the path followed by the sub-signs through the SN. The dotted figures and the letters indicate constancies in the participation of the Icon-in A-, the Index-in B-, and the Symbol-in C (Magariños de Morentin 2008: 145).

\subsection{Some differences between the two operative models}

The general aim of the semiotic nonagon is to be a logic and diagrammatic device with which have under cognitive control the available knowledge related to any sign, e.g., a concept, an object or a behavior. The purposes is

\footnotetext{
${ }^{5}$ It is known that Jacques Lacan has participated in the seminars that François Recanati dictated in Paris, on Peirce. Thus, paraphrasing and decontextualizing a well-known saying by Jacques Lacan (1972-1973 [1981]: 113-114) we could also argue that reality-even if it is not the same as Lacan's "the Real" - is that which "does not cease not to be inscribed" symbolically.
} 
to understand a sign but also to be able to construct a new one. It is about understanding and being able to explain the specific singularities of the sign that will be described in nine, twenty-seven or eighty-one aspects according to the needs of the ongoing semiotic investigation.

The SN seeks to answer a precise question: what is this? Or, how much do we know exactly about our Dynamic Object under research? Of course, the SN will not answer by itself, but will show aspects and interrelations of the sign, and perhaps also some empty spaces due to the researcher's limited knowledge.

The SN allows only a synchronous analysis of any sign. It represents a conceptual space, therefore, unitary, unique and synchronous. Time-in a hypothetical diachronic analysis - must be carried out by successive synchronous analyzes. The changes in the history of a sign-or just the history of an aspect of the sign-have to be visualized by overlaying successive SNs. Consequently, each superposed synchronic-and historical-grid of the sign (Guerri 2014 [2016]: 37) will show the conceptual changes that can be detected over time in each of the nine or twenty-seven aspects.

On the other hand, the internal and external relations of the $\mathrm{SN}$ can also be considered, towards the interior of the $\mathrm{SN}$ and towards the exterior world (Guerri 2014 [2016]: 35).

The Value of Value-the Argument-is the place of the Brief, of the reason to be, the political strategy of that sign in a certain community and time. The $\mathrm{VV}$ is the plot strategy that allows inferring the other eight sub-signs. The necessities, laws, sociocultural values of the Argument are those that enable the abductive process that allows to propose a solution-a new sign-to the problem raised in the VV.

The Value of the Existence - the Dicisign as a proposition ${ }^{6}$ - is the place of connection of the sign with the external world. The VE will account for the value of the EE - the Index - fundamentally, in its quantitative aspects, by comparison in the world outside the sign itself.

The Value of Form - the Rhema-is the place to evaluate the formal, aesthetic values that already exist in the world and that will therefore condition a priori some aspects of the sign (Guerri 2014 [2016]: 17-20).

On the other hand, if an abstract sign is analyzed, a concept such as "Manipulation" (Figure 8), the SN will allow to understand the cognitive forms of manipulation (Acebal 2016: 97-110), while the diagram of the ten classes of signs (Figure 9) will allow organizing the figures of manipulation as social products, as contextual behaviors (Acebal 2016: 110-113).

\footnotetext{
${ }^{6}$ Every proposition is verified and gains a specific value in a concrete context. "Symbols which also independently determine their objects [VE or Dicisign] by means of other term or terms, and thus, expressing their own objective validity, become capable of truth or falsehood [by qualitativequantitative comparisons], that is, are propositions" (CP 1,559, 1867). [emphasis in the original]
} 


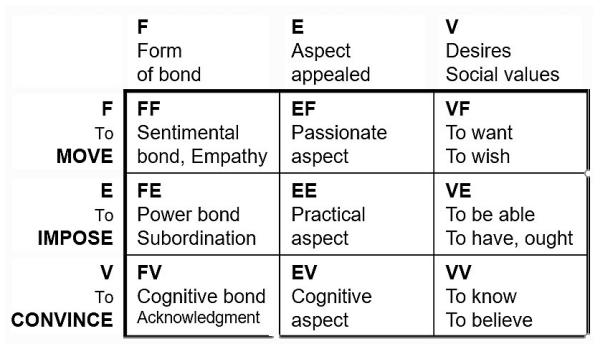

Figure 8: adapted diagram of the SN by Martin Acebal (2016: 101) for the sign "Forms of manipulation".

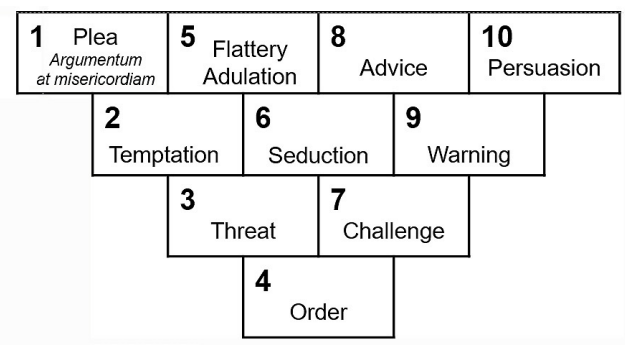

Figure 9: adapted diagram of the ten classes of signs by Martin Acebal (2016: 111) for the "Figures of manipulation".

\section{Some results of the use of the Semiotic Nonagon}

\subsection{The Graphic Language TSD}

The most important semiotic operation that I could carry out from the concept of category and from the classification of Peircean signs is undoubtedly having understood that César Jannello's "Theory of Delimitation" (1984 [1988]: 483-486) was nothing less than, with my later developments, the third graphic language after the 15th Century Perspective-conic projections-and the 19th Century Monge System-orthogonal projections. In the early 1970s, Jannello (1977: 24-28) created the Morphic Paradigm - a dictionary of form-(Guerri 1988b; 2012: 101-121), a graphic-geometric system that relationally orders all the figures that Geometry studied entitatively. However-and despite having got, already in 1968, the Collected Papers of Charles S. Peirce for the library of the Faculty of Architecture-Jannello denied the possibility of a Tactic Paradigm-a grammar of form. Despite Jannello's position, I was able to define for the III Congress of Palermo in 1984, the Tactic Paradigm (Guerri 1988a: 352) from a pure triadic logic. By the time the Proceedings were published in 1988, we had already developed the necessary drawings to graphically demonstrate the existence and functioning of this graphic grammar (Guerri 1988b: 398-401). The 2009 doctoral thesis "From the Theory of Delimitation to the Graphic Language TSD", develops in detail that story of a specific new visual semiosis produced by TSD or relational projections (Guerri 2012).

\subsection{The treatment of color}

Theories of the syntax of color, and the perception of color have both been comprehensively addressed over the two past centuries. Meanwhile, the problem of the treatment-or use, in the broadest sense-of color, while routinely accommodated, has never been satisfactorily sorted out since the first 
attempt by Goethe in his well-known Zur Farbenlehre (1810). In 2001, William Huff presented a paper on the treatment of color at an International Congress of SEMA-Sociedad de Estudios Morfológicos de la Argentina. With his student at Pittsburgh and Buffalo, Huff had compiled a list of thirty-five criteria of discrete treatments of color. Generally agreeing with the paper's semiotic approachoriginally proposed by Martin Krampen according to Charles Morris's semiotic model-I recommended the submission of the long list of criteria to the SN. After a re-examination of the initial thesis, the list of criteria remained of twenty-four. One criteria of the prior list was discarded as inappropriate; some were seen as different aspects of the same category and were merged. Consequently, in the process of sifting, not all twenty-seven prescribed categories were immediately evident; for in the reapportionment of the original list, a few boxes turned up empty. Notwithstanding, by virtue of the nonagon's combinative operation, a diagnosis could be made about what-particular to the treatment of colormight go into any empty box: Credible new, previously unforeseen criteria were prompted (Guerri and Huff 2005; 2006; 2014). Although, for descriptive purposes, the twenty-seven boxes SN were completed, synthetically there are only three general criteria for the use of color:

1. Reasons related to color theories-Firstness-for example: Mondrian decides to use only primary colors;

2. Technical-technological reasons, having or not the pigment in an artisanal or industrial version-Secondness-for example: due to the poor quality of the available paints, the mosaics guaranteed color durability; and

3. Socio-cultural, political reasons-Thirdness-for example: the color for mourning is black for us but it is white in Japan.

The bibliography quoted at the end of this paper, shows other fourhand written articles with William Huff, where the NS is used to understand or systematize various conceptual problems (Guerri and Huff 2004; 2007a; 2007b).

\subsection{The manumission of the images}

The article in Lexia-(17-18, 2014: 71-90) devoted to Efficacious Images-proposes a revision and an expansion of the concept of performativity from a Peircean perspective. Written with three other colleagues, it seeks to demonstrate how the linguistic origin of the concept of performativity proposes only a symbolic nature for that notion, thus, limiting image analysis. The notion of the Peircean triadic sign allows to show the possibility and the need to incorporate the iconic and the indexical aspects in the analysis of visual performativity. Furthermore, by using the SN the nine sub-signs of what we called Contingent Performativity were displayed. The new concept was illustrated with an incident that took place in December 2011 in the city 
of Buenos Aires. The traditional commemorative-this time along a very long series of great photographs of the police repression of 2001-had to meet, at the end in the Plaza de Mayo, a monumental Christmas tree installed each year by the city government, which consequently was set on fire by the visitors.
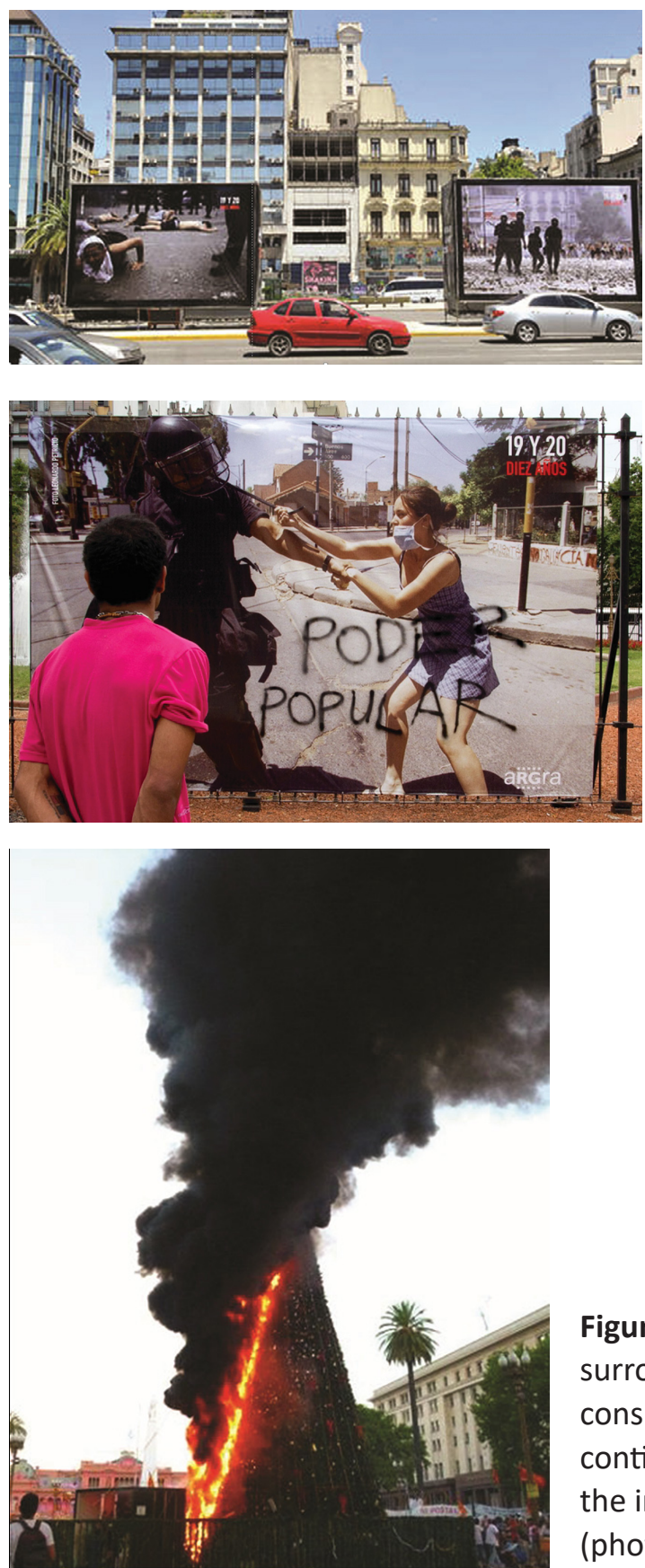

Figure 10: several gigantographies where displayed along the axis between the Congress and the Pink House all installed in the same context of background where those pictures were originally taken (photo ARGRA).

Figure 11: this photographwithout a black frame and located on the floor-blends into the background and shows the effect of its $1: 1$ size with respect to the visitors, even giving rise to the addition of graffiti.
Figure 12: finally, the Christmas tree surrounded by a high metal fence is considered an affront-due to the contingent performance achieved by the images, and is therefore burned. (photo by Cristina Voto) 
Thus, the images are actors, agents capable of altering, of modifying the spaces, the objects and bodies that surround them, of altering the course of events, of creating a performance scene, of producing a new dramatic accomplishment redistributing roles, sets and actions. It is this contingent performativity of the images-iconic, indexical, symbolic-that created the conditions so that what had been customary-a monumental Christmas tree surrounded by a high metal fence-becomes visually, materially, and politically inadmissible.

\begin{tabular}{|c|c|c|c|}
\hline & $\begin{array}{l}\text { F } \\
\text { Theoretical conditions of performativity } \\
\text { Relationship of the sign with Itself }\end{array}$ & $\begin{array}{l}\text { E } \\
\text { Economy, effects of performativity } \\
\text { Relationship of the sign with its Object }\end{array}$ & $\begin{array}{l}\text { V } \\
\text { Political values of performativity } \\
\text { Relationship of the sign with its Interpretant }\end{array}$ \\
\hline $\begin{array}{r}\mathbf{F} \\
\text { Iconic } \\
\text { Performativity }\end{array}$ & $\begin{array}{l}\text { FF } \\
\text { Color, Visual texture, Form } \\
\text { Perspective } \\
\text { Gestalt Theory } \\
\text { Cultural construction of perception } \\
\text { Limit }\end{array}$ & $\begin{array}{l}\text { EF } \\
\text { Size 1: } 1 \\
\text { Reduction of distances, Absence of frame } \\
\text { Perspective enlargement } \\
\text { Expansion of space } \\
\text { Threshold }\end{array}$ & $\begin{array}{l}\text { VF } \\
\text { Perspective as symbolic form } \\
\text { Narrative flow } \\
\text { Aesthetics of a popular revolt } \\
\text { Perceptual continuum }\end{array}$ \\
\hline $\begin{array}{r}\text { E } \\
\text { Indexical } \\
\text { Performativity }\end{array}$ & $\begin{array}{l}\text { FE } \\
\text { Photographs from } 2001 \\
\text { Gigantography } \\
\text { Photojournalistic technology } \\
\text { Site }\end{array}$ & $\begin{array}{l}\text { EE } \\
\text { Immediate contiguity } \\
\text { On-site placement of gigantographies } \\
\text { Inscription of images in urban life } \\
\text { Overprint }\end{array}$ & $\begin{array}{l}\text { VE } \\
\text { Body involvement of } \\
\text { citizens and spectators } \\
\text { Proxemical plot } \\
\text { Spatial continuum }\end{array}$ \\
\hline $\begin{array}{r}\text { V } \\
\text { Symbolic } \\
\text { Performativity }\end{array}$ & $\begin{array}{l}\text { FV } \\
\text { Mnemonic traces of "popular power" } \\
\text { Debates } \\
\text { Controversies about the events of } 2001 \\
\text { Conventionalized readings } \\
\text { Historical membership }\end{array}$ & $\begin{array}{l}\text { EV } \\
\text { Emotional, pragmatic and cognitive } \\
\text { empathy } \\
\text { Recognition of theme represented } \\
\text { Political identification }\end{array}$ & $\begin{array}{l}\text { VV } \\
\text { Annual commemoration of } 19 / 20^{\text {th }} \\
\text { December } 2001 \text {. Identity interpellation } \\
\text { Political commensurability/ } \\
\text { incommensurability } \\
\text { Discursive continuum }\end{array}$ \\
\hline
\end{tabular}

Figure 13: adapted SN of the sign Contingent Performativity of images (Acebal et al. 2014: 87). This SN synthesized the main concepts of a contingent performativity-iconic, indexical, and symbolic aspectsof the photographic installation called 19 and 20. Ten years. The SN allows not only to visualize a taxonomy of the sub-aspects of the semiotic process, but also to establish their interrelationships and interdependencies.

\section{As a kind of conclusion}

"All that you can find in print of my work on logic are simply scattered outcroppings here and there of a rich vein which remains unpublished. Most of it I suppose has been written down; but no human being could ever put together the fragments. I could not myself do so" (CP 2, 1903). By acknowledging this statement, and having elapsed more than a century from Peirce's writings, time is come to reconsider his philosophical proposal also in terms of an operative semiotic model ${ }^{7}$. Besides, being a designer-an analyst and a producer of

\footnotetext{
${ }^{7}$ Mathematicians and theoretical physicists also care about reality and truth: "While not rejecting the idea of 'reality-as-it-is-in-itself'[Dynamic Object], model-dependent realism suggests that we cannot know 'reality-as-it-is-in-itself', but only an approximation of it provided by the intermediary of models. [...] A model is a good model if it: Is elegant [1ness]; Contains few arbitrary or adjustable elements [2ness]; Agrees with and explains all existing observations [3ness], and makes detailed predictions about future observations that can disprove or falsify the model if they are not borne
} 
concrete products or behaviors - I need Semiotics to be a tool to think about those impossible 8 Dynamic Objects that can only be operated as Immediate Object through triadic design thinking, and therefore, also, with the help of the Semiotic Nonagon.

The $\mathrm{SN}$-as a diagrammatic-icon-is an operative model that relies on the logic of the three Categories (CP 1.300, 1894) proposed by Charles S. Peirce, and the geometric structure of the diagram itself. The nine-box matrix establishes taxonomic differences for each box to provide systematic information of the sign which, at the same time, always implies complex interrelations of conceptsForm, theoretical considerations-, actualizations-Existence, economic considerations - , and strategies-Values, political considerations.

Peirce argued that diagrammatic-icons always improve reasoning and advance knowledge (CP 1.54, 1896; 1.383, 1890; 2.778, 1902). The proposal of the SN collects much of this statement. However, if the Peircean theory of sign could access a representation, this representation should be performed in the multidimensionality of hyperspace, which would allow to show this infinite set of interpreters and representations. At the same time, the multidimensionality of hyperspace could not access any representation-given its structural complexity-that could be fruitful for an analytical or projective practice. Therefore, the SN starts from maintaining the central concepts of the theory of the Peircean sign, but operating a cut for the purposes of the application. The operation consists of cutting the hyperspace that the sign represents, transforming it into a diagram (CP 2.277, 1902) that, in this case, flattens the relationships of the Peircean sign, showing them in its graphic extension, in a two-dimensional space and therefore operable on the surface of a simple sheet of paper.

"We cannot make a machine that will reason as the human mind reasons until we can make $a$ logical machine (...) which shall be endowed with a genuine power of self-control" (EP2: 387, 1906) [emphasis mine]. Nevertheless, the $\mathrm{SN}$ can be considered a machine to think with. It can be characterized as "a logical machine" that responds to "a genuine power of self-control" given by the recursive logic of the Peircean triadic categories (CP 1.417, 1896) and the geometrical logic of the grid. The $\mathrm{SN}$ is proposed as an operative modelpractical and effective-to analyze any kind of problem, concrete or conceptual, that may arise in the course of qualitative research or by a practice of design. The semiotic nonagon provides no final solution to any conceptual or practical

out [eventually, several future SNs]." (Hawking and Mlodinow 2010: 51)

8 It is not completely unreasonable to assimilate the explanation of what is considered "the real" for a patient in a psychoanalytic session with the also impossible attempt of every semiotician to account for reality. Already in 1969 Lacan (1969-70 [1992]: 186) wrote: "If the real is defined by the impossible, it is situated at the stage where the registration of a symbolic articulation is defined as impossible to demonstrate" [translation and emphasis mine]. 
problem but, essentially, it is a tool that enables mapping the complexity by representing it with a relational logic of the different aspects included.

\section{References}

ACEBAL, Martín. 2016. Las figuras de la manipulación. In GUERRI et al., Nonágono Semiótico. Un modelo operativo para la investigación cualitativa, 97-113. Buenos Aires: EUDEBA and Ediciones UNL.

ACEBAL, M., BOHÓRQUEZ NATES, M., GUERRI, C., and VOTO, C. 2014. La manumisión de las imágenes. In Lexia 17-18, 2014, 71-90. Turin: Aracne. https://www.academia.edu/10284308/La_Manumisi\%C3\%B3n_de_las_ im\%C3\%A1genes (accessed 09 January 2020)

BENSE, Max and WALTER, Elizabeth. 1973. Wörterbuch der Semiotik. Köln: Kiepenheuer \& Witsch. Español: La Semiótica. Guía alfabética. Barcelona: Anagrama, 1975.

GUERRI, Claudio F. 1988a. Semiotic Characteristics of the Architectural Design Based on the Model by Charles S. Peirce. In M. Herzfeld and L. Melazzo (eds.). Semiotic Theory and Practice, Proceedings of the III Congress of the IASS-AIS. Palermo 1984, 347-356. Berlin: Mouton de Gruyter.

GUERRI, Claudio F. 1988b. Architectural Design, and Space Semiotic in Argentina. In T.A. Sebeok and J. Umiker-Sebeok (eds.), The Semiotic Web 1987, 389-419. Berlin: Mouton de Gruyter.

GUERRI, Claudio F. 2000. Gebaute Zeichen: Die Semiotik der Architektur. In U. Wirth (ed.), Die Welt als Zeichen und Hypothese. Perspectiven des semiotischen Pragmatismus von Charles S. Peirce, 375-389. Frankfurt: Suhrkamp.

GUERRI, Claudio F. 2001. Lenguajes, Diseño y Arquitectura. Cuadernos 17, 211250. Jujuy: Ediciones UNJ.

GUERRI, Claudio F. 2003. El nonágono semiótico: un ícono diagramático y tres niveles de iconicidad. deSignis 4, 157-174. Buenos Aires: GEDISA-FELS.

GUERRI, Claudio F. 2012. Lenguaje gráfico TDE. Más allá de la perspectiva. Buenos Aires: EUDEBA.

GUERRI, Claudio F. and HUFF, William S. 2004. Analyses of the Bauhaus's Preliminary Course under its Three Masters. In B. LAMIZET (Ed.) Proceedings of the 8th. International Congress of the IASS-AIS, Lyon, France (CD-ROM).

https://www.academia.edu/41693205/ANALYSES_OF_THE_BAUHAUS_S_ PRELIMINARY_COURSE_UNDER_ITS_THREE_MASTERS (accessed 09 January 2020) 
GUERRI, Claudio F. and HUFF, William S. 2005. A Comprehensive Treatment of Color, Submitted to the Semiotic Nonagon I. In J. L. NIEVES and J. HERNÁNDEZ (eds.), Proceedings of the 10th Congress of the International Colour Association, vol. 2, 1521-1524. Granada: AIC.

GUERRI, Claudio F. and HUFF, William S. 2006. A Comprehensive Treatment of Color, Submitted to the Semiotic Nonagon II. In J.L. CAIVANO and M. LÓPEZ (eds.), Color: ciencia, artes, proyecto y enseñanza, 191-202. Buenos Aires: Nobuko.

https://www.academia.edu/16332326/A_Comprehensive_Treatment_of_ Color_Submitted_to_the_Semiotic_Nonagon (accessed 09 January 2020)

GUERRI, Claudio F. and HUFF, William S. 2007a. Tres maestros del Curso Preliminar de Diseño en la Bauhaus. deSignis 11, 185-194. Buenos Aires: GEDISA-FELS.

http://www.designisfels.net/revista/estetica-y-semiotica-bordes-de-larepresentacion (accessed 09 January 2020)

GUERRI, Claudio F. and HUFF, William S. 2007b. Yves Klein's Monochrome or why Examples Fail to Convey Meaning Congruently. In Communications. Proceedings of the VIII Congress of the IAVS-AISV, Vol. 1, 91-98. Istambul: Kultur University.

GUERRI, Claudio F. and HUFF, William S. 2014. A Comprehensive Treatment of Color, Submitted to the Semiotic Nonagon III. Leporello version edited by the authors:

https://www.academia.edu/16332326/A_Comprehensive_Treatment_of_ Color_Submitted_to_the_Semiotic_Nonagon (accessed 09 January 2020)

GUERRI, Claudio et al. 2014. Nonágono Semiótico. Un modelo operativo para la investigación cualitativa. Buenos Aires: EUDEBA and Ediciones UNL, $2^{\text {nd }}$ edition 2016.

GÖTHE, J.W. von. 1810. Zur Farbenlehre. 2 Vols. Tübingen: Cotta.

HAWKING, Stephen and MLODINOW, Leonard. 2010. The Grand Design. New York: Bantam Books.

JANNELLO, César V. 1977. Para una poética de la prefiguración. Summarios 9-10, 24-28.

JANNELLO, César V. 1980. Diseño, lenguaje y arquitectura. Buenos Aires: FAUUNBA.

JANNELLO, César V. 1988. Fondements pour une sémiotique scientifique de la conformation délimitant des objets du monde naturel. In M. Herzfeld and L. Melazzo (eds.), Semiotic Theory and Practice, Proceedings of the III Congress of the IASS-AIS, Palermo 1984, 483-496. Berlin: Mouton de Gruyter. 
LACAN, Jacques. 1972-1973. Encore-Aún. El Seminario XX. Buenos Aires: Paidós, 1981.

MAGARIÑOS DE MORENTIN, Juan A. 1984. El mensaje publicitario. Buenos Aires: Hachette. $2^{\text {nd }}$ edition, Buenos Aires: Edicial, 1991.

MAGARIÑOS DE MORENTIN, Juan A. 2008. La semiótica de los bordes. Córdoba (Arg.): Comunicarte.

PEIRCE, Charles S. 1931-58. Collected Papers of Charles Sanders Peirce. In C. HARTSHORNE y P. WEISS (eds.) vols. 1-6; and in A. W. BURKS (ed.), vols. 7-8. Cambridge: Harvard UP.

PEIRCE, Charles S. 1998. The Essential Peirce. Selected Philosophical Writings. V. 1 (1867-1893). HOUSER, N. \& KLOESEL, C. (eds.). V. 2 (1893-1913). Bloomington and Indianapolis: Indiana University Press.

SHERIFF, John K. 1994. Charles Peirce's Guess at the Riddle. Bloomington: Indiana UP. 


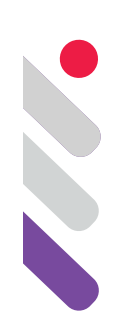

\title{
Trajectoires de la sémio-linguistique
}

DOI: 10.24308/IASS-2019-8-011

\author{
Anne Hénault \\ Université Paris-Sorbonne \\ anne.henault@outlook.com
}

Qu'il me soit permis, avant tout, d'adresser tous mes vifs remerciements aux universités de Buenos Aires, de Córdoba et de Rosario qui nous accueillent, ainsi qu'aux organisateurs qui ont si parfaitement su planifier ce 14th World Congress of Semiotics. Je voudrais également exprimer toute ma gratitude à nos chères collègues, Marita Soto (UNA) et María Teresa Dalmasso (AAS) qui ont orchestré l'événement avec une grâce, une vigilance et un sens de l'accueil exceptionnels. Le résultat de tant de soins est que nous sommes reçus dans une atmosphère chaleureuse, libérale et plurielle qui facilite grandement les échanges entre les divers courants des recherches sémiotiques mondiales dont AIS/IASS est la réunion et l'expression. Et le résultat de tant de compréhension se traduira, immédiatement, pour notre discipline, par des alliances et des performances scientifiques accrues.

Je suis heureuse de prendre la parole dans cette session partagée avec Lucia Santaella. D'autres Congrès AIS nous avaient donné l'occasion de nous rencontrer si bien que Lucia Santaella fut un des premiers auteurs auxquels j'ai pensé comme porte-parole de la séméiotique élaborée à partir des travaux de Ch. Sanders Peirce, lorsqu'autour de l'an 2000, j'ai mieux senti l'importance de faire dialoguer les recherches sémiotiques de l'Europe et de l'Amérique, à partir d'un point de vue pratique, celui de leurs applications dans les divers domaines de la vie sociale ; une expérience de ce genre s'imposait ; l'idée était de sélectionner quelques uns de ces domaines d'application où deux des grandes écoles de sémiotique, l'une inspirée par C.S.Peirce et l'autre dérivée des principes de F. de Saussure) étaient alors très présentes. L'idée était de réaliser un montage tel qu'il permettrait de publier, face à face, pour chacun des domaines retenus, quelques applications fortement représentatives de la manière dont, d'une 
part, le courant peircien et, d'autre part, le courant saussurien ${ }^{1}$ abordaient ces domaines et les optimisaient éventuellement. Le tout aboutit au volume de 758 pages $^{2}$ qui fut publié par les Presses Universitaires de France (PUF) sous le titre Questions de sémiotique.

Cet ouvrage, donc, a publié deux textes importants de L. Santaella Braga: Une introduction générale sur ce que sont les travaux pratiques de la séméiotique de C.S. Peirce ("Introduction - La mise en œuvre de la séméiotique de Peirce. Difficultés et stratégies» ( $p$ 431-440) et un article mettant en évidence l'originalité de la conception peircienne de l'esthétique, («L'esthétique de Peirce et l'art» p745-752). Je me réjouis de ce que ce Congrès AIS nous fournit l'occasion de prolonger des échanges aussi essentiels.

La conférence de Lucia Santaella que nous venons d'entendre a insisté sur les liens de la sémiotique et de la communication, puis elle a exposé les diverses contributions que la séméiotique, issue des vues de Peirce, a apportées à la maîtrise des " destinées expansionnelles de la communication» (Th. Sebeok) telles que nous les observons après l'explosion digitale; elle a affirmé également qu'il faudrait aussi intensifier la recherche du côté de la sémiotique des systèmes de signification. Cette directive, fermement assumée, contient la promesse d'une intensification des échanges, entre le courant peircien qui se voulait sémiotique de la communication et le courant saussurien qui s'est fait connaître comme sémiotique de la signification, en découvrant et en exploitant d'une manière systématique, un certain nombre d'ensembles de relations abstraites, donc de clusters de la signification (tels que les structures narratives, les structures élémentaires, les structures modales ou les dispositifs aspectuels) par lesquels s'organisent les divers partages du sens au sein de la vie sociale.

\section{Trajectoire I : D'où venons-nous ?}

Une physique du sens dont la construction théorique est fascinante.

Comme Paolo Fabbri, je redoute un relâchement des exigences initiales (théoriques et pratiques), qui ont fondé la sémiotique, en particulier chez ceux qui se réclament de l'héritage du courant européen (issu, principalement, des travaux de Saussure, Hjelmslev et Greimas; en réalité, c'est une longue liste de précurseurs qu'il faudrait citer ici). Et je soutiendrai, avec Paolo, qu'il y a un risque suicidaire pour la sémiotique, à tenter de s'affranchir étourdimentdes

\footnotetext{
${ }^{1}$ A. Hénault, dir.2002, Questions de sémiotique, Paris, PUF, coll. Premier cycle. Par exemple, pour Sémiotique et biologie, le courant saussurien présentait une analyse narrative (réalisée par F.Bastide) de l'expérience de Claude Bernard prouvant la fonction glycogénique du foie tandis que le courant peircien était représenté par Jesper Hoffmeyer et Claus Emmeche exposant « l'actionsigne des membranes » dans la vie organique.

${ }^{2}$ Les épreuves étaient beaucoup plus amples : la maison d'édition nous obligea à retrancher en catastrophe, plus de 200 pages, ce qui ne fut pas fait dans des conditions optimales.
} 
principes épistémologiques et des règles de méthode par lesquels elle a commencé à se construire.

Mais je n'irai pas jusqu'à dire, comme Paolo Fabbri, que la sémiotique est en crise. Ou plutôt, je parlerai seulement d'une crise de croissance, assortie, actuellement, d'une nouvelle période de travail underground, notamment à propos de la sémiotique du sensible et des passions, avec des résultats, euxmêmes déjà impressionnants et très prometteurs pour l'avenir.

Voici donc, d'abord, en quelques mots, comment je pourrais résumer la trajectoire initiale de la sémiotique, vue par la génération de ceux qui ont travaillé directement avec A. J. Greimas, Cl. Levi Strauss, E. Benveniste ou d'autres pionniers de la période "structuraliste " $^{3}$. Nous pensons profondément que tout ce travail théorique, rebutant pour les nouveaux venus en sémiotique, est, en réalité, nécessaire et incontournable. La génération dont Paolo Fabbri s'est fait le porte-parole n'a aucun mérite à demeurer fidèle au socle de connaissances sémiologiques et sémiotiques qui s'est constitué, en Europe, tout au long du $X X^{\circ}$ siècle. En effet l'entrée en sémiotique de cette génération s'est faite sous le signe du plaisir neuronal: Chacun des chercheurs les plus engagés aura été attiré, captivé en même temps que sidéré par la beauté abstraite des premières découvertes de Saussure, concernant les structures profondes du langage. Nous comprenions parfaitement à quel point elles deviendraient instrumentales lorsqu'on finirait par savoir définir les niveaux d'abstraction réellement pertinents pour nos différentes recherches et lorsque on accepterait que les évidences ne soient pas de même nature, au niveau profond et au niveau de surface. Ce qui impliquait de renoncer à un immémorial «soi-disant bon sens interprétatif» que, dès ses premiers résultats, la sémiotique saussurienne bousculait résolument.

Nous nous sommes embarqués dans cette aventure cognitive, sans calculs de carrière et sans même avoir la possibilité de vérifier si ces nouvelles orientations de la recherche étaient un leurre aussi trompeur que les Sirènes

\footnotetext{
${ }^{3}$ Ce terme est trompeur, on le sait. Greimas avait une position intéressante à ce sujet ; il considérait qu'avec le carré sémiotique, il avait effectivement repéré, dans l'immanence du langage, une structure au sens propre du terme ; mais que cela ne faisait pas de lui, pour autant un " structuraliste ", terme abusif forgé par les médias qui n'y connaissaient rien ; qu'aucun des gens classifiés ainsi par les médias ne pouvait se voir comme un "structuraliste " (ni d'ailleurs, n'avait découvert la moindre structure ) même si le terme était commode pour singulariser, historiquement, une période ; le malentendu provenant du fait que toute démarche vraiment scientifique aboutit nécessairement à découvrir des régularités qui se schématisent comme des structures. Archimède était plus structuraliste que Michel Foucault, Barthes et Lacan réunis. Finalement ce que désignait ce terme journalistique était ce qui apparaissait, au début des années soixante, comme la $1^{\circ}$ génération de penseurs capables de construire un savoir de type solide et objectif, dans des domaines qui avaient été désignés comme la chasse gardée des littéraires, depuis l'époque récente où, avec le romantisme, on avait commencé à opposer esprit littéraire intuitif et humaniste à esprit scientifique objectif et rationnel. Une attitude qui n'avait cours ni avec Léonard de Vinci, ni avec Descartes, Leibniz ou Gœthe.
} 
d'Ulysse ou si elles étaient vraiment une des sciences du futur. Peut-être n'étions-nous pas suffisamment conscients du risque que nous prenions, en adoptant les schématismes de la sémiotique saussuro-hjemslévienne, un geste qui impliquait une véritable spécialisation et qui allait donc nous couper de la parole commune et des échanges fluides et immédiatement compris ; nous nous exposions ainsi au rejet de ceux qui allaient décréter que nous étions en train de perdre tout bon sens, tandis que nous pratiquions une plongée des plus radicales, dans l'abstraction, avec l'obligation (toujours assez difficile à accepter), de passer par la mise entre parenthèses, l' époché du référent.

La suite de notre histoire a montré que cette suspension des évidences forgées par les divers «bon sens», élaborés et imposés par les différentes cultures, était rigoureusement nécessaire pour permettre à la recherche de commencer à faire apparaître ces universaux que sont les clusters de relations presque vides de charges sémantiques qui sont l'objet déclaré et le résultat, d'ores et déjà permanent, de la théorie de la signification.

Nous ne mesurions pas la charge de travail que cela allait représenter pour nous : une fois engagés sur cette voie, il nous fallut nous ensevelir dans de difficiles lectures transdisciplinaires, des élaborations théoriques et de minutieux travaux d'analyse qui exigent des investissements de temps si considérables qu'ils ne sont plus guère acceptés, aujourd'hui, par les jeunes chercheurs pressés qui nous rejoignent.

Notre obstination était soutenue par une exaltation cognitive qui nous aiguillonnait tous de la même façon et qui, donc, homogénéisait et soudait le groupe, malgré l'incroyable disparité de nos attentes, de nos provenances et/ ou de nos formations antérieures. Cette stimulation thymique tenait, en partie, à la sensation rare provenant de l'impression que nous éprouvions tous, sans jamais en parler entre nous- de mobiliser des ressources mentales, des zones de nos cerveaux tout autres que celles qui avaient été sollicitées par nos formations et nos pratiques antérieures. Dès nos premiers efforts, en direction d'une compréhension sémio-linguistique des vues si radicalement novatrices de F. de Saussure ${ }^{4}$, nous étions conscients de pénétrer dans un monde du savoir entièrement nouveau, ce qui déclenchait en nous la griserie que suscitent les découvertes de continents inconnus.

Une posture épistémologique rigoureusement formelle et factuelle, très éloignée de l'attitude philosophique et/ou spéculative propre au travail peircien.

Si nous consentons à considérer le face-à-face entre les deux sortes de sémiotiques dont il est question dans cette séance, avec le recul qu'implique la notion de Trajectoires, thème de ce congrès, force est de constater que le seul véritable obstacle à notre intercompréhension provient du fait que cette

${ }^{4}$ Hénault, 2019,9-54. (in Histoire de la sémiotique) 
sémiotique n'est absolument pas de la philosophie, au contraire de ce qui advient chez Umberto Eco ou chez Peirce. Elle n'est pas de la spéculation comme chez beaucoup d'essayistes, elle est une attitude mentale tout à fait différente. Et la vraie difficulté que rencontrent ceux qui ne sont pas suffisamment préparés à la découverte de la sémiotique européenne, tient à ce qu'il leur faut accepter, à un moment où à un autre, la sorte de mutation qui permet de parvenir à une approche différente (moins intuitive et plus directement objectivable) des significations langagières. Avec la sémiotique saussurienne, l'attitude d'explicitation prétendument substantielle, est suspendue, mise entre parenthèses, au profit d'une démarche démonstrativement formelle.

Pour le texte verbal, les premiers exemples de ces pratiques, ont été fournis par A.J.Greimas, avec les diverses analyses qu'il a consacrées à des nouvelles comme "La ficelle » ou " Deux amis » de Maupassant ou à des textes de sciences humaines comme ceux de G.Dumézil ${ }^{5}$. Cette approche formelle permet de dépasser les interprétations, d'apparence substantielle, auxquelles nous avons été conditionnés, selon les traditionnels pactes de lecture des grands textes nationaux qui remontent à l'Antiquité grecque ou romaine; I'apprentissage du sens s'est fait par une sorte d'habitude ou d'imprégnation, sans que soit jamais radicalement mis en examen le rôle joué, dans la formation du sens, par les architectures latentes de la langue elle-même. Au contraire la sémiotique formelle est une invitation à descendre en dessous du développement verbal, pour observer, décrire et calculer le jeu relationnel du système qui le sous-tend.

Pour le texte visuel, un certain nombre d'excellents chercheurs, très proches de Greimas, ont animé des ateliers de sémiotique visuelle qui ont obtenu des résultats, bien connus, ici à Buenos Aires. Dans ce domaine, les travaux de Jean-Marie Floch continuent à faire autorité. Le succès de sa célèbre étude ${ }^{6}$ de " Composition IV » de Kandinski, tient à la manière dont il est parvenu à analyser, démonstrativement, le vocabulaire chromatique et graphique de Kandinski, propre à cette période et ainsi, à suivre le jeu complexe de références visuelles par lesquelles ces composantes abstraites se chargent réciproquement de bribes de significations, à la fois narratives et a-temporelles. II a pu élucider les énigmes de ce texte visuel, abstrait et figuratif à la fois, lorsqu'il a réussi à démontrer, en détail et avec très grande précision, comment était tramé le signifiant plastique dans ce tableau. ${ }^{7}$ Ce déchiffrement n'est pas radicalement

\footnotetext{
${ }^{5}$ A.J.Greimas, ( 1979), « Des accidents dans les sciences humaines » in A.J.Greimas et E. Landowski dirs., Introduction à l'analyse du discours en sciences sociales, Paris, Hachette Université, pp. 28-60

${ }^{6}$ Hénault dir, 2002, 121-151 : op.cit. note 1

7 Depuis lors, on a pu voir transposer ces résultats dans de nombreux catalogues d'expositions de Kandinski, à travers le monde ; malheureusement, le plus souvent, les emprunteurs de ces analyses se gardent bien de signaler la source sémiotique de leur compréhension et de leurs analyses.
} 
différent de celui qu'il fallut faire de la pierre de Rosette, pour déchiffrer les hiéroglyphes.

Ceci n'est pas le lieu où nous attarder sur les émotions mentales que suscitent ces manières de concevoir la recherche et je n'essaierai pas, non plus, de convertir ceux qui refusent, avec scepticisme ou ironie, des expériences cognitives auxquelles ils n'ont pas été préparés. Mieux vaut, toutefois, ne pas oublier que le genre de sensations mentales et de plaisirs neuronaux que nous évoquons sont des stimuli qui ont fait leurs preuves, dans les processus de recherches des sciences dures, même si ce sont principalement les grands chercheurs en mathématiques qui acceptent d'en parler le plus volontiers. ${ }^{8}$

Chacun, ici, connaît le rôle qu'aura joué A.J.Greimas dans l'instauration de la sémio-linguistique à Paris, dans toute l'Europe, puis finalement, à peu près partout dans le monde. Ce chercheur français d'origine lithuanienne, dont la vie personnelle a été particulièrement bouleversée par les remous de I'histoire politique et sociale de l'Europe, du XX' siècle, a construit, une œuvre robuste et d'une seule coulée que rien ne semblait pouvoir faire dévier, de sa trajectoire ; il conquit la liberté et la possibilité de le faire, à partir du moment où, ayant soutenu ses thèses d'état et, ayant ainsi acquis la possibilité de mener une vie d'enseignant-chercheur dans l'enseignement supérieur, il commença à développer les vues originales que sa rencontre profonde (et éblouie) ${ }^{9}$ avec les œuvres de Saussure, Hjelmslev, R.Blanché, H.Reichenbach et Merleau-Ponty lui inspirait.

L'ensemble de son œuvre a le classicisme des grands textes et ne se périme pas. C'est le socle théorique qu'il a su élaborer avec une très grande clarté et transmettre profondément, (de 1967 à sa mort en février 1992,) aux auditeurs de ses fameux séminaires de l'Ecole des Hautes Etudes en Sciences Sociales (EHESS), dont Paolo Fabbri qui nous a si fermement appelés à respecter et à prolonger scrupuleusement ce socle théorique. C'est aussi la méthode et l'ensemble de procédures interdéfinies à partir desquelles se sont développées

\footnotetext{
8 Ce thème a fait l'objet d'un long débat entre l'auteur de ces lignes et le grand poète et mathématicien, Yves Bonnefoy, à propos de la manière dont les chercheurs en mathématiques parviennent à réaliser des démonstrations historiquement réputées infaisables, parfois après deux cent ou parfois même quatre cents ans de recherches acharnées. Leur guidage mental passe souvent par des rythmes captivants parce que beaux, intenses, rapides avant de se traduire par les enchaînements d'opérations cognitives qui sont la solution, enfin découverte et partageable universellement (in Présence de la recherche, $n^{\circ} 3$, Sept. 2001, pp7-28)

9 On trouvera des témoignages des passions cognitives et des inspirations contagieuses qu'A.J.Greimas a puisées principalement chez ces auteurs (mais aussi, chez quelques autres, moins connus et peut être moins affirmés, tels que Etienne Souriau, Ch.Singevin ou R.Ruyer, dont nous comprenons, chaque jour davantage, combien ils ont compté pour lui) dans les divers entretiens privés ou publics qu'il a accordés au fil des années, ainsi que dans les comptes-rendus de débats publics qu'il a soutenus avec quelques interlocuteurs privilégiés.
} 
les applications de la sémiotique européenne. Le Dictionnaire ${ }^{10}$ (rédigé avec Joseph Courtès), l'ensemble des ouvrages théoriques et pratiques publiés par Greimas et ses élèves les plus proches, entre 1966 et 1986, composent, avec les précurseurs dont ils se réclament, le corpus théorique, base de cette manière novatrice d'aborder l'appréhension formelle des significations. Pour ce qui est des applications généralisables dans la vie courante, le volume Questions de sémiotique ${ }^{11}$ offre un échantillon représentatif des résultats atteints par les nombreux ateliers pratiques qui s'étaient greffés autour du séminaire magistral.

Aujourd'hui, un exemple d'application démonstrative d'un concept nouveau, en voie de validation par la sémiotique, a une portée comparable à celle de la $1^{\circ}$ démonstration d'un problème mathématique, finalement formulée et validée ${ }^{12}$, après être restée insoluble, parfois pendant des siècles et elle accroît le jeune savoir sémiotique dans les mêmes proportions. De même que les noms de leurs découvreurs demeurent associés à chaque nouveau théorème démontré, de même, en sémiotique, le nom de Greimas est attaché plus spécialement à l'économie d'ensemble de la théorie ainsi qu'aux principaux concepts opératoires de la sémiotique narrative ${ }^{13}$. D'autre part, de nombreux autres noms de chercheurs sont attachés à de notables progrès théoricopratiques de la sémiotique, nous avons déjà mentionné Jean-Marie Floch , pour tout ce qui est sémiotique visuelle (l'image, quelle qu'elle soit, artistique ou scientifique, humoristique ou publicitaire, dessin ou peinture, photographie ou Bande dessinée) ; il faut évoquer aussi Louis Panier et Jean Delorme, pour la sémiotique biblique, Michel Arrivé ${ }^{14}$ pour la proto-narratologie de Saussure et pour l'explicitation/application de la notion de connotation lancée par Hjelmslev. Ces noms sont prononcés ici, à titre d'exemples, mais, en réalité, la sémiotique est redevable à une longue liste d'excellents chercheurs, que vous connaissez bien évidemment.

Le temps est venu, maintenant, pourcette si jeune discipline, de consentir à rédiger un premier vrai Cours de sémiotique générale, organisant une progression optimale pour une initiation raisonnée à ses acquis et à ses projets ; il inclura les noms de ces pionniers, avec la juste explicitation de leurs apports respectifs. $\mathrm{Si}$ vous le voulez bien, nous ne nous attarderons pas davantage, aujourd'hui sur ce qui concerne les développements de cette première sémiotique, fréquemment

\footnotetext{
${ }^{10}$ A.J.Greimas, J.Courtès, Sémiotique, dictionnaire raisonné de la théorie du langage, Paris, Hachette Université, 1979

${ }^{11}$ Op.cit. cf. Note 1.

${ }^{12}$ Ce fut longtemps le cas pour la quadrature du Cercle, résolue par Leibniz ou pour le $2^{\circ}$ théorème de Fermat, problème mis au concours au milieu du XVII siècle et résolu, pour la $1^{\circ}$ fois, en 1994 , à Cambridge, par Andrew Wiles.

${ }^{13}$ dont le fameux carré sémiotique, la syntaxe narrative ou la codification de « l'écriture symbolique » d’allure algébrique, inspirée par les recherches du logicien Hans Reichenbach ${ }^{14}$ dans la composante strictement sémiotique de son œuvre, une sémiotique pure, qu'il distinguait fortement de la linguistique qu'il pratiquait aussi de manière experte
} 
désignée soit comme "sémiotique du discontinu " soit comme "sémiotiquestandard ". Elle a bénéficié d'innombrables introductions, traduites en de nombreuses langues. Le tout est déjà très accessible.

\section{Trajectoire II. Où en sommes-nous, aujourd'hui ? Sémiotique des passions et/ ou sémiotique du sensible}

\section{Bref historique de la sémiotique des passions}

Tentons de retracer brièvement la trajectoire des quelques trente années de recherches acharnées qui ont suivi la première annonce, faite par Greimas, en $1977^{15}$, de la nouvelle orientation qu'il entendait donner à la recherche, en direction de la sémiotique des passions ; ce fut lors d'une séance mémorable de son séminaire de l'Ecole des Hautes Etudes, à laquelle, par un heureux hasard, assistait Umberto Eco, qui, en présence d' A.J.Greimas (désormais A.J.G.), se comportait encore, à cette époque-là, comme un jeune et presque timide apprenant, même s'il s'était déjà largement fait connaître par plusieurs ouvrages de sémiologie bien diffusée.

Cette nouvelle orientation vers la question des passions était présentée comme une nécessaire conséquence des excellents résultats obtenus, en 1975-76, avec les travaux sur les modalités en linguistique et en sémiotique (principalement vouloir, pouvoir, savoir, devoir) qui semblaient concerner particulièrement l'expression passionnelle. Ces résultats avaient offert le moyen de commencer à aborder (avec des concepts opératoires, non pas philosophiques mais réellement élaborés par la sémiotique) ce nouveau domaine de la signification.

D’autre part, la foule assidue du séminaire de Greimas, (phénomène de société à l'époque, au même titre que le séminaire de son ami et disciple, Roland Barthes) considérait que les années 1964-1977 avaient déjà suffisamment travaillé la théorie de la narrativité pour qu'il soit possible de la décrire comme le système conceptuel capable de modéliser et de segmenter rationnellement le développement de n'importe quel récit. S'il en était ainsi, ce devait être parce que la première sémiotique, en gestation depuis $1956^{16}$ pouvait désormais être comprise comme la sémiotique discontinue qui s'imposait pour représenter les schématismes de l'action. Puisque l'élaboration de cette sémiotique du discontinu avait atteint un palier satisfaisant, le moment était venu de s'intéresser à la sémiotique du continu, « qui n'existait pas encore mais dont la place était marquée d'avance ${ }^{17}$, pour traiter les schématismes de la

\footnotetext{
${ }^{15}$ Actes sémiotiques, Bulletin $\mathrm{n}^{\circ} 1$, Automne 1977.

${ }^{16}$ A.J.G., 1956 « Actualité du Saussurisme », republié in Th.Broden et F. Ravaux Kirkpatrick eds. in A.J.Greimas, 2000, La mode en 1830, Paris, Puf

${ }^{17}$ Ces mots reprennent en écho la célèbre formule par laquelle Saussure annnonçait la survenue de la sémiologie)
} 
passion, tels qu'un certain nombre d'observations sémio-linguistiques avaient commencé à les décrire.

Pour beaucoup des habitués de ces fameux séminaires, ce changement de cap était agréablement surprenant mais aussi très bienvenu, car l'extrême docilité qu'A.J.G. avait obtenue de la plupart des groupes de recherches qui travaillaient selon son inspiration, risquait de conduire à d'écœurants automatismes explicatifs et à une désastreuse routine mentale, appliquant mécaniquement les divers schémas à succès. Dans son dernier ouvrage, On $n^{\prime} y$ voit rien, l'historien d'art, Daniel Arasse formule une critique humoristique ${ }^{18}$ des mauvais usages de ces schémas, dont certains ont voulu faire de confortables petites machines à déchiffrer le sens. Voici cette critique, une simple remarque en passant, au cours d'une "description " (sic) fouillée et désinvolte, de $L a$ Femme dans la vague de Courbet.

Si je voulais, je dirais que c'est un triangle sémiotique. Pas besoin Du fameux carré, vous savez, le carré sémiotique, celui qui montre comment, pour aller d'une chose à son contraire, il faut passer par son contradictoire pour se retrouver dans l'impliqué ou le contraire passer par l'impliqué pour se retrouver dans le contradictoire et là zip ! c'est facile. Bon j'arrête. Trop compliqué et puis, la sémiotique, on peut faire sans.

Dans l'esprit d'A.J.G. lui-même, sa " nouvelle " orientation en direction de la sémiotique des passions et du sensible, n'était pas une vraie nouveauté. Elle était latente depuis qu'il avait pu commencer à suivre, (de manière intermittente, en raison de ses affectations à l'étranger) les cours de M. MerleauPonty au Collège de France. Il s'était plongé dans la lecture de toute son œuvre dont la Phénoménologie de la perception. Pour qui s'accorde une lecture lente de Sémantique structurale, il est évident que l'impact de la pensée de MerleauPonty sur ce premier manifeste de la sémiotique est constant et colossal et qu'il vaut mieux repartir de Sémantique structurale, pour comprendre sa conception du perçu et du sensible, en général.

Pour les auditeurs du séminaire, la recherche en sémiotique des passions, officiellement décrétée en 1977, a suscité de nombreux travaux de recherche, publiés principalement entre $1979^{19}$ et 1995 . Mentionnons, pour mémoire:

- le bref article « De la modalisation de l'être ${ }^{20}(1979)$ qui posait comme principe :

18 Op.cit. p.88

19 Dont Actes Sémiotiques, Bulletin n³9, 1986, Les passions, explorations sémiotiques.

20 Texte inaugural du séminaire 1979-1980, publié par A.J.Greimas, in Actes sémiotiques , $\mathrm{n}^{\circ} 9$, 1979, puis dans Du sens II, 1983, p.93-102. 
"L'espace signifiant qui, au niveau des structures profondes, est articulé à l'aide dela catégorie thymique est à considérer comme homo-topique et comme hétéro-morphe par rapport à la totalité des articulations modales régissant, au niveau des structures sémiotiques de surface les relations entre les sujets et les objets " ou encore "La modalisation se présente comme le résultat d'une série de sous articulations signifiantes de la masse thymique amorphe » (p 95)

-ainsi que la réponse qu'il a suscitée de la part du mathématicien Jean Petitot, élève de R.Thom, in "Les deux indicibles ou la sémiotique face à l'imaginaire comme chair», un article qui répondait point par point aux thèses de 1979 et concluait ainsi :

« Nous avons tenté de montrer pourquoi et comment, pour être conforme à sa quête d'une anthopologie de l'imaginaire, la sémiotique devait dépasser la conception structuraliste formaliste réduisant le sens à son articulation en valeurs linguistiques. Cet accent mis sur la nature bio-anthropologique et corporelle de l'imaginaire comme chair aura pu apparaître au lecteur comme une descente aux enfers de la substance. Mais il n'en est rien. Comme nous l'avons, en effet, montré ailleurs (Petitot 1982a et 1982c), cette " substantialisation " apparente peut se ramener aux effets substantiels d'une opologisation dynamique-à partir de la théorie des catastrophes- du concept de structure.Il ne s'agit donc pas tant de passer d'une conception formelle à une conception substantielle que d'une conception formaliste à une conception dynamique de la forme » in H.Parret et H. Ruprecht, 1985, p. $302^{21}$

Mentionnons également divers articles et numéros spéciaux sur les passions qui ont jalonné les Actes sémiotiques, tout au long de ces années-là, pour aboutir à la publication

-en 1987 de l'étonnant album De I'Imperfection par AJG et

-en 1991, de Sémiotique des passions par AJG avec J. Fontanille, un ouvrage où les deux auteurs tentaient d'expliciter et d'appliquer " sémiotiquement " (c'est-à-dire, à l'époque, avec les seuls résultats de la sémiotique standard) les vastes intuitions qui étaient les leurs, à propos de la " sémiotique des passions ", laquelle, dans le développement du texte, devint peu à peu, subrepticement " sémiotique du sensible ".

-en 1994, de notre Le pouvoir comme passion,,22 où nous exposons les premiers résultats d'une sémiotique continuiste qui s'appuierait sur la notion d'éprouver. ${ }^{23}$

\footnotetext{
${ }^{21}$ Jean Petitot in H.Parret et H. Ruprecht, 1985, Exigences et perspectives de la sémiotique, Recueil d'Hommages à Algirdas Julien Greimas (p.302).

${ }^{22}$ A. Hénault, 1994. Ouvrage actuellement épuisé. Une nouvelle édition est prévue, en janvier 2021.

${ }^{23}$ Ce volume publie également l'enregistrement du dernier débat public entre A.J.Greimas et P.Ricœur qui eut lieu en 1989, précisément sur la sémiotique des passions.
} 
Toutes ces publications étaient animées de l'intense espoir de rééditer rapidement, pour la sémiotique des passions, les importants résultats de la sémiotique narrative standard, sans prendre garde au fait que les propositions de Greimas, en narratologie, s'inscrivaient dans une longue chaîne de recherches qui avaient mobilisé, avant lui, à travers toute l'Europe, depuis le milieu du XIX ${ }^{\circ}$ siècle d'innombrables spécialistes du conte populaire et des vieilles légendes. La sémiotique narrative dont il commence à parler en 1964 (Séminaire à l'Institut de mathématiques Henri Poincaré) est l'aboutissement d'au moins un siècle de recherches sémio-anthropologiques (auxquelles Saussure lui-même s'est intensément adonné24). Il faudra probablement autant de temps pour parvenir à des résultats utilisables, en sémiotique des passions.

Actuellement, la sémiotique des passions n'est plus le courant central de la recherche sémiotique. Mais on aurait grand tort de considérer comme obsolètes ou en tout cas, négligeables, ses diverses productions. Elles constituent pour la sémiotique du sensible, un acquis sur lequel il sera nécessaire de revenir, aussi longtemps que les recherches actuelles n'auront pas permis de réaliser une modélisation efficace des schématismes discursifs du sensible.

\section{Trajectoire III. Sémiotique du vivant : schématisations empiriques de l'éprouver et saisie neuronale d'actes sémiotiques identifiables}

Les recherches actuelles sont riches et diversifiées. Le sens, le sensible, le réel, Essais de sémiotique appliquée, ce gros livre noir qui vient tout juste de sortir, aux Presses Universitaires de la Sorbonne, à l'occasion de ce congrès mondial, permettra de prendre la mesure de cet éventail de centres d'intérêt, assumés par nos jeunes chercheurs, à travers le monde. En tant que chercheur passionné par l'éprouver, responsable de l'introduction de ce concept dans les problématiques de la recherche actuelle, nous sollicitons le privilège de nous attarder un peu sur cette notion, actuellement travaillée par un certain nombre de nos chercheurs. Après quoi, avant de conclure, nous dirons quelques mots d'une autre recherche en cours, dont Le sens, le sensible, le réel, Essais de sémiotique appliquée présente, d'une manière très détaillée les premiers résultats ; il s'agit d'une expérimentation qui montre concrètement comment la sémiotique et la neuro-physiologie ont commencé à converger concrètement.

\section{Schématisations empiriques de l'éprouver. Premières expérimentations.}

Avec la publication, en 1994, de notre Le pouvoir comme passion, un volume qui commençait à tirer les leçons de l'épuisement provisoire de la thématique des passions en sémiotique, nous avons tenté une expérimentation radicale, en constituant un rare corpus d'écrits personnels (datant de l'année

${ }^{24}$ Voir M.Arrivé , 2007, A la recherche de Ferdinand de Saussure, chapitre III, 83-100, Paris, PUF. 
1622) d'un jeune homme brillant et ambitieux, désireux d'obtenir du jeune roi, Louis XIII, une faveur qui le mettrait définitivement à l'abri des aléas de la vie de cour.

Ces écrits ne verbalisaient rien de cette vive passion du pouvoir mais ils la trahissaient, malgré leur auteur, par d'infimes indices qui projettent sur ces écrits " un parfum de proprioceptivité ${ }^{25}$, parfaitement décelable et susceptible d'être décrit et analysé. Nous avons forgé la notion d'éprouver pour désigner ce suprasegmental de l'expression, et nous avons proposé de rattacher cet éprouver à la strate des expressions primitives de signes de vie, assez largement commune à tout ce qui est vivant et nous avons, dès ce moment-là, commencé l'élaboration du méta-terme qui pouvait résulter de ces observations, si elles convergeaient avec d'autres résultats du même genre.

Tout se passe comme si la communauté des chercheurs en sémiotique était, actuellement, en train de valider l'expansion que promet à la recherche sémiotique cet infinitif substantivé, "/l'éprouver/ ", par rapport à la sémiotique des passions et du sensible et cela pour trois raisons :

- parce que L'éprouver s'est avéré bien plus saisissable que ne le pensaient, initialement, les linguistes ;

- parce que c'est une notion qui échappe à l'anthropocentrisme inclus dans le lexème "passions";

- et parce que les recherches actuelles de la biologie ne permettent plus de séparer radicalement les sensibilités de l'humain de celles de l'animal et du végétal. Penser en termes d'éprouver permet de traiter, sémiotiquement, l'ensemble des sensibilités du vivant, dans la mesure où les recherches biologiques de la botanique et de la zoologie des cinquante dernières années, permettent de décrire une communication végétale et une communication animale bien plus élaborées que ce qui avait été pressenti jusqu'alors: Qui peut prétendre aujourd'hui décrire sémiotiquement la manière dont se crée et s'échange le sens dans l'anthroposphère, sans tenir compte de la proprioception des animaux et des végétaux ainsi que des diverses structures, formes et canaux par lesquels surgit le sens, partout où il y a de la vie faisant société ${ }^{26}$.

\footnotetext{
${ }^{25}$ Cette formule hardie est due à A.J.G et figure dans les premières pages de Sémiotique des passions.

${ }^{26}$ Dans sa réflexion sur le sensible, Greimas était hanté par la question : « Les amibes ont-elles une âme?".

Aujourd'hui, il s'intéresserait probablement à la recherche contemporaine sur les monocellulaires qui a montré comment le physarum polycephalum, mis au défi d'atteindre de la nourriture à travers un labyrinthe, élabore rapidement l'itinéraire optimum, qu'ensuite il respecte scrupuleusement parce que ses essais infructueux sont pour lui désormais balisés par des sécrétions autorépulsives; ce qui signifie que ces êtres vivants, ni animaux ni végétaux, auxquels on n'a reconnu, pour l'instant, ni cerveau ni capteurs sensoriels, sont champions de la survie et que ce résultat est obtenu par un guidage rigoureux d'éprouver minimal, en mode attraction vs répulsion - soit une bien énigmatique sémiotique élémentaire. À explorer.
} 


\section{Pour une sémiotique de l'éprouver}

Certes au départ, le verbe " éprouver » appartient au vocabulaire commun et chacun l'entend, d'après ses propres expériences vécues. Mais une fois qu'il a commencé à entrer dans le travail sémiotique, ce terme s'est trouvé exposé aux /désémantisations/ raisonnées (Dictionnaire, ${ }^{27}$ p.93) qui proviennent des premiers résultats obtenus.

Pour garantir l'univocité des calculs de sens qu'il devra permettre, chaque terme du métalangage sémiotique passe, de cette manière, par des désémantisations successives, en fonction des résultats analytiques dont il conserve la mémoire. C'est ainsi que l'actant/Sujet/, S, de la narratologie n'inclut pas nécessairement le sème /humain/ et que l'actant/Objet/, $O$, n'inclut que fort rarement le sens de "chose " : ils se sont trouvés maximalement dépouillés de la figurativité liée aux histoires d'humains, pour devenir des places syntaxiques interdéfinies. Et de ce fait ils ont constitué une catégorie discriminatoire (cf. Dictionnaire p.107).

Nous n'en sommes pas encore à ce stade, avec la sémiotique de l'éprouver. Ici, le problème initial était de faire apparaître concrètement la dimension de sensibilisation continuiste qui parfois, marque involontairement certains écrits, et produit ainsi une sorte de suprasegmental de l'écrit, dont il n'avait jamais été tenu compte jusqu'ici ; on croyait qu'il était par définition, impossible de rencontrer du suprasegmental à l'écrit puisque ce terme de supra-segmental, désignait l'expressivité somatique in presentia et qu'il était, donc, réservé à l'expression orale, par ses effets d' intonation, d'accentuation ou de troubles articulatoires (Dictionnaire, p371), tous indices concrets, non exprimables verbalement, par lesquels peut se trahir une énonciation préoccupée ou passionnée. L'écrit n'était pas supposé pouvoir être porteur de marqueurs de cette sorte.

Cela paraissait impossible par définition, puisque le suprasegmental est un langage du corps, en deçà et au delà des mots. Le suprasegmental, c'est le corps qui se donne en spectacle et/ou qui se trahit en livrant par ses mimiques, ses intonations, ses jeux de regards, ses tremblements, ses couleurs livides, grises ou cramoisies, ses essouflements, ses émanations, les secrets d'un trouble émotionnel. Il livre ainsi, souvent malgré la personne concernée et à son insu, des /éprouvés/ qui ne peuvent, ne veulent (et souvent ne doivent) pas être signifiés, car, selon la situation de communication où ont lieu les intéractions sociales, ils peuvent faire échouer le projet de toute une vie, ou, tout simplement condamner à mort celui qui ne sait pas être sur ces gardes.

Cette réalité sociale était bien celle qui avait cours dans le temps où Richelieu s'était donné les moyens de dompter une société pointilleuse (piques

27 Dans ce contexte Dictionnaire ne peut signifier que Sémiotique, Dictionnaire raisonné de la théorie du langage, par A.J.Greimas et J.Courtès, Paris, Hachette Univ, 1979. 
d'honneur, constantes querelles de préséances qui définissaient le statut social et finalement le pouvoir et le rôle social de chacun) et batailleuse (ces hécatombes de très jeunes gens en duel qui ont tellement inspiré Alexandre Dumas). Cette société dut apprendre, littéralement " à son corps défendant ", à contrôler tout le suprasegmental de l'oral mais aussi celui de l'écrit. Les mémorialistes du temps mentionnent les changements de comportements qui commencèrent dès que Richelieu eut obtenu les pleins-pouvoirs pour se faire obéir au moyen des plus effroyables châtiments (conspiration de Chalais et tant d'autres).

L'expérience du Pouvoir comme passion s'est concentrée, sur l'année 1622, (exactement un an avant l'arrivée au pouvoir de ce Richelieu qui allait changer si profondément l'expression personnelle et les communications sociales à la Cour de France).

\section{Extension des domaines de l'éprouver.}

Quoi qu'il en soit, le travail sur Le pouvoir comme passion, entamé en 1983 et publié en 1994, a atteint le but limité qu'il s'était fixé, en montrant que du sensible pouvait s'exprimer à l'écrit aussi, tout en n'étant pas dit, tout en échappant à la lexicalisation, à la mise en phrases, aux diverses articulations (phonologiques, sémantiques et syntaxiques) qui, par définition, font que les langages verbaux sont des sémiotiques discontinuistes. L'éprouver et/ ou l'éprouvé (par opposition au formulé/formuler) est la dénomination qui a paru la plus adéquate pour désigner ce genre de circuits du sens qui, par delà les langages vocaux, caractérisent l'ensemble du vivant faisant société. Aujourd'hui, les biologistes (H.G. Döbereiner à Brême, F. Baluska à Bonn, Audrey Dussutour à Toulouse) parlent, des frontières difficiles à établir entre le règne animal et le règne végétal lorsqu'il s'agit de colonies intelligentes de monocellulaires sans cerveau, tels les blobs décrits par les chercheurs que nous venons de mentionner. Les agronomes biologistes (dont B.Moulia et H.Cochard, INRA , Clermont-Ferrand) étudient /la proprioceptivité/ des végétaux et leurs tropismes sociaux (solidarités ou antagonismes, entre espèces ) tandis que les humains emploient depuis si longtemps des «expressions» comme «je ne peux pas le (ou la) sentir ou se contentent de le faire sentir.

L'extension des domaines de l'éprouver promet à la sémiotique de joyeuses découvertes.

\section{Saisie neuronale d'actes sémiotiques identifiables}

Aujourd'hui, un chercheur venu des "sciences dures " comme David Piotrowski continue à fournir quelques unes des références auxquelles il conviendra de se rapporter pour prendre la mesure de ce qu'est devenue l'assiette épistémologique de la sémiotique dans le contexte des sciences 
cognitives et des neuro-sciences. En effet, notre recherche sémiotique actuelle a réellement commencé à opérer la jonction qui était prévisible avec divers groupes de chercheurs, opérant selon l'épistémologie des sciences dures. Des travaux comme ceux de P.Cadiot, de J.Lassègue, David Piotrowski, Victor Rosenthal et de Y-M. Visetti ainsi que ceux de J.Petitot et des nombreux spécialistes des questions de Morphogénèse dynamique, posées par les travaux du mathématicien R.Thom, achèvent de donner leur quotient de réel aux fforts théoriques de la sémiotique dont j'ai dit quelques mots au début de cette conférence-

On sait désormais démontrer que les plus élémentaires de ces schématismes abstraits (que la pensée sémiotique a commencé à traquer avec Saussure et après Saussure, avec Hjelmslev et après eux avec tous ceux -dont AJ Greimas et Paul Ricœur, convaincu par Greimas- qui assumaient les mêmes exigences théorématiques), ont des corrélats électro-encéphalographiques qu'il est devenu possible de distinguer expérimentalement, ce qui signifie qu'il est également devenu possible d'isoler et de montrer leur traduction neurobiologique.

Faute d'avoir le temps de résumer, ici, les huit étapes de la démonstration par laquelle David Piotrowski (D.P.) analyse le fait que l'acte sémiotique élémentaire de conscience de signifié reçoit une traduction neuronale parfaitement spécifique (op.ct. 98-115), nous devrons nous contenter de citer, à l'appui de cette affirmation, la conclusion de cette même étude de D.P $(2019)^{28}$ : " L'intelligibilité phénoménologique du signe : la preuve par la N400 », sachant que dans le texte ci-dessous, " EEG » se lit « corrélats électroencéphalographiques ».

De la question d'une possible intelligibilité phénoménologique du signe, nous avons proposé en ces pages un traitement bien en deça de son authentique portée philosophique et épistémologique : un traitement technique et empiriquetechnique, en ce que nous avons commencé par produire une architecture fonctionnelle du signe pourvue d'un sens phénoménologique, empirique en ce que nous avons ensuite voulu montrer en quoi cette architecture pourvue d'une signification phénoménologique coïncide avec les signatures EEG de diverses activités mentales portant sur des unités lexicales. En somme nous aurons tenté d'établir par les voies canoniques des sciences de l'expérience, l'unité du sensible et de l'intelligible sémiolinguistique, et par là même reconnu la sémiolinguistique comme science des morphologies signifiantes. (p.116)

28 "L'intelligibilité phénoménologique du signe : la preuve par la N400 » In Le sens, le sensible, le réel, essais de sémiotique appliquée, A. Hénault et al., dir, 2019, Paris, Sorbonne Université Presses, 83-116. 
Notre sémiotique actuelle assume désormais, toujours plus radicalement, sa double appartenance, scientifique et littéraire. Les échanges entre les sémioticiens, issus de formations strictement littéraires et les sémioticiens venus de la biologie, des mathématiques reçoivent, pour aboutir, la médiation des sémioticiens du concret (architectes, urbanistes, économistes ou médecins). Les efforts à déployer pour cette intercompréhension sont assez considérables mais, à l'évidence, le jeu en vaut la chandelle. 


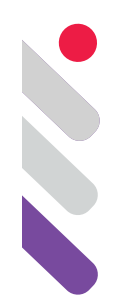

\title{
A Non-Anthropocentric Semiotics of the Writing in the Era of the Posthuman Literacy ${ }^{1}$
}

DOI: 10.24308/IASS-2019-8-012

\author{
Sung do KIM \\ Korea University \\ dodo@korea.ac.kr
}

\section{Introduction}

In the era of artificial intelligence, a new configuration of reading, writing, and textuality would signal a need to rethink our most basic humanistic and anthropocentric assumptions about the question of agency in writing in general and in narrativity in particular. In the posthuman era, if the human writer or the author has morphed into a cyborgian assemblage of human and machine, the questions of the subjectivity, the agentivity and the authorship are essential. However, these issues - the agentive role of nonhuman objects among others - have received less attention in semiotics. Drawing on non-anthropocentric cybersemiotics inspired by the works of Hayles and Latour's concept of the nonhuman actor as mediator, this work will focus on how the process of digital writing machine could be inscribed in a complex set of non-anthropocentric and posthuman semiotic practices. We would regard, as one potential model of the non-anthropocentric cybersemiotics of algorithmic writing, his actor network theory for two reasons. Firstly, this theory is symmetrical with respect to human and non-human agents, and secondly, inspired by the Greimassian semiotics, it can be defined as semiotics of materiality. (Law 1999:4)

The implications of this radical epistemological change to the notion of singular, stable, exclusively human agentivity of writing and subjective authorship will be discussed, concluding that a non-anthropocentric reconceptualization of digital writing machines serves to deconstruct the humanistic and anthropocentric belief systems that have framed our understanding of the writing in general and the narrative creativity in particular. This non-

${ }^{1}$ This work is a shortened and revised version of the article published in the following reference. Sung do Kim. 2019. A Non-Anthropocentric Approach to The Digital Writing: Some Remarks on The Agency of Digital Writing. Netcom [Online], 33-1/2. 
anthropocentric vision of extended writing in the era of artificial intelligence will also lead to a paradigmatic disruption of taken-for-granted binaries across digital and embodied signifying practices in textual and narrative production and semiosis. The purpose of this article is to discuss the question of agency in writing in general in considering the importance of computational writing machines and robot authors as the industrialized digital writing disseminates in a global scale.

\section{The emergence of new regime in the history of writing: computation as writing}

A new ecology of writing in the era of automatic and algorithmic writing is triggering entirely new aspects in deconstructing the common assumption that humans have exclusively been supposed to be the writer or the author in the conventional semiotics of writing and narrativity. In particular, as demonstrated by the very rich polysemy of the French word "écriture," the semantic, anthropological and technological extension and intension alluded to in the term of writing will be rapidly broaden with the digital revolution. (Kim 2018). Keeping in mind the adventure of writing that humanity has experienced over the past five thousand years, it is hardly an exaggeration to say that digital writing technology has provoked a profound change in the concept of writing system. In sum, a new regime of the writing is created: the machine itself can write and read nowadays. It could create even a poem or novel. According to Clarisse Herrenschmidt (2007), three fundamental inventions were produced in the graphic history of humanity: 1) the writing of the spoken language, what is commonly called writing, born in the 4th millennium BC in Sumer; 2) the writing of numbers with that of the coin struck around $620 \mathrm{BC} ; 3$ ) the writing of code with digital writing which was born for the first time with computer writing (1936 then 1948) and a second time with reticular writing (1969). After seizing the omni-potentiality of this new writing, she underlined a semiotic paradigm shift in the perspective of the graphic revolution as follows.

L'outil informatique, né par et pour le calcul, a ramené au même procédé d'écriture numérique les textes, les arts et pratiques de l'image, les sons de la musique et de la voix vivante. Cette extension manifeste une telle ampleur que le trouble nous prend à parler encore d'"écriture", Pourtant, oui, la machine écrit et écrit tout. (399).

Une révolution graphique figure-t-elle une révolution ? Oui. Si l'on prend en compte la volonté de ses acteurs, qui désirèrent avec leur invention changer l'Homme et le monde (...) Non. Car personne n'a véritablement choisi, oeuvré, milité pour la situation dans laquelle nous nous trouvons, celle d'un gigantesque chambardement sémiologique. (499). 
Languages, numbers and codes do not realize the same semiological universe. The interest of this triptych is that it invites us to ask ourselves whether digital writing or computer coding is on the way to becoming a new form of general equivalent, in place of money. In sum, one might assert that the digital media revolution is intimately related to the writing revolution. In particular, writing machines that have emerged with the development of artificial intelligence produce some complex and fundamental problems associated with the nature and the cultural practices of writing. In this regard, one of the semiotic tasks is to meditate on these words of Turing: "Mechanism and writing are from our point of view almost synonymous." According to Jean Lassègue (2012), computer science is the result of a convergence between the way of conceiving of number, language and the physical world, a convergence that only the history of writing has made possible.

What is hidden behind the expression "digital technologies" actually corresponds to the formal system covering the whole domain of the calculable - i.e. of the "writable" by a computer machine. Computer science, as its name suggests, is automatic information, more precisely it is the techno-science of information processing by automatic machines. And any computer programming supposes a discretization and a formalization, namely, a writing system. Far from dethroning the written word, digital technologies are multiplying its functions and making its uses more complex. When the information and communication sciences interrogate the "computerized media", they effectively question writing practices. For that reason, we think that to understand current digital technologies, it is first necessary to re-examine the semiotic nature of writing. According to this point of view, the computer is a plural and complex writing machine which has at least one very clear effect: the extension of the field of writing - as much as that of calculation.

As Stiegler (2014), inspired by the phehistorien André Leroi-Gourhan (2012), pointed out, writing is fundamentally a technique, and technique is one of the fundamental elements of human nature. In addition to the technical dimension, the writing also embraces a symbolic or cultural dimension. Identifying writing as a technology of human intelligence suggests that writing shapes meaning, the interrelationships of communication in human communities and a common world. Therefore, our point of view on writing is first of all a conception on technique, consisting in saying that the technique is anthropologically constitutive of the human being. The epistemology of this work is to affirm that the two dimensions of writing, namely its technical (or material) dimension and its symbolic (or cultural) dimension are inseparable. 


\section{The question of agency and autonomy of writing}

When agency is confined to consciousness and intentionality, there is little scope for extending its reach beyond the human. (Knappet \& Mafouris 2008). This human-centered view of agents and artefacts still determines epistemological basis in algorithmic writing machines. Because of this anthropocentric perspective of agency, the material or environmental counterpoints to human agency of writing have generally been given short shrift in the semiotic grammatology and digital studies as well, arguing that agency, in the real sense of the word, is a property of the human individual. Even though, thanks to the Actor-Network Theory, the idea of decentralized agency has gained momentum across the human and social sciences, we can find very little research in semiotics trying to understand the material agency of writing. In this context, the non-anthropocentric semiotics of writing attempts to (re) conceptualize the agency of writing as distributed and possessed in relational networks of human writer and materiality of writing including computational writing machines.

Since Searle's Chinese Room thought experiment, a conventional perception would suggest that computers merely match patterns and understand nothing. However, this view depends on an intensely anthropocentric view of semiosis, namely, process of meaning production and appropriation. By contrast, we could explore a cybernetic vision of writing in the thoughts of the Italian novelist Italo Calvino who delivered in 1967 his famous lecture "Cybernetics and Ghosts" in Paris. In an inspiring and even provocative manner, he raised a challenging question whether or not a computer could possibly reproduce the linguistic signs, literary conventions, anthropological constraints, social roles. From the very beginning, Calvino reminds his audience of a primal scene of the literary production: a storyteller can use a limited amount of words to create potentially unlimited number of stories by selecting and arranging certain words; in other words, he puts "the possibilities implied in his own language" into a specific forms, "by combining and changing the permutations of the figures and actions, and of the objects on which these actions could be brought to bear. Influenced by Claude Levi-Strauss' structuralist anthropology, Calvino affirms that the basic narratives operations might be invariant or quite universal between folks or cultures, "but what can be constructed on the basic of these elementary processes can present unlimited combinations, permutations, and transformations." (Calvino 1986: 6)

Calvino's answer to his opening question whether a poet can be replaced by a computer is ambivalent. On the one hand, in a perfectly material manner, he argues that a poet has always been a writing machine insofar as he combines letters according to defined rules and historically and culturally rooted conventions. (Duncan 2012). By analogy with Turing test, Calvino raises 
the even more speculative question whether or not a "writing machine" may be developed "that would bring to the page all those things that we are accustomed to consider as most jealously guarded attributes of our psychological life, of our daily experiences, our unpredictable changes of mood and inner elections, despairs and moments of illuminations". In this regard, it is legitime to identify Maillardet's writing machine conceived already in 18th century as marking a significant moment in the conceptualization of the relation between human and machines. Retreating from the materialism of the writing machine, the nineteenth century entrenched an idealist concept of the human at the heart of the study of literature.

However, in the digital era, even writing itself has been accelerated, automated, and banalized to a degree that it is beginning to disappear - as the media theorist Vilem Flusser proclaimed - from human culture altogether, becoming diffused into hidden and non-conscious, non-human processes.

"Our literature is not monumental...it does not demand consideration and contemplation. It is documentary, it teaches and instructs. Our literature wants doctors rather than wise men. It is written quickly to be read quickly. And this speed explains the dynamics of the ever-increasing flow of literature in which we are swimming." (Flusser 2011 :77)

One might also evoke the statement of Friedrich Kittler that "we do not write any more". "Human-made writing", he explains, "passes through microscopically written inscriptions which, in contrast to all historical writing tools, are able to read and write by themselves." (Kittler 1997:40). It is not only a matter of text messages, internet comments, spell-check, algorithmically generated input suggestions, but a matter of (not)knowing, on the part of the user, how these writings operate in the first place at the level of the program. (Tenen 2017). Flusser describes this condition as a "new illiteracy". In a similar context, Dan Sperber predicted in 2002 the disappearance of writing in a near future "The revolution in information and communication technology may soon turn writing into a relic of the past: it will be replaced by the automatic transcription of speech -The very symbols used in the different writing systems result from a compromise between the needs of the hand and those of the eye. Printing, and now the computer, have made possible the development of new characters which, however, must still remain similar enough to handwritten ones. This constraint could altogether disappear; a new evolution of writing systems could emerge, exclusively guided by considerations of visual ergonomics and esthetics."

Motivated by a non-anthropocentric perspective on the nature of writing, this paper will argue for a radically different view of writing's agency in digital writing technologies. Some scholars such as Hayles would call it cybersemiosis of the digital materiality. The non-anthropocentric approach of digital writing 
provides a theoretically robust way to understand how human-machine assemblages operate to configure new kinds of meanings and how these interact with nonhuman life forms to create a hybrid media ecology of writing. How do we, humans, write with computational writing machines? What are the semiotic activities do human writers and automatic machine agents share, what are the common grounds between the two? Eventually, we must elaborate concepts of these meeting points that would allow to pinpoint the proper mode of existence of both the subjectivity of human writing and machine agent of industrial and computational writing, without reducing one to the other.

Digital writing technologies are machines that behave on a scale and mechanism different from human writing. The algorithms of computational or automatic writing are invisible, intangible and extremely fast for human writers. Therefore, these computational algorithms have to be put in a textuality of human writing. In this regard, digital studies should assess the problem of interface between human writer and agents of writing machine, and the way the relation between these two categories have been conceptualized. In this regard, one could refer to Simondon's philosophy of the modes of existence since digital writing techologies are machines with their own mode of existence and proper semiosis. Also, digital algorithms of these writing machines have to be transcoded in written signs of human languages. In this regard, Turing 1936's seminal article, "On Computable Numbers" marked an inspiring moment, since he remarked with a great insight that computational machines are at their core writing machines. (Collomb Cléo \& Samuel GOYET, 2015, 2016).

However, a computational writing's algorithm that is different from the textuality of human writing, it is required to construct an extended and nonanthropocentric concept of writing that could embrace human and machine writing. This question of intermediation between two categories of writing have been dealt both in English-speaking digital theorists and French mediologists specialized in the semiotics of digital writing. However, they did not provide a non-anthropocentric conception of the agency of digital writing technologies in attributing a simple auxiliary role to the writing machines. Drawing on recent works done by Goyet $(2015,2016)$, this work would suggest a nonanthropocentric cybersemiotics of writing to rethink the nature of writing in general in the era of artificial intelligence in reexamining the relationship between human and machine writing and the question of the agentivity. The non-anthropocentric model of writing encourages students of digital media to reconsider human actor and non-human actor in the production of digital textuality with equal weight, acknowledging that the degree of agentivity and even creativity in human and machine writing has become blurring. In the era of artificial intelligence, people observe robots make poems and create a piece of movie and comedy. 


\section{Elements for the non-anthropocentric epistemology of writing}

\subsection{The relevance of ANT to machine writing: the performativity of the}

algorithmic program

The Actor-Network Theory could be considered as a method that turns our attention towards the way our world is assembled, the ways in which networks of people, ideas, discourse and material things are configured and maintained by complex relations. Therefore, ANT is based upon the assumption that not only are physical objects (tools, mediators) and symbolic tools (discursive practices) important, but that such tools can be seen as "actants", which, once endowed with power or responsibility, act on behalf of humans, have agency. An actor being called an actor-network, this theory assumes that it partakes of a greater source of uncertainty about the origin of the action. For Latour actions are not simply a human attribute, but instead an association between agents of different natures. Latour affirms that ANT does not attempt to establish symmetry between humans and non-humans. The interest in the object doesn't signify any privilege given to objective material in opposition to subjective language, values, symbols, and feelings. Non-humans can only communicate with humans on account of important processes, such as translation, articulation, delegation, and displacement to other areas or levels.

ANT is not yet a familiar model in machine writing and semiotic grammatology. There is still no application in digital studies. ANT dismantles the dichotomy between the social and the natural, the cultural and the material. It is accompanied by a subtle examination of material things or non-human actor. The basic assumption of the ANT is that the actors of social communication involve both human beings and technology, and that the material properties of a technology are developed and used in a system of social relations. That is, the ANT resists predetermined distinctions between human systems and material entities. Thus, ANT can bring about epistemological shifts in the social interpretation of digital writing machines and writing in general. In addition, ANT enables digital writing and human writing to be understood as a social practice. ANT can focus on the network of human actancy and non-human actancy, beyond the privilege of human agency. ANT offers an alternative to human agency and anthropocentric concept of writing, challenging asymmetric explanations between human and non-human action of writing. This can overcome the limits of existing digital writing studies and semiotics of media. In fact, existing digital writing studies lack an inquiry into its material aspects. ANT challenges the generalization of social systems at the macroscopic level and describes the microscopic movements of human realities and non-human realities in society. In computational writing and writing in general, the concept of actancy breaks down the anthropocentric view of agency, and gives more value to other actions performed by non-human actors. The concept of agency 
is created by actors, symbolizing humans as resources rather than as users. The agency is not predefined or predetermined, but is composed of different sources of materiality, human actors and nonhuman actors. In this sense, the potential benefits of ANT provide a new perspective for digital writing studies with the various dimensions of material and technological actors.

Recognizing the fact that the machine behaves: the performativity of writing and computer code sources

Archi-text must dismantle human-centered scriptural representations of computational processes to visualize that the machine is involved in digital text production. That is, the machine behaves and its activity belongs to the calculation. It is not difficult to renounce the human-centered conceptualization of the machine by archi-text. It is possible to admit that the machine behaves without stating that the machine acts as a human being. Archi-texts are not just crystallizing human values. Archi-texts also respond to the instructions of the machines.

The archi-text may be a non-humanized concept. This embodies the concession of technological and symbolic demands. In other words, the machine is counted. Binary writing suggested in Turing's report of 1946 can be considered as an archi-text. In this report, he says it is a binary code. Binary writing can be understood as one of the bridges between technique and language, under the form of 0 and 1 . Humans can read such binary writing, but binary writing is particularly adapted to machine activity. Turing also says that such symbolism, if it is close to computational behavior, is handled hard by humans.

The effects or impact of technology have long been of interest to social sciences. From the viewpoint of technological determinism, the role of technologies in which technology determines social sphere has been mitigated by social constructivism. In another perspective, the sociology of science and technology, especially actor network theory, has recently come to the concept of performativity to scrutinize the effects of artifacts. New pointers on the concept of performativity can help to avoid the deterministic approach by segmenting the effects of artifacts into a continuous work of one performance. The concept of performativity has already been used to understand the behavior of computer code. Latour implicitly refers to Austin's work in Aramis ou l'amour des techniques, stating that computer programs do what they say.

"Programs are recorded as text, and the mouse is engraved like eauxfortes or printed as a picture like a drawing. But are such programs acting on what they say? Yes. Because, everything, texts and things work. They are behavioral programs, and its writers put the realization to the electrons, to the signs, to the inertia, or to the neurons" (Latour 1992: 182).

In other words, the performance here is about the performance of the technique. it is executable code, which is an artifact of the written language. We have dealt with a chain of writing in the code source in that it participates in the 
stabilization of executable code. However non-executable code sources can also be subject to artistic production. It is also important to identify the code source as a product of the practice of collective writing. From this point of view, the code source should not be regarded as an artifact only in the conceptualization of technique devices, but rather as a space of writing and writing, a space of interaction between humans, and a space of writing and interaction between humans and machines. ANT observes that behavior is not simply a property of human beings, but a combination of actors. Behavior is also the second sense of technical mediation. In other words, humans are not the only realities that influence their actions. Rather, behaviors are mediated by the interdependent effects of actors. The conceptualization of material artefacts, in particular inhuman agents as intermediaries, creates a transformative nature of material objects. Such material objects can translate other actors of the assembly into a learning network.

Thus, ANT can cause epistemological changes in the social interpretation of algorithmic writing and writing in general. In addition, ANT helps understand digital writing and writing as a social and semiotic practice. ANT can focus on the network of human actancy and inhuman actancy, beyond the privilege of human free will.

ANT offers an alternative to human action and to human centralization, calling into question the asymmetrical explanations between human and inhuman materiality. This may go beyond the limits of existing digital research. Existing digital writing and writing research lacked an investigation into its material aspects. ANT challenges the generalization of social systems at the macroscopic level and describes the microscopic movements of human realities and inhuman realities in society. In narrative creation and digital writing, the concept of action breaks the vision of the human-centered agency and gives more value to the other actions of inhuman actors. The concept of agency is created by actors, symbolizing man as a resource rather than as a user. The agency is neither predefined nor predetermined, but is made up of different sources of materiality, human actors and non-human actors. In this sense, the potential advantages of ANT offer a new perspective for digital writing with the different dimensions of material and technological actors.

\subsection{Post human literacy}

The relationship between the human and the technological was also questioned by Hayles $(1999,2006)$. Hayles proposes a posthuman understanding of the relationship between the human and technological, seeing them as interdependent and merged at the level of social practice:

"In the posthuman, there is no essential difference or absolute demarcation between bodily existence and computer simulation, cybernetic mechanism and biological organism, robot teleology and human goals." (Hayles 
1999: 3). Writing machines in this view are more like technical individuals inscribed in networks of social, economic and technological relations, some of which are human, some nonhuman. The non-anthropocentric semiotics of writing is concerned with the notion of the constantly changing assemblage of human and machine writing, in particular how it may be instantiated in the interplay between print-based and digital media in the literacy practices of writers in digital media ecology.

Like human writers, writing machines and robot authors also have their embodiments, and their embodiments matter, no less than for humans. This article affirms that the non-anthropocentric semiotics of writing could be significantly enhanced by interweaving insights and theoretical constructs from ANT and posthuman theory of writing, focusing in this paper on Latour's concept of the object as mediator as opposed to intermediary, and Hayles's recent studies concerning the nature and ontological status of materiality and objects in reading and writing machines.

If we consider computational writing as distributed and hybridized, then a further theoretical strand of work may also help us to understand a posthuman context more fully. The notion of posthumanism is often associated with Haraway, in particular her 'cyborg manifesto' (1991), through which she introduces the metaphor of the cyborg as a challenge to essentialism in the feminism of the time, but also as a wider metaphor for the hybrid, blurred nature of identities in general. Haraway's cyborg deconstructs dichotomized boundaries and ways of organizing the world and categorizing human and nonhuman subjects, such as human / animal, organism / machine, physical / non-physical, arguing that post-war developments in science and technology have disrupted these taken-for-granted divisions. The prototypical notion of the cyborg is often associated with a form of literal hybrid materiality involving non-biological features such as implants. However, the notion of the cyborg can also be applied to practices and the subjectivities constituted by a posthuman concept of writing, leading to what might be termed a cyborg ontology of writing and literacy. As Hayles (1999) states: 'In the posthuman, there are no essential differences or absolute demarcations between bodily existence and computer simulation, cybernetic mechanism and biological organism robot teleology and human goals' (3). She suggested to explore the notion of embodied virtuality, definied as: '...the cultural perception that material objects are in-terpenetrated by information patterns'. (Hayles 1999: 13-14). Applying Hayles's concept of embodied virtuality, it is important to recognize that the construction of posthuman literacy might embrace the presence of nonbiological agents of writing as a new kind of subjectivity of writing. 


\section{Conclusion: towards a new ecological concept of writing}

This paper has argued that the contemporary media environment has become permeated by networks of digital mediation. Writing with a nonanthropocentric view requires human writers to think about the way non-human elements impact us as writers as well as our human readers. ANT theoreticians and posthuman scholars have addressed the need to acknowledge the power of material objects as well as the owners that reflect back on the humans who use them. In the digital era action of writing requires not just an agent but a wide array of practices, techniques, knowledges and combinations of human and non-human actants. This is especially apparent in reflexive way that human users often act in reaction to the agency of the technology they are using. A non-anthropocentric semiotics of writing doesn't ignore the human agency of writing or the author, but acknowledges that accounting only for human writers isn't enough to ensure describe the cybersemiosis of digital textuality constructed by non-human actants of writing. Viewing the human activity of writing only through a humanistic perspective limits the reach and power of the writing machines because it fails to acknowledge the autonomous actions and power inherent in digital agents of algorithmic writing and specifically in the technology that empowers us in the first place.

The non-anthropocentric semiotics of writing could be connected to the pansemiotics that affirms that communication is any form of semiosis including human-machine interface. (Petit 2013). In this regard, it could be inspired from Peirce for whom pansemiotics expands the claims of Saussurean semiotics beyond cultural domain of human communication and signification. In contrast to the Saussure's semiotics which is entirely anthropocentric, it subsumes human sphere as a subspecies of semiotic processes, rather than an exclusive interpreter or generator of signs. Therefore, it might have implications for a semiosis of digital writing machine. That Peirce conceived the sign-object relationship as generative source of an autonomous interpretant could provide the most insightful view to explore how human and non-human agents are interacting in semiosis. The Peircian semiotics can be an efficient model that allows to explore an original model to locate and to seize the principle of semiotic mediation in the agential forces of human writer and materiality of writing.

The non-anthropocentric semiotics of algorithmic writing would suggest that the anthropocentric concepts of semiotics might be revised to be applicable in the non-human domain of writing. We can see the value of nonanthropocentric semiotics of writing as an alternative model of digital writing studies and semiotics of media, an alternative way to integrate human writing and computational writing machines. We can see it as potential ground for a new semiotic grammatology in the digital era. Algorithmic writing media emerged in 
the era of artificial intelligence is an entirely new ecological condition, a new medium, a new Umwelt, a new space-time, and a new world of semiotics. The environment in which Homo Digitalis live is a totally new technical and social environment that is apt to transform the conditions of writing in general.

\section{REFERENCES}

BACHIMONT, Bruno. 2007. Ingénierie des connaissances et des contenus. Le numérique entre ontologies et documents, Paris : Hermès.

BACHIMONT, Bruno. 2010. Le sens de la technique : le numérique et le calcul. Paris : Éditions Les Belles Lettres.

BOUCHARDON, Serge. 2014. La valeur heuristique de la littérature numérique. Paris : Hermann.

BOUCHARDON, Serge eds. 2011. Explorer les possibles de l'écriture multimédia. Les Enjeux de l'information et de la communication 12(2), 11-24.

BOUCHARDON B, Serge, PETIT, Victor. 2018. L'écriture numérique ou l'écriture selon les machines. Enjeux philosophiques et pédagogiques. Cahiers COSTECH numéro 2.http://www.costech.utc.fr/CahiersCOSTECH/spip.php?article69

CALVINO, Italo. 1986. Cybernetics and Ghosts. In The Uses of Literature. San Diego, New York, London: Harcourt Brace \& Company, 3-27.

COLLOMB, Cléo et GOYET, Samuel. 2015. Meeting the machine halfway. communication au colloque Reconfiguring human and non-human, Finlande, Université de Jyväskylä.

COLLOMB, Cléo et GOYET, Samuel. 2016. Do computers write on electric screens?. Communication+1, 5, Article 2, 1-26.

DERRIDA, Jacques. 1967. De la grammatologie, Paris: Minuit.

DUNCAN, Denis. 2012. Calvino, Llull, Lucretius: Two Models of Literary Combinatorics. Comparative Literature Vol. 64, No. 1, 93-109

FLUSSER, Vilem. 2011. Does Writing Have a Future ? University of Minnesota Press.

GIFFARD, Alain. 2012. L'industrialisation du lecteur. Medium, Nº 32 - 33, 342-355.

HARRAWAY, Donna. 1991. Simians, Cyborgs and Women: The Reinvention of Nature, New York: Routledge, and London: Free Association Books. 
HAYLES, Katherine.1999. How We Became Posthuman: Virtual Bodies in Cybernetics, Literature and Informatics, Chicago: The University of Chicago Press.

HAYLES, Katherine. 2002. Writing Machines. Cambridge, Massachusetts: MIT Press.

HAYLES, Katherine. 2005. My Mother Was a Computer: Digital Subjects and Literary Texts, Chicago: The University of Chicago Press.

HAYLES, Katherine. 2012. How We Think: Digital Media and Contemporary Technogenesis. Chicago: The University of Chicago Press.

HERRENSCHMIDT, Clarisse. 2007. Les trois écritures : Langue, nombre, code. Paris: Gallimard.

KIM, Sung Do. 2018. Une généalogie critique des théories de l'écriture : Histoire et épistémologie du pluralisme graphique. SIGNATA 9, 155-192

KITTLER, Friedrich. 1997. Literature, Media, Information Systems: Essays (Hrsg. von John Johnston). Amsterdam.

KNAPPET, Carl \& MALAFOURISM, Lambros (eds.) 2008. Material Agency: Towards a Non-Anthropocentric Approach. New York: Springer.

LASSEGUE, Jean eds. 2012. What is Turing's Comparison between Mechanism and Writing Worth? in Cooper S.B., Dawar A., Löwe B. (Eds.) How the World Computes, Springer, 450-461.

LATOUR, Bruno.1992. Aramis ou l'amour des techniques. Paris : La Decouverte.

LATOUR, Bruno. 2005. Reassembling the social: an introduction to actor-networktheory. Oxford New York: Oxford University Press.

LAW, J., 1999. After ANT: Complexity, Naming and Topology. In Actor Network Theory and After, edited by J. Law and J. Hassard. Blackwell : Oxford, 1-14.

LEROI-GOURHAN, André. 2012. Milieu et techniques : Evolution et techniques. Paris : Albin Michel.

MANOVICH, Lev. 2010. Le langage des nouveaux médias [2001], trad. de l'anglais par Richard Crevier, Dijon : Les Presses du réel.

PETIT, Victor. 2013. Internet, un milieu technique d'écriture. In E. Rojas (eds.). Reseaux socionumeriques et mediations humaines. Le social est-il soluble dans le Web ? Paris : Hermes-Lavoisier, 155-173.

SOUCHIER, E., JEANNERET, Y. \& LE MAREC, J. (dir.). 2003. Lire, écrire, récrire : objets, signes et pratiques des médias informatisés. Paris : Éditions de la BPI. 
SPERBER, Dan. 2002. The future of writing. Virtual symposium "text-e". BPI.

STIEGLER, Bernand, (Dir.).2014. Digital Studies : organologie des savoirs et technologies de la connaissance, Limoges : Fyp éditions.

TENEN, Denis. 2017. Plain Text: The poetics of computation. Stanford: Stanford University Press.

TURING, Alan. 1950. Computing Machinery and Intelligence. Mind, LIX, $\mathrm{n}^{\circ} 236$, 433-459.

[16] [17] Katherine Hayles, Writing Machines, MIT Press, 2002.

[18] Louise Merzeau, " Du signe à la trace, ou l'information sur mesure ", Traçabilité et réseaux, Hermès 53, CNRS éditions, 2009, pp. 23-31.

[19] Hayles, 1999, pp.13-14.

[20] Souchier et Jeanneret, "Pour une poétique de «l'écrit d'écran» ", Xoana, 6 : 97-107. 1999, p.102.

[21] "L'écrit d'écran : pratiques d'écriture et informatique ", Communication \& langages, $n^{\circ} 107,1996$, p.118.

[22] Latour, Bruno. Aramis ou l'amour des techniques. Paris : La De'couverte. 1992, p.182.

[23] Victor Petit, " Internet, un milieu technique d'écriture ", in E. Rojas (éd.), Réseaux socionumériques et médiations humaines. Le social est-il soluble dans le Web ? Hermès-Lavoisier, Paris, 2013, p. 155-173. 


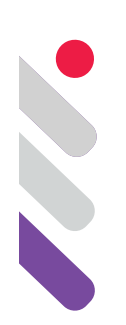

\title{
¿Por qué hay sentido y no más bien nada? Experiencia, cognición, sentido
}

DOI: 10.24308/IASS-2019-8-013

\author{
Jean-Marie Klinkenberg \\ Universidad de Lieja (Bélgica), Real Academia de Bélgica \\ jm.klinkenberg@uliege.be
}

\section{1. ¿Cómo surge el significado de la experiencia?}

\subsection{Convencionalidad y experiencia}

Si las teorías del significado son numerosas, a menudo son descriptivas. Son muy detalladas sobre la manera de describir el significado, pero quedan mudas a propósito de su naturaleza.

Algirdas-Julien Greimas, uno de los maestros de la disciplina, observó en 1970: "Se puede decir que los progresos de la semiótica, en los últimos tiempos, consisten esencialmente en la elaboración de su campo de maniobra, en la exploración de las posibilidades estratégicas de captar el significado. Sin saber nada más sobre la naturaleza del sentido, hemos llegado a saber mejor dónde se manifiesta y cómo se transforma" (1970: 17).

Ha pasado casi medio siglo: el catastro de lo que se acaba de llamar "campo de maniobra" se ha aclarado espectacularmente, y el contenido de este campo se ha vuelto notablemente enriquecido. Pero la cuestión de la naturaleza del sentido, señalada por Greimas, ha quedado pendiente. Como también estas otras dos preguntas, vinculadas a la primera: las de saber cómo y por qué nace este sentido. Parafraseando la famosa fórmula de Leibniz, nuestras disciplinas apenas se han preguntado “¿Por qué hay sentido y no más bien nada?”, dejando este problema a la filosofía.

De hecho, todas las ciencias del sentido -la semántica lingüística tanto como la semiótica que la enmarca - se basan, implícitamente o no, en el axioma de la convencionalidad: postulan un acuerdo preliminar a todo intercambio y la existencia de un sistema externo a las conciencias individuales, un sistema que se impondría imperativamente a ellas. Es este axioma que Ferdinand de Saussure explota con el concepto de "lengua". 
Pero, siendo un axioma, el principio de convencionalidad deja en la sombra lo que subyace a la convención, ignorando deliberadamente una interfaz crucial: ¿cómo surge el sentido de la experiencia? Este es un problema muy irritante, porque plantea la cuestión del vínculo que debe establecerse entre un significado que parece no tener fundamento físico y los estímulos físicos que provienen del mundo exterior, estímulos que, como tales, no parecen tener sentido.

La respuesta puedo formularla provisionalmente bajo la forma de un juego de palabras: el sentido proviene de los sentidos.

\subsection{Ejemplo de la percepción visual}

Haré mi demostración desde la percepción visual pero, mutatis mutandis, los mecanismos que describiré son válidos para todo tipo de percepción.

¿Pero, hablar aquí de sensorialidad no sería traicionar la semiótica? De hecho, considerar la forma de la expresión puede parecer irrelevante para nuestra disciplina, ya que esta estudia principalmente las formas.

Sin caer en la tesis de McLuhan, según la cual "el mensaje es el medio" (una fórmula sin duda polémica), se puede argumentar que la consideración de este sustrato perceptivo es indispensable en la primera descripción de cualquier sistema, porque la materia debe, para convertirse en sustancia semiótica, ser percibida. Sin embargo, las cargas de todo tipo, primero físicas y fisiológicas, luego culturales, pesan sobre este proceso de percepción y, por lo tanto, intervienen en la selección de elementos del mundo que se harán relevantes; es decir, en el análisis final, en el establecimiento de formas.

Una descripción semiótica puede evitar el estudio fisiológico del canal considerado ya que ha integrado en su descripción de formas los caracteres que son consecuencias de las restricciones de este canal. Pero esta economía, sin embargo, no se puede hacer cuando nos acercamos a un sistema que aún no se ha estudiado realmente en su especificidad. Por ejemplo, una semiótica general de los enunciados visuales presupone pues el examen de ciertas propiedades del canal visual, propiedades que tendrán una influencia decisiva en las formas de las texturas o de los colores, y cómo las instituimos en sistemas. Fenómenos como "contraste", "orientación" e incluso "espacialidad", que ingenuamente consideramos fundamentales en cualquier análisis de las imágenes, resultan construcciones puras, realizadas sobre la base de estímulos físicos.

La pregunta a la que debe responder una semiótica cognitiva visual es la siguiente: ¿cómo pueden estas transformaciones de estímulos brutos conducir al desarrollo de aquellas construcciones aparentemente evidentes? y, más allá de estas unidades plásticas, ¿cómo pueden estas transformaciones conducir a la identificación de entidades referibles a objetos del mundo, elementos constitutivos de enunciados icónicos? 
Es la tarea de la percepción, una actividad integradora, como voy a demostrarlo.

\section{La construcción del sentido visual}

\subsection{Primera percepción: el campo}

La actividad consiste en primer lugar en elaborar calidades translocales: en otras palabras, calidades que son la propiedad común extraída de una serie de sensaciones distribuidas en el espacio. El producto de esta elaboración es el campo.

Si esa producción es posible, es porque nuestro sistema de percepción está programado para detectar y registrar similitudes. Es lo que demuestra el experimento clásico de Metzger, quien colocó a sus sujetos en condiciones tales que la luz reflejada por una pared tenía una distribución uniforme en toda la retina: lo que era percibido en este caso no era una superficie, como era de esperar, sino una niebla luminosa rodeando a los sujetos en un espacio con distancias indefinidas.

Por lo tanto, el ojo no se limita a identificar múltiples puntos yuxtapuestos, sino que genera una continuidad a partir de aquellos datos discretos: si todos los puntos tienen las mismas propiedades (por ejemplo, de luminancia), serán percibidos como constituyendo un todo único. $Y$ este conjunto puede, gracias a una segunda percepción a la que llego, constituir una sola mancha. Y la calidad percibida globalmente podrá ser calificada translocal. ¿Pero por qué esta translocalidad? Su ventaja es obvia: es una economía enorme; en lugar de tratar una masa de datos discretos, el sistema nervioso central solo tiene que gestionar una sola información.

\subsection{Segunda percepción: el límite}

Equipado para identificar similitudes, el sistema también puede identificar diferencias. La diferencia es, por lo tanto, el primer acto de una percepción realmente organizada; estimulado de manera desigual en sus diferentes lugares, el sistema percibe el cese o el cambio de la calidad translocal y pone en evidencia este pasaje: por ejemplo, de blanco a negro o gris. Hablaremos de límite.

El mecanismo principal involucrado aquí es bien conocido: es la inhibición cruzada.

Cada neurona fotosensible del ojo (cono o bastoncillo) no se limita a transmitir información al sistema nervioso central: gracias a las superficies de contacto que son las sinapsis, influye en las neuronas vecinas y está influenciada por ellas. $Y$ es la totalidad de aquellos reprocesamientos que, reagrupados, se transmitirán a la corteza. Esta influencia de una neurona en sus vecinas es doble: según la organización de la red y la de los estímulos, a veces va en la dirección de 
la excitación, a veces en la de la inhibición. Una neurona fuertemente excitada (por ejemplo, 3A en este esquema) amplifica la excitación de su vecina (por ejemplo, 4A) cuando esta ya es importante; pero disminuye la sensibilidad de otra vecina (por ejemplo, 2A) cuando es débil. El sistema perceptual "borra" las pequeñas diferencias y exagera las grandes, de acuerdo con un umbral fijo o variable, pero siempre contingente. Es este mecanismo cognitivo el que crea la línea.

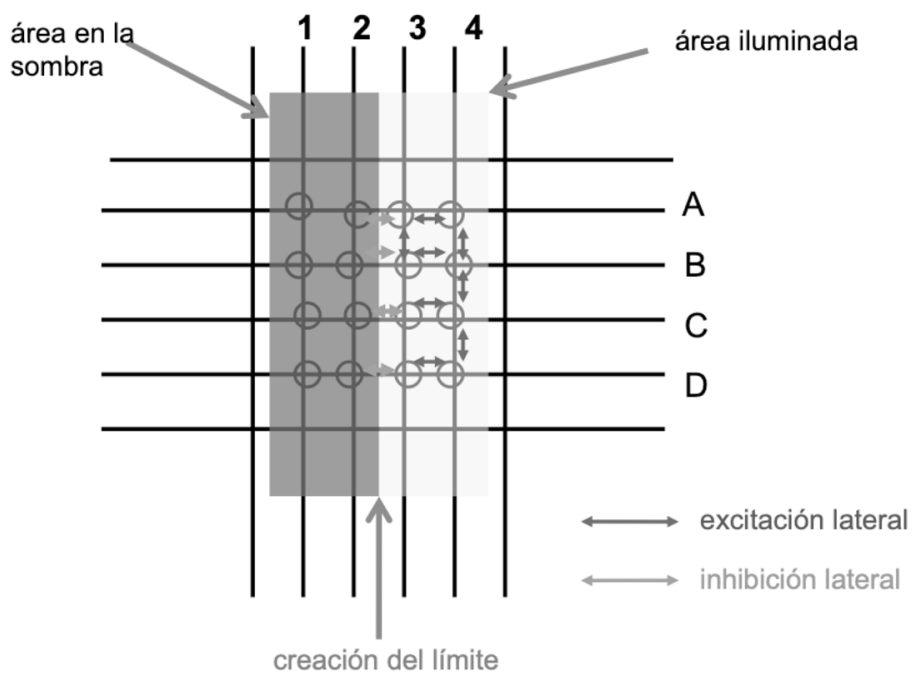

Fig. 1. La retina: inhibición y excitación laterales, creación del contraste

\subsection{Desde la calidad hacia la entidad}

La detección de una calidad translocal en un campo, y la detección de límites entre calidades dentro de este campo tiene una consecuencia importante: hace posible que distingamos una entidad, dotada de esta calidad, y que la discriminemos frente a su entorno: en este papel blanco, uno puede discernir lo que ahora es una mancha (entidad) azul (calidad). En cierto modo, podemos decir que la entidad es una calidad que se ha convertido en una cosa gracias a nuestra actividad perceptiva. La aparición de la entidad está permitida por la percepción de una discontinuidad en el campo perceptual. Una discontinuidad que segmenta el campo en dos entidades.

\subsection{Fondos y figuras}

La identificación de entidades nos permite introducir un nuevo par de conceptos importantes: la figura, en oposición al fondo. La operación de segregación que la establece es el segundo grado de una organización diferenciada del campo (la primera siendo la aparición del límite). La figura es 
lo que sometemos a un mecanismo de exploración local. El fondo es lo que no sometemos a este tipo de atención, y que será analizado por mecanismos de discriminación menos potentes. Los efectos de esta oposición son bien conocidos. Señalo uno que no carece de importancia en el establecimiento de sistemas visuales: el fondo parece estar dotado de una existencia debajo de la figura, que, por lo tanto, aparecerá más cerca del sujeto que el fondo.

La identificación de las figuras es el resultado de un sistema de procesadores especializados que trabajan los estímulos sensoriales. Estos procesadores se denominan extractores de motivos (cluster detectors). Son grupos de células que desencadenan su acción solo si el campo receptivo que enfrentan contiene ciertas configuraciones. Por lo tanto, existen extractores de contraste, que como vimos permiten el desarrollo del límite, pero también por ejemplo extractores de dirección, que entran en vigencia solo si el estímulo tiene una orientación específica. También se conocen detectores de puntos y líneas (delgados, gruesos, orientadas de esta u de otra forma, etc.), detectores de bordes, etc.

\subsection{La estrategia de la agrupación}

No hay magia aquí, sino el efecto de un sistema jerárquico, en el que los datos se reprocesan en todos los niveles. La agrupación de las señales se efectúa mediante cinco capas sucesivas de células nerviosas, a través de un conjunto complejo de conexiones laterales, ya sea excitatorias o inhibitorias. Y notamos que el número de conexiones laterales, inhibitorias o excitatorias, es notablemente alto en cada nivel. Por ejemplo, en la base misma de las células receptoras, cada una de ellas ya se puede poner en comunicación con una o dos células en el caso de los bastones, pero con 15 a 20 en el caso de los conos.

Esta jerarquía permite ilustrar el reprocesamiento de la información por parte del sistema, en el diagrama simplificado que sigue (Stent 1972): vemos que en cada nivel el número de neuronas disminuye, y que cada neurona transmite al nivel superior una síntesis diferenciada de los que recibió del nivel inferior. Por ejemplo, la impresión de luminosidad estará asegurada en dos casos: cuando el centro de un área está fuertemente iluminado, las sinapsis inhibitorias, que son la mayoría, no prevalecen contra la acción de las sinapsis excitadoras centrales; y cuando el centro de la zona está débilmente iluminado, las zonas periféricas estando fuertemente iluminadas, la acción de las sinapsis inhibitorias también se ve debilitado. 


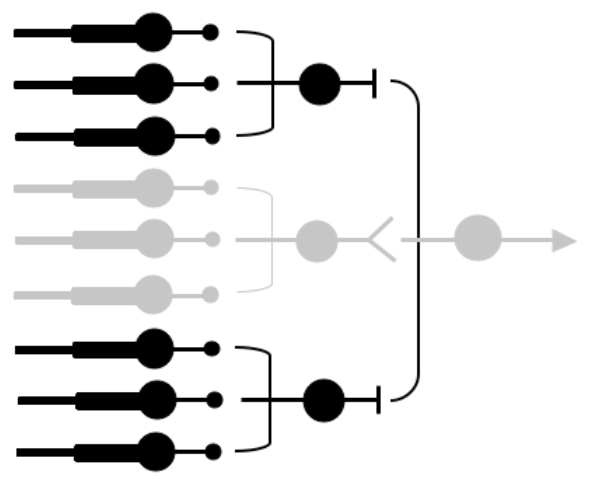

-1 sinapsis inhibitorias en gris: zonas iluminadas

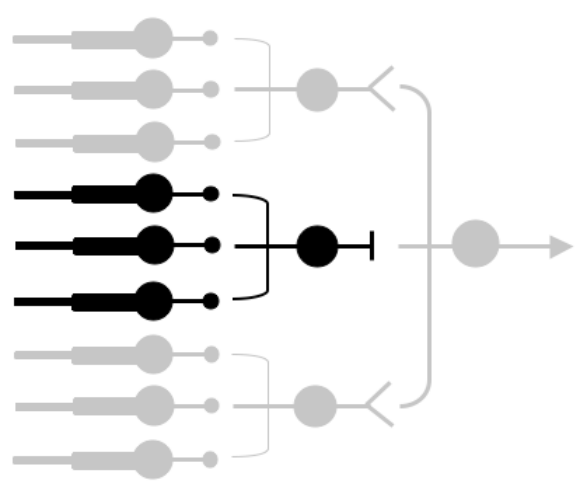

$-<$ sinapsis excitadoras en negro: zonas en la sombra

Fig. 2. Agrupación: destrucción de información pero ganancia de sentido

Podemos decir que hay una recalificación de los impulsos nerviosos. Como fenómenos eléctricos, obviamente no hay diferencia entre los que circulan en cualquier lugar de la red y los que se pueden medir en una fibra del nervio óptico. Sin embargo, el significado de tal impulso ha cambiado. La importancia de estas recalificaciones es aún mayor ya que los campos del receptor están estructurados de una manera más compleja. Gradualmente, por ejemplo, es posible definir una alineación horizontal de puntos como linea, gracias a los extractores de motivos que acabo de mencionar. Estos detectores son configuraciones adaptativas, que elaboran modularmente límites, esquinas, etc.

Así captamos el nacimiento del sentido: es una estrategia pragmática de la materia viva, que combina economía y eficiencia. La agrupación de datos abundantes, por razones de economía, pero en espacios cada vez distintos, con fines de eficiencia.

Esta estrategia de agrupación, cuyo éxito ha sido respaldado por la evolución, se confirma en todos los niveles de percepción. Como lo hemos visto, comienza en los órganos periféricos. Pero la encontramos también con la categorización (a la que volveré al § 4.2.) : esta, por supuesto, consiste también en una reagrupación de informaciones, operada en otro nivel.

Volvamos ahora a los mecanismos de la experiencia visual para destacar dos aspectos fundamentales y complementarios: umbral y oposición. 


\section{Registrar la diferencia: la estructura dipolar}

Es importante subrayar que la calidad solo puede ser identificada a través de una maniobra de diferenciación: si se percibe la forma, es porque contrasta con el fondo.

Pero, por el solo hecho de que está segregada, la entidad entra en relación con este fondo, que tiene una calidad translocal distinta de la primera: la hoja en la que se extiende una mancha azul también es una entidad que tiene su calidad. Así, vemos que la noción misma de entidad presupone la de interacción: de hecho, podemos distinguir entidades solo a través de una relación de contraste entre dos cualidades.

\subsection{Diferenciación y umbralización}

El aspecto más importante en este mecanismo de diferenciación es el umbral, obtenido gracias al doble fenómeno de excitación lateral y de inhibición lateral. Con esto quiero decir que los estímulos reciben un tratamiento diferente en función de si están por debajo o por encima de cierta intensidad, llamada umbral.

Los que están por debajo de este umbral no se tienen en cuenta. Hay ecualización, es decir que, por un lado, el sistema se niega a tener en cuenta las diferencias. Todas las pequeñas variaciones se alisan, y las distintas calidades que teóricamente podrían haberse distinguido en otra configuración se reducen a una misma calidad translocal.

En cambio, las variaciones del estímulo que exceden este umbral de intensidad constituyen una calidad distinta. Aquí, el sistema se niega a tener en cuenta las similitudes, y exagera las diferencias. Asistamos así a la formación de un contraste revelador.

Por lo tanto, las entidades (visuales, pero también táctiles, olfativas, gustativas) siempre resultan de un procedimiento de umbral: la fijación de un cierto valor pone de relieve las entidades correspondientes a este umbral, que otro umbral habría hacho ignorar.

Se debe subrayar que aquellos umbrales no existen como tales en la naturaleza: son producidos mediante una interacción entre los estímulos y los órganos perceptivos, y son fijados por estos últimos. Son un orden y una discontinuidad introducidos en el continuo ya construido.

Un buen ejemplo es el fonema: corresponde a una zona compartimentada cortada en un continuo de sonidos.

\subsection{Variación de umbrales}

Aquellos umbrales son por lo tanto arbitrarios. Funcionan incluso a un nivel muy básico, en el que uno no está acostumbrado a admitir su arbitrariedad: categorías que parecen evidentes, como derecho versus curvo, son, por 
el contrario, sumamente problemáticas. De hecho, la rectilinealidad es un concepto, mientras que la percepción solo nos ofrece imágenes distorsionadas y granulares de su soporte: lo que llamamos líneas rectas son líneas discontinuas producidas por pilas de células desalineadas, que a su vez se reorganizan en segmentos, ellos mismos agrupados. Por lo tanto, entre la recta y la curva hay una demarcación que es en gran medida arbitraria.

Y, arbitrarios, los umbrales pueden variar. Varían según diferentes parámetros, fisiológicos, pero también culturales y pragmáticos. Algunos de estos están directamente relacionados con la sensorialidad afectada -cada una teniendo sus propios umbrales-, y otros varían de manera consciente y voluntaria. Un mismo campo también puede ser divido - "umbralizado" según varios criterios distintos. Por ejemplo, el campo visual puede estructurarse de acuerdo con criterios a veces cromáticos, a veces de luminancia, a veces de textura. En este caso de umbral múltiple, los rangos discriminados no coinciden necesariamente, lo que conduce a una complejidad que bien conocen los analistas de las imágenes.

Objetivar el funcionamiento de estos umbrales es pues mostrar cómo y por qué, al nivel más básico, actúan los órganos que los producen o, a un nivel más elaborado, mostrar cuáles son los factores (cognitivos, sociales, históricos, etc.) que intervienen para variarlos, consciente o inconscientemente.

La variación de los umbrales tiene evidentemente un impacto en la estructura del mundo percibido y, por lo tanto, en el significado que se le atribuye: un umbral más bajo o más fino, o umbrales múltiples harían aparecer entidades más numerosas y más pequeñas; por el contrario, al elevar el umbral, obtenemos tipos más abstractos.

\subsection{El dipolo y su universalidad}

La umbralización no sería posible si nuestros órganos no estuvieran equipados para comparar estímulos vecinos. En otras palabras, si no pudieran distinguir al menos dos ocurrencias sensoriales. Por lo tanto, el aparato que produce la comparación debe tener al menos dos receptores, o permitir que se midan dos estados del mismo fenómeno en dos momentos distintos.

Esto es lo que llamo el principio de contraste elemental, o dipolo, percepción diferencial de una cantidad física (por ejemplo, la intensidad luminosa). Poner en evidencia el papel de este mecanismo ofrece una confirmación fisiológica al principio estructuralista de oposición.

llustremos el primer mecanismo (sensores espacialmente separados). Sin explotar el ejemplo sencillo de los humanos, que tienen dos ojos, dos narices, dos orejas, que proporcionan dipolos de anasemiosis, y que tienen dos brazos, dipolos de catasemiosis, podemos citar el ejemplo de tal insecto capaz de orientarse gracias a sus estrías dorsales, o de otro entomóptero que sabe 
evaluar la altitud a la que vuela en función de las modificaciones sufridas por las formas ubicadas en su campo de visión. Ilustración del segundo mecanismo (un solo sensor que percibe la grandeza en dos momentos): la natación de cierta bacteria, un ser aún unicelular. Aquella bacteria tiene sensores especializados en el reconocimiento de una molécula específica en el medio ambiente (sea un alimento, sea una sustancia repelente). El comportamiento adecuado para ella consiste en acercarse a las áreas de alta concentración de alimento y escapar de las zonas repulsivas, lo que se realiza midiendo en dos momentos diferentes la concentración de las moléculas en cuestión y actuando en consecuencia sobre sus flagelos motores.

Esta percepción dipolar es la estrategia que el ser vivo ha desarrollado para gestionar su entorno. Este individuo está inmerso en muchos flujos entrecruzados: flujos de materia (viento, corrientes de agua, alimentos), flujos de energía (calor, gravedad), flujos de radiación (la luz). Todos estos flujos están orientados y se caracterizan por una variación a lo largo de un eje, es decir un gradiente. Vivir y construir el sentido del mundo en que uno vive es gestionar aquellos gradientes, y el dipolo o creación de oposiciones es la herramienta utilizada para lograr este resultado. Dado que el gradiente crea contrastes en el espacio (o en el tiempo), se necesitan dos sensores acoplados para percibirlos (o un solo sensor que percibe la cantidad en dos momentos diferentes).

\section{Tres complejidades del proceso cognitivo básico}

Identificar espacios, contornos y entidades es ciertamente interesante y efectivo, pero sigue siendo bastante limitado si pretendemos explicar el funcionamiento de los sistemas semióticos, especialmente en su aspecto cultural. Tengo ahora que mostrar cómo, en tres sucesivos niveles de complejidad, llegamos a las semiosis más sofisticadas.

\subsection{Estabilización en el tiempo: recordación}

Primera complejidad: el conocimiento elemental puede ser almacenado en la memoria.

Este almacenamiento permite comparar calidades $\mathrm{y}$, por lo tanto, entidades, más allá de la experiencia inmediata. Meditemos la frase de Kant: "Si mi pensamiento dejara escapar siempre las representaciones precedentes (...) y nos las reprodujera al pasar a las siguientes, jamás podrá surgir una representación completa (...) ni siquiera podrían aparecer las representaciones básicas de espacio y tiempo, que son las primarias y más puras". Por lo tanto, una conciencia temporal supone una cierta continuidad, y no puede ser compatible con una estructura granular. 
Hemos visto que el reconocimiento de las entidades resulta de un sistema jerárquico de procesadores que son los cluster detectors. Pero no solo extraen una entidad: también atribuyen una forma estable a estas entidades. Aquellos extractores deben, de hecho, adiestrarse para desempeñar plenamente su papel. Estos grupos de células se activan solo si el campo receptivo al que están conectados contiene ciertas configuraciones estabilizadas. El resultado de la interacción es, por lo tanto, una unidad constitutiva del sistema visual: un punto, una orientación, un espesor. Pero vemos ahora que la percepción de estas unidades también es un fenómeno de recordación.

\subsection{Estabilización en el objeto: coordinación}

Sin embargo, el efecto comparador de la memoria es de interés solo mediante una segunda complejidad: la coordinación. La experiencia de las calidades a lo largo del tiempo puede revelar coordinaciones regulares entre las calidades establecidas por una sensorialidad dada o por varias sensorialidades distintas. Por ejemplo, una calidad a puede tender a manifestarse sistemáticamente al mismo tiempo que una calidad $b$.

Así es como aparece la noción de objeto. El objeto no es más que un conjunto organizado de calidades dotadas de una cierta constancia en el tiempo. Por ejemplo, podemos experimentar repetidamente calidades coordinadas, como "rojo", "esferoide", "suave", "jugoso" (una experiencia en la que intervienen sensorialidades distintas). Este objeto, hecho de calidades coordinadas, se puede almacenar en una clase, a la que le daremos, por ejemplo, la etiqueta de "tomate".

Esta coordinación de calidades es producida por dos mecanismos que operan simultáneamente, conocidos como "procesamiento distribuido", un mecanismo neurológico bien documentado. Este tratamiento es posible gracias a los circuitos neuronales que actúan simultáneamente, para excitarse unos a otros, o para inhibirse. Para retomar mi ejemplo, simplificándolo considerablemente, las redes neuronales que detectan la calidad "roja" excitan las redes correspondientes a la característica "suave". ¿Por qué esta estimulación recíproca? Porque la combinación de las dos calidades "liso" + "rojo" corresponde a una experiencia previa repetida, y que su emparejamiento constituye así una agrupación económica. Por otro lado, las mismas redes que detectan la calidad "roja" inhiben la calidad "áspero", la combinación "rojo" + "áspero" no correspondiendo a una experiencia repetida y teniendo un costo cognitivo más alto. Estos procesos no solo son paralelos: también son cruzados y acumulativos: las unidades que detectan "rojo" excitan "liso" e inhiben "áspero", pero al mismo tiempo, los centros que detectan "suave" excitan "rojo" e inhiben ellos también "áspero".

Por lo tanto, es preciso destacar la flexibilidad que permite el mecanismo: las características que están ausentes de una entidad, o que conocen una cierta 
variación, no impiden la identificación de esta entidad, ya que esta identificación se puede obtener a pesar de esta ausencia o a pesar de esta variación.

Esta es la explicación de la plasticidad de la categoría, que sigue siendo eficiente a pesar de la variación de los casos individuales. Por ejemplo, puedo reconocer perfectamente mi tomate a pesar de sus variaciones de luz, de posición, de punto de vista, de forma, de tamaño o de color.

Por supuesto, las variaciones deben mantenerse dentro de un límite, este límite obviamente no es estricto. El procesamiento paralelo distribuido explica un hallazgo importante de la teoría de prototipos. En esta teoría semántica, el prototipo es, como sabemos, la subclase de elementos que mejor actualiza la clase; en otras palabras, el modelo de entidades que tiene las cualidades sobresalientes que definen la clase. Así, el gorrión y el mirlo (como categorías, y no como instancias individuales contingentes) son prototipos de la clase de "pájaros"; el avestruz y el pingüino son menos representativos de esta clase: de hecho, no vuelan y, aunque no es zoológicamente esencial, el vuelo es importante en la representación que tenemos de un pájaro; el kiwi es aún menos representativo: no vuela, y ni siquiera tiene alas, de tal forma que su caso es difícilmente discutible... En términos cognitivos, podemos decir que el prototipo corresponde a la categoría elaborada sobre la base de experiencias en las que observamos la mayor superposición de atributos, gracias al mecanismo de procesamiento distribuido.

Acabo de hablar de categoría. De hecho, poco a poco, a partir de la excitación de una neurona, nos hemos acercados a esta noción capital no solo para la filosofía sino también para la semántica. Es la evidenciación y el almacenamiento de calidades coordinadas lo que hace posible elaborar categorías y, en consecuencia, integrar entidades en aquellas clases. Desde la percepción más elemental, hemos llegado a la abstracción y a las enciclopedias más complejas. En efecto, la categoría "tomate" es una abstracción, como el fonema; la categoría es el producto de la desensorialización o amodalización de las experiencias.

\subsection{Estabilización intersubjetiva: socialización}

Tercera complejidad. La estabilización de las calidades a lo largo del tiempo y su coordinación en el objeto se vuelve particularmente efectiva tan pronto como las categorizaciones a las que conducen se pueden compartir dentro de la comunidad social en la que se desarrolló. La estabilidad intersubjetiva de la categoría se agrega así a las otras dos estabilidades ya estudiadas (estabilización en el objeto y en el tiempo); una tercera invariancia se suma a las variaciones temporales y espaciales.

Compartir o comunicar solo es posible bajo dos condiciones.

La primera es la amodalización de la que acabo de hablar. La amodalidad del sentido significa que este último está desconectado de la experiencia 
inmediata (una categoría como "peligrosidad" puede movilizarse tanto frente a un tigre como antes de una amanita phalloides o una toma de corriente).

La segunda condición es la elaboración de artificios que son los signos, que a menudo han sido los objetos de la disciplina semiótica. Los signos permiten la misma desconexión: si puedo movilizar la categoría "peligrosidad" antes de la amanita faloides, la experiencia de esta peligrosidad ha, felizmente para mí, sido hecha por otros, y me ha sido transmitida solo por enunciados.

La función de los signos consiste en almacenar reservas de significado. Este almacenamiento es posible gracias a una memoria, lo que implica una conciencia, incluso limitada. El signo postula bien esta memoria, ya que está definida por emparejamientos más o menos regulares de formas del plano del contenido con formas del plano de la expresión.

Es a este nivel que se establece la cultura, que luego se le puede dar una definición semiótica: una cultura se define como un conjunto coherente de productos de estabilización intersubjetiva.

La estabilidad intersubjetiva no solo se suma a las otras dos: puede retroactuar en la estructura misma de estas dos. Un aficionado a los tomates puede ver perfectamente, durante su existencia, aparecer en los mercados tomate cereza, luego beefsteack tomate, que no había experimentado hasta ahora; incorpora las manifestaciones en la categoría, cuyo contenido se modifica así. Esta retroalimentación desencadena un proceso de recategorización, capital en las culturas, y explica el dinamismo de la semiosis.

Por lo tanto, hemos examinado el proceso de génesis del sentido, explicando los mecanismos que permiten la aparición de las categorías. Y es el fenómeno mismo del signo como sustituto lo que se explica aún más por estos mecanismos cognitivos. Porque es una vez más la asociación de calidades, esta vez en un proceso inferencial, es decir a un cuarto nivel de complejidad que es la base de la función semiótica.

Pero esta es otra historia... Para más detalles sobre esta historia, y sobre el problema de la génesis de la significación, me permito referir a nuestro opus Principia semiotica.

\section{REFERENCIAS}

GREIMAS, Algirdas-Julien. 1970. Du sens. Essais sémiotiques. Paris : Le Seuil.

GROUPE $\mu$ [Francis Édeline, Jean-Marie Klinkenberg]. 2015. Principia semiotica. Aux sources du sens. Bruxelles : Les Impressions nouvelles.

STENT, Günther Siegmund. 1972. Cellular Communication. Scientific American, $227,3: 42-51$. 


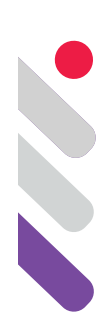

\title{
Presentación del proyecto semiótico: actualidad de René Thom
}

DOI: 10.24308/IASS-2019-8-014

\author{
Isabel $\operatorname{Marcos}^{1}$ \\ CICS.NOVA, FCSH, \\ Universidade Nova de Lisboa \\ isamar@fcsh.unl.pt
}

\section{INTRODUCCIÓN}

El proyecto "ACTUALIDAD DE RENÉ THOM (https://www.actualityrenethom.com)" está organizado en torno a un seminario mensual (Año 1: 2017/2018; Año 2: 2019; Año 3: 2020) y a una serie de coloquios internacionales (ARTHOM2018: Diciembre 2018; ARTHOM2019: Junio 2019) en la Universidad Paris Diderot y simultáneamente ONLINE. Esta investigación colectiva e interdisciplinaria reúne los campos de estudio predilectos de René Thom cuyo lenguaje morfológico hace de mediador entre las formas de racionalidad, desde las ciencias exactas hasta las humanidades (Largeault 1985a, 1985a, 1990). Esta interdisciplinaridad "en acto» ha sido posible gracias a la reunión de varias instituciones (CICS.NOVA, FCSH - Universidad Nueva de Lisboa, Portugal; Institut Humanités Sciences Sociétés (IHSS) - Universidad París Diderot, Francia; LabEx COMOD Universidad de Lyon, Complex Systems Digital Campus; UMR Espace 7300 CNRS; y FR3621 CNRS Agorantic - Universidad de Avignon) y redes de investigadores en ciencias y en filosofía (S.F.B.T -Société Francophone de Biologie Théorique ; el Cercle de Philosophie de la Nature y SEMA, Sociedad de Estudios Morfológicos de Argentina), no solamente en Paris y a nivel nacional (Francia, Portugal), sino también en el plano europeo e internacional. La reflexión que llevamos a cabo sobre la dinámica de las formas busca establecer una cultura científica común mediante una circulación posible entre los componentes de la racionalidad moderna (Espinoza 1997), implicando a todo investigador interesado por la vía morfológica, sus raíces (antiguas y modernas), su evolución y las barreras que le fueron opuestas, sus herramientas y sus implicaciones en

${ }^{1}$ Este trabajo está financiado con fondos nacionales a través de la FCT - Fundação para a Ciência e a Tecnologia, I.P., dentro del proyecto «UIDB/04647/2020» de CICS.NOVA - Centro Interdisciplinar de Ciências Sociais da Universidade Nova de Lisboa. 
una vía que busca producir un saber "de la cualidad" (Pinchard 1992)- es decir, un conocimiento de lo cualitativo como tal. Confortados con nuestros resultados del año pasado (éxito del $1^{\text {er }}$ y $2^{\circ}$ coloquio internacional y notoriedad creciente del seminario mensual, en curso de publicación donde editores reconocidos - Springer, Peter Lang, Revista Semiotica), tenemos indicadores evidentes del porvenir y de la pertinencia de este proyecto.

Este artículo pretende dar a conocer la trayectoria y los avances fundamentales de la semiótica del filósofo y matemático francés René Thom (medalla Fields, 1958). Varios semiotistas (Brandt, Petitot, Wildgen, etc.) han erigido su semiótica en torno a los avances de la semiótica Thomiana. Pero lo paradójico es que Thom brilla por su casi-ausencia en nuestro medio, mientras que su herencia semiótica es estructurante para nuestra disciplina, y que permite el diálogo con un amplio número de campos de investigación en los que él ha trabajado - matemáticas, biología, filosofía, psicología, antropología, lingüística, sólo por citar los más importantes.

\section{LOS DESAFÍOS DE UNA SEMIÓTICA THOMIANA:}

Cómo resumir lo que constituye la herencia de la semiótica thomiana.

Existen esencialmente dos escuelas. La escuela danesa de Per Aage Brandt y la escuela francesa de Jean Petitot. Ambas ponen inmediatamente en evidencia la existencia de varias semióticas distintas, lo que Brandt (1992, 1994, 1995, 2004, 2010) demuestra a través del conjunto de su obra: la teoría de las catástrofes y la teoría de las saliencias y de las pregnancias. Son dos tipos de modelización topológica del sentido, dos semióticas:

1. "La primera permite considerar de manera complementaria los estados y las transiciones entre los estados. Esta modelización funda una semiótica como pensamiento del signo, interpretada por la segunda modelización, es decir, la teoría de las saliencias y de las pregnancias. Para Thom los signos son generalmente motivados: el significante está motivado por su sentido a causa de su eficacia biológica fundamental, y los efectos arbitrarios que se pueden observar en el lenguaje son derivados de una motivación semiótica de base. Los signos emergen del comportamiento animal relacionado con los grandes tipos de regulación comportamental (descubrimiento de las presas y de los predadores, reconocimiento de las parejas sexuales, etc.) Esta concepción del signo difiere mucho de las concepciones estructuralistas, según las cuales el vínculo entre significante y significado es arbitrario.

2. La segunda modelización da cuenta de la manera que tiene un objeto de atención, una "saliencia", de significar mediante la "pregnancia" que lo invade. Las saliencias son acontecimientos perceptivos, precisamente rupturas de continuidad en lo sensible, susceptibles de atraer la atención de un organismo consciente - por ejemplo, un grito en el silencio - , y que invitan a interpretarlos en términos orgánicamente apropiados: esta investidura lo vuelve significativo, «pregnante» de sentido (Brandt: 2010)". 
Ambas escuelas quieren rehabilitar el conocimiento común (entre ciencias humanas y ciencias exactas), donde los fenómenos son directamente portadores de sentido. Es por lo que estas escuelas evocan un "giro realista" (después del "giro lingüístico" o "linguistical turn"). El carácter de la "Semiótica thomiana" es esencialmente cualitativo, más que cuantitativo. En efecto, la posición de Thom está resumida en su obra de 1991 titulada Predecir no es explicar (Prédire n'est pas expliquer) (Thom, 1991); subraya que la explicación (siempre cualitativa) de un fenómeno que le da sentido y lo vuelve inteligible, por lo tanto, "lingüísticamente descriptible", no puede reducirse a la acción de dominio por predicción, efectuada en términos de modelos cuantitativos.

Según Petitot (2004), estamos habituados al maniqueísmo de las "dos culturas". De un lado, la naturaleza, la objetividad, la explicación causal, la técnica: es el dominio de las ciencias exactas, cuantitativas; del otro, la cultura, la autorreflexión, la comprehensión, la toma de un sentido existencialmente experimentado: es el de las ciencias humanas, cualitativas. Pero, este maniqueísmo, que acentúa la frontera entre el espíritu y la materia, la cultura y la naturaleza, ¿se estará convirtiendo en una «nueva frontera del conocimiento»?

Aquí es donde la semiótica thomiana encuentra toda su pertinencia en el levantamiento de una tal barrera, por medio de la construcción en el curso del proyecto "Actualité de René Thom" de una semiótica general proveniente de esas dos semióticas thomianas: la teoría de las catástrofes y la teoría de las saliencias y de las pregnancias.

\section{LAS FUENTES DE LA SEMIÓTICA THOMIANA}

Hay que volver a las fuentes, al fundamento de la obra de René Thom, para comprender bien la especificidad de la proposición científica ante la cual estamos, la originalidad de sus aportes, el interés para la semiótica general, pero igualmente el debate epistemológico llevado a cabo, tanto con nuestra disciplina como en la posible transferencia de paradigma entre Ciencias Humanas y Sociales y Ciencias exactas.

Vamos a dar una visión de las fuentes más importantes de la semiótica de Thom desde mediados de los años 1960. Esta teoría semiótica responde a las ideas fundamentales de la teoría de las catástrofes y de la teoría de las pregnancias y saliencias, y se inspira en una larga serie de fuentes teóricas; distinguiremos sólo las principales (nos inspiramos en los trabajos de Bundgaard and Stjernfelt 2007, 2015 et 2010):

\subsection{EN MATEMÁTICA}

Brouwer, Riemann, Poincaré, Weyl y Christopher Zeeman (1977): El eje matemático de la semiótica thomiana es esencialmente una teoría fenomenológica: ella pretende que, en numerosos casos interesantes, por 
ejemplo, en biología, a veces no se puede precisar el detalle del proceso bioquímico subyacente, sino únicamente describir el conjunto de los cambios discontinuos posibles (llamados "catástrofes") a nivel de la superficie. El inventario posible de tales conjuntos de cambios abruptos se reduciría entonces a las siete "catástrofes elementales" para dinámicas simples llamadas de "gradiente": el gradiente "de altura" entre el alto y el bajo de la montaña! ¿ंo un gradiente entre el héroe y el antihéroe?) Ello le ha dado a la reflexión thomiana el carácter de una teoría fenomenológica que describe el comportamiento de superficie de sistemas muy diferentes, y ello independientemente de su substrato, físico u otro. Entonces, esta independencia del medio o del substrato ha dado inmediatamente un aspecto semiótico a la teoría: a saber, la posibilidad de que aspectos (discontinuos) estables de la fenomenología de la superficie hayan servido de signos referentes al proceso subyacente más complejo.

\subsection{EN BIOLOGÍA}

Conrad Hal Waddington (1957), Jakob von Uexküll (1934), Kurt Goldstein, Max Delbrück, Konrad Lorenz y d'Arcy Thompson: Los fundamentos de Thom derivan de la "Catastrophe Theoretical Biology". Waddington ha inventado un conjunto de conceptos para describir un metabolismo, Thom los ha presentado como los "atractores" de un sistema dinámico. Retomó de la obra de Waddington, Stabilité Structurelle (Thom 1987), la noción generalizada de "chreod" (que es una vía de desarrollo preferencial en un proceso), noción pertinente para todos los procesos dinámicos biológicos. Una de las realizaciones más importantes de Thom - según él - es su interpretación semiótica de las primeras fases de epigénesis. Es también la razón por la cual algunas de las más importantes inspiraciones semióticas están ancladas en su "bio-lingüística" y provienen de los primeros etólogos tales como Lorenz, Pavlov, y von Uexküll.

\subsection{EN FILOSOFÍA}

Aristóteles (2014), Kant, Husserl y Peirce: Thom ha avalado toda su vida, en una forma de base, el realismo aristotélico. Es, por supuesto, explícitamente el caso en su "Esquisse d'une Sémiophysique" (Thom 1988) y de su esbozo de una ontología del sentido común basado en una reinterpretación de la Física de Aristóteles como un proyecto de físicas ingenuas, pero ya es un punto clave de su primera concepción de la relación entre espíritu y materia. Según Thom, la percepción es un asunto de extracción de la forma o de la estructura, dicho de otra manera, de la información morfológica de la materia en la cual se realiza esta extracción. Esto implica que los estados de representación significante establecidos en el cerebro están gobernados por los mismos principios morfogenéticos que la manifestación fenomenal de sus objetos de referencia (las cosas y los procesos). Si es el caso, entonces, es evidente que el hilemorfismo 
aristotélico nos confronta a una tarea mayor que consiste en establecer los tipos de estructura que organizan la interacción entre entidades espaciales, y producen así el andamiaje de estos procesos generales y los acontecimientos que los humanos perciben y conceptualizan. En su lado semiótico, la teoría de las Catástrofes tiene explícitamente cuidado en establecerlo: ella busca plantear los principios que gobiernan la interface semiótica entre las formas fenomenales y las formas representativas.

\subsection{EN PSICOLOGÍA}

Max Wertheimer y Wolfgang Köhler: Thom en su artículo de 1973 dice: "El hecho de que una teoría de la pregnancia de las formas sea posible fue la doctrina esencial de la Teoría Gestalt que W. Köhler ha ensamblado con valentía y lucidez". El entrelazamiento entre epistemología y semiótica está subrayado en la frase bien conocida de Thom "Lo que debe ser buscado, es una teoría del lenguaje que implique simultáneamente una teoría del conocimiento" asegurándose así que esa "ontología inteligible" esté intrínsecamente conectada a su semiótica: la duplicidad de la saliencia y de la pregnancia en la ontología se refleja en la duplicidad del "nombre" y del "verbo" en lingüística.

\subsection{EN ANTROPOLOGÍA}

James George Frazer, Lucien Lévy-Bruhl y Gilbert Durand (1960): La semiótica de Thom avanza reflexiones sorprendentes sobre la caza del animal como implicada en los orígenes del simbolismo. Les ideas principales descansan sobre una idea semejante a la de Uexküll, de una estructura circular que conecta el metabolismo animal con una acción exterior, descubriendo los signos en la búsqueda de una presa. El animal debe ser capaz de reconocer ciertos signos para buscar su presa (predadores, parejas sexuales, rivales, yc.). "En nuestra tesis 1996 hemos demostrado que los signos emergen del comportamiento animal relacionado con sus grandes tipos de regulación comportamental" (Thom: 2003).

\subsection{EN LINGÜÍSTICA}

Lucien Tesnière (1959), Roman Jakobson (1896-1982), Kenneth Pike, J. Ross y Hansjakob Seiler: Parece sensato afirmar que la teoría del lenguaje de Thom, intelectualmente afinada, posee un cierto parentesco con la de Tesnière, que no está construida en el mismo terreno. Cuando ustedes afirmen que la salida central conducente a la lingüística es saber cómo el lenguaje puede simular sintácticamente la estructura de los acontecimientos en una situación dada, y una vez que pretendan que estas estructuras de acontecimientos se reagrupan en tipos determinables, entonces el resto sigue: deben existir formas semánticas recurrentes que puedan rearticular esta estructura interaccional, y 
deben existir entidades lexicales encargadas de expresar ese tipo de contenido, a saber, los verbos. Contrariamente a Tesnière, Thom busca explícitamente llevar la estructura lingüística al mundo.

\subsection{EN SEMIÓTICA}

Eco, Hjelmslev, Propp, Greimas, Jean Petitot, Per Aage Brandt: Thom retrabaja principalmente el cuadrado semiótico de Greimas en su versión narratológica, es decir, como formalización de una secuencia cíclica ordenada de transformaciones de estados o de puntos narrativos decisivos (interpretados como "catástrofes"). Su reinterpretación de esto consiste en:

1. arrancar del cuadrado semiótico su "atuendo lógico" ("Estructuras cíclicas en semiótica", Thom 1980: 193-208 et 1990: 67-91);

2. proponer una modelización dinámica de su andamio formal y lógico en términos de estructura morfológica cíclica.

Si bien no parece haber profundas afinidades teóricas entre Thom y Greimas, el proyecto de desarrollar interpretaciones dinámicas de los modelos formales tiene por supuesto una significación histórica importante: la naturalización del sentido. Thom anticipa el esquematismo general de Petitot y la naturalización de la estructura que inicialmente era efectuada en términos de topologización del cuadrado semiótico (Petitot 1985).

\section{EL ITINERARIO CIENTÍFICO DE THOM}

“En 1958 recibe la medalla Fields en el Congreso Internacional de Matemáticas en Edimburgo. En los años sesenta, tiene contactos científicos con un grupo de matemáticos (Peixoto, Lefschetz) que trabaja sobre la "estabilidad estructural" en USA. En 1962, recibe el "Premio de los Laboratorios" de la "Académie Française des Sciences" y, de 1963 a 1988, es profesor permanente en el "Institut des Hautes Études Scientifiques" en Paris (IHES). Esta institución de Investigacion Avanzada permite a profesores de alto nivel concentrarse en la investigación a un nivel internacional, recibiendo invitados del mundo entero. De 1966 a 1968 René Thom escribe su libro "Stabilité structurelle y morphogenèse", que no fue publicado hasta 1972.

En 1966, publica su primer artículo en biología teórica y en 1967 presenta una lista de siete catástrofes (Ilamadas también "catástrofes elementales") que son la base de la mayor parte de las aplicaciones en biología y en humanidades. En 1969, se encuentra con Pierre Delattre, un físico, fundador de la "Sociedad de Biología Matemática", quien la dirige hasta la fecha de su muerte; a partir de entonces René Thom asume la dirección de esta sociedad. Los años 1970 a 1976 vieron el éxito de las aplicaciones de la teoría de las catástrofes (CT) a muchas ciencias. En 1974, Thom publica una serie de artículos y un libro de bolsillo: "Modelos matemáticos de la morfogénesis".

Mientras Thom recibía premios y honores internacionales, Christopher Zeeman (1992) inició una controversia concerniente a la aplicación de la teoría de las 
catástrofes (Cf. Sussmann y Zahler, 1978). Esto frena la rápida aplicación de ese tipo de modelo de construcción en algunas áreas de matemáticas aplicadas.

No obstante, un gran grupo de sabios de casi todas las disciplinas se juntó en la Conferencia de Cérisy (1982) para discutir sobre la obra de Thom (Petitot, 1988).

En 1988 tuvo lugar en París un congreso internacional de matemáticas en honor de Thom quien presentó su nuevo libro "Esquisse d'une Sémiophysique". En 1990, publicó el libro "Apologie du Logos".

Recibió igualmente honores en Polonia, Francia y Brasil. En 1994 en Paris (Porte) un último congreso estuvo dedicado a la obra de René Thom en el campo de las matemáticas, la biología, la filosofía, el psicoanálisis y la semiótica" (Wildgen 2010).

Para más detalles, ver la introducción de Wildgen a este propósito (Wildgen \& Brandt 2010).

En 1992, Per Aage Brandt (director de la escuela thomiana danesa) organizó, en la Universidad de Aarhus, un seminario de un mes donde Thom presentó largamente la "Semiótica Thomiana como Filosofía del Sentido" bajo una perspectiva aristotélica. En esa época yo comenzaba mi doctorado en semiótica con Brandt sobre Lisboa: morfogénesis y semiogénesis (Marcos (Ed.) 1996, 2007) (nociones claramente thomianas). El encuentro con Thom ha trastornado mis investigaciones y mi posición científica (encuentros durante este seminario en Dinamarca, luego en París en 1994 y en los momentos en que pude someterle mis ideas); Thom me mostraba mediante la Semiótica Thomiana, cómo trabajar a partir de los grandes conceptos matemáticos en el seno de mi propia disciplina (intradisciplinaridad) y la importancia de "no limitarse a una disciplina" sino definir un campo de conocimiento (interdisciplinario). Yo ya me encontraba ante un "vuelco interdisciplinario", pero fue sólo después que me di cuenta del poder científico de la Semiótica Thomiana, por una parte, y por otra parte que me había convertido en una pionera en Semiótica Thomiana, precisamente en el campo de las ciencias del territorio (arquitectura, urbanismo y geografía).

\section{CONCLUSIÓN}

En resumen: La herencia de Thom es fecunda en ideas profundas y revolucionarias, que provienen de una intuición rica y de una impresionante anticipación del estado actual de las ciencias, incluyendo sus potencialidades y sus riesgos. El carácter de la semiótica thomiana (conocida también como semiótica morfodinámica en sus desarrollos de Petitot, de Brandt y de Wildgen para citar los tres autores más importantes) es esencialmente cualitativo más bien que cuantitativo. En efecto, la posición de Thom está resumida en su obra de 1993 Predecir no es explicar; es decir, que la explicación (siempre cualitativa) 
de un fenómeno, que le da sentido y lo vuelve inteligible, "lingüísticamente descriptible", no puede ser reducida a la acción de prever, en términos de modelos cuantitativos.

Según Petitot, estamos habituados al maniqueísmo de las "dos culturas". De un lado la naturaleza, la objetividad, la explicación causal, la técnica: es el ámbito de las ciencias exactas, cuantitativas; del otro la cultura, la autorreflexión, la comprensión, la toma o adquisición de un sentido existencialmente verificado: es el de las ciencias humanas, cualitativas. Este maniqueísmo, que acentúa la frontera entre el espíritu y la materia, la cultura y la naturaleza, ¿se estará convirtiendo en una "nueva frontera del conocimiento"? Frente a esta pregunta, la semiótica thomiana pone al pensamiento morfológico como horizonte de investigación e invita a una rehabilitación del conocimiento común, donde los fenómenos son directamente portadores de sentido, portadores de un "giro realista". Esta hipótesis condujo a Thom a una demostración central: las morfologías son universales y crean la posibilidad de elaborar un lenguaje de formas con su propia sintaxis y su propia semántica, modelizables mediante las catástrofes elementales de Thom. Esta herencia y esta semiótica nos han conducido a elaborar una teoría específica basada en la morfología. Para levantar este desafío hemos organizado un seminario, seguido por varios coloquios y una política editorial a fin de reactivar toda la Actualidad de René Thom.

\section{REFERENCES}

ARISTÓTELES, 2014. CEuvres complètes, (Pierre Pellegrin dir.) Paris: Éditions Flammarion

BRANDT, Peer Aage, 1992. La charpente modale du sens. Pour une sémiolinguistique morphogénétique et dynamique, Aarhus: Aarhus University Press.

BRANDT, Peer Aage, 1994. Dynamiques du sens, Aarhus: Aarhus University Press.

BRANDT, Peer Aage, 1995. Morphologies of Meaning, Aarhus: Aarhus University Press

BRANDT, Peer Aage, 2004. Spaces, Domains, and Meaning. Essays in Cognitive Semiotics, no4, European Semiotics, Bern: Peter Lang

BUNDGAARD, Peer \& STJERNFELT, Frederik, (Eds.) 2015. Investigations Into the Phenomenology and the Ontology of the Work of Art. Dordrecht: Springer

STJERNFELT, Frederik, 2007 Diagrammatology. Ontology, and Semiotics, Dordrecht: Springer 
DURAND, Gilbert, 1960. Les structures anthropologiques de l'imaginaire, Paris: Dunod

ESPINOZA, M. 1997. « Essai VI : René Thom : de la théorie des catástrofes à la métaphysique ", en Les mathématiques et le monde sensible, Paris: Ellipses.

HADRIEN, Gens, 2014. Jakob von Uexküll explorateur des milieux vivants, logique de la signification, Paris: Hermann

JAKOBSON, Roman, (1896-1982). Essais de linguistique générale, t. I-Il. Paris: Minuit

KULL, Kalevi, 2001. Jakob von Uexküll: An introduction. Semiotica 134 (1/4).

LARGEAULT, Jean, "Préface » 1990. en Apologie du logos (Thom, René), Paris: Hachette, 9-29pp.

LARGEAULT, Jean, 1985a. Systèmes de la nature (Prefacio de René Thom), Paris: Vrin.

LARGEAULT, Jean, 1985b. Principes de philosophie réaliste. Paris: Klincksieck

MARCOS, Isabel, (Ed.) 2007. Dynamiques de la ville. Essais de sémiotique de l'espace, Collection Intersémiotique des Arts, Paris: L'Harmattan

PETITOT, Jean 1985. Morphogenèse du sens. Paris, PUF. Petitot, Jean 1992. Physique du sens. Paris: Éditions du CNRS

PETITOT, Jean (Ed.) 1988. Logos et Théorie des Catastrophes, Genève: Editions Patiño

PETITOT, Jean, 2004. Morphologie et esthétique. Paris: Maison \& Larose.

PINCHARD, Bruno 1992. La raison dédoublée. (Suivi de La transcendance démembrée / par René Thom), Paris: Aubier

PORTE, Michèle (Ed.) 1994. Passion des formes, 1-2 vol., Fontenay-Saint Cloud: E.N.S. Éditions

SUSSMANN, H.J. and R.S. ZAHLER 1978. "Catastrophe Theory as Applied to the Social and Biological Sciences: A Critique", in: Synthese 37, 117-216

TESNIÈRE, Lucien, 1959. Eléments de syntaxe structurale. Paris: Klinksieck

THOM, René 1972/1977. Stabilité structurelle et morphogenèse. Essai d'une théorie générale des modèles, Paris: InterEditions.

THOM, René 1974. Modèles mathématiques de la morphogenèse, Paris: Union Générale d'Editions 
THOM, René 1980. L'espace et les signes, Semiotica, 29, 3-4: 193-208.

THOM, René, 1973. "L'évolution temporelle des catastrophes ». Colección Applications of global analysis, I. Symposium Utrecht State Univ., Utrecht

THOM, René, 1987. "An Inventory of Waddingtonian Concepts. Conference at the Waddington Memorial Conference", Oaxtepec, 1 - 5 septembre 1987, Mexique. Theorical Biology. Epigenetic and Evolutionary Order from Complex Systems, Goodwin \& Saunders eds., Edinburgh: Edinburgh University Press

THOM, René, 1988. Esquisse d'une sémiophysique. Physique aristotélicienne et théorie des catastrophes, Paris: InterEditions

THOM, René, 1990. Apologie du logos, Paris: Hachette

THOM, René, 1991. Prédire n'est pas expliquer, Paris: Eshel.

THOM, René, 2003. "Letter to Gilbert Durand 1976" en Oeuvres complètes. CDROM editado por el Institut des Hautes Etudes Scientifiques, Bures-sur-Yvette

UEXKÜLL, Jakob von, 1934. Mondes animaux et monde humain suivi de la théorie de la signification, Paris: Denöel.

WADDINGTON, Conrad Hal, 1957. The Strategy of the Genes. London: George Allen \& Unwin

WILDGEN, Wolfgang \& BRANDT, Per Aage, (Eds) 2010. Semiosis and catastrophes : René Thom's semiotic heritage, Bern, Bruxelles, Frankfurt: Peter Lang

ZEEMAN, Christopher 1992. "Controversy in Science: on the Ideas of Daniel Bernoulli and René Thom", in: Niew Archief voor Wiskunde, 11 (3): 257-282)

ZEEMAN, Christopher, 1977. Catastrophe Theory: Selected Papers 1972-1977, Cambridge: Addison-Wesley 


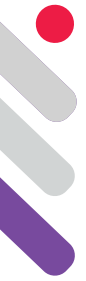

\section{The Semiotic Method}

This article's aim is to attempt a repositioning of semiotics within the various disciplines, clarifying its aims and specificities. Few are able to fully grasp what semiotics actually is: does it deal with signs? Society? Communication? Its confusion with other kinds of knowledge risks excluding semiotics from all areas of knowledge, denying it recognition. We might say that we encounter resistance because the semiotic language is a technical one and difficult to learn. Those of us who master it have a superior capacity for using it adeptly, and this presumptuous position alienates rather than encourages. Another approach, which comes from the discomfort provoked by this lack of clear intent, is to hide behind stronger and more distinguished disciplines, with the hope of achieving recognition as single scholars.

What the discipline needs is a return to form in order not to have to make such an enormous effort to distinguish itself. This way it can simply present itself as the science of signification, the only theory describing signification. And the language, which is technical, must be explained, paraphrased and translated; prior knowledge must not be assumed. This requires the creation of a well-defined semiotics. Analytical philosophy already deals with the sign as a reference point better than we do, sociology with society and communication, and philosophy of language with language in a philosophical sense. What interests us are signs, of course, but within networks, within fabrics of signification. We work on this, no other discipline does. Let's offer ourselves as a science of signification, clearing the field of ambiguous definitions.

\section{The Method as Modus Operandi}

Semiotics, however, cannot limit itself to saying that it is the science of signification. It must also be explicit about how it explains signification. Almost all the natural and social sciences have methods they articulate with their theories, epistemologies and philosophies. The peculiarity of semiotics is that 
it has a method that is not only an organon of tools and concepts, but also and more exactly (at least in the school of Algirdas Julien Greimas) a modus operandi on both levels of meaning: 1) it is a path, a sequence of operations to follow; and 2) it is a procedure of segmentation suited to the semiotics that one encounters. This means it is characterised by the fact it indicates the phases of description. It is a method in the etymological sense of the word, ( $\mu \dot{\varepsilon} \theta \circ \delta \circ \varsigma$, méthodos), made up from $\mu \varepsilon \tau \alpha$ (méta) - in the direction of, in search of - and

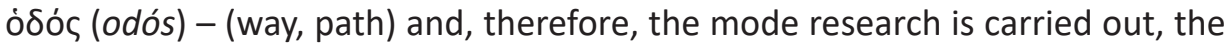
mediations that allow this to happen. The semiotic approach to the knowledge of perceived reality is generally founded in the method of its description, the more accurate and analytical the better.

Over the course of his work, Greimas simply provided models of description. He reflected at length on the method of meta-language as a 'receptacle' of categories and concepts. But he overlooked the value of the modus operandi, of $\mu \varepsilon \dot{\varepsilon} \theta \delta o \varsigma$. There are studies on the "systemicity of procedure" -Alessandro Zinna (2004) distinguished between the procedures of constitution and the body of analysis by the similarity, difference or opposition of the examples-but we rarely examine the processual nature of the procedure, its syntagmatic, modal and aspectual dimensions, the linking of phases that characterise it. We want to lift the veil on this lack of continuity with Greimas. Post-Greimassian semiotics has been capable of communicating its descriptive terminology (enunciation, narrativity, tensivity) to the outside world, but was too quick to renounce the idea of effective schema of action for analysis. These are not ready-made solutions. The procedure for description clearly meets with both internal and external resistance. It is useful to return to this point, bringing together Greimas' directions on procedure and reformulating them so as to better communicate them and relate them to the era of digital information.

\section{Semiotic Operativity}

In Greimas, "being scientific" is synonymous with operativity, a postulate that comes from Hjelmslev (1943). From Greimas's perspective, "the semiotic theory is operative only when it implies procedures of analysis" (Greimas and Courtés 1979, "Operativity"). And "an object can be grasped only through its analysis" (ibid.), that is "through being decomposed into smaller units and through the reintegration of those units into the totalities that they constitute" (ibid.). The text is the unit of analysis and the level of pertinence (in Greimas), but understood as a fabric of structural relationships, a process of internal relationships structured into hierarchies (another definition borrowed from Hjelmslev). Structural Semantics had not yet taken this direction, but was already announcing it as a 'research method'. Indeed, Recherche de méthode (An Attempt at a Method) was the subtitle chosen by Greimas for the book's first edition in 1966. This was 
done away with in subsequent editions, though the Spanish (Madrid: Gredos 1971) and English (Nebraska: University of Nebraska Press 1983) translations still maintain it.

Starting with the analysis of Lithuanian myths and folklore, then moving onto poetic texts, literary stories and visual texts, Greimas suggested paths for description that were in keeping with the concept of the 'generative path of meaning', Hjelmslev's idea of the stratification of meaning over profound and superficial levels. On one hand he explained the schema of action in description, and on the other, the modes of segmentation, adapted to the expressive forms of the texts analysed. Thus, if the fathers of structuralism taught us that perception is the perception of difference, it was Greimas who showed us how to understand these structural differences, how the structures become operative once they have been perceived.

\subsection{Description}

The procedures of description and the procedure of segmentation are closely linked, but must not be confused. Let us follow some of Greimas' steps on how to carry out this analysis: "The intent of the method is that formal segmentation procedures progressively replace our intuitive comprehension of the text and its articulations" (Greimas 1973, Engl. transl: 615). And later, continuing with The Piece of String by Maupassant (1884): "The description can be broken down into scenes, although it obeys a sort of spatiotemporal 'logic' of representation and obeys temporal laws (ibid.). The final chapter of The Social Sciences: $A$ Semiotic View, entitled 'Ethnic Literature', is entirely devoted to the subject of description: "The essential purpose of science in general and semiotics in particular is to replace intuition or implicit working hypotheses with hypothesis models that we are able to elaborate" (Greimas 1976a). According to Paolo Fabbri and Paul Perron (1991), the formulation of cognitive operations that allow description by satisfying the conditions of scientificity (coherence, exhaustiveness and simplicity) offer a strategic guide to research, transforming the procedures of description into procedures of discovery.

It is, however, in the essay Figurative Semiotics and the Semiotics of the Plastic Arts that Greimas illustrates the course of action for this procedure: "We have segmentation procedures which, in large measure, are founded on intuitive graspings whose mechanisms we must start trying to describe precisely so that we can formulate general rules for their use" (Greimas 1984, Engl. transl.: 638). This means, therefore, I) grasping, II) clarifying the procedure and III) formulating rules for its use. Or, as explained using different words a few pages later: grasp the rules intuitively, interpret them and formulate them (ibidem: 644). It is "in conformity with generally accepted intuitions that plastic objects are signifying objects" (ibid., my italics.) and this deeper signification is "founded on intuitive 
conviction" (ibid.: 648). Though initially rejected, intuition ends up playing a key role in the procedure, to the extent that it warrants its own entry in the Dictionary, as a "component of the cognitive competence of the subject, which manifest itself at the time of the elaboration of the work hypothesis" (Greimas and Courtés, 1979. 'Intuition' designates the intervention of a subject with a certainty (for a sort of evidence), who establishes a want to do, eager to test his hypothesis" (ibidem). Conceived and posited at the beginning of the analysis, intuition appears as a knowledge that comes from skills and visual memory "for a sort of evidence", as Greimas ambiguously states (ibid.), and articulated with other knowledge.

Various contributions added to Greimas' article on the plastic and the figurative, facilitating the passage from the visual to the visible, increasing reflections on poly-sensoriality and sensory motor skills, on point of view and the enunciation of the visible, observing the placement of the figural between the figurative and the plastic, giving evidence of the role played by light, texture, material and format. But it is important to understand if and how advances are made in the perfection of descriptive abilities. An artwork, especially in performance and installation art, teaches us that intuition intervenes at the beginning of the analysis, but that it also recurs throughout the reading process, appearing at different levels of intensity. We will return to this subject later on (§ 4.).

\subsection{Segmentation}

The process of segmentation indicates how to sub-divide the text. Greimas' analysis of Maupassant's short story, Two Friends (1883), focusses on this problem of breaking down a text on both a theoretical and a practical level. Though dressed up as an 'exercise', it actually presents itself "as a methodological model for the strategy of the semiotic research" (Greimas 1976, trad. it.: 245), useful for explaining how any discourse functions. Here Greimas passes wholesale from the idea of a semantics with an identifiable structure within "semi", minimal though dense units, to a semantics embedded within structures that are much broader, narrative and, more superficially, discursive. The subdivision of content into sequences cannot be entrusted solely to the presence of graphic markers or morphological signallers on the plane of expression. It should take place through the location of profound isotopes, procedures of grammatical and semantic anaphorisation, spatial, temporal and actorial discontinuity, and alternation between pragmatic and cognitive instances both within the narration and of the narration itself, so both enunciative and enunciatory. Prose and poetry, on the level of the relationship between semantic organisation and discursive actualisation, are comparable despite being characterised by different demands (ibidem: 6). 
Poetry faces Greimas (1972, edited) with the problem of "second language", which is abstract, consisting of rhyming formants and contrasts subtended throughout the figurative dimension of the world and levelled down to signifieds whose meaning is thus revived. Having understood this as an autonomous semiotics, a projection of the pragmatic onto the syntagmatic, he is prompted to search for the poetic in literature, in the visual arts, in music, in heightened esthesic perception. With the procedure of the super-segmentation of the signifier, Greimas broadens Hjelmslev's concept of analysis from linear, verbal languages to tabular languages and the visible. Greimas' first "Atelier of Visual Semiotics", already around from 1970, sees him joined by Denis Alkan, Ada Dewes, Jean-Marie Floch, Diana-Luz Pessoa de Barros, Felix Thürlemann and Alain Vergniaud.

Interest in 'plastic semiotics' in the visual leads Greimas (1984) to formulate a particularly articulated procedure that is, in different parts, one of segmentation of the signifier: 1) constitution of the 'frame-format' in relation to the 'out of frame' 2) the elaboration of a topological grid for the sub-division of areas and the orientation of elements; 3 ) the identification of chromatic categories and eidetic categories, such as the capture of contrasts and analogies; 4) semi-symbolic homologation. So, the first operation, according to Greimas, is that of considering the real frame or tracing out the ideal frame that separates-unites the text (the unit of pertinence) from or to the outside world. The second is to draw a grid with vertical, horizontal and diagonal axes that allow for the emergence of over-determinate topological categories (high/low, left/right, central/periphery, incorporating/incorporated) and to position the various elements accordingly. The third operation consists of locating eidetic and chromatic iterations and contrasts. The fourth and final operation requires the correlation of opposing pairs on the expressive plane with opposing pairs on the plane of content, or 'semi-symbolic homologation'.

\section{3. 'Embedded' Capture of Meaning}

It is worth bearing in mind that these categories are never established a priori, but that they derive from direct observation of the manifestation tactics of signification. Greimas insists that Structural semiotics, both its theory and its analytical methodology, is rooted within the much-broader anthropology. Figurative and plastic semiotics expressly choose anthropology as their starting point (Greimas 1984, trad. it.: 196). The visible is for semiotics a shared, empirical and cultural reality.

The three phases of the description procedure (intuition, clarifying the procedure, formulating the rules for its use) and the entire procedure of segmentation (from the demarcation of the frame-format that indicates the inside-outside boundary, to the examination of the spatial, eidetic and 
chromatic components with the semi-symbolic correlation that comes from it) can be extended to the analysis of practices and forms of life. Both the procedure of description and that of segmentation are regulated by Greimas, but each time they must be adapted to the particular, transformative situation of the researcher's doing and being. The model requires a certain intuition for intercepting the way the phenomenon functions, and a clarification of the way in which it acts, as well as the rules that are used. Thus, Jacques Fontanille asked himself, when considering a work by Marc Rothko, whether the total sum of the parts perceived by the first sensory impressions should not be favoured over segmentation - "Before segmentation, it is necessary to assemble the whole!" (Fontanille 1994, our transl.). Observations by Jacques Geninasca (2003) on the embedded capture and the format of the artwork as a result of the coupling of perception and perceiver also move in this direction. They remain within the imprint of the descriptive procedure but correct it, injecting modifications that arrive from the practice of the visible.

\section{Intuition}

It will have been noted that Greimas' value judgement on intuition changes over time. Initially, Greimas (1976) is quick to substitute intuition with explicit hypotheses of work. Later, particularly with regards to figurative and plastic semiotics, he rehabilitates intuition, giving it an autonomous, fixed role within the procedure (Greimas 1984). The scholar semioticised the concept of intuition, though a more expansive and systematic clarification updated by research developments within the discipline was yet to come.

Greimas' recommendations on the praxis of description emphasize the perceptive processes in everyday life. Even Jean-François Bordron (2011), outlining the phases of iconic constitution starting with the three Kantian Critiques, attributes primary importance to intuition. The moment of composition and stabilisation of forms is thought to take place through three syntheses: 1) the capture of any thing as a modification of the mind through intuition that corresponds, according to Bordron, to the indexicality in which alterity asks to be interrogated; 2 ) the reproduction of this thing in the imagination, which corresponds to iconicity where what is provided by intuition is maintained, assuming a temporal form and therefore a morphology; 3) the recognition within the concept that authorises the thing's identification in the sense that it is recognised by the concept: it is the field of form in the sense of Hjelmslev and therefore the field of identification and recognition, of articulation in symbolic forms. Greimas' model is similar to this framework, but with the added empirical vocation of sharing and negotiating the experience through the clarification of rules, without reducing it down to a purely mental and individual activity. 


\subsection{The Knowledge of the Senses}

Leibniz was the first to develop a systematic doctrine of intuition as a source of implicit knowledge. Certainty linked to proof signals a different way of knowing, through a "glance", which acts as a bridge between the event taking place and previous experience (Leibniz 1684), a summary of stored information. Intuition builds a bridge between what happens to us in any given moment and our own personal 'encyclopaedia'. It is a sensation of coherence or incoherence with the object of analysis, which is picked up by the body's sensory and motor system. Intuition means filtering sensory inputs that are continually mutating, and sensing forms of content associated to forms of expression, values in the patterns that can be seen. Therefore, "the more perfect knowledge is that which is both adequate and intuitive" (ibidem).

Intuition is the lynchpin of Kant's transcendental aesthetic. In his Critique of Pure Reason (1781-1787) he distinguishes between 'pure intuition', that of space and time as pure a priori sensory forms of sensitivity, and empirical intuition, which refers to the phenomenon through a sensation. To paraphrase Kant, intuition cannot be sensory because it contains the way in which we are affected by objects. The intellect is instead the ability to think of the object of sensory intuition. Neither of these two properties should be favoured over the other, but thoughts, without content, are empty; intuition, without concepts, is blind. Just as it is necessary to make our own concepts sensorial (by adding an object to intuition), it is also necessary to make our own intuitions intelligible by bringing them within concepts. ${ }^{1}$ What renders Greimas' descriptive praxis (1984) and Bordron's sequence on iconic constitution (2011) similar is the interdependence and Kantian circularity between the sensory and the intelligible.

Artistic and culinary practices invest heavily in experimentation with the sensory world in terms of the senses (Lévi-Strauss, 1962). Intuition means estimation in cooking - "how much salt? As much as you need!" and in painting, in which neither the unconscious nor instinct figure, but a knowledge embedded through exercise, which precedes insight and is based on probabilistic contingency (Migliore 2012). Fabbri (1987, ed. 2000: 52) translates this knowledge as "a kind of discernment or sagacity, something similar to the sense of smell", whilst Eco assimilates it with "the agility of Nous, which works counter to the more complicated operations of dianoia [...], but there is nothing ineffable in th way it works (Eco 1990, Engl. transl.: 33). Eco (1968), starting from Luigi Pareyson's theory of formativity, valorises the interrogation of the subject as if it were a path with obstacles, using very solid criteria: the premonition of success, the 'divination of form'. Peirce, who does not explain intuition, and as such the remainder of its own cognitive epistemology, in a logical way (C.P.

${ }^{1}$ Cfr. Kant (1781- 1787), B75-A51, tr. it., p. 169, author's italics. 
5.262, Questions Concerning Certain Faculties Claimed for Man, 1868), takes care to theorise guessing as a "natural insight" that would help us to "guess right' (Peirce, The Order of Nature, 1878, § 6.418; The Architecture of Theories, 1891, § 6.10; "Guessing", 1929, § 7.40).

Worthy of our attention is the comparison between the Western concept of intuition and the Arabic firâsa, a complex notion that defines the capacity to leap from the known to the unknown by inference (on the basis of clues) (Ginzburg 1979). In the Sufi language, the term indicates a penetrating shrewdness and is attributed to the son of the god of Serendipity. A 'lowly' form of intuition, "the organ of conjectural knowledge" based on the senses and belonging to hunters, mariners and women, is distinguished from a 'high' form that is extra-sensory and exclusive to an elite (ibidem) $)^{2}$. Firâsa is more or less equivalent to mètis as defined by Detienne and Vernant (1974): a real link between the human animal and other animal species" (Ginzburg, op. cit.: 102). "An intuition is not proven but experienced. And it is experienced through the multiplication and variation of the conditions for its use" (Bachelard 1932), so as to become virtuosos or "professional amateurs" (Marrone 2015).

A very clear definition of what happens in intuition is provided by John Dewey:

"Intuition" is that meeting of the old and new in which the readjustment involved in every form of consciousness is effected suddenly by means of a quick and unexpected harmony that is in its bright abruptness, like a flash of revelation, although in fact it is prepared by long and slow incubation. Often times, the union of old and new, of foreground and background, is accomplished only by effort [...]. When old and new jump together like sparks when the poles are adjusted, there is intuition. This latter is thus neither an act of pure intellect in apprehending rational truth nor a Crocean grasp by spirit of its own images and states, but a re-creation in which the present impulsion gets form and solidity whil the old is literally revived, given new life and soul through having to meet a new situation (Dewey 1934: 277).

\subsection{Levels of Expertise}

It is worth further exploring the hypothesis put forward by Greimas and Courtés (1979) that when it comes to description, intuition is a "component of the cognitive competence". Stuart and Hubert Dreyfus (1986) identified five levels of skill acquisition, taken up in semiotics by Fabbri (1989): novice, advanced beginner, competent, proficient and expert. The novice arrives with a great

\footnotetext{
2 Similarly, Husserl separated "eidetic intuition" from "empirical intuition". Whilst the latter refers to single objects, "eidetic intuition" allows us to grasp the essence of the phenomena, going beyond preconceived ideas and cultural judgements with a process of elimination, or phenomenological reduction (epoché). In Husserl's take on intuition, knowledge is provided by conscious perceptions that are mediated by intentionality" before being and that makes full use of being. See Lévinas 1930 .
} 
many rules, like someone who has learned the grammar of a foreign language but "falters in the language as a whole", which they are yet to confront. The novice is "context-free" (ibidem: 64-65). Then the novice advances and begins to let go of the rules, becoming an advanced beginner. They grasp a number of empirical principles and circumstantial aspects, keeping track of previous cases in which they worked. On the third level, the competent "gives it a go", integrating necessity and a lack of confidence in their skills with the passionate implication of fear, risk and, conversely, the enjoyment of making an attempt, a pleasure the novice and advanced beginner do not have. Higher up the scale, the proficient "by now picks up on salient elements" and reflects on the roles and relationships that inter-define them (ivi). Finally, the expert "is like a poet. They know what there is to know after having forgotten what they had learned. They hide all the rules that they have learned in the incorporation of tacit knowledge. They don't 'know' anything anymore" (ivi). Fabbri calls this the "extraordinary sum of incorporated knowledge that allows us to be experts in something" (ibid.: 59).

As such, intuition as a "cognitive competence", posited at the outset of the analysis (Greimas and Courtés, 1979), is the tangible proof of a now tacit knowledge, because, with training, it has been incorporated. It certifies the possession of the third level of ability as a minimum, according to the codification by Stuart and Hubert Dreyfus (1986), and is a precondition for sound semiotic analysis. But intuition is entwined with the researcher's pre-existing knowledge and capacity. It is not enough to have tools and concepts. A knowledge of the field of research must be added to the method. Today, when everyone claims their right to speak alongside the "legions of idiots" online (Eco), it is necessary to dust off the theory of levels of skill, knowledge and ability required in order to be qualified. Often this awareness is also lacking in the semiologist who, for example, has to analyse the data provided by social media in order to study trends, but does not know where to start. The semiologist online often comes across as a novice. They arrive with their toolbox, but are not familiar with the world they are aiming to explore. The expert, on the contrary, is someone who knows the field and the object of research, and has trained, gaining such confidence as to be in a position to offer projections, predictions, intuitions on the future of the case being examined.

\section{4. "Intuition" (2017). An Exhibition}

The exhibition Intuition, curated by Daniela Ferretti and Axel Vervoordt and set in the Palazzo Fortuny-Fondazione Musei Civici in Venice, visually explained the concept of intuition as an in-tueor, a "looking inside", which though it is an "illumination of the soul" (Descartes), it is not the enemy of rational thought. Indeed, as a sensation, it often guides thoughts and behaviour. Artists such as El 
Anatsui, Jean Arp, Joseph Beuys, Georges Braque, Marcel Broodthaers, Alberto Burri, Eduardo Chillida, Willem de Kooning, Anish Kapoor, Kimsooja, Yves Klein, André Masson, Ana Mendieta, Duane Michals, Joan Miró, François Morellet, and Saul Steinberg explored the theme through different expressive genres and systems, leading the visitor through the activation of relationships between substances intended both as form and perception.

In particular, Un coup d'œil sur la nature et ses environs $(1925,205 \times 160$ $\mathrm{cm}$, Private collection) by Max Ernst imagines the "glance" as a submersion, a kind of dive into the sea's abyss. Or, at least, that is what the technique of frottage with a black pencil would suggests.

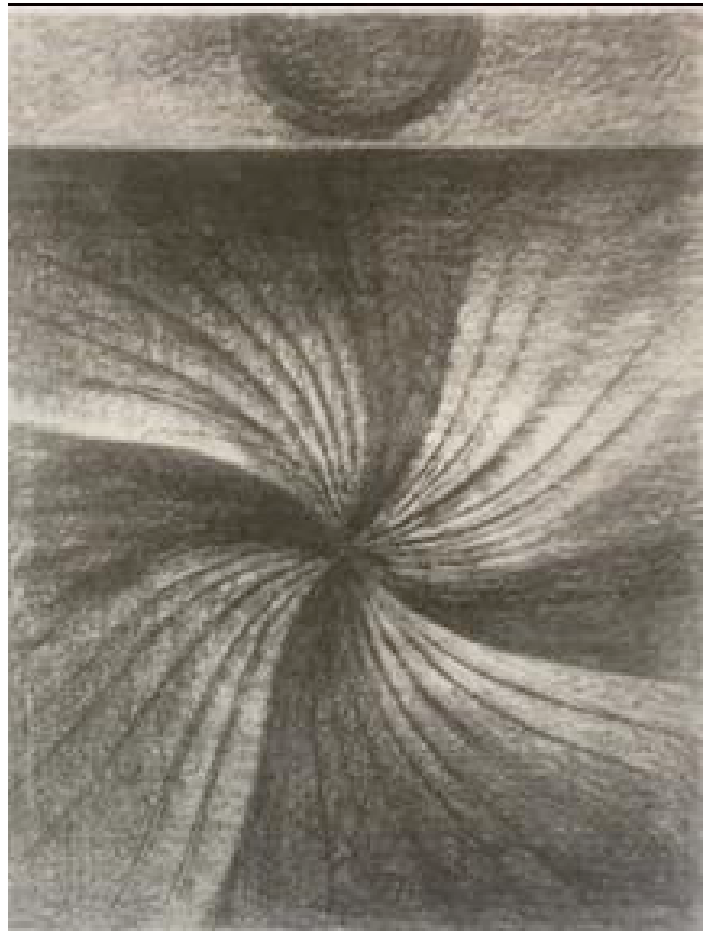

Fig. 1. Max Ernst, Un coup d'œil sur la nature et ses environs, $1925,205 \times 160 \mathrm{~cm}$, frottage, from the series Histoire naturelle, Private Collection.

The frame marks out a body of water and a strip of sky that continue past the border. If we trace the axes of the topological grid, the meeting point between the sky and the water coincides exactly with a whirlpool that simulates the act of immersion, anticipating it. This figural signifier, open and centrifugal, contrasts with the round and closed form of the sun, placed at the centre on the same vertical axis, but higher up. The perspective with its central vanishing point created by the vortex, together with the plane of the scene, brought closer, place the spectator in the middle, coinciding with the trajectory of the dive. Semi-symbolically, the whirlpool corresponds to the sun as an attractive process 
on the level of the enunciated (and an immersive one on an enunciatory level). It is in a fixed state of the world. The vortex, as a relational figure between the work and the body of the spectator, emerges because of its structural difference to the static and detached form of the sun. Contrary to what one might think, intuition is not a punctual act, but a process that takes place over time and that, in narrative terms, unites the perceived and the perceiver. Within this process, the coup d'oeil metaphorically represents the moment of illumination: a vertigo in Max Ernst, as risky as it is attractive and necessary.

\section{Conclusion}

Intuition as a method in itself, and one of the most elaborate methods in philosophy, because of its duration and coherent rules that tend toward precision, was postulated by Gilles Deleuze (1966), drawing on Bergson and identifying three specific rules. The method of intuition essentially involves problematizing (critical of false problems and inventor of real ones), differentiating (with its decomposition - découpages - and recomposition - recoupements), and temporalizing (Deleuze 1966). Deleuze's notes on intuition in Bergson chime with the stance taken by Greimas, and are of utmost importance to the strengthening of the semiotic procedure of description.

With intuition, affectivity gives the object a volume in space via affect. Affect transforms the body into 'something other than a mathematical point'. Recollection-memory links instants to each other; interpolates the past in the present. Then contraction-memory contracts matter to make quality appear (Deleuze 1966, Engl. transl.: 25). The goal of intuition is "to overcome experience in order to reach the conditions of experience" (ibid.: 22); it is "the movement by which we emerge from our own duration, by we which we make use of our own duration to affirm and recognize the existence of other durations, above and below us" (ibid.: 32-33). "Without intuition as a method duration would remain for us a merely psychological experience and we would remain prisoners of what is given to us" (ibid.: 33).

The formation of an organon of categories and concepts in Greimas has gone hand in hand with the development of a procedure for analysis, both in terms of the description and the segmentation of the object. This model, which is neither prescriptive nor peremptory but that Greimas limited to suggesting us, came from repeated readings of myriad texts. Other levels of pertinence, today, such as "practice", "strategy" or "form of life" do not render it invalid. Rather, thanks to their focus on enunciation in action, these levels allow us to think of the procedure as a path for research and discovery through sense experience. The investigation into the role of intuition responds to this same interest. 


\section{Bibliography}

Bachelard, Gaston. 1932. L'intuition de l'instant. Paris: Stock. Engl. transl. The intuition of the instant. Evanston: Northwestern University Press 2013.

Bordron, Jean-François. 2011. L'iconicité et ses images. Etudes sémiotiques. Paris: PUF.

Deleuze, Gilles. 1966. L'intuition comme méthode. In Gilles Deleuze, Le bergsonisme. Paris: PUF, pp. 1-28. Engl. transl. The Intuition as a Method in Philosophy, in Gilles Deleuze, Bergsonism, New York: Zone Books 1988, pp. 1335.

Détienne, Marcel \& Jean-Pierre Vernant. 1974. Les ruses de l'intelligence. La "mètis" des Grecs. Paris: Flammarion.

Dreyfus, Hubert \& Stuart Dreyfus. 1986. Mind Over Machine: The Power of Human Intuition and Expertise in the Era of the Computer. New York: Free Press.

Eco, Umberto. 1990. I limiti dell'interpretazione, Milano: Bompiani. Engl. transl. The Limits of Interpretation, Bloomington and Indianapolis: Indiana University Press 1990.

1968. La definizione dell’arte. Milano: Mursia.

Ferretti, Daniela and Axel Vervoordt (eds.). 2017. Intuition, catalogue of the exbibition at the Palazzo Fortuny-Fondazione Musei Civici, Venezia, Mai 13November 6. Gent: MER.

Fabbri, Paolo. 2001. Conclusioni. In Paolo Fabbri, G. Marrone (eds.). Semiotica in nuce II. Teoria del discorso. Rome: Meltemi, pp. 359-365.

1989. Conoscenza tacita e discorsività. In P. Fabbri, Elogio di Babele. Rome: Meltemi 2003, pp. 53-67.

1987. Moduli e parabole. Ragionare per figure. In P. Fabbri, Elogio di Babele. Rome: Meltemi 2003, pp. 44-52.

Fabbri, Paolo \& Paul Perron. 1991. Postfazione. In Algirdas J. Greimas, Semiotica e scienze sociali. Torino: Centro Scientifico Editore, pp. 217-225. Engl. transl. Foreword. In Algirdas J. Greimas, The Social Sciences, a Semiotic View. Minneapolis: University of Minnesota Press 1990, VI-XII.

Fontanille, Jacques. 1994. Sans titre... ou sans contenu?. In Fernande SaintMartin (ed.). Approches Sémiotiques sur Rothko (Nouveaux Actes Sémiotiques, nn. 34-36). Limoges: Pulim. 
Geninasca, Jacques. 2003. Il logos del formato. In Documenti di Lavoro del Centro Internazionale di Scienze Semiotiche, 3. Rome: Aracne Editrice 2013.

Ginzburg, Carlo. 1979. Spie. Radici di un paradigma indiziario. In Aldo G. Gargani (ed.). Crisi della ragione. Torino, Einaudi, pp. 59-106. Engl. transl. Clues: Roots of an Evidential Paradigm. In Carlo Ginzburg, Clues, Myths, and the Historical Method. Baltimore and London: The Johns Hopkins University 1989, pp. 96-125.

Greimas, Algirdas J. 2017. Mitologiche. Una semiosfera lituana. In Paolo Fabbri (ed.). Documenti di Lavoro del Centro Internazionale di Scienze Semiotiche, 9, Rome, Aracne Editrice.

1987. De l'imperfection. Perigueux: Pierre Fanlac.

1984. Sémiotique figurative et sémiotique plastique. In Actes sémiotiques. Documents, vol. 60. Engl. transl. Figurative Semiotics and the Semiotics of the Plastic Arts. In Greimassian Semiotics (New Literary History, vol. 20, n. 3, Spring). 1989, pp. 627-649.

1976a, Sémiotique et sciences sociales. Paris: Seuil. Engl. transl. The Social Sciences, a Semiotic View. Minneapolis: University of Minnesota Press 1990.

1976b. Maupassant. La sémiotique du texte: exercises pratiques. Paris: Seuil. Engl. transl. Maupassant, The Semiotics of Text: Practical Exercises. Amsterdam, Philadelphia: John Benjamins Publishing Company 1988.

1973. Description et narrativité. A propos de "La Ficelle" de Guy de Maupassant. In Revue Canadienne de Linguistique Romane, 1; Engl. transl. Description and Narrativity: The Piece of String. In New Literary History, 20, 1989, pp. 615-626.

1972. Essais de sémiotique poétique. Paris: Larousse.

Greimas, Algirdas J. \& Joseph Courtés. 1979. Sémiotique. Dictionnaire raisonné de la théorie du langage. Paris: Hachette. Engl. transl. Semiotics and Language: An Analytical Dictionary. Bloomington: Indiana University Press 1982.

Hjelmslev, Louis. 1943. Omkring sprogteoriens grundlæggelse, Festskrift udgivet af Kobenhauns Universitet, Copenaghen: Ejnar Munksgaard. Engl. transl. Prolegomena to a theory of language. Madison: University of Wisconsin 1969.

Jakobson, Roman. 1973. Questions de poétique. Paris: Seuil.

Leibniz, Gottfried Wilhelm von. 1684. Mediationes de cognitione, veritate et ideis. Engl. transl. Meditations on Knowledge, Truth and Ideas. In Gottfried Wilhelm von Leibniz, Philosophical Essays. Indianapolis: Hackett 1989, pp. 23-27. 
Lévinas, Emmanuel. 1930. Théorie de l'intuition dans la phénomenologie de Husserl. Paris: Alcan. Engl. transl. The Theory of Intuition in Husserl's Phenomenology, Evanston: Northwestern 1995.

Lévi-Strauss, Claude. 1962. La pensée sauvage. Paris: PUF. Engl. transl. The Savage Mind. Chicago: University of Chicago Press 1966.

Marrone, Gianfranco. 2015. Dilettante per professione. Palermo: Torri del Vento.

Migliore, Tiziana. 2012. Dipingere: i segni e le sostanze, foreword to James Elkins, La pittura cos'è: un linguaggio alchemico. Milan: Mimesis, pp. 207-242.

Parret, Herman. 1975. Un entretien radiophonique avec Greimas, voice recording, not transcribed.

Peirce, Charles S. 2003. Opere, Massimo Bonfantini (ed.). Milan: Bompiani.

Poincaré, Henri. 1908. Science et Méthode. Paris: Flammarion. Engl. transl. Scienza e metodo, Claudio Bartocci (ed.), Turin: Einaudi 1997.

Zinna, Alessandro. 2004. Le interfacce degli oggetti di scrittura. Teoria del linguaggio e ipertesti, Rome, Meltemi. 


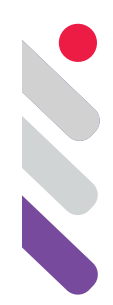

\section{Trajectories of Meaning in Space and Value Systems}

DOI: 10.24308/IASS-2019-8-016

Pierre Pellegrino

Lausanne, Switzerland

pellegri@bluewin.ch

\section{Problematic: space and articulation of meaning}

Before any reflection on the course of meaning and the exchanges that it supposes, what it circumvents or crosses, its types and its variants, its trajectories and its bifurcations, the question of the very definition of space arises here.

At the foundation of modern semiology, the discussions carried out on the definition of the semiotic space can be recalled in the problem posed by Peirce in a conference he gave at Harvard ${ }^{\circ}$ : “... to the extent that it is a continuum, space is a simple law ... , a law with all that it has in general, ... but that does not prevent it from being also a thing ..." (Peirce 1889a). Even if it is the strict application of a law, the thing is not the law. Then is space a law of interposition, an interval, or something offered by a body, an extent?

Thus, according to Peirce, "If we try to generalize the results obtained, we can say that the continuity of space acts in such a way as to subject an object to the influence of modes of existence which are not its own, not in that it participates in them, but in that it opposes them" (Peirce 1889b). But, these modes of existence are, however, those of objects which, for some, are not simply juxtaposed, but composed with each other.

If space is both law and thing, this supposes therefore to grasp it in a definition as a general framework as much as a particular filling, and so to differentiate it between agent and patient, active and passive, as well as to articulate its forms and its modes of existence, the modes of spatialization that it imposes on substances (Hjelmslev 1943). What values takes its cuttings into forms of the human life; how can it make sense? 


\subsection{Space, from absolute to relative}

Let's come back here to some of the different understandings of space. Philosophers each pronounce on principles of which they form a system. For an epistemology of science, these principles are not necessarily however antagonistic, but often relating to axioms and postulates aiming at different problems. Let's take a quick look at them to come up with an overall theory.

Empty space and infinity: Several definitions of the space of pre-Socratic philosophy conceive of it as an empty and unlimited space, like кहvov кa $\alpha \pi \varepsilon\llcorner\rho o v$, kenon and apeiron (Anaximandre 585 B. C), empty and limitless, without closure, as constituting an infinite continuity; or even as kevov kal $\alpha \tau \mu_{0}$, empty and unbreakable (Démocrite 433-370 B. C). This conception of space as emptiness endures up to contemporary philosophy and to the modern arts, architectural and theatrical notably (Brook 1968).

Continuous vs discontinuous: Peras and apeiron are also defined as the generative principles of the world and its order, kosmos (Anaximandre $585 \mathrm{~B}$. J.-C). The order then supposes limits, the space is consequently discontinuous, divided by these limits; yet its continuity paradoxically remains underlying. Order the world needs limits. Today the space of economic globalization and it of political borders are in question.

The envelope, the matrix: Within these limits, space can be conceived as

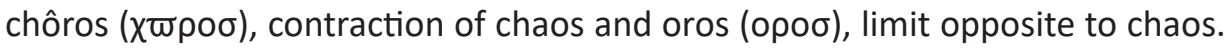
Space is then the opposite of chaos. If chaos is a gaping void, bottomless, the chôros is a receptacle void, a matrix (Platon 360 B. C). Oriental philosophy has developed a conception of empty space as constitutive, generative of the full (Lao Tseu 479 B. C.). This emptiness of emptiness can notably be seen today in traditional organization of space as in behavior in Japan (Barthes 1970).

Place and space: Full of a body that occupies it, the topos is defined by limits. The place is neither the matter nor the shape of the enveloped body; it is different from what it contains. It is the border of the envelope, the first immobile boundary (Arostote 327 B. C.). The place is then recognized to exist in the replacement of one body with another, in antimetastase. But also, the space must not be too large, otherwise it loses its envelope significance; which Sitte noted very well for the correction of the Ring in Vienna (Sitte 1889), made of empty spaces which could not be places.

Place and displacement: Bodies occupy places, take positions there, but that only for a time. Placements and displacements are ephemeral. For Heraclitus,

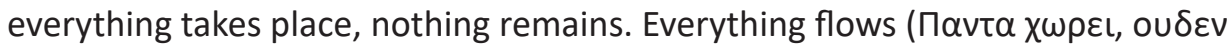

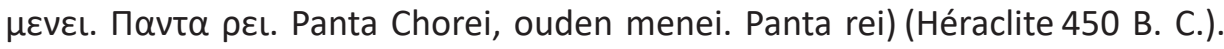
The tides of life take everything away. Conversely, for Parmenides, if the one is not, nothing is. Unity at all results from unification, and its measurement from a unit of measure. Without unity everything collapses into excess. 
Space, movement: In Roman thought, according to its etymology, space is a form of movement: the spatium is an open space, an endless stroll (Pellegrino 2008); in contrast, the stadium is a building and a measure of displacement. The city is traversed in a quiet pleasure, it is a place of civilities and reliance. Republic expands in an Empire and speed becomes the very condition of control of space. Space and movement are correlated (Pellegrino 2000). The contemporary metropolitan agglomeration has the problem of flows, it is struggling to find an organization that can make different speeds compatible by inscribing them in different spaces.

Extent and form: Extension is what remains of the material thing when I extract from it my previous cognitive constructions and my existential marks (Descartes 1641). The metaphor of the candle, of which nothing remains when it has melted, except an extended matter, without form, clearly indicates that the extension opposes the form, to the point of destroying it, but that it is also the very condition of any construction. It remains to be seen whether, in order to define its form in a unitary manner, the construction can be conceived in one piece, as advocated by Descartes, like a utopia, at once, with the intention of avoiding thus having to find a progressive synthesis of several successive constructive gestures.

Situation and partition: The question is also to know if the space is pure extensum, if it can be defined only by a situation and relationships, or if it must be conceived as a place, with an extension and limits. Or if the situation is a relation of two bodies with regard to their extension, or not (Leibniz 1700).

Behind this question is hidden that of identity, equality and congruence between bodies, namely whether they can be conceived as such by a modification of their parts or not, and to what degree these parts are not only internal but also homogeneous to each body.

Absolute space, relative space: Without relation to bodies, absolute space is always immobile, while relative space is the measure of absolute space, its mobile dimension (Newton 1687). Absolute space is unlimited but passive; relative it is limited but active. Relative space is limited by what it is related to. Like the limitless in the limitless, relative space is of the same species but not of the same size as absolute space, the end of which it never reaches since it does not have one.

So, the place, which is a part of the space, is always a relative space, it is defined in the extension by limits, and openings, and in the relation by adjacencies, and connections. In the making of territories, places are always relative to others, even if they enclose themselves within their own limits.

Empty and full, absolute or relative space: The trajectories of the mobile bodies and the divisions of the extent raise the question of the dominance of matter in the definition of relative space, and its opposition to emptiness. Under 
certain dimensions there is an empty vacuum, in which the relative spaces are at the limit of the absolute; and under some others we have a full vacuum, structured by gravitational fields in which the matter and the waves which cross it are inflected until their trajectories

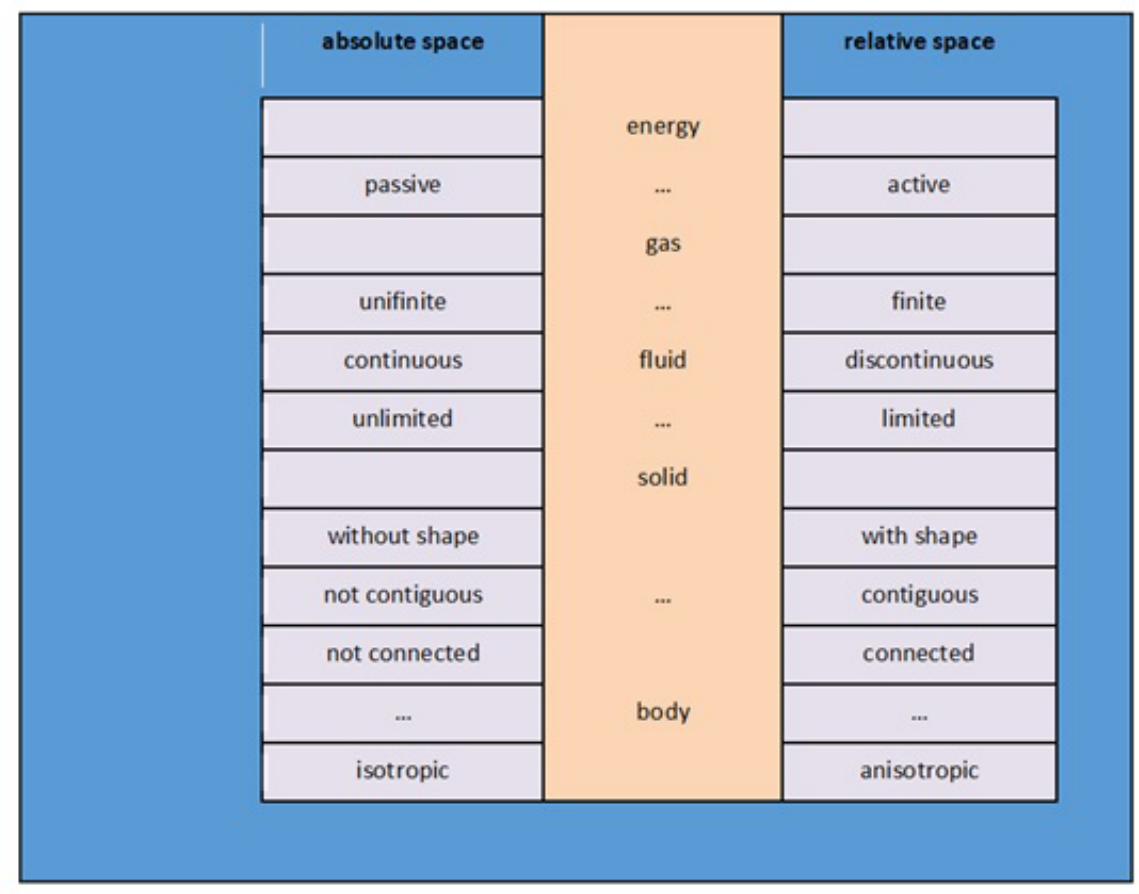

Figure 1. Synthesis of absolute and relative

Space: To summarize, we can schematically conceive that we have on the one hand an absolute space which is a space of extension unlimited but receiving limits, a space open but supporting closings; and on the other hand, a relative space which is a space of relationships, contiguous to some but discontiguous to others, connected and disconnected by its relationships

\subsection{Space and form}

Now, to be able to understand it in the terms of semiotic articulations, it remains to grasp how space takes shape. Following Kant, we will first admit to do this that for the thinking subject, space is not a thing or a substance, but a form, a priori form, the form of our external sense; it allows us to grasp our external reality. According to Kant, there are bodies outside of us, that is to say "things of which, while not knowing absolutely what they can be in themselves, we become aware by the representations that their influence on our sensitivity gives us" (Kant 1783). In space we represent the objects on which we act not 
only as distinct but also as apart from each other; it is there that "we determine their form, their magnitude and the relationships" that we grasp between them (Kant 1781). That said, to put exteriority as what is outside of us is already recognize it as a reality distinct from us (and not as the deceptive appearance of a phenomenon); and if space is the form of apprehension of this reality, there is therefore indeed an external reality which is grasped.

We must therefore also admit that, for us, space is not only an a priori form, form of our intuition, but also, in a "progressive condensation of being" (Kant 1756), formal intuition, by admitting then that it is also in itself a reality external to us, a constructed reality, such that our own body detaches itself from it and that we recognize it as such as a finite object and cut off from an infinite extent (from an absolute space), on the one hand; and on the other hand that like two objects in space, our body and the body of the other are distinct firstly because they do not occupy the same place in this extension (in a space of relation). There is no contradiction in admitting that space can be, for us and in itself, a priori form and cutting, separation between a subject and what he is not, as much as relationship between he and his objects.

Before grasping in its deep dimensions this space of the subject, I have therefore here to deal with the constitution of value in semiotic processes, and which semiological value systems can constitute the spaces of the relative and the absolute in their oppositions.

\section{The theory of value}

Peirce, in his philosophical writings defines the sign by exchange, something for something else (aliquid pro aliquo); a sign (or representamen) is "something which for someone takes the place of something in some respect or in some capacity". It "stands for" something "not in all respect", but by "reference to some kind of idea" or "foundation" (Peirce 1989). It produces in the mind of the one who receives it an equivalent or more developed sign. From the play and the opposition of these equivalences comes value.

Modern semiology, as defined by de Saussure, is a theory of value even more than a theory of the sign. De Saussure gave to it these objectives: "We can conceive of a science which studies the life of signs within social life; it would form part of social psychology, and therefore of general psychology; we would call it semiology (from the Greek semeion, "sign") ", (de Saussure 1915).

\subsection{Linearity, space, time}

Dealing with the semiotics of space, it is then a question of taking up and discussing these definitions of sign and value by inscribing them in those of space and sense of space. 
It should first be noted that when reading the Cours de Saussure, we find explicitly used of extent and space, and defined forms that they give to languages. De Saussure poses the space in time of the production of linguistic value: "The signifier being of an auditory nature takes place in time alone and has the characters it borrows from time: $a$ ) it represents an extent $b$ ) this extent is measurable in one dimension, it is a line". Meaning alone allows the ear to make the relevant, "sufficient and precise" divisions in this "continuous ribbon". The signifying elements "appear one after the other; they form a chain". By writing, "we substitute the spatial line of graphic signs for succession over time". The fact remains that in other systems space is multidimensional, and that the divisions of matter correlate all the dimensions relevant to the values it opposes.

\subsection{Value and system}

For de Saussure, the word is part of a system in which it is "clothed" not "only with a meaning, but also and above all with a value, and it is quite another thing". So how does value differ from meaning? For de Saussure, value, "in its conceptual aspect", is an element of meaning, it "differs from it, while being under its dependence".

The value is thus split into exchange value and comparison value: "[...] even outside language, all values seem to be governed by this paradoxical principle.

They are always made up:

1. By something dissimilar capable of being exchanged for that whose value is to be determined;

2. By similar things that can be compared with that whose value is in question.

These two factors are necessary for the existence of a value".

The conceptual part of value as much as its material part consists only of "relationships and differences with other terms of language". These relationships and these differences constitute the language system. "A linguistic system is a series of differences in sounds combined with a series of differences in ideas"; this combination "generates a system of values" which constitutes "the effective link between the phonic and psychic elements within each sign".

The signifier and the signified each taken apart are "purely differential and negative"; the characteristic of "the linguistic institution" is to "maintain the parallelism between these two orders of differences"; but "their combination is a positive fact". In the comparison of their value, the signs are "positive terms", they are "only distinct". Between them "there is only opposition". 


\subsection{Space and value system}

These differences can be relevant and are articulated in oppositions forming a system, this system cuts out, articulates and combines entities in a linguistic space. The spatial dimensions are evident in the examples that de Saussure uses to explain the linguistics he offers in his Course:

Tapestry and oppositions of colors, opposition of signs

Game of chess, states of the system

Sheet of paper recto verso, arbitrariness of articulation

Line, ribbon, linearity of the process

Place in a chain, limitation of arbitrariness

Street and relationships, relative situation

Signs of politeness, collective habit and rule

Fashion and body, convenience and constraints

Balance of the justice, symbol and convention

The system is made up of differences, but difference presupposes position, and position in space is constructed by following a system of oppositions. Oppositions in the system and positions in space report between them to produce sense.

\subsection{Space and process}

If the terms are opposed in a system of signs, they also take a position in a game and are linked to each other. Their position does not only result from what opposes them, into the system, but also from what binds them in their succession, into the process. The consecutive combinations formed by successive terms, the syntagms, are supported by extension. From my point of view, we must add to this that it is not only a question of position, juxtaposition and opposition, but also of composition; a speech or a text must be composed and this composition takes into account what its components suppose.

\subsection{Chaining and association}

A linguistic unit "is comparable to a specific part of a building". Component of a column, each of the components can replace another occupying the same position in the elevation between pedestal and architrave, in particular a Doric capital, an Ionian, Corinthian, or other.

Syntagmatic relationship and paradigmatic association oppose in presence and absence: The syntagmatic relationship is in praesentia, it rests on two or more units equally present in space. On the contrary, the associative relation unites terms in absentia, in mental comparison in a virtual mnemonic series. 
This being the case, the Course affirms that associative coordinations are not supported by extent. For me, on the contrary, they are coordinations of extent fragments. And I would say that syntagmatic sequence and associative relationship intersect; we can note that there is one of the terms of the associative relationship which is present in the syntagmatic sequence and which gives rise to paradigmatic association. The units each have a meaning and a value, on which the double relationships, paradigmatic and syntagmatic, are established (Godel 1957).

The paradigmatic commutations, substitutions of the values of exchange of signs thus cross the syntagmatic positions, relations, combinations of the values of oppositions of signs, and this crossing is a mechanism of economy (Prieto 1980), it works on the system of places.

\subsection{Synchrony, diachrony}

In diachrony transformations do not consist in dismissing oppositions of values by others, but in relying on them to control the modifications of the language. De Saussure's mechanisms are those of agglutination and analogy, both of which are space devices. Agglutination is an agglomeration of existing terms. The analogy, ( $\alpha$ v $\alpha$ tov $\lambda$ oyov: according to the calculation, in a geometrical mediation, $a: b:: b: c)$ is a relation which allows to create a new term , $x$, using the relationships between existing terms ( $\mathrm{x}: \mathrm{c}:: \mathrm{a}: \mathrm{b}$ ). In space, we can add to these two, all mechanisms that deconstruct and reconstruct existing terms in various morphisms to produce others.

\subsection{Reference values, identities and location}

These mechanisms can also use the context, transforming it into a cotext to tap into what it brings, and create new relationships. De Saussure sketches a geographic linguistics, in which he defines the intercourse opposed to the steeple spirit. The steeple spirit intends to center particular values on a place of belonging, to which it provides with external borders; the intercourse goes beyond the limits established by particularizing the singular features of a language that progress in extent. These two movements of particularization each oppose in its own way a total transformation of the values of the semiotic exchange.

It is about the space of languages, the formation of linguistic territories, where distinctive features are propagated by contagion from near to close, or by displacements of populations, by borrowing words from afar, or even through media diffusion. Territories made up of displacements as much as places, where extend, meet, oppose or merge features of language, inside or beyond physical barriers or political borders. 


\section{Values of space and social bond}

To deal with the social link in space, and show how it gives it value, we must understand the genesis of the meaning of the same and the other, as that of the one and the multiple, according to two dialectics, the one specific, the other numerical. The first constitutes a logic of space, the second operates counts in space so that the same not only differs from the other but also can be recognized as multiple (Prieto 1991).

Unlike an empty, monotopic space, made up of the absence of the body of the other, the space of the genesis of places lays its foundations in a diatopy between one and the other as between text and context. The context is for the text the place of an allotopy; it is made up of other texts which project the images of an environment conceived elsewhere.

The diatopy is an articulation of the dialectic of the one and the multiple by that of the same and the other; but this articulation is first created in the margin or the interstice, at the periphery of the territories: "where the extent and the chance of the substance make it possible to receive the anomalies and the exceptions coming from the other as generators of general images of the world" (Lotman 1966).

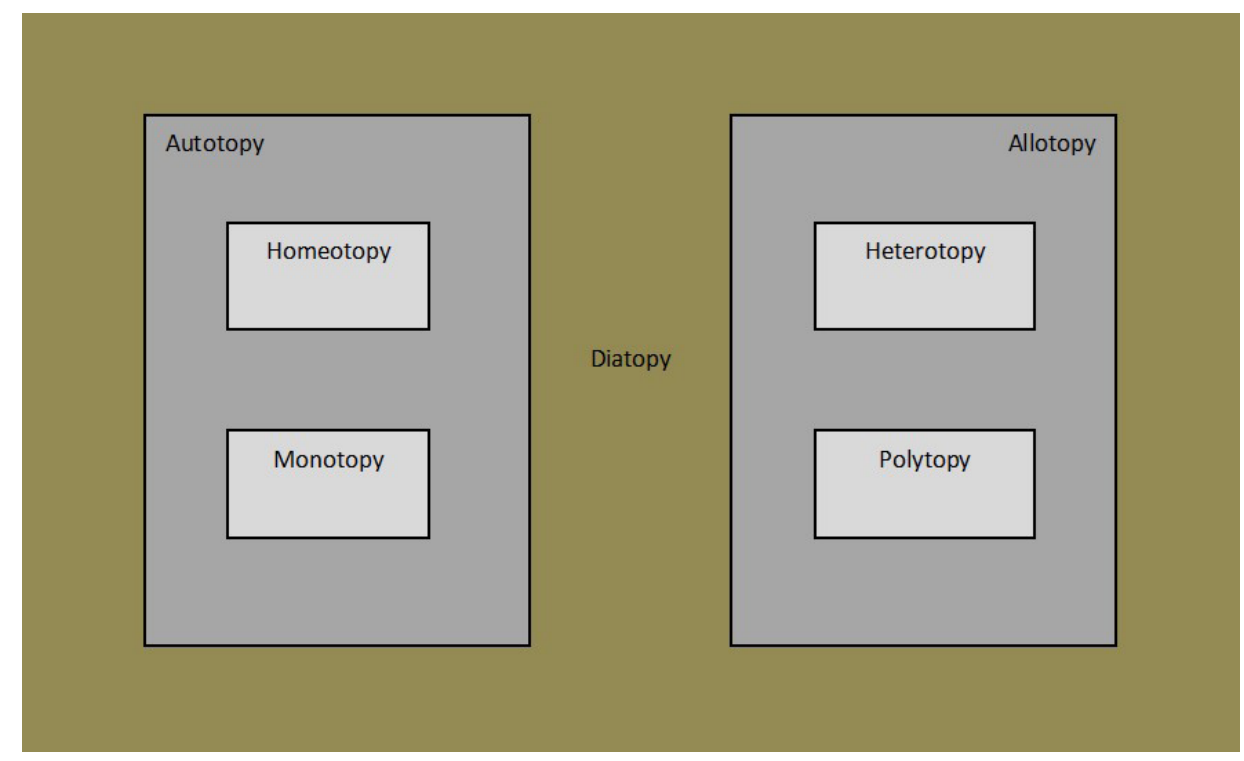

Figure 2. Dialectic of the same and the other as of the one and the multiple in the space of social bond 


\subsection{Spaces and modes of spatialization of the social bond}

In the relative space of the dialectics of the same and the other as of the one and the multiple, the topoi are the results of modes of spatialization which aim at conjuring forces. The divisions of the territory are made and unmade according to the modes of spatialization of human facts (Pellegrino 2000). A division of space can presuppose another on various scales, those of a cell, a building, a place, a landscape, a region. Their assembly and the structure which they manifest in different types of configurations are articulated by the modes of spatialization of personal and social life; these modes project on the territory variances and invariances specific to each kind of space.

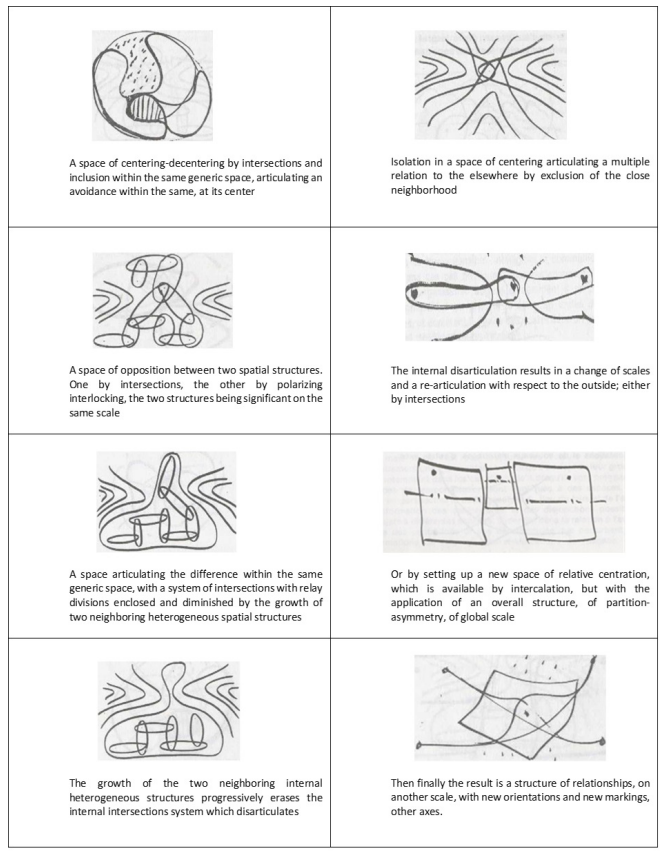

Figure 3. Formation, deformation and transformation of spaces of social bond, urbanization of a rural area

\subsection{Synchronic and diachronic space}

The analysis of synchronic stabilities observes the existence of spatial units and relationships, each having a relevance and a meaning based on practices developing in different times and from different origins; sometimes we see the joint permanence of two structures, one older the other more recent, including other units and other relationships on scales of another size. However, these two structures are never completely autonomous; the second being added to the first, they form two articulated subsystems in a larger structure which includes them; their articulation can be done through the integration of breaks, offsets, deviations, as well as by superimpositions, interlocking, or intersections, depending on whether the presuppositions, understood as rules, allow or not the passage of one configuration cut to another. 
An origin structure plus new spatial units, new forms and new relationships, constitute a system of diachronic transformation insofar as a restructuring makes possible the liquidation of a lack and the formation of a new sensible equilibrium in the social existence. The moment of transformation requires the transition from a simple structure to a more complex system whose complexity will be partially absorbed in a new equilibrium (Pellegrino 1986).

\section{Space and subject construction}

But the subject is not reduced to the institutions which control its forms of life, no more than to the matter from which emerges the value it takes in his most direct journeys or his wandering. It crosses the spaces of social ties, strengthens them by its presence or endangers them.

He self was built by the cutting, away - there, and the otherness, subject - object (Freud 1920). In the formation of its space, from the present to the absent, it projects the same rules, extended from here to elsewhere (Piaget 1977). From the singular (body) to the universal (thought), it thus brings into play the "semiotic function" of the place it occupies.

\subsection{Space and difference}

According to Prieto, knowledge always takes place in the subject and not in the object: "[...] an object does not occur as such in material reality but rather appears as such in mental representation that the subject constructs : an object, in fact, is nothing other than a fragment of material reality that the subject recognizes also precisely as such, in other words as a fragment of this reality" (Prieto 1995).

Being is constructed in space and in time: The subject is "constituted as such by discovering the being that constitutes the spatial object which is its body and by discovering [...] its duration and its existence in time".

Being builds up its otherness in space: In the dialectic of space, where each geometric point is one and other in relation to another, "by discovering who he is, the subject necessarily discovers the other, that he is not".

Being builds its identity over time: In the dialectic of time, "by discovering that it lasts, or that it lives, that it is alive - to live as the living beings last - the subject inevitably discovers that he dies, that he is dying, that he dies because - since he is alone, not being the other who succeeds in being - he is alone in dying who succeeds in living" (Prieto 1991).

Space and time are not just an aspect of a being; these are the conditions of his existence, his chance to give meaning to his presence or absence, to his life and to his death. The trajectories of meaning in time and space cause stability and displacement of oppositions, permanence and transformations of value systems. 
- "Where are you been my blue eyes son? Where are you been my darling youg one?" Bob Dylan

- "Para misturar a vida eu preciso de espaço". To mix life I need space. Fado de Lisboa

- "K'na mèrir, yegour sirèm". Go away, die, and come back that I love you. Armenian proverb

- "Et nous allions ... berçant notre infini sur le fini des mers". And we were going ... Rocking our infinity on the end of the seas. Baudelaire, Le voyage

- "L'homme, ivre d'une ombre qui passe, porte toujours le châtiment, d'avoir voulu changer de place". The man, drunk with a passing shadow, always carries the punishment, for having wanted to change places. Baudelaire, Les hiboux

- "Fidèle à l'immense quai, chaque soir, je vais revisiter l'océan". True to the huge quay, every evening, I go revisit the ocean. Victor Hugo, Oceano nox

Thus, on the spatial horizon, there is an orientation of life. The consciousness that the subject has of his singularity, of his own value, this consciousness is taken in the spatiality of his living environment, conditioned by bodily factors (sensation ...), institutional factors, a memory. The sense of space is acquired in a space of meaning articulating meaning and means of making sense. Trajectories do not exist without territories, and infinity is only conceived from the finite.

\section{References}

Anaximandre. 585 B. C. Fragments. Fr trans. in M. Conche Fragments et témoignages. Paris : PUF. 1991.

ARISTOTE. 327 B.C. Physique, Fr, trans. H. Carteron et P. Pellegrin. Paris : Belles Lettres. 2002.

BARTHES, Roland. 1970. L'empire des signes. Genève : Skira

Brook, Peter. 1968. Empty Space. Fr. transl. L'espace vide. Ecrits sur le théâtre. Paris : Seuil. 1977.

Démocrite. 433-370 B. C. Tétralogies, fragments. Fr. trans. in Les Présocratiques. Paris : Gallimard. 1988. 
Descartes, René. 1641. Méditations métaphysiques. Paris : Larousse. 1973.

Freud, Sigmund. 1920. Au-delà du principe de plaisir. In Essais de psychanalyse. Fr. trans. Paris : Payot. 1963

Godel, Robert. 1957. Sources manuscrites du cours de linguistique générale de F. de Saussure. Genève : Droz.

Héraclite. 450 B. C. Fragments. Fr. trans. M. Conche, Paris : PUF. 1986.

Hjelmslev, Louis. 1943. Prolégomènes à une théorie du langage. Paris : Minuit. 1966.

Husserl, Edmund. 1907. Ding und Raum. Fr. trans. Chose et espace. Paris : PUF. 1989

Kant, Immanuel. 1756. Nouvelle définition du mouvement et du repos, La monadologie physique. Fr. trans. in : CEuvres Philosophiques. Paris : NRF. 1980.

Kant, Immanuel. 1783. Prolégomènes à toute métaphysique future. Fr. transl. Paris : Vrin. 2001.

Lao Tseu. 479 B. C. Tao Te King. Fr. trans. S. Mitchell. Paris : Editions Synchroniques. 2012.

Leibniz, Gottfried Wilhelm. 1700. Mathesis Generalis. Fr. trans. in Mathesis Universalis. Paris : Vrin. 2018.

Lotman, Yuri. 1966. La sémiosphère. In : L'Univers de l'esprit. Fr. trans. Limoges : PULIM. 1999

Newton, Isaac. 1687, 1726. Philosophiæ Naturalis Principia Mathematica. Fr trans. Principes mathématiques de la philosophie naturelle. Paris : Dunod. 2005.

Peirce, Charles Sanders. 1889a. Seventh Harvard Lecture. Fr. trans. C. Chauviré, in Le Raisonnement et la Logique des choses - Les Conférences de Cambridge . Paris : Cerf. 1995

Peirce, Charles Sanders. 1889b. Third Harvard Lecture. Fr. trans. C. Chauviré. In Le Raisonnement et la Logique des choses - Les Conférences de Cambridge. Paris : Cerf. 1995

Pellegrino, Pierre et. al. 1986. Espace et Développement. Paris : UNESCO.

Pellegrino, Pierre. 2000. Le sens de l'espace, Livre 1, L'époque et le lieu. Paris: Anthropos. 
Pellegrino, Pierre. 2008. Urban settlements, from the origin of the city to the contemporary land. In ELSA, Vol. 1. II, Lausanne - Thessalonique : ICAR.

Piaget, Jean et. al. 1977. Recherches sur l'abstraction réfléchissante. II, L'abstraction de l'ordre des relations spatiales. Paris : PUF.

Platon. 360 B. C. Timée. Fr. trans. A. Rivaud. Paris : Belles Lettres. 1985.

Prieto, Luis Jorge. 1975. Pertinence et pratique. Paris : Minuit.

Prieto, Luis Jorge. 1991. Ipotesi sulla significazione dell'opera d'arte. In Saggi di semiotica, Vol.Il, Sull'arte e sul soggetto. Parma : Pratiche.

Prieto, Luis Jorge. 1995. Saggi di Semiotica, Vol.III, Sul significato. Parma : Pratiche.

de Saussure, Ferdinand. 1915. Cours de linguistique générale. Edition critique de Tullio de Mauro. Paris : Payot. 1972.

Sitte, Camillo. 1889. Der Städtebau nach seinen künstlerischen Grundsätzen. Fr. trans. L'art de bâtir les villes. Paris : Equerre. 1980. 


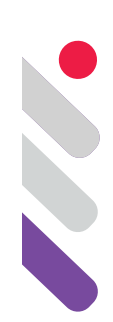

\section{Transdisciplinary Trajectories: The Audacity of Design and the Resilience of Signs}

DOI: 10.24308/IASS-2019-8-017

Farouk Y. Seif

Antioch University Seattle, USA

Fseif@antioch.edu

\section{Introductory juxtaposition: "aiming at" versus "navigating through"}

The notion of trajectories is not to aim at a particular target and to follow a prescribed direction or a known place. In particular, the idea of transdisciplinary trajectories is essentially a navigational process that requires a distinctive way of thinking and doing. But before we go further, I would like to recognize the fundamental distinction between the two notions of "aiming at" and "navigating through." Aiming at a known target or thing is following a specific direction. Perhaps aiming at a particular target and following a prescribed direction are efficient and appropriate ways in medical treatments and military tactics, where the aim is usually to solve a problem or to eradicate a hostile physical thing. But navigating through unknown territories for the purpose of seeking qualitatively desired outcomes is an effective nonlinear, reiterative process constantly adjusted pragmatically by feedback and feedforward.

The strategy of aiming at a target and the approach to navigate through a trajectory have their own appropriate places and distinct purposes. The difference between aiming at and navigating through is consequential; aiming at should not be considered as a one-size-fits-all methodology. The crucial issue is that aiming strategy and navigating approach should not be used to replace each other in encountering all sorts of challenges in life. In dealing with social and cultural challenges, which require a transdisciplinary approach, aiming strategies intended to fix what is broken or not working in order to maintain the status quo are limited and misbegotten, and consequently misleading. That is why trajectories should not be construed as aiming at physical things, following a predetermined path to an expected and known result. Transdisciplinary trajectories are navigational processes augmented by the courage to persevere through the paradoxical thinking of design and the ability to tolerate the shifting role of signs. 


\section{The audacity of design and the resilience of signs}

For human beings, as "semiotic animals" (Deely 2010), to know anything about reality is to rely on the resilient action of signs, and to construct or reconstruct reality is to rely on the audacity of design. The concept of design is about the courage to create, despite all odds, and goes beyond mere manufacturing products and making things. Design is much more than aiming at producing things or making artifacts; it is an intentional activity that, while it navigates a pathless journey, it celebrates the emergence of a desired and perhaps unexpected outcome. The nature of signs is ephemeral and changeable; therefore, signs are resilient and transient. Of course, when we speak of semiotics, which Peirce considers "too vast, and the labor too great, for a first-comer" (CP 5.488), we also speak of the action of signs (semi osis), which are far from being exclusively words or residing in the linguistic domain. It is important to be aware of the common mistake of considering semiology as semiotics - the pars pro toto fallacy. Certainly, both design and semiotics offer multifarious theoretical and broad pragmatic activities that are pregnant with meaning and intentionality.

In the triadic relation-representamen (sign vehicle), object (being represented), and interpretant (creation of a new sign in the interpreting mind) - the sign is indifferent to cognitive or natural circumstances. An object is not necessarily a thing to aim at. There is a distinction between what we call "things" and what we perceive as "objects." Things are actual physical items, whereas objects are mental concepts of things. The distinction is significant in our understanding of the difference between aiming at a physical thing and navigating toward an object in the mind.

Another noteworthy matter is that our awareness of the difference between objects and things might change our understanding of the distinction between what is real and what is true; as I argued elsewhere (Seif 2016), what is real is not always true. Sometimes the real becomes true, and sometimes the true can become real. For example, the perception of a body of water in the vast desert is real; the mirage of water, although no water is present, is a true optical phenomenon (Seif 2019). The irony is that a real thing is only recognizable as a result of being an object in the human mind. There are inverted relations and a spectrum of gradations-as expressed in Greimas's semiotic square-between real and true, and things and objects. This is precisely why we can change objects in the mind more easily than we can change physical things. ${ }^{1}$ This also

\footnotetext{
${ }^{1}$ The peculiar distinction between the "real" and the "true" is significant to our understanding of the difference between our awareness of objects and our perception of things (Seif 2016, 2019). Such a distinction is also invaluable to our comprehension of the difference between aiming at a real thing as a targeted solution and navigating through toward a true object as a desired outcome. But the challenge is that the words "things" and "thoughts" are interrelated; the origin of the word "reality" is the Latin res, which means "thing" and comes from the verb reri, meaning
} 
makes it clear why sociocultural challenges cannot be eliminated by aiming at prescribed solutions.

To engage in design and interpret signs is to have the courage to persevere through the contradictions between hope and despair, between what is and what could be, between audacity and resilience. Throughout history, human beings have always persevered through the paradoxes associated with the act of interpretation and creation. To engage in the process of design thinking and semiotic interpretation is to tolerate ambiguity and uncertainty, and to face the reversibility and transparency of signs. Indeed, such a process makes design outcomes unpredictable and sign relations indeterminate; hence is the navigational process through trajectories.

Understanding contradictions requires not only the courage to traverse their boundaries without slipping into an either-or position, but also the resilience necessary to tolerate the negation of pluralities. The courage to traverse the boundaries of differences and to tolerate the negation of contradictions is in the very nature of semiotic animals; it requires going beyond their rational thinking into intentional meaning-making of a desired future. It is well established linguistically that design is a purposeful act and semiotics is about signification; as an act of creation and interpretation, design and semiotics signify purpose. As the drive for meaning-making activity, intention allows hu mans not only to perceive and understand reality as past and present, but also to envision the future. For reality, as John Deely (2002: 110) asserts, "is not only a question of what is, but as well of what could be and of what should be and what will in future be." However, the challenge is that what could be, or should be, is an invisible relation of qualities to navigate toward.

\subsection{Qualities are invisible relations}

Certainly, the purpose of design thinking and semiotic interpretation is to achieve quality. In the Peircean sense, qualities are qualia ${ }^{2}$ that are experienced through feeling. Because qualities are "shapeless, formless, indescribable" (Pirsig 1974: 253), and their description largely ineffable, they cannot be named or seen, they must be felt (Alexander 1979). Paradoxically, since quality (or quale) is invisible, we cannot aim at it but can only navigate a pathless journey to achieve it. In other words, qualities are not physical things to aim at

to think (Bohm 1980). It is imperative that we abandon thoughts that confuse aiming at physical things with that which allow us to navigate toward desired outcomes. Such thoughts are limiting and not in tune with our lifeworld.

$2 \quad$ Although the word "qualia" has been around since the time of Plato and Aristotle, it was Charles Sanders Peirce-in his Lowell lectures on "The Logic of Science" in 1866-who introduced the term "Quale" as a novel philosophical framework to capture the felt experience of qualitive phenomenal character that goes beyond the visual perception of physical materials. Qualia do not fall under sensory experiences and are not restricted to or simple sensations such as visual and tactile experiences (CP 6.221-222). 
or prescribed destinations to arrive at; rather, qualities are invisible relations. Anticipating physical things as the upshots of design thinking and semiotic interpretation is indeed the mother of all confusion.

The widespread perception of design outcomes as mere deliverables is a common mistake. There is a critical difference between what design outcomes signify and what design deliverables represent. Generally, traditional design disciplines-industrial design, fashion design, graphic design, etc.-focus on making things (deliverables) in the hope that these things may bear qualities. But the broad scope of design seeks qualities (outcomes), at the outset of the process, that can be concretized in deliverables. In other words, outcomes are a manifestation of qualities. Deliverables may contain qualities, but they are not qualities themselves.

Phenomenologically, qualities (or qualia) are a tipping point between physical and metaphysical polarities. Quality is the invisible relation between matter and its substance, between a physical thing and its essence. This is to say that quality is the essence of physical things, not a thing as such. The essence of things is like a diamond with multiple facets of brilliance and beauty. Interestingly, the Arabic words essence l̀æåÑ (jawhar) and diamond İæåÑå (jawharah) are etymologically interrelated. ${ }^{3}$ This means that while such brilliant and beautiful qualities are invisible, hidden inside physical things, qualities are manifested through multi-facets. This also means that the brilliance and beauty of the outcomes of design thinking and semiotic interpretation cannot be achieved head-on by aiming at physical matters or expected results. Indeed, this achievement necessitates the courage to tolerate, conceive, and imagine invisible relations.

\subsection{The courage to design and the shifting role of signs}

The scope of semiotics covers many different spheres of human thought and action. A sign is resilient, and not only at one semiotic moment of time; each element of the triadic sign shifts its role and never permanently remains the same. Considering this triadic relation, it is impossible for signs to exist in absolute reality. Neither is it possible to aim at a sign. Signs are always in relations with other signs, in which sign relations are formed by intentionality and interpretation. The process of these relations is open, dynamic, interpretable, and transparent. This is why trajectory is a challenging pathless journey we must take to transcend the absolute reality frequently associated with autonomous physical existence.

\footnotetext{
${ }^{3}$ Although the Arabic word "diamond" l̀æåÑå (jawharah)-or lææçãN (jawahir) for plural diamonds-is generally used to refer to gemstones or jewels, the diamond is at the top of all precious stones, and historically is the most romanticized as a symbol of innocence, purity, and everlasting love.
} 
This brings us back to the subtle difference between things and objects and their relations to signs, which through "the highest grade of reality is" to be reached (CP 8.327). Signs are neither physical things nor just objects. Signs are neutral to things and objects, true and untrue, real and imaginary-for instance, the sign of a unicorn is not a physical thing, but a legendary object. But a sign of a dinosaur is an object in the mind and also could be a real thing to perceive if you were living in prehistoric times. Since thinking is in signs, according to Peirce, our thoughts mediate between things in the world and our experience of them as objects in our minds. So, to construct or reconstruct reality is to rely not only on sign interpretation, but also on design thinking.

According to John Deely, experiencing reality is through signs, where both mind-independent things and mind-dependent awareness come together. Our experience of reality begins first when objects come into existence through signs in the human mind. Without signs there could be no objects, and without objects there could be no awareness of things in the world. What is remarkable about sign relations is "their permeability to the otherwise distinct orders of what does and what does not exist independently of finite mind" (Deely 2005: 470).

It is often difficult to understand the relation between objects and things, and their connections to the role of signs. This difficulty forces many of us to think of reality as hardcore reality, mere physical things that need to be targeted in order to fix or maintain that which has been in existence. Yet reality includes not only that which existed, but also that which exists or will exist. Things can be targeted by aiming at, but objects can only be manifested through the navigating process of actualizing possible desired outcomes. Once we have the courage to change our habitual thoughts about the notion of objects, it is much easier to change our perception of physical things and change them.

\subsection{Problem solving aims at targeted solutions - design navigates toward desired outcomes}

Generally, problems fall into two categories: "wicked" problems and "tamed" problems (Rittel and Webber 1973). Solving tamed problems does not go far beyond managing existing reality or maintaining the status quo by aiming at a predetermined result. Wicked problems cannot be solved by such strategies. But there is a tendency to try to fix wicked problems temporarily by avoiding the nature of paradoxes that are at the core of design thinking and the shifting role of signs. It is important to be aware of the differences between what we perceive as problems and what we experience as paradoxes. Unfortunately, paradoxes are often perceived as a problematic dualism that must be fixed to favor one pole over the other. But life challenges are full of ill-defined or wicked problems, which are akin to paradoxes and cannot be solved or resolved by aiming at a targeted solution. 
Problem-solving strategies in dealing with contradictory social challenges are ineffectual if derived from a mechanistic fallacy that is blind to the nature of paradox (Seif 2017, 2019). Sometimes a problem-solving strategy is a good immediate reaction to a wicked problem, ${ }^{4}$ but it is not an ultimate response to life challenges. Such wicked problems can be dealt with effectively only through reframing their challenges and the reiterative process of reflection on thoughts and actions to transform the status quo into a new reality. When we navigate the trajectory of design thinking and semiotic interpretation, we reflect-in-action (Schön 1983) and engage in praxis without depending on the categories of established theories and techniques within traditional disciplines and idiosyncratic biases. This why a desired outcome is achieved by design thinking and semiotic interpretation innate to the navigation of transdisciplinary trajectories, which are paradoxically challenging.

\section{Paradoxical challenges of navigating transdisciplinary trajectories}

Navigating transdisciplinary trajectories can be a source of frustration and joy simultaneously. One of the most astonishing aspects of design and semiotics is that paradoxical thinking-thinking and doing despite all odds-may go against what is understood as common sense into unexpected uncommon sense (or extraordinary sense). Common sense is expected in solving problems by aiming at a targeted solution, whereas uncommon sense is needed for seeking desired yet unexpected outcomes. Again, aiming at a known target or a thing is following a known direction and a linear process, whereas navigating through trajectories, as a journey through the unknown toward desirable outcomes, is intrinsically a nonlinear and reiterative process, constantly adjusted expediently and intentionally but not deliberately.

There is a difference between an intentional act and a deliberate act. A deliberate act is a linear utilitarian succession appropriate for a problem-solving strategy to arrive at a particular target. An intentional act is a navigational process that, while it seeks desirable outcomes, tolerates ambiguity and is comfortable with uncertainty about that which emerges unexpectedly. But the question might arise, how do we navigate toward a desired outcome that is an unseen quality and not a thing out there to see and aim at?

\footnotetext{
${ }^{4}$ For clarification, I am not implying that problem-solving strategies are useless or inconsequential. What I am saying is that these strategies are not appropriate for all problems or challenges. While problem solving is a very efficient strategy for aiming at targeted solutions, the integration of design thinking and semiotic interpretation is the most effective approach to navigate through social challenges and life paradoxes. Although problem-solving strategies to social or individual chal lenges frequently arrive at temporary solutions to problems, they sub stitute different and short-lived conditions that will sooner or later trigger crises and despair. For instance, using technical fixes in attempting to solve wicked social, economic, and political problems is an approach we have repeatedly seen fail (Seif 2016, 2017, 2019).
} 
Peirce tells us, "our knowledge is never absolute but always swims, as it were, in a continuum of uncertainty and of indeterminacy" (CP 1.171). Design always deals with ambiguity and uncertainty, and signs require resilience that is far greater than merely coping with the rapidly changing world with its profound instability and unknown future. The most intrinsic principle of design thinking and semiotic interpretation is our ability to tolerate this ambiguity and to be comfortable with such uncertainty. This principle suggests that design and semiotics neither aim at a single target nor use linear strategies. It also suggests that signs can be understood in relation to other signs, and that sign relations are formed by intentional design.

The courage to engage in design and the endurance to tolerate the shifting role of signs demand that we be comfortable navigating through what I call "diaphanous space and polychronic time" (Seif 2013), transcending the nostalgic past, the gravity and limitations of the present, and the linear projections or forecasts the future. Reality is multi-dimensional, which is intrinsic to the very idea of design and semiotics, going beyond the traditional disciplines of the humanities and the sciences. The idea of navigating through diaphanous space and polychronic time is a cognitive and noetic experience that is essential for design thinking and semiotic interpretation.

In order to avoid hopelessness and overcome the paralysis often associated with the disparate need to maintain the status quo, we have to navigate through space-free and time-free-reality ${ }^{5}$ to allow the possibility for imaginative thinking, reframing, and innovative action. Perception of things exists in a specific space and time, but awareness of objects does not need to exist in here-and-now reality. Therefore, the challenge of this navigation requires a different kind of intelligence in order to liberate us from the gravity and limitations of the here-and-now reality; it demands a spatial and temporal intelligence that the ancient Egyptians perceived as $A k a$, "intelligence of the heart" (Seif 2013, 2019).

Navigating transdisciplinary trajectories is challenging because it takes a longer time and greater efforts to deal with uncharted territories than with linear steps. Such navigation relies on conceptualization, which operates metaphorically as a crystallization process in which seeking qualities leads to numerous possibilities and options for physical manifestations. ${ }^{6}$ The process is

\footnotetext{
${ }^{5}$ The idea of space-free and time-free reality (Gebser 1949) is congruent with the Heideggerian notion of "being-in-the-world," which is our projection onto the world of possibilities that lie before us or may be concealed from us. Heidegger's word Dasein, which literally means beingthere, is an indication of not just being-in-the-world, but also being present in the past-presentfuture dimension. Paradoxically, then, while we are being-in-the-world, we must also withdraw from the world in order to reconstruct the very essence of reality (see Gebser 1949; Heidegger 1927; Sartre 1948; Seif 2019).

${ }^{6}$ For example, pursuing the quality or essence of redness can lead to several possible physical forms, ranging from a red rose, red apple, red pepper, to red lips-all share the same attributes
} 
the same as in a diamond, in which its quality or essence lies hidden under layers of matter, beginning as graphite and emerging slowly to its ultimate expression as a diamond.

Such a navigation is a heroic journey, to borrow a concept from anthropologist Joseph Campbell (1949), which requires courage and resilience. This journey also demands the capacity for perseverance through paradoxes and the ability to deal with the distinction between the known reality and un unknown reality. We must face the challenges of abandoning our current familiar world and the tendency of maintaining what exists in this world in order to acquire the courage to enter an unfamiliar future world, returning with a gift that may be used to improve our lifeworld.

\section{The transdisciplinarity of De-sign: the fusion of design and signs}

The polar opposition of humanities and sciences, coupled with the hyper specialization of knowledge, has obscured the continuity of the lifeworld. To assume that a discipline is an absolute, self-standing body of factual knowledge is to mask out the human reality within which all transdisciplinary inquiries take place. Again, based on Peirce's caution, our knowledge is never absolute and always uncertain and undetermined. By viewing one part of reality through a magnifying glass and aiming at a specific target and predetermined result, experts in autonomous disciplines end up focusing their attention on separate and fragmented knowledge, consequently repeating failing decisions and worsening actions.

Design and semiotics are not autonomous disciplines, they are undisciplined perspectives. The transdisciplinary trajectories underscore the innate attributes of design and semiotics. Design thinking and semiotic interpretation bring into focus the most optimum and desirable outcome; not by focusing on one discipline, but by bringing disciplines into focus. The difference is like that between holding a magnifying glass to focus on a point versus putting on a pair of glasses to see clearly 360 degrees around, thereby, discovering magnificent interconnections.

It seemed reasonable then to infuse design and semiotics into a transdisciplinary, coherent body of work in which the search for le mot juste leads to the notion of De-sign. ${ }^{7}$ Since the transdisciplinarity of De-sign challenges the fixed boundaries that separate the humanities from the sciences, it sets

or qualities of redness. That is why aiming at a specific thing often limits numerous possibilities.

7 It is imperative to note that the two words "design" and "sign" share the same etymological roots. The word "design" from the Latin designare means to "mark out, to devise, to choose, to make a sign" (signum); hence, etymologically, "design" and "sign" really mean De-sign. Not only do these etymological roots reveal the remarkable connection between design and signs, but they also suggest that the qualities of design and signs are remarkably isomorphic (Seif 2019). 
us free from the self-imposed bondage of limited perceptions of reality. Design is not only a transdisciplinary trajectory toward actualizing possibilities for a meaningful future, but ironically is also the "predisciplinary" way for interpreting and reconstructing reality, a way of thinking and acting in the world that has been forgotten or ignored.

\subsection{Transdisciplinary navigation and three categories of exploration}

A crucial issue for De-sign is the type of exploration: search, research, and inquiry. Although these three words are often used interchangeably, they cannot be regarded as synonyms. The subtle differences among these categories are of fundamental importance in navigating transdisciplinary trajectories. Albeit the boundaries among these categories of exploration are somewhat transparent, each category provides information that is different and is not enough by itself for transdisciplinary trajectories.

Creating knowledge is much more than arriving at an absolute fact or an unlimited certainty. Knowledge as a product of search and research conducted in specialized disciplines seems to be elevated to the status of a relic for utilitarian consumption. Search is a concept attainment process: metaphorically, a "springboard" that leads to a finding, a bridge that connects to further steps of exploration, a way to find or discover something new about the present. Research is basically a concept recall process, characterized by the metaphor of an "empty chair" - the curiosity that seeks an answer to why a chair is empty, when there must be an entity to be found or recalled that once occupied that chair. Research is generally a way for understanding the past and present.

On a fundamental level, inquiry depends on concept formation, which is unlike concept recall or concept attainment. Such an inquiry demands imaginative and integrative skills, exemplified by the metaphor of a "symphony composition" that utilizes search, research, and inquiry. Specifically, de-sign inquiry is a way to conceptualize, interpret, imagine, and achieve a desired future. In concept formation, there are no preconceived ideas to be targeted, fixed answers to be remembered, or solutions to be discovered. Inquiry is systemically formed, interpreted, reinterpreted, and judged by a free and creative mind. The free movement within simultaneous multiplicities, transcending the appearance of things and creatively handling a range of polarities, is inherent to de-sign inquiry. To genuinely conduct de-sign inquiry is not only to tolerate ambiguity and be comfortable with uncertainty, but also to integrate insights and patterns of thoughts from different disciplines.

\subsection{Generalists as de-signers versus experts as a problem-solvers}

Being a generalist is indispensable in design thinking and semiotic interpretation. As a generalist, one may be perceived as being superficial, an 
amateur, or a "jack of all trades and master of none." Oddly enough, however, while experts play within the boundaries of specific disciplines, aiming at particular targets to remain experts in their respective disciplines, the unintended consequences of such specialization often reveal a serious deficiency. Problemsolving experts measure the efficiency of the targeted results of their solutions, but as generalists, de-signers rely on good judgment and mature feelings to assess the effectiveness of their de-sign outcomes.

Of course, one can be an expert in a specific discipline while not losing sight of the illusionary boundaries between one's own discipline and other disciplines. Being an expert in a particular discipline is the foreground, yet simultaneously other disciplines are in the background for integration; both are fundamentally important in perceiving the whole picture. Focusing on a discipline does not mean being oblivious to other disciplines; just as in driving, your gaze focuses ahead, and yet you are aware via your peripheral vision of the other visual elements residing in the outer boundaries of the visual field (Seif 2019).

Peirce envisions the doctrine of signs as unbroken knowledge (CP 8.342), Thomas A. Sebeok (2001) argues that semiotics should not be treated as a specialization, and Gregory Bateson (1972: 21-22) views knowledge as "knitted together, or woven, like cloth, and each piece of knowledge is only meaningful or useful because of the other pieces." Based on Peirce's principle of "synechism" (continuity of life) and his doctrine of "fallibilism" (falsifiability of knowledge), it is evident that the expert researcher in a specific discipline plays within the boundary of that discipline, whereas the transdisciplinary inquirer plays with boundaries of various disciplines.

\section{Concluding remarks: transdisciplinary trajectories in the transmodern world}

It is imperative to comprehend transdisciplinarity as a total system. It should not be viewed as a new discipline, a super-discipline or hyper-discipline (Nicolescu 2002, 2010). In this sense, transdisciplinarity is different from interdisciplinarity. ${ }^{8}$ The prefix "trans" in transdisciplinarity indicates "that which is at once between the disciplines, across the different disciplines, and beyond all disciplines" (Nicolescu 2008: 2).

We live in a transmodern world that goes beyond modernity and postmodernity. Clearly, the very nature of transdisciplinary trajectories is a

\footnotetext{
8 Frequently the terms transdisciplinary and interdisciplinary are used interchangeably and described vaguely. I believe there is a significant difference between the two approaches of transdisciplinarity and interdisciplinarity. Whereas an interdisciplinary method, or multidisciplinarity method, uses knowledge from different disciplines but stays within their boundaries, transdisciplinary trajectories synthesize connections among disciplines into a coherent whole.
} 
navigational process appropriate for this transmodern world, where reality is a multi-dimensional and integrative hyperreality. To live mindfully and effectively in such reality, we must go beyond the tendency of seeking efficiency by aiming at things, frequently utilized in many disciplines of the humanities and sciences, into navigating toward qualities, in which design thinking and semiotic interpretation are at the heart of transdisciplinary trajectories. Unquestionably, there are significant and far-reaching consequences of embodying transdisciplinary trajectories.

It is really inconceivable for us to live in the transmodern world without being aware of and embracing the inclusive idea of design and the broad scope of semiotics. However, the unknown or concealed is that the fusion of design and semiotics, De-sign, is categorically the nucleus of these transdisciplinary trajectories par excellence. The vision of De-sign aims to open all disciplines of the humanities and sciences not only to that which they share, but also to that which lies beyond their known boundaries. Such vision makes Design our trajectory toward envisioning a meaningful reality that goes beyond absoluteness. Navigating transdisciplinary trajectories would seem possible only if we go beyond the contemporaneous perception of absolute disciplines and ephemerality of knowledge, focusing on preconceived results and aiming at predetermined targets that barely exist or are short-lived in the paradoxical phenomena of life.

Since transdisciplinary work integrates disciplines from the humanities and sciences and transcends their traditionally established boundaries, the very core of De-sign does not rely on a specific discipline. Playing within the boundary of a specific discipline may achieve development of that discipline, but playing with the boundaries of disciplines often transforms those disciplines, resulting in breakthrough knowledge that changes human perception and understanding of reality and enables humans to persevere through paradoxes.

Transdisciplinary trajectories are not only about how human beings understand and create their reality, but also about the human capacity to deal with the paradoxical phenomena of life. In this sense, transdiscipli nary trajectories allow us to discover the love of learning and transform us into lifelong-learners competent to question absolute knowledge and capable of moving beyond merely being inquisitive about information, to becoming reflective contemplative knowers, to integrating all aspects of the transmodern lifeworld (Seif 2019).

One can reasonably conclude that Charles Sanders Peirce achieved the status of a great philosopher and semiotician by embracing the trans disciplinary trajectories that embody design thinking and semiotic interpretation throughout his life. Embodying transdisciplinary trajectories, Peirce became a polymath: mathematician, humanist, logician, phenomenologist, spiritual thinker, and 
designer. I suggest that Peirce embraced transdisciplinary trajectories, by the integration of the idea of design and the notion of sign, even without naming De-sign as such. The recent attempt to embrace transdisciplinary trajectories is best exemplified in my book De-sign in the Transmodern World: Envisioning Reality Beyond Absoluteness (Seif 2019). Transdisciplinary trajectories cross and transcend many boundaries. This is exactly why De-sign cuts through to the heart of the matter.

\section{References}

ALEXANDER, Christopher. 1979. The Timeless Way of Building. New York: Oxford University Press.

BATESON, Gregory. 1972. Steps to an Ecology of Mind. Chicago, IL: The University of Chicago Press.

BOHM, David. 1980. Wholeness and the Implicate Order. New York: Routledge.

DEELY, John N. 2002. What Distinguishes Human Understanding? South Bend, IN: St. Augustine's Press.

DEELY, John N. 2005. "Defining the Semiotic Animal: A Postmodern Definition of Human Being Superseding the Modern Definition 'Res Cogitans'," American Catholic Philosophical Quarterly 79.3 (Summer), 461-481.

DEELY, John N. 2007. Intentionality and Semiotics: A Story of Mutual Fecundation. Chicago: University of Scranton Press.

DEELY, John N. 2010. Semiotic Animal: A Postmodern Definition of "Human Being" Transcending Patriarchy and Feminism. South Bend, IN: St. Augustine's Press. 2010.

GEBSER, Jean 1949. The Ever-Present Origin, trans. Noel Barstad and Algis Mickunas. Athens, OH: Ohio University Press, 1985.

HEIDEGGER, Martin. 1927. Being and Time, trans. John Macquarrie \& Edward Robinson. New York: Harper \& Row Publishers, 1962.

NICOLESCU, Basarab. 2002. Manifesto of Transdisciplinarity, trans. Karen-Claire Voss. Albany: SUNY Press.

NICOLESCU, Basarab (ed.). 2008. Transdisciplinarity: Theory and Practice. New York: Hampton Press. 
NICOLESCU, Basarab. 2010. "Methodology of Transdisciplinarity-Levels of Reality, Logic of the Included Middle and Complexity," Transdisciplinary Journal of Engineering \& Science, Vol. 1 (December 2010), The ATLAS, 19-38.

PEIRCE, Charles Sanders. (1839-1914). The Collected Papers of Charles S. Peirce, Vols. I-VI, ed. Charles Hartshorne and Paul Weiss. Cambridge, MA: Harvard University Press. Vols. VII-VIII, ed. Arthur W. Burks (same publisher, 1958). References from this source are abbreviated as CP followed by numbers that refer to the volume and paragraph with a period in between.

PIRSIG, Robert M. 1974. Zen and the Art of Motorcycle Maintenance: An Inquiry into Values. New York: HarperCollins Publishers.

RITTEL, Horst and Melvyn M. WEBBER, 1973. "Dilemmas in a General Theory of Planning." Policy Sciences, 4(2), 155-169.

SARTRE, Jean-Paul. 1948. The Psychology of Imagination, trans. Jonathan Webber. New York: Philosophical Library.

SCHÖN, Donald A. The Reflective Practitioner. New York: Basic Books. 1983.

SEBEOK, Thomas A. 2001. Global Semiotics. Bloomington, IN: Indiana University Press.

SEIF, Farouk Y. 2013. "Resilience and Chrysalis Reality: Navigating Through Diaphanous Space and Polychronic Time," in Changing Worlds \& Signs of the Times, Selected Proceedings from the 10th International Conference of the Hellenic Semiotics Society, 2013, ed. Eleftheria Deltsou \& Maria Papadopoulou, 2016, 52-66.

SEIF, Farouk Y. 2016. "What is Real is Not Always True! Reconstructing Reality in a Transmodern World," in Is It Real? Structuring Reality by Means of Signs, ed. Zeynep Onur, et al. Cambridge Scholarship Publications, 46-65.

SEIF, Farouk Y. 2017. "Semiotic Paradoxes: Antinomies and Ironies in a Transmodern World," in Semiotics and its Masters, Vol. 1, Semiotics, Communication and Cognition (SCC) 18, ed. Kristian Bankov and Paul Cobley. Berlin: De Gruyter Mouton, 237-251.

SEIF, Farouk Y. 2019. De-Sign in the Transmodern World: Envisioning Reality Beyond Absoluteness. Bern, Switzerland: Peter Lang AG, International Academic Publishers. 


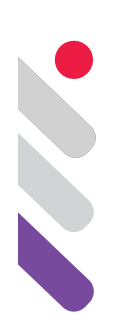

\title{
Reading Trajectories: Semiosis, Graphic Design and Ideology
}

DOI: 10.24308/IASS-2019-8-018

\author{
Prof. Dr. Evripides Zantides \\ Cyprus University of Technology, Cyprus \\ evripides.zantides@cut.ac.cy
}

\section{Introduction}

Hierarchy of information in graphic communication is an essential parameter that contributes to readability, as well as in attracting and directing the viewer's gaze in specific areas of interest on print or digital surfaces. It organises the content in a specific order, and provides emphasis on visual points like crescendo or decrescendo would do in music. Both for print, or screen-based applications, an entry point to a visual area defines where semiosis starts and the reading journey begins. While there are endless ways to enunciate this focal point, there are certain variables that are responsible for reading trajectories to be achieved.

"The aim of this paper is to discuss a series of visual variables that have the semiotic competence to contact a visual journey, as well as examine them through specific examples like advertisements or logos. In so doing, it investigates how these variables interrelate, and create hierarchies for the construction of messages.

Even though readability and legibility refer to the ease and clarity that a viewer navigates through the linguistic messages, the terms actually concern two separate notions. Readability refers to the comfort of the overall reading experience and how letterforms are arranged on a page or a website, whilst legibility is more specific, and concerns how well a typeface is designed with its letterforms distinguished among them. There are often graphic design examples with good legibility, but bad readability which in turn create unattractive design trajectories and create visual fatigue. As such, the paper also seeks to discuss these parameters, and the typographic factors that affect them, in respect of macro-readings of print advertisements and graphic symbols. 


\section{Semiotics as a tool for analysing images and written texts}

To understand how hierarchy of information is directed on a visualgraphic surface, for example an advertisement or a logo, a variety of semiotic analysis techniques can be applied separately, as well as in combination, to the verbal and nonverbal messages, using the following three-step process.

First, we can identify the prevailing visual entry point to the reading of the advertisement or a logo, and look for the most dominant verbal or nonverbal signs that attract the attention or the gaze of the viewer. Kress and Van Leeuwen (2006) refer to this as salience, which results from the composition of elements within a picture or a page. While the placement of these elements can create different hierarchical structures of salience, they are also made 'to attract the viewer's attention to different degrees' and select some elements as more important and valuable than others (ibid:177). In respect of this process, and considering the structure and mechanisms of visual perception, Saint-Martin (1990) defines "the basic unit of visual variables as the coloreme. The coloreme corresponds to that aggregate of visual variables perceived in the visual representation by way of an ocular fixation, or focus of the gaze." (ibid: 5). Once the viewer's gaze is captivated by/drawn to a focused point, one can claim that semiosis begins, i.e. a reading path evolves and navigates the reader through a visual journey of the advertisement. Key entry points within an advertisement are extremely important as "they mark transitions or the beginning of the message" (Ryan and Conover 2007).

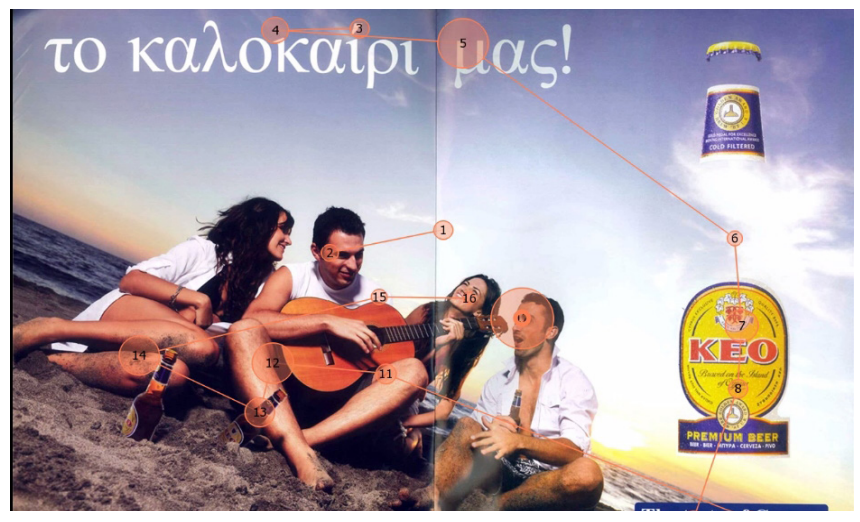

Figure 1: Coloreme example with eyetracker on a KEO beer advertisement Keo beer-our summer, October 2011, TV Mania magazine

Visual entry points and hierarchical navigating systems are vital from a semiotic point of view, as they modify the order in which visual information is provided to the viewer and therefore guide the construction of meaning. An example, using an eye tracker to catalogue this process, can be seen in Figure 1 above. As we can observe, the tracker captures the eye of the viewer looking firstly at the central man holding a guitar, and then goes to the headline, followed by the beer-bottle and finally the slogan. We can easily argue that the 
specific composition of elements is carefully designed so that this reading path is preferred.

Analysing verbal and nonverbal messages in advertisements separately and in conjunction, as suggested in the aforementioned compiled semiotic model, is a common practice in visual semiotic approaches. However, a semiotician's goal would be to consider the advertisement as a whole and then to proceed with a fragmentary analysis of it, an analysis of the components, as "[o]ne advantage of working with units is that they are manageable". Nevertheless, by working segmentally, it must be noted that "the semiotician should not isolate details arbitrarily or for their own sake but rather should ensure that each part is always considered as a part of a whole" (Floch 2000: 10). Consequently, as a first step, it is important to understand the whole structure and what the advertisement is all about.

Secondly, we can explore the meaning of all nonverbal representations. Barthes (1977), in his essays Rhetoric of the Image and The Photographic message, suggested theoretical and semiotic tools for analysing and understanding advertisements, especially in respect of the connotative mechanisms that assign meanings to photographs/images on an ideological and cultural level. In Rhetoric of the Image, he distinguishes three kinds of messages in an advertisement: the linguistic message, which includes all textual information , the symbolic message, which refers to all visual connotations that derive from the arrangement of nonverbal signs (the connoted image), including the connotative aspects of colours, and, thirdly, the literal message, which refers to non-coded meanings that derive from the denoted image, specifically, all nonverbal signs in the image that do not have any conventional cultural codes.

Regarding the symbolic message of nonverbal modes of representation, Barthes (1977) also draws attention to connotation procedures. In this framework, he describes six procedures that can impose a second, latent (or connotative), meaning on a photograph:

1) Trick effects: any faked, artificial intervention in the plane of denotation to construct false significations;

2) Pose: double structures, denoted or connoted, of represented participants in photographs because of their pose, profile shot, gaze and position;

3) Objects: meanings derived from the objects photographed and their associations with cultural ideas;

4) Photogenia: an informational structure which embellishes the image using techniques of lighting, exposure and printing. One might argue that this corresponds to the way that coloreme has already been described, a means to achieve a reading path through lighting techniques within an image; 
5) Aestheticism: the idea that a photograph refers to a painting, or, in the wider sense, it could be argued, the ability to allude to other familiar aesthetic structures, a kind of intertextual reference that also incorporates colour as a semiotic resource on its own; and,

6) Syntax: the signifier of connotation is found when numerous photographs come together to form a sequence. For example, in advertising, this would correspond to advertising campaigns or teasers where meaning is derived once viewers are exposed to the overall series of images.

Another important semiotic factor in the analysis of an advertisement is the context of its scenery; in other words, the environment where everything is taking place. For this aspect, Dyer (1989) introduces the term settings to describe the overall set-up, background and environment where the advertised product is placed in advertising images, and as such it is also adopted as a semiotic parameter for the current research.

In a study of Goffman's gender advertisements combining content analysis with semiotic analysis, Bell and Milic (2002: 218) point out that, "Systemic Functional Semiotics of the visual image as developed by Kress and Van Leeuwen (1996) relates texts to their particular cultural and situational contexts". Building on this argument, and to complete the semiotic tools for the analysis of nonverbal messages, we also adopted three kinds of interactive meanings or metafunctions as suggested by Kress \& Van Leeuwen (2006: 148). Particularly, these three semiotic resources that derive from the interaction between the producer/designer and the viewer of an advertisement are:

1) Interactive contact: structured by criteria such as where do represented participants in the images look in relation to the assumed viewer of the advertisement; for example, do they gaze at the viewer or not?';

2) Interactive distance: concerns the distance of objects or participants represented in the images; for example, close, medium or long shot, and 3) Interactive attitude: explores the angle from which the participants represented are seen by the anticipated viewer; for example, frontal, oblique, high, eye-level or low angle.

Overall, nine semiotic resources are suggested for analysing methodologically the nonverbal messages of advertisements. These are: Trick effects, Pose, Objects, Photogenia, Aestheticism \& Colour, Settings, Interactive contact, Interactive distance and Interactive attitude. It must be noted that other visual semiotic studies adopt similar factors, but they might use different names or include additional factors that were not considered necessary for the purpose of our analysis.

Thirdly, the meaning of all verbal representations was explored. Apart from exploring all denotative linguistic messages, as suggested in the 
aforementioned Panzani Pasta advertisement essay, Barthes (1977) interestingly looks at connotative meanings of written language, such as Italianicity, deriving from signifieds of "...the sign Panzani that gives not simply the name of the firm but also, by its assonance, an additional signified, that of 'Italianicity'" (ibid: 33). It is interesting to note that Barthes requires a special metalanguage to account for the signifieds of connotation and uses the suffix -icity for a "...condensed essence of everything that could be Italian" (ibid: 48). What is neglected, however, in Barthes' essay and other similar studies, is the semiotic aspects of the typographic articulation of the linguistic messages in advertisements. These aspects entail key semiotic parameters of the visualisation and organisation of written language in advertising space. In support of this argument, and to emphasise the importance of typography in visualising verbal language, Barron (1998) states that "in a given society, on a given language, at a given time' the characteristics of written language shape and reflect the social, economic, educational, legal or technological factors of that society" (Walker 2001: 10). Consequently, incorporating a framework of semiotic analysis for the verbal text would require an in-depth investigation into how to perceive and interpret the full connotative meaning of linguistic messages of the adverts that takes into account their typographic appearance, i.e. their form (or graphic rendering) and not just their substance.

Given that the number of potential visualisations and arrangements of verbal messages in an advertisement is endless, we adopt seven graphic semiotic variables for typography which were initially targeted at the semiotic aspects of the graphic language of maps and identified by Bertin (2011). These are:

1) Shape: the forms and shape, characteristics that letterforms have, uppercase or lowercase, and variations in font shapes;

2) Size: the scale that linguistic messages take, how big or small they are, and also through length, the space they occupy;

3) Value: the various tones of shades, various degrees or changes from light to dark in the writing of linguistic texts;

4) Texture: variations in patterns within the letterforms, changes within the letterform area;

5) Colour: colour appearances, changes in hue at given equal values;

6) Orientation: the angle and changes in alignment of written texts ranging from the vertical to the horizontal, and

7) Planar placement: changes in the positioning of the written text, along the $x$ and $y$ axis, looking at placement in the advertising space. When looking at these semiotic resources, it is always important to consider that "none of these visual variables can be considered independently as a basic unit of visual language, because at the same time that one is 
present, the others are manifested" (Saint-Martin 1990: 17), and that in every point of the visual field all variables are always present.

Additionally, the term Linguistic is incorporated as a tool for any connotative mechanisms in the linguistic messages, like the use of suffixes described earlier for Italianicity or other cultural associations/metaphors or intertextual references that allude to ideological connotations. Furthermore, to complete the semiotic tools for the verbal semiotic analysis, coloreme is also considered, as in the case of nonverbal messages, to define any hierarchical visual structures in the written text.

Overall, nine semiotic resources are suggested for analysing methodologically the semiotics of verbal messages in the advertisements. These are: 1) Coloreme; 2) Shape; 3) Size; 4) Value; 5) Texture; 6) Colour; 7) Orientation; 8) Planar placement; and 9) Linguistic.

The objective of all the aforementioned tools is to execute a semiotic analysis and extract any multiple layers of connotative cultural meanings that are directly connected with ideology. This is supported by the perspective, as formulated by Barthes (1977: 49), that "the common domain of signifieds of connotation is that of ideology". For a complete semiotic analysis, the three steps above are suggested, without, however, necessarily following the aforementioned order. Looking at these parameters segmentally, one needs to examine how they work in combination as well. Verbal and nonverbal relationships are not accidental; most of the time they play an important role in the overall construction and communication of messages, by complementing, supporting or interpreting each other. It is only through the simultaneous study and association of the overall segments and semiotic assumptions on a connotative level that cultural meanings, ideology and latent messages are revealed.

Table 1: Compiled semiotic model

\begin{tabular}{|c|c|c|c|c|}
\hline \multicolumn{2}{|c|}{1 STTPP } & \multicolumn{2}{|c|}{2 SSTEP } & \multirow{2}{*}{ 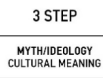 } \\
\hline & 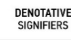 & 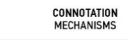 & 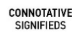 & \\
\hline \multirow{6}{*}{ verbal } & & 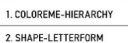 & & \\
\hline & & 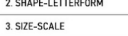 & & \\
\hline & & 4. mulus & & \\
\hline & & 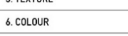 & & \\
\hline & & 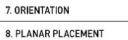 & & \\
\hline & & ounuousic & & \\
\hline \multirow{5}{*}{ Non-vereat } & & 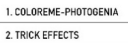 & & \\
\hline & & 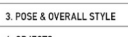 & & \\
\hline & & 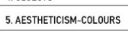 & & \\
\hline & & 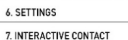 & & \\
\hline & & 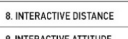 & & \\
\hline
\end{tabular}


The three-step process and all the analytical tools selected to define the aforementioned compiled semiotic model would not only satisfy the purpose of analysing semiotically a corpus of advertisements, but would also respond to how hierarchical structures and patterns are formulated.

The compiled semiotic model combining all the aforementioned semiotic resources for verbal and nonverbal messages in adverts can be seen in Table 1. A slightly different version has also been used to study the national identity signs in institutional print advertisements of the Cyprus Tourism Organisation (see, for example, Zantides, 2016). The suggested compiled semiotic model is very useful for anyone who wants to study and understand how meaning is constructed in advertisements, as well as how is associated with products or services.

In general, is a unique tool that combines constructively and efficiently the semiotic parameters that verbal texts carry too as well as discusses them in relation to the representations portrayed in the images.

\section{Implementing the compiled semiotic model on advertisements of Cyprus Airways}

Cyprus Airways, also known as 'the official carrier of Cyprus', was a public company supported by the government throughout its operation until its bankruptcy and closure in 2015. Cyprus Airways was established on 24 September, 1947 as a joint venture between the British Colonial Government of Cyprus, which held $40 \%$ of the share capital, and BEA (British European Airways), with private interests owning the rest of the company.

In 1960 the government of the newly independent Cyprus became the majority shareholder with a $53.2 \%$ holding, while BEA's stake was reduced to $22 \%$. The rest of the shares were held by private individuals. It was also at this point that Cypriot nationals began to be hired and trained to serve as flight crews, whereas until then the company was staffed exclusively with British expatriates from BEA.

The Turkish invasion of 1974 suspended all the airline's flights and operations, because it caused the closure of Nicosia International Airport, the only non-military airport of the island then. Consequently, a new small terminal was rapidly built in Larnaca and the airliner started its operations again in February 1975.

In the mid-1980s the company reached its record profits when it started offering flights to many other destinations, especially to cities of the United Kingdom. Being an ex-British colony, Cyprus was, and still is, a popular tourist destination for the British.

Bad management and poor investment choices, alongside the global financial crisis in 2007-08, led the airline to cease its operations on 9 January, 
2015, when the European Commission prevented the Cypriot government from giving any further financial aid to the company.

\section{Nationness}

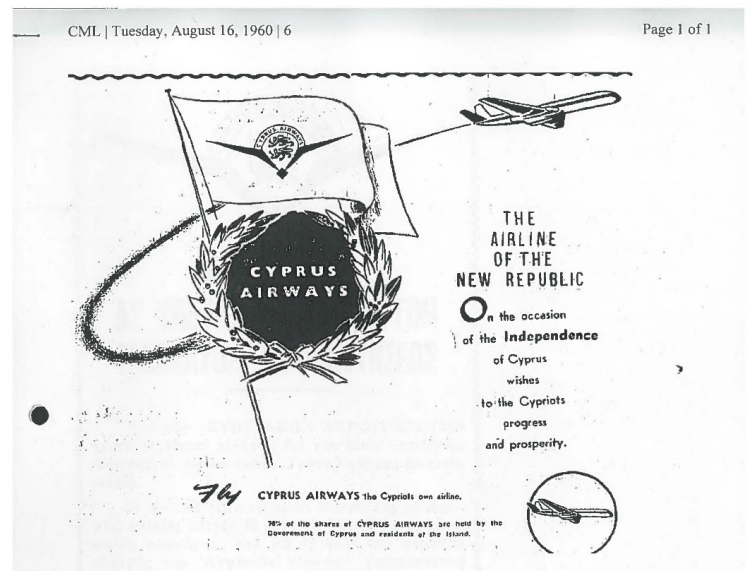

Figure 2: Airline of the new republic, 16 August 1960, Cyprus Mail newspaper

In the advertisement shown above (Figure 2) dated from 16 August, 1960 (the day that Cyprus declared independence), Cyprus Airways claims the nationness of the newly founded state and introduces itself as 'THE AIRLINE OF THE NEW REPUBLIC'. Written in an uppercase, sans-serif typeface, this display type becomes a major message in the visual hierarchy of information in the advertisement. A paragraph follows the headline and completes it by stating 'On the occasion of the Independence of Cyprus wishes to the Cypriots progress and prosperity.' Written with a dropped capital ' $O$ ' and the word independence in bold letters, the wish has a twofold semiotic dimension. First, it alludes to the type paragraph arrangement of the early $16^{\text {th }}$ century in order to signify status and formality, whilst the bold lettering of the word 'Independence' with a capital 'I' highlights the importance of the event. Nationness is, moreover, portrayed in the concluding, smaller-sized sentences at the bottom of the advertisement asserting 'Fly CYPRUS AIRWAYS the Cypriots own airline' and ' $78 \%$ of the shares of CYPRUS AIRWAYS are held by the Government of Cyprus and residents of the island'. While both texts invite the people of Cyprus to celebrate the common, collective 'ownership' of the company, in conjunction with the independence of their country, the flowing lines of the casual script lettering of the word 'Fly' imitate the flowing line above, which represents the flying movement of the airplane.

From a macro reading of the advertisement, we observe that there are three major groups of information in respect of eye direction. We assume that the entry point of the advertisement would be the name of the company since the white, uppercase 'CYPRUS AIRWAYS' words on the black circle create an 
eye-catching contrast with the rest of the information, which completes the hierarchy as follows: 'The airline of the new Cypriot Republic', followed by the word 'Fly' and the text that accompanies it. We can easily verify this argument with an eye tracker; however, the imaginary lines created by the specific layout inevitably create an interesting visual loop.
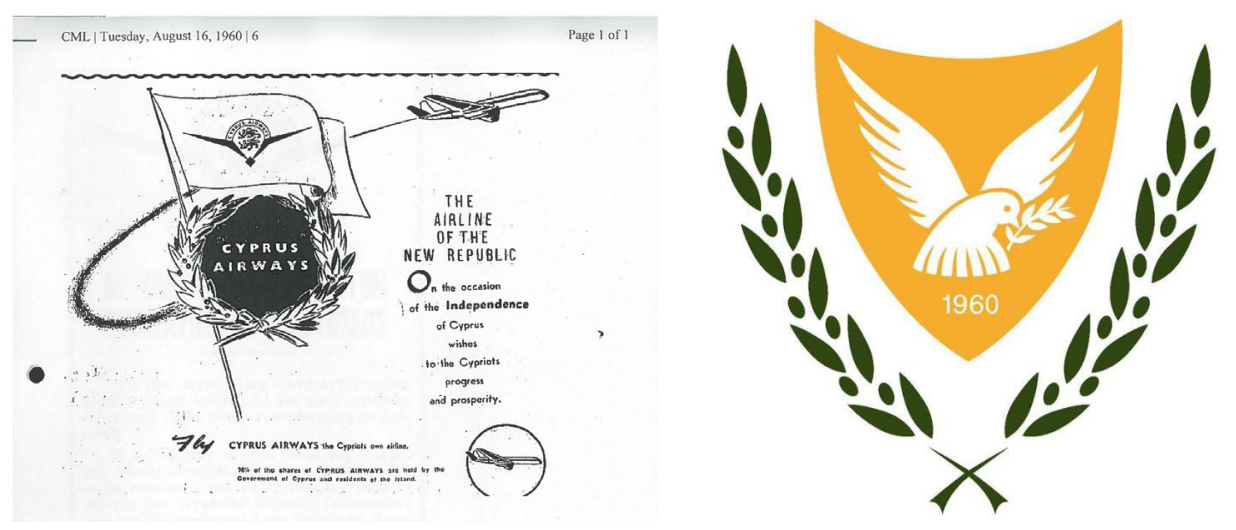

Figure 3: Detail from the advertisement and The Cypriot coat of arms, https://en.wikipedia.org/wiki/Coat_of_arms_of_Cyprus

Turning to the nonverbal signs of the advertisement, we observe an intertextual reference to the Cypriot coat of arms because of the olive branches adjacent to the 'CYPRUS AIRWAYS' text (Figure 3). Interestingly, a plane takes off out of the coat of arms, flanked by the olive branches, which symbolise peace, and flies gloriously from left to right, in accordance with the standard eye movement of western readers.
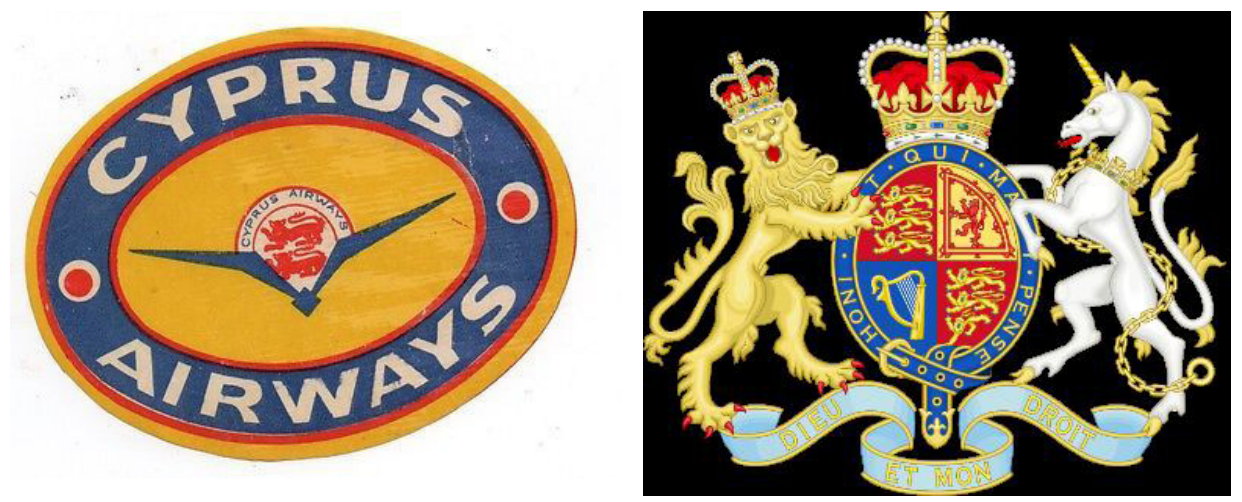

Figure 4: Luggage label for Cyprus Airways, Pinterest Cyprus Airways and The arms of the United Kingdom, https://en.wikipedia.org/wiki/ Coat_of_arms_of_Cyprus 
On the flag, coming out of what seems to be the Cypriot coat of arms, we notice the older Cyprus Airways logo used when the airline was controlled by British European Airlines. Under the company name there are two drawings of lions that incorporate visual elements taken from the royal coat of arms of the United Kingdom, marking the airline with colonial status (Figure 4). Nevertheless, taking into account the connotative assumptions of both the verbal and nonverbal elements, we can argue that this advertisement clearly assigns the cultural meanings of nationness and collectiveness to the company.

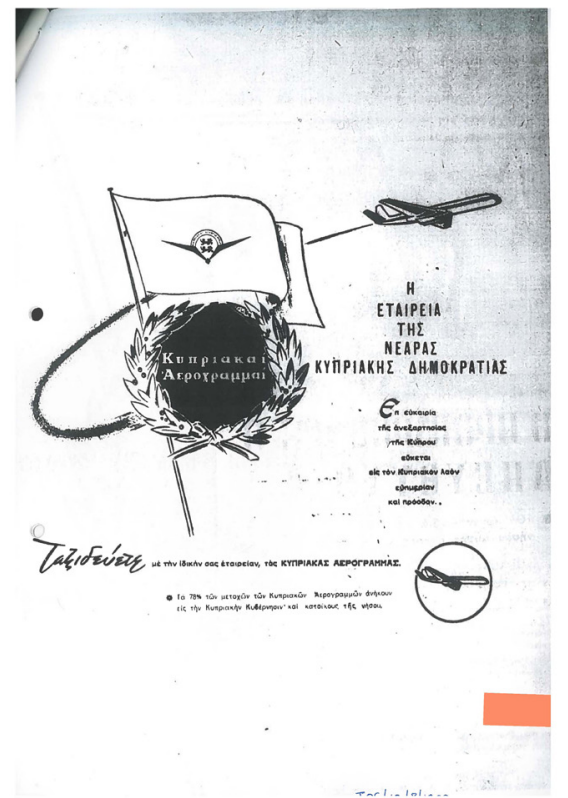

Figure 5: Airline of the new republic in Greek, 16 August 1960, Eleftheria newspaper

It is worth noting that on Independence Day, Greek versions of the same advertisement were published as well (Figure 5). While the same semiotic resources and interpretations apply to the Greek example, the company makes sure that its Cypriot nationality is established and the message is communicated to all of its local and non-Greek speaking citizens. It is evident that the company is claiming nationality, not just from the verbal messages displayed on the advertisement, but also from the nonverbal signs. The diversity of formats in the typefaces used, together with their orientation and placement, dress up the linguistic messages with a number of connotative national meanings. The specific advertisement is one of the richest in national identity signs and exhibits the highest degree of commercial nationalism in the corpus. 
A national animal becomes the official logo of Cyprus Airways: the flying mouflon

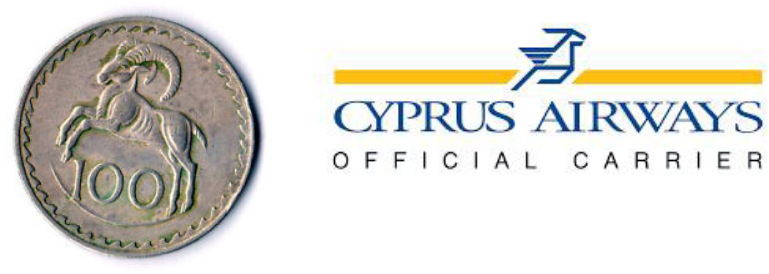

Figure 6: 100 mils coin, https://www.collectors. com/coins/world-coins-cyprus/1106

Cyprus Airways new logo, https://el.wikipedia.

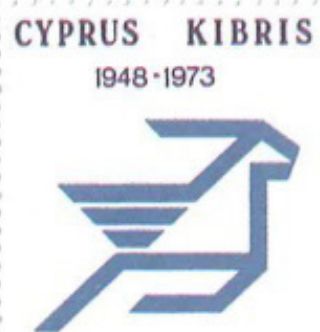

CVPRUS AInWAVS org/wiki/Cyprus_Airways_Logo.svg

Stamp '25 years Cyprus Airways', 24 September 1973, https://colnect. com/en/stamps/stamp/

After state independence, a new logo was designed for Cyprus Airways (Figure 6). The logo was designed in the shape of Cyprus' national animal, the mouflon, a type of wild sheep found only on the island. As an animal unique to the island, the mouflon has appeared on a range of official state documents since independence-i.e. postage stamps, coins and banknotes-and is a common fixture in everyday culture. The galloping or, more popularly known as the 'flying' mouflon logo, was designed shortly after independence, in 1962, by David Collins on the instruction of the BEA.

The abstract, line version of the mouflon as an iconic sign for the Cyprus Airways logo is a successful idea, both in terms of concept and execution. While it uses an all-too-familiar national symbol, it manages to transfer it semiotically to the aviation context in a very effective way. The uplifted front leg of the mouflon, alongside the three lines on its back, conveys the idea of speed and motion. Consequently, we also get a feeling of elevation, as if the mouflon is about to take off. Thurlow and Aiello (2007) refer to icons and symbols of speed in airline tailfin designs, for example rays and stripes, and argue that these are different semiotic techniques that can portray motion and movement like spirals and waves too. While the blue colour of the mouflon and the text 'CYPRUS AIRWAYS' allude to the blue sky, the orange coloured line that looks like a runway for the mouflon anchors the logo to the official national iconography by evoking the colours of Cyprus' national flag.

What seems to be a bad manipulation of the Garamond typeface for the lettering of 'CYPRUS AIRWAYS' differentiates the text from the sans-serif 
uppercase (and differently coloured) words stating that the company is the 'OFFICIAL CARRIER' of the Republic of Cyprus. While this headline and the new logo nationalise the airlines linguistically, it is a sign that stands alone visually and incorporates nationness in a categorical and direct way.

Collectiveness

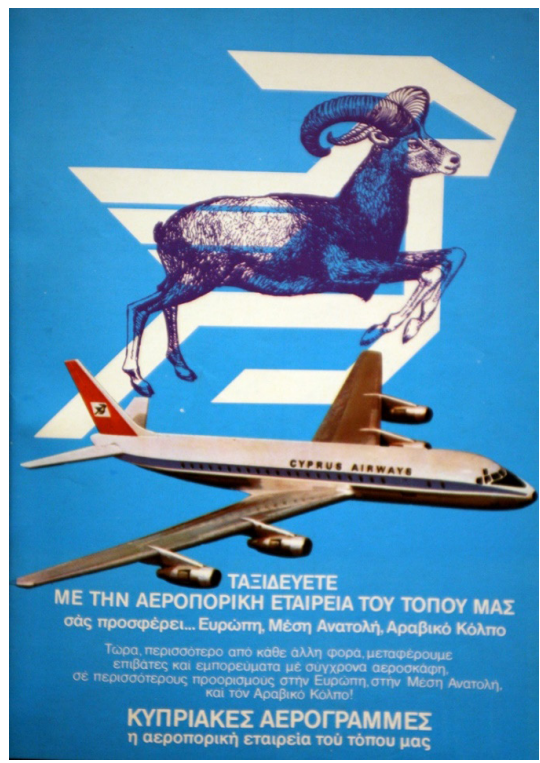

Figure 7: Cyprus Airways mouflon, 9-22 October 1977, Radioprogramma magazine

The next advertisement (Figure 7), has another interesting national story to tell us. What is worth noting in this advertisement, though, is the headline text under the plane stating 'travel with the airline of OUR country'. This is repeated twice at the bottom: 'Cyprus Airways, the airline of OUR country'. The pronoun 'our' in this context reflects a collective habit, suggesting collectiveness, a practice that we share regardless of status and position in society. The airline simply levels these distinctions through a technique that we have already seen in other examples that portray commercial nationalism. The headline's typeface, a white uppercase sans-serif, reflects the importance of the company to the country: it is loud, pure, and straightforward, as well as friendly and inclusive. As it progresses in the next decade of the 1980s, the company becomes more confident and achieves its most profitable period. As such, it claims exclusivity for the routes that it offers and is presented as a rising star in aviation history. 


\section{Exclusivity}

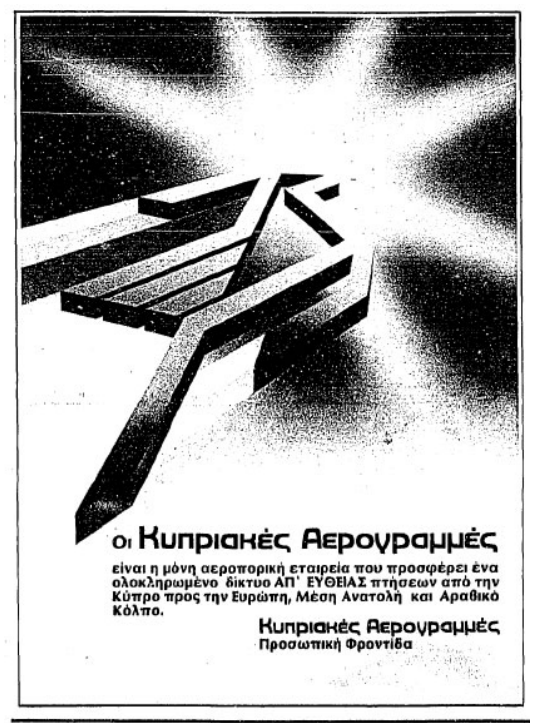

Figure 8: Cyprus Airways to the stars, 4 August 1985, Phileleftheros newspaper

As already stated, Cyprus Airways' operations and profits grew at an impressive rate in the 1980s. It was one of the first airlines to operate the wide-bodied Airbus $A 310$ and expanded its international routes significantly. All these achievements are reflected in the advertisement from 1985 (Figure 8). The 3-D logo design, adding volume, vitality and power to the hitherto 2-D abstract design, as well as its dynamic placement in a diagonal trajectory facing a shining star in the sky, is outstanding. It effectively transforms the galloping mouflon into a magnificent flying Pegasus, or a futuristic transformation that highlights the company's transformation into a world-class operator. It resembles a real plane that reaches beyond the sky to become a star itself, a quite powerful visual metaphor of rise and success. The operational expansion of the airline is underscored in the statement below: 'Cyprus Airways is the only airline company that offers direct flights from Cyprus to Europe, Middle-East and the Arab countries'. Since the aviation market expanded after only a few years after Cyprus joined the European Union in 2004, Cyprus Airways had flight monopoly for many destinations, and as such the company used this argument of exclusivity it its advertising campaigns. In addition, we observe a sub-slogan stating 'Personal Care' under the concluding text at the bottom right of the advertisement, implying the national sign of hospitality, a major Cypriot cultural value that will be examined below. 


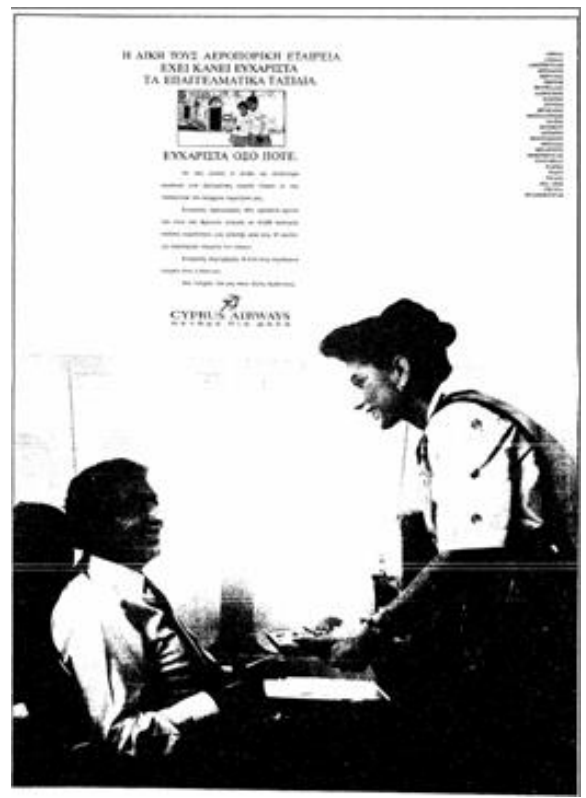

Figure 9: Cyprus Airways hospitality and children, 9 June 1991, Phileleftheros newspaper

The typical hospitality treatment gesture of offering food or drinks is the major representation in the advertisement of Figure 9. Within this hospitable environment on board, both participants are smiling to each other and enjoy the pleasures of the airline's hospitality. We also observe at the top of the advertisement a smaller picture with children in front of a typical Cypriot house. The headline in upper case letterforms above and below, states that 'Their airline company has made business trips as pleasurable as never before'. This is a multi-layered sentence with interesting implications. While it implies collectivity that begins in an early stage with an investment on children, it also portrays Cypriotness through the architecture of the house and the facial characteristics of the adults and children in the whole advertisement.
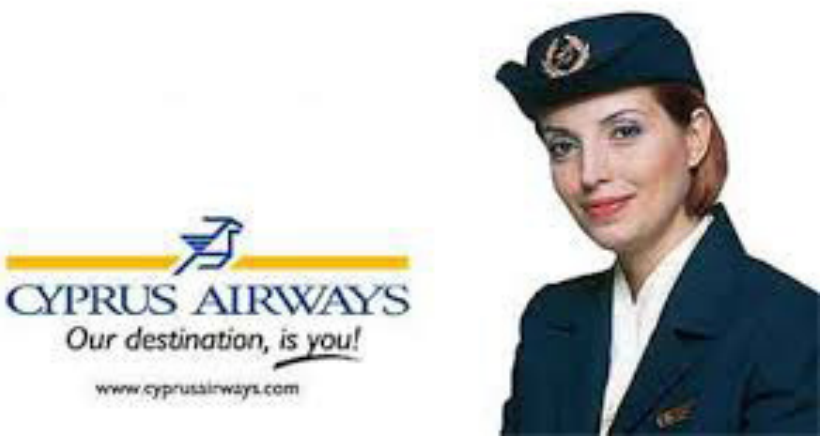

Figure 10: Our destination is you, Banner from official website before closure, 2000s 
Furthermore, in the early 2000s, the slogan 'Our destination, is you!' started accompanying the logo in the advertisements ${ }^{1}$. The text makes customers the airline's number one priority in an interesting, friendly typographic way, as if customer service was central to the company's vision. While lowercase, sunsserif italic letters are used to portray friendliness and speed, the two words 'is you!' are underlined with a marker to highlight the importance of personal care and hospitality.

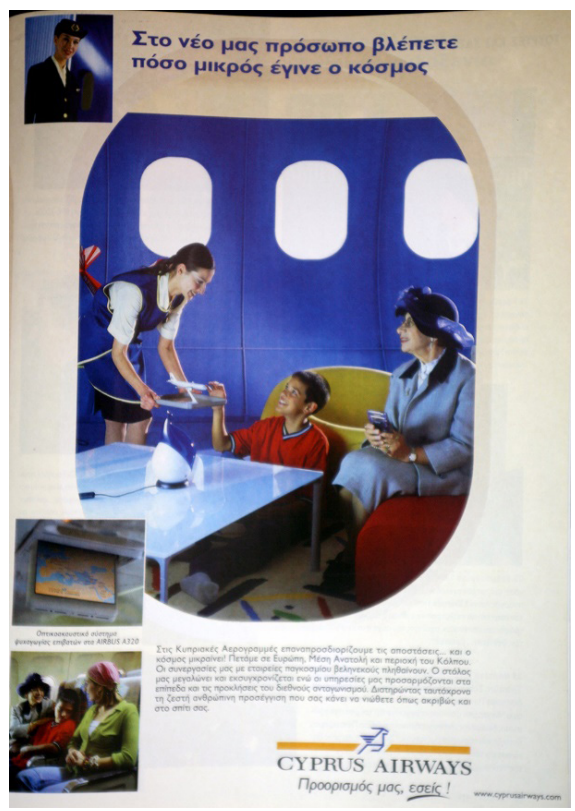

Figure 11: Cyprus Airways hospitality kid, 25 May 2001, Selides magazine

Hospitality is a major quality attributed to the Cypriot people. As a unique selling point, it is used very often in Cyprus' tourism organisation campaigns to attract visitors and promote Cyprus both locally and abroad. It comes as no surprise that we find it in the advertisements of the 'official carrier' of Cyprus as well. For Evgeniou (2016), 'Hospitality has been an integral part of the Cypriot culture from the ancient times and the powerhouse which has helped to build our modern economy' (Hospitality and Leisure, 2018). Cyprus Airways incorporates hospitality in its advertisements mainly through gestures that portray 'treating the customer' well or through relevant headlines and slogans. An airhostess in Figure 11 is an example of such a gesture, but with an additional hospitality twist. She treats her customers in home settings that have been formulated to look like being inside of an airplane. The home environment adds even more to hospitality since it is associated with personal care and treatment as a cultural

${ }^{1}$ Part of this section has been presented as Zantides, E. (2017). Interrelations and multi-semiosis of national identity and cultural meanings in print advertisements of Cyprus airways: our destination is us. Paper presented at 13th World Congress of Semiotics, Kaunas. 
practice. The slogan under the Cyprus Airways logo, 'Our destination, is you!', confirms that the customer is at the center of the airline's concerns and services.'

Table 2: Semiotic analysis of Cyprus Airways advertisements and cultural meanings

\begin{tabular}{|c|c|c|c|c|}
\hline & $\begin{array}{l}\text { DENOTATIVE } \\
\text { SIGNIFIERS }\end{array}$ & $\begin{array}{l}\text { CONNOTATION } \\
\text { MECHANISMS }\end{array}$ & $\begin{array}{l}\text { CONNOTATIVE } \\
\text { SIGNIFIEDS }\end{array}$ & $\begin{array}{l}\text { MYTH/IDEOLOGY } \\
\text { CULTURAL MEANING }\end{array}$ \\
\hline \multirow{4}{*}{ VERBAL } & $\begin{array}{l}\text { of the new republic } \\
\text { official carrier } \\
\text { of our country }\end{array}$ & \multirow{4}{*}{$\begin{array}{l}\text { Coloreme } \\
\text { Letterforms } \\
\text { Size } \\
\text { Value } \\
\text { Texture } \\
\text { Colour } \\
\text { Orientation } \\
\text { Placement } \\
\text { Linguistic }\end{array}$} & state ownership & NATIONNESS \\
\hline & $\begin{array}{l}\text { Cypriots airline } \\
78 \% \text { state holders } \\
\text { our airline-country }\end{array}$ & & all people's ownership & COLLECTIVENESS \\
\hline & $\begin{array}{l}\text { the only airline } \\
\text { bridge of Cyprus }\end{array}$ & & monopoly & EXCLUSIVITY \\
\hline & $\begin{array}{l}\text { our destination is you } \\
\text { personal care }\end{array}$ & & individual treatment & HOSPITALITY \\
\hline \multirow{3}{*}{ JN-VERBAL } & $\begin{array}{l}\text { olive branches } \\
\text { map of Cyprus } \\
\text { flag of Cyprus } \\
\text { orange colour } \\
\text { mouflon }\end{array}$ & \multirow{3}{*}{$\begin{array}{l}\text { Coloreme } \\
\text { Trick } \\
\text { Pose-Style } \\
\text { Objects } \\
\text { Aesthetism-Colour } \\
\text { Settings } \\
\text { Inter. Contact } \\
\text { Inter. Distance } \\
\text { Inter. Attitude }\end{array}$} & $\begin{array}{l}\text { Cypriot coat of arms } \\
\text { country's flag } \\
\text { official signs }\end{array}$ & NATIONNESS \\
\hline & $\begin{array}{l}\text { word cloud } \\
\text { mouflon }\end{array}$ & & outstanding & EXCLUSIVITY \\
\hline & $\begin{array}{l}\text { treating guests } \\
\text { home environments }\end{array}$ & & welcoming gestures & HOSPITALITY \\
\hline
\end{tabular}

A semiotic study of the verbal and nonverbal messages of the advertisements identified the following four main cultural meanings: nationness, collectiveness, exclusivity and hospitality as shown in Table 2 above. Specifically, these cultural meanings were identified through the use of the compiled semiotic model.

\section{Concluding remarks}

In the semiotic analysis of Cyprus Airways advertisements, we have identified four major cultural meanings. These are nationness, collectiveness, exclusivity and hospitality. Hospitality, is a national identity sign with a major cultural meaning. It has always been central to Mediterranean countries and small close-knit societies. Additionally, the appearance of official signs like the map and flag of Cyprus have made some of the examined advertisements exemplary cases of national ideology. Such a clear manifestation is due to the fact that Cyprus Airways had to build a marketing strategy based on the fact that it was a publicly funded service, as well as the air carrier of a relatively small and newly independent state that placed a premium on the prestige and international awareness it could gain by sustaining its own national airline. 
As times and culture change, so does the advertising discourse. While after state independence in 1960, the company flags the national identity of the new republic, often through collective thinking, it also adjusts to the highly competitive conditions of the aviation market. For example, during its most profitable period, in the 1980 s, the company appears to be a highly dynamic and exclusive airline, whilst in the last years prior to its bankruptcy and closure, it evokes the national repertoire as a defence mechanism in the face of its lost market share. Unfortunately, this strategy, portrayed in both verbal and nonverbal messages, was not able to ensure the survival of the company. The rhetoric of national ideology is never enough to deal with major economic challenges, especially when the population of 'native consumers' it addresses is far too small. In order for the idea of 'collective national ownership' to succeed, the agent that implements it-whether this is the state or not-has to have the management skills and financial resources to support it.

The way we read an image or a written text, separately or in combination, depends on many factors which, according to the intention of the graphic designer, can be adjusted to define a pleasant and meaningful visual journey. A predefined hierarchy of information, can not only direct the viewer to specific areas, but also provide the structure and route for the construction of ideological messages.

\section{References}

BARTHES, Roland. 1977. Image-Music-text. London: Fontana Press.

BELL, Philip \& Marko MILIC. 2002. Goffman's Gender Advertisements revisited: combining content analysis with semiotic analysis. Visual Communication. 1(2), 203-222.

BERTIN, Jacques. 2011. Semiology of Graphics: Diagrams, Networks, Maps. In French 1967, [1983] Translated and edited by William J. Berg. Wisconsin: University of Wisconsin Press. California: Esri Press.

DYER, Gillian. 1989. Advertising as Communication. London: ROUTLEDGE.

EVGENIOU, Evgenios. 2016. Hospitality and Leisure-PwC Cyprus. https://www. pwc.com.cy/en/publications/assets/hospitality-and-leisuregroup-sept2016.pdf (accessed: 25 March 2020).

FLOCH, Jean-Marie. 2000. Visual identities. London: Biddles Ltd.

KRESS, Gunther \& Theo VAN LEEUWEN. 2006. Reading Images : The Grammar of Visual Design. London, United Kingdom: Routledge. 
RYAN, William \& Theodore E. CONOVER. 2007. Graphic Communications Today. Clifton Park, United States: Cengage Learning, Inc

SAINT-MARTIN, Fernande. 1990. Semiotics of Visual Language. Indiana University Press.

THURLOW, Crispin \& Giorgia AIELLO. 2007. National pride, global capital: A social semiotic analysis of transnational visual branding in the airline industry. Visual Communication. 6(3), 305-344.

WALKER, Sue. 2001. Typography \& Language in Everyday Life: Prescriptions and Practices. London and New York: Routledge.

ZANTIDES, Evripides. 2016. Looking inwards, designing outwards: National identity and print advertisements of the Cyprus tourism organisation. Visual Studies. 31(3). 248-259. 


\section{TRAYECTORIAS DE LOS OBJETOS}





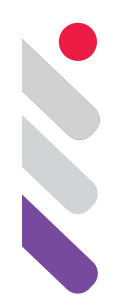

\title{
Semiótica de un proceso utópico y otro distópico en América Latina: dos senderos antitéticos hacia la autenticidad
}

DOI: 10.24308/IASS-2019-8-019

\author{
Fernando Andacht \\ Universidad de la República, Uruguay \\ fernando.andacht@fic.edu.uy
}

\section{El largo y sinuoso camino hacia la autenticidad: el index appeal encuentra la parresia}

Mientras escribo esta versión final, actualizada de la conferencia que presenté en el 14을 Congreso Mundial de la Asociación Internacional de Estudios Semióticos, en Buenos Aires, el mundo parece encarnizado en probar una de las ideas centrales que procuré desarrollar en ese multitudinario evento científico en Buenos Aires. Me refiero al poder nada discreto sino exuberante y explícito de la parresia, del hablar verdadero o brutalmente franco, que estudia Foucault en los años 80 del siglo $20 .{ }^{1}$ Dos mandatarios occidentales hablan sobre cómo tratar la crisis mundial del Corona Virus y ambos generan un masivo rechazo que llega al pedido de destitución de los dos presidentes. ${ }^{2}$ Esa reacción encarnizadamente adversa no parecería ser infrecuente en el campo siempre polémico de la política partidaria; sin embargo, en estos dos casos es la manera feroz y directa de expresar una visión del todo incorrecta políticamente la que genera asombro y repudio en buena parte de la sociedad. Ellos dos son ejemplos paradigmáticos de "parresiastas", tal es el nombre que Foucault (2001) utiliza para describir a personas que dicen absolutamente todo lo que piensan en un acto de habla sincericida. Si bien no se restringe

\footnotetext{
${ }^{1}$ Este estudio del discurso veridictorio está recogido en volúmenes editados con sus seminarios tanto en Estados Unidos (Foucault 2001), como también en Francia (Foucault 2010, 2011), ya próximos a su deceso.

2 Me refiero a los innumerables llamados en las redes sociales a manifestarse ruidosamente contra el discurso de Jair Bolsonaro que minimiza la gravedad de la pandemia. Casi todos ellos exigen su inmediata destitución. El otro duramente criticado es el presidente de EEUU Donald Trump.
} 
a los políticos, el teórico francés (Foucault 2010: 168) explica que la parresia produce considerable tensión en el funcionamiento de la democracia. Aunque para quienes detestan sus intervenciones públicas nada podría ser más ajeno o irritante que considerar sinceros a actores políticos como Bolsonaro o Trump, ese elemento es precisamente lo que define la parresia, el acto semiótico de no guardarse nada al hablar y, algo más, el sufrir las consecuencias que conlleva su decisión de actuar así. Además, como planteo más adelante, se trata de enunciar una verdad sin ningún tipo de adorno o amortiguación, lo cual inevitablemente implica un considerable riesgo para quien así se expresa, ya sea para su vida - un célebre caso histórico con el que empieza el estudio de Foucault (2001: 20) - o para el vínculo que mantiene hasta ese momento con su interlocutor (Foucault 2011: 14).

En este trabajo, procuro describir una nueva manifestación de lo que hace ya varios años describí como "el giro indicial" (Andacht 2003) en la mediatización de la sociedad y de la cultura contemporáneas, a saber, el predominio de los signos indiciales por encima de los icónicos y simbólicos, en la clasificación de la semiótica triádica de Peirce. La popularidad creciente del género televisual del reality show, a inicios del siglo 21 , determinó que un fenómeno inédito se manifestase a través de los innumerables formatos televisivos que surgieron tras el desembarco de la nave insignia, el programa de cable holandés Gran Hermano de Endemol. Me refiero al "index appeal" (Andacht 2016) o transpiración semiótica, que considero el principal ingrediente de la atracción del género. Ya no prevalece el glamour o belleza corporal, ni la elegancia o sofisticación del guión de telenovelas y series, sino los signos involuntarios que emite el cuerpo instalado en un ámbito inequívocamente artificial (Andacht 2010: 42). Son esos signos los que describe al inicio de su clásico libro sobre el orden de interacción el canadiense Goffman (1959: 4): “De las dos clases de comunicación - expresiones dadas (given) y expresiones emitidas (given off) - este informe se ocupará primariamente de las últimas" ${ }^{3}$, es decir, de la dotación de signos no intencionales e inseparables del cuerpo, como el sonrojo, la palidez del miedo, o el temblor de inseguridad, etc. Lo más relevante para el presente texto es la producción de un efecto de autenticidad en el universo mediático basado en la generación de esa transpiración semiótica. Un fenómeno que comenzó como una performance restringida al entretenimiento masivo se ha extendido gradual y masivamente a actividades serias como la política (Andacht 2005).

Las dos figuras políticas latinoamericanas de las que se ocupa mi análisis generan en sus apariciones mediáticas un efecto de sentido similar, y eso es algo que contrasta notoriamente con la ideología que ellos encarnan y que sus

\footnotetext{
${ }^{3}$ Imposible mantener el juego de palabras inglés de give/give off en la traducción, los verbos que Goffman (1959) opone en base al eje de la presencia/ausencia de voluntad por parte de quien se comunica así.
} 
seguidores admiran con tanto fervor como rechazo sus detractores. Popularidad y repudio de electores y opositores, respectivamente, del expresidente uruguayo José Pepe Mujica y del presidente brasileño Jair Bolsonaro provienen del estrato semiótico indicial. Pero no me detendré exclusivamente en su gestualidad, como parece anunciarlo mi foco en lo indicial, sino en el tipo de discurso al que Foucault dedica sus seminarios finales: la parresia o decir verdadero. Aunque parezca extraño usar como objeto de estudio de la semiosis indicial el discurso verbal de un político, veremos que el teórico francés explica que la clave de la parresia radica en la producción misma de un tipo de enunciación concebida como un hecho inseparable del enunciador, y que además produce consecuencias graves, incluso letales, para quien así se expresa. La parresia se caracteriza entonces por un irrefutable vínculo existencial que surge por la decisión de no guardarse nada para sí o de decir todo lo que se piensa, sin atenerse a las consecuencias, según expone Foucault (2001: 13): "en la parresia, el parresiasta actúa sobre las mentes de otras personas mostrándoles del modo más directo posible lo que él realmente cree." Usaré esta caracterización de dicha noción, y no la que del Diccionario de la Real Academia (n.p.) española: "Apariencia de que se habla audaz y libremente al decir cosas, aparentemente ofensivas, y en realidad gratas o halagüeñas para aquel a quien se le dicen." Nada hay de gratificante en el acto parresiasta según el análisis foucauldiano, ni tampoco en las intervenciones discursivas de los dos políticos latinoamericanos que considero aquí, al menos no de modo universal. Por eso, cabe decir que Mujica y Bolsonaro pueden verse como figuras casi alegóricas de una visión utópica y otra distópica de la democracia latinoamericana. Para seguidores y detractores, por sus frecuentes declaraciones y actitudes, estas figuras son representan lo peor y de lo mejor del universo político contemporáneo, y a su manera, ellos son encarnan la autenticidad que tiene para ofrecer la izquierda y la derecha en el continente e incluso fuera de sus fronteras.

En lo que sigue, intento explicar por qué un efecto semiótico que cobró notoriedad en un ámbito mediático de diversión banal y comercial, y que recibió una sanción moral extremadamente negativa, como el reality show en sus diversas producciones, puede servirnos para entender la popularidad y la violenta controversia en torno a figuras políticas notorias en la escena mundial. La búsqueda interminable del nuevo santo Grial mediático, a saber, la experiencia y/o creencia de que se está ante alguien auténtico, así en un reality como ante personajes muy visibles de la democracia contemporánea, se basa en la producción natural o artificial del signo indicial, ese que Peirce (CP 7.628) ${ }^{4}$ define como un "verdadero síntoma", y que incluye todo lo que forzosamente golpea nuestros cinco sentidos: el "percepto (cuya) inexpresividad (surdity)

${ }^{4}$ Cito la obra de Peirce del modo convencional: $\boldsymbol{x} . x x \boldsymbol{x}$ remite al Volumen y párrafo de The Collected Papers of C. S. Peirce (1936-1958). 
consiste en que éste no afirma nada". Más allá de las palabras usadas por estos políticos, lo distintivo de la parresia es la explosiva ocurrencia del acto mismo, el hecho de que ellos la enuncian en un lugar y en momento determinados, de modo tal que lo dicho queda adherido indisoluble y ostensiblemente a quien así habló. Y es también clave el que lo dicho trae aparejado un alto riesgo para a su reputación o inclusive para su vida.

\section{Sobre la afinidad teórica de la parresia y de la semiosis indicial}

Quiero contar ahora brevemente cómo llegué a conocer los seminarios foucauldianos dedicados al estudio de esa singular manera de hablar a calzón quitado, según la expresión coloquial, que es en esencia la parresia. Para analizar el movimiento de poesía oral o slam de grupos de jóvenes neoyorkinos, Rivera (2015) recurre al acto semiótico descrito por Foucault:

A través de la paradójica institucionalización del amateur, la poesía slam joven como sitio liminal de la protesta cultural facilita el desarrollo de una estética de poesía juvenil que valoriza la parresia, o valiente acto de decir la verdad (truthtelling) y al hacerlo cumple un rol vital en la formación y autentificación del sujeto para los poetas jóvenes en la ciudad de Nueva York.

Mi argumento es que esta técnica discursiva y performativa también es útil para analizar el comportamiento público de personajes políticos como el exguerrillero y expresidente José Pepe Mujica, pues propongo que en la parresia se basa el efecto de autenticidad de su persona, de su identidad pública, que para sus seguidores o admiradores no tendría diferencia alguna con la íntima o personal. Así de potente es la impresión que ambos causan cuando actúan en el escenario del mundo. Una escena del documental El Pepe. Una vida suprema (Kusturica 2018) lo registra de modo inequívoco, en el comienzo del film. Poco antes del minuto 4, la cámara muestra al entonces mandatario de Uruguay en su cama, durmiendo y luego saliendo de ella en calzoncillos. El montaje de su despertar alterna tomas de su casa de aspecto modesto y rural, con el registro de sus dichos a un muy atento y admirado interlocutor, el director Emir Kusturica. Mujica habla sobre el sentido cósmico de la existencia, mientras la banda sonora desgrana el tango En una tarde gris. Se produce así una parresia visual, algo no teorizado por los filósofos clásicos que cita Foucault ni por él: las imágenes de un hombre con aspecto común en ropa interior equivalen a un hablar a calzón quitado; maximizan su aspecto informal, la clásica y comentada ausencia de corbata en la ceremonia final de su presidencia ${ }^{5}$. Nada hay del fasto

\footnotetext{
5 Mujica le comenta a Kusturica, mientras se viste, que él usará el mismo traje - y la misma ausencia flagrante de corbata - que usó para la asunción de mando, en 2010. Esa muestra de su simpleza espartana junto a su ya legendaria falta de respeto por el decoro asociado a su cargo, son parte de la parresia visual.
} 
o protocolo esperado para representar al entonces presidente en el último día de su mandato, poco antes de salir rumbo a la ceremonia de asunción del nuevo mandatario, el 1ㅇ. de marzo de 2015. ¿Qué discurso más netamente parresiasta puede concebirse que contemplar la cabeza del poder mayor en democracia, que la imagen del presidente de todos los uruguayos paseándose en ropa interior? Y es pertinente para mi análisis el hecho de que Mujica protagoniza esa escena con entera conciencia de estar exponiéndose al mundo así; su descuidado aspecto no ha sido capturado por una cámara indiscreta.

En el caso de Bolsonaro, el actual presidente de Brasil, se puede observar su condición de parresiasta incorregible en innumerables declaraciones de su época como diputado, durante la campaña electoral y más recientemente en el modo en que habló con la población sobre la llegada de la pandemia del Covid19 a su país. En cada una de esas ocasiones, Bolsonaro concitó una violenta ola de repudios de sus opositores en redes sociales y en las calles de grandes ciudades brasileñas. Un ejemplo ilustrativo de esa intensa actividad en Facebook es el anuncio de una pequeña antología de este notorio parresiasta bajo el título "As piores frases do Bolsonaro" (Fig.1), o las reproducciones de su gestualidad bélica en la campaña de 2018 , acompañadas de frases de repudio al hoy presidente ${ }^{6}$. En el momento en que escribo esta versión final de mi trabajo, se pide con insistencia su destitución, que se lo expulse de la presidencia mediante el proceso de terminación de su mandato (impeachment), el mismo que terminó con la presidencia de Fernando Collor de Mello, en 1992. Si nos detenemos en el gesto de Bolsonaro cuando imita esgrimir armas de fuego (Fig. 2), es fácil comprender que este signo alcanza para provocar la reacción violenta en su contra de quienes no votaron por el candidato que resultó ganador de la elección presidencial de 2018.

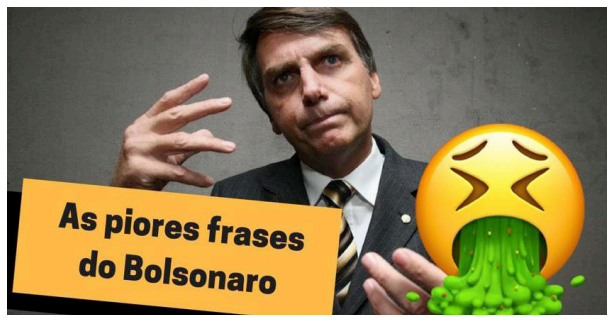

Fig. 1 Meme contra el discurso de Jair Bolsonaro en Facebook

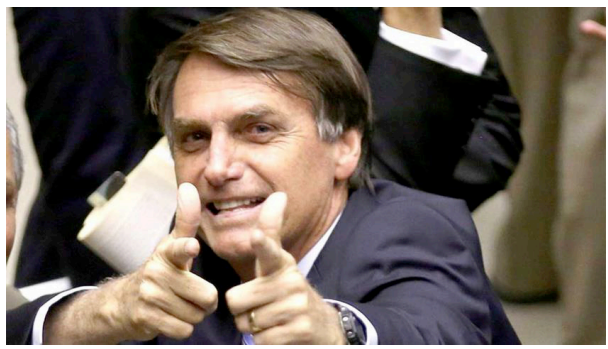

Fig. 2 Reproducción del gesto que usó Bolsonaro en la campaña presidencial

\footnotetext{
${ }^{6}$ Fischer y Vaz (2019) analizan y describen su conducta como la del "bufón" político, en base a un estudio del semiólogo francés Landowski sobre la importancia de esa figura en la política contemporánea.
} 
No es lo mismo exponer argumentos en un debate televisado a favor de la posesión de armas de fuego que representar esa ideología con ese gesto característico de sus presentaciones electorales. Tal enunciación merece el calificativo de 'parresiasta'. Este ejemplo sirve para comentar una importante distinción analítica que introduce Foucault cuando describe la parresia como "actividad de habla" y la contrasta con "acto de habla". El segundo término remite a la teoría de J. L. Austin, es una "enunciación performativa"; en su seminario de 1982, Foucault distingue la calma protocolar del acto de habla con la audacia con conciencia del riesgo en que incurre el parresiasta. Pienso en la afinidad de la función fática - un saludo - con el acto convencional de declarar abierta una sesión o de bautizar a alguien -, por un lado, y la audaz acción de acusar a un dictador y poner en riesgo su vida, como hace Platón con Dionisio, el tirano de Siracusa, (Foucault 2001: 16, 2010: 49), por el otro:

a modo de contraejemplo, como una forma de enunciación que es exactamente la opuesta de la parresia, [...] la enunciación performativa. Uds. saben que una enunciación performativa requiere un contexto particular, más o menos estrictamente institucionalizado, un individuo que posee el estatus requerido [...]. Dado esto como la condición para que un enunciado sea performativo, (alguien) entonces realiza ese enunciado. (Foucault 2010: 61)

En el caso de la parresia, lo que ocurre, esclarece Foucault (ibid.) es distinto, la enunciación tiene este formato: "Yo soy el que piensa esto y por eso lo digo ahora pese a quien le pese'". Así él procura diferenciar la clase de "compromiso" de alto riesgo que causa la actividad temeraria de la parresia, pues ésta nunca es ceremonial, como sí lo son los enunciados performativos en la teoría de Austin. Dicha distinción me permite introducir la afinidad semiótica de la parresia con una clase de semiosis o acción de los signos en el modelo triádico de Peirce, que es la misma que prevalece en el entretenimiento televisivo del reality show: la indexicalidad.

Peirce analiza la relación entre el signo y el objeto dinámico, es decir, lo real tal como existe por fuera o, más exactamente, en el límite mismo de la acción sígnica, como la fuerza que lo conduce teleológicamente hacia la interpretación (Ransdell 2007). Cuando define el índice o signo indicial, el lógico se basa precisamente en el atributo de lo 'dinámico', concebido éste como una fuerza que engendra la díada de acción y reacción, tal como ocurre en el mundo de la percepción:

Un signo, o representación, que se refiere a su objeto no tanto por causa de alguna similitud o analogía con él, no porque esté asociado con características generales que ese objeto pueda poseer, sino porque está en una conexión dinámica (incluyendo lo espacial) tanto con el objeto individual, por un lado, y 
con los sentidos o la memoria de la persona para quien éste sirve como un signo, por el otro. (CP 2.305 - [énfasis mío])

El rasgo distintivo de la parresia como actividad semiótica de un enunciador es la "conexión dinámica" que define el signo indicial. Por eso, propongo como una analogía posible con la parresia la práctica de hacerse una marca corporal: el acto de tatuarse algo en una zona muy visible del cuerpo, en la cara concretamente. Quien se haga esa marca imposible de obviar, de no tener que ver al mirar a la persona se parece a lo que ocurre cuando alguien acomete un acto parresiasta. Salvo el caso de un prisionero a quien se le haya infligido tal seña, el ostentar esa huella corporal ineludible constituye una afirmación rotunda, se la lleva como síntoma o expresión elocuente de lo que se cree bueno para exhibir y decir sobre sí mismo al mundo. Así opera la parresia como acto semiótico: alguien se planta ante el Otro y le propina esos signos, que no corresponden a la 'verdad' concebida como creencia o conclusión que resulta de aplicar el cuarto método, ese que Peirce denomina 'científico' en "La fijación de la creencia" (1877). La parresia es lo que esa persona piensa y que está convencida que es verdadero, aquello que no se quiere guardar y que elige decir en su totalidad; esa es la etimología de 'parresia'7. Por ende, esas palabras, gestos o actitud que se describen como parresiastas irrumpen en la comunicación de modo semejante a "un tremendo trueno (que) indica que algo de consideración ocurrió, aunque podemos no saber precisamente cuál ha sido el acontecimiento" (CP 2.285).

Imagino al lector intrigado por haber clasificado como indicial lo que en mis ejemplos remite de modo sustancial a palabras, es decir, a signos simbólicos por excelencia (además de gestos y posturas). Propongo considerar esa actividad semiótica en su globalidad - cuerpo, palabras, tono, mirada y muy especialmente la situación comunicacional en la que ese acto ocurre - como si fuera una mancha corporal que revela una enfermedad o un tatuaje que hace otro tanto con respecto a un afecto vocinglero - pues "el signo (indicial) significa su objeto sólo en virtud de estar realmente conectado con él. De esa naturaleza son todos los signos naturales y los síntomas físicos. Llamo a tal signo un índice" (CP 3.361).

Cuando Foucault contrasta el discurso del profeta con el del parresiasta, explica que este último "no deja nada librado a la interpretación" (2011:16). Su descripción recuerda la típica distinción entre pornografía y erotismo: la primera es vulgar y agresiva pues lo exhibe todo, mientras que la segunda persigue un fin estético, y para conseguirlo es tan importante lo que muestra como lo que apela a la imaginación e interpretación del espectador:

7 "Etimológicamente parrhēsia es la actividad que consiste en decir todo: pan rêma. (...) El parresiasta es la persona que lo dice todo." (Foucault 2011: 9) 
el parresiasta, de nuevo por definición, y a diferencia del profeta, no habla en acertijos. Por el contrario, él dice las cosas tan clara y directamente cómo es posible, sin ningún disfraz ni adorno retórico, así sus palabras pueden de inmediato recibir su valor prescriptivo. El parresiasta no deja nada librado a la interpretación. Por cierto, él deja algo para que sea hecho: deja a la persona a quien se dirige la dura tarea de tener la valentía de aceptar esa verdad, de reconocerla, y volverla un principio de conducta. Él deja esa tarea moral, pero, a diferencia del profeta, él no deja el difícil deber de la interpretación (Foucault 2011: 16 - [énfasis mío])

Cabe destacar ahora la aclaración de Foucault sobre el único deber que le asigna la parresia al Otro, a su interlocutor: aceptar o - yo agrego - repudiar, ese discurso que es lanzado vigorosamente como verdadero. En cualquier caso, hay una reacción potente, explosiva. De nuevo, conviene evocar la asimilación medical que hace Peirce de la semiosis indicial, pues arroja luz sobre el análisis foucauldiano de la parresia: “¿qué es un índice, o síntoma verdadero? Es algo que, sin necesidad alguna racional, es forzado por el hecho ciego para que corresponda con su objeto" (CP 7.628). Nada está más unido a la existencia de alguien que su síntoma o su (casi) indeleble tatuaje: "La parresia entonces [incluye] la afirmación de la verdad, y luego, además de esta afirmación, un elemento implícito que podría llamarse el pacto parresiástico del sujeto consigo mismo, mediante el cual él se ata a sí mismo tanto al contenido de la afirmación como al acto de hacerla: yo soy la persona que habrá dicho esto (Foucault 2010:65).

El "pacto doble" al que se refiere Foucault supone que no solo alguien diga que está enunciando la verdad, sino que además cuando lo hace se señale a sí mismo como alguien que queda definido por ese acto semiótico. Así justamente funciona el índice que "es un signo que se refiere al Objeto que éste denota en virtud de ser realmente afectado por ese Objeto" (CP 2.248). No es, en cambio, indicial lo que vuelve posible el realizar un acto performativo, sino simbólico: quien casa o bautiza a alguien lo hace en virtud y en nombre de algo tan general como la institución que lo antecede y que seguirá estando allí luego de que ella o él ya no cumpla esa función protocolar.

Para completar mi abordaje, acudo al análisis del discurso que Goffman (1981:144-145) propone para analizar "el formato de producción del enunciado" en tres componentes discursivos: el animador, quien utiliza su cuerpo o da la cara, diría; el autor, quien es responsable por el contenido; y el representado (inglés, 'principal'), "alguien cuya posición es establecida por las palabras que son habladas, alguien que está comprometido por lo que las palabras dicen". En un programa televisivo de noticias no coinciden los tres componentes del formato enunciativo, mientras que en una conversación informal y espontánea normalmente están unificados en quien habla. La fusión de los tres elementos 
enunciativos corresponde a "las dos condiciones suplementarias requeridas para poder hablar de parresia [...] No sólo debe esa verdad ser la opinión personal de quien está hablando, sino que debe decirla como siendo lo que él piensa. [...] El parresiasta da su opinión, dice lo que piensa, personalmente firma, se podría decir, la verdad que afirma (Foucault 2011: 10-11).

\section{Sobre las andanzas indiciales de dos notorios parresiastas del Mercosur}

En esta sección, analizaré ejemplos de parresia cometida por los dos políticos elegidos para mi análisis, José Mujica y Jair Bolsonaro. Como señalé arriba, la noción no se refiere sólo ni única ni principalmente a sus gestos - el ejemplo característico del signo indicial - sino al acto mismo de hablar como ellos lo hacen, en contextos y con muy numerosos interlocutores a quienes arriesgan antagonizar radicalmente. Lo fundamental de los ejemplos que ilustran la actividad parresiasta de estas figuras políticas es que a pesar de que su radio de acción se sitúa en la región del Mercosur, por el alcance muy grande de su actividad discursiva, ambos han trascendido largamente las fronteras de sus países y de sus electorados. Lo que dicen en sus actos de parresia le llega a un vasto público, parte del cual, inevitablemente, será del todo antagónico a esos dichos.

\subsection{Dos intervenciones del parresiasta levógiro José Mujica}

Presentaré dos instancias de la abundante parresia de quien fuera miembro de la guerrilla del Movimiento de Liberación Nacional Tupamaros y presidente del Uruguay (2010-2015). Por su ideología decidí designar su actividad como la de un parresiasta levógiro, por analogía con el desvío de la luz polarizada que causa una sustancia hacia la izquierda del observador. La primera instancia de parresia es la que registró un informativo de la televisión uruguaya en ocasión del regreso del equipo de fútbol seleccionado, el día 30 de junio de 2014, tras su eliminación en el Mundial de Fútbol de la Fifa, en Brasil. Uno de los momentos más notorios de la actuación del equipo fue un incidente tan violento como inesperado que generó infinidad de titulares en todo el mundo: la mordida del jugador estrella uruguayo Luis Suárez a su rival Giorgio Chiellini, durante el partido entre Uruguay e Italia, el 24 de junio. Esa grave falta determinó la expulsión inmediata del goleador celeste del campeonato y su suspensión por nueve partidos y cuatro meses. El entonces presidente Mujica acudió a recibir a los jugadores al aeropuerto en la madrugada del 30 de marzo; un periodista se acercó a él para preguntarle qué opinaba de la sanción que se le había impuesto a Suárez. Sin dudarlo, el mandatario respondió "Los de la FIFA son una manga de viejos hijos de puta". Acto seguido, se cubrió la boca mientras sonreía con picardía (ver Fig. 3), con el típico gesto de quien ha dicho lo que no debía y se arrepiente. Pero lo que nos permite clasificar ese acto como 
parresiasta es que cuando el periodista lo consultó para saber si podía citarlo, sin titubear Mujica le respondió “iPublicalo!". Con plena conciencia de haber dicho algo reñido con el decoro de su alto cargo, Mujica asumió plenamente su enunciado, y lo completó con un gesto que parodiaba la contrición, pues aceptó con alegría que su dicho fuese difundido y multiplicado por los medios, tal como en efecto ocurrió.

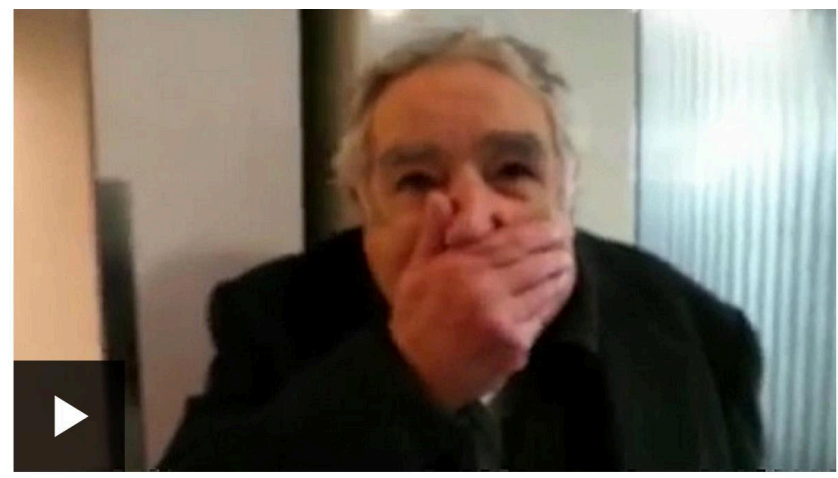

Fig. 3 José Mujica tras haber insultado a las autoridades de la FIFA ante un periodista, el 30 de marzo de 2014

El segundo ejemplo de la parresia levógira de este personaje político ocurrió en un documental de Emir Kusturica. Cuando mate a mano, él se dedica a evocar con aire soñador sus andanzas como guerrillero tupamaro, ante un embelesado interlocutor, el director de El Pepe. Una vida suprema (2018), Mujica le confiesa: "Es la cosa más linda entrar a un banco con una (pistola calibre) 45 así... (Mujica gesticula como si quisiera mostrarle a su interlocutor cómo era tener de nuevo el arma en su mano) iTodo el mundo te respeta! (sonríe)."

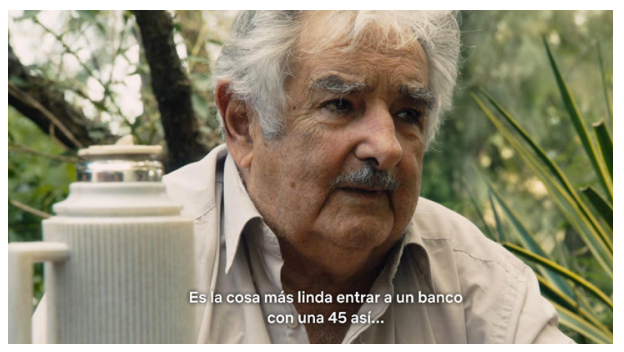

Fig. 4 Mujica relata cómo se sentía al entrar a robar un banco armado de una pistola calibre 45 , en su época de guerrillero tupamaro (fotograma de El Pepe. Una vida suprema)

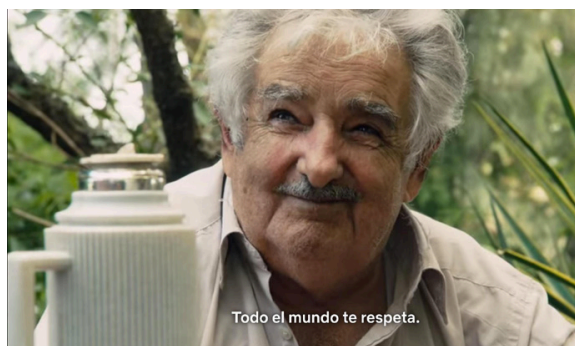

Fig. 5 Mujica culmina su narrativa con una franca sonrisa y el final del enunciado parresiasta (fotograma de EI Pepe una vida (fotograma de $E$ I Pepe. Una vida suprema) 
Importa destacar que en el medio del relato hay un plano contraplano que nos permite ver de cerca, en primer plano el efecto que provoca en el director/ entrevistador lo dicho por Mujica: hay en él una gran fascinación por sus palabras y sus gestos (Fig. 6).

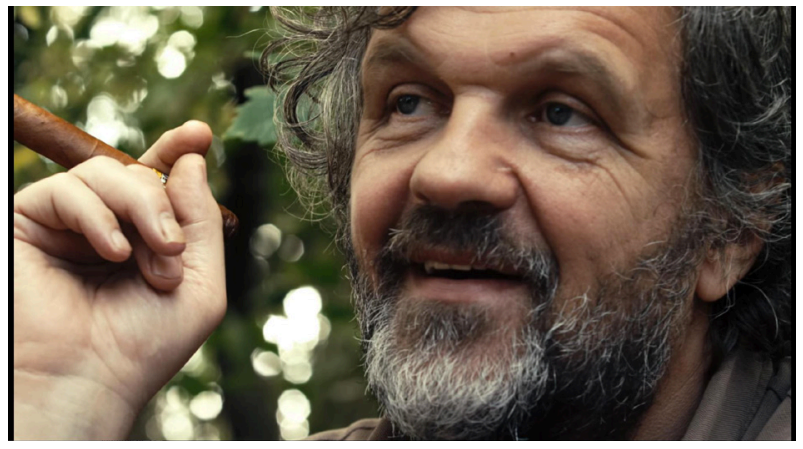
Fig. 6 La actitud fascinada del director y entrevistador E. Kusturica ante el relato de Mujica al entrar a robar un banco con una pistola calibre 45. (fotograma de El Pepe. Una vida suprema)

Más temprano, en el documental, Mujica había pronunciado algunas palabras con un tono muy pausado, como si deseara preparar al otro para recibir un mensaje de una hondura insondable. Para ese fin, el expresidente uruguayo asume un rol diferente al del parresiasta, pero uno que también forma parte de las "formas aletúrgicas (que) sirven para la producción de verdad" (Foucault 2011: 3), a saber, el discurso del profeta. Así lo diferencia Foucault (2011: 15) de la forma discursiva de la parresia: "el profeta revela, muestra, o arroja luz sobre aquello que está escondido de los hombres, pero de otra manera, o más bien al mismo tiempo, él no revela sin ser oscuro, y él no devela sin envolver lo que dice en la forma del acertijo."

Tras afirmar de modo solemne que él no sería quien es "de no haber vivido esos diez y pico de años de profunda soledad", cuando fue uno de los rehenes de la dictadura en varias mazmorras, Mujica enuncia con gran lentitud algo que cabe clasificar como un discurso de índole profética: "Por eso es curioso, Kusturica. Lo que te voy a decir no se puede agarrar con espíritu de almacenero. (extensa pausa) A veces lo malo es bueno (otra pausa) A veces, al revés (pausa) lo bueno es malo."

Borges termina "La Trama" ([1960]1996:171), uno de sus relatos mínimos, de apenas dos párrafos de extensión, con una advertencia sobre cómo lidiar con la exclamación de sorpresa que lanza un personaje antes de que lo ultimen varios atacantes: "estas palabras hay que oírlas no leerlas". Lo mismo es válido para comprender cabalmente el alcance del pronunciamiento de Mujica, que incluye un metamensaje explícitamente aristocrático, que se encarga de reforzar y volver explícito el sentido profético que el entrevistado elige para dirigirse a su entrevistador. Podría decirse, evocando de nuevo el brevísimo relato borgeano, que aunque él no lo sepa, el director serbio ha llegado hasta allí, y no me refiero 
sólo a la modesta chacra de Mujica en las afueras de Montevideo, sino a ese encuentro soñado, imaginado e idealizado por él, para escuchar ese acertijo, para atesorar las palabras que le llegan tras la advertencia del exguerrillero. Es como si Mujica le dijese: lo que voy a decir(le) no es para cualquiera, para entenderlo hay que ser una persona con una capacidad especial para sortear la aparente contradicción, y superar la complejidad del enigma proferido.

Se rumoreó en Uruguay que el anunciado y luego aplazado estreno de El Pepe. Una vida suprema en Netflix, su distribuidora mundial, hasta el día 27 de diciembre de $2019^{8}$ se debió a la existencia de enunciados como el arriba citado, es decir, a la parresia pronunciada con evidente satisfacción por el protagonista del documental, al evocar nostálgico su época de asaltante para la guerrilla. En 2019, tuvieron lugar las elecciones presidenciales en Uruguay, y aunque Mujica no era candidato a ese cargo, bien pudo haber existido temor de que declaraciones como la citada arriba le restaran votos (de indecisos) a su fuerza política, el Frente Amplio. Sea como fuere, los dos ejemplos de parresia presentados son tan inseparables de la persona José Mujica exguerrillero y expresidente - hoy senador - como lo son un síntoma o un tatuaje grabado en pleno rostro. No hay margen para la ambigüedad o para alguna distancia entre esos dichos y la persona que los emite, como sí ocurre con una convención, por ejemplo. Por ende, el riesgo de provocar consecuencias adversas en la opinión pública pudo haber causado cierta ansiedad en filas de su agrupación política. No podemos olvidar que el correr riesgos es un factor esencial del discurso parresiasta. La evidente admiración irrestricta del director/entrevistador de Mujica a lo largo del film probablemente es compartida por los seguidores de esa figura política en Uruguay, y en el mundo. Pero es igualmente probable que sus dichos parresiastas fueron vigorosamente repudiados por quienes no comulgan con su ideología ni con su partido político.

\subsection{Dos momentos discursivos del parresiasta dextrógiro Jair Bolsonaro}

Con idéntico criterio al que usé para analizar los dichos y actitudes del político uruguayo, describiré al hoy presidente de Brasil como un parresiasta dextrógiro, mediante la analogía con una sustancia química que hace desviar la luz polarizada hacia la derecha del observador, en atención a su ideología política. Para el primer caso me remonto a su etapa parlamentaria, como lo hice con Mujica y su período guerrillero, en el otro usaré un incidente vinculado

\footnotetext{
${ }^{8}$ El debut mundial del documental fue el 02 de setiembre de 2018, en la 75o. edición del Festival de Venecia. Uno de los muchos titulares sobre el curioso anticlímax que causó el diferir su estreno ya anunciado en Netflix: "Estreno de la película de Emir Kusturica sobre Pepe Mujica fue aplazado El Pepe, una vida suprema, del serbio Emir Kusturica, llegaba a la plataforma de streaming el pasado 23 de agosto, pero el estreno se aplazó hasta nuevo aviso." (Portal La Red21, https://www.Ir21.com.uy/cultura/ 1408950-la-pelicula-de-emir-kusturica -sobre-pepemujica-desde-este-viernes-en-netflix)
} 
con esta figura que ocurrió en 2019, durante su mandato presidencial en Brasil.

El primer ejemplo de parresia ocurrió el día 13 de abril de 2015, en una entrevista televisiva, cuando el entonces diputado Jair Bolsonaro declaró públicamente, como lo muestra el meme que tomé de las redes sociales (Fig. 7) que su sangre como donador era preferible a la donada por un homosexual. Bolsonaro justificó sus dichos como no discriminatorios así: "Son datos. La sangre es vida, es el combustible de nuestro cuerpo. Entre mi sangre y la de un homosexual... no lo digo yo, es el Ministerio de Salud quien lo dice". ${ }^{9}$

Reafirmó de ese modo una posición que él había sostenido en una entrevista televisada en 2011 - la cual fue presentada uno de los animadores de ese programa como las declaraciones del "diputado federal más polémico de Brasil" - y que fue condenada por un Tribunal como "homofóbica" en 2015. Por haberlo dicho Bolsonaro debió pagar una multa de $\mathrm{R} \$ 150.000$.

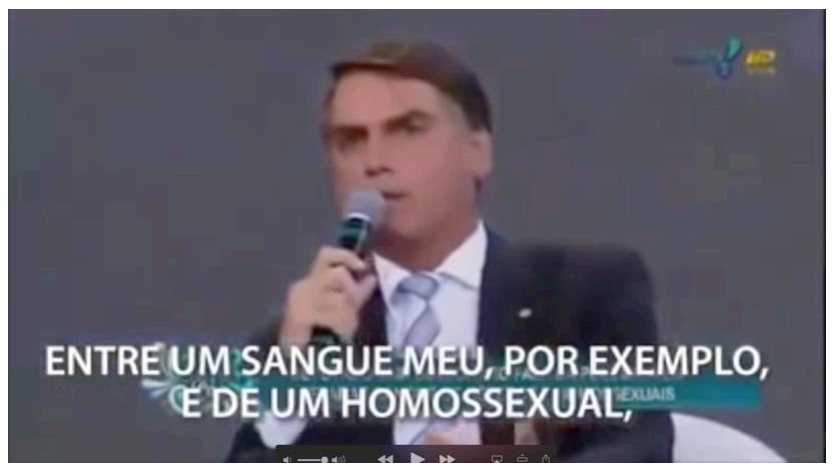

Fig.7 Declaración del diputado Jair Bolsonaro sobre la transfusión de sangre no confiable de un homosexual, 13.04.2015

Lo que considero central en esa enunciación pública del político brasileño hecha mediante un medio de comunicación masivo como la televisión es que al hacerla él no puede no ser consciente del elevado riesgo que corre. No se trata apenas del seguro repudio de la población que se identifica con esa opción sexual, sino también del rechazo de sus simpatizantes, y de los demás actores políticos que, más allá de su opinión real sobre el asunto, no lo dirían nunca en público de un modo tan explícito que, en palabras de Foucault (2011:16), "no deja nada librado a la interpretación". La parresia se sitúa en las antípodas no sólo de lo políticamente correcto, sino también de lo que es la cautela elemental en el discurso de un político que, en aquel momento, ya manifestaba intenciones de aspirar a la presidencia. Hay en ese acto parresiasta un elemento sincericida que excede la caracterización de Bolsonaro como un populista de la derecha más conservadora de su país. Son declaraciones como ésta, posiblemente, las

\footnotetext{
${ }^{9}$ Tomé estos dichos de una nota en el HuffPost, edición brasileña, con el título "Antes de pedir para deixar o PP, Jair Bolsonaro afirma que sangue de homossexuais 'não é confiável" https:// www.huffpostbrasil.com/2015/04/14/antes-de-pedir-para-deixar-o-pp-jair-bolsonaro-afirmaque-sangu_n_7064858.html
} 
que culminan en la tentativa de asesinato contra su persona que tuvo lugar el 6 de setiembre de 2018, en la ciudad de Juiz de Fora, durante un acto electoral. Esa consecuencia letal es uno de los riesgos principales de la parresia, según la define Foucault $(2010,2011)$.

El segundo ejemplo de actividad parresiasta que elegí presentar tiene la peculiaridad de no ser un discurso enunciado directamente por Jair Bolsonaro, sino por alguien que no podría describirse como un partidario ni simpatizante del presidente brasileño. Su ocurrencia tuvo lugar durante su actual mandato. Como expliqué arriba, en el análisis de la parresia, ésta se basa en la indexicalidad semiótica, es decir, en la clase de acción sígnica que consiste en la resistencia, en un mecanismo de acción y reacción material, como la huella que queda impresa en el suelo, o el tatuaje sobre la piel. Así, esta segunda ilustración debe considerarse ante nada un signo indicial, la representación de un fuerte impacto de la actividad parresiasta de Bolsonaro, y también de la multitud de reacciones que ésta determina como el efecto de un "verdadero síntoma" (CP 7.628). Si tuviera que caracterizar figuradamente mi segundo ejemplo diría que es un lacerante grito.

Se trata de una actividad parresiasta que proviene de un colega y amigo brasileño de Facebook, a quien llamaré aquí ' $A B$ ', con iniciales ficticias. Bajo el llamativo título "SOMOS TODOS BOLSONARO", el 23 de agosto de 2019, AB se expresó en su muro sobre los muy abundantes comentarios negativos sobre el presidente de su país así:

Parem de gritar no Facebook contra o presidente - ele nos representa. Parem, porque ninguém que pense diferente de você vai ouvir; e porque não há a menor chance de uma revolução ser feita pelas redes sociais. Bolsonaro foi eleito com a maioria dos votos válidos, essa é a regra que vale (e a regra tem que valer). Sim, é verdade que os votos que ele obteve não representam a maioria dos eleitores. Mas isso é um problema mais dele - que deveria olhar para o todo e não somente para os seus -, do que da gente - que deveria olhar mais para si do que para o outro. Bolsonaro é a nossa cara. Ou melhor, tem o nosso jeito. Ou dá para dizer com tranquilidade que o brasileiro, por exemplo, fala bem, conhece das coisas, valoriza o estudo, respeita as diferenças e entende o que é a lei? Bolsonaro talvez seja a melhor representação daquilo que, no fundo, como brasileiros, sempre fomos: um povo mesquinho, preconceituoso, ignorante, desconfiável, personalista, desrespeitoso, animalesco. (...) Em que atos aparentemente normais estão minhas pequenas corrupções diárias? Até onde eu chegaria para garantir a satisfação dos meus desejos pessoais? Quando foi que eu abri mão de pensar, passando a aceitar as maiores atrocidades, com as justificativas mais vãs? Em que parte de mim, dos meus gestos e da minha vida estão esses valores que permitem e legitimam a existência de um presidente como Bolsonaro? Depois disso, a gente pode começar a pensar em sair de onde está. (Muro de $A B$, en Facebook, 23/08/19 [énfasis mío]) 
La operación retórica desplegada en el muy extenso mensaje subido al muro de esta red social nos choca desde el inicio, pues la rúbrica "TODOS SOMOS..." se ha usado en las redes para expresar congoja colectiva, por ejemplo, ante el asesinato de los creadores de la publicación satírica Charlie Hebdo, en París, el 7 de enero de 2015. El estatus intelectual de mi colega brasileño y sus típicas contribuciones no hacían esperar en absoluto estas exasperadas palabras. Los elementos que destaqué en negrito conforman el núcleo del acto parresiasta acometido por AB.

Sin evaluar si el actual mandatario de su país sea todo lo malo que sus colegas universitarios o amigos afirman una y otra vez que Jair Bolsonaro es como político y como ser humano, el acto parresiasta de $A B$ consiste en proclamar del modo más rotundo y sincericida imaginable que todos, no sólo los votantes de ese político, sino la nación entera brasileña debería desistir de esa tesitura hostil, porque es un fiel reflejo de lo que se denuncia incansablemente en las redes como los peores defectos del mandatario: "Bolsonaro tal vez sea la mejor representación de aquello que, en el fondo, como brasileños, siempre fuimos: un pueblo mezquino, prejuicioso, ignorante, no confiable, egocéntrico, irrespetuoso, animalesco". El discurso de AB cumple con todos los rasgos que definen la parresia: a) el texto aparece en su propio muro; $b$ ) no sólo él lo suscribe, sino que aparece al lado de su fotografía; c) al hacerlo, $A B$ eligió difundirlo a la totalidad de sus 4276 amigos de Facebook; d) y lo más importante: por el hecho de quedar asociado material e inequívocamente con esta proclama, $A B$ se expuso al riesgo no menor de dañar el vínculo con un gran número de esas amistades, a ser atacado y posiblemente bloqueado por muchas de esas personas ${ }^{10}$.

Considero que la analogía que propuse arriba para la naturaleza semiótica de la parresia es válida en este caso: el acto discursivo cometido por $A B$ equivale a colocar un tatuaje sobre su cuerpo en el lugar más visible, sobre su rostro. Todos pueden apreciar la decisión que tomó de exhibir ese signo tan llamativo como una opinión innegablemente suya, propia, como un signo de identidad indicialmente anexado a su persona. Foucault tiene razón al afirmar que nada es menos parecido a un acto de habla, a un performativo como '(yo lo) bautizo (Juan)' que la parresia, tal como la ilustra esta especie de manifiesto insólito en una red social. No se trata de estar investido de un poder jurídico o protocolar y por ende convencional, como los signos simbólicos - sino de tomar la decisión de lanzarse al vacío con un incendiario discurso sincericida, que arriesga ofender, de vulnerar irreversiblemente el lazo amistoso de un buen número de esos miles de amigos o conocidos. Ese gesto ilustra bien el funcionamiento indicial de la

\footnotetext{
10 No considero aquí, por no ser relevante, la consideración sobre el grado de auténtica amistad o apenas de conocimiento, e incluso de una relación más tenue de esos miles de "amigos de Facebook" de AB.
} 
parresia: un mecanismo de acción y reacción contundente. Frente a la actuación parresiasta del presidente Bolsonaro denunciada y atacada por innumerables usuarios brasileños en las redes, encuentro esta reacción igualmente feroz y golpeadora contra ese ataque. El punto interesante aquí es que sería muy difícil, diría implausible, concluir de la lectura de este texto la adhesión de $A B$ a la ideología o a la actuación política de Bolsonaro; nada en sus intervenciones, la de sus amigos de Facebook, o su propia condición social y cultural lo indica. Un modo posible de describir este acto semiótico es que se trata de un índice igual y contrario a los que él denuncia en su muro de Facebook. Él los acusa de hipócritas, pero un dato clave para el análisis de su discurso es que $A B$ se incluye a si mismo en una zona limítrofe de esa grave y masiva acusación contra sus compatriotas, pues el autor también forma parte de la nación denigrada. Lo único que podría exonerarlo de ser blanco de su feroz diatriba es justamente el haber reaccionado con exasperación parresiasta ante los constantes ataques contra Bolsonaro, el hecho innegable de haberse separado un poco al menos del pelotón atacante. Surge entonces la extraña situación semiótica del parresiasta que simultáneamente los y se denuncia a sí mismo, pero al hacerlo no deja de poner en riesgo el vínculo, como puede observarse en los muy abundantes comentarios que suscitó el mensaje citado en su muro.

\section{Conclusiones preliminares la parresia y el giro indicial de la política}

Lo que une los ejemplos discutidos en la sección anterior, el comentario hostil a la población homosexual del propio Jair Bolsonaro y la diatriba áspera y exasperada del académico brasileño en su red social contra quienes lo atacan es el hacer muy difícil para el analista el poner en tela de juicio su autenticidad, su carácter de "verdadero síntoma" (Peirce). El carácter sincericida de la entrevista televisada en 2015, en la que el diputado Bolsonaro se ufana de no aceptar una transfusión de sangre que provenga de un homosexual - supuestamente basándose en datos del Ministerio de Salud de su país - por ser una opción no segura, así como la intervención extensa y encolerizada de mi colega y amigo de Facebook sobre las durísimas y recurrentes críticas contra Bolsonaro no inducen a dudar de su autenticidad. Esa es una de las claves de la parresia como acto semiótico: su carácter indicial no nos habilita a dejar de lado de su tangible vínculo existencial con el cuerpo del parresiasta.

Los dos ejemplos en torno a la figura de Jair Bolsonaro traen a la mente la imagen del cuerpo sobreexpuesto del expresidente uruguayo José Mujica que discutí antes. Tanto su descuidado andar en calzoncillos, al inicio de un documental (Kusturica 2018) que se dedica a exaltar su personalidad humana y política, como las dos flagrantes transgresiones contra el protocolo mínimo que analicé - su lenguaje soez en una entrevista y la entusiasta aprobación a haber robado bancos como guerrillero - sirven de garantía de la autenticidad de 
esas instancias discursivas. Y ese es precisamente el efecto fundamental de la parresia en estos tiempos. Más allá del carácter levógiro - Mujica - o dextrógiro - Bolsonaro - de estos parresiastas latinoamericanos, cuya reunión podría escandalizar a algún lector, lo esencial es que sus intervenciones provocan en sus dilatados públicos fuertes reacciones, que son propias de la semiosis indicial, es decir, reactiva, de algo que se impone a nosotros de modo compulsivo, como un golpe o como la hipnótica visión de un tatuaje en el rostro de alguien.

En una época donde la palabra y especialmente el discurso tradicional político que ha sido tradicionalmente el sostén de la democracia parece haber decaído en su poder persuasivo, surge con fuerza inaudita el giro indicial, esa manifestación factual, pegada al cuerpo de quien expresa algo como su opinión, su verdad, y coloca el propio cuerpo como la garantía última de su afirmación. Un meme que vi hace ya bastante tiempo en Facebook hacía la siguiente pregunta retórica: "¿Qué han hecho los uruguayos para merecer a Mujica?". Otro meme que vi ahora en la misma red social está compuesto por varias imágenes del presidente J. Bolsonaro en poses chocantes, grotescas (Fig. 8), todas ellas clasificables como parresiastas (empuñando un arma de guerra, haciendo gestos grotescos, etc.) y abajo se le la frase "Créalo si quiere, eso es un presidente". Tiene 12.000 compartidos y casi 700 comentarios. Elijo la glosa de quien lo compartió con otro amigo brasileño: "Un día, nuestra generación

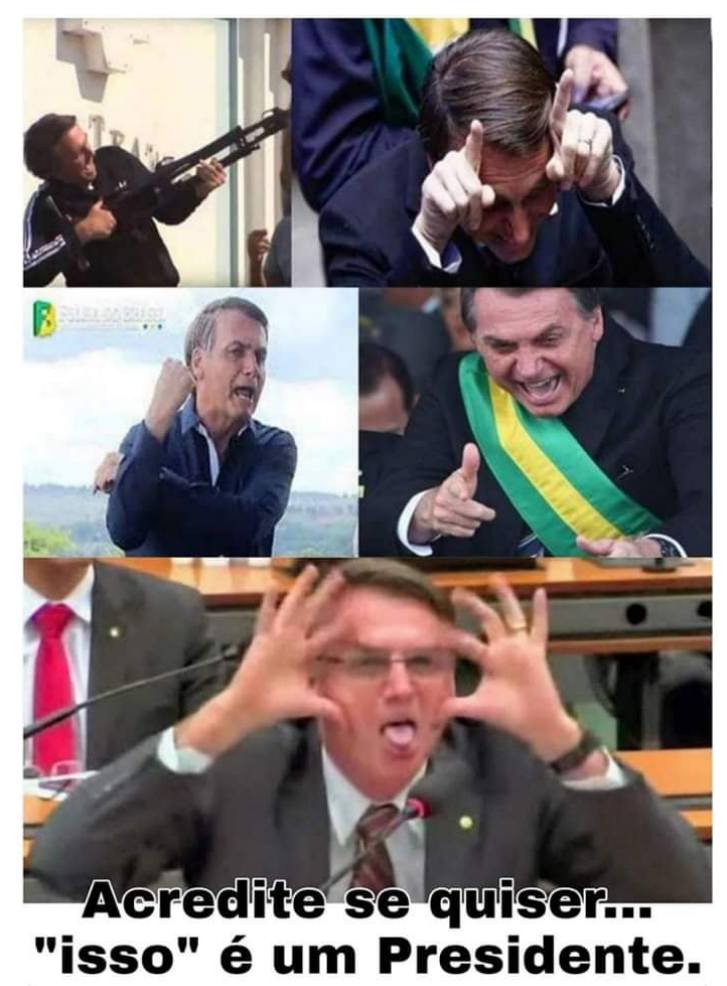

Fig. 8 Meme hecho con un collage de imágenes grotescas de J. Bolsonaro 
futura mirará en nuestros ojos y preguntará: ¿tú dejaste que eso suceda?"11 Del modo más claro imaginable, tenemos así las dos senderos antitéticos hacia la autenticidad, el utópico encarnado por la figura del expresidente y exguerrillero uruguayo José Pepe Mujica, un tótem viviente de la ideología de liberación revolucionaria de la segunda mitad del siglo 20, y el camino distópico que pone en escena a través de sus dichos y actitudes el presidente de Brasil Jair Bolsonaro. Pero también incurre en parresia el singular defensor/atacante cuyo manifiesto de Facebook analicé en la sección anterior. Detrás del fenómeno de la parresia, observo el mismo anhelo por una experiencia casi tangible de significación, la que aporta el giro indicial, la prevalencia del signo que opera como un síntoma verdadero, y consigue que tengamos la experiencia de acercarnos lo más posible a la materialidad auténtica del otro.

\section{Referencias bibliográficas}

ANDACHT, Fernando. 2003. El reality show: una perspectiva analítica de la televisión. Buenos Aires: Grupo Editorial Norma.

ANDACHT, Fernando. 2005. Representaciones de lo real mediático en el Brasil contemporáneo: auto-imagen nacional en la era del reality show. Cuadernos del CLAEH, 90 (28), $28-44$.

ANDACHT, Fernando. 2010. On the media representation of reality: Peirce and Auerbach, two unlikely guests in the Big Brother house. En S. van Bauwel y N. Carpentier (eds.) Trans-reality television. The transgression of reality, genre, policits and audience. (pp. 37-64). Lanham: Lexington Books.

ANDACHT, Fernando. 2016. Sobre el inesperado desembarco indicial del reality show en el siglo 21. Espacio Abierto, 25 (4) , 239 - 252.

BORGES, Jorge Luis. 1996 [1960]. La trama. En J. L. Borges. Obra Completa II (p. 171). Buenos Aires: Emecé.

FISCHER, Sandra; Aline VAZ. 2019. A manipulação do autêntico e a profanação do contrário - um imaginário populista no Brasil? III Congreso Latinoamericano de Teoría Social, 2019, Buenos Aires. Actas del III Congreso Latinoamericano de Teoría Social.

FOUCAULT, Michel. 2001. Fearless Speech. J. Pearson (Ed.). Los Angeles: Semiotext(e).

${ }^{11}$ El texto original portugués: "Um dia, nossa geração futura olhará em nossos olhos e perguntará: ¿você deixou isso acontecer?" 
FOUCAULT, Michel. 2010. The Government of Self and Others. Lectures at the Collège de France 1982-1983. F. Gros (Ed.). (G. Burchell, Trans.) London: Palgrave/ Macmillan.

FOUCAULT, Michel. 2011. The Courage of the Truth (The Government of Self and Others II) Lectures at the Collège de France 1983-1984. F. Gros (Ed.). (G. Burchell, Trans.) London: Palgrave/Macmillan.

GOFFMAN, Erving. 1958. The presentation of self in everyday life. New York: Doubleday Anchor.

KUSTURICA, Emir. 2018. El Pepe. Una vida suprema. [Film documental]. Kramer \& Sigman Films, Argentina.

PEIRCE, Charles Sanders. 1931-1958. The Collected Papers of C. S. Peirce. Vol. I-VIII, Charles HARTSHORNE, Paul WEISS \& Arthus BURKS (eds.). Cambridge, Mass.: Harvard University Press.

RANSDELL, Joseph. 2007. On the use and abuse of the immediate/dynamical object distinction (Versión 2007-04-22). Prepublication paper in Arisbe. The Peirce Gateway. https://arisbe.sitehost.iu.edu/menu/library/aboutcsp/ ransdell/useabuse.htm

RIVERA, Takeo. 2013. Youth poets, amateur counter-conduct, and parrhesiastic value in the amateur youth poetry slam. Performance Research 18 (2), 114-123. 


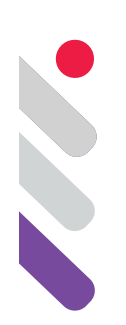

\title{
Territorios artísticos en disputa. La obra de Eduardo Kac
}

DOI: 10.24308/IASS-2019-8-020

\author{
Pampa Arán \\ Centro de Estudios Avanzados/ FCS/ UNC \\ Argentina \\ aranpampa@gmail.com
}

El arte es el laboratorio de la libertad. E.Kac

En una entrevista (González, 2009) Paolo Fabbri sostiene que hoy no cabe la pregunta qué es el arte, sino cuándo y cómo es arte, lo cual no solo lleva implícita la relatividad de la respuesta, sino la pregunta acerca del territorio cercado del arte como práctica y como discurso y a la movilidad incesante de sus límites, dada la porosidad que hoy marcan las fronteras de lo artístico. Y básicamente, esta es la cuestión que aquí presento a partir del breve análisis de la obra experimental del brasilero Eduardo Kac (1962, Río de Janeiro) que enfocaré desde la reflexión semiótica, situándola no tanto en el campo de los signos, sino en la eficacia de los signos, los procesos de significación que desata y transversalmente, en el campo de la biopolítica.

Siguiendo la hipótesis de Fabbri, cuándo y cómo un hecho es artístico, puedo entender las audacias de Kac a partir de la afirmación de Bajtín, pensador al cual acude insistentemente ${ }^{1}$ : "un acto humano es un texto en potencia y puede ser comprendido (...) tan sólo dentro del contexto dialógico de su tiempo (como réplica, como postura llena de sentido, como sistema de motivos)" (Bajtín, 1979/1982, p. 298). Y este concepto de interacción real con otros seres naturales y artificiales, es lo que tempranamente Kac intenta, según dice, "para iniciar un diálogo visual con otros artistas y participantes de localidades remotas (...) promovido por los participantes" (Kac 2000, 30). Enfatizo esta idea que será el eje de mi ponencia: intersectar fronteras entre lo natural y lo artificial es desde el comienzo el objetivo de un arte que combina

${ }^{1}$ En diciembre 2018 presenté un trabajo sobre A. Machado y E. Kac en el marco del Encontro Anual Nacional GT/ANPOLL/Estudos Bakhtinianos, organizadas por Grupo de Pesquisa/PUC-SP/ CNPq Linguagem, Identidade e Memória (PUC, San Pablo). 
semióticas sintácticas y asintácticas, algo así como un nuevo espacio semiótico interactivo, en buena medida lúdico, pero también conceptualmente complejo, que propone formas de habitar el mundo buscando la relación entre otros y con otros no necesariamente humanos.

Ya en 1985 Kac crea el arte de la telepresencia con medios telemáticos (telecomunicación + informática), usando las redes telefónicas, Internet o galerías convencionales buscando la interacción entre seres humanos, animales y máquinas programadas, dando prioridad a la experiencia personal a distancia, pero que a su vez está incorporada (o programada) en la obra. Es una nueva etapa en la desmaterialización del objeto artístico en tanto arte que pierde la forma de los objetos y soportes tradicionales, pensando el objeto artístico como icono material y simbólico del valor del arte y ubicando el debate estético en escenarios virtualmente compartidos. Pero la tecnología ayuda a verlo como un espectáculo global movido por muchos espectadores o participantes de todo el mundo en tiempo real pensando la obra como un discurso que interpela al otro y más que como producto, como hecho artístico en proceso inacabado. Esto dice Kac en su Manifiesto:

Los robots pertenecen a una nueva categoría de objetos y situaciones que rompe con la taxonomía tradicional del arte. Donde antes se hablaba de límites y fronteras ahora encontramos nuevos territorios. Estos nuevos terrenos artísticos están abiertos a nuevas posibilidades y se relacionan entre ellos de manera productiva. En estos nuevos terrenos heterodoxos nacen criaturas híbridas sin un modelo que las preceda. Combinada con los medios de telecomunicaciones, la robótica da lugar al arte telepresencial, en que el robot es el huésped de un sujeto alejado. (...) Los robots existen en una confluencia de debate creativo y exploración conceptual (...) (Kac, ekac.org, online)

Estas precisiones nos ubican en el punto al que queríamos llegar desde nuestra interpretación de esta obra como una maquinaria semiótica que busca configurar lo artístico desde nuevos territorios no cercados, desde los cuales producir también criaturas híbridas, sin precedentes, algo así como un nuevo génesis. Incorpora objetos que pueden replicar formas de inteligencia artificial, responder e imitar, mirar y ser mirado como el pájaro robótico conviviendo con pájaros reales o bien asistir a la "conversación" entre un pájaro y un helecho. ¿Arte transdisciplinar en el concepto y en la práctica, nos preguntamos? Y siguiendo a Fabbri, un arte que propone a la semiótica nuevos estatutos de significación al producir ya no solo objetos fronterizos, sino multimodales (González, 2009), con nuevos significantes y formas de la expresión.

Así, la "conversación" entre un canario y un helecho (Essay concerning human understanding, 1994) o Rara avis (1995/6) Esta última presentación efectúa una experiencia interactiva de telepresencia en la que un pájaro 
telerrobótico, un guacagamayo brasilero, cohabita en una jaula junto a pájaros verdaderos. Fuera de la pajarera, los espectadores pueden seguir la escena desde el punto de vista del guacamayo, utilizando un casco de realidad virtual y al mismo tiempo, ir dirigiendo los movimientos del pájaro, lo cual permite al que se incorpora a la escena ser simultáneamente, hombre y pájaro, entre otros pájaros. Los robots artísticos no son esculturas, ni pinturas, ni video arte, ni performances. Pertenecen a una nueva categoría de objetos y situaciones que rompen con las categorías conocidas, el robot puede ser huésped de un espectador remoto, inventar nuevas conductas, interactuar, no son formas fijas ni cerradas "existen en la unión del debate creativo y la exploración conceptual que se manifiesta en los expandidos dominios telemáticos y cibernéticos" (Kac, 2000:34).
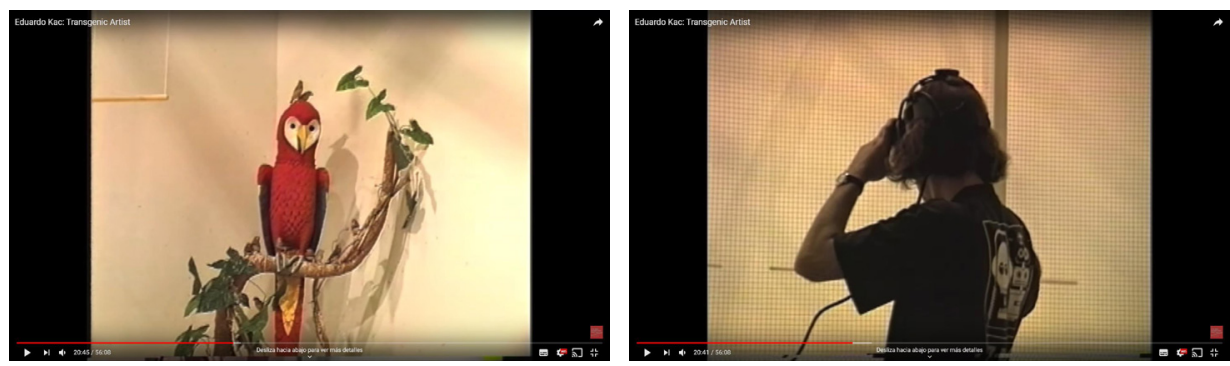

Figura 1. Exposición Rara Avis: experiencia interactiva de telepresencia, recuperada en la conferencia "Eduardo Kac: Transgenic Artist", para la $24^{\circ}$ Chicago Humanities Festival (Illinois, 9 de noviembre de 2013). Conferencia completa disponible en: https://www.youtube.com/watch?v=3LSJVDOm1Mg

Hasta aquí, la obra de Kac es arte dialógico, como lo denomina, en la medida en que intenta convertir las exposiciones en una enorme plaza pública a la manera de una feria donde se teleconecta el universo de la vida natural con la vida artificial. La espacialidad se vuelve temporalidad y el espectador es parte de la obra, el autor artista está ausente y más bien parece que es una programación de la máquina, una interfaz en diferentes niveles que permite cierto tipo de información y de comunicación. Se aproxima a la semiosfera multimedial de la que habla Fabbri, con objetos o situaciones de diferentes sistemas sígnicos que se traducen entre sí. (González, 2009). Por otra parte, la obra se presenta como experiencia intersubjetiva que acontece: lo que cada uno hace o dice sobre un objeto que manipula, natural o artificial, afecta y es afectado por lo que otros dicen o hacen; no hay producto final ni acabamiento de la obra, nunca hay imagen fija, es puro proceso.

Pero hacia fines del siglo XX, Kac comienza a desplegar la posibilidad de generar un arte en el que la idea de la creación tenga por objeto los seres 
vivos y su propio cuerpo, el que aloja su ADN que es su memoria genética, pero también es la memoria de la especie. Estas nuevas "acciones artísticas", como quisiera llamarlas, desembocan en el bioarte o arte transgénico que tiene como idea la aceptación de la biodiversidad planetaria y de una evolución que ha sido incesante y que cada vez más es objeto de una transformación dirigida con intereses puramente económicos. ¿Cabe pensar que es posible resistir, no a las mutaciones que están en la misma naturaleza y en la evolución humana, sino al objetivo y a la calidad de lo mutable?, ¿tiene aquí el arte espacio para decir algo?

En este punto quiero responder siguiendo las reflexiones de Florencia Garramuño (2015) al hablar de la "inespecificidad" del arte contemporáneo, que se expresa como redefinición del potencial político del arte a partir de los modos de incorporación material y conceptual del vínculo yo - otro, que en el caso de la obra de Kac sería "del otro que no es como yo". Si bien estas transformaciones del arte pueden rastrearse a lo largo de la Modernidad y especialmente a partir de la década del '60, lo que caracteriza estas nuevas formas es, siguiendo a Garramuño, una experiencia de puesta en común o de comunidad, si se prefiere, que no es ni una esencia ni una pertenencia, sino un modo de existencia. A través del análisis de diferentes prácticas artísticas, no solo literarias, el ensayo avanza sobre lo inespecífico de obras de artistas latinoamericanos, en materia de soportes, lenguaje y medios.

Y lo que, además de esta caracterización del arte contemporáneo, me ha llevado a trasladar estas reflexiones de Garramuño a la obra de Kac, es el modo en que esta investigadora vuelve a pensar lo no específico del arte contemporáneo llevado al discurso de la especie que se sostiene, según su decir, en la "producción de diferencias como base de la distinción excluyente" (Garramuño, 2015:181). En esta perspectiva, el arte contemporáneo, sin fronteras internas o externas específicas, propone modos de alteridad que alojen todas las formas del bios sin distinción de jerarquías y que en definitiva, conviertan lo ético en estético. Escuchemos².

Se suceden así una serie de audaces experimentos con biotecnología: por ejemplo Time capsule (1997) que se expuso en el centro cultural, Casa de las Rosas, en San Pablo. En esa ocasión Kac se implanta en su tobillo con un sistema de cámaras de TV y de scanners, un chip de memoria con un número de identificación que queda registrado en una base de datos, método diseñado para rastrear animales y prisioneros o esclavos que antes eran marcados a fuego en ese mismo lugar del cuerpo. Este implante lo hace frente a una foto de sus

\footnotetext{
2 Para entender de qué forma Kac se acerca y se conecta con las obras que analiza Garramuño, véase "What if art could truly create biological life?", conferencia dictada en el marco de TEDxViena en diciembre de 2015. Disponible en: https://www.youtube.com/ watch?v=IS_5WJteCC8
} 
antepasados que fueron llevados a los campos de concentración en Polonia, confrontando así los modos de persecución humanos y las formas de registro (analógico y digital) del pasado y del futuro, la memoria del cuerpo individual y la del cuerpo social.

¿Qué interpretación del hecho artístico y público podemos hacer? Kac intenta problematizar el modo en que hoy se puede rastrear a cualquier persona en el sistema, así como los modos en que la especie humana ha ido "implantando" ciertas condiciones genéticas, que es el ADN que heredamos como identificación personal. ¿Podremos en el futuro sustituir estos implantes biológicos por otros artificiales que puedan cambiar nuestros rasgos identitarios o nuestra memoria?, ¿Podrá el que dice "yo" albergar a otro y ser un nosotros? El arte de Kac comienza así a convertirse en un bioarte que propone una redefinición del estatuto de la humanidad y de su condición biológica, que en este primer ciclo se completa con la obra Génesis (1999), que explora la idea de que los procesos biológicos son hoy escribibles y programables, así como son capaces de almacenar y procesar datos de un modo semejante a las computadoras digitales. Los procesos biológicos pueden transcribirse como programas computarizados.

Una de las experiencias (entre muchas otras) más conocidas y publicitadas de Kac ha sido el conejo Alba (2000), que, haciendo realidad a criaturas imaginarias, da vida a un conejo verde fluorescente que brilla en la oscuridad, producido con proteínas de medusa utilizando métodos de biología molecular.

En la extensa explicación que da Kac a la aparición de la conejita Alba (2002), llamada Bunny GFP (Green Fluorescent Protein) que es un sistema de información inocuo para el animal, usado en investigación animal como marcador, dice que el genoma humano es solo parte del amplio espectro genómico de la vida y que hoy la ingeniería genética lleva a explorar límites y posibilidades de lo que llamamos humanidad (p.22-24). Pero sucede que la vida no es solo un problema genético, sino también social y el arte transgénico intenta darle una faz política a la biodiversidad y a la responsabilidad del hombre en su cuidado, no porque el hombre sea un ser superior, que no lo es en el orden de lo viviente, sino porque socialmente es distinto de otras especies.

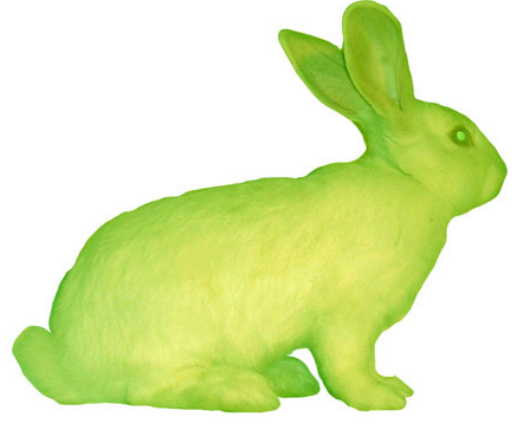

Figura 2. Alba, la coneja

fluorescente (2000). Imagen extraída del sitio web oficial de Eduardo Kac.

Disponible en: http:// www.ekac.org/gfpbunny. html\#gfpbunnyanchor 
Si se asume tal responsabilidad, es necesario "poner sobre la mesa" los peligros y beneficios de la ingeniería genética que a todas luces es una "revolución en curso" (p.27), que ha dejado de ser solo un problema científico, para ser actualmente un problema político y económico. $Y$ aquí reside fundamentalmente el papel del arte que se atreve con estos seres, que dejan de ser solo objetos artísticos para ser otros seres diferenciados pero semejantes, contribuyendo a revelar las implicancias culturales de la ingeniería genética, librada solo al manejo de los intereses políticos y económicos y mantenida en secreto o dentro de una élite de expertos.

Kac, que después de una batalla legal con el laboratorio, nunca pudo adoptar en familia a la conejita, afirma que la participación responsable del arte en el sostenimiento de la biodiversidad amenazada, inaugura para el arte nuevas dimensiones simbólicas.

Con la idea de cambiar profundamente la comunicación e interacción genética con las especies y siempre retomando su idea original de arte interactivo, Kac crea una "plantimal" a la que Ilama Edunia (2003/2008), (de la serie Historia natural del enigma) que es una flor en la que Kac implanta un gen de su ADN sanguíneo que se ve como venas rojas en los pétalos de la flor, integrando otro ser, parcialmente vegetal, parcialmente humano.
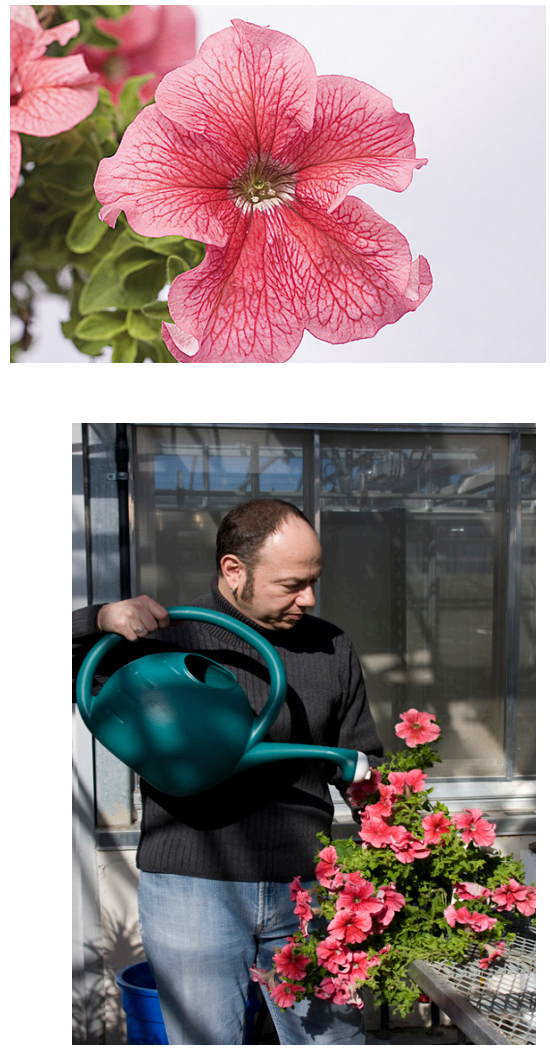

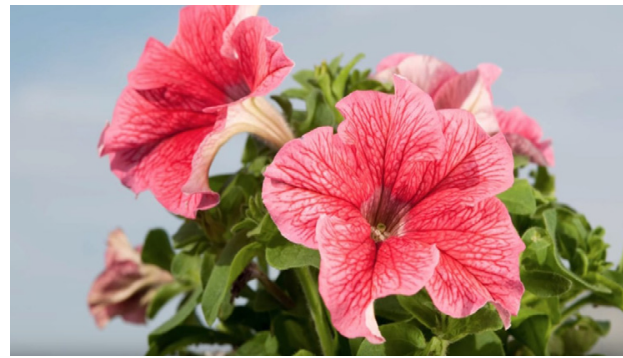

Figura 3. Edunia, de la serie Natural History of Enigma (2009). Imágenes extraídas del sitio web oficial de Eduardo Kac.

Disponible en: http://www.ekac.org/ nat.hist.enig.html 
Es un modo también de mostrar que ambos formamos parte de un espectro muy amplio de la vida planetaria y que ésta tiene un flujo de información modificable.

La nueva flor es de la cepa de la Petunia, inventada y producida por Kac a través de biología molecular. No es una flor que se encuentre en la naturaleza. Edunia tiene "venas" rojas sobre sus pétalos rosa brillante y un gen del artista se plasma en cada célula de estas venas. Es decir, el gen de Kac produce una proteína sólo en las venas. El gen fue aislado y secuenciado a partir de su sangre. El fondo rosado del pétalo, sobre el cual las venas rojas se hacen visibles, evoca el tono rosado de la propia piel de Kac. El resultado de esta manipulación molecular es una floración que crea una imagen viva de la sangre humana circulando a través de las venas de una flor.

Lo notable del hecho es que, mientras en todos los seres humanos, el gen seleccionado por Kac es responsable de la identificación de cuerpos extraños, en esta planta de hibridación, es precisamente lo que el artista integra en el "otro", creando así una nueva clase de "yo" que es parcialmente flor y humano. Lo expresa en estos términos:

En otras palabras, seremos transgénicos. A medida que se desmorona el concepto de especie, basado en las barreras de reproducción, a través de la ingeniería genética, la misma noción de lo que significa ser humano está en juego. Sin embargo, esto no constituye una crisis ontológica. Ser humano significará que el genoma humano no es una limitación, sino un punto de partida. (Kac, 1998)

No quiero terminar mi exposición sin referir que las críticas positivas y negativas de la obra de Kac son múltiples porque, como señala Levy (2010), los cambios de paradigmas científicos influyen siempre en el arte, como sucedió en el Renacimiento, pero también suscitan temores, desconfianzas y rechazos sociales.

Personalmente creo que el proyecto de Kac se asienta en un pensamiento utópico que paradójicamente desata un proceso de interpretación en la memoria cultural que puede convertirse en distópico. Tenemos demasiado fresca la memoria de los experimentos producidos en los campos de exterminio en el siglo pasado y ese dramático sentido social alojado en la memoria colectiva ha desatado numerosas críticas, a las que se han sumado ecologistas, ambientalistas y defensores de las especies amenazadas, que sostienen el abuso de usar plantas o animales sin que ellos puedan impedirlo o permitirlo, o argumentos basados en dogmas religiosos vinculados a los relatos bíblicos sobre la creación del universo.

Por otra parte, están los defensores del campo cercado de lo artístico poniendo en duda que el arte de Kac sea tal y esta fue la base de mi pregunta inicial acerca, no de si es arte, sino cuándo y cómo es arte. La extensa e intensa 
exposición mediática del artista y de su obra, han colocado esa producción tanto en el mercado como en los medios y ello ha sido visto como "(...) un doble juego de legitimación: en primer lugar, el aumento de la empatía social con las biotecnologías gracias a su divulgación amable a través de proyectos artísticos y, en segundo lugar, la utilización de la polémica de lo transgénico para la autopublicitación de la obra y del artista." (Albelda y Pisano, 2014, p.123).

Me resulta difícil e inapropiado plantear aquí todas las objeciones críticas sean negativas o elogiosas que ha recibido la obra de Kac y que pueden revisarse incluidas con las referencias en su página oficial de la web (y en mi bibliografía). Me parece oportuno como dice Sloterdijk (Roncallo, 2008) dejar de pensar en una lógica binaria y opositiva como es nuestra tradición occidental y comenzar a hacerlo desde lo que se conoce como tercero excluido tertium non datur (que Lotman ya había señalado en Cultura y explosión) desde la estética y los territorios disciplinares y creo que en esto las semióticas de Lotman, Sebeok y Fabbri han dado algunos pasos importantes. Pero se abre una enorme y fascinante tarea en varias dimensiones del proceso de producción, circulación e interpretación de la significación e incluso desde las estrategias de enunciación, pues me pregunto si la obra de Kac no es un modo de cambiar el lugar de enunciación de la ciencia, dando visibilidad al secreto de la ciencia y proponiendo enunciados no totalmente logocentrados.

Y recuperando el epígrafe que puse al comienzo de mi exposición, "el arte es el laboratorio de la libertad", cierro también con palabras de Kac en una entrevista:

- Lo interesante del arte es que no tiene límites, internos ni externos, por eso es siempre difícil definir lo que es arte. Pero, en ese sentido, el arte resulta curioso en relación a la ciencia. El arte es sólo singularidad. Cuando Pollock hace sus manchas sobre la tela, es imposible repetir ese acto. El momento de hacer en el arte es fundamental e irrepetible. La ciencia es lo contrario, es la repetición, lo previsible, la hipótesis, la constatación, son mecanismos que definen su práctica. En el arte, esa libertad infinita que dificulta su definición es al mismo tiempo su característica más importante. (Kac, entrevista con Ali- Brouchoud, 2006).

\section{Bibliografía}

ALBELDA, José y Serena PISANO. 2014. Bioarte: entre el deslumbramiento tecnológico y la mirada crítica. Arte y políticas de identidad. Universidad de Murcia, España, vol.10-11, julio-dic 2014, pp113-134 https://digitum.um.es/ xmlui/bitstream/10201/43116/1/219221-775101-2-PB.pdf 11/11/2018.

ALI-BROUCHOUD, Francisco. 2006. Acerca de la biología del arte. Entrevista con el artista brasileño Eduardo Kac. Página/12, martes 4 de abril de 2006. 
Sección Cultura y Espectáculos. En 10/11/2018 http://www.ekac.org/pagina12_ BA.2006.pdf

BAJTín, Mijaíl. 1982. El problema del texto en la lingüística, la filología y otras ciencias humanas. Ensayo de análisis filosófico. Estética de la creación verbal. México: Siglo XXI.

FABBRI, Paolo. 1995. Tácticas de los signos: ensayos de semiótica. Bs. As: Gedisa.

GARRAMUÑO, Florencia. 2015. Mundos en común. Ensayos sobre la inespecificidad en el arte. México: Fondo de Cultura Económica.

GONZÁLEZ, Rayco (2009) "Sobre las fabulaciones del arte. Entrevista a Paolo Fabbri". En Artecontexto. Revista digital de cultura y arte contemporáneo, 1 diciembre 2009.

https://www.artecontexto.com/es/blog/sobre_las_fabulaciones_del_arte_ entrevista_a_paolo_fabbri.html\#[3/08/2019]

KAC, Eduardo. Telepresencia y bioarte. Interconexión en red de humanos, robots y conejos. http://www.ekac.org/kac4.html

KAC, Eduardo. Foundations and Development of Robotic Art.

KAC, Eduardo y Marcel.lí ANTUNEZ ROCA. 1996. Arte robótica: un Manifiesto.

http://www.ekac.org/kac.roca.sp.html. [3/08/2019]. Publicado originalmente en Leonardo Electronic Almanac, vol 5, no5, 1997)

KAC, Eduard. 2002. GFP Bunny: a coelhinha transgênica. Trad al portugués. I. Machado. Revista galáxia, 3, PUC, S. Pablo, Brasil. (Gentileza I. Machado).

LEVY, José Alberto. 2010. A bioarte. International Journal of Biosafety and Biosecurity, Vol.1, no 0.01/11/2010. En http://www.ekac.org/bioarte_levy.pdf [12/08/2019]

LÓPEZ DEL RINCÓN, Daniel. 2015. Bioarte. Arte y vida en la era de la biotecnología. Madrid: Akal

MACHADO, Arlindo. 2000. Cuerpos y mentes en expansión. El paisaje mediático. Bs. As: Libros del Rojas, pp 51-58. 


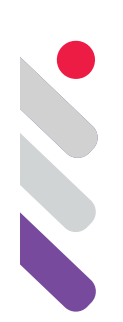

\title{
Semiosis of the Body in Arab Sexological Literature
}

DOI: 10.24308/IASS-2019-8-021

\author{
Mohamed Bernoussi \\ University of Meknes \\ barnoussim@ymail.com
}

Before dealing with the semiosis of the body in the sexological literature of the Middle Ages, I would first like to briefly mention some recent semiotic approaches to the body and comment on the difficulties and pitfalls associated with such undertakings. I will provide three examples to illustrate this purpose. The first concerns the book written by Jacques Fontanille entitled Sema et Soma ou figures du corps (Sema and Soma or faces of the body). The first characteristic in Fontanille's approach is the delimitation of the three axes of identity of the body: the flesh-self which refers to the set of semi-motor references, the selfbody-idem (a corporeal instance in the course of construction) and the selfbody-ipse (characterized by the identity of attitudes). The book takes an original path towards the so-called semiology of the Paris School, namely the openness onto phenomenology and psychoanalysis, an opening doubled by a revision of certain formalizing ambitions, particularly as regards actantial semiotics. Indeed, Fontanille is reconsidering the narrative syntax and seems more and more inclined to admit randomness and the accidental in the capturing of the body, something which some people have hailed as very daring, even if semioticians, like Landowski $(1998,2004)$, have substantially developed it in their work. The narrative patterns and the semiotic lines are more and more relativized in favor of the sensible and the various figurative manifestations of the act. Henceforth, corporality is preferred to the body because it allows for a better grasping of the sensitive side of the observed phenomenon.

For Marrone (2016), the second illustration, what makes the realization of a semiotic of the body difficult is the fact that the latter constitutes the place and the means of the signifying process. It is preceded by what Eco calls the encyclopedia, the library or the texts. Marrone expresses this difficulty in the following way: "Taking the body into consideration means thinking of it as an element and a process that is already social, that already has a cultural 
destiny marked by specific interests, programs and values, helping to shape and deconstruct them." (Marrone 2016: 150).

Thus, human subjectivity is based on the body, which is not based on abstract naturalness, but is constituted and reconstructed from presubjective experiences and inter-subjective instances. The term corporeality or embodiness accounts in a better way for the anchoring of this entity in meaning and in the sensible. Corporeality is not only something that looks at meaning and perception, neither is it only subjective and inter-subjective but also spatial, insofar as places are a structural element of bodies. For Marrone, corporeality can be approached as a text, but should in no way be reduced to canonical textual forms (stories, movies, songs, etc.). It requires specific models of analysis, developed from particular modalities through which the body and perception access meaning, developing and modifying substances and forms of expression. That is why, for the same author, the problem lies in the difference of principle between the bodies represented (level of the enunciated) and bodies representing (level of enunciation) which are difficult to define.

The third example concerns the ideas of José-Enrique Finol (2017) who considers a concept like that of the body-spherec ${ }^{1}$, following Lotman's semiosphere (1999), capable of accounting for the importance of the body in the generating and in the management of all semiotic activities.

As we can see, each of these approaches, or more precisely, each of these ideas on a possible semiotic approach to the body, suggests new and judicious investigations, but raises many reservations and leaves open several questions. These approaches do not strictly constitute a method, neither are they elements of a method, because each approach presents a sketch of problematic modeled on a given semiotics, without stating it openly nor being aware of the constraints of such a relation: the Semiotics of the passions (Fontanille \& Greimas, 1991), the encyclopedic or textual body (Marrone, 2016) and the global body or the anthropo-semiotic approach (Finol 2017). These reservations do not decrease their heuristic value, because we can invest the relevance of the narrative, of the textuality and of the global dimension of the body into a semiotics of the body that relies mainly on the achievements of the narrative and discursive semiotics to see how the body is both signified and communicated. We also think that certain concepts, such as textual strategy, encyclopedia, and interpretation versus use, can complete and constitute a semiotic approach of the body, thus never losing sight of the expression of this body. What does this mean exactly?

This means that, each time, one has to ask the following question: what kind of body is it? Are we interested in the written, the photographed,

\footnotetext{
${ }^{1}$ This study is a modified version of my article "Semiosis du corps dans la littérature sexologique arabe " published in Semiotica 129, Berlin/Boston, Walter de Gruyter, 2016.
} 
the performed-in-the-reality-of-everyday life, the dreamed of or the fantasized body? As we can see, to each of these supports of the body, and therefore to each of these corporealities, corresponds a specific semiotics. There is diversity, certainly, but there is also a stable element of method, namely, that the body painted, carved, written, analyzed or narrated is a semiosis endowed with a form and a content, which are well and truly written in an encyclopedia or in a culture that regulates the practices, the symbolic and the imaginary without, however, controlling neither their evolution nor their regularity. In other words, the terms of access of the body to meaning through a given form and substance must be constantly attached to other pre-existing forms and substances. In a more concrete way, studying the semiosis of the female body in the sexological literature, our concern in this study, is to analyze the specificities of the different forms and different contents that give it meaning within a network texts with which they maintain permanent negotiating relationships.

\section{The body in sexological literature}

Before starting I would like to evoke the general context of that literature. The Arab-Islamic literature has given a privileged place to the body before and after the arrival of Islam. There are cultural and social reasons for this. Before the advent of Islam, the Arab society, based essentially on a tribal system, lived mainly at the rhythm of wars and intertribal attacks. The motives of these wars were often unclear or undetermined, but the body constituted a sufficient reason for waging them. The body of the other was to be dominated in two radically opposite ways according to the sex, since the male body of the other was to be annihilated and the female body to be possessed. Thus, this society saw the development of the phenomenon of Sabi, that is to say women gained as war loot. The political economy of these loots of war is rather complex: they were regarded as a valuable commodity and were therefore endowed with an important exchange value; but they were especially regarded as a formidable means of revenge and humiliation of the enemy. Then, a whole political economy of these beings developed into a means of exchange and as a marker of a certain social superiority that lasted several centuries. The preIslamic poetry that hailed the exploits of the warriors hailed at the same time the beauty of these 'human commodities.

Despite the advent of Islam, this activity has been renewed more or less tacitly, and more or less discreetly. With the phenomenon of Muslim conquests, the Sabi will give way to a flourishing trade of courtesans and youths that will develop and become elaborate, giving rise to a body literature as varied as diverse. The first two seminal texts of Islam, the Qur'an and the Hadith, although setting rules and dikes for these activities, will recognize the importance of the happiness procured by courtesans and youths, to the point of making this 
happiness the ultimate reward promised to the faithful in the afterlife (SavageSmith 2016, Bernoussi 2020).

The Qur'an reserves a privileged place to the body, and a study of the discourse related to the latter remains to be done, since its place is exemplary in this sacred text. To go straightforwardly to the essential, it suffices to say that the body is boasted as the primary source of pleasure and that the pleasure of coitus is the most defended. The verb nakaha and its derivatives is frequently used in the sacred text to praise the pleasure that God creates for believers; sometimes even severe warnings are addressed to those who try in one way or another to sulk or neglect this pleasure. As we have written elsewhere (Bernoussi 2008 and 2020), the goal is to control the res erotica by placing it within a restricted framework, that of religion and morality, without ever minimizing its importance or power. In fact, with regard to the body, things have not changed much compared to the pre-Islamic period, the latter having kept the same freedom and the same liberality. The change lies in the fact that this liberality is practiced and exercised under the control of religion or God.

The Hadith, which is in fact a kind of explanation and abrogation of the texts of the Qur'an, will go in the same direction. The Hadiths, as well as the various biographies devoted to the prophet, are real general surveys on the body as a source of pleasure and blossoming of the individual. Better still, these texts contain many repressive passages against all those who want to diminish the body's importance. In all these texts, the prophet explicitly condemns all extremism and renunciation of the pleasures created by God on earth. The words of the prophet threaten to excommunicate anyone who does not respect this balance.

Our corpus, which is limited and arbitrary like any self-respecting corpus, has chosen two illustrious figures of this literature of and on the body, which mark two epochs and two different spaces. Al-Jâhidh, in the nienth century, offers us in his writings a point of view of the scholarly culture on the body and sex at the dawn of the young and already powerful Arab-Islamic culture. AlSuyûtê, an Egyptian scholar of the fifteenth century, leaves a considerable work on sexology, thus leaving a treasure for any researcher on the body at a time marking the beginning of the decline of Arab-Islamic culture.

\section{Al-Jâhidh or the body of literate scholars}

Let's start with Al-Jâhidh. We are in the nienth century, which corresponds to the second century of the Hegira calendar, that is to say at the time of expansion and power of Arab-Islamic culture. Abu Amr Ibn Bahr Al-Jâhidh, who is the incarnation of this power, left many works that have become famous until today on various linguistic, literary and scientific subjects. He also left many books dealing with the body; we have selected three: Risalat fakhr al-sûdâne 
'alâ al-bidâne (Epistle on black body 's pride on white one), Mufâkharat aljawâri wal-ghilmân (Boastings of courtesans and handsome youths), Risalat fi kitâb al-kiâne (Treatise on the book of courtesans-artists, or Al- Kiâne). The term "al-kiâne" refers to courtesans, equivalents of opera singers of the late nineteenth and early twentieth century, who had both artistic and sexual gifts. These artistic gifts were mainly concentrated in music or singing, sometimes even in both.

The epistle entitled Fakhr al-sûdân 'alâ al-bîdân comes in the form of anecdotes and curiosa, better known in Arabic literature as 'annawâdir' (quirks), but this fragmented form has a specific purpose: to defend and illustrate the sense of superiority and pride that black people seem to cultivate vis-à-vis the white. The central element of this pride seems to be the body, especially its expression. The language of the black is an easy language, fluent, cheerful and eloquent in the image of their body that is powerful and extremely elegant. In this sense, a detail constantly reoccurs to the author causing the same stupefaction, namely the ring in the ear.

These very sensitive, active and fertile bodies, therefore, are so among them, for they easily lose their original qualities when mixed with white bodies. Al-Jâhidh is formal un stressing that blacks who are very fertile and very sensitive are no longer so once mixed with whites. For Al-Jâhidh, the mix does not work.

Black women are renowned for their sexual qualities, but especially for the warmth of their bodies and their sex, which can be sometimes beneficial, a theme that will be very successful in erotic literature to the point of becoming a topic or a stereotype. But to precisely prevent against any typification, Al-Jâhidh presses to rectify that this sexuality is to relativize since "desires and pleasures are habits and customs". (Al-Jâhidh, 2000: V, 155).

Relations between blacks and whites are not explicitly mentioned by Al-Jâhidh, but they are treated anecdotally, however. It is worth reminding that the anti-slavery policy, announced and defended by the prophet himself, was among the criteria of choice that contributed to the success of the new religion. Islam appears from the beginning as a hopeful religion for the blacks, even though starting from this second century of the hegira, these black communities, composed mostly of slaves, began to ask questions about the effectiveness and the possibility of implementing such promises. Slavery continues with racist prejudices and stereotypes inherited from the Jahilia². One of these attacks against the blacks was to treat them like animals and ridicule them. Many anecdotes report zoophilic stories wherein these black tribes excelled. Al-Jâhidh does not allow himself any comment and even less

\footnotetext{
${ }^{2}$ See M.Bernoussi "La révolution des zinges et des karamiats : un épisode refoulé de la culture arabo-musulmane ", Actes du Congrès III Sémiotique et société, nouvelles approches nouveaux défis, Meknès, Infoprint, 2015.
} 
any form of modal constructions. Anecdotes are simply reported as is. In this defense and illustration, the blacks are evoked as envelope (exclusive reference to sensuality) and as flesh referring especially to their agility and flexibility. Several variants of this theme are found in the Moroccan popular culture.

The second text of Al-Jâhidh more explicitly bears the influence of the rationalist current of the Mu'tazilites, since the argumentative aims are more present and the question of sexual taste linked to gender mobilizes original demonstrations and audoacious interpretations of the sacred texts.

The title of Moufakharat al jaouari walghilmane or (jousting between those who prefer boys and those who prefer girls) should not mislead the reader, because it engages in a serious exercise, that of the debate over a seemingly libertine subject. The text is governed by this duality and antagonism, for it combines anecdotes and stories belonging to the kind of annawadir, curiosa, but all melted in the exercise of debate.

The epistle begins by legitimizing such a subject that is wrongly considered to be unimportant or even immoral. Al-Jâhidh believes that any subject is interesting, especially that dealing with sex and sexual tastes. He begins by quoting many respectable people who have approached this subject in no more serious contexts and in situations. Al-Jâhidh begins with the prosopopoeia of those who prefer boys and cites several types of texts attesting that the criterion of masculinity is among the fundamental criteria of beauty in general. Henceforth, the text has a fundamental accrediting value; it testifies, legitimates and shows that the taste for boys is now part of the culture. As we will see, Al-Jâhidh will vary this male inter-textuality by using both religious and secular texts. Thus, for many poets, the beautiful woman is a woman who has masculine traits and forms. The sacred text provides ample evidence on this subject; the Qur'an speaks of beautiful boys who serve the faithful in paradise: "There will circulate among them [servant] boys [especially] for them, as if they were pearls well-protected." (Attour 52:24). The Qur'an is cited as a textual authority to show that the pleasures of paradise, which are among the supreme pleasures that every believer desires, reserve a place of choice for boys. The pleasure of boys, as evidenced by its advocate, is a refined pleasure and that is why it is much more present in urban poets and city dwellers in general. Rural Arab poets do not know this pleasure, however, and even when they chant the virtues of the woman they use grotesque and vulgar metaphors.

Other arguments in defense and illustration of 'boys' do not directly cite the sacred text, but indirectly refer to its ambiguities and its aporia. It concerns the fact that boys are more discreet and less subject to scandal than girls or women. Sexual repression in the name of zina, i.e., unauthorized sexuality, that is to say not controlled by religion, does not concern sex between men according to Al-Jâhidh. It must be said that for the latter, and contrary to the 
opinion of all other theologians, the relationship between men cannot be considered zina, because they are not explicitly prohibited by the founding texts. Al-Jâhidh, like the Mu'tazilites supported, at that time, the principle, very disputed elsewhere, according to which all that is not explicitly forbidden is authorized. We understand then how people, still according to Al-Jâhidh, fled this repression through the attraction for boys and how this taste can be attributed to the excessive control that society exerts on female bodies. This practice ends up transforming homosexuality as a palliative or a compensation for a frustrated heterosexuality.

Al-Jâhidh uses then other arguments referring to Arab poetry. In this context, the poet Abu Nawâss is cited as a key figure of the libertine tradition who left many poems glorifying the beauty and sensuality of the male body. This poetry deserves a little pause, because its analysis can allow us to reconstruct some aspects of semiosis of male bodies of the time. To illustrate this semiosis, I will approach it through the metaphorical networks on which it rests and which are exclusively visual, but with a tactile background. When one reads the many poems devoted to the body of young men, al-ghilmân, one notices the frequency of the metaphor in which their body is compared to a qadêb, a strand or a solid branch of a tree. What is highlighted in this body is its slenderness, as thin as a branch, referring especially to the solidity, or more precisely to its erectility. Qadêb designates, according to the dictionary Lissan Al Arab by Ibn Manduur, "the sweet sword", the male sex as well as that of the animal, and by way of illustration, Ibn Manduur cites the sex of the donkey. Another criterion of the beauty of the male body as celebrated by this poetry is the quality of the skin or the quality of the grain of the skin. The metaphor that comes up very often is the one where the skin of these young boys is compared to figures or small sand dunes. The common points between the two are the responsiveness of this skin to the least external excitement, flexibility and the delectable granules. We reach here an archetypal figure of the Arab imagination. The sand is here at the crossroads of a series of contents initially of static order, related to the quality of the grain of the skin and to the color on the one hand; on the other hand, sand refers to the sensitivity and vivacity of this skin at the slightest breath or sigh. In this comparison, the body is animated and metamorphoses incessantly under the effect of the breath and the sighs of the one who wants it, in the same way that a dune or a landscape of the sand continues to model itself according to the soft breezes, to passing violent winds or to unpredictable storms. What is put forth is the reactivity of the bodies and their extraordinary sensitivity, but also the variety, the suppleness and the firmness of these same bodies.

The arguments advanced by those who defend the attraction by courtesans emphasize the repressive machine and what awaits the one who cultivates these tastes. Mister Courtesan, the expression used by Al-Jâhidh, therefore resorts to 
the arguments of religious orthodoxy, but more interestingly, Mister Courtesan will also quote passages from the Qur'an to support his tastes and defend the legitimacy of this desire. Many passages speak of huris and beautiful women who populate the Paradise and who are exclusively there for the faithful. It is one of the secrets of the power and success of the Qur'an in lending itself to interpretations and in providing such different and varied quotations.

Let us go back to the body of courtesans. What is immediately emphasized in this body is its capacity to arouse desire, or to be more precise, its mimesis of desire. The descriptions all focus on the movements, the walking and especially the rhythm of this walk that each part of the body seems to accomplish. It is a body watched and subjected in its movements to over-interpretations, even to phantasmagorias, which by the force of repetition are standardized, and become part of the culture of the body and seduction in general. The defender of the courtesans gives us here a certain phenomenology of the female body in the culture of that era. What essentially characterizes this body is its strong semiotic content, both in terms of communication and in terms of signification. The way to invest the space of this body, that is to say the way it walks and looks, is subject to codes and suggests scenarios and complex narrative programs, because it is very closely related to the situation of communication and to the semiotic interaction between the movements of the body and the one who watches them. Most often, the bodies of moving courtesans are described in reverse, very rarely on the spot. It is a sign which is reduced here to a signal, for the primary function of this sign is to kindle the desire. One can imagine how, in such contexts of seduction, a whole grammar of the demarche and the movements of the body have developed, and were linked to all the semantics and to the situations of communication which spread later in Arab-Muslim culture. A coded language of the body has been constituted, with its respective rhythms, movements and meanings. This language has progressively exceeded the sphere of courtesans by becoming over time a language designed to seduce, but also to communicate at a distance among those interested, without the knowledge of the people present. In a society where the relations between men and women are supposed to be controlled and where all direct and intentional communication is prohibited or reduced to the strict minimum, recourse to indirect means of communication is necessary; it is there that the movements of the head, eyes, mouth, lips, hips, etc. turn into so many strategies to forestall this censorship and establish themselves as real weapons of seduction.

The aesthetic dimension is just as present in the attachment to bodies, but intermittently as we will see, what we fear most is to love these bodies, while it is just a matter of owning them for the sake of pleasure. In general, what is highlighted is the harmony of features and limbs. Overweight is not often appreciated, contrary to what we can believe. It is even depreciated. Firmness 
is also a criterion often mentioned. The body of the woman especially that of her sex, is often appreciated and valued through mainly male criteria. The sex of the woman must be huge: in stories and peddled anecdotes, beautiful women have a sex that looks like a huge "Ire" (denomination of a big penis), preferably with folds. The evocation of the sex of the woman thus often refers to the sex of the man who must be obviously large, but which is often postulated as such. It is often this sex that is appreciated by women, but in a much nuanced way, not to say paradoxical, if one believes the anecdotes peddled by Al-Jâhidh. The paradox of the writings of male and female sexes interests us, because in all these stories, the size of the penis gives place to a disappointment one time in two: the woman is at the beginning impressed by the size of the penis but once introduced, she realizes that she is disappointed and that the first impression is wrong. In these stories devoted exclusively to the size of the penis, the presence of the mother-in-law is necessary. In the narrative economy of these stories, the mother-in-law plays the role of an adjuvant who intervenes to help the girl to bear the inconvenience related to the size; of course, it is a narrative device that allows the realization of an archetypal fantasy.

The epistle entitled al Kiyane, that is to say, the courtesans who sing, begins with a long captatio where Al-Jâhidh quotes a series of authors and texts aiming at defending such a subject, for, according to him, it allows him to know better the culture or the society. The phenomenon of the slave singers is the highest level of refinement and prestige. Better still, for Al-Jâhidh, the phenomenon of kiyanes can be explained in a rational way, since any society needs this kind of distractions and entertainment. These are important attributes of any selfrespecting culture. But what is even more interesting in the approach of the famous Mu'tazilite is the operation of deconstruction to which he gives himself through the discourse on courtesans.

Compared to religious orthodoxy, which is never out of sight, Al-Jâhidh reactivates again the Mu'tazilite's aforementioned principle that which states that all that is not explicitly forbidden in the Qu'ran is authorized and, therefore, lawful. But if no text prohibits or evokes this phenomenon in the Qur'an, it is because it is authorized. Al-Jâhidh goes even further and deconstructs the dogma of the body-propriety (Hurm) referring to the past where relations between men and women were very liberal and where one woman was appreciated by several men at the same time, since jealousy, source of all that, did not exist. For Al-Jâhidh, the feeling of jealousy is not natural, it is historical. The author sketches here an archeology of this feeling in Arab culture and society. This is an original and unprecedented approach in Arab-Muslim culture. For the first time, a text opposes other dominant texts that clear out history, thus trying to rehabilitate it. For Al-Jâhidh, the origin of jealousy and suspicion that now surrounds any mixed society goes back to a founding event, that of the 
prophet's wives, an event that saw the relationship between men and women strictly regulated and subjected to a total separation. Before that time, a famous practice existed among the Arabs; it was that of frequenting women without necessarily having any sexual trade, such relations which favored the exchange, the mutual respect and a serenity of the body, altogether. Al Hijaab, or the veil, which now separates men from women has given rise to voyeurism, jealousy and other harmful behaviors. The veil introduces suspicion, over interpretation and at the same time the misinterpretation of the body, that is to say its use (Eco, 1992).

The epistle then exposes several anecdotes or dramas of jealousy known since the beginning of Islam. Al-Jâhidh sketches a kind of political economy of this feeling in the society of the time. In fact, jealousy can constitute a regulative motive for the male appetite, effective in repudiating or divorcing; often, a simple rumor can be a sufficient reason for divorce. This phenomenon allows a roundabout way of liberalizing bodies and a much more important circulation.

Being a body on the periphery of the encyclopedia, the body of courtesans is not subject to jealousy. Considered by all men as entertainment, it is a body that is promoted to free movement contrary to the body of the wife or hurma, literally meaning 'the forbidden', primarily considered a private property before being, or not at all or very rarely considered, an object of pleasure. For Al-Jâhidh, this is a contradiction, for how can one be jealous for one's women and not for one's courtesans? In fact, the body of kiyanes is a body beyond the private and the public, the need, the desire and the duty. The body of the kiyanes is certainly a body which belongs to the master, but which can be at any moment shared or offered to others.

The body of the kiyanes is a liberated body in a way, because it is not subject to the property regulation of the body of the forbidden women, applying here mainly to the mothers. The forbidden body is the procreative body and this criterion of procreation is at the source of the prohibition that afflicts it. The body of kiyanes, on the other hand, is a body dedicated to pleasures and the sublimation of pleasures; it is a body that plays a vital role in the success of the well catered tables of the lords of that time. The liberty or liberality which characterizes this body makes it less agonizing for virility and paternity than that of women destined for procreation. But it is a body that represents at the same time another danger that should not be underestimated. One of the risks of this free and liberalized body is to become attached to it. Love or attachment is considered by Al-Jâhidh a terrible disease that affects the body and soul and is very difficult to heal. Because according to Al-Jâhidh, the causes of this situation are multiple. Attachment is therefore an excess of love, because love does not represent danger as long as it does not exceed the sexual appetite. AlJâhidh quotes here the animal model as a canonical model; the sexual appetite 
relativizes attachment to the other, but when one deviates from this rule, when the other or the view of the other is sought for something else, one gets so much used to it that one becomes dependent.

In fact, if this body proves to be formidable, it is because first and foremost, it is a body that is exposed to others in all its beauty. Just recall here the verbal derivative of Kiyane, Takayana, which is to put on makeup. It is there to be watched, admired, but especially to be listened to, even to be touched in certain exceptional situations. This body thus offers a synesthesia that explains its power and the warning of Al-Jâhidh and the mistrust of his contemporaries. Al-Jâhidh describes this synesthesia as follows:

When the kiyane makes the way for singing, the eye fixes it, the ear listens to it, and the heart gives up its weapons, since each of the listening and the sight hurry to reach the heart the first to pour all their contents. This is what excites the sense of touch. Three pleasures meet but that never meet at the same time in the person and that the other senses cannot produce. "(Al-Jâhid 2000b: 130)

The body of kiyane, being an absolute body, is related to the Fitna (obsession, stress and total loss of control). It is a body that deploys sophisticated seduction strategies. Among the fatal strategies of this body we find a synesthetic effect that tends to hit several senses at once and a fetish that takes various aspects: the small tuft of hair or scented hair, the cord of the panties called tukka or the letter wetted by her saliva are all semiotic artifices that help to prolong the seductive power of this body, even when it is physically absent.

In addition to the strategies deployed by the kiyanes, Al-Jâhidh focuses mainly on their management of men. As an object of refined pleasure, kiyane is more aware than anyone of the paradoxical situation in which she finds herself; it must offer a sublime image of pleasure and refinement, that is to say, unique and personalized, but for several men. Al-Jâhidh analyzes this strategy of always remaining elusive, to make each of these men believe that he is unique, if not the only one, and to continue to take care of them all at the same time.

Despite its ambivalence between the recreational and the argumentative forms, Al-Jâhidh's text remains the first to transform the body into a true object of discourse after the Qur'an and the Haddith. But it is a discourse that tries to relativize the axiology related to the body and sexuality and make it an exclusively cultural affair, because from one tribe to another, from one society to another, from one community to another, the body changes and declines differently.

From now on, it is a body re-enfranchised in history, in culture and in a political economy specific to the Arab-Muslim society of that time. This has very important inter-textual consequences compared to authoritative texts 
like the Quran and the Haddith. These are implicitly amended because they are ambiguous or not explicit enough on specific issues related to the body. The moral or religious argument is relegated to the background, but does not return to other passages as a leading argument; the verses of the Qur'an are summoned from the beginning in the epistle on the disputation of young boys and courtesans. This has the unexpected virtue of showing that this text can lend itself to both different and opposite interpretations.

The last element of conclusion can be seen in Al-Jâhidh's desire to understand the power of kiyane, and in subjecting her body to a strictly semiotic examination where her power lies in the total synesthesia that she offers. The body of the kiyane transcends and surpasses the body of the harem, bodyflesh $^{3}$ destined to procreate, the plastic body of the courtesans, the body wrap intended to arouse desire. Now, the body of the kiyane offers a corporality that fascinates, because it refers to a sublimated image and sublime in relation to male corporality. It is not distressing for paternity (because it does not present itself as an inner body) and it is not distressing for virility (because it does not present itself as plastic). The body of the kiyane is a total body, because playing on several levels at the same time. It is a flesh body, but also a body wrap. In this subtle game, she awakens feelings as contradictory as elusive and ensures not to create competition between males. It is a contradictory body, perfectly expressing the contradictions of male sexuality. The second case study regards Al-Suyûtê, a scholar of the fifteenth century.

\section{Al-Suyûtê}

Jalaal Aldine Al-Suyûtê represents a typical and an atypical case of the Muslim theologian as the Arab-Muslim culture recorded it and records it again in the 16th century.

Al-Suyûtê astonishes by the solidity of his character and the singularity of his career. Having retired from the world at the age of forty and having openly distanced himself from the political power of the time, Al-Suyûtê left behind an unorthodox work on sexuality, which demarcated itself significantly and in a discreet way of tradition. It was the same tradition wherein it was customary, and without the slightest contradiction, that a cleric consecrate a work to sex. First, he would not compose a single work on that topic, but several. Then, in all his writings, sex is not a subject of composition as is the custom, but a real concern, and the woman is also a real subject of concern and a real source of questioning. In the preface to Al Wishhah, he states in this sense:

Many people wrote about coitus, some were talkative, others very concise; some master their subjects, others barely knew what they were talking about. In any

\footnotetext{
${ }^{3}$ As we can see here and as i told Fontanille during the congress of Buenos aires I use his categories with caution.
} 
case, the most interesting work devoted to this subject is that of Tuhfat al 'arûs wa mut'at annufûs of Al Tijani. As for me, I wrote a lot of small books on this subject, I also wrote other more important books ... I then composed a synthesis of all his writings and summarized the most beautiful and significant anecdotes, I augmented it with valuable synthesis and called it Al-Wishâh fi fawâ'id al-Nikâh. (Al-Suyûtê, 2002: 18)

Among his writings, we have retained two texts Al-Wishâh fi fawâ'id alNikâh, (Benefits of coitus) and Al Ibdâ' fi funûn al-Jins wal Jimâ' or Chaqâiq A-utruj fi Raqâiq al Runje (The creative imagination in the arts of coitus or the sweets and subtleties of sexual simpering). The first is deployed over 150 pages and divided into two major parts. It discusses in three main chapters techniques of attracting women, what they like or hate, and propriety in bed. The second book begins with love passion and its harmful consequences, before devoting itself to coitus, its different forms and positions, a chapter that is the subject of special care.

The second work consists of 338 pages divided into seven parts of unequal length. The first part begins with curiosa about sex, peddled anecdotes, stories recited according to tradition, etc. The second part deals with the language of coitus and explains how the dictionary names the different participants in coitus: the female and male sexes, the animal sex, and the different excitation and erection states. The third part, which is the longest, takes up famous anecdotes, reproduced in almost the same way since the pre-Islamic period: famous courtesans, lecherous ladies, lords transformed into a real maniac of nocturnal matters and stories of this sulphurous Baghdad of the Abbasid era, where the shadow of the Thousand and One Nights hovers permanently. The fourth part deals with the place granted in Arabic poetry to the sexual question, the aim being to show how the most representative element of this culture, oral literature, gives this subject a place of choice, but also to highlight the deeply rooted tradition of coitus, which makes it a cultural phenomenon. The last three parts, finally, are technical and clinical parts on the anatomy of the male and female reproductive systems. Al-Suyûtê shows mainly his knowledge of medicine, since the fifth part focuses on the anatomy of both sexes, while the sixth part discusses the pathologies related to coitus and ways to remedy it. The last part, then, titled the art of coitus, is a kind of synthesis where technical and medicinal considerations are intertwined with more subtle questions, such as the female orgasm, less poetically named by Al-Suyûtê as "itching", the disturbances pertaining to orgasms of the two sexes and the means to remedy them: the aphrodisiacs or coitus cuisine.

As we can see from this summative presentation, the text offers a heterogeneous, not to say hermetic representation of coitus and its main actor 
or actant: the body. This semiosis presents a plan of expression that mixes at times randomly and at others hazardously several forms, that is to say several genres: anecdote, short story, commentary or scientific explanation, quotation, sometimes motivated sometimes arbitrary, for no reason other than that of pleasing the reader and entertaining him. This polyphony poses a problem for the reader who is embarrassed to fix a precise representation of the body; sometimes in the same plane of expression, one can find two or more radically opposed contents, which require a permanent interpretative alertness.

The two texts of Al-Suyûtê surprise therefore by the genres used. The chronicle coexists with the story, the tale, the anecdote, the long poem, the commentary and the anatomical description, even of a clinical vocation. These forms very present in the text are available in different rhythms and lengths. One can find there the long story, close to an episode for example of $A$ Thousand and One Nights, as one can meet there the joke or even the excerpt quoted or reproduced without the least bibliographic scruple.

Al-Suyûtê begins with literary anecdotes about coitus since the preIslamic era. The coitus and body of the woman occupy a place of choice, which shows the extent to which the effective sexual performance is important in the same way as the language performance. Poetry opens the door to many poetic possibilities. Literature is the expression of what the reality of the physical body cannot perform or rarely does so. Here is an example of the description of a body as a Bedouin imagines it:

Al-Kâli told, Abu Bkr Ibn Darîd said, Abderrahmân Ibn Akki Al- Asma'î according to his uncle said: a Bedouin said to his cousin: Order me a white woman lying, beautiful and proportionate, standing, her tunic touches only the curve of her hips, the tips of her breasts and the droop of her buttocks, as she stretches out, her forms overflow on both sides and above these other forms remain firm like barely-ripe fruits. The Bedouin replied: where do you want me to find you that, in paradise? (Al-Suyûtê 2002: 193).

Al-Suyûtê dedicates then an entire chapter to the language of coitus and offers the reader a guided tour of the dictionary. It is an opportunity to let the social and cultural treasures of Arabic express themselves and to show the richness of substantives and verbs from A to Z. Each of these verbs or nouns crystallizes one or more narrative programs. Most of these narrative programs unfold around themes close to war, combat and military strategy. Their semantics and their semic features make it possible to find the same metaphorical knots where both sexes, both female and male, follow a semiosis of extremes: the sex of the man or the woman can only be too small or too big, too entrepreneurial or too passive, too big or too narrow, too wet or too dry, etc. A good part of these substantives are also onomatopoeia that reproduce more 
or less realistically, more or less fantasized, sometimes close to the caricature, the sound of a penetration or a back and forth under its multiple rhythms.

The lexicon and literature of the body are relayed to second position by the scientific discourse, devoting numerous anatomical descriptions to the body of the woman, citing Greek or Roman authors and inserting therein many passages drawn from the pre-Islamic literature.

As we can see, it is a text crossed by a strong inter-textuality which pushes us to question the effects that it can have on contents. We decided to approach this content through three components: the first concerns what we have called the text of the body or coitus, the second, the para-text of coitus, which surrounds and prolongs the text (Genette, 1987) and the last, the intertext of the body or coitus (Kristeva, 1969; Genette, 1982), that is to say all the reprises and echoes that Al-Suyûtê's text does to other texts used explicitly or implicitly.

\section{The coitus text}

By text of coitus, we mean all that concerns the description of bodies in their static or dynamic state. Two radically opposed isotopes characterize the discourse on women and on coitus. Al-Suyûtê highlights the psychology of women, both simple and complex. The latter can be presented as a capricious animal with which it is necessary to use gentleness, flattery and cunning, as it can be presented in a simple way, that is to say someone you can submit if you have certain qualities. According to Al-Suyûtê, the criteria for choosing the ideal man are, according to women, a rich man, well supplied in kind, reckless and violent at the same time. The preferred form here is that of the narrative. The commentary and the voice of the narrator disappear to let the story express itself in raw and unbridled manners, but using poetic detours. One of these detours is the form of advice often given by the mother-in-law to her daughter or directly to her own son-in-law to achieve coitus. The form of the advice, supported by the reference to the matrimonial institution, anesthetizes the scruple or the moral gaze that may arise on such a performance. Henceforth, the narrative - which is close to any pornographic narrative - can unfold in the most free and serene way. The prosopopoeia of the mother-in-law is here a fetishistic artifice thanks to which she simulates her presence at the time of coitus that she seems to describe in a scrupulously detailed, but also believed manner. Pedagogy and obscenity merge through the detour of the advice to allow a speech that otherwise has no chance of existing except in the fold of repressed fantasies and delusions. What characterizes the text dealing with these pieces of advice is their strong content of synonyms and adjectives; it is the overflowing and unbridled imagination of the mother-in-law and the plethora of erotic findings all destined to make the son-in-law crazy. This raises 
many remarks as to their reception or interpretation. Here, both author and reader, like the characters themselves, that is to say, the mother-in-law and her daughter, embark on a delicious game of dupes where the epidictic form of the advice, which is pretended to accept and admit, gradually gives way to these motives and these vicissitudes forced to settle in a sovereign and unbridled way. The narrative schema of this story is quite simple. The mother, the principal actant, is the mistress of ceremonies, where the adjuvant, her daughter, helps her to put into practice the minutiae of several scenarios, all intended to possess the husband or son-in-law, reduced here to a sex which you must never let rest. The story does not unfold in a linear way by reproducing the course of coitus from beginning to end, but offers small flash scenes, very condensed and very stereotyped. Here are some examples:

When your husband puts his hand on you, snore, turn your ass slowly and let you go. And if he seizes anything from your body or your organs, raise your voice, snoring and sighing, play with your hands and your eyes.

And if he penetrates you, pronounce obscene words to excite him, simper and react to his vigorous to and fro movements by coming back and forth just as vigorous, then take his left hand and put the side between your buttocks and a finger in your anus ... (Al-Suyûtê, 2008: 34-35)

We stop here the quotation and leave the mother-in-law or rather the venerable Al-Suyûtê in his delirium or his advice, which are only an effective semiotic artifice intended to write and describe the disorder of the senses and signs. But the Sheikh is not only at one poetic finding, for he has another, even more daring, and this time, it is the meeting of the mother-in-law and the sonin-law who is authorized in the name of advice and happiness of the household. The speech this time is different and radically opposed. The lexical field is that of animal vigor in all its nakedness: cutting down, biting, scratching, blocking, jamming, penetrating with force, etc. are the verbs that come back into the mouth of the mother-in-law; the narrative schema follows the steps of a spun metaphor where the step-son is a lion who grabs his prey, the beautiful girl, immobilizes her and does not let her go until after having enjoyed her several times.

But to this frenzy succeeds in the same chapter other texts radically opposed in form and content. The discourse of gentleness and subtlety can suddenly appear and unfold, making one forget, as if by magic, the violence of the past discourse. This is the opportunity for example, after the lion and its vigor, to linger and meditate on the great lesson of the pigeons. The latter are offered as a model of gentleness, patience and endurance to introduce paratext coitus. 


\section{The coitus para-text}

By the coitus para-text, we mean all the preliminaries which precede and follow the proper action of penetration and enjoyment. Indeed, a whole chapter is devoted to the art of good manners in bed and of preliminaries. It is clear that in this part, it is the Greek corpus which is summoned and Socrates is at its head. The latter is particularly appreciated by Al-Suyûtê, because by advising lovers to speak during and after the sexual act, Socrates emphasizes the uninhibiting and liberating virtues of language. Not only is speech the difference between man and animal, but it has the virtue of veiling and mitigating the violence of desire. Socrates gives us here a semiotic explanation of uninhibition. Here, the semiotic system of speech, which opposes a speaker and a locular, requires a more elaborate and longer work than the system of gaze or touch. AlSuyûtê is particularly sensitive to this explanation of Socrates where the effort required during the encoding and decoding of the verbal message allows the gaze or touching to pass without much embarrassment; he explains that: "when the man puts his hand on the one he desires, by speaking to him and attracting (diverting would be the right word) his attention, he and his locutor are less inhibited, since each is busy deciphering what the other means ... " This must continue even after coitus according to Socrates. The speech must make sure to veil and soften the violence of the eye, even to annihilate it. Indeed, the look must be completely disabled during coitus. The look is something that kills the excitement of the man and the woman should not look at him; it is even better that she closes her eyes. On the other hand, speech must be very active during coitus. The woman must continually excite the man through her sighs, her simpering, her little cries, etc., called al ghange. It is a practice apparently very common in Arab-Muslim culture; Al-Suyûtê quotes many authenticated anecdotes that show how much this second language was appreciated in ArabMuslim society. Better still, the venerable Sheikh goes so far as to propose, according to some of the exercises, to teach a courtesan just bought how to utter these delicious little cries; the venerable Sheikh does it in the following way:

It is said that when you have a courtesan or an inexperienced free woman, teach her al Ghange in the following way: sprinkle cold water by surprise, or sting there a needle without her seeing you. In reacting, she will scream and sigh. Repeat the action several times, always by surprise. Then she will get used to al ghange. "(Al-Suyûtê 2008: 47-48)

If cries and sighs must tell the intensity of desire almost primitively, the word is also encouraged in what is subversive, even obscene. This obscenity has a metonymic value; it mimes and signifies the intensity of desire and is situated 
on two temporalities: what is and what becomes. At the same time, it serves as a means of communication which informs both partners about the present state and the progress of the communication and at the same time makes it possible to prevent possible distractions or lapses. It's a kind of permanent captatio. But here, there is no real interaction, in the true sense. The woman must reproduce these simpering and cries from the start. The question of simulation or sincerity did not cross the mind of the sheikh or his references (sanades). This is a question that is non-existent in all the Arab-Muslim tradition since the woman is naturally hot, nymphomaniac and eager to mate as soon as she is alone with a man.

\section{The inter-text of coitus}

As we can remark, the text of Al-Suyûtê draws on more or less proportionate, more or less scrupulous texts of different origins and making. In Al-Suyûtê, the dictionary is very present, the sacred texts of the Qur'an and the Hadith as well , but the most important part is left to the anecdotes and the stories of the oral repertoire authenticated by the chain of those who narrate them. This string of reciters is a kind of hard core, of magma that resists time and change even when it comes to a subject as changeable and evolving as the body and sexuality. The Greek corpus is cited as well as Socrates, Pythagoras, Hippocrates and Galen, but in a parsimonious and cautious way. The sacred texts serve as an anchor point, a hard base that stabilizes and the same time serves as a relay for practices and coded representations of the male and female body. The body of the prophet plays the role of sex-symbol, by its performance and by its durability. The string of sanade reciters guarantees the authenticity of these performances and the Haddiths that account for them; it shows at the same time that these perceptions are out of time. These Haddiths play a very important role in the social representations and codes that govern the body. They are necessary because they give rise to behaviors or justify others. One only has to see the Haddiths invented to get to the evidence of their role. This shows that even if the authoritative texts did not exist, the semiosis of the performance would have invented them. Texts, semiosis and behaviors influence each other mutually and infinitely.

But the model of the chain of reciters does not concern only the words of the prophet; it also concerns facts and memorable anecdotes on coitus. The chain of sanades assures them a very important perlocutionary value whatever the fantasy, the merry making or the salacity that characterize some. These anecdotes are told pell-mell, conveying, so to speak, a certain doxology of coitus, but mixing in a normal way heterodox practices and utterances. The question that arises here is that of their impact on Al-Suyûtê's own text, on the author's own voice. In this overwhelming flow of quotations, names of authors, 
practices of all kinds, the author's self disappears or, to be more precise, melts in this inter-textuality where his voice joins the collective voice. Not that AlSuyûtê has nothing to say, nor that his own text does not exist. It exists; only he is obliged to resort to inter-textuality to express himself and to say things that other texts have not said before: the coitus with the castrated apparently very appreciated; the pleasure of the uncircumcised considered more intense than among the circumcised; voyeurism highly recommended as preliminaries, lesbianism, etc. Inter-textuality is here a kind of safe conduct, the condition of the existence of the individual voice that must always blend into the collective voice and which must know how to manage this game of dupes between the individual and the collective.

Another question arises from the first one; it concerns the fate of these novelties within inter-textuality where the sanade denies history and presents frozen and ahistoric contents. This question hides another, that which concerns the memory of coitus. We know from semiotics that memory is a strategic signified (Violi 2014); that is to say a set of signs chosen and reconstituted to the detriment of other signs and reconstructions for someone according to more or less objective criteria, a more or less conscious ideology to be presented or transmitted to someone else, for a purpose and according to a more or less precise strategy. We also know since Jurij Lotman (1999 and 2006) that in front of "strange and atypical" contents, other stabilized and transmitted contents react through phenomena of pure and simple rejection, of adaptation, even of explosion or surrender. This is to say that this same culture can simply reject the new content that imposes itself on it, reduces it to its opposite, which is not it, adapt it, or assimilate it to the meaning as it may prove to be incapable of doing so and to be overtaken by the brutal novelty of these foreign contents. This is revealed through breaks, revolutions or through radical changes.

When we examine the quoted texts by Al-Suyûtê, one is struck by the absence of remark, of commentary or of any work or criticism vis-à-vis the texts quoted. In fact, it is not even texts in the sense of a proper and irreducible entity; the simple reason that these texts do not possess the least spatio-temporal, i.e., historical particularity. It is rather a kind of aggregate, of a "tattooed memory" or hard core reproducing in a way certainly detailed and varied forms, but serving a single and unique content without any filtering. One of the effects let us say it clearly - of this false inter-textuality, is that time seems to be fixed. Al-Suyûtê can quote or reproduce a text from a period that dates back to eight centuries ago, relay it by another text of a century ago without there being any indication that several centuries separate the two texts in question. Not only is there no chronology in these quotes, but there is no sense of history. The text reproduces and seems to take pleasure in this bliss of the same, the Qur'an and the Haddith, the anecdotes. What happens to Pythagoras and Socrates? 
What is the destiny of the Greek corpus? What happens to the contributions of Al-Suyûtê himself who is moving forward, as we have seen, under the mask of "they tell?" The Greek corpus, like Al-Suyûtê's own enlightened discourse, seems to be mere ornament, mark of respectability of an unbridled speech on coitus. This does not mean that it plays no role. It has one, that of asserting the aggregate which tells and repeats this bliss of the same where time no longer exists and where the coitus of the pre-Islamic Bedouin is that of the Muslim conqueror or translator of Aristotle, enjoying the human and material wealth of conquests. The aggregate filters and controls everything, including inputs and at times avant-gardist ideas of Al-Suyûtê himself. The latter, as we have seen, even though he had something to say, does not succeed in this in a distinct and audible way. His strategy of the masked I does not reveal itself in a very conclusive way. The novelty of his message is not lost, but seems relegated to the periphery, constituting at the same time a buffer zone or a free zone in which a whole culture likes to take refuge from time to time when criticisms of closure and stagnation become heavy or when it wants to remember his past glory in relation to a repressed present.

The culture of the body in Al-Suyûtê is a genealogical culture dominated by the model of the sanade which reproduces texts guaranteed by reciters while making sure that their historical anchoring seems non-existent. These texts have a very important juridical and persuasive value in regard of an ideology of the same. They serve as models and give rise to behaviors and practices that will be reported or commented upon, producing new texts, and so on and so forth. This inter-textuality, however, has no memory of its own because it is expressed verbatim through genealogical narratives cited by others and maintains a vision and a codification of the frozen body since the pre-Islamic era.

\section{References}

JAHIZ, Abou Ottmane Amr Ibn Bahr Al. 2000. Fakhr al soudane alal Bidan (De la fierté des noirs sur les blancs in Oyoune Assoude Mohamed (ed.), Rassail Al Jahiz, (Epitres V) (121-162). Beyrut : Dar Alkoutoub Alilmia

-2000a Moufakharate al jaouari wal ghilmane (Disputatio sur les courtisanes et les éphèbes) in Oyoune Assoude Mohamed (ed.)Rassail Al Jahiz,(Epitres I) (71109). Beyrut : Dar Alkoutoub Alilmia.

-2000 Risalatfi kitab Al-kiâne(Epître sur Le livre des courtisanes-artistes, ou Alkiâne) in Oyoune Assoude Mohamed (ed.)Rassail Al Jahiz, (Epitres I) (109-136). Beyrut : Dar Alkoutoub Alilmia.

SOYOUTÉ, Jalal Eddine Al. 2002. Al Wishaah fi faouaid annikaah, (Des Bienfaits du coît). Almaya : Tala. 
-2008. Al Ibddaa fi founoune aljinse waljimaar ou chaqaiiq Alutruj fi Rakaaik al Runje (L'imagination créatrice dans les arts du coït ou des douceurs et des subtilités des minauderies sexuelles). Le Caire : Al Hourria. Etudes critiques

BERNONUSSI, Mohamed. 2008. Le corps comme non signe dans la culture arabomusulmane. Semiotica 170 : 295-303, special issue by Mohamed Bernoussi, Berlin, New York/Walter de Gruyter.

-2010. «Notes pour une sémiotique de la culture marocaine», in M. Leone, ed., Analisi delle culture, culture dell'analisi, Lexia, n. 5/6 : 368-383. Roma: Aracne.

- 2012. "Moulay Abquader, sidi H-med et les autres" in Valentina Pissanty et Stefano Traini (eds), From Analysis to theory: Aftertoughts of the Semiotics of culture, (VS 114 ), 93-109. Milano: Bompiani.

-2014. "La révolution des zinges et des karamiates» in Mohamed Bernoussi (ed.). Sémiotique et société. Nouvelles approches, nouveaux défis. Actes du III congrès de l'association marocaine de sémiotique, Meknès : Infoprint.

- 2020. Sémiotique du corps dans la culture marocaine, à paraître. Eco, Umberto. 1978. Il superuomo di massa. Milano: Bompiani.

-1992. Les Limites de l'interprétation. Paris: Grasset.

FINOL, José-Enrique. 2017. La corposphère. Anthropo-sémiotiques du corps. Sarreubruk, PUE.

FONTANILLE, Jacques et GREIMAS, Algirdas, J. 1991. Sémiotique des passions, des états de choses aux états d'âme. Paris, Seuil.

FONTANILLE, Jacques.2004. Soma et séma. Figures du corps. Paris: Maisonneuve et Larose.

GENETTE, Gérard. 1982. Palimpsestes. Paris: Seuil.

-1987. Seuils. Paris: Seuil.

KRISTEVA, Julia. 1969. Semiotikè, Recherches pour une sémanalyse. Paris: Seuil.

LANDOWSKI, Eric. 1998. La société réfléchie. Paris, PUF.

-2004. Présences de l'autre. Paris, PUF.

LORUSSO, Anna-Maria. 2010. "II Punto di vista semioculturale”, In Leone Massimo (ed.), Analisi delle culture et culture dell analisi, Lexia 5/6. Roma: Aracne.

-2010a . Semiotica della cultura. Bari: Laterza.

LOTMAN, Jurij. 1999. La Sémiosphère. Limoges: PULIM. 
-2006. Tesi per una semiotica della cultura, a cura di Franciscu Sedda. Roma. Meltemi.

MARRONE, Gianfranco, 2016. Introduction à la sémiotique du texte, traduit de I'italien par Mohamed Bernoussi ; Paris, Mimésis.

SAVAGE-SMITH, Emilie. 2006. "In Medieval Islamic Cosmography, where is paradise?" in The Cosmography of Paradise: The Other World from Ancient Mesopotamia to Medieval Europe, Londres, The Warburg Institute ("Warburg Institute Colloquia », 27).

VIOLI, Patrizia. 2014. Paesaggi della memoria. Bologna: Bompiani. 


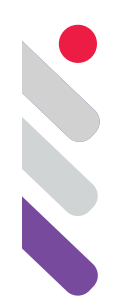

\title{
Trayectoria de la semiótica de las mediatizaciones hacia las plataformas mediáticas $^{1}$
}

DOI: $10.24308 /$ IASS-2019-8-022

\author{
José Luis Fernández \\ UBACYT- FSOC - UBA - UNTREF \\ unjlfmas@gmail.com
}

\section{Introducción. La trayectoria desde la experiencia de investigación}

La reunión alrededor de la reflexión y de la presentación de experiencias sobre trayectorias dentro de cualquier disciplina, y la Semiótica no es diferente en esto a otras, abre un abanico amplio de posibilidades de exposición. Y esto se presupone desde la primera convocatoria del Congreso, que parte de "la extraordinaria pluralidad de sentidos que surge de sus usos contemporáneos".

Hemos elegido organizar nuestra presentación desde el punto de vista de nuestro equipo de investigación que, gracias a subsidios de la investigación universitaria, hemos desarrollado una trayectoria de trabajo de cerca de un cuarto de siglo, en el que se han visto, primero, conmovidos sus objetos de estudio y luego, progresivamente, sus formulaciones teóricas y sus enfoques metodológicos.

Es posible que un primer acercamiento a este modo teamcéntrico de presentar genere un cierto efecto de etnocentrismo y soberbia. Pero se podría argumentar lo contrario: mientras hablemos de los grandes temas y autores de la disciplina, tendremos garantizado un espacio, aunque sea menor, en el gran escenario académico; en cambio, al hablar desde nuestra experiencia de investigadores, nos arriesgamos a convocar solamente al segmento que tiene intereses en áreas comunes. De todos modos, aunque no sepamos sus límites, la decisión es estilística y sabemos que muchos de nuestros rasgos, en ese nivel, nos resultan poco controlables.

\footnotetext{
${ }^{1}$ En esta versión escrita de la presentación en panel dentro del Congreso, se sigue con bastante fidelidad la exposición oral, que fue realizada para abrir campos de discusión a nivel internacional. Se ha mantenido por ello un cierto tono coloquial. No se incluyen todas las referencias bibliográficas que serían necesarias porque ocuparían demasiado del espacio disponible. Por todo ello, se piden disculpas.
} 


\section{De mediatizaciones del sonido en mainstream a intersticiales}

Siempre debemos disculparnos, en los países periféricos, cuando defendemos posiciones que crecen en un ambiente local. Pero tal vez ya estemos maduros para presentar lo que consideramos logros locales, sin por ello pretender jerarquías demasiado particulares. Una breve síntesis de esos logros debe incluir: la definición de semiosis social como espacio en red de la producción del sentido; el cuestionamiento del sentido común de las audiencias a partir de la propuesta de diferenciar producción y reconocimiento reconociendo un hiato entre emisión y recepción; la recuperación de las clasificaciones sociales de los discursivo, como medio, género y estilo en tanto interpretantes-clave en la incorporación del modelo triádico peirciano; el enfoque en cada tipo de mediatización, describiendo su funcionamiento social más allá de lo específicamente textual, como los aportes sobre transposición, metadiscursividad o la consideración sobre el film no filmico en Traversa; el estudio original sobre diversos medios, lenguajes y géneros y las propuestas novedosas en estudios sobre lo enunciativo mediático.

Tanto Eliseo Verón, como Oscar Steimberg y Oscar Traversa, hasta donde conocemos, han evitado hablar de una corriente argentina de estudios semióticos sobre mediatizaciones y se debe respetar esa voluntad implícita. Pero esos rasgos descriptos, seguramente entre otros posibles de seleccionar, hablan de un estilo de trabajo que ha organizado la vida académica de decenas de investigadores a través de un buen número de décadas².

Pero los contactos regionales e internacionales nunca se disolvieron y se profundizaron con la relación con la Federación de Estudios Latinoamericanos de Semiótica (FELS). Desde el principio, la noción de lo latinoamericano en nuestra asociación regional, excedió a lo territorial. Y lo interesante es que -buena parte de ese recorrido en común- se produce en momentos en que las investigaciones sobre las nuevas mediatizaciones obligan a un doble movimiento: abrir las puertas $y$, al mismo tiempo, a revisar para defender los principios teóricos y metodológicos de la propia disciplina, desafiada por las transformaciones en sus objetos de estudio.

El clima, apenas sugerido aquí, de la Semiótica de los medios en la Argentina de los años 80 , facilitaba el enfocar una investigación en el espacio vacante de lo radiofónico, en un momento en que esa mediatización enfrentaba nuevos cambios. Desde el primer momento entendimos que la radio se construía en sistema con lo telefónico y lo radiofónico. Las industrias de lo informativo y de lo musical no se explican sin la interacción de los tres medios en un modo que hoy denominaríamos como en plataforma más que en red. Fue una revolución lateralizada por lo escritural y lo audiovisual, pero aun el cine

\footnotetext{
${ }^{2}$ No hace falta aclarar que no pretendemos referirnos al conjunto de la semiótica argentina, sino tan solo a la que se enfocado durante décadas en las mediatizaciones.
} 
y la gráfica tuvieron que establecer relaciones de dependencia con el sistema sonoro.

Entre los 60 y los 80, las mediatizaciones del sonido resistieron la pérdida de centralidad, que pasó a la televisión, con la revolución sonora de lo estereofónico y la edición en estudio y la miniaturización y la portabilidad sosteniendo su importancia en lo intersticial, para desembocar en la telefonía móvil y la digitalización que abrirían, desde lo sonoro, la puerta a las nuevas mediatizaciones digitales y en red (Fernández 2017a).

La comunicación en la vía pública y las mediatizaciones del sonido fueron múltiples y ocuparon espacios centrales de la cultura y, permanecen fuera de las preocupaciones centrales de la sociedad, pero obligando a comprender la fuerza resiliente y disruptiva de su insistencia intersticial

Si se entrevista, como hemos hecho hace algunos años, a caminantes que recorren en la ciudad de Buenos Aires, una calle muy concurrida y con mucha exposición de comunicación en vía pública, en los alrededores del cruce de las avenidas 9 de Julio, Corrientes, acerca de qué registran haber visto y comprendido, y a qué lo atribuyen, se comprobarán dos fenómenos de interés: recuerdan muy poco y lo que recuerdan está relacionado con algún interés coyuntural (apetito, cansancio, deseo) o estilístico (interés por la tecnología o la política). Es decir que la participación en el intercambio discursivo, como ocurre con la radio, no está relacionada solamente con la oferta, sino con la interacción con diversidades de, por decir así, las demandas en recepción.

Así descriptas, las mediatizaciones del sonido y las gráficas en vía pública (a veces se presentan también audiovisuales, pero con este régimen de recepción) pueden denominarse como intersticiales, tal como Igarza (2009) denomina a las mediatizaciones móviles en producción, si bien en estos casos se trata de intercambios en broadcasting y solamente en recepción. Pero ambas mediatizaciones requieren la acción del receptor para, más que recibir pasivamente, interactuar con los textos que busca o que lo encuentran a él. Como sea, en el mismo movimiento, la temática actual de la movilidad tiene una trayectoria previa a la de la explosión del smartphone (Scolari y Logan 2014).

Denominaremos aquí como intersticial a todo fenómeno que se presente -que sobreviva, que interactúe con otros- sin estar en la consideración central de las preocupaciones sociales y/o académicas. No se trata de fenómenos ocultos, es decir, nuestro trabajo no ha sido el de la develación sino más bien el de la puesta en evidencia. Desde ese punto de vista, tratamos de presentar en primer plano interacciones, intercambios, espaciales micros, muchas veces inadvertidos entre lo que se ha considerado, de un modo macro, como geopolítica de los flujos internacionales de contenidos (Martel 2012: 415).

Para introducirnos de entrada en las vidas mediáticas intersticiales, aunque no secundarias, y una vez que superamos la fascinación por los 
conceptos centrales de un autor como Bruno Latour, podemos aprovechar como propia su experiencia leyendo diarios: los problemas para comprender en un mismo espacio las series conflictivas de los hechos, de las políticas y de los discursos (Latour 2007, p. 15-21). Así nos ocurre cuando tratamos de dar una visión generalista - tan valorada, sin embargo-sobre las mediatizaciones.

Las mediatizaciones intersticiales, como las de sonido y las de vía pública instalan en los estudios semióticos una problemática específica respecto de la complejidad: no resulta sencilla la elección de un corpus que represente el tema a estudiar, ni presuponer siquiera, qué enunciadores y enunciatarios son pertinentes para ese fragmento de la semiosis. Esa complejidad, se puede aceptar y comprender mejor ahora cuando plataformas de uso cotidiano como Facebook, Twitter, Instagram, Google, WhatsApp y YouTube, por mencionar a las de mayor incidencia social, incluyen en sus pantallas/interfaces muy diferentes discursividades.

Tal vez como parte de ese fenómeno, se produce la complejidad creciente de las diversas líneas de investigación en diferentes disciplinas, que nos obliga a precisar cuál es nuestra unidad de análisis en nuestros proyectos de investigación.

La unidad de análisis que proponemos como general, desde los estudios semióticos sobre mediatizaciones, es la de sistema de intercambio discursivo mediatizado; denominamos así a todo proceso de interacción/pasaje de textos (materiales portadores de sentido social) entre actores humanos o maquínicos, individuales o institucionales, en toma directa o con desplazamientos temporales, en contextos semejantes o diversos; la única gran categoría de sistemas de intercambio discursivo que se opone a los mediatizados son los intercambios cara a cara, pero reconociendo situaciones grises o híbridas, por ejemplo, cuando se da una conferencia o clase a un público amplio, con el soporte de textos en pantalla o amplificadores de sonido.

Las relaciones que constituyen un sistema de intercambio discursivo serán recuperadas en diversos niveles de análisis, por ejemplo, los ecosistemas de intercambio mediático, en sus diversos momentos que se solapan, se han definido como en Broadcasting: un emisor centralizado para $n$ receptores; definido así, incluye a la industria del libro; en tanto que modelo, es más importante por la indeterminación de los receptores que por su cantidad; pero cuando el número de receptores se hizo muy amplio, se convirtieron en medios masivos; el modelo que habitualmente se opone al broadcasting es el de Networking. Lo denominamos así -y no netcasting, como también suele hacerse- porque, en términos estrictos, la más elemental recepción obliga a alguna toma de decisión por parte del receptor quien, por otra parte, es frecuente que pueda contestar inmediatamente; es decir, siempre el receptor tiene que hacer alguna acción, algún trabajo. De todos modos, como veremos, 
ni todos de los que participan en sistemas de networking lo hacen publicando, ni todos los intercambios que tecnológicamente se producen en red, estimulan la interacción de todos los participantes. Por último, denominamos Postbroadcasting a este gran sistema (?) de la actualidad en el que ni los medios masivos, en retroceso, tienden a morir, ni todo parece ser intercambios en red; lo que sí se ve es que los medios incorporan posteos o formatos de red a los géneros tradicionales, y las plataformas mediáticas tratan de incorporar textos del broadcasting, sean espectáculos deportivos o links a medios informativos tradicionales. Denominamos así a este sistema híbrido pero central en la actualidad mediática, a falta de mejor denominación, porque al menos sirve para recordar que el broadcasting no ha muerto.

\section{Plataformas, performances, circuitos y circulaciones de lo musical}

¿Cómo llegamos, desde la sociosemiótica de las mediatizaciones de sonido a enfocarnos en lo que denominamos como vidas de lo musical, tanto en sus componentes mediáticos, como en sus diferentes espacios sociales de desempeño?

En primer lugar, compartimos con otros investigadores un campo de estudio de lo radiofónico y las mediatizaciones de lo musical, que tienen en cuenta enfoques espaciales (de Oliveira Menezes 2007; de Araújo 2007). En La construcción de lo radiofónico (Fernández 2008) presentamos, por primera vez nuestro modelo de trabajo en diversos artículos provenientes de investigaciones individuales dentro del grupo. Se reconstruyó allí el modo en que la mediatización radiofónica surgió en la ciudad de Buenos Aires. En artículos de Ximena Tobi, Matías Gutiérrez Reto, Damián Fraticelli, Mónica Berman, Betina González y Mariano Lapuente se describieron, tanto el surgimiento del medio como institución y como discurso, como las relaciones que la nueva mediatización estableció con la ficción, la música popular y los deportes.

Mientras La construcción de lo radiofónico veía la luz, desarrollábamos otras dos series de actividades. Por un lado, publicamos una serie de trabajos sobre espacios gráficos y urbanos (Fernández y Sznaider 2008) y, por el otro, nos cruzamos con los trabajos de Rubén López-Cano (2008), para profundizar nuestras indagaciones con diferentes aspectos de la actividad social y musical en los espacios urbanos. En paralelo, el vínculo con investigadores, creadores e intérpretes de la vanguardia electroacústica, especialmente Oscar Pablo di Liscia, nos obligó a encuadrarnos en la materialidad de lo acústico con lo tecnológico y lo espacial (Basso, Di Liscia 2009). La primera presentación de los resultados de esas interacciones se produjo en el Dossier "Música, espacios y medios. Algunas convergencias y divergencias", de nuestra revista L.I.S. que incluía trabajos de López-Cano, Di Liscia y Martín Liut (Fernández, ed. 2010). 
El segundo momento de publicación de resultados fue la edición de Postbroadcasting. Innovación en la industria musical (Fernández 2014) con artículos desde el estudio grupal de plataformas en streaming. Allí se incluyeron artículos sobre diversos fenómenos en plataformas, producto de las investigaciones de Daniela Koldobsky, Jimena Jáuregui, Mariano Lapuente, Joel Vargas, María Lucila Nuñez y Georgina Campos. Varios de ellos todavía no habían comenzado sus estudios de posgrado, pero en todos los trabajos se aplicó el esquema metodológico.

En el momento de publicación de Postbroadcasting..., habíamos comenzado a estudiar performances musicales en vivo y cara a cara, como los diversos tipos de milongas, espacios dedicados a la danza del tango en Buenos Aires y a construir tipologías de músicos desempeñándose en espacios públicos, como las estaciones de subterráneos.

El estudio de nuevos circuitos de producción y distribución musical, que están relacionados con espacios urbanos diferentes y alternativos para establecer contacto entre los músicos y sus audiencias, y diferentes modos de intervención en el espacio social, nos puso en interacción, entre otros, con autores como Víctor Lenarduzzi (2012), el ya mencionado Cid Jurado (2015), Pablo Semán (2015) y López-Cano (2018), entre diversos investigadores y equipos dedicados al estudio de la música popular, sus mediatizaciones y sus relaciones con diversos tipos de performances

Como uno de los tipos de resultados de nuestro recorrido, hemos construido tres periodizaciones que relacionan vidas musicales $y$ mediatizaciones: la que denominamos interna porque tiene que ver con las consecuencias que cada mediatización tiene sobre el producto final musical, ese que antes de lo digital se compraba finalmente como objeto y que ahora circula mayoritariamente como archivos en plataformas de streaming (Fernández 2014: 34-36). También construimos una periodización que denominamos como cultural, porque relaciona presencias en las vidas de lo musical en el conjunto de las mediatizaciones de prácticas artísticas y sus relaciones con diversos espacios de performances en vivo. Por último, propusimos una periodización de las mediatizaciones del sonido, con especial enfoque en lo musical, desde la presencia callejera y en conciertos, hasta la escucha con auriculares en movilidad (Fernández 2017b). Esas periodizaciones no las hemos propuesto como historizaciones concluyentes sino como aproximaciones heurísticas para comprender de un modo innovador fenómenos que se suceden pero que no necesariamente se relacionan directamente.

¿Cómo continúa nuestro proyecto de investigación en la actualidad? En dos vertientes: se avanza en el estudio de aspectos específicos de los intercambios en plataformas musicales $y$, por otro lado, estamos estudiando un conjunto de centros culturales ubicados en el barrio de Villa Crespo, un 
barrio tradicional habitado por sectores de la clase media, ubicada en el centro geográfico de la Ciudad de Buenos Aires. Durante los últimos años, el vecindario se ha transformado por la presencia de un movimiento teatral independiente y la aparición de un circuito de centros culturales alternativos, a menudo no legalmente habilitados, con una fuerte presencia de performances musicales.

En la actualidad, los centros culturales deberían ser importantes objetos de estudio porque presentan relaciones entre vidas musicales en plataformas mediáticas y actuaciones cara a cara. Es decir, se trata de casos privilegiados de postbroadcasting.

Nuestra hipótesis es que, a través de esas relaciones, se están generando nuevos circuitos de prácticas musicales sostenibles más allá del alcance de las grandes plataformas, como Spotify, y de las grandes disqueras que, a través de las plataformas en streaming, han visto volver a crecer sus ganancias y su hegemonía (Rocha Alonso 2016).

En el proyecto se comenzará estudiando desde un punto de vista sociosemiótico la presencia de los centros y sus actividades en plataformas mediáticas, propias o no, especializadas o generales. Luego, se agregarán dos metodologías diferentes: observación participante (Agar 2006) y se registrará el desarrollo de las performances, incluyendo la observación de la interacción de los miembros del público con los músicos y entre diversos sectores entre ellos. También se aplicarán entrevistas en profundidad entre gestionadores de los centros y asistentes (Ginesi 2018). Los primeros resultados sobre esta investigación han comenzado a publicarse (Videla 2019) y nos llevan a relacionarnos con enfoques redológicos, para los cuales, la información y resultados que obtenemos deben ser una materia prima necesaria.

La otra línea de investigación se enfoca en lo que tendemos a denominar como proceso de maduración de las plataformas. Denominamos así al recorrido de sofisticación de usos que toda plataforma, y sus usuarios en red, emprenden, sea por sucesivos rediseños de los desarrolladores, sea por los usos cada vez más sofisticados que van imponiendo sus usuarios (WhatsApp va dejando la exclusividad en mensajería interindividual y Spotify en música).

El proceso de maduración de las plataformas genera procesos divergentes que dificultan la investigación y aún la intervención profesional en sus usos. Frente a esa situación se requieren diversas líneas de investigación, entre ellas la que tienen que ver con fenómenos de curaduría (Koldobsky 2016) y de recomendación (Cingolani 2017).

En la línea de los temas de recomendación en las plataformas y la presencia de algoritmos maquínicos para la realización de esa tarea de convergencia de consumos, le prestamos atención a un artículo no académico, pero con muy buena información de Sophia Ciocca (2017), presentada como una "ingeniera en software" que va a explicar el lugar de "...la ciencia detrás de las 
recomendaciones personalizadas de música". El artículo presenta descripciones de los métodos de Spotify para construir una playlist semanal, Discover Weekly que, desde 2015, presenta cada lunes a usuarios premium 30 temas que cada uno de ellos "nunca ha escuchado pero que probablemente amen". Ciocca afirma que nadie conoce mejor sus gustos musicales que este servicio y para nosotros tiene el interés de desafiar en ciertos aspectos a las costumbres del análisis semiótico.

Según Ciocca, Spotify aplica tres modelos de recomendación diferentes: modelos de filtrado colaborativo; Natural Language Processing (NLP) models, mediante softwares de análisis de textos y modelos de análisis de audios en bruto.

En el filtrado colaborativo, mientras Netflix utiliza las evaluaciones en estrellas de sus usuarios, en Spotify se tiene en cuenta la aprobación implícita en las solicitudes de músicas. Como datos adicionales se aplican otras informaciones del streaming como la utilización de los temas en las propias playlists de los usuarios y las visitas a las páginas de los músicos. Es, por decirlo así, el sistema algorítmico más sencillo, matchea usuarios y calificaciones parecidos

El segundo tipo de recomendación de Spotify, es a través de los Natural Language Processing (NLP), que son los modelos que están más cercanos a las prácticas del análisis discursivo. Según Ciocca ellos utilizan lo que denominan "vectores culturales" o "términos top". Esto permitiría establecer vectores para determinar parecidos y asociaciones entre diferentes temas musicales. Hemos discutido la necesidad de sofisticar las clasificaciones estilísticas para, luego, sofisticar los clústeres que clasifican temas musicales según sus etiquetados o vectores (Fernández 2018b).

El tercer modelo de recomendación que sugiere Ciocca nos resulta de interés porque cuestiona la necesidad de contar con teorías discursivas, lo cual, si bien debe inquietar a los semióticos, también puede verse como una oportunidad de reconstruir objetos y enfoques de estudio. Se trata de la aplicación de Modelos de audio en bruto (Raw Audio Models) ${ }^{3}$. Lo de audio en bruto remite a que se trabaja con perfiles sonoros de los temas musicales, más allá de su clasificación genérico-estilística. Este tipo de modelo de recomendación sería útil para listas predictivas sobre temas nuevos o desconocidos por el usuario. Según esto, los nuevos temas no estarían incluidos en paradigmas genéricoestilísticos, sino que se los asociaría a patrones de uso (momentos, actividades o estados de ánimo). Si bien cuestiona lo que entendemos como actividad metadiscursiva necesaria para comprender las circulaciones culturales, tiene el interés de asociar temas y usuarios de lo musical por lo que se considera la materia prima de la música: los perfiles de audio.

\footnotetext{
${ }^{3}$ Las tecnologías clasificatorias de estos perfiles de audio son las convolutional neural networks, la misma tecnología que está en la base del reconocimiento facial. Sobre ésta área, nueva para nosotros, estamos avanzando en estos momentos
} 
Como se ve, nuestras dos líneas de investigación nos llevan hacia las fronteras de nuestra disciplina: en un caso, hacia afuera, a interactuar con la etnografía, la ecología de los medios y la redología y hacia adentro, a observar y entender desde otro punto de vista la materialidad musical y su relación con las recepciones no conscientes.

\section{Conclusiones. Del broadcasting al postbroadcasting}

Un objetivo central ha sido representar la trayectoria de investigación de un equipo de trabajo, de un modo que no acentúe lo individual del proceso y en el que tampoco gane la escena la defensa de un modo de trabajo. Si en algo se ha conseguido esos objetivos, habrá dependido del empleo de un enfoque micro desde el puede capturarse la complejidad de ciertos procesos, que suelen quedar disimulados desde lo macro, ocultando sus aportes a los procesos de producción de sentido.

La Semiótica, enfrentando largos procesos de investigación como disciplina de base, debe adaptarse a la profundización de estudio de sus objetos y, además, a la transformación histórica de los mismos. Las mediatizaciones han sufrido transformaciones constantes durante el siglo XX y en el pasaje al siglo XXI.

El cruce de estudios sobre mediatizaciones de sonido y plataformas musicales con el estudio de comunicación y música en espacios públicos o especializados, representa buena parte de lo importante que está ocurriendo en el gran ecosistema mediático de nuestra época: postbroadcasting es la denominación que proponemos para este momento.

La complejidad y la pluridisciplinariedad no se eligen, se imponen a las investigaciones desde la semiótica de las mediatizaciones. La respuesta no debe ser la resistencia, nada disolverá las incumbencias semióticas, sino que el camino es la adaptación y la porosidad de las fronteras.

Esperamos que haya quedado en evidencia la importancia de estudiar, por un lado, mediatizaciones y aspectos intersticiales, aun en plataformas que están en el centro de la escena sociocultural. En lo micro y en lo intersticial, parecen esconderse claves de la cultura contemporánea.

\section{REFERENCIAS}

BASSO, Guillermo \& DI LISCIA, Oscar Pablo. 2009. Música y espacio: ciencia, tecnología y estética. Bernal: Universidad Nacional de Quilmes.

CID JURADO, Alfredo Tenoch. 2015. Visión espectacular, visión mediatizada en el caso del flashmob. En Letra. Imagen. Sonido L.I.S. Ciudad Mediatizada (10), 43-60. Buenos Aires: UBACyT. 
CINGOLANI, Gastón. 2017. "Sistemas de recomendación, mediatizaciones de lo preferible y enunciación". En BUSSO, Mariana y CAMUSSO, Mariángeles (Eds.) Mediatizaciones en tensión: el atravesamiento de lo público, 30-47. Rosario: UNR Editora.

CIOCCA, Sophia. 2017. How Does Spotify Know You So Well? En Medium Corporation. Recuperado en https://medium.com/s/story/spotifys-discoverweekly-how-machine-learning-finds-your-new-music-19a41ab76efe. (Accedido: 10 de Febrero de 2018).

DE ARAÚJO DUARTE VALENTE, Heloísa. 2007. Música e mídia. Novas abordagens sobre a canção. São Paulo: Via Lettera/Fapesp.

DE OLIVEIRA MENEZES, José Eugenio. 2007. Rádio e cidade: vínculos sonoros. São Paulo: Annablume.

FERNÁNDEZ, José Luis. (Dir.). 2008. La construcción de lo radiofónico. Buenos Aires: La Crujía, pp. 9-73.

FERNÁNDEZ, José Luis. (ed.). 2010. Dossier: “Música, espacios y medios. Algunas convergencias y divergencias. En: L.I.S. Letra, imagen, sonido. Ciudad mediatizada № 3, 1er. Semestre 2009, 155-185. Buenos Aires: UBACyT.

FERNÁNDEZ, José Luis (Coord.). 2014. Postbroadcasting. Innovación en la industria musical. Buenos Aires, La crujía.

FERNÁNDEZ, José Luis. 2017a. Semiotics and interstitial mediatizations. En: Bankov, K. y Cobley, P. (Eds.) Semiotics and its masters, 169-182. Berlin: de Gruyter, Mouton, pp..

FERNÁNDEZ, José Luis. 2017b. “La vida en plataformas: auriculares + smartphones". En PARDO ABRIL, Neyla. Semióticas. Materialidades, discursividades y culturas, 256-273. Bogotá: Instituto Caro y Cuervo, Imprenta patriótica.

FERNÁNDEZ, José Luis \& SZNAIDER, Beatriz. 2008 “Retornos de la gráfica vanguardista en un plan visual urbano". En: Figuraciones 4. La muerte de las vanguardias. Buenos Aires: IUNA, pp. s/p. http://repositorio.una.edu.ar/ bitstream/handle/56777/436/Retornos\%20de\%20la\%20gr\%c3\%a1fica\%20 vanguardista.pdf?sequence=2\&isAllowed=y (Accedido: 8 de Febrero de 2020).

IGARZA, Roberto. 2009. Burbujas de ocio. Buenos Aires: La Crujía.

KOLDOBSKY, Daniela. 2016. Mediatización de la música y memoria: de las partituras a los archivos de red. En CINGOLANI, Gastón \& SZNAIDER, Beatriz (eds.). Nuevas mediatizaciones, nuevos públicos, 59-76. Cuadernos del CIM. Rosario: UNR Editora. 
LENARDUZZI, Víctor. 2012. Placeres en movimiento. Cuerpo, música y baile en la "escena electrónica". Buenos Aires: Aidós Editores.

LÓPEZ-CANO, Rubén. (ed.) (2008) Músicas, ciudades, redes: creación musical e interacción social. Salamanca: SiBE - Caja Duero, www.lopezcano.net. Accedido: 22de septiembre de 2015.

LÓPEZ-CANO, Rubén. 2018. Reciclaje musical. En Música dispersa. Apropiación, influencias, robos y remix en la era de la escucha digital, 217-266. Barcelona: Musikeon Books.

MARTEL, Frederic. 2012. Cultura Mainstream. Cómo nacen los fenómenos de masa. Madrid: Santillana Ediciones.

ROCHA ALONSO, Amparo. 2016. Proyecto burbujas: circuitos de música en Buenos Aires. En Letra. Imagen. Sonido L.I.S. Ciudad Mediatizada (15), 35-48. Buenos Aires: UBACyT.

SEMÁN, Pablo. 2015. Introducción. En GALLO, Guadalupe \& SEMÁN, Pablo (comps.). Gestionar, mezclar, habitar, 7-14. Buenos Aires: Editorial Gorla.

SCOLARI, Carlos Alberto \& LOGAN Robert. 2014. El surgimiento de la comunicación móvil en el ecosistema mediático. En L.I.S. Letra. Imagen. Sonido. Ciudad mediatizada, (11), 67-82. Buenos Aires: UBACyT.

VIDELA, Santiago. 2019. Vidas on/off line de lo musical: relación entre plataformas mediáticas y espectáculos en vivo en centros culturales. En Revista Sociedad, (39) 227-240, Buenos Aires: FSoc, UBA. 


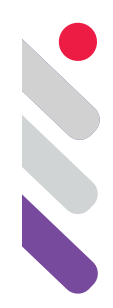

\section{Le web 2.0 : Une nouvelle trajectoire pour la sémiologie audiovisuelle?}

DOI: 10.24308/IASS-2019-8-023

François Jost

Sorbonne Nouvelle Paris 3

francois.jost@sorbonne-nouvelle.fr

Une chercheuse américaine, Claire Wardle, fait le constat que l'étude des tweets est très majoritairement consacrée aux tweets textuels, aux sites Web ou aux articles publiés via des URL et au fact-checking de ce que disent les politiciens (Wardle 2019). Elle en voit la raison notamment dans le fait que l'étude de la langue naturelle est bien plus avancée que ce qu'elle nomme les "techniques d'étude des images et de la vidéo ». Comme si, au fond, la sémiologie de l'image fixe et animée n'existait pas. Je m'accorde avec elle sur le fait que l'étude du verbe, ici comme ailleurs, l'emporte sur l'image. Que ce soit en raison du manque d'outils d'analyse me semble plus discutable. Mais ce n'est pas mon propos. Ce que je voudrais faire dans ce texte, c'est montrer comment éprouver des concepts qui se sont révélés opératoires dans d'autres domaines pour voir dans quelle mesure ils sont utiles pour analyser un objet du web 2.0. Ou dans quelle mesure il faut les adapter, les rectifier ou les abandonner.

Depuis que j'écris, j'ai changé de nombreuses fois d'objets d'étude, mais je crois que ma méthode d'investigation n'a pas beaucoup changé. Elle a toujours été pensée sous le signe de la trajectoire. Pas d'une trajectoire directe qui me dirait par avance quel point j'atteindrai, mais plutôt une trajectoire à l'aboutissement incertain. Je savais d'où je partais, pas forcément où j'arriverai. Assurance du terminus a quo mais sûrement pas du terminus ad quem. Ma première trajectoire m'a mené de la sémiologie du cinéma à la pragmatique de la télévision.

Le résultat majeur a consisté d'abord à ne pas considérer que le cinéma et la télévision étaient un même langage, comme l'affirmait Metz (Metz 1972) et qu'il fallait, pour comprendre l'un et l'autre, non pas chercher la vérité dans la seule analyse immanente, mais dans la relation qui réunit plusieurs acteurs (producteur, diffuseurs, critiques, organismes de régulation, spectateur, enfin), en bref, dans une approche pragmatique plutôt que structurale. 
Ce qui caractérise cette approche structurale, c'est d'abord que, si le message est correctement codé et décodé, il est le même pour l'émetteur et le récepteur. Du même coup, le projet de la sémiologie est d'arriver à une typologie d'entités qui permettent de se repérer dans la multiplicité du sensible. Cette conception a été rejetée par de nombreux chercheurs et, d'une certaine façon, l'étude du paratexte a été un premier pas pour s'en détacher. En étudiant les " seuils » du texte, selon le mot de Genette (Genette 1987), on montrait que le seul examen du texte n'était pas suffisant pour le comprendre. Ainsi, écrire sur la couverture d'un livre " roman » ou " autobiographie » modifiait la consigne de lecture. Tandis que le roman requerrait « a willing suspension of disbelief ", l'autobiographie incitait à rattacher les événements vécus par le narrateur à l'auteur dont le nom était inscrit sur la couverture. Et l'on vit aussi bien du côté de l'analyse de discours que de la sémiologie fleurir l'idée de contrat ou de pacte. Le paradoxe de ces concepts, c'est qu'en donnant l'apparence de s'écarter de l'immanentisme, ils réintroduisaient l'idée que comprendre un texte pour le récepteur, c'était l'envisager de la même façon que l'émetteur et de sa visée.

Tout cela est le symptôme d'une époque où l'on considérait le texte comme objet idéal et non comme un livre pris dans un processus de communication commerciale. L'idée de contrat supposait aussi la construction d'un auteur honnête et sincère, disant ce qu'il avait fait et non pas celle d'un éditeur parfois guidé par le seul souci de vendre. Depuis quelques années on a vu se multiplier les cas d'injonctions contradictoires. Un livre, mettons le Da Vinci Code, est présenté comme un roman et, en même temps, pris au sérieux par les lecteurs qui cherchent dans Paris les signes décrits par le texte. Au moment où je quitte Paris, une affaire a éclaté qui montre clairement que le paratexte n'est plus une indication de ce qu'est un texte. Un écrivain, Yann Moix, vient de publier un livre, Orléans, indiqué " roman " sur la couverture, qui raconte une enfance persécutée. Sa famille s'est retournée contre lui considérant que c'était un tissu de mensonges. Pas de suspension de l'incrédulité, en l'occurrence.

Le reproche de mensonge s'applique parfaitement à une autobiographie, mais pas au roman, qui se moque de la vérité. C'est un cas de plus en plus courant. Cela m'a amené à remplacer le schéma communicationnel du contrat par celui de promesse, qui colle mieux avec la situation dictée par le commerce et le marketing dans lequel nous sommes (Jost).

La conclusion que j'ai tirée de tout cela en ce qui concerne les genres télévisuels est double : en tant qu'elle permet de construire les traits définitoires d'un genre, la démarche structurale est justifiée. Par exemple, il est important de définir la fiction ou la télé-réalité ou la comédie pour savoir quelles sont la signification et les limites d'un genre. En revanche, considérer qu'un programme donné est unanimement rattaché à tel ou tel genre par tous les acteurs de la communication est une erreur. Le même objet peut être reçu comme roman par les uns, comme autobiographie par les autres. 
Ce que je voudrais faire aujourd'hui c'est une approche qui se fonde sur les mêmes fondements épistémologiques pour aborder un objet non plus télévisuel mais propre au web et montrer comment une approche structurale peut s'articuler avec une approche pragmatique.

Cet objet c'est le " mème ». Si le mot est français au départ, il a été avancé à l'origine par Richard Dawkins dans Le Gène égoïste (1976) pour qualifier « un élément d'une culture ou d'un ensemble de comportements qui se transmet d'un individu à l'autre par imitation ou par un quelconque autre moyen non génétique ". Forgé par analogie avec " gêne " sur le calque français " même ", " the word has been appropriated to describe a type of online content that is usually visual and takes on a particular anesthétique design, combinions colorful, striking images with block text. It often refers to other cultural and media events, sometimes explicitly but mostly implicitly " (Wardle 2019). Cette définition a une extension beaucoup trop large et il est difficile de se faire une idée de ce qu'elle désigne. Pour An Xiao Mina qui y a consacré un livre, " an internet meme [is seen] as a piece of online média that is shared and remixed over time within a community " (Mina $2019: 6$ ). Ce peut être toute sorte d'objets : "Photo remixes, selfies, YouTube songs, hashtags jokes - this is the "silly " stuff of meme culture " (ibid. : 11). Selon cette conception, il y a des text memes, des video memes, des physical memes, des performative memes, des selfies memes. Pout l'auteur, fidèle en cela à Dawkins, l'intérêt se porte d'abord sur le mode de propagation et les fonctions du mème. Dans ce texte, je retiendrai une caractérisation beaucoup plus restrictive de l'objet, telle qu'elle est formulée par le Larousse de la langue française : " concept (texte, image, vidéo) massivement repris, décliné et détourné sur Internet de manière souvent parodique, qui se répand très vite, créant ainsi le buzz ". La forme privilégiée du mème est le détournement visuel d'une image déjà connue sur la Toile. Néanmoins celui-ci est plus ou moins visible et, plutôt que de raisonner sur la fonction sociale des mèmes en général, je voudrais en mettre au jour la diversité au travers de l'analyse de quelques images.

Commençons par celles-ci (image 1) :

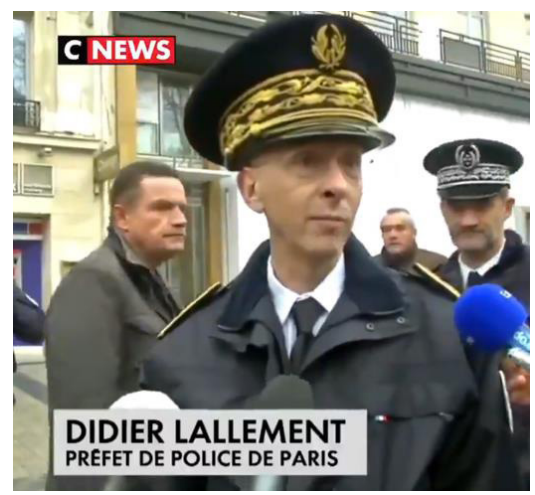

image 1 


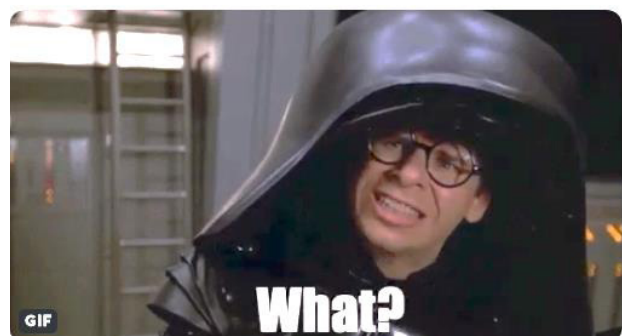

image 2

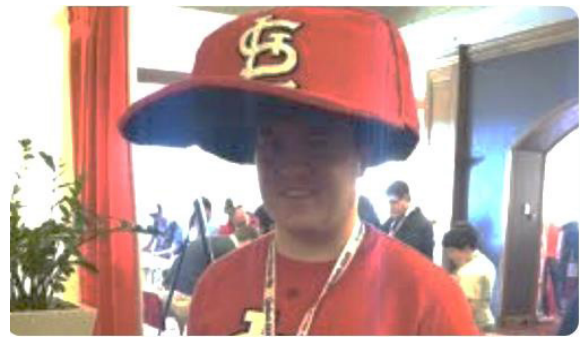

image 3

Vous pouvez trouver cette image amusante sans rien savoir de l'homme qui s'y trouve, si ce n'est que c'est un préfet et qu'il est un peu ridicule. Pour s'en convaincre, il suffit de faire un test de substitution que nous permettent des mèmes de cette image. D'autres personnes peuvent porter une casquette et susciter le même effet comique à condition à condition qu'il y ait un écart anormal entre le couvre-chef et le visage.

Du point de vue sémiologique, on dira que c'est une figure in praesentia, un travestissement. Les éléments qui rendent la photo cocasse sont dans l'image. Le procédé fonctionne aussi bien avec des personnages connus comme Darth Vader (illustration 2) qu'avec les joueurs d'une équipe de Base-ball (illustration 3) . Même si l'on ignore que Les Cardinals de Saint-Louis sont une franchise de baseball de la Ligue majeure de baseball située à Saint-Louis, Missouri et qu'ils évoluent dans la division Centrale de la Ligue nationale, on peut sourire de la

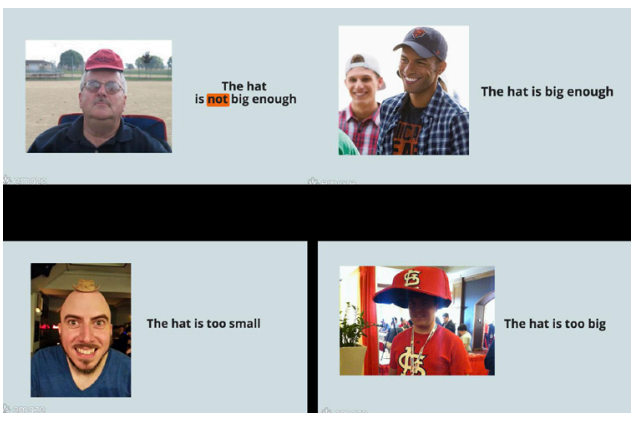

image 4

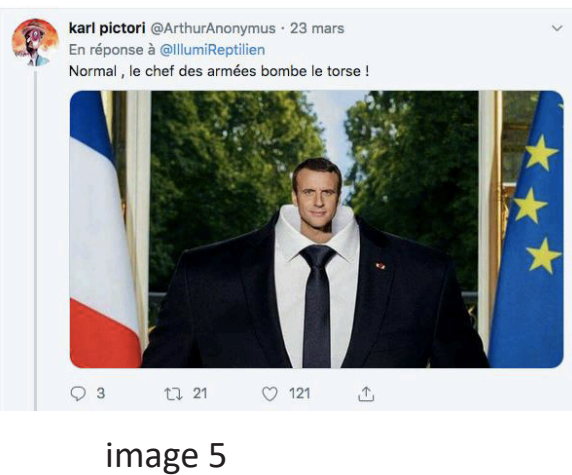

disproportion de la casquette par rapport au visage. C'est ce que confirme cette juxtaposition de quatre façons d'adapter un couvre-chef à sa tête (Image 4) La fonction de ce mème est donc essentiellement ludique. II est fait pour faire rire.

D'autres mèmes dérivés de la photo initiale peuvent adjoindre à la dimension ludique une connotation critique. Comme l'image 5 où l'on voit le président de la République française dans " un costume trop grand pour lui ", ce qui est une expression française pour signifier qu'un homme est dépassé par sa tâche. Une deuxième dimension se fait jour, la dimension satirique, la satire 


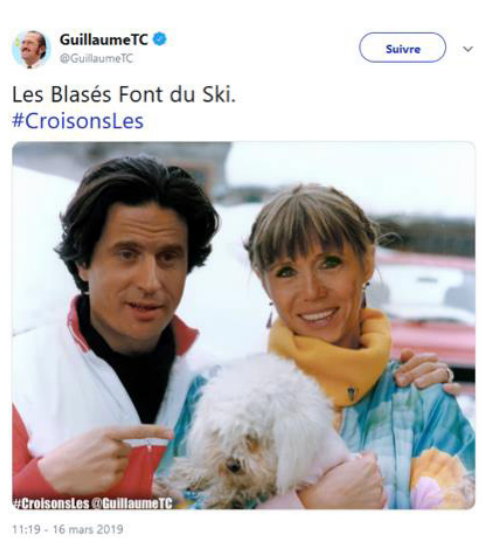

image 6

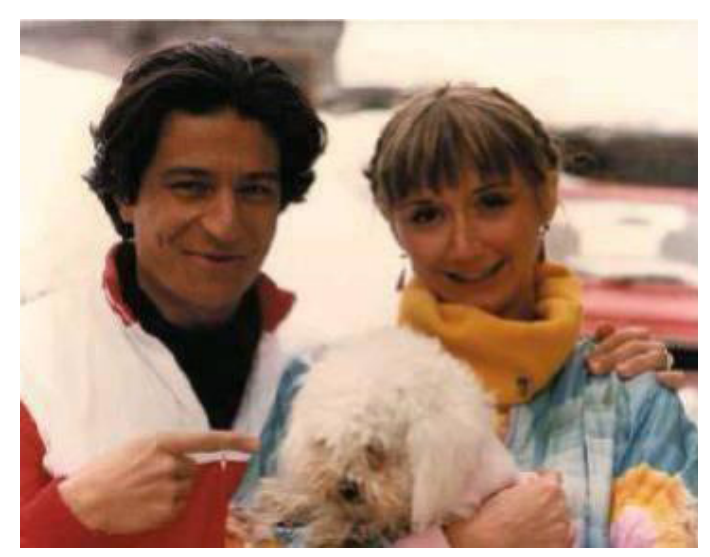

image 7

étant entendue comme un " écrit, un discours qui attaque quelque chose ou quelqu'un en s'en moquant » (Dictionnaire historique de la langue française, Robert).

Comparons maintenant avec l'image 6. Un Français y reconnaît assez facilement le Président de la République et son épouse. Sans doute reconnaîtil aussi la référence qui se cache dessous : le renvoi à un film culte en France, Los Bronzeados hacen esqui (7). J'imagine que, pour un public étranger, c'est beaucoup moins évident. D'un point de vue rhétorique, on dira donc que c'est une figure in absentia, une parodie, puisque celle-ci consiste à transformer une image existante. Mais, si l'on veut comprendre l'usage social de cette image, cette description est très insuffisante. Telle qu'elle est reproduite ici elle perd $90 \%$ de son sens. Ce n'est pas le renvoi aux acteurs Christian Clavier et MarieAnne Chazel qui compte le plus en effet. C'est le fait que ce mème est publié par un spécialiste des mixtes d'image au moment où Macron se trouve aux sports d'hier avec sa femme, moment qui coïncide avec une manifestation des Gilets jaunes à Paris. Le trucage est donc assorti d'une visée critique, satirique qui nécessite un travail inférentiel de la part du spectateur pour comprendre cet effet qui n'a rien d'un donné puisqu'il n'est nullement dans l'image. Pour que l'identification référentielle fonctionne, il faut que l'internaute partage une culture commune avec les autres. Culture largement télévisuelle, qui unit les générations en raison du nombre de passage de ce film à la télévision.

Ce travail inférentiel qui situe l'image entre le simple ludique " pour de rire " et le satirique n'est pas toujours facile à effectuer. Regardez ce GIF (8). Pour une personne non spécialiste de la politique française, il met en scène une femme anonyme. Pour un Français un tant soit peu informé, c'est la ministre du travail qui est en charge de dossiers brûlants : le chômage, la formation professionnelle. Si l'on possède cette clé, le GIF est bien destiné à la tourner en ridicule. Pour le spectateur qui reconnaît la référence à une autre image, le trait 


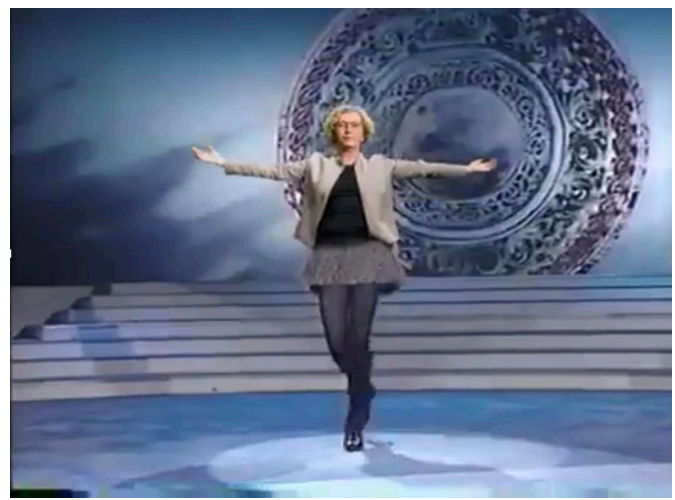

image 8

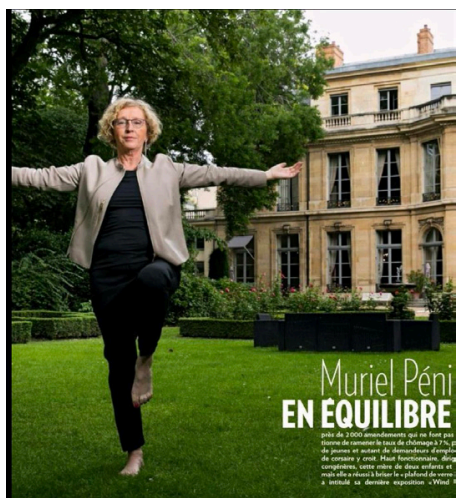

image 9

est beaucoup plus méchant. La ministre a en effet été photographiée pour Paris Match dans une pose légendée "En équilibre ". Son jeu de jambes renvoie à un spectacle qui a eu beaucoup de succès : Riverdance (10). Du coup, le GIF est une façon de se moquer de sa communication qui apparaît clairement pour ce qu'elle est. La journaliste qui m'a fait connaître l'image 8 image n'avait pas saisi la référence à la seconde parue dans un magazine. Cela montre que les mèmes sont essentiellement compris par les savoirs latéraux du spectateur, ce que ne peut saisir une approche seulement structurale. Gageons que la reconnaissance n'est pas la même pour les jeunes et pour un vieux sémiologue qui reconstitue la culture populaire comme d'autres allaient jadis chercher les références filmiques dans la culture savante.

Voici une autre hésitation entre la lecture in praesentia et la lecture in absentia (11). Du point de vue in praesentia, l'image a une signification claire : le " Grand Débat », organisé pour répondre aux Gilets jaunes est une imposture : sous la cloche "Résultats du Grand Débat ", il n'y a qu'un doigt d'honneur. Le contraste entre le visage séducteur de Macron et son visage déformé par la colère ou la méchanceté signifie qu'il ne faut surtout pas faire confiance à ses promesses. Mais, ce qui est intéressant ici, c'est que ce message est structuré avec des références que seule peut comprendre la génération « jeune ». L'image renvoie en effet à We Are Number One, une chanson chantée par le méchant

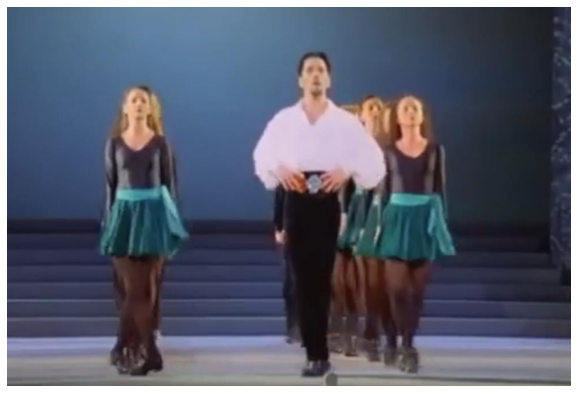

image 10 


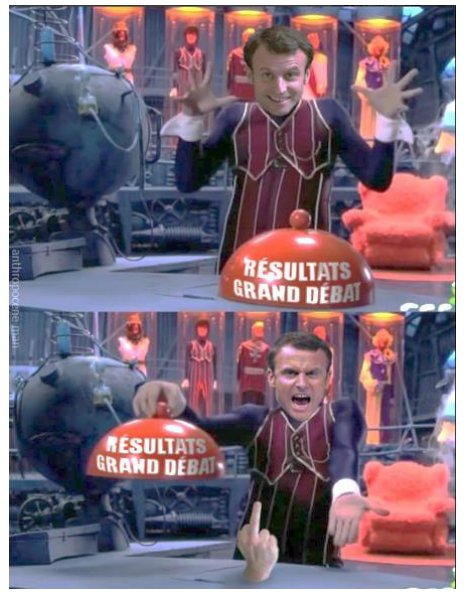

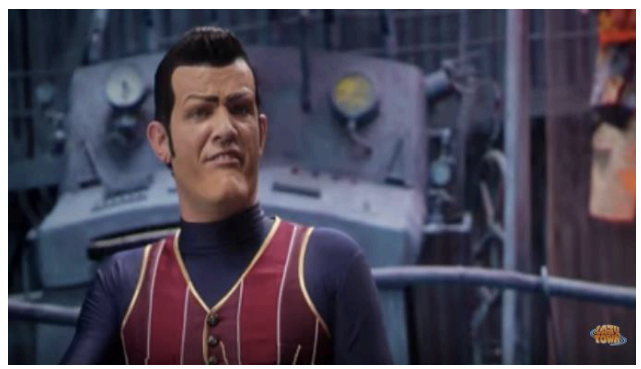

image $11 b$

Rotten dans le programme de télévision islandais pour enfants LazyTown, qui, au 7 juillet 2019, a été vu 61 millions de fois sur Youtube. Et ce clip a donné lieu à une multiplicité de mèmes au point qu'il a été le plus parodié en 2016. Compréhensible par tout le monde en tant que figure in praesentia, il prend une valeur générationnelle en tant que figure in absentia.

Un troisième type de même peut être exemplifié par cette photo de Macron et sa femme déjeunant avec des amis dans une station de sports d'hiver. Non retouchée, elle ne ressortit pas en apparence aux figures in praesentia ou in absentia. Cette image (12) est ironique, puisque qu'elle consiste à rapprocher deux éléments concomitants, la marche pour le climat et les vacances de Macron. La phrase "Trinquons à la manif du climat ", sur le compte Twitter d'une comique belge bien connue en France où elle a une émission de radio est plus que satirique : c'est une critique directe au président, qui joue sur une corde très sensible puisque les Gilets jaunes à la même époque reprochaient au pouvoir d'être coupé du peuple. Un autre internaute enfonce le clou en commentant la même image de la façon suivante : « ils déjeunaient hier à La
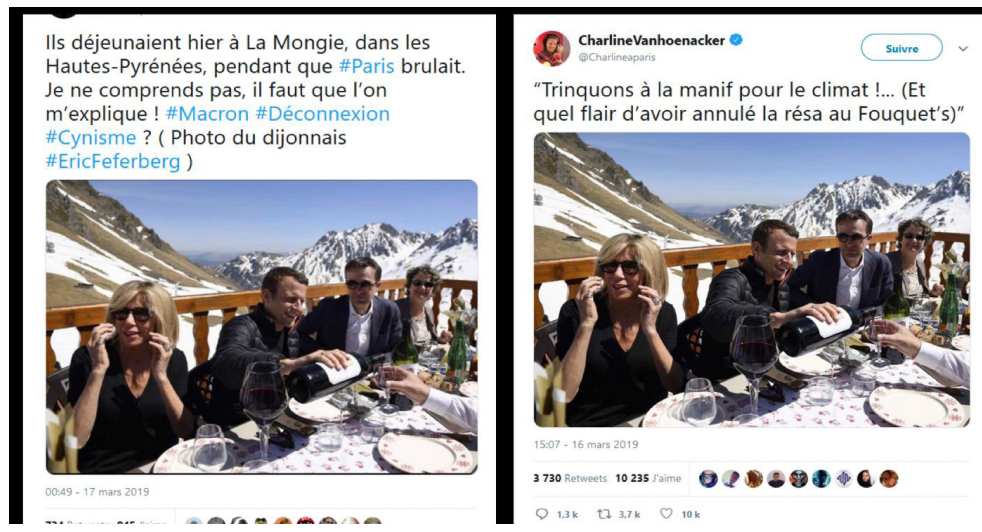

image 12 

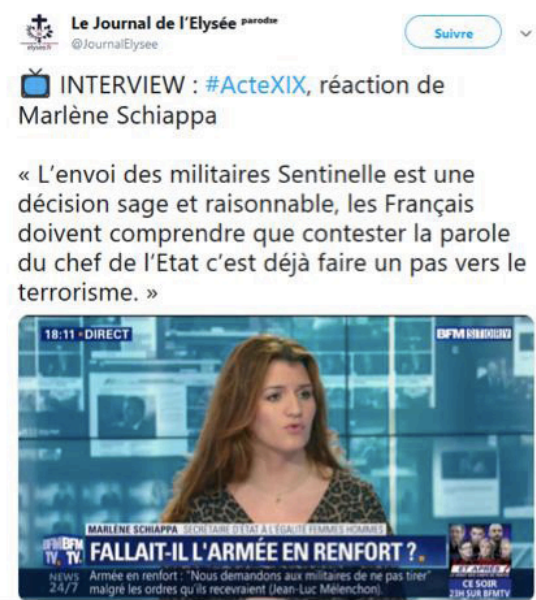

image 13

Mongie, dans les Hautes Pyrénées pendant que \#Paris brûlait. Je ne comprends pas, il faut qu'on m'explique! \#Macron \#Déconnexion \#Cynisme ? "

Pour continuer avec la métaphore $d u$ feu, on peut dire que ce rapprochement d'une image et d'un texte l'alimentent. Problème : la photo ne date pas de mars 2019, comme il est inscrit au bas de l'image, mais de deux ans auparavant, 2017. La photo est un mème, si l'on se réfère à la définition floue que j'en ai donné au début, d'image « combining colorful, striking images with block text ", mais ne se présente pas comme tel. Elle se présente sur un troisième mode, après le ludique et le satirique, qui est l'énonciation sérieuse. D'un point de vue sémiologique, ces tweets semblent renvoyer au monde réel. Ce qui en fait des images détournées, c'est le texte.

Du divertissement explicite on est passé à un commentaire sur le monde réel, qui est construit pour être pris au sérieux. En ce point le mème devient fake news et entraîne avec celle-ci des discours propres aux complotistes comme « il faut que l'on m'explique ».

Autre façon, plus insidieuse encore, de faire passer une pure fiction pour la réalité, l'emploi d'une fausse citation. C'est le cas de l'image qui a tous les atours d'une vraie information, aussi bien visuellement que textuellement puisque le texte est entre guillemets (illustration 13) : « L'envoi des militaires Sentinelle est une décision sage et raisonnable, les Français doivent comprendre que contester la parole du chef de l'état, c'est déjà faire un pas vers le terrorisme ». Bien que cette phrase n'ait jamais été prononcée par la secrétaire d'état, le rapprochement avec le titre inscrit par la chaîne de télévision la rend vraisemblable. Le nom du compte Le Journal de l'Élysée avec son identifiant @journalElysee est un deuxième piège tendu. II n'est pas sûr que l'internaute ordinaire, qui ne fait pas une étude sémiologique, perçoive le tout petit " parodie ". Autres fake news du même genre, cette phrase attribuée à une responsable politique : " II y un âge, lorsqu'on devient un poids financier très important pour la société, où la 


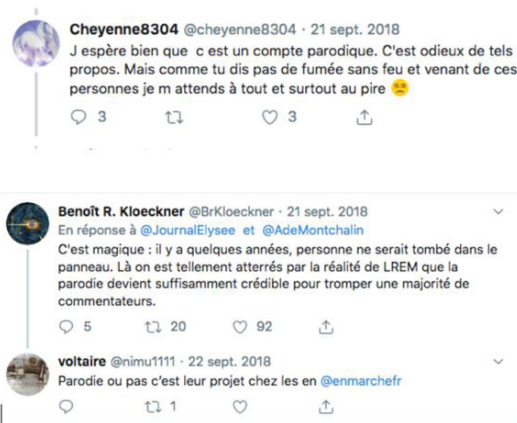

question de la fin de vie anticipée doit être posée ; il faut en finir avec les tabous » : 748 retweets et 697 J'aime. L'examen des commentaires montrent que de nombreux internautes prennent cette déclaration au sérieux et que même ceux qui croient qu'il s'agit d'une parodie trouvent que cette phrase aurait pu être prononcée par la ministre (image 14) :

Dans ce cas, il est évident que le paradigme de la sémiologie structurale n'est pas suffisant, puisque rien ne différencie le mème d'une information " sérieuse ", rien ne différencie la désinformation de l'information.

Pour résumer, j’ai dégagé trois types de mèmes :

- un mème purement ludique qui vise essentiellement à faire rire en utilisant les ressources d'une pop culture partagée ; le terme parodie lui convient assez bien ;

- un mème, instrument critique de l'actualité, de la société et des politiques, qui reprend les fonctions traditionnelles de la satire ;

- un mème sérieux, qui se présente comme la réalité et qui avance donc masqué et qui, finalement, n'est rien d'autre qu'une fake news.

On a constaté que les figures in absentia sont celles qui produisent les réceptions les plus diverses en fonction des savoirs latéraux que l'on possède.

Ludique, satirique et sérieux sont en fait trois modes d'énonciation, mais aussi trois modes de réception. Cela signifie que ce ne sont pas des donnés. C'est le récepteur qui, en fonction de ses connaissances, de sa culture, de son suivi de l'actualité ou des médias, va inférer que le mode d'énonciation utilisé par l'émetteur est ludique, satirique ou sérieux. Et la visée et l'effet produits ne coïncident pas forcément. Même quand une image est d'abord faite pour rire, sans trop se préoccuper du message, l'internaute malveillant peut y trouver 


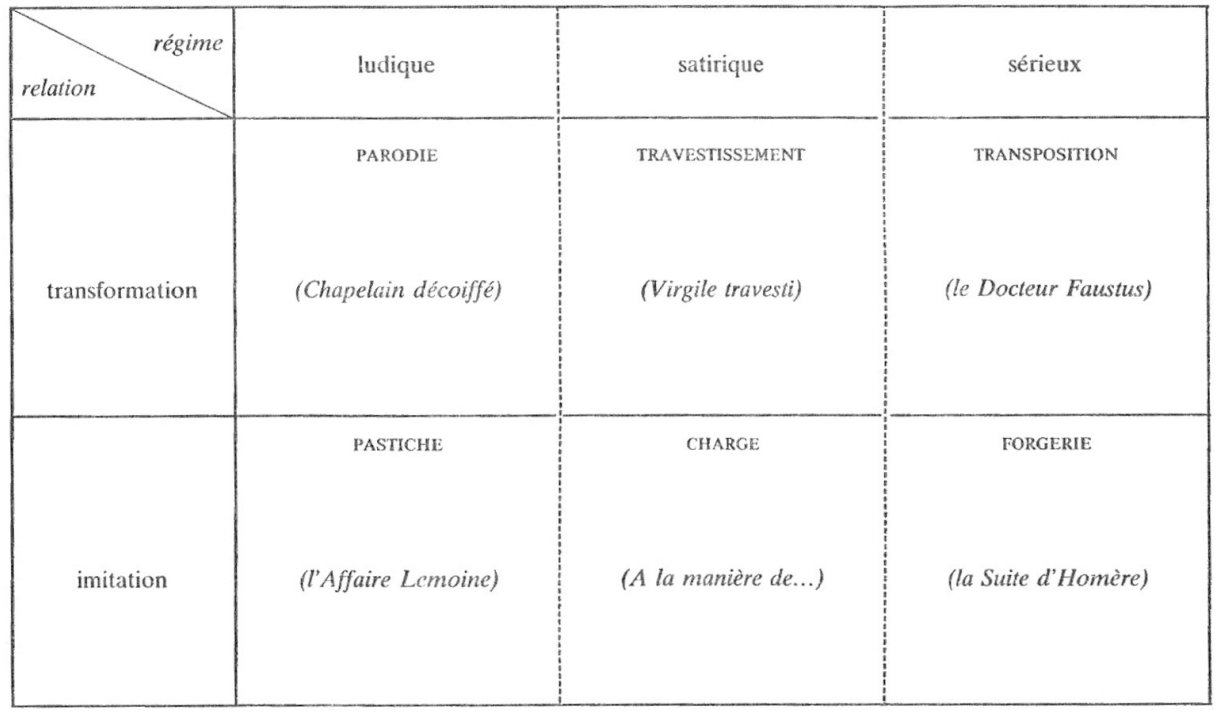

image 15

une intention critique. Certaines images, on l'a vu, peuvent être interprétées à partir de leur rhétorique in praesentia ou in absentia. Pour ces raisons, l'analyse que j'ai développée se distingue d'une approche purement structurale et de la théorie du contrat.

Parmi les représentants de la première, je placerai Genette qui, pourtant, en forgeant les concepts d'hypertexte et d'hypotexte semble s'en éloigner. L'hypothèse est en effet que sous tout texte il y a d'autres textes. Cela aboutit à un tableau de toutes les formes de " palimpsestes » (Genette 1982) [ill. 15]

Si l'on retrouve les trois termes que j'ai utilisés - ludique, satirique, sérieux -, ils n'ont ni tout à fait le même sens ni le même rôle heuristique. Pour Genette, "sérieux " signifie transposer un texte dans une autre époque, par exemple, sans visée ironique ou dévaluante. De mon côté, j'utilise plutôt une acception searlienne d'énonciation sérieuse par opposition à fictive (Searle 1982). De même un texte "satirique " s'en prend à un autre texte, alors que dans mes exemples, il s'agit d'une critique du monde réel, dont la visée peut être politique. Chez Genette, il s'agit de décrire le plus précisément possible des types de textes à travers ce qu'il appelle leur "régime ". D’une certaine façon, ce sont des essences ou des entités qui ne peuvent être vraiment décrites que par une exploration savante des textes de la littérature mondiale ou par ce que Genette appelle des " contrats explicites " comme le Virgile travesti, dont le titre renvoie clairement au travestissement, ou implicites comme l'Ulysse de Joyce qui entre en résonance avec L’Odyssée. 


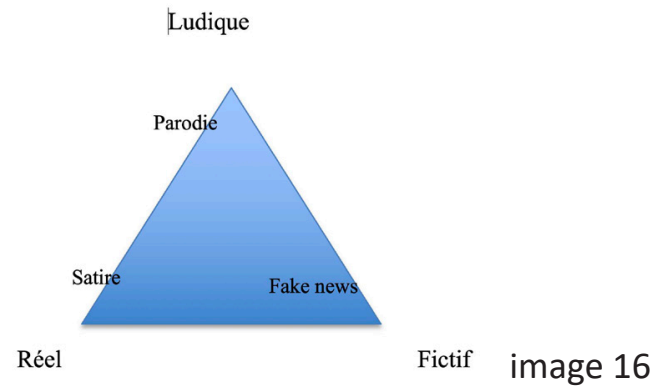

La théorie du contrat va plus loin, puisqu'elle admet qu'un texte se donne pour ce qu'il est, roman quand il est roman, autobiographie quand il est autobiographie. Or, je l'ai dit, c'est une théorie optimiste qui ne correspond plus à l'état de l'édition comme commerce et, encore moins, à l'internet où les mèmes s'avancent sans forcément prévenir de ce qu'ils sont vraiment (Jost 1998). Croire que le récepteur s'aligne sur les visées de l'émetteur est naïf. La visée de l'internaute qui fait une fake news peut être de tromper son destinataire. Celle du récepteur devrait être de s'informer, c'est-à-dire d'augmenter sa connaissance du monde.

Puisque notre colloque est placé sous le signe de la trajectoire, je voudrais pour finir faire un petit retour sur mon propre itinéraire épistémologique.

Placé devant la difficulté de catégoriser les genres télévisuels d'hier et d'aujourd'hui, qui pullulent et se transforment sans cesse, j'ai d'abord distingué trois modes d'énonciation authentifiant, fictif et ludique (Jost 1997), plus tard conçus comme les trois interprétants de tout genre : le monde réel, le monde fictif et le monde ludique, que j'ai représenté par un triangle. Cette figure, néanmoins, n'est pas une carte où les programmes seraient à une place fixe, comme dans une carte de géographie. Comme je l'ai dit en introduction, le même programme peut être situé dans différents mondes selon les acteurs. C'est particulièrement vrai des genres hybrides comme la télé-réalité, qui peut être renvoyée à la réalité, à la fiction ou à jeu, selon la manière dont on l'interprète. S'agissant de mèmes et de l'humour, je retrouve un même mode de fonctionnement, ce qui n'est pas étonnant puisqu'il tient à l'approche pragmatique, où le récepteur ne saurait s'identifier à un modèle idéal valable pour tous.

Je pourrais tenter de placer mes trois espèces de mèmes sur ce triangle et l'on aurait quelque chose du même genre (ill. 16):

Si ce schéma est assez satisfaisant d'un point de vue ontologique, il ne faudrait pas néanmoins le considérer comme une description exacte du fonctionnement communicationnel. La fake news est évidemment fictive en tant qu'elle est inventée, mais elle peut être prise soit au sérieux et être 
considérée comme une information sur le monde réel, soit prise comme une bonne blague par ceux qui la reconnaissent d'emblée. De même, la frontière entre la parodie et la satire n'est pas fixée d'avance, elle dépend très fortement des savoirs latéraux du récepteur et de sa capacité à reconnaître les couches de références. Du point de vue de la réception, on pourra par exemple classer les commentaires de cette façon (ill. 17):

Ludique

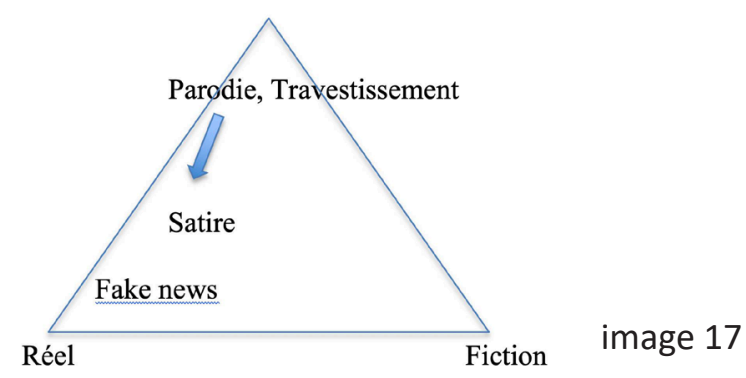

Un commentaire comme " parodie ou pas, c'est leur projet » (illustration 14) montre par exemple que la parodie, même si elle est identifiée comme parodie, peut être considérée comme une assertion vraie sur la réalité. De même, un commentaire sur les illustrations - "C'est un gouvernement d'hydrocéphales... J'ai honte »- est à la fois critique pour le gouvernement et ne voit pas forcément l'aspect ludique qui a été ajouté par le grossissement de la casquette. D’autres interrogent d'ailleurs le statut de cette image : « Dis-moi que c'est un montage ".

Analyser la réception en conservant le terrain tracé par réel-ludiquefictif montrerait beaucoup de décalages du même genre. Mais il est temps de conclure. L'étude des mèmes convainc que des concepts élaborés dans le champ des études télévisuelles peuvent être opératoires pour un autre objet, I'internet, à condition de leur faire subir quelques transformations. Elle montre aussi comment une approche structurale peut s'articuler avec une approche pragmatique qui prend en compte la signification sociale des images. C'est le dernier point sur lequel je voudrais insister en revenant sur ces « mèmes fake news » qui me semblent avoir le plus d'incidences sociologiques et politiques. Car, pour moi, la sémiologie se doit d'avoir une portée sociale et ne pas se contenter de faire plaisir à ses adeptes. "Research has shown, écrit Claire Wardle, that when people are fearful, oversimplified narratives, conspiratorial explanation, and messages that demonize others become far more effective. These memes did just enough to drive people to klick the share button. "

Une récente étude de l'agence Reuters montre, d'une part, que les moins de 35 ans sont fortement dépendant de leur smartphone et qu'ils vont vers les 
réseaux sociaux pour s'informer, contrairement aux plus de 35 ans qui préfèrent les sites d'informations. D'autre part, que leur préférence va vers les formats les plus visuels. Si l'on ajoute à cela le rôle du biais de conformité qui pousse l'usager à approuver d'emblée ce qui corrobore ses préjugés ou ses croyances, il faut considérer avec circonspection ce type de mèmes porteurs de fausses nouvelles.

Beaucoup de textes sur les réseaux sociaux partent de l'idée que tout ce qui touche au web est forcément nouveau parce que cela se trouve sur le web. Cette conception amnésique de la communication suscite beaucoup de discours euphoriques et dysphoriques sur la liberté de l'internaute, sur cette communication sans frontière, sans toujours s'apercevoir que les problématiques soulevées ont une histoire. Dans ce contexte, la sémiologie est souvent laissée de côté comme si, vieille discipline, elle était liée à de vieux objets. Confronter les outils d'hier aux objets audiovisuels d'aujourd'hui me semble un passage obligé vers la sémiologie du web 2.0.

\section{Ouvrages cités}

GENETTE, Gérard. 1982. Palimpsestes. La littérature au second degré, Seuil, coll. Poétique

GENETTE, Gérard. 1987. Seuils, éditions du Seuil, coll. Poétique.

JOST, François. 1998. "Le Genre télévisuel. Du contrat à la promesse », Bruxelles, Degrés $n^{\circ} 94$, été ; trad. esp. : "El Género televisual : del contrato a la promesa", Revista de Cine ${ }^{\circ} 1$, Facultad de Artes, Universitad de Chile, Santiago, décembre 2001

JOST, François. 1997. "La promesse des genres ", Réseaux n81, janvierfévrier ; trad. angl. "The promise of genres", Réseaux, The French Journal of Communication, vol. 6, $\mathrm{n}^{\circ} 1,1998$, University of Luton Press); https://www. persee.fr/doc/reso_0751-7971_1997_num_15_81_2883; https://www. academia.edu/220307/The_promise_of_genre

METZ, Christian. 1972. Langage et cinéma, Paris, Larousse

SEARLE, John R. 1982. Sens et expression, trad. fr., Paris, Minuit.

WARDLE, Claire. 2019. " Misinformation Has Created a New World Disorder ", Scientific American, https://www.scientificamerican.com/article/ misinformation-has-created-a-new-world-disorder/ 


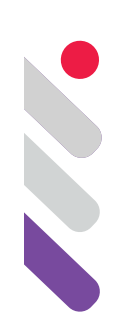

\title{
Vecindades digitales. Hacia qué objetos apuntan los índices
}

DOI: 10.24308/IASS-2019-8-024

\author{
María del Valle Ledesma \\ Universidad de Buenos Aires, Argentina \\ mariadelvalle.ledesma@gmail.com
}

\section{VECINDADES DIGITALES ${ }^{1}$}

Una reflexión sobre sentidos de lo urbano en Buenos Aires en los albores del siglo XXI

\section{Introducción}

Desde los leprosos expulsados fuera de los muros de las ciudades antiguas y medievales hasta las casas tomadas de la actual Buenos Aires, desde el ágora griega a la que accedían sólo los ciudadanos hasta los barrios cerrados de las afueras de Buenos Aires, desde la nave de los locos botada hacia ninguna parte hasta los cortes de calles en reclamo de trabajo, es posible reconocer la disputa más o menos violenta, más o menos explícita por el acceso y distribución del espacio urbano.

Sin embargo, la evidencia de esta disputa permaneció oculta -bajo la idea que procesos sociales y formas espaciales son cosas distintas o que los espacios apenas son los escenarios de aquellos procesos- hasta hace apenas cuarenta años, cuando con el giro hacia la espacialidad, los estudios urbanos (Lefrevre 1976, Castells 1977, Harvey 1977, Soja 2008) plantearon posiciones dirigidas a dar cuenta de la interpenetración de los procesos sociales con las formas espaciales, explorando los modos de construir espacios y tratando de entender cómo prácticas humanas diferentes crean y utilizan diferentes conceptualizaciones del espacio.

La irrupción de la digitalidad ha incorporado un nuevo elemento a la ecuación: la aparición del espacio virtual ha ocasionado un fuerte impacto en el ordenamiento territorial en razón de la lógica de la globalidad y la importancia creciente de las transacciones intangibles: en ocasiones, esta nueva lógica

\footnotetext{
${ }^{1}$ Debo este nombre a mi colega y amiga, la Dra. Mónica Pujol.
} 
separa aquello que es contiguo en el orden territorial mientras que une espacios alejados, desprovistos de toda contigüidad.

Mi presentación apunta a adentrarse en ese terreno apelando a las herramientas del semiótico y el analista del discurso antes que a las del geógrafo o del urbanista de quien tomaré prestados sus marcos conceptuales. Este trasvase de herramientas, quizás un tanto audaz, apunta a generar una ficción en el sentido que otorga Rancière al término (2010: 67): un momento de suspensión de las formas de enunciación habituales al abordar el tema intentando que, en ese espacio abierto, anide la reflexión antes que la demostración. Se trata de indagar e impulsar la indagación; se trata de instaurar una mirada sobre la ocupación y distribución de los espacios para pensar la división de lo sensible en camino hacia una política (Rancière 2005a, 2010b).

Se parte de pensar que, en ocasiones, esta nueva lógica separa aquello que es contiguo en el orden territorial mientras que une espacios alejados, desprovistos contigüidad 'real' pero dotados de continuidad simbólica. Una red de índices de diverso tenor organiza la circulación de los sentidos territoriales.

Esta situación parece un excelente punto de partida para pensar el lugar que tiene el que mira en la constitución de los índices. Si bien 'dirigen compulsivamente la mirada hacia su objeto', el objeto inmediato al que se dirigen es apenas una parte del objeto dinámico, que -lo sabemos- es un amasijo de modos de considerar eso que llamamos 'objeto'.

El trabajo parte de considerar dos acontecimientos ocurridos en la ciudad de Buenos Aires a mediados de la década pasada como una lente a través de la cual reflexionar sobre algunos los sentidos de la distribución del espacio urbano en el primer umbral del siglo XXI a la luz de los conceptos peirceanos de índice y objeto. Se postula que ambos hechos, de diferente carácter y significado, son expresión de algunos de los rasgos que ha traído consigo la nueva globalización urbana e ilustran de manera bastante gráfica los nuevos modos de vecindad propuestos en estas primeras décadas del tercer milenio.

Los hechos en cuestión son: la inclusión de Buenos Aires como ciudad de diseño en la Red de Ciudades Creativas del Programa de la UNESCO y la aparición en línea del Mapa Interactivo de Buenos Aires, ocurridos en los primeros años del siglo XXI. Más allá de la coincidencia de fechas, ambos hechos están ligados por su carácter digital y en tanto acciones realizadas con la implicación directa del gobierno de la ciudad, son portadores de un fuerte acento performativo.

En el primer caso, una autoridad externa -la UNESCO- dio curso al pedido realizado por la propia ciudad para ser incluida en una red extranacional de ciudades y en el segundo, es el mismo gobierno quien puso a disposición de los habitantes y visitantes de la ciudad, 'todas sus parcelas, fotos de fachada, 
códigos de zonificación correspondientes y rubros de habilitación permitidos', según se enuncia en el mismo mapa ${ }^{2}$.

La inclusión de ambas acciones en el terreno del mundo virtual -algunas de cuyas notas más saludadas desde posturas neoliberales son la cercanía ciudadana y la democratización- las convierte en vía regia para avanzar en una reflexión sobre el modo en que se piensa la continuidad espacial, la cercanía -y por extensión, la lejanía, la extrañeza- en una de las grandes ciudades contemporáneas. Quede claro que ambos acontecimientos se propondrán como fragmentos de las dinámicas urbanas sólo a modo de exemplum: no se busca encontrar allí las claves de las mutaciones y transformaciones, sino que, a la inversa, se partirá de una caracterización de dichos cambios para ilustrarlos a la luz de ambos acontecimientos.

Mi argumento, orientado principalmente al análisis crítico de las recientes transformaciones urbanas, apunta a mostrar, a partir de las vecindades, cómo el proyecto político urbano de una ciudad como Buenos Aires dilata y contrae sus fronteras en movimientos de inclusión uniformante y exclusión diferenciante.

Más concretamente, el análisis de la designación de Buenos Aires como Ciudad de Diseño y la puesta en línea del Mapa Interactivo de la Ciudad apunta a reflexionar sobre los usos del espacio y los sentidos en disputa propuestos por el proyecto político urbano de la ciudad de Buenos Aires vinculado a la concepción de ciudad como enclave económico autónomo. La glamorosa (y creativa) ciudad del diseño coexiste con la excluida (y peligrosa) ciudad de las villas; al ponerlas en relación, se busca generar un cierto malestar en la reflexión, una cierta incomodidad frente a las notas ditirámbicas de los proyectos de desarrollo de las nuevas ciudades.

\section{Buenos Aires, ciudad creativa}

En el 2005, Buenos Aires fue declarada Ciudad de Diseño integrándose así a la serie de ciudades que habían merecido o merecieron más adelante el galardón: Berlín, Montreal, Kobe, Nagoya, Seúl, Shenszhen y Bilbao.

El ademán de la UNESCO perteneciente a su programa de Red de Ciudades Creativas inscripto dentro del Proyecto de Alianza Global para la Diversidad Cultural busca generar puentes entre 'lugares del mundo para fomentar su desarrollo' tomando como atributo un aspecto central de la vida urbana contemporánea, en este caso, el diseño (De la Resolución de la UNESCO sobre Ciudades Creativas).

Las ciudades creativas, inteligentes o innovadoras constituyen un nuevo modo de concebir la ciudad como espacio de articulación, gestión y promoción de distintas expresiones del capital inmaterial. Su base teórica está expresada en la Declaración de las Naciones Unidas sobre las ciudades

2 Mapa Interactivo de Buenos Aires (febrero de 2015 versión 3.0). 
y otros asentamientos humanos en el nuevo milenio. 'Celebramos que las ciudades y los pueblos desempeñen una función económica cada vez mayor en un mundo en vías de mundialización, y que se haya avanzado en la creación de modalidades de asociación público-privadas y el fortalecimiento de las pequeñas empresas y las microempresas. En las ciudades y los pueblos radica la posibilidad de aprovechar al máximo los beneficios de la mundialización y paliar sus consecuencias negativas. La buena gestión de las ciudades puede brindar un entorno económico capaz de generar oportunidades de empleo y de ofrecer distintos bienes y servicios' (De la Resolución de la UNESCO sobre Ciudades Creativas).

La formulación de la UNESCO celebra el nuevo tipo de ciudad: la ciudad empresa basada en la explotación del capital inmaterial. Esta ciudad capaz de aprovechar los beneficios de la mundialización y al mismo tiempo, limar sus asperazas aparece casi como un tesoro deseable para una ciudad como Buenos Aires, orgullosa de sí misma pero siempre a desgano de sus ataduras a un cuerpo pequeño podríamos decir, invirtiendo la metáfora de Martínez Estrada.

Para la presentación ante la UNESCO solicitando ser incorporada al Programa, Buenos Aires exhibió su mejor perfil, describiéndose con rasgos casi ditirámbicos como ciudad referente para América Latina, como lugar de concentración del mercado nacional para aumentar el consumo y el aumento de los valores inmobiliarios y como centro productor de profesionales de la ciencia y la cultura:

Claramente [Buenos Aires] se está proyectando como una ciudad referente del diseño hacia América Latina gracias a la convergencia de múltiples factores coyunturales y culturales, que redundan en un ámbito fértil para este tipo de actividades. En este sentido, podríamos nombrar algunos factores de importancia, entre muchos otros, que sugieren que la producción de bienes de consumo diferenciados, y por lo tanto intensivos en diseño, es la más acorde para Buenos Aires. Por una parte, la ciudad concentra la mayor porción del mercado nacional, tanto en volumen como en diversidad económica y cultural, lo que podría convertirse en una oportunidad única para detectar nuevas tendencias de consumo que inspiren a las empresas a generar nuevos productos. En segundo lugar, el alto costo inmobiliario, debido a la densidad demográfica, dificulta la radicación de empresas de producción a escala, y por lo tanto exige una fabricación de productos con alto valor agregado. Por otra parte, la ciudad cuenta con una gran oferta de profesionales y de centros de estudio e investigación, por lo que el flujo de información y conocimiento, invalorable para la especialización y la innovación, se ve ampliamente favorecido por la cercanía. Finalmente, la ciudad de Buenos Aires, ha sido tradicionalmente un nodo cultural de importancia en América Latina, que favoreció el rápido desarrollo del turismo, y que le otorgó una gran impronta de identidad cultural en el imaginario latinoamericano. (de la Presentación hecha por Buenos Aires ante la UNESCO, pág 3). 
Sorprende la manera en que se expresa la histórica controversia entre Buenos Aires y el Estado Nacional. En esta presentación, nada liga a Buenos Aires con Argentina. No hay una sola palabra que indique que es una ciudad atada a un territorio nacional. Al contrario, se subraya su característica de nodo cultural y se enfatiza el gran futuro que le espera como referente para América Latina.

Como ente autónomo, Buenos Aires se presenta de manera vital, acorde a los ritmos de la época: capaz de incentivar el consumo, de abrir espacios para nuevos productos gracias a la diversidad económica y cultural, dos elementos indispensables en estas nuevas ciudades llenas de inmigrantes de todo el mundo que tallan su perfil con un cosmopolitismo del siglo XXI. En la presentación, Buenos Aires hace gala de los múltiples sectores que la habitan, casi un caleidoscopio de etnias que hacen a su diversidad cultural y también de un espectro variadísimo de perfiles económicos, con su extensa clase media. Además, aprovechando una imagen construida a partir del trabajo realizado durante más de un siglo por la educación pública y gratuita solventada por el Estado Nacional, se enorgullece de su carácter de ciudad culta y civilizada.

A lo largo de toda la presentación, elude toda relación con la nación por medio de diversas estrategias expositivas que eliden, transforman, sugieren. Un solo ejemplo: la declaración, refiriéndose a la UBA, dice que Buenos Aires 'cuenta' con una universidad pública y gratuita. El uso de verbo contar como sinónimo de poseer, resulta sospechoso en tanto elide un aspecto central: la universidad pública y gratuita de Buenos Aires es financiada por el gobierno nacional. Como se ve, en la promisoria descripción, la ciudad se apropia del patrimonio nacional y no muestra ninguna voluntad de compartir nada con el Estado Nación.

La retórica del postulante (el Gobierno de la Ciudad) es autorreferente y performativa; modula el pasado modifica el presente incluso volviendo inexistente aún lo que existe empíricamente (el ser capital de la República); al cambiar de signo las instituciones (la Universidad como creación de la ciudad) y opera sobre el futuro, clasificando de nuevo lo que fue clasificado.

El ejemplo apunta a mostrar cómo se rompe la continuidad territorial y se desvinculan los sitios a cambio de nuevos dispositivos territoriales. Para el Programa de la UNESCO, Buenos Aires está más cerca de Berlín que de Rosario. Para Buenos Aires, los vecinos deseados son aquellas ciudades que conforman la red. Así el programa de la UNESCO, es expresión de la aparición de una nueva política urbanística que bajo el objetivo explícito de vincular ciudades que poseen y protegen una tradición creativa en la literatura, el cine, la música, las artes populares, el diseño, el arte digital y la gastronomía, intenta mostrar una versión amigable de la globalización como escenario en el que conviven culturas irreconciliables. 
Si se tienen en cuenta los planteos acerca de la disminución de la economía nacional respecto a conjuntos sociales específicos enraizados en lugares específicos (Sassen 1991) y la perspectiva subsiguiente que postula la mayor autonomía de la ciudades del siglo XXI respecto de la región y el Estado (Smith 1998; Burgel 2014 ), queda claro que estas vecindades digitales referirían a una constelación de ciudades de gran autonomía político, económica y administrativa respecto del territorio regional y estatal y se inscribirían en una dinámica de desarrollo paralelo (entre ellas), antagónico (o prescindente) respecto del desarrollo nacional.

La celebración de la ciudad de diseño que se encuentra en las declaraciones del Gobierno de la Ciudad y de los cultores del diseño, oculta las notas oscuras que acompañan este tipo de modelo. Para que Buenos Aires sea vecina de Berlín o Bilbao es preciso avalar el proceso de gentrificación en la ciudad que produce el desplazamiento de los sectores populares de ciertos barrios como Palermo, San Telmo, Barracas y La Boca en beneficio de personas con mayor poder adquisitivo ${ }^{3}$. El Centro Metropolitano de Diseño de Buenos Aires, eje de la ciudad creativa, los lugares de diseño en Palermo, los desarrollos realizados en La Boca y San Telmo abonan cada desplazamiento de la población tanto de manera directa -cuando deben abandonar el lugar por desalojo o indemnizacióncomo indirecta -cuando al aumentar la valoración fiscal, no pueden sostener el pago de los impuestos o del alquiler-. Al ritmo de esa huida, aumentan las vallas de seguridad, los muros que separan los nuevos condominios y los espacios privados donde otrora había espacios públicos.

\section{El mapa interactivo de la ciudad de Buenos Aires}

En la misma década, el Gobierno de la Ciudad puso en línea el Mapa Interactivo de Buenos Aires, un sistema de información geográfica basado en el uso de cartografías temáticas y fotografías satelitales, para ser visualizado mediante una interfaz gráfica de ordenador que opera en el entorno de Internet. Accediendo a su portal, es posible obtener diversos datos sobre la ciudad y recorrerla digitalmente revisando sus fachadas o deteniéndose en sus cobijos. A través de sus niveles de lectura, es posible saber de manera inmediata cuál es el código de edificación vigente en la zona, cuáles son las habilitaciones municipales o cómo ir de un lugar a otro, evitando las zonas con congestión o peligrosas. Para este trabajo, la puesta en línea del Mapa Interactivo de Buenos Aires ofrece una oportunidad para mostrar otra cara de las vecindades planteadas por la digitalidad, analizando el tratamiento discursivo que se da a

\footnotetext{
${ }^{3}$ El proceso de gentrificación es complejo y en Buenos Aires viene desarrollándose desde 1979 como ha señalado De Virgilio. No se quiere decir acá que este proceso sea el resultado de haber declarado a Buenos Aires ciudad creativa sino que el ser ciudad creativa contribuye a profundizar el proceso de gentifricación.
} 
los asentamientos informales, villas, caracterizados por la irregularidad en la forma de acceso al suelo, la transgresión a la propiedad y/o a las disposiciones reglamentarias y la autoconstrucción de viviendas de gran precariedad. (Cravino 2006).

Se parte del trabajo realizado por Santángelo (2012) quien, con el objetivo de desmitificar la supuesta neutralidad del Diseño de Información, analiza la utilización de los actuales Sistemas de Información Geográfica (SIG) basados en el mapeo del planeta mediante el uso de imágenes satelitales. Su análisis hace foco en el sitio de Internet Mapa Interactivo de la Ciudad de Buenos Aires ${ }^{4}$ y demuestra cómo a partir de codificaciones universalistas, el Diseño de Información plantea y reproduce discursos en los que falta o se omite información relevante sobre algún aspecto de la realidad empírica, en este caso, las villas de la ciudad ${ }^{5}$.

Santángelo no ignora que los mapas son representaciones construidas y que, si bien están instalados en el imaginario social como una representación objetiva y neutral del mundo, son producidas desde espacios de podery autoridad que condicionan la presentación o elisión de sus aspectos constitutivos. No ignora por lo tanto que, en los mapas papel, tampoco están consignadas las villas. Sin embargo, lo que asombra a Santángelo y le permite dar una vuelta de tuerca a la lectura cartográfica, es la particular combinación en el sistema del mapa interactivo de dos modos de visualización que coexisten: la cartográfica y la fotográfica, advirtiendo un quiebre entre lo que se aprecia en la imagen fotográfica satelital y la información brindada por la cartografía icónica.

Este quiebre es brutal: mientras que la fotografía satelital muestra las urbanizaciones precarias emergentes, la cartografía niega su existencia señalando que las superficies ocupadas son nulas, elidiendo todo registro catastral y sobre todo, el registro fotográfico de las fachadas de los edificios (información que no es satelital). Así la navegación del mapa de Buenos Aires traslada al navegante digital, apenas cruzando una calle, de un prolijo alineamiento de las fachadas a un espacio inhabitado.

Sólo una calle separa las edificaciones de ese territorio vacío que, si hemos de creer a los GPS que se manejan con la información del Mapa Interactivo, son territorios cuya cercanía sólo puede traer peligros inconmensurables. Se está acercando a una zona peligroso, anuncia una voz neutra a los automovilistas

\footnotetext{
${ }^{4}$ Santángelo analiza las versiones en línea de difusión pública, 1.6 (Beta) y 2.0 (Beta) del mapa de la Ciudad de Buenos Aires, consultadas en agosto de 2010.

${ }^{5}$ Según las cifras del censo del 2010, las villas y asentamientos de la Capital se concentran en cuatro de las 15 comunas en las que está dividido el distrito: las dos que conforman la zona sur (la 4 y la 8), la 7 (Flores y Parque Chacabuco) y la 1, que agrupa los barrios de Constitución, Monserrat, Puerto Madero, Retiro, San Nicolás y San Telmo. Respecto de la población total del distrito, las villas y asentamientos representan casi el 6 por ciento de los 2.890 .151 habitantes. (La Nación, 2011).
} 
mientras el mapa interactivo muestra un territorio blanco como un enorme salar que nadie se atreve a cruzar. En su análisis, Sántangelo compara ese espacio vacío y sin embargo peligroso, con los dragones y monstruos que ornamentaban los mapas medievales mostrando los peligros que asechaban a quien se aventurara más allá de las rutas conocidas. Esta feliz analogía subraya el carácter monstruoso que las villas adquieren para el vecino -el buen vecinode Buenos Aires.

Pero la elisión es mayor todavía. Algunos datos suministrados por organismos gubernamentales de la ciudad brindan información sobre cultura, salud y educación, y pueden ser visualizados sobre el mapa ícono-diagramático, pero, al navegar la zona sobre la representación cartográfica satelital, en donde efectivamente se observan las urbanizaciones precarias emergentes, la información producida, categórica en cuanto a los datos catastrales, nada dice sobre la existencia de esos centros de salud, esas escuelas o salitas de primeros auxilios. Como señala Sántangelo, los esfuerzos de ciertas carteras gubernamentales, como Centros de Salud y Asistencia Comunitaria, Centros de Alfabetización, Educación Básica y Trabajo públicos, Bibliotecas Comunitarias son negados por el propio gobierno que los desconoce en las zonas donde efectivamente se observan los asentamientos (Santángelo 2012: 370).

Lo que vuelve particularmente significativa la navegación por estas vecindades, es la coexistencia de la analogía fotográfica con los diagramas cartográficos. En la representación de las zonas de la ciudad que están en regla con las leyes de propiedad y ocupación del espacio, la relación entre ambos sistemas es isomórfica mientras que en las zonas donde la ciudad es hecha en base a la transgresión, hay ausencia de isomorfismo. Las fachadas que existen en la realidad no pueden aparecer en el mapa porque están prohibidas por los sistemas de propiedad. Dicho en términos de Rancière, la policía pone una mordaza a la política (Rancière 2010).

Buenos Aires, publicados en páginas web, blogs y YouTube por vecinos, organizaciones sociales y medios alternativos de comunicación. "Nos encontramos con una sorpresa", señala Gutman, que se desempeña en el Observatorio de América Latina (OLA) de la New School University, de Nueva York.

"Intentando ver qué pasaba en los arroyos y lugares que eran objeto de protestas o demandas de transformación, utilizamos el Google Street View. Pero, muy pronto descubrimos en sus imágenes un gran contraste con las que subían los vecinos y asociaciones vecinales mostrando graves problemas de contaminación", señalan los autores.

Comprobaron, por ejemplo, que del tramo a cielo abierto donde el arroyo Sarandí desemboca en el Río de la Plata, las imágenes del Google Street View mostraban vallados de madera o mampostería que ocultaban la contaminación 
y basura del arroyo. "Sin embargo, el arroyo se encontraba expuesto en toda su dimensión contaminante en las imágenes subidas en videos, webs y blogs, como por ejemplo en el blogspot Villa Corina. Siguiendo con este tema vimos, al superponer la grilla celeste que marca el recorrido del Google Street View sobre la ciudad, que la mayoría de las villas de emergencia (con excepción de las villas 31,20 y 21-24 de la CABA), sólo tienen recorridos por sus contornos y ninguno en su interior", explican.

\section{El carácter performativo ${ }^{6}$}

El acto institucional de consagrar a Buenos Aires como ciudad de diseño o la presentación oficial de un hipertexto que dice representar a la ciudad de manera objetiva en tanto modalidades del discurso de la autoridad, encarnan una acción y ejercen un poder vinculante.

Esta capacidad, que se manifiesta en el punto nodal de la declaración -Buenos Aires es ciudad de diseño- o de la afirmación -estos territorios son fiscales-, remite a una convención, a un patrón de comportamiento autorizado que permite que las palabras y las acciones tengan el poder de transformar la realidad, que sean performativas.

Ambos actos, en tanto performativos, instauran un nombre -ciudad de diseño- o un territorio -este es el límite- que autorizan y desautorizan un conjunto de relaciones sociales incluidas en la formación de la ciudad.

Sin embargo, la ciudad real se resiste a reconocerse totalmente en esas formulaciones. Si se dice ciudad de diseño o estos son los límites hay una condición discursiva de reconocimiento social previa a la propia formulación que actuará en la construcción de una cierta Buenos Aires sobre la que también actuarán otros vectores, institucionales o no institucionales. La Buenos Aires implicada en ambas afirmaciones no es homogénea. Es una ciudad fragmentada, atravesada, es una ciudad dislocada.

Cuando la ciudad de Buenos Aires es declarada, en virtud de los fueros exhibidos en su presentación, miembro de una red de vecindades virtuales, las acciones materiales que se desprenden de aquí son bien precisas. En el mismo momento, se moviliza una red de acuerdos, becas, incubaciones, movilidades y sobre todo de recursos que le son otorgados por el sólo hecho de ser una ciudad creativa.

La declaración performativa no sólo formaliza un proceso que venía gestándose de manera espontánea (el del diseño) sino que el poder simbólico de ser ciudad de diseño, oficializada por la UNESCO, toma las riendas de ese proceso y lo encauza en una dirección. Así Buenos Aires se ve obligada a

6 En el análisis del carácter performativo se sigue especialmente a Austin (1981) y Bordieu (1985) aunque se han tenido presentes las posiciones de Derrida (1998). 
diseñarse para poder ser considerada igual a sus pares. Los barrios destinados al diseño se embellecen; la ciudad es pintada, hermoseada. La cultura gana las calles, los murales y graffitis forman un arco que es visitado por los turistas. El mercado inmobiliario de parabienes.

Lo que el performativo oculta, es la falacia del nombre: la ciudad de diseño es sólo un sector de la ciudad, pero sus consecuencias arrastran como un efecto de dominó, otras piezas del juego. Como dijimos, para que exista, es preciso que se transformen el espacio y las relaciones de propiedad. Es preciso que Barracas, San Telmo, Palermo, Recoleta (el pequeño circuito que conforma la sinécdoque con que se plantea el todo) cambien de dueño y de fisonomía.

Por su parte, en el caso la realización del mapa -incluido en el discurso del gobierno con abundantes declaraciones acerca del reconocimiento a la diversidad cultural y las estrategias de inclusión de todos los sectores- la performatividad del discurso de la autoridad es tal que vuelve inexistente aun lo que existe empíricamente. Así como en la presentación ante la UNESCO, se borraba por elisión la relación con la Argentina, el mapa borra de un plumazo al $6 \%$ de la población de Buenos Aires, clasificando a las casas y edificios según un derecho a la visibilidad desprendido del derecho de propiedad. Quien vive frente a una villa, no tiene vecinos cruzando la calle. Aquellos desposeídos, no tienen categoría en los mapas de la ciudad de Buenos Aires.

Es ambos casos, la performatividad, en su juego inmanente, es casi omnipotente. Se arroga el derecho a calificar la ciudad entera o la totalidad de sus viviendas según una norma. Ambas construyen la ciudad discursivamente como un todo, pero el todo que construyen es diferente en cada caso. En términos peirceanos, el objeto inmediato señala compulsivamente al derecho de propiedad. En definitiva, pareciera que la performatividad de estos actos contiene un doble gesto. En primer lugar, muestra que ningún discurso sobre la ciudad puede abarcar su totalidad y en segundo lugar, instaura vecindades diferentes a las habituales.

\section{Conclusiones}

Desde la perspectiva con que Bordieu (1985) completa la teoría de Austin, la performatividad sólo se puede explicar por la fuerza delegada que le otorgan a los discursos los grupos sociales que construyen conflictivamente las leyes del mercado lingüístico. Sabemos que la palabra de la autoridad es especialmente performativa pero si además, la autoridad obliga a la interiorización de su modelo, el carácter performativo se acentúa. En este punto, los dos ejemplos que analizamos, corren distinta suerte, aunque para la mirada del analista resulten complementarios.

Se partió de la consideración de que tanto en uno como en otro hecho se condensan ciertas claves de la producción de espacios en Buenos Aires que 
permiten hacer una lectura de las transformaciones del tejido político, social y económico expresadas en el nuevo contexto urbano. Ambos hechos visibilizan espacios que habitualmente aparecen separados: los espacios del diseño y los espacios de la villa y en ambos hechos se sintetiza buena parte de las formas de transformación urbana a la que se está asistiendo: autonomía de la ciudad respecto de la nación, consolidación de la ciudad como empresa que explota el capital cultural, fragmentación urbana, migración interna, crecimiento de la urbanización informal.

Con la denominación vecindades digitales se ha apuntado al carácter contradictorio de la ocupación de los espacios: lo global valorado sobre lo local: vecindades y cercanías globales, negación del semejante cercano incluirse como vecino de la ciudad. Varios estudios han mostrado cómo más allá de los mapas, esas vecindades son negadas en la realidad también ya que no sólo los ricos se aíslan de los pobres sino que aún en sectores pobres cercanos a las villas se ha construido garitas de cuidado, barreras y rejas (Prevot Shapira 2001).

Para nuestro trabajo, lo excluido se vuelve índice.

El proyecto de Bs As de incluirse en una constelación de ciudades de gran autonomía político, económica y administrativa respecto del territorio regional y estatal que se expesa en la creación de la ciudad de Diseño transforma los límites geográficos en función del proyecto; los límites son virtuales. Buenos Aires, lo decíamos, en este proyecto, se excluye voluntariamente de Argentina y se enlaza con Asia, Europa y América del Norte. De manera inversa, el planteo del Mapa Interactivo condena a la virtualidad a aquello que tiene existencia real. Las casas precarias de las villas de emergencia, aquellas que son sufridas en calor, frío y hacinamiento por sus habitantes, se esfuman en el ciberespacio que no les da derecho a la existencia.

Al contrastar la ciudad creativa con el modo en que el mapa de la ciudad elide parte de sus habitantes, se ha hecho aparecer con claridad la tensión entre la métropoli selectiva que participa en las redes mundiales y el otro modo de hacer ciudad, informal, periférico, negado. Con el contraste se ha querido enfatizar la crítica a un discurso dominante caracterizado por haber borrado de su horizonte la atención a los patrones locales de socialización en el espacio, de uso de la ciudad y de vida cotidiana.

Quiero subrayar la necesidad de enfatizar la reflexión sobre la dialéctica espacio público-espacio social, sobre las prácticas espaciales de los sujetos anónimos de la ciudad, $r$, que escuche los avances en las lecturas del espacio como arena liminal y elusiva, pero también como producto concreto de una historia y una temporalidad específicas (Sevilla 2010)

$Y$ en esto nos ayudan, otra vez, aquellos que se hacen un tiempo (Rancière 2010) para tomar la voz. 
En efecto, el carácter colaborativo (y contradictorio) de la digitalidad ofrece a los negados, borrados, estigmatizados, algunas posibilidades de revancha. Los habitantes de esos territorios, usando posibilidades ofrecidas por Google Map suben a esa plataforma sus propias fotografías y documentan su presencia. De esta manera, si se mira el mapa del Gobierno de la Ciudad, no hay fachadas -lo dijimos- pero si miramos Google Map, cientos de casillas con sus calles polvorientas, con sus habitantes (mujeres, jóvenes, niños, ancianas) toman por asalto el espacio vedado y nos sonríen desde el ciberespacio. Vale la pena mirar esas fotografías tan diferentes a las que sacan los fotógrafos cuando miran la pobreza. Estas son fotos miradas por los habitantes de esas tierras. Son sus primeros planos, sus selfies, sus encuadres. Ellos han copado el espacio.

El espacio virtual se concibe como objeto de debate. $Y$ las prácticas discursivas de un sector de población que por primera vez ha accedido a la producción de contenidos socialmente reproducibles, se vuelven constitutivas respecto de un territorio que, aunque no puede operar en la regulación jurídica, sí opera a nivel simbólico e identitario sobre todo el grupo.

Entonces, toman la palabra.

\section{Bibliografía}

AUSTIN, John. 1981. ¿Cómo hacer cosas con palabras?, Buenos Aires: Paidós.

BOURDIEU, Pierre. 1985. ¿Qué significa hablar? Las reglas del intercambio lingüísitico. Madrid: Akal.

BURGEL, Guy. 2014. La revancha de las ciudades. Buenos Aires: EDUNLA

CARMAN, María. 2011. Las trampas de la Naturaleza. Buenos Aires, Fondo de Cultura Económico.

CASTELLS, Manuel. 1977. Sociología del espacio industrial. Madrid: Ayuso.

CRAVINO, Maria Cristina. 2006. Las villas de la ciudad. Mercado e informalidad urbana. Buenos Aires: Universidad Nacional de General Sarmiento.

DERRIDA, Jacques. 1998. Márgenes de la filosofía. Madrid: Cátedra.

DIAZ ORUETA, Fernando LOURES SEOANE, María. 2003. La ciudad posfordista: economía cultural y recualificación urbana en Revista de Economía Crítica, № 2., Valladolid: Ed Economía crítica.

FOUCAULT, Michel. 1987. Historia de la sexualidad I: La voluntad de saber. Madrid: Siglo XXI. 
http://www.macba.cat/uploads/publicacions/contratextos/capital_financiero/ Capital_financiero_neilSmith.pdf (consultado en noviembre 2016).

LEFEBVRE, Henry. 1976. Espacio y Política: El derecho a la ciudad, II. Madrid, Península.

MANSILLA LÓPEZ, José. 2014. Multifuncionalidad y externalidades en contextos urbanos. Ideas para una política antigentrificación, Recurso electrónico en línea https://www.academia.edu/5506829/Multifuncionalidad_y_ externalidades_en_contextos_urbanos._Ideas_para_una_pol\%C3\%ADtica_ antigentrificaci\%C3\%B, (consultado en diciembre 2014).

MONTIGNY, Gilles. 2008. Guy Burgel, La Revanche des villes, Espace populations sociétés (En ligne) http://eps.revues.org/247 (consultado en febrero 2015).

PREVOT SHAPIRA, Marie. 2001. Fragmentación espacial y social: perfiles y realidades en Perfiles Latinoamericanos no 16, México: Flacso.

RANCIÈRE, Jacques. 2005. Políticas estéticas, Barcelona: Universidad Autónoma de Barcelona.

RANCIÈRE, Jacques. 2010. El espectador emancipado, Buenos Aires: Manantial.

SANTANGELO, Miguel Angel. 2012. Dragones ocultos. La elisión discursiva de la realidad en el diseño de información, en Actas VII. Congreso Internacional de semiótica: En búsqueda de los contornos de una disciplina de Parra O., Elizabeth; Rodrigo Moulian T.; Rodrigo Browne S.; Norma Huerta A.; y Ricardo Baessolo S. (eds.). Valdivia: Ediciones Universidad Austral de Chile. pp 359-396.

SASSEN, Saskia. 1991. The Global City, New York, London, Tokyo. Princeton: Princenton University Press.

SASSEN, Saskia. 2010. Territorio, autoridad y derechos. De los ensamblajes medievales a los ensamblajes globales. Madrid: Editorial Katz.

SEVILLA BUITRAGO, Álvaro. 2010. Urbanismo, biopolítica, gubernamentalidad: vida y espacio en la renovación de los estudios urbanos. Boletín $\mathrm{CF}+\mathrm{S}, 44$, pp. 41-49. Recurso electrónico en línea: http://habitat.aq.upm.es/boletin/n44/ aasev.html (Consultado el 28 de enero de 2015).

SMITH, Neil. 1998. El redimensionamiento de las ciudades: la globalización y el urbanismo neoliberal.

SMITH, Neil. 2012. Nueva frontera urbana. Revanchismo y gentrificación. Madrid: Traficantes de sueños. 
SOJA, Edward. 2008. Postmetrópolis. Estudios críticos sobre las ciudades y las regiones. Madrid: Traficante de sueños.

YUDICE, George. 2002. El recurso de la cultura. Usos de la cultura en la era global. Barcelona: Gedisa.

\section{Documentos citados}

Declaración de la UNESCO sobre Ciudades Creativas (A/RES/S-25/2 del 9 de junio de 2001).

https://www.google.com.ar/webhp?sourceid=chrome-

instant\&ion=1\&espv=2\&ie=UTF-8\#q=declaracion\%20de\%20la\%20unesco activa a febrero 2020)

Presentación de Buenos Aires ante la UNESCO (mimeo)

Mapa Interactivo de Buenos Aires (febrero de 2015 versión 3.0). Disponible en: http://mapa.buenosaires.gob.ar/

Diario 'La Nación’ 5 de octubre de 2011 


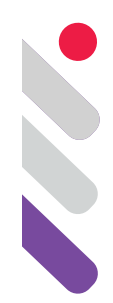

\title{
Rostros gigantes: tamaño versus proporción en la semiótica del poder ${ }^{1}$
}

DOI: 10.24308/IASS-2019-8-025

\author{
Massimo LEONE \\ Universidades de Turín y Shanghái \\ massimo.leone@unito.it
}

\begin{abstract}
"Wenn man einen Riesen sieht, so untersuche man erst den Stand der Sonne und gebe acht, ob es nicht der Schatten eines Pygmäen ist."

["Cuando se vea a un gigante, primero se debería observar la posición del sol y averiguar que no se trate de la sombra de un pigmeo."]

Novalis, Das Allgemeine Brouillon, 1798-99, 107.
\end{abstract}

\section{El rostro gigante de Miguel Ángel}

En el marzo de 1505, el entonces papa Julio $\|^{2}$ convocó a Miguel Ángel ${ }^{3}$ en Roma para encargarle la creación de una sepultura monumental. En sólo dos meses, el pontífice y el artista se acordaron sobre proyecto y precio. Miguel Ángel viajó entonces a Carrara con el intento de elegir los bloques de mármol blanco para el nuevo monumento. El trabajo de elección y extracción del precioso material tardó mucho más. Durante ocho meses, el artista florentino permaneció en Carrara, pasó los días y las noches en las canteras, escrudiñó las montañas, observó sus cándidas entrañas de hito en hito, olió el polvo, tanteó las venas, oyó el fragor de los bloques al destacarse de la madre montaña, y hasta sintió en su boca el polvillo del mármol, el mismo col que, a su decir,

\footnotetext{
${ }^{1}$ Una primera versión de este texto fue presentada como conferencia plenaria en ocasión del XIV Congreso Mundial de Semiótica, en Buenos Aires, el 13 de septiembre de 2019. Agradezco todos los organizadores por la extraordinaria oportunidad.

This project has received funding from the European Research Council (ERC) under the European Union's Horizon 2020 research and innovation programme (grant agreement No 819649 FACETS).

2 Giuliano della Rovere; Albissola Marina, República de Génova, actual Italia, 5 de diciembre de 1443 - Roma, Estados Pontificios (actual Italia), 21 de febrero de 1513; papa desde 1 de noviembre de 1503 hasta 21 de febrero de 1513.

3 Caprese Michelangelo (República de Florencia, actual Italia), 6 de marzo de 1475 - Roma (Estados Pontificios, actual Italia) 18 de febrero de 1564.
} 
había sido amamantado en su niñez, "latte impastato con la polvere di marmo", "leche amasada con polvo de mármol", en el pueblito de Settignano, donde vivía su nodriza, y trabajaban los canteros que extraían la "pietra serena". Pero al mirar el mármol, al oírlo, al tocarlo, al olfatearlo, incluso al catar su polvo, Miguel Ángel, según nos cuenta su biógrafo personal Ascanio Condivi (Fig. 1), ${ }^{4}$ no buscaba en el corazón de las canteras el rostro del papa Julio II. Miguel Ángel quería esculpir al propio Dios.

Tras pasar ocho largos meses estudiando las inmensas montañas de Carrara, empezó a ver que algo gigantesco, un monstruo invisible, un ser de tamaño extraordinario vivía en aquel blanco material. A los ojos del artista, los recovecos de las canteras se transformaron paulatinamente en dedos, pies, piernas, brazos, hombros; músculos blancos aparecían en las paredes, una sangre láctea latía en ellas, y más arriba en la montaña se hinchaba un pecho de gigante, y las laderas se torcían en cintura poderosa, y aún más arriba, en la cima de los Alpes Apuanes, ya se veía la cara de un hombre, su boca cerrada, la mirada fija hacia el mar, los cabellos alborotados por el viento tempestuoso que sopla a esa altura.

Fue entonces que Miguel Ángel dejó de buscar los bloques más aptos para dar forma de mármol a los caprichos de sus clientes y empezó a creer que en la montaña entera se escondía la figura de un gigante, creado a imagen y semejanza de Dios. Concibió por lo tanto el proyecto titánico de liberarlo, de transformar la montaña en la estatua de un coloso de mármol que con su mirada luciente orientara los navegantes hacia los puertos de Toscana:

Stette in quei monti con due servitori, et una cavalcatura, senza altra provisione, se non del vitto, meglio d'otto mesi. dove un giorno quei luoghi veggendo, d' un monte, che sopra la marina riguardava, gli venne voglia di fare un Colosso, che da lunghi apparisse a' navaganti, invitato massimamente dalla comodità del masso, donde cavare acconciamente si poteva, et dalla emulatione delli antichi, iquali forse per il medesimo effetto che Michelagnolo, capitati in quel loco, o per fuggir l'otio, o per qual si voglia altro fine, v'hanno lasciate alcune memorie imperfette, et abbozzate, che danno assai bon saggio de l'artifitio loro. Et certo l'harebbe fatto se'l tempo bastato gli fusse, o l'impresa per laquale era venuto, l'havesse concesso. ${ }^{5}$

[Permaneció en esos montes con dos servidores, un caballo y ninguna otra provisión excepto la comida más de ocho meses. Y un día, observando en esos lugares un monte, del que se gozaba una vista hacia la marina, nació en él el deseo de esculpir un Coloso que desde lejos apareciera a los navegantes, y fue inspirado máximamente por la ductilidad de la piedra, en la que se podía esculpir fácilmente, y por la emulación de los antiguos, los cuales, tal vez inspirados como Miguel Ángel, cuando que se habían hallado allí, o sea para huir el ocio, o sea

${ }^{4}$ Ripatransone, 1525 - Ripatransone, 10 dicembre 1574.

5 (Condivi 1553: 14 verso). 
para cualquiera otra finalidad, habían dejado algunas memorias imperfectas, y esbozadas, que son una buena prueba de su ingenio. Y cierto Miguel Ángel hubiera cumplido con su deseo, si el tiempo hubiera sido suficiente, o si la impresa, para la cual había ido allí, lo hubiese permitido]; trad. nuestra.

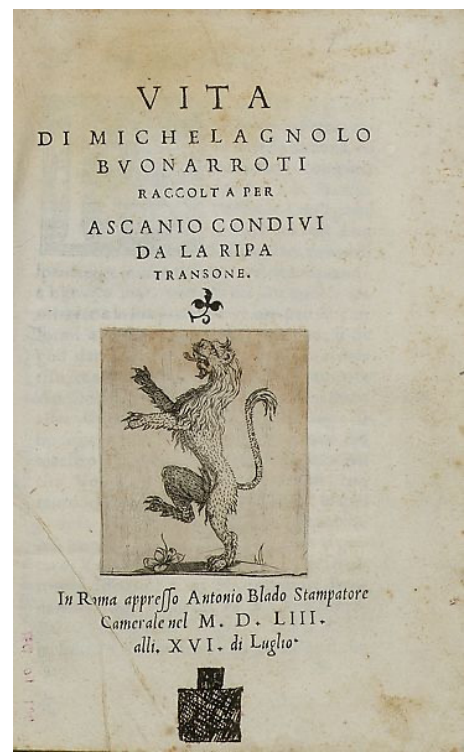

Fig. 1: Ascanio Condivi. 1553. Vita di Michelagnolo Buonarroti raccolta per Ascanio Condivi da la Ripa Transone. Roma: appresso Antonio Blado Stampatore Camerale.

El proyecto colosal nunca se concretizó. En 1506, Miguel Ángel volvió a Roma y descubrió que ya Julio II no se interesaba más por su propia sepultura y dedicaba sus atenciones a otras obras y batallas.

\section{El rostro gigante en la antigüedad}

Pero tampoco se había realizado el proyecto de aquel otro escultor excelso el cual probablemente había inspirado a Miguel Ángel en su "emulación de los antiguos". Como lo relatan las fuentes griegas y latinas, Dinócrates de Rodas, ${ }^{6}$ también conocido como Estasícrates o como Quirócrates, fue el primero a concebir el plan de transformar una montaña en la escultura de un hombre. No quiso representar a un gigante, sin embargo, ni a un dios, sino a un jovencito que, en su época, había adquirido el estatus divino y conquistado todo el mundo conocido: Alejandro Magno. ${ }^{7}$ Cuenta Vitruvio, ${ }^{8}$ en el II libro del De Arquitectura, que el ambicioso arquitecto y urbanista Dinócrates había dejado su natía Macedonia para seguir en las batallas el ejercito de Alejandro, encontrar al grande imperador y proponerle cara a cara un proyecto

\footnotetext{
${ }^{6}$ Nacido a finales del siglo IV a.C.

7 Pela, Macedonia, Antigua Grecia, 20 o 21 de julio de 356 a. C. - Babilonia, 10 o 13 de junio de 323 a.C. Sobre la historia y la filología del proyecto, se consulten Schama 1995; Desideri 2001; Speake 2002; Cagnazzi 2005; Della Dora 2005.

8 Marcus Vitruvius Pollio, Roma (Italia) c. 80-70 a.C. - c. 15 a.C.
} 
extraordinario. Dinócrates, en efecto, también había visto un gigante en una montaña, aunque no se tratara de los Alpes Apuanes de Miguel Ángel sino del monte Athos, donde siglos después se constituiría el enclave de los monasterios ortodoxos. Pero Dinócrates no había observado esta montaña con los ojos del escultor, como lo hará su homologo florentino, sino con los del arquitecto y urbanista. Por lo tanto, le propuso a Alejandro de transformar el monte Athos en la inmensa estatua de un hombre, el cual sujetaría en su mano izquierda una ciudad y, en la derecha, una copa desmesurada, hacia donde confluirían todos los ríos de la montaña. Miguel Ángel había leído a Vitruvio, y la historia del proyecto de Dinócrates le había impresionado. Como su antesignano griego, el florentino también murió sin haber transformado la montaña en un gigante. Sin embargo, el coloso empezó a vivir en las artes visuales.

\section{El rostro gigante en la modernidad}

Los estudiantes italianos hoy entregan sus tesis con frontispicios banal- $y$ tristemente homologados, pero en el siglo XVII los utilizaban para agradecer de manera hermética a sus benefactores. En el frontispicio de las Conclusioni entregadas por el estudiante español Cristoforo Lozano en 1666 para obtener el título de doctor en la Universidad "Sapienza" de Roma aparece una imagen dibujada por Pietro da Cortona ${ }^{9}$ y grabada por François Spierre (Fig. 2)..$^{10}$

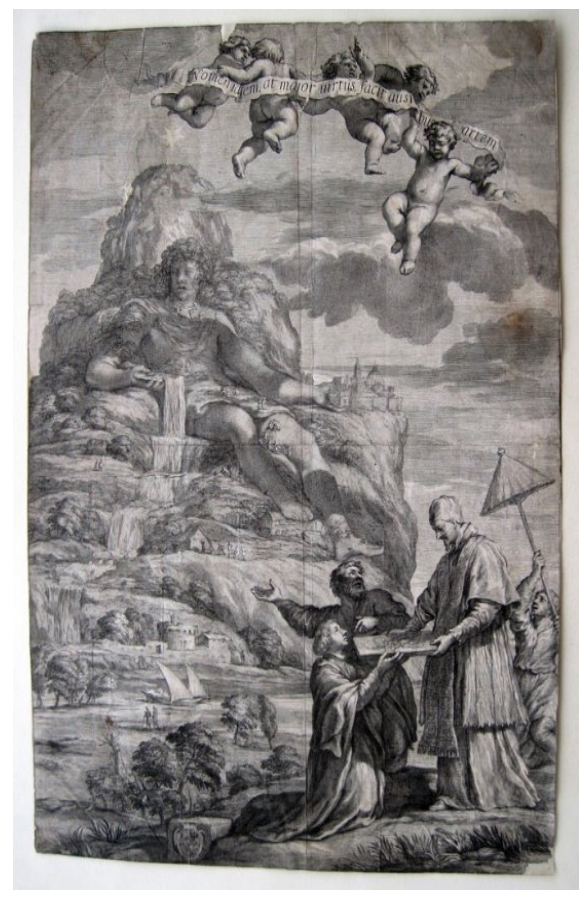

Fig. 2: Frontispicio de la tesis de Cristophorus Lozanus. 1666. Diseño de Pietro da Cortona. Grabado de François Spierre. Grabado en Roma. 37,2 x 27,1 cm. Londres: British Museum.

\footnotetext{
9 Pietro Berettini; Cortona, Italia, 1 de noviembre de 1596 - Roma, Italia, 16 de mayo de 1669.

10 Nancy, 12 de noviembre de 1639-Marsella, 6 de agosto de 1681.
} 
Representa al artista italiano que, de rodillas, entrega al Pontífice el mismo grabado, mientras que un tercer personaje, el anciano arquitecto y urbanista Dinócrates, indica con sus gestos, postura, y rostro la correspondencia entre la imagen entregada y el grabado mismo. El mensaje visual del frontispicio, un caso ejemplar de mise en abyme, juega con la homonimia entre el Emperador macedonio Alejandro y el Papa Alejandro $\mathrm{VII}^{11}$ incitando al segundo a reconocerse en su glorioso homónimo a través de una serie de signos sibilinos, como los robles a los pies de la montaña, referencia a los que aparecían en el blasón del pontífice.

Tal vez el estudiante español Cristoforo Lozano había leído el libro que un compatriota suyo, el diplomático y hombre de letras Diego de Saavedra Fajardo, ${ }^{12}$ había publicado algunos años antes, en 1640, con gran éxito internacional: Idea de un Príncipe Político Christiano representada en cien empresas. En esta versión cristianizada de Maquiavelo, la Empresa 40, titulada "Pese la liberalidad con el poder. Quae tribuunt, tribuit" (Fig. 3), se refiere sibilina pero significativamente a la concepción del poder encarnada por el proyecto de Dinócrates:

A los príncipes llaman montes las divinas Letras, y a los demás, collados y valles. Esta comparación comprende en sí muchas semejanzas entre ellos; porque los montes son príncipes de la tierra, por ser inmediatos al cielo y superiores a las demás obras de la Naturaleza, y también por la liberalidad con que sus generosas entrañas satisfacen con fuentes continuas a la sed de los campos y valles, vistiéndolos de hojas y flores, porque esta virtud es propia de los príncipes. Con ella, más que con las demás, es el príncipe parecido a Dios, que siempre está dando a todos abundantemente. Con ella la obediencia es más pronta, porque la dádiva en el que puede mandar hace necesidad, o fuerza la obligación. El vasallaje es agradable al que recibe. ${ }^{13}$
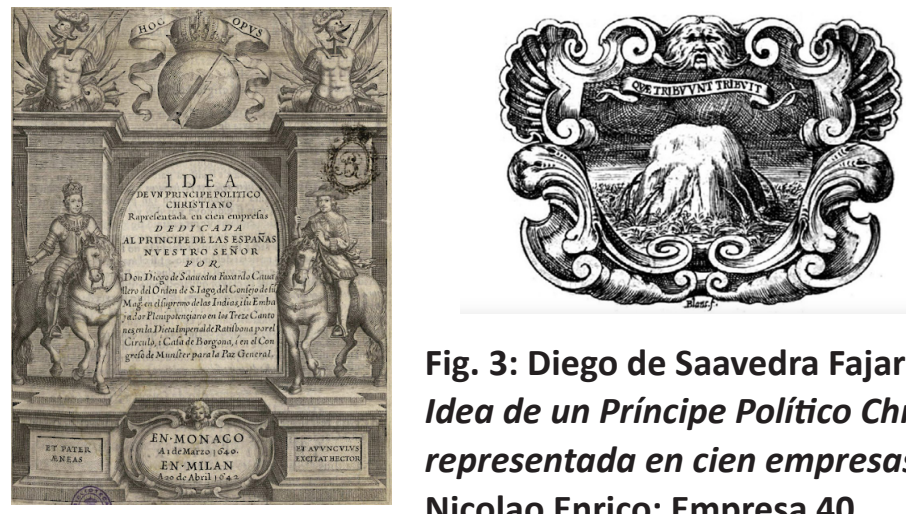

Fig. 3: Diego de Saavedra Fajardo. 1640. Idea de un Príncipe Político Christiano representada en cien empresas. Münster: Nicolao Enrico: Empresa 40.

\footnotetext{
${ }^{11}$ Fabio Chigi; Siena, Italia, 13 de febrero de 1599 - Roma, 22 de mayo de 1667; papa desde 7 de abril de 1655.

12 Algezares, Murcia, 6 de mayo de 1584 - Madrid, 24 de agosto de 1648.

${ }^{13}$ Diego de Saavedra Fajardo. 1640. Idea de un Príncipe Político Christiano representada en cien empresas. Münster: Nicolao Enrico: Empresa 40.
} 
El recurso a la imagen del poder como montaña transformada en gigante no exaltó solamente el dominio absoluto de pontífices y monarcas sino también él del estado, como en el famoso frontispicio creado por Abraham Bosse ${ }^{14}$ para el Leviatán de Thomas Hobbes ${ }^{15}$ en 1651 (Fig. 4): en este grabado, el poder absoluto se representa a la vez como una montaña más alta que las otras, como la efigie de un soberano, y como un cuerpo gigante creado por los cuerpos de una muchedumbre.

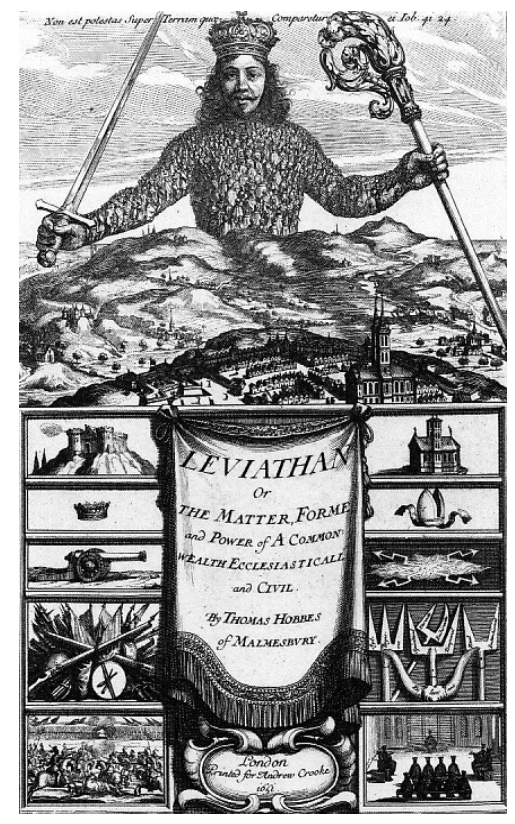

Fig. 4: Abraham Bosse. 1651. Frontispicio de Leviathan, de Thomas Hobbes. Londres: Andrew Crooke.

Incluso en la Francia republicana, en 1796, Pierre-Henri de Valenciennes ${ }^{16}$ pintó un Monte Athos transformado en monumento para Alejandro (Fig. 5). ${ }^{17}$ Muchos lo interpretan como una representación alegórica del poder republicano, y sin embargo no se puede excluir que el intento del pintor francés fuera de aludir a su propia estética de la pintura de paisaje, luego programáticamente descrita en la obra Elemens de perspective pratique à l'usage des artistes, suivis de reflexions et conseils à un élève sur la peinture et particulièrement sur le genre du paysage (1799) (Fig. 6). En ella, se subrayaba la exigencia de considerar la pintura de paisaje como si fuera la de un retrato, exactamente como el rostro de Alejandro que, en la pintura de Valenciennes, parece surgir naturalmente del monte Athos.

\footnotetext{
${ }^{14}$ Tours, Francia; c. 1602-1604 - 14 de febrero de 1676.

15 Westport, cerca de Malmesbury, 5 de abril de 1588 - Derbyshire, 4 de diciembre de 1679.

16 Toulouse, 6 de diciembre de 1750-París, 16 de febrero de 1819.

17 Véase Wilson-Chevalier 1997.
} 


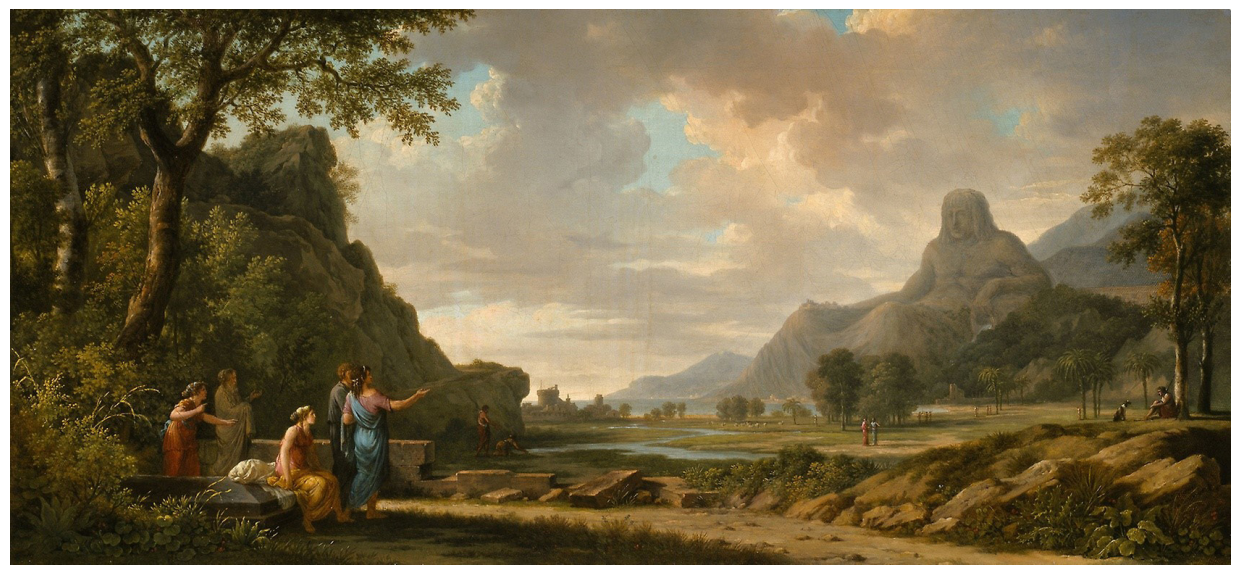

Fig. 5: Pierre-Henri de Valenciennes. 1796. Monte Athos transformado en monumento para Alejandro. Óleo sobre lienzo. 41,9 × 91,4 cm. Chicago, IL: Art Institute.

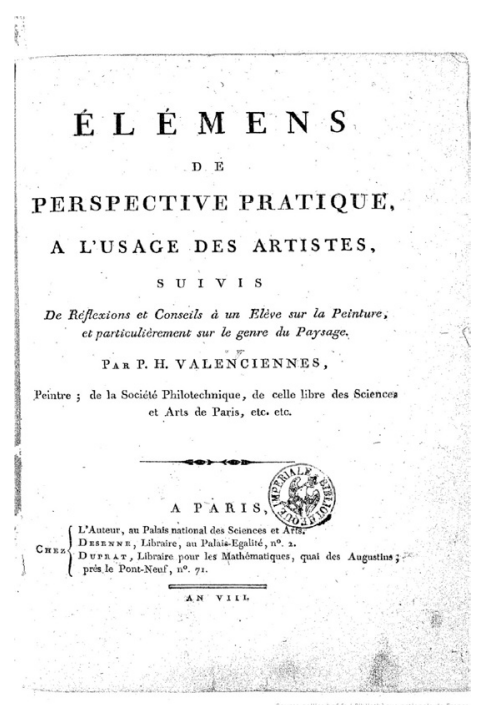

Fig. 6: Pierre-Henri de Valenciennes. 1796. Elemens de perspective pratique à l'usage des artistes, suivis de reflexions et conseils à un élève sur la peinture et particulièrement sur le genre du paysage. París: DesenneDuprat.

De hecho, lo que ni la arquitectura de Dinócrates ni la escultura de Miguel Ángel habían podido conseguir, o sea la transformación de una montaña entera en el cuerpo de un poderoso gigante, permanece y de alguna manera se realiza en simulacro en el imaginario político y visual del Occidente. Pietro da Cortona y su estudiantil cliente lo utilizaron para alabar al papa Alejandro VII; Diego de Saavedra Fajardo para delinear las virtudes del príncipe cristiano; Thomas Hobbes para aludir al poder del estado absoluto, y Pierre-Henri de Valenciennes para enfatizar la superioridad de la Republica, así como la dignidad de la pintura de paisaje. 


\section{El rostro gigante en el Oriente}

Otra realización visual del proyecto de Dinócrates se encuentra en una obra publicada en 1721 por el célebre arquitecto austriaco Johann Bernhard Fischer von Erlach, ${ }^{18}$ campeón de la arquitectura habsburguica, o sea en el Entwurf einer historischen Architektur (Fig. 7), una comparación trans-cultural y trans-histórica de todos los grandes edificios del pasado.

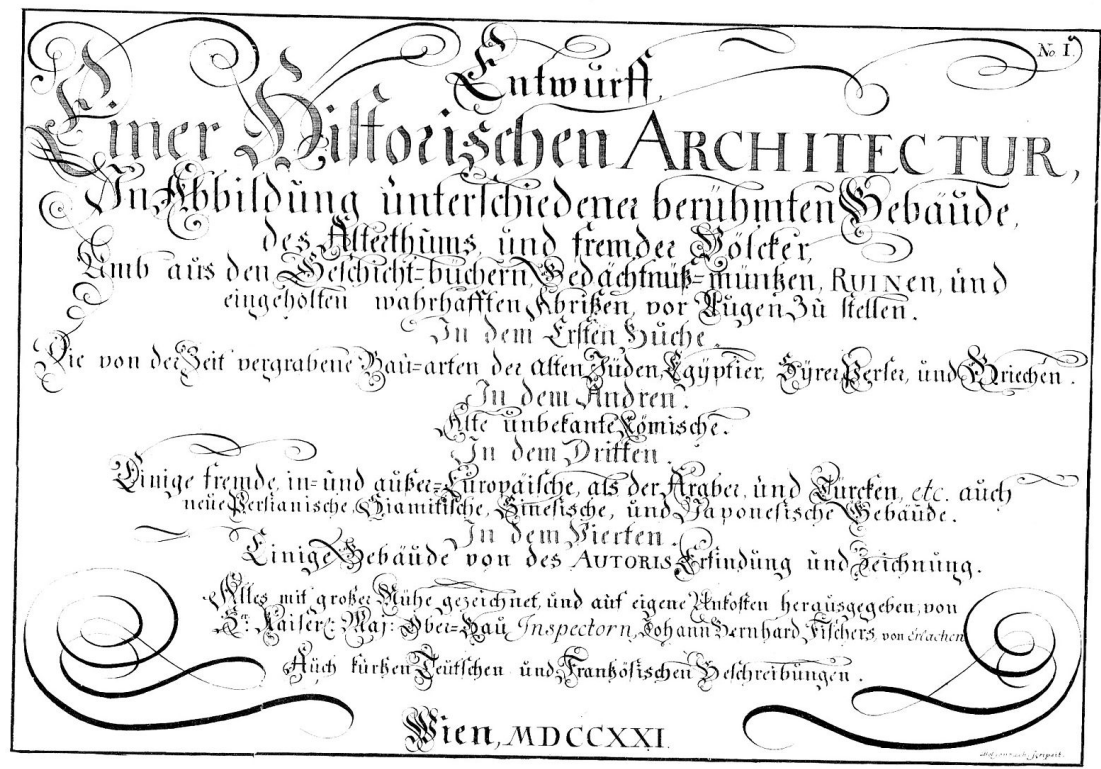

Fig. 7: Johann Bernhard Fischer von Erlach. 1721. Entwurf einer historischen Architektur. Viena, Tabula XVII.

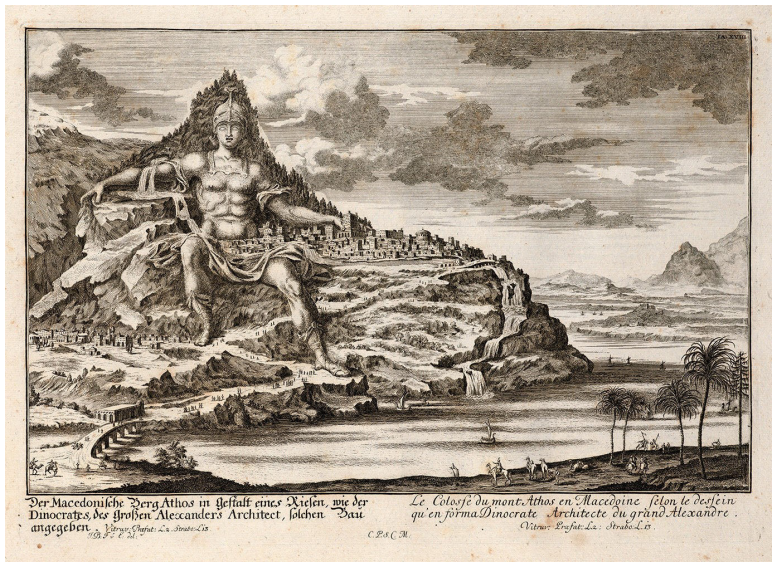

Fig. 8: Johann Bernhard Fischer von Erlach. 1721. Entwurf einer historischen Architektur. Viena, Tabula XVII.

${ }^{18}$ Graz, 20 de julio de 1656 - Viena, 05 de abril de 1723. 
Cabe subrayar que Fischer von Erlach no compara el proyecto de Dinócrates a arquitecturas occidentales, sino a obras de Oriente medio o extremo. En la Tabula XVII, titulada "Der macedonische Berg Athos in RiesenGestalt" (Fig. 8), el arquitecto austriaco menciona que la reina asiria Semíramis también había hecho esculpir su retrato gigante en la montaña ahora conocida como Behistún, en la provincia de Kermanshah, al oeste de Irán. Seguramente, la fuente de Fischer von Erlach es Diodoro Sículo, ${ }^{19}$ que relata el episodio en el Il libro de su Bibliotheca Histórica (13):

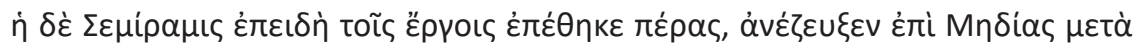

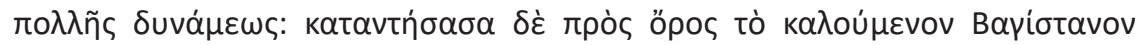

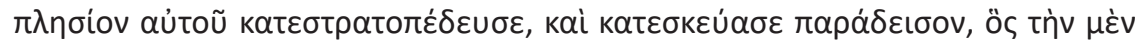

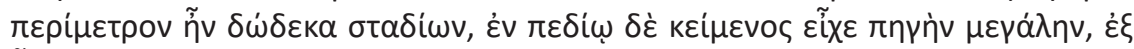

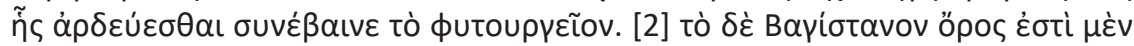

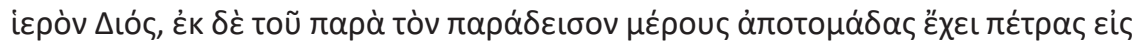

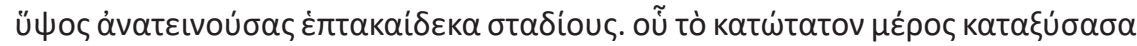

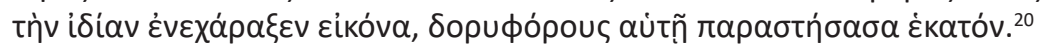

[Semiramis, habiendo logrado sus labores (en Babilonia), marchó sobre los Medios con un vasto ejército; pero cuando llegó a la montaña llamada Bagistanón, acampó cerca de ella y preparó un paraíso, cuya circunferencia era de doce estadios, y que, al estar en la llanura, tenía una gran fuente, de la cual todas las plantas podían ser regadas. La montaña en sí es sagrada para Zeus, y tiene rocas abruptas en la ladera hacia el jardín, que se elevan a diecisiete estadios de altura. Después de cortar la parte inferior de la roca, hizo que su propio retrato fuera esculpido allí, junto con los de un centenar de guardias asistentes.] (trad. nuestra).

Es interesante que, en otro pasaje de la misma obra, Diodoro Sículo relate como Alejandro Magno, en su marcha de Susa a Ecbatana, hubiese desviado su camino para admirar aquel paraíso. Pero Fischer von Erlach considera que aquella escultura gigante que Dinócrates no pudo realizar se concretizó no solamente en el Oriente medio, sino también en el extremo. En la misma Tabula XVII, cita a Erasmus Finx, ${ }^{21}$ mejor conocido como Erasmus Francisci, hoy considerado como uno de los primeros escritores profesionales de la modernidad. En 1668, este prolífico y polifacético autor alemán quiso aprovechar de la nueva pasión europea para los viajes exóticos publicando un libro que fue muy vendido y leído, Ost- und West-Indischer wie auch Sinesischer Lust- und Stats-Garten: in drey Haupt-Theile unterschieden (Fig. 9), en el que describía todos los paisajes extraordinarios encontrados por los exploradores europeos. En la página 1070,

\footnotetext{
${ }^{19}$ Agira (Italia), c. 90 a.C. - c. 30 a.C.

20 Diodoro Sículo (90-30 a.C.). Bibliotheca Histórica, II, 13.

${ }^{21}$ Lübeck, 16 de noviembre de 1627 - Núremberg, 20 de diciembre de 1694.
} 
en la sección dedicada a los jardines chinos, Erasmus Francisci escribe:

Zwischen der Hauptstadt Chung-king und der Stadt Tungchuen, in der ReichsLandschaft Suchuen, ist am Ufer des Flusses Fu ein abenteuerlicher Berg zu schauen. Denn wiewohl er ziemlich hoch; hat man ihn doch recht wie einen natürlichen Menschen gebildet; ihm Kopf, Augen, Nasen, Ohren, Brust, Bauch, Arme und Beine gemacht und eine sitzende Postur gegeben. Seine Füße zeugt dieses Berg-Bild. [...] Solches ungeheure Berg und Götzen-Bild wird unter dem Namen $\mathrm{Fe}$, Göttlich von Ihnen, zu gewissen Zeiten verehrt und angebetet.

[Entre la capital Chung-king y la ciudad de Tungchuen, en el reino de la provincia de Suchuen, se puede ver a orillas del río Fu una montaña maravillosa. Ya que es bastante alta, se le ha dado la forma de un hombre natural; se le hizo cabeza, ojos, narices, orejas, pecho, abdomen, brazos y piernas y se le dio una postura sentada. Esta montaña-figura muestra sus pies. [...] Periódicamente, tal montaña monstruosa y la imagen del ídolo son objetos de devociones y ofrendas bajo el nombre de Fe, deidad de ellos.] (trad. nuestra).
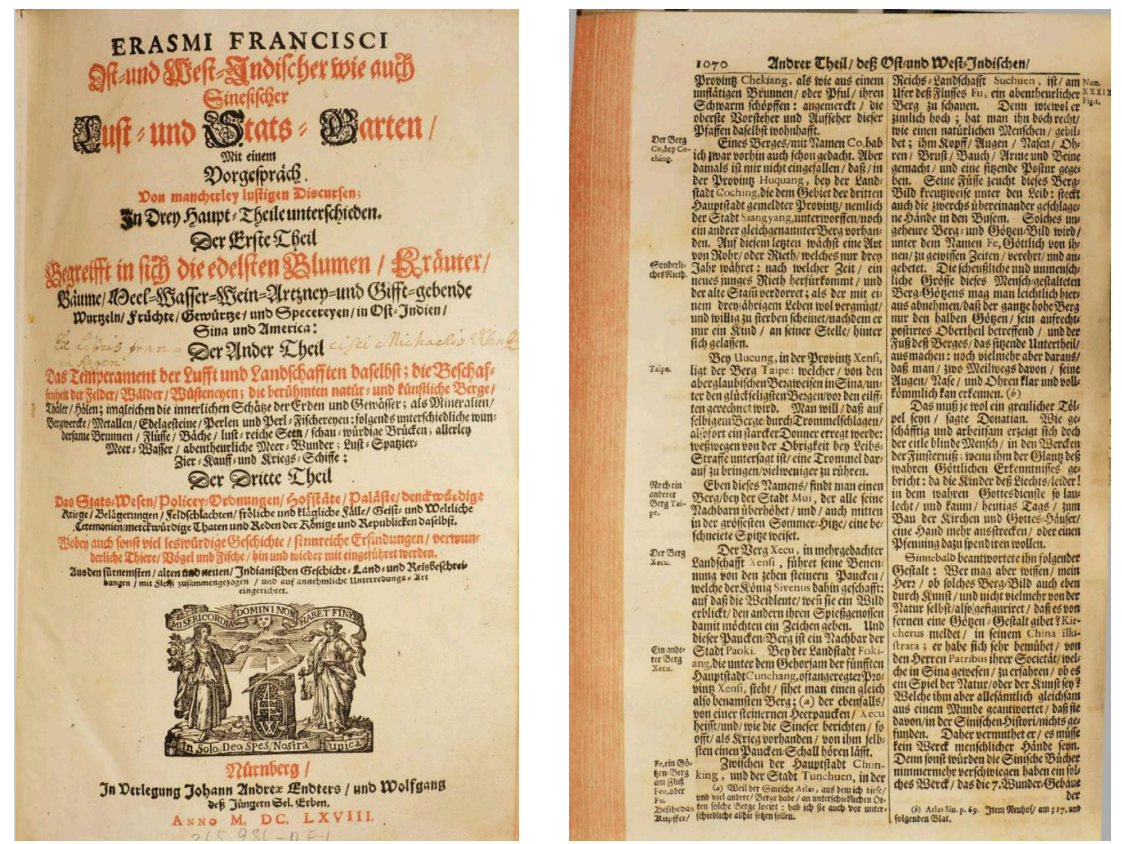

Fig. 9: Erasmus Finx. 1668. Ost- und West-Indischer wie auch Sinesischer Lust- und Stats-Garten: in drey Haupt-Theile unterschieden. Nürnberg: In Verlegung Johann Andreae Endters: 1070.

La página siguiente contiene un grabado en el que se representa la montaña venerada por los chinos de Chung-king (Fig. 10). Chun-King es el antiguo nombre de Chongqing, en la provincia de Sichuan. El nombre de la montaña mencionada por Erasmus Francisci, $\mathrm{Fe}$, probablemente corresponde a la manera en la que, en el dialecto de la ciudad, se pronuncia el nombre de la 
montaña Fo, o sea Jin Fo Shan（金佛山) (Fig. 11), Jin Fo (金佛) significando la "divinidad dorada" y representando lo sublime de la montaña.

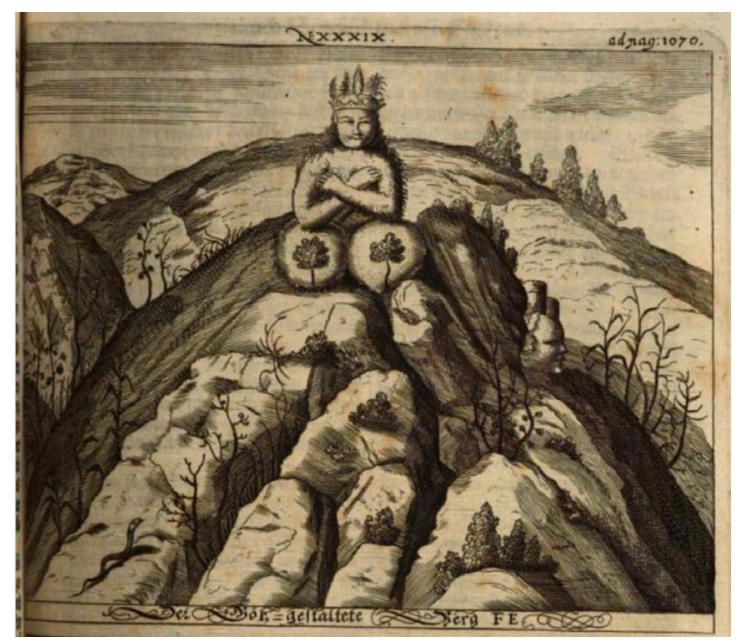

Fig. 10: Erasmus Finx. 1668. Ost- und WestIndischer wie auch Sinesischer Lust- und Stats-Garten: in drey Haupt-Theile unterschieden. Nürnberg: In Verlegung Johann Andreae Endters: 1070.

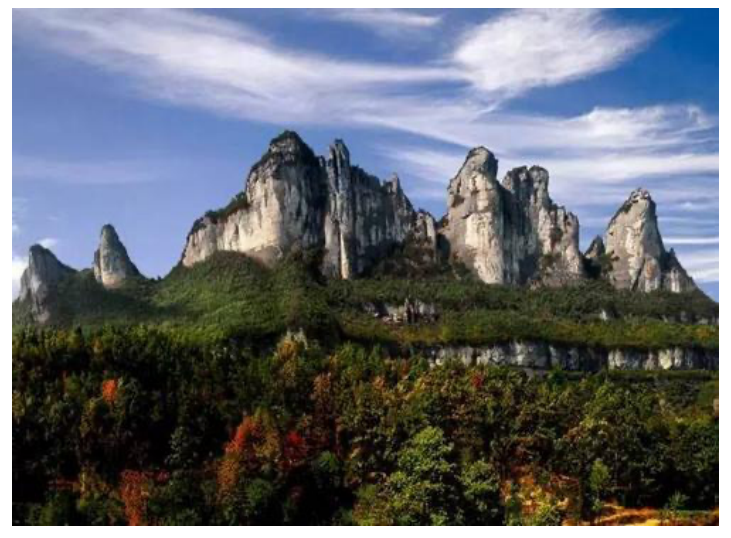

Fig. 11: 金佛山, Jinfo Shan

En el marco de una semiótica de las culturas se puede formular una nueva interpretación de esta serie de textos, los verbales que cuentan de proyectos colosales incumplidos, los visuales que los representan, y otros textos que, en palabras e imágenes, evocan su cumplimiento en un espacio exótico y oriental. Esta interpretación no concierne únicamente la historia, sino el presente, y la relación que los seres humanos establecen entre la naturaleza, el espacio, el poder, y la ambición. Hay un elemento fundamental en la historia de Dinócrates y Alejandro Magno que Miguel Ángel ignoró, que Pietro da Cortona no quiso recordar, que Diego de Saavedra omitió mencionar, que no aparece ni en el frontispicio del Leviatán ni en la pintura de Pierre-Henri de Valenciennes, y que Fischer von Erlach no enfatizó en sus referencias a los colosos orientales mencionados por Diodoro Sículo y Erasmus Francisci. 


\section{Retóricas del tamaño humano}

El elemento es el siguiente: como relatan varias fuentes antiguas, Alejandro Magno no quiso transformar la montaña en su gigantesca efigie. Plutarco, ${ }^{22}$ en el capítulo 72 (5-8) de la Vida de Alejandro, lo recuerda de forma

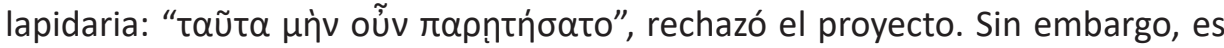
Vitruvio mismo, en el segundo libro del De Arquitectura (Fig. 12), que expone en detalle las razones por las cuales el joven Emperador no apoyó el plan del visionario arquitecto:

[...] delectatus Alexander narratione formae statim quaesiit, si essent agri circa qui possent frumentaria ratione eam civitatem tueri. cum invenisset non posse nisi transmarinis subvectionibus, Dinocrates, inquit, attendo egregiam formae compositionem et ea delector, sed animadverto si qui deduxerit eo loci coloniam fore ut iudicium eius vituperetur. ut enim natus infans sine nutricis lacte non potest ali neque ad vitae crescentis gradus perduci, sic civitas sine agris et eorum fructibus in moenibus affluentibus non potest crescere nec sine abundantia cibi frequentiam habere populumque sine copia tueri. itaque quemadmodum formationem puto probandam, sic iudico locum inprobandum, teque volo esse mecum, quod tua opera sum usurus. ${ }^{23}$

[Alejandro quedó gratamente satisfecho ante la descripción de tal proyecto y al momento preguntó si alrededor de la ciudad había campos que la pudieran abastecer con sus cosechas de trigo. Al manifestarle que no era posible el abastecimiento si no era mediante el transporte de ultramar, contestó: "Dinócrates, observo con atención la magnífica estructura de tu proyecto y me agrada. Pero advierto que si alguien fundara una colonia en ese mismo lugar, quizás su decisión sería muy criticada. Pues, así como un recién nacido sólo puede alimentarse con la leche de su nodriza y sin ella no puede desarrollarse, de igual manera una ciudad no puede crecer sí no posee campos cuyos frutos le lleguen en abundancia; sin un abundante abastecimiento no puede aumentar el número de sus habitantes ni pueden sentirse seguros. Por lo tanto, en cuanto a tu plan pienso que merece toda clase de elogios, pero la ubicación de la ciudad debe ser desaprobada. Es mi deseo que te quedes a mi lado, pues quiero servirme de tu trabajo.] (trad. Don Joseph Ortíz y Sanz).

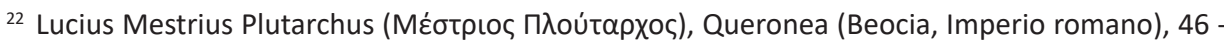
Delfos (Fócida, Imperio romano) 127.

${ }^{23}$ Marcus Vitruvius Pollio. De arquitectura, II, 2. 
LOS DIEZ LIBROS

\section{DE ARCHÎTECTURA}

DE M. VITRUVIO POLION

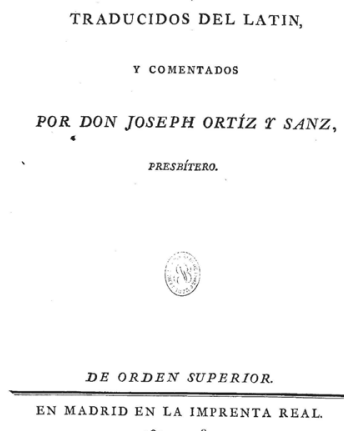

AR० Dะ 1787 .

Fig. 12: Vitruvio, De arquitectura,

trad. en castellano.

En el texto vitruviano, la respuesta de Alejandro a Dinócrates es menos abrupta que en Plutarco, más gentil y más articulada; sobre todo, destaca la representación del Emperador como hombre sabio e iluminado, el cual no cede a la ambición personal de ver una montaña entera transformada en un gigante que tenga la ciudad literalmente en su mano, sino se preocupa primero por las condiciones de los ciudadanos mismos, con una mirada desde abajo hacia arriba, y no viceversa. En otro trabajo de Plutarco sobre Alejandro, el De Alexandri magni fortuna aut virtute, el autor Ilama a Dinócrates "Stasícrates", lo califica de escultor, y explicita que su proyecto fuera de esculpir la efigie de Alejandro en el monte Athos, exactamente como Miguel Ángel había soñado con hacerlo en los Alpes Apuanes:

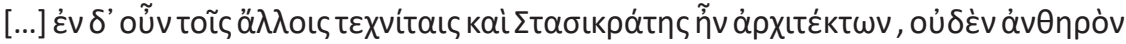

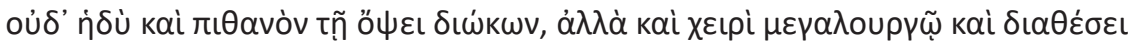

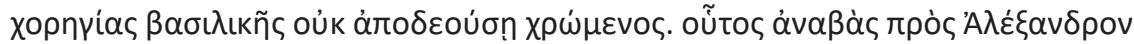

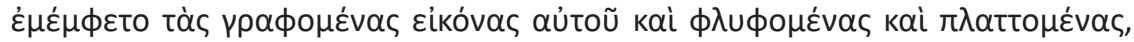

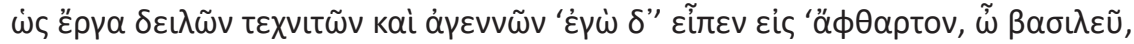

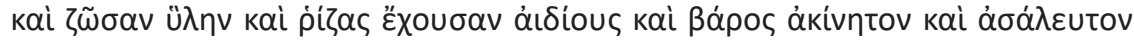

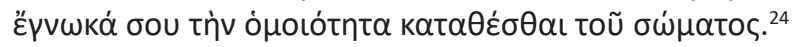

["Pero yo, Su Majestad", dijo, "he concebido el proyecto de colocar su semejanza en material vivo e imperecedero, con raíces que sean eternas e inamovibles

${ }^{24}$ Lucius Mestrius Plutarchus “(46-127). De Alexandri magni fortuna aut virtute, II, 2: 431. 
e inquebrantables de peso". En efecto el Monte Athos en Tracia, en esa parte donde se encuentra su cumbre más alta y visible, tiene superficies y alturas bien proporcionadas, extremidades y articulaciones y proporciones que sugieren la forma humana. Cuando se haya tallado y trabajado adecuadamente, se le podría llamar la estatua de Alejandro, y así será; con su base asentada en el mar, en su mano izquierda abarcará y mantendrá una ciudad poblada de diez mil habitantes, y con su derecha verterá de un cuenco de libación un río que fluya siempre hacia el mar. En cuanto al oro y al bronce, al marfil, a los materiales de madera y a los tintes, que componen esas imágenes miserables que se pueden comprar y vender, robar o fundir, irechacémoslas todas!"] (trad. nuestra).

En este pasaje se declara abiertamente el intento adulatorio del proyecto y se revela también su finalidad estética, la misma que subyacía a la ambición desmesurada de Miguel Ángel: muchos siglos antes que Walter Benjamin se preocupara de la pérdida del aura en la reproducción mecánica de las obras de arte, los antiguos ya se habían percatado del carácter perecedero de las pinturas, de las esculturas, e incluso de la arquitectura: los pigmentos podían secarse y dispersarse, los colores desteñirse, las tablas de madera marchitarse y agrietarse, incluso el mármol y el oro, los materiales de la eternidad, podían ser sujetos a golpes, hendiduras, astillas, muescas, y sobre todo, a pesar del tamaño monumental, las obras en general se podían robar, como demuestra su rapaz circulación por el mundo tras los saqueos, las guerras, y los hurtos. Y tampoco había que confiar en la arquitectura, las ruinas atestiguando ya con demasiada elocuencia el carácter efímero de los templos, de los mausoleos, hasta de los palacios y de las murallas. No, la única manera de otorgarle eternidad a la efigie de un emperador-dios era de transformar una montaña entera en su simulacro.

El opúsculo de Plutarco enfatiza la arrogancia del artista para subrayar su carácter inmoral y contraponerle la virtuosa humildad de Alejandro. Con este fin, su respuesta también se modifica, ya que en el De Alexandri magni fortuna aut virtute el emperador macedonio no se preocupa del aporte de grano a los ciudadanos que van a vivir en su mano gigante, sino contesta de la manera siguiente:

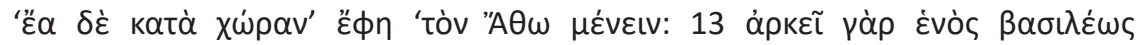

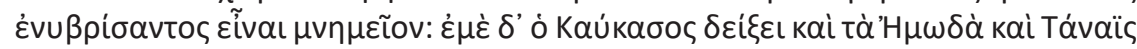

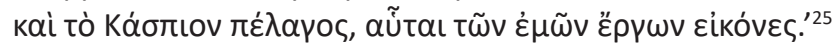

["Pero", dijo, "deja que Athos permanezca como está. Es suficiente que sea el memorial de la arrogancia de un rey; pero mi impronta mostrará el Cáucaso y el rango Emodian y el Tanaïs y el Mar Caspio; esta será la imagen de mis obras."] (trad. nuestra).

${ }^{25}$ Lucius Mestrius Plutarchus (46-127). De Alexandri magni fortuna aut virtute, II, 2: 431. 
Maliciosamente, en la contesta de Alejandro relatada por Plutarco, el monte Athos se vuelve referencia a Jerjes, que lo cortó con un canal y fracasó militarmente. Por lo tanto, se perfila aquí una oposición entre la concepción griega del poder, que huye la arrogancia y el dominio espacial y morfológico sobre la naturaleza que esta soberbia conlleva, y la concepción persa, que fracasa justamente porque no entiende los límites de su dominio. ${ }^{26}$ Interpretada histórica y antropológicamente, esta dialéctica resultaría el fruto de una semiótica de la cultura orientalista, que no sería difícil confutar. La atribución de gigantismo antropomórfico a China, por ejemplo, es un puro orientalismo, dado que las fuentes de Erasmus Francisci probablemente se habían equivocado al ver las estatuas de Budas gigantes esculpidas en las rocas de Sichuan. Además, mientras en Europa Pierre-Henri de Valenciennes aconsejaba de tratar la pintura de paisaje como si fuera la de un retrato, en China, donde el género del retrato fue introducido después de la pintura de paisaje, los pintores y teóricos recomendaban exactamente lo opuesto: había que reconocer el paisaje en el rostro de una persona, según la receta de la antigua fisiognomía china, y no el rostro de una persona en el paisaje. Esto sugería, por ejemplo, el Shenxiang quanbian (神象全編), la Guía completa a la fisionomía del espíritu, compilada por Yuan Zhongche (袁忠徹), en la primera dinastía Ming (1367-1458) (Fig. 13). Claramente inspirada por el Daoismo, la Guía proponía que

La cara [debería] dividirse en Cinco Montañas (wuyue) y Cuatro Ríos (sidu). Las Cinco Montañas son la frente, el mentón, la nariz, el pómulo derecho y el pómulo izquierdo; los cuatro ríos son las orejas, los ojos, la boca y las fosas nasales.

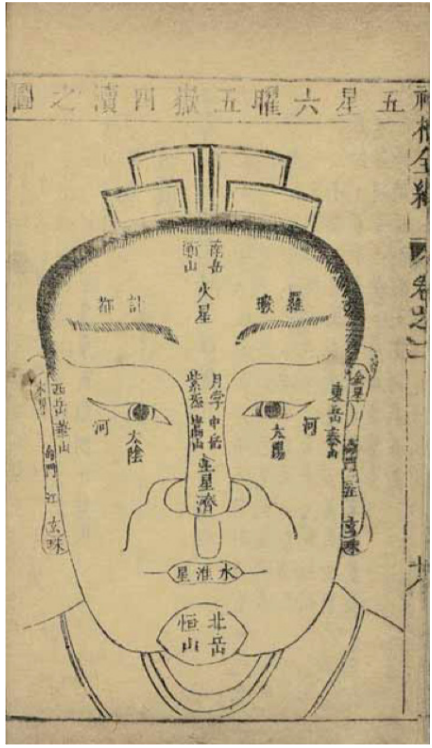

Fig. 13: Shenxiang quanbian, "Guía completa a la fisiognomía del espíritu" ( 神象全編), compilada por Yuan Zhongche (袁忠徹), alias Gongda o Jingsi, de la primera dinastía Ming (1367-1458). Edición de época Ming, Biblioteca Nacional Central de Taipéi, Taiwán.

${ }^{26}$ Véase Warnke 1994. 
La dialéctica por lo tanto no es entre Occidente y Oriente, sino entre una concepción que imagina el poder como capaz de plasmar la naturaleza a su imagen y semejanza, y una que, al revés, rechaza este poder como arrogancia peligrosa, sugiriendo que sea la naturaleza misma a dictar el tamaño de las acciones humanas. Cada vez que, en la historia, los humanos elijen la primera opción, exaltan la ambición de Dinócrates y olvidan el sabio rechazo de Alejandro.

\section{Rostros gigantes contemporáneos}

Eso ha ocurrido también en la época contemporánea. El 19 de marzo de 1934, el periódico estadounidense Washington Herald publicaba una caricatura del artista Gutzon Borglum, ${ }^{27}$ el cual en esa temporada estaba esculpiendo las caras gigantes de lo que hoy se conoce como El Monumento Nacional Monte Rushmore (Fig. 14). En la leyenda, se leía el siguiente comentario sarcástico:

Gutzon Borglum, who has been in Washington perfecting plans for the Mount Rushmore Committee, says of the Memorial: "Alexander the Great wanted to convert the Olympian mountain into Sculpture, Michael Angelo wished to carve colossal figures on Carrara mountains - America alone is achieving in a national memorial the dreams of these great men".

[Gutzon Borglum, quien ha estado en Washington perfeccionando planes para el Comité del Monte Rushmore, dice sobre el Memorial: "Alejandro Magno quería convertir la montaña olímpica en escultura, Miguel Ángelo deseaba tallar figuras colosales en las montañas de Carrara. Solo Estados Unidos está logrando en un monumento nacional los sueños de estos grandes hombres.] (trad. nuestra).

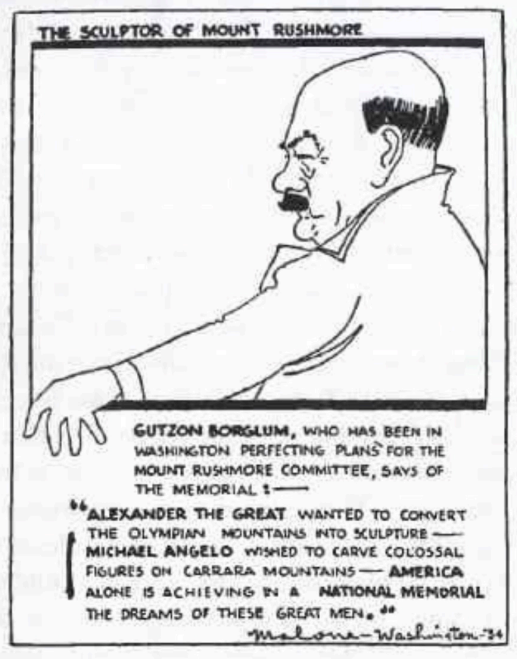

Fig. 14: Caricatura del artista Gutzon Borglum publicada por el periódico estadounidense Washington Herald el 19 de marzo de 1934.

\footnotetext{
27 John Gutzon de la Mothe Borglum; Bear Lake, Idaho, EEUU, 25 de marzo de 1867 - Chicago, Illinois, EEUU, 4 de marzo de 1941.
} 
El creador del Monumento Nacional Monte Rushmore era inspirado por antiguos proyectos de convertir montañas enteras en efigies de protagonistas de la historia de una nación. Sus fuentes, sin embargo, habían sido equivocadas: Alejandro había rechazado el proyecto de Dinócrates, volviéndose, en los relatos míticos del episodio, emblema del soberano que sabe como moderar su arrogancia. Pero los ideales políticos de Gutzon Borglum eran otros: admirador del líder fascista italiano Benito Mussolini y de las películas racistas de David Wark Griffith, el escultor de Monte Rushmore era un miembro del Ku Klux Klan. Su concepción del poder y del hombre, a pesar de las declaraciones de fe política democrática, era la del nietzscheano Übermensch, de alguien que domina el mundo, la naturaleza y los otros hombres, y emprime su efigie en la historia de manera violenta e indeleble.

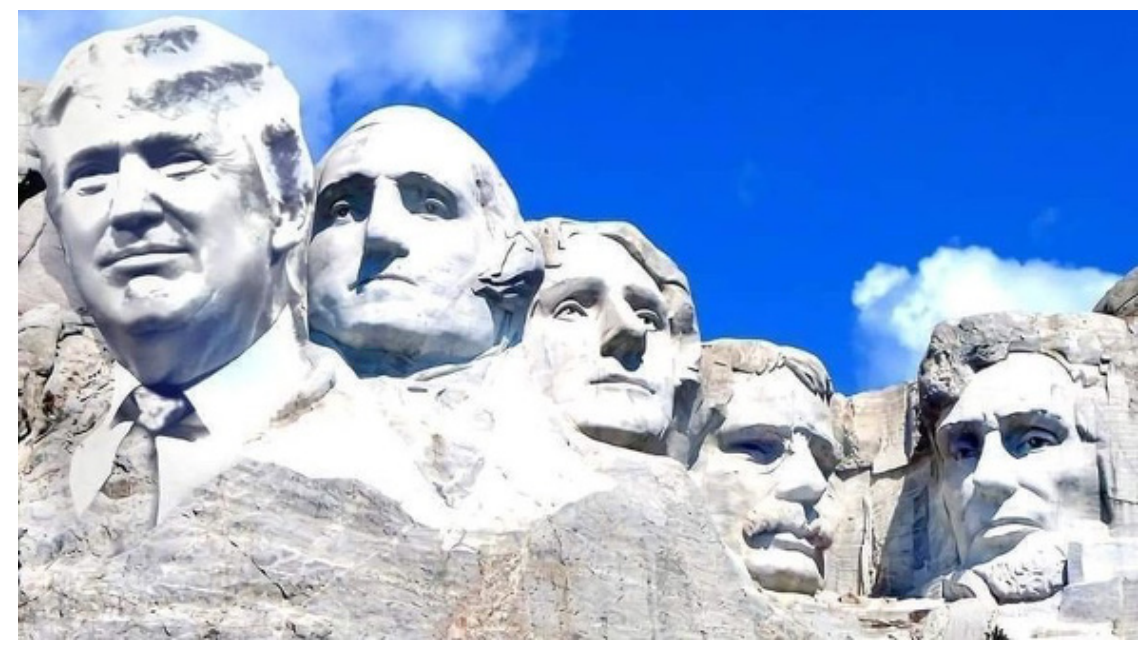

Fig. 15: La efigie de un quinto presidente en el Monte Roushmore, imagen anónima.

\section{Conclusión: rostros humanistas}

Se relata de Donald Trump que, en algunas entrevistas, habría expresado la voluntad de aparecer como quinto presidente del Monte Rushmore (Fig. 15). La historia, desafortunadamente, se repite. Una nación entera, la más poderosa del mundo, ha apoyado un político que le prometió "hacerla grande de nuevo". La tarea de una semiótica de la cultura consiste entonces en indicar que otro modelo ideológico es posible, y se contrapone al sueño de Dinócrates. No se trata de un supuesto modelo occidental sino de un modelo humanista, según el cual el valor de los proyectos humanos no se mide en relación a su tamaño sino a su proporción. Nadie formuló este principio mejor que el humanista 
italiano Leon Battista Alberti ${ }^{28}$ al criticar el proyecto de Dinócrates. En el De re aedificatoria, escrito en 1450, sexto libro, capítulo cuarto se lee "Quis enim audeat, quicumque ille fuerit, seu Stasicrates, ut refert Plutarchus, seu Dinocrates, ut refert Vitruvius, qui en monte Athos Alexandri effigiem facturum se polliceret, in cuius manu civitas affidaret milium capax hominum decem" / "Porque quien tuviera tan atrevimiento sea quien haya sido, o Estasícrates, como refiere Plutarco, o Dinócrates, como refiere Vitruvio, que prometió que haría la semejanza de Alejandro en el monte Athos, en cuya mano estuviese asentada una ciudad en que cupiesen diez mil hombres?"

Fig. 16: Francesco di Giorgio Martini. 1470. Trattati di architettura, ingegneria e arte militare. Post 147705-ante 1487. Torino: Biblioteca Reale, Codex Saluzziano 148.

En 1470, el pintor, escultor y arquitecto de Siena Francesco di Giorgio Martini ${ }^{29}$ tradujo el De re aedificatoria del latín al vulgar italiano y lo publicó por primera vez. ${ }^{30}$ Seis años después, apareció su propio tratado, Trattati di architettura, ingegneria e arte militare, en el que procuraba seguir la enseñanza de Vitruvio y desarrollar una teoría de la arquitectura que fuera exactamente opuesta a la encarnada por la propuesta de Dinócrates a Alejandro: el cuerpo del hombre, y no su ambición desmesurada, tenía que representar la medida de todo proyecto. En el nuevo tratado, aparece una nueva imagen del mito de Dinócrates (Fig. 16), en la que no el cuerpo gigante en la montaña, sino el joven y perfectamente proporcionado cuerpo del Emperador tiene en su derecha la ciudad. $^{31}$

\footnotetext{
${ }^{28}$ Génova, Italia, 18 de febrero de 1404 - Roma, 25 de abril de 1472.

${ }^{29}$ Siena (Italia), 23 de septiembre de 1439 (jul.) - 29 de noviembre de 1502 (jul.).

${ }^{30}$ Se lea Callebat 1994.

31 Se consulte Lotz 1940.
} 
Hay entonces que esperar que los próximos líderes políticos del planeta escuchen a Alberti, y no a Dinócrates, y ganen consenso y poder no prometiendo hacer sus naciones grandes, sino hacerlas proporcionadas. ¿Y qué es, de hecho, la justicia, sino la forma la más sublime de proporción? El eslogan del futuro no tendrá que ser "let's make my country great again", sino "let's make my country just again".

\section{Bibliografía}

CAGNAZZI, Silvana. 2005. II grande Alessandro. Historia: Zeitschrift für Alte Geschichte, 54(2): 132-143 (Stuttgart: Franz Steiner Verlag).

CALLEBAT, Louis. 1994. La Tradition Vitruvienne au Moyen Age et à la Renaissance : Eléments d'Interprétation. International Journal of the Classical Tradition, 1(2): 3-14 (Dordrecht: Springer).

CONDIVI, Ascanio. 1553. Vita di Michelagnolo Buonarroti raccolta per Ascanio Condivi da la Ripa Transone. Roma: appresso Antonio Blado Stampatore Camerale.

DELLA DORA, Veronica. 2005. Alexander the Great's Mountain. Geographical Review, 95(4): 489-516 (New York, NY: American Geographical Society).

DESIDERI, Paolo. 2001. La montagna nel pensiero ecologico degli antichi, in Silvia GIORCELLI BERSANI (ed.), Gli antichi e la montagna. Ecologia, religione, economia e politica del territorio, acta del congreso, Aosta (21-23 de septiembre de 1999), 23-25. Turín: Celid.

LOTZ, Wolfgang. 1940. Eine Deinokratesdarstellung des Francesco di Giorgio. Mitteilungen des Kunsthistorischen Institutes in Florenz, 5(6): 428-433 (Florencia: Kunsthistorisches Institut in Florenz, Max-Planck-Institut).

SCHAMA, Simon. 1995. Landscape and Memory. New York: Vintage (Ch. 7: "Dinocrates and the Shaman: Altitude, Beatitude, Magnitude": 385-446)

SPEAKE, Graham. 2002. Mount Athos: Renewal in Paradise. New Haven, CN.: Yale University Press; Ch. 1, "Athos BC": 12-16

WARNKE, Martin. 1994. Political Landscape: The Art History of Nature. London: Reaktion Books.

WILSON-CHEVALIER, Kathleen. 1997. Alexander the Great at Fontainebleau, in Nicos HADJINIKOLAOS (ed.), Alexander the Great in European Art: acta del congreso (22 de septiembre de 1997-11 de enero de 1998), 25-33. Salónica, Grecia: Organization for the Cultural Capital of Europe. 


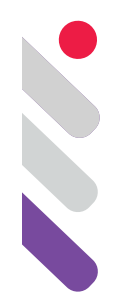

\title{
Semiosis de las artes performativas: a partir del cuerpo de las envolturas
}

DOI: $10.24308 /$ IASS-2019-8-026

\author{
Rocco Mangieri \\ Universidad de Los Andes. Facultad de Artes. \\ Laboratorio de semiótica y socioantropología \\ roccomangieri642@hotmail.com \\ roccomangieri642@protonmail.com
}

\section{Introducción}

El arte performativo es un espacio heterogéneo de prácticas semióticas ${ }^{1}$ (Greimas A.J, Courtés J, 1982). A través de nuestra propia experiencia como investigadores en el campo de la danza, del teatro y las artes visuales, nos hemos dado a la tarea de articular la teoría semiótica con las prácticas en las cuáles la corporeidad es un aspecto primordial. Desde hace un tiempo, veníamos trabajando sobre la figura del cuerpo envuelto y de la huella como inscripción de superficie en las representaciones teatrales y visuales ${ }^{2}$.

A lo largo de las primeras fases de investigación una de las primeras figuras que nos motivó fue el tratamiento del cuerpo en la pieza multimedial y dancística "Kreatur" de Sasha Waltz. Particularmente los momentos donde los cuerpos están entrecubiertos y protegidos por una especie de nube, densa y semi-transparente. Una pieza muy sofisticada que hace uso asemás de un efecto muy poderoso de envoltura sonora, diseñada por el colectivo Soundwalk. El tema del performance es el cuerpo del migrante y la dramaturgia de la aceptación del otro. El color de la piel como envoltura juega aquí un rol muy importante, así como su textura, su permeabilidad, su resistencia (Fig.1).

\footnotetext{
1 Una práctica semiótica comprende la noción de proceso, acción, escena y estrategia. Para el concepto ampliado de práctica semiótica ver Semiotica.Diccionario razonado. A.J.Greimas y J.Courtés p. , también Pratique semiotique, de J.Fontanille (2008), www.unilim.fr

2 Proyecto de investigación transdisciplinario AR-88-15-10-A, financiado por el Consejo de Desarrollo científico CDCHTA. Universidad de Los Andes. Facultad de Artes-Mérida.
} 


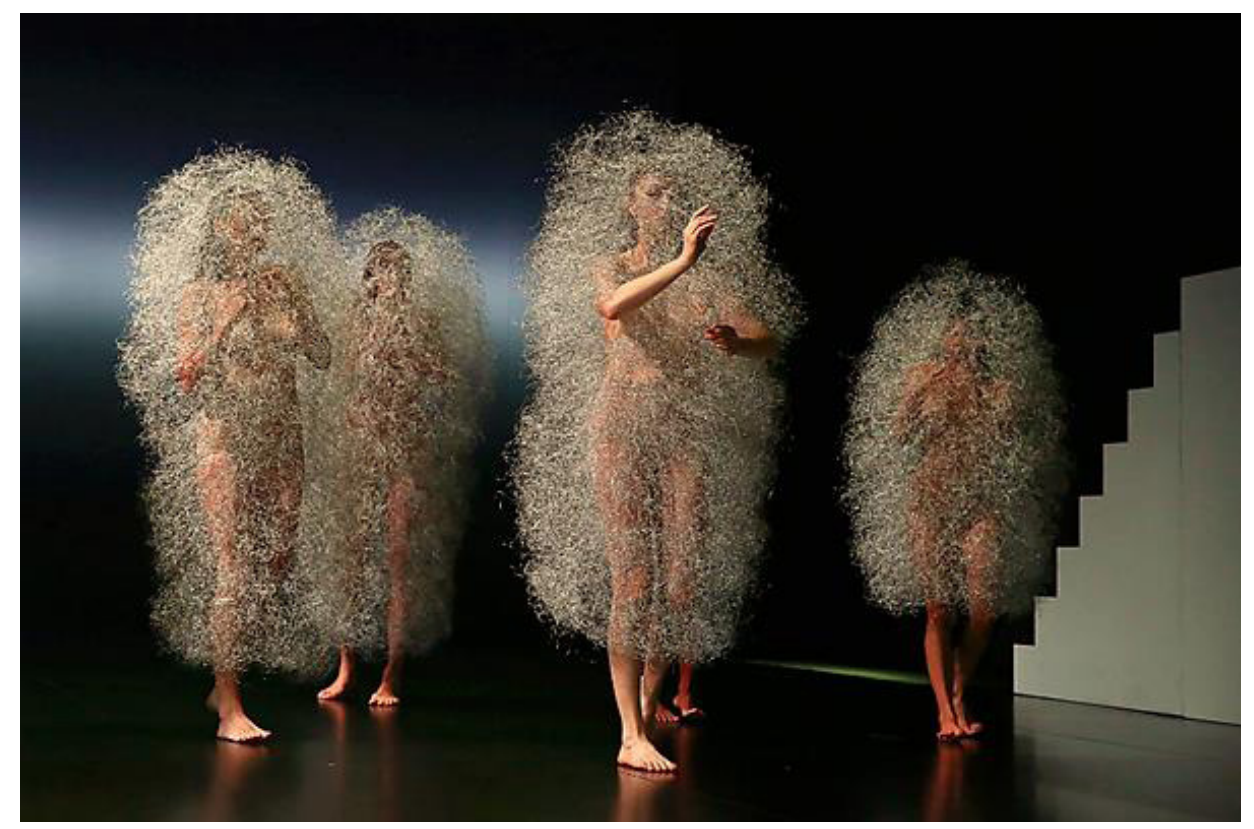

Fig.1 "Kreatur", de Sasha Waltz. Photo: Andrea Mohin/The New York Times, 2018.

En este punto nos conectamos con un texto de Didier Anzieu (Anzieu, 1999) y al mismo tiempo con las propuestas de algunos modelos de la corporeidad propuestos recientemente por Jaques Fontanille y Patrizia Violi (Fontanille 2011, Violi). A lo largo del recorrido, la imagen del cuerpo-envoltura fue requiriendo otras articulaciones de sentido que estaban previstas en el metalenguaje semiótico de la corporeidad: cuerpo-carne, cuerpo-situado, cuerpo-movimiento.

\section{Modelos y categorías}

Fontanille ha hecho énfasis en el rol semiótico de la envoltura y de la huella como categorías centrales en la lectura de los procesos de significación de la corporeidad. Hay allí un enlace teórico entre el modelo de Umberto Eco sobre los modos fundamentales de producción sígnica, que inicia de algún modo con la semiótica del reconocimiento y el papel clave de las huellas, trazas e improntas, y el modelo generativo-narrativo (Eco 1975, Fontanille 2000). El modelo de Fontanille se centra en una sintaxis figurativa de la forma, a través de cuatro grandes figuras (enveloppe, chair, creux, point), que podrían dar cuenta, a nivel del proceso de significación, de buena parte de las configuraciones de la corporeidad en el mundo natural y a nivel de las transformaciones corporales en el ámbito de las artes. Estas figuras del cuerpo pueden ser vistas como actantes 
del proceso de la semiosis (Fig.2). El modelo Incorpora el rol de la huella (empreinte) una vez que se hayan estructurado en la forma de un cuadrado lógico los cuatro grandes tipos de cuerpo. Ambos autores, citan y se refieren a la fenomenología de Merlau Ponty (1999), y también a los significados y alcances de lo que se ha denominado como embodiment ${ }^{3}$.

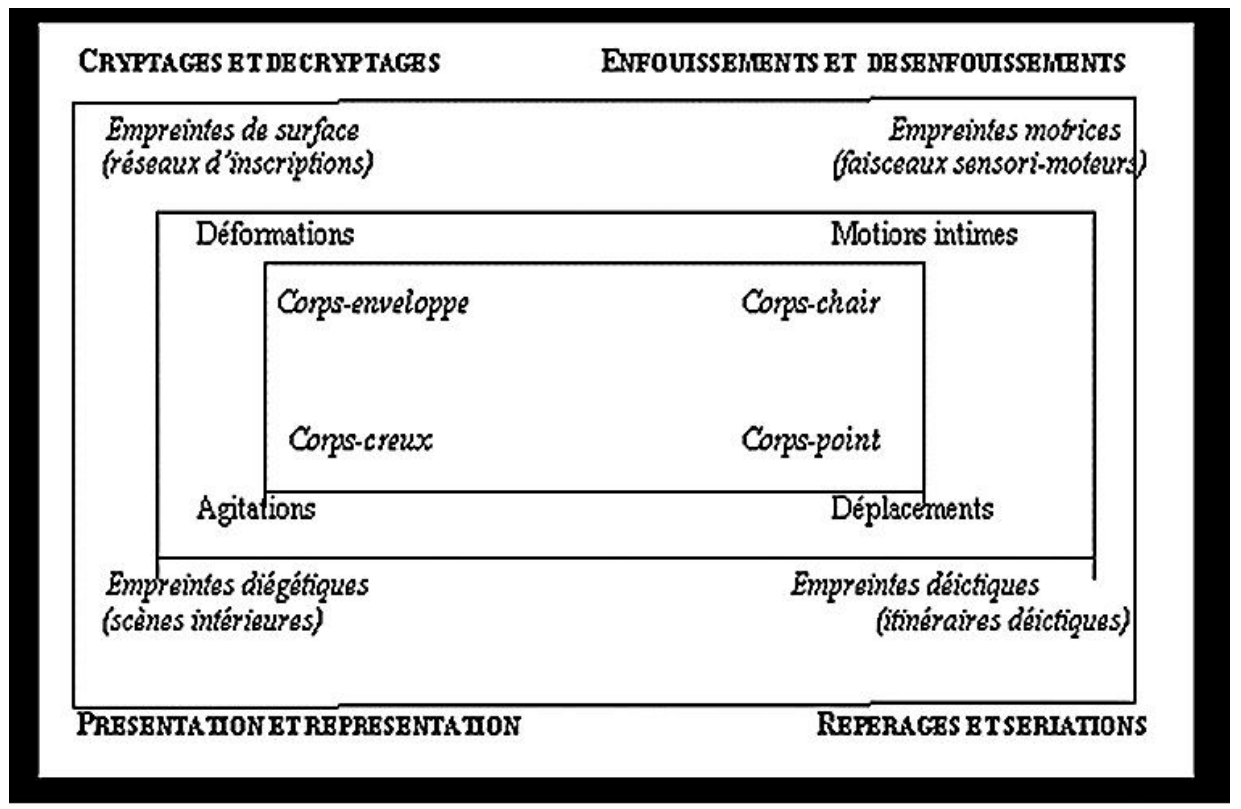

Fig.2, Cuadrado semiótico de la sintaxis figurativa del cuerpo-actante. Jaques Fotanille (2011)

El modelo funciona en principio como un encaje de categorías lógicas. Las categorías más externas y generales se refieren a los modos de cryptageenfuoissements-presentation- réperage. El segundo marco lógico es la lógica semiótica de las improntas o huellas: de superficie-motrices-diegéticasdeícticas. El tercer marco de referencia es el deformación-movimientos íntimosagitaciones-desplazamientos. El marco interior y campo central de análisis es en principio el del cuerpo como unidad somática: cuerpo-envoltura, cuerpo-carnal, cuerpo-hueco, cuerpo-situado (corps-enveloppe, corps-chair, corps-creux, corps-point).

\footnotetext{
${ }^{3}$ Entendemos por embodiment los estados intersubjetivos de co-participación cognitiva y emocional. También puede traducirse como un proceso de encarnación entre actores que co-participan en una práctica semiótica. El termino actor se utiliza aquí en cuanto categoría semiótica a nivel del plano de la enunciación. Ver de Patrizia Violi texto "Beyond the body: towards a full embodied semiosis" (2008), también en www.semanticscholar.org. Franciso Varela, The embodied mind (1991), "Embodied mind: an introduction", en www.thebrain.blog. com .
} 
La semiosis del cuerpo, como parte de una semiótica del mundo natural, es un proceso de dinámicas sincréticas (enactivas y psicosomáticas). Siendo así, las relaciones entre los "vértices" es fluida. Tanto en la kinesis cotidiana, donde el proceso de débrayage enunciativo es de muy baja intensidad (ya que no implica la auto- observación o lo que los somatólogos denominan como selfanalysis) y las potencias motrices y kinésicas se despliegan en un campo de habitus y de eficacias prágmáticas cotidianas. Pero, dentro de las prácticas del arte performativo, el débrayage que efectúa el sujeto de la enunciación, es un dispositivo necesario y recurrente que garantiza la eficacia y la calidad estética de la acción.

Nuestras corporeidades producen incesantemente sentido, ese "algo que circula entre nosotros y establece la base de las intersubjetividades" y que muchas veces no podemos aún nombrarlo. Esta fuerza circulatoria del sentido parece basarse en la indiferenciación más que en formas y figuras previas estructuradas. Cuando menos, no con la misma nitidez estructural que solemos asignarle en semiótica. Nos inclinamos mejor hacia la idea de la borrosidad activa y viva del sentido, vista como una circulación de energías y de materias que, en un segundo momento, pueden asumirse como estructuras de significación de elementos polarizados y diferenciados. Este es un estado somático común en las artes del cuerpo y del movimiento.

\section{Los cuerpos de la envoltura: envolturas pre-narrativas y envolturas narrativas}

El cuerpo-envoltura es definido, en primer lugar, como una superficie topológica material y sensible, continua y envolvente, sobre la cual se van inscribiendo nuestros relatos y actos performativos. Las trazas, huellas o incisiones que se registran en el cuerpo-envoltura no dependen exclusivamente de un principio de intencionalidad como tal. Las reacciones, los signos y trazas de la piel como síntomas revelan, como en el proceso de un revelado fotográfico, algo que el mismo sujeto no ha narrativizado y que, puede permanecer insignificante para un tercero. Los semiólogos han seguido en buena parte los estudios de Didier Anzieu y otros psicólogos y psicoanalistas, que convierten la materialidad sensible y carnal de la piel (conservándola como soporte físico fundamental), en una superficie significante de huellas constitutivas de nuestra subjetividad y presencia en el mundo.

Nos parece muy motivante la distinción, aceptada por Violi y Pozzato (e implícitamente por la semiótica tensiva de Zilberberg y de Fontanille, entre envoltura-prenarrativa (o proto-narrativa) y envoltura-narrativa ${ }^{4}$

\footnotetext{
${ }^{4}$ La introducción en la teoría semiótica del concepto de envoltura pre-narrativa es relativamente reciente y procede de los estudios a nivel de la psicomotricidad, la somática y del psicoanálisis. Citamos especialmente a los trabajos de Daniel Stern (Stern,1992). Stern vincula las figuras de las envolturas pre-narrativas con las "fantasías inconscientes" que poseen una estructura proto-narrativa. Este nivel de envoltura es supramodal e integrador. Ver, www. thepshycoanalyticmuse.com, Dr. Mark Wiborn, November, 2012.
} 
Una distinción propuesta por los psicoanalistas en sus estudios sobre la dimensión psicosomática. Es una distinción figural de mucho alcance teórico dentro de nuestras investigaciones. Las envolturas narrativas presuponen una subjetividad intencional dotada de una competencia cognitiva-afectiva que comienza a articular de algún modo la semiosis difusa y rizomática primaria, en la cual el sujeto ya posee los esquemas de un saber-hacer que aparece en arcos temporales más largos: aquí el cuerpo percibe sus envolturas naturales como frontera material y psíquica, como borde-límite o como espesura carnal de intercambio de signos y trazas.

Las envolturas pre-narrativas son anteriores a las narrativas (Stern, 2010).Muy probablemente estas envolturas primarias, estando nuestro cuerpo en fase de transformación y de crecimiento, son fundamentalmente sonoras y táctiles. Ambas envolturas son estereométricas y profundamente envolventes. Nuestra proto-subjetividad flota y se mueve envuelta en sonoridades y tactilismos hápticos constantes. Nuestros pequeños y vivaces cuerpos están en un entorno similar al de un ambiente sonoro 8D actual .De hecho, no es raro reencontrar estas hermosísimas figuras plásticas y estéticas en los performances contemporáneos, donde el artista retoma continuamente, a veces obsesivamente, las morfologías de una envoltura pre-narrativa, protoenvolturas cromáticas, luminosas, elásticas, difusas, mórbidas, más o menos indiferenciadas y topológicamente continuas basadas en transformaciones retóricas del pliegue( Fig.3 y 4).

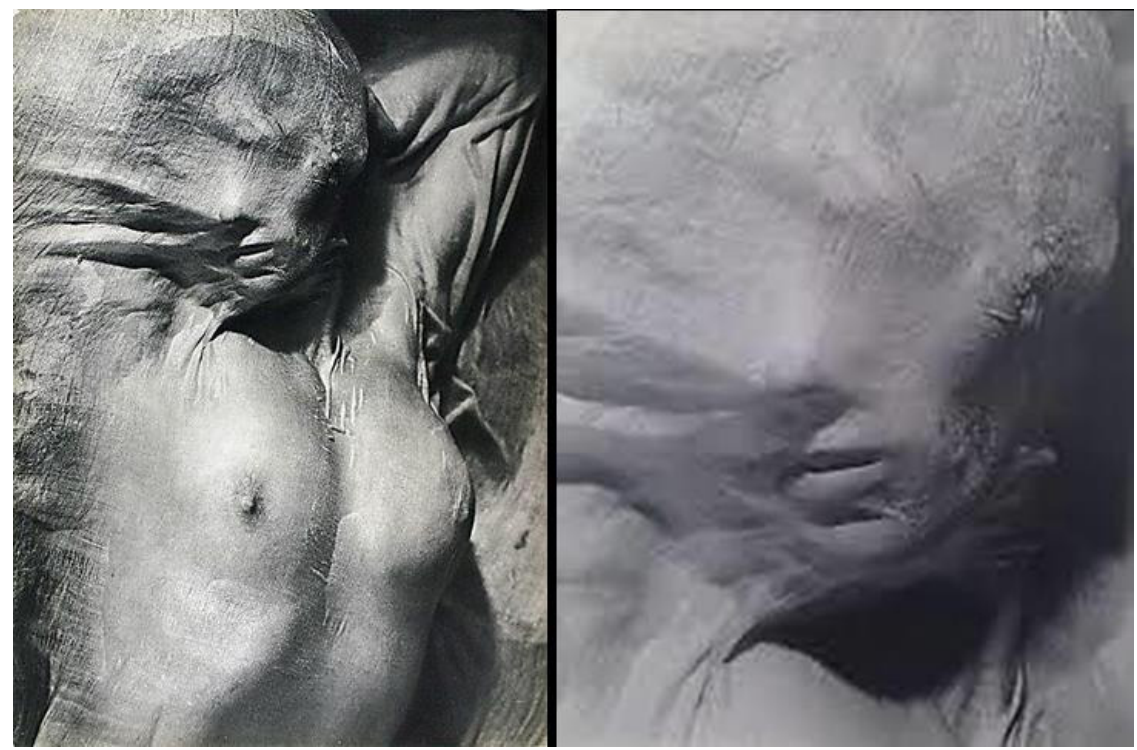

Fig 3 y 4. Nude under vet sik, Erwin Blumerfeld, 1937, www.amyfeldtman. com 
La inclusión de una corporeidad pre-narrativa ha abierto para la semiótica un espacio de suma importancia y epistemológicamente necesario para la revisión y reconfiguración de sus modelos y categorías. Muy especialmente, entre otras, las nociones semióticas de sujeto, subjetividad, narración, recorrido, soma y sema. Este nivel de pre-narratividad y de un proto-sujeto que posee en sus primeras fases la capacidad sensorial y afectiva de relacionarse sinestésicamente con el mundo y de trazar un dibujo de las intersubjetividades, ha requerido también (lo cual podría revisarse críticamente) un proceso de formalización consistente que pueda representarse como una sintaxis psicosomática o somática de base de los subsiguientes procesos semióticos de orden narrativo, como expusimos antes refiriéndonos a los estudios de Fontanille y de Violi .

Las envolturas narrativas, suponen el paso o transformación hacia otros estados subjetivos y la instauración de términos diferenciadores (sujetoobjeto, exterior-interior, presente-pasado, exteroceptivo-interoceptivo) o, cuando menos, de algunas estructuras que aunque no radicalmente opositivas, registren grados o escalas de términos que puedan situarse en una lógica de la significación, como por ejemplo las escalas cromáticas y de temperatura , donde son las zonas medias y no los extremos son los que hacen circular la semiosis. El nivel de complejidad para la elaboración de conjuntos o series de figuras narrativas suficientes para elaborar una lógica profunda de la significación es una tarea difícil, aunque tiene sus recompensas. En este trabajo hemos retomado las propuestas del cuadrado semiótico de la sintaxis somática y figural, sabiendo que requiere de modificaciones y amplitudes (Fontanille 1999; 201-202).

En el interior de las prácticas semióticas performativas, los artistas trabajan al mismo tiempo sobre propuestas combinatorias, fluidas y ambivalentes, dificultando la diferenciación radical entre el efecto de envolturas narrativas y prenarrativas. Creemos que es mejor fijarse detalladamente en estas tácticas de indiferenciación o des-diferenciación que dedicarse obstinadamente en describir campos diferenciales muy estructurados. Con esta mirada podemos encontrar ejemplos a veces muy radicalizados en un modo o forma de envoltura u otro, pero también propuestas plásticas oscilantes de enorme interés.

\section{Trayectorias convergentes: semiosis, intercorporeidad, embodiment}

Uno de los modelos de referencia más estable en relación a este tema ha sido hasta ahora el de la sintaxis figurativa de Fontanille al considerar las huellas como base de la construcción figurativa de una lógica abierta de la semiosis corporal. Esta semiosis debe ser descrita además como una sintaxis psicomotora fundamental, pre-linguistica y psicosomática. Violi propone las relaciones fundamentales entre la fuerza, el actor, la forma y el aura. De esta 
manera se pueden tratar de describir los trayectos de producción de sentido que se mueven y que adquieren forma en el curso de la acción (en el sentido de Gestalt muy pregnantes), a partir de una condición polisensorial y multimodal de la corporeidad primaria, hasta el nivel de las sintaxis figurativa y discursiva (Violi, 2006). Un esquema, que articula el modelo de Fontanille con la propuesta de Violi podría esquematizarse así. (Fig.5)

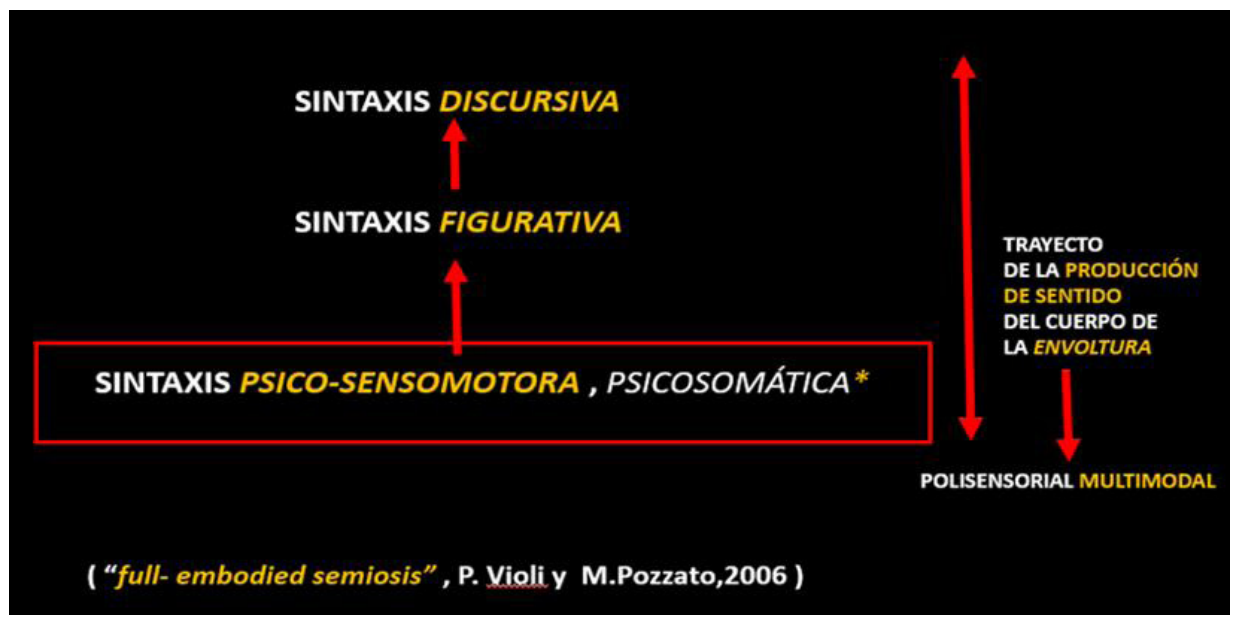

Fig.5 Trayecto de producción de sentido y posibles estadios de figurativización a partir de una base polisensorial y psico.-sensomotora pre-verbal hasta el nivel de la sintaxis discursiva (Diagrama del autor).

Nos resulta fascinante la posibilidad de articular estas propuestas generales junto a algunos (re)descubrimientos de las dinámicas del peripersonal space realizadas a nivel de las neurociencias y la psicosomática, incluso en los modelos y categorías de los psicomotricistas, como en el caso de Daniel Calmels y otros $(2004,2009)$. Los investigadores de la psicomotricidad, tienen una visión integral del cuerpo que articula al mismo tiempo categorías espaciales, temporales, actitudinales $e$ incluso emocionales. Lo mismo ocurre con los promotores de las ciencias somáticas que de hecho no han nunca excluido (ya a partir de los años noventa) dos elementos esenciales como la intercorporeidad física y la emocional (el embodiment). La teoría de Csordas es un ejemplo notable que ha sido revisitado en los estudios actuales sobre la corporeidad en la danza y las artes del movimiento, en las propuestas de Victor Fuenmayor en su laboratorio de semiótica y psicomotricidad de Barcelona (Csordas 1994, Fuenmayor 2010, Mangieri 2013). Los practicantes y estudiosos de las artes performativas están históricamente acostumbrados a sistemas de trainings en los cuáles es esencial un proceso de integración orgánica cuerpo-mente, como en el caso de la enseñanza de Grottowski, Thomas Richards, Eugenio 
Barba y tantos creadores, que basan el proceso de formación del cuerpo del actor y del bailarín en el alcance progresivo de la pre-expresividad: un estado somático extra-cotidiano, un "estado de lujo" sobre el cual debe apoyarse toda la performatividad del cuerpo del actor. Por lo general, los creadores y artistas no concuerdan plenamente con la idea de una sintaxis o una gramática fundamental salvo excepciones, sino que trazan los contornos de un estado somático indiferenciado, no articulado en oposiciones y que permite, hablando en términos de la biomecánica la surgencia del impulso.

\section{El cuerpo de las envolturas}

Las figuras del cuerpo envuelto han sido fundamentales y han ejercido una fuerte atracción como campo de estudio y de reflexión. Cuando asistimos y percibimos este tipo de acto performativo que además casi siempre está vinculado al discurso político, se activan nuestros sensores del embodiment con mucha más intensidad que la que se produce, por ejemplo, cuando vemos una escena fílmica o leemos un texto que describe o narra una evento. Los artistas del performance han ido adquiriendo todas las competencias de un saber-hacer somático capaz de involucrarnos hacia el interior de las tonalidades, los ritmos y las respiraciones del cuerpo del otro. Los cuerpos pueden estar envueltos o cubiertos, incluso semi-ocultos con superficies de diversas texturas, opacidades, transparencias y al mismo tiempo configurarse como cuerpo-carne o cuerpohueco. $^{5}$

En el tránsito dentro de la red corporal de las envolturas está, sin duda, la piel. Conocemos su relevancia semiótica como instancia material y simbólica de producción de sentido. Como "superficie de escritura" y sobre todo (atendiendo al problema de la memoria y las configuraciones de una autobiografía corporal) como superficie de inscripción de huellas, improntas, trazas o incisiones. En este punto nos conectamos, además de las propuestas ya mencionadas, al modelo de producción de las funciones-signo de U. Eco, con la posibilidad teórica y operativa de articular las semióticas generativas-narrativas con las semióticas interpretativas (Eco 1975, Mangieri 2019). Los actos de producción de huellas (en una gama extensa de figuras posibles) han sido muy recurrentes y relevantes en las artes performativas desde sus inicios, sobre todo en las artes del cuerpo y del performance. ${ }^{6}$ (Fig.6)

\footnotetext{
${ }^{5}$ Es lo que ocurre durante la pieza "Kreatur" de Sasha Waltz: el diseño del vestuario no fue concebido como un traje del actor o para representar un rol temático fijo, sino como una serie de materiales y substancias que cubren, encierran, protegen o expanden el cuerpo. Paralelamente al juego cambiante y programado de las envolturas visibles, el espectador está siempre envuelto en un ambiente sonoro.

${ }^{6}$ Nos referimos a una posible articulación teórica entre los modos de producción semiótica por reconocimiento, tal como han sido propuestos por U.Eco en el "Tratado de Semiótica" y el modelo de la sintaxis figurativa de los cuatro cuerpos-actantes de Jaques Fontanille. Es lo que parecen indicar si bien no de manera explícita los trabajos de Patrizia Violi y María Pía Pozzato sobre el cuerpo, la memoria y la huella ( Pozzato\&Violi, 2002).
} 


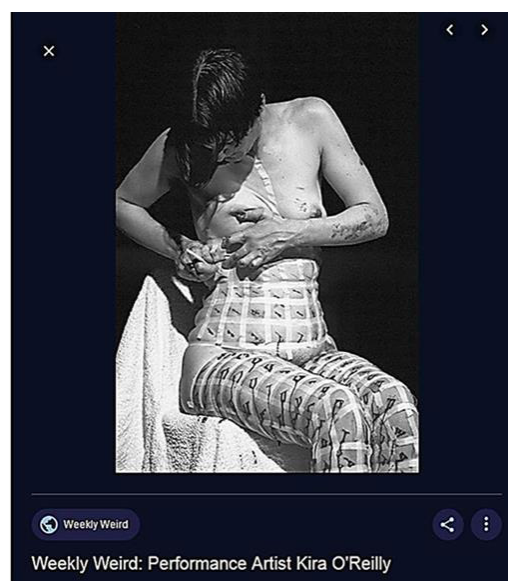

Fig.6 Kira O"Reilly. Trilogy of the Body. Political body. Week Performance Festival, Venezia 2014. La artista Kira O’Reilly, escribe-inscribe trazas en los intersticios que deja la envoltura, con un bisturí y su propia sangre. Hace de su envoltura somática (materia viva de su yo-piel) una cartografía cuadriculada.

En estas experiencias la postura puede ser entendida en el sentido de una técnica del cuerpo muy refinada y ritualizada (Mauss, 1937) y además como estilo somático (Ponty, 1999; 115-121). La postura, desde esta óptica, merece volver a estudiarse con mayor precisión dentro del campo semiótico. No solamente como un componente más de las dinámicas deícticas del corps-point, sino más bien como una figura superior de la sintaxis figurativa y figural. En el ejemplo siguiente, la postura como estilo somático integrador de la actitud deíctica es más intensa significativamente que la misma envoltura, funcionando en buena medida como un actante de control de toda la forma plástica. Sabemos, en este caso, que la poética somática de Martha Graham situaba el centro de energía en la pelvis (Fig.7). En los procesos creativos de auto-observación sensible, los artistas siempre han localizado en su cuerpo un actante de control somático que funcione en cierta medida como centro de coordenadas y de modulación interna de la acción.

En las artes performativas vistas como territorios muy densos $y$ atravesados por muchas prácticas semióticas, la semiosis de la envoltura configura un vasto espacio de experimentaciones y soluciones visuales, plásticas, espaciales, multimodales y polisensoriales. El cuerpo envuelto nos remite a un embodiment de la sensación táctil (textura, temperatura, tono), a un proceso de intersensorialidad, y al mismo tiempo promueve en nosotros otros enlaces dentro de otros campos figurativos, topológicos, eidéticos y a estados tonales y rítmicos del cuerpo. ${ }^{8}$

\footnotetext{
${ }_{7}$ El trabajo pionero de Martha Graham sobre el cuerpo de la envoltura es un ejemplo relevante en las artes performativas de la modernidad. Pero también en relación al cuerpo carnal de las emociones y de los estados patémicos (las figuras del dolor y del lamento), y de lo que nosotros denominamos como cuerpo-extendido, una de las variantes del cuerpo-situado (corp-points). Al igual que su antecesora Mary Wigman, Graham inauguró la eficacia expansiva del traje como configuración y expansión del espacio personal. Para una más extensa definición del actante de control ver "Formas de vida" (Fontanille, 2017) Cap. La transparencia y lo visible.

8 Una visualización atenta de los trabajos de Marta Graham, así como del artista y coreógrafo Merce
} 


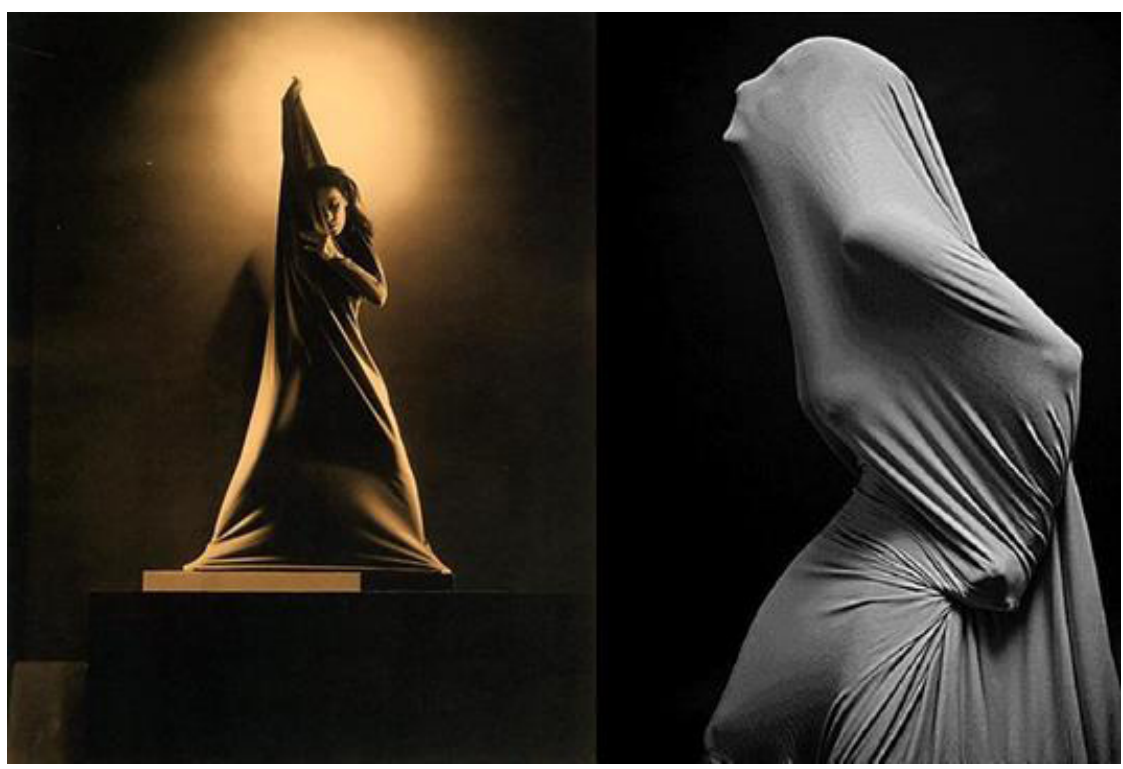

Fig.7 Imperial gesture y Lamentation, Martha Graham.(Re-enancting), Graham Foundation Library, NY, www.grahamfoundationlibrary.com

\section{Estilos somáticos}

Hemos denominado como cuerpo-situado o cuerpo en situación lo que J. Fontanille denomina como corps-points y que fundamentalmente representa el cuerpo de las deixis de "posicionamiento" o de situacionalidad. Más allá de las sintaxis discursivas y figurativas de los cuerpos posicionados, este "vértice" del modelo abarca más en profundidad a las figuras somáticas y emocionales de lo situado, que se ubican mucho más cerca del significado y potencia perceptiva de la postura.

Entendemos por postura, no solamente una expresión corporal superficial de la colocación del cuerpo en el espacio, sino un estilo de estar en el mundo, entre las cosas, los objetos, las atmósferas y los entornos emocionales, intersubjetivos. Las buenas fotografías están repletas de figuras corporales posturales de enorme interés. Muchos fotógrafos se han dedicado a la exploración atenta y acuciosa de las posturas de nuestros cuerpos dentro o fuera de los códigos o esquemas de posicionamiento social, estético, disciplinario. La pintura y el dibujo son también un reservorio valiosísimo. Los artistas captan, muy probablemente a través de una suerte de "saisie analogisante" (el comienzo de la trayectoria del embodiment emotivo y tonal) el estilo de un cuerpo. Una singularidad emocional y tonal de estar-en-el-mundo y un perfil anatómico

Cunningham, confirma este aspecto y es una excelente muestra de la imbricación sintagmática de estas figuras. 
singular y único, desde la mirada del dibujante, del escultor experto. Pensemos por ejemplo, en la posibilidad de posturas olvidadas y hasta cierto punto "fuera de lugar" o anacrónicas, así como a posturas más permanentes y ancladas en las figuras de las prácticas semióticas cotidianas (Fig. 8 y 9).

Las reglas de la danza clásica y las danzas tradicionales y populares folklorizadas (que reducen la significación mítica y lúdica) se basan en sistemas de lateralidad muy fuertes que delimitan con precisión las partituras kinésicas y gestuales del cuerpo en su despliegue espaciotemporal. Podemos decir que, a partir de las sintaxis de la danza moderna o premoderna, el código de la lateralidad en sentido estricto pasa a segundo plano. Sobre este punto se han señalado los procesos constantes de la des-lateralización desde Isadora Duncan hasta Pina Baush?
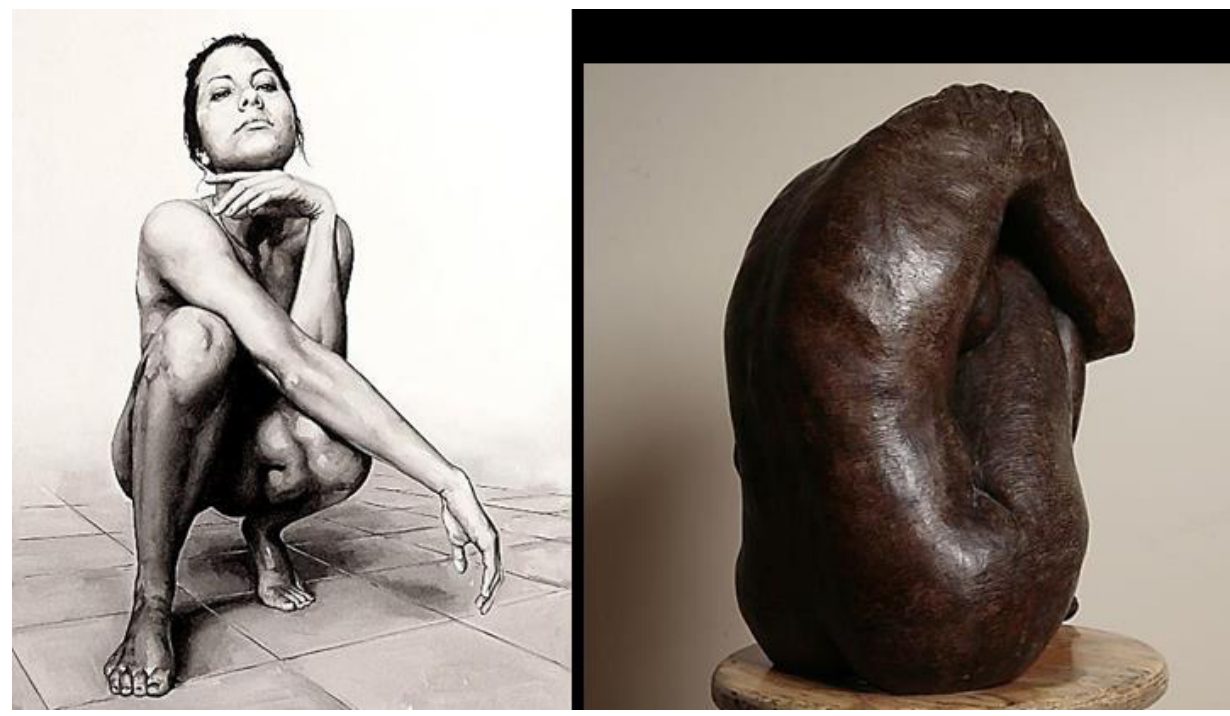

Fig 8 y 9, Posture de Silvio Porzionato, 2017. Sculpture art work, de Pet Sherrad, 2008

\section{Envoltura, gesto, postura}

Las posturas del cuerpo envuelto comunican las tonalidades de un estado somático particular. No se trata solamente de un problema de visualidad en sentido lato, sino más de un estado somático-figurativo que nos hace circular a través de los cuatro vértices de una lógica figurativa como la expuesta (enveloppe-

9 El trabajo de Pina Baush, un buen ejemplo es el uso reiterado de la caída abrupta y sucesiva durante el desplazamiento del cuerpo en un espacio acotado, como lo que ocurre en su pieza "Café Müller". Aún sin experimentar directamente las mismas sensaciones, el espectador se encarna en el proceso del estado somático del performer, por la forma, intensidad y tono de enganchar: el maestro Edward Hall utilizaba el término entrainment y Eugenio Barba la palabra sats. 
point-chair-creux). Además, nos moviliza a buscar una mayor cantidad de términos o categorías que puedan interdefinirse, como los estados de atención somática de Csordas (1999), o los esquemas de las funciones del cuerpo-piel en el psicoanálisis y la psicosomática o incluso, en relación a los modelos de la psicomotricidad donde la figura de la envoltura se articula con el cuerpo del sostén y de la protección. El psicomotricista argentino Daniel Calmels, y más atrás en el tiempo, las bellísimas lecturas de Julia Kristeva a partir de una serie de pinturas de "La Virgen y el Niño" de Giovanni Bellini y Mantegna. ${ }^{10}$ (1980; 237-270) son un ejemplo notable(Fig. 10 y 11).
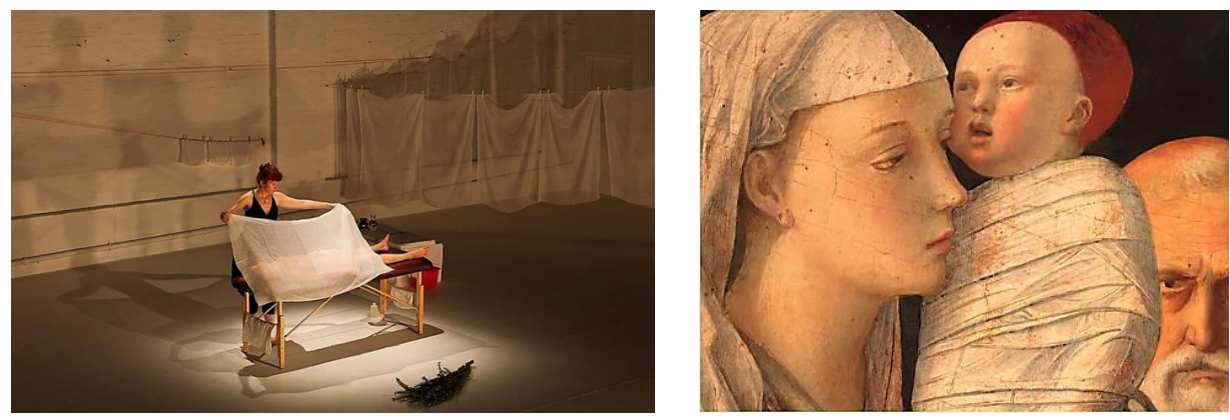

Fig.10 y 11. I Stand Up, Julia Vulcan, Trilogy of the body, Ritul Body, Week performance festival, 2016. Presentación del niño (detalle), Giovanni Bellini 1460, https://www.pinterest.com/ $\operatorname{pin} / 840765824155775903 /$ ?lp=true

\section{Envolturas tónicas}

Habría que precisar y reiterar que el acto y la forma resultante de envolver un cuerpo es por sí mismo, dependiendo ciertamente del contexto de comunicación, densamente significante. Cuando menos para los dos cuerpos que interactúan entre sí, como en el caso de los cuidados de la madre con su niño, o del performer que manipula el cuerpo del visitanteo el suyo propio. Casi siempre, previamente al acto de envolver-desenvolver, las culturas tradicionales realizan secuencias de tonificación corporal de manera directa y operativa como en el caso del Shantala hindú o del Otonomaki japonés, o de manera complementaria pero no como un programa narrativo separado, como en el caso del transporte lateral del niño sobre el costado, el pecho o la espalda del cuerpo de la madre en los habitus de las culturas periféricas, (Fig.12). ${ }^{11}$ En el

\footnotetext{
${ }^{10}$ Daniel Calmels ha desarrollado una valiosa investigación sobre los estados somáticos de sostén, de protección y de juego del infante. Uno de los textos más conocidos de Julia Kristeva sobre la relación corporal madre-hijo se encuentra en el libro Desire in Language, en el capítulo sobre la pintura de Bellini y Mantegna (Kristeva, 1980).

${ }^{11}$ Se trata de muchísimas técnicas del cuerpo, de prácticas semióticas que deberían estudiarse sobre todo con los modelos y categorías de una semiótica del curso de la acción (Fontanille
} 
performance in situ de Julie Vulcan, los asistentes son convocados a recostarse desnudos sobre una camilla de tonificación. El cuerpo es untado en aceites aromáticos y masajeado. Luego se envuelve el cuerpo y se imprime el residuo que ha quedado sobre nuestra piel. Se produce una huella singular de ese cuerpo. La tela de lino o de algodón es colgada luego de escribir una frase sobre ella. El público es convidado y el proceso continúa durante todo el día.

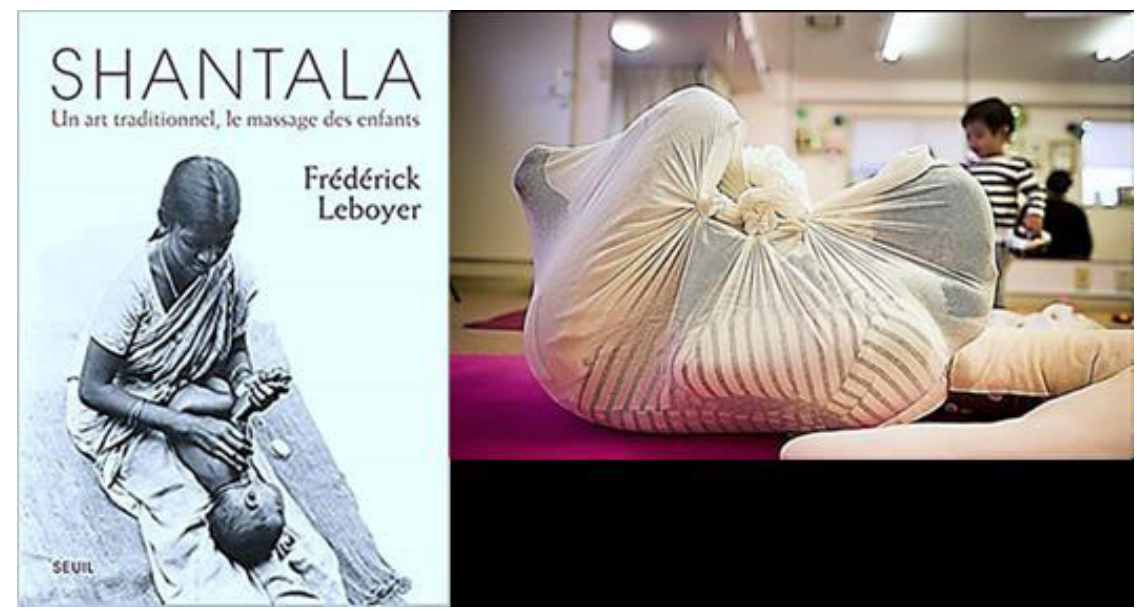

Fig.12 Masahe Hindú Shantala, y terapia anti-stress japonesa Otonomaki. www Seuilpress.com, www.japanculturetoday.com

\section{Superficies y formas de inscripción}

Quiero terminar con una vuelta sobre la semiosis de la envoltura que podría dar al lector una idea más acotada del objetivo central de esta investigación. Estamos convencidos que un punto de partida para la lectura de la corporeidad humana, en el contexto de las piezas o acciones de las artes performativas, es el cuerpo de la envoltura. Hay muchas razones para decir esto. Desde el ámbito del psicoanálisis hasta las ciencias psicosomáticas y más recientemente la semiótica narrativa y cognitiva, se ha promovido la idea de que nuestros cuerpos son un sistema de envolturas sensibles que deben estudiarse hasta un nivel pre-narrativo, en el cual el protosujeto de la semiosis no pertenece a estados polarizados o diferenciales. Esto nos permite obtener un tipo de integración sensorial en el mundo, aún sin tener acceso a las lenguas maternas como tales, es el envoltorio-piel que, desde el nacimiento funciona como una superficie de escritura y registro de huellas y trazas, en una dinámica

2016, Thereau 2004). Hay bellísimos y sugerentes ejemplos en las figuras corporales de carga y transporte de niño por las madres africanas, balinesas y asiáticas en general, en los ritmos de las actividades cotidianas (Bateson 2006, Mead 1951). 
de intercambios y regulaciones entre lo interno y lo externo. ${ }^{12} \mathrm{El}$ diagrama siguiente, hace foco en las envolturas pero esta figura puede ser remplazada por otras figuras sintácticas y morfológicas convenientes. (Fig.13)

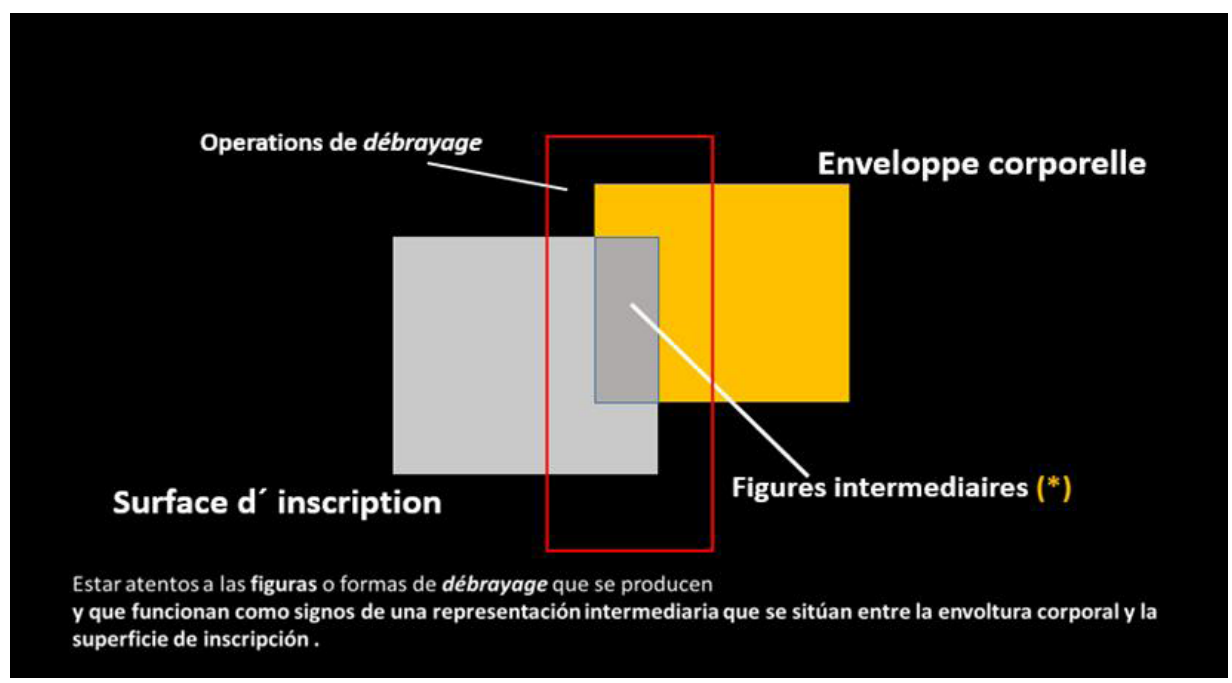

Fig.13. Figuras intermediarias e interacción entre superficies de inscripción y envolturas. (Diagrama de autor). En las prácticas performativas del arte, estamos atentos a la zona de confluencia entre los efectos de envoltura y las huellas producidas en las superficies de inscripción de los cuerpos actuantes. Podemos considerar el trabajo de débrayage sobre envolturas primarias de orden más carnal (la piel misma) o sobre envolturas secundarias por expansión, multiplicación o expansión (vestuario, objetos y artefactos).

En el territorio donde nos hemos desplazado, la mirada semiótica debe estar atenta a las figuras intermediarias entre envolturas y superficies de escritura-inscripción, las cuales se producen en el débrayage enunciativo como proceso de observación a una relativa distancia del acto performativo, o de las series de figuras que emergen del espacio cultural donde se organizan las narrativas y dramaturgias del cuerpo personal. Aquí, hemos recorridos algunos de estos trayectos figurativos, algunos de ellos han sido nombrados bajo alguna isotopía figural. Es una cartografía inicial y, a mi modo de ver, prometedora. Hay, sobre todo, un interés cuando menos interdisciplinario y junto a esto el hecho de "poner a prueba" la eficacia de nuestros modelos y categorías de análisis y de interpretación.

\footnotetext{
12 Para ampliar estos aspectos ver las funciones de la piel como envoltura, superficie de inscripción y memoria en la obra de Didier Anzieu (Anzieu, 1995). Disponible en Scribd.com (español) y en www.psychaanaliyse.com (en francés).
} 
Los artistas performativos contemporáneos juegan seriamente a envolverse en diversas materias y substancias del mundo natural o del repertorio tecnológico. No es nada aventurado hablar también hoy con profundidad e interés del extenso campo de las envolturas sonoras y visuales que capturan y modulan las corporeidades juveniles de todo el mundo ${ }^{13}$. También, como señalamos antes, es sintomático el hecho comprobable de que ha sido la mujer (en sus manifestaciones políticas y artísticas) a partir de finales de los años sesenta, la protagonista central de la construcción de estas figuras que al mismo tiempo funcionan (recordemos las funciones del yo-piel de Anzieu) como un espacio personal de defensa, protesta, resguardo simbólico y de extensión. ${ }^{14}$

\section{Referencias bibliográficas}

ANZIEU, Didier. 1995. Le moi peau. Paris: Dunod.

BATESON, Gregory. 2006. La unidad sagrada. Barcelona: Gedisa.

CALMELS, Daniel. 2004. Juegos de crianza. Buenos Aires: Biblos. .2009. Del sostén a la transgresión. Buenos Aires: Biblos.

CITRO, Silvia coord. 2011. Cuerpos plurales. Buenos Aires: Biblos.

CSORDAS, Theodore. 1994. Introduction: "The body as representation and being in the world", en Th.Csordas editor, Embodiment and experience. The existential ground of Culture and Self. Cambridge: University Press, 1:24.

ECO, Umberto. 1975. Trattato di semiótica generale. Milano: Bompiani.

FISCHER-LISTE, Erika. 2006. "Embodiment: from page to stage" en Semiotics bodies, aesthetics and embodiments. W. North ed. Kassel: University Press.

FINOL, José Enrique. 2015. La corposfera. Ecuador: CIESPAL.

FONTANILLE, Jaques. 2000. "Semiotique du corps : I'enveloppe et le mouvement", en www.unilim.fr.

\footnotetext{
${ }^{13}$ El estudio de las envolturas sonoras (narrativas y pre-narrativas) es un trabajo que tenemos pendiente. Abarcaría en principio, luego de su ingreso al modelo sintáctico, el análisis inductivo más que deductivo a partir de casos y experiencias performativas singulares, sin perder de vista las relaciones de lo auditivo con lo visual, lo táctil y lo olfativo.

${ }^{14}$ Han sido las artistas mujeres las que han introducido a partir de finales de los años setenta, nuevos procesos y perspectivas discursivas en el espacio de producción de sentido de las artes performativas. Sobre todo, a nivel de lo que se ha denominado en el ámbito de la estética, de la sociología y la historia del arte como políticas del cuerpo. En este trabajo hemos puesto algunos de sus ejemplos.
} 
. 2004. Pratiques semiotiques, en www.unilim.fr.

2011. Corps et sens. Paris : Puff.

.2013. "Figures of the body and the Semiotics of imprints", en www.researchgates.com.

. 2016 a. "El cuerpo y sus envolturas, del psicoanálisis a la semiótica del cuerpo", en Tópicos del Seminario 11. México: BUAP-Universidad de Puebla.

. 2016 b. "Análisis del curso de la acción de las prácticas", en

Contexto 25, p 127-152.

2017. Formas de vida. Lima: Universidad de Lima.

FUENMAYOR, Víctor. 2010. “Corporeidad, semiosis y memoria”, en Situarte 9. Maracaibo: LUZ ed.

GREIMAS A.J, COURTÉS. J. 1982. Semiótica. Diccionario razonado. Madrid: Gredos

KRISTEVA, Julia. 1980. Desire in language, NY, Columbia Press.

LLATOUR, M. 2016. "Source psychomotrice de l'experience du temps ou le tonus comme un sixiéme sens", en Rechérche 182, Bordeaux.

LIVOIR-PETERSEN, M. 2009. “Le dialogue tónico-emotionnel”, en Recherche, 157, Bordeaux.

MANGIERI, Rocco. 2013. " Corp extraordinaire,corp vivant”, en Interdiscipline et arts du spectacle vivant, Helbo, Bouko, Verlinden ed. Paris : Honoré Champion.

. 2017. "Kinésica y proxémica en entornos urbanos", en LIS-Ciudad mediatizada 9, 145-170. Buenos Aires: UBA ed.

MAUSS, Marcel. 1934. Les techniques du corp, en www.researchgates.net.

MEAD, Margaret. 1951. "Growt and Culture: a photographic study of balinese childhod", en New York Academic Science, vol.2. NY: Putnam\&Sons.

PONTY, Maurice. 1999. Fenomenología de la percepción. Buenos Aires: Altaya.

STERN, Daniel. 1992. The 'Pre-Narrative Envelope': An Alternative View of Unconscious Phantasy" in Infancy. Bul. Anna Freud Centre, Vol. 15, pp. 291318.

THEREAU, Jaques. 2004. "Le cours d'action, méthode élémentaire”, en www. reserarchgates.net. 
VARELA, Francisco et alter. 1996. The embodied mind. Cogbnitive science and cognitive experience, Cambridge, MIT Press.

VIOLI, Patrizia; POZZATO, María. 2002. "Introduction: Sense and sensibility", en Versus 93. Milano: Bompiani.

VIOLI, Patrizia. 2008. "Beyond the body: Towards a full embodied semiosis", en Frank Diven ed. Language and mind, vol.2. Belin: Mouton de Gruyter, 241-264.

VERON, Eliseo. 1988. “Cuerpo significante”, en Educación y comunicación, Rodriguez J.L editor. Barcelona: Paidós.

ZILBELBERG, Claude. 2003. "Breviario de semiótica tensiva”, en Revista de las ciencias del lenguaje 27. Puebla: BUAP, Ed.Universidad de Puebla. 


\title{
Del espacio a la ciudad. Trayectorias semióticas
}

DOI: 10.24308/IASS-2019-8-027

\author{
Isabella Pezzini \\ Sapienza Università di Roma \\ isabella.pezzini@uniroma1.it
}

\section{Leer y escribir el espacio: una metáfora y un programa de investigación}

En los últimos años, uno de los temas en los que se ha centrado mi trabajo es el análisis semiótico del espacio y de la ciudad: de este interés surgen las reflexiones que les propongo hoy. ${ }^{1}$ La "trayectoria" que me gustaría seguir es la que concierne a la metáfora de la lectura del espacio, fuertemente presente en la literatura semiótica de orientación estructural. Roland Barthes, en su conferencia de 1967 sobre "Sémiologie et urbanisme", declara explícitamente que el programa de una semiología urbana consistiría en elaborar los medios para pasar de escribir y leer la ciudad como una metáfora a su transformación en un programa científico. Creo que hasta la fecha esta transformación se ha logrado en gran medida. En primer lugar, hay un paso decisivo a través del cual esta lectura en cierto punto pasa de aplicarse a la dimensión del signo (espacial, arquitectónico, urbano...), donde se configura como decodificación, a aplicarse al texto, donde se configura necesariamente de una manera más articulada, como análisis e interpretación ubicados en diferentes niveles. Este es un pasaje que implica un fuerte vínculo entre la semiótica del espacio y la semiótica narrativa, inicialmente tratadas de forma autónoma. El estudio de las estructuras espaciales dentro de la narrativa y, en general, dentro de los textos y discursos nos ha permitido profundizar y articular significativamente la cuestión. Podemos distinguir, por ejemplo, entre diferentes tipos de espacialidad, que interactúan entre sí en la construcción del significado: el espacio del texto, es decir, el espacio en el que se inscribe un texto (la página, el lienzo...); el espacio en el texto, es decir, el espacio representado, y finalmente el espacio como texto,

\footnotetext{
${ }^{1}$ Esta intervención proviene de un trabajo reciente de "memoria activa" - es decir recopilar escritos que considero de alguna manera fundadores por una persectiva semiótica sobre el espacio y la ciudad (Pezzini y Finocchi eds. 2020), y, precedentemente, MARRONE, Gianfranco \& PEZZINI, Isabella (eds.). 2006 y 2008. Ciertamente, con esto no propongo de "mirar el pasado", pero me parece interesante reorganizar esta trajectoria a partir del presente, y me parece que este reconocimiento todavía puede estar lleno de ideas y indicaciones para explorar más.
} 
el espacio de nuestra experiencia considerado y establecido como si fuera un texto, de acuerdo con una serie de procedimientos regulados. ${ }^{2}$

Hoy que la investigación semiótica se ha abierto progresivamente al "mundo de la vida" y sus formas - pienso en particular a los estudios sociosemióticos y de semiótica de la cultura- el círculo se cierra de alguna manera. Las habilidades desarrolladas en el estudio de textos ayudan a tratar el espacio vivido como texto. No solo eso, sino que el análisis y la lectura de los lugares pueden convertirse en un estímulo para la escritura e incluso para el proyecto de los mismos.

Sin embargo, los espacios de nuestra experiencia cotidiana, presentan una apertura y una complejidad que dificultan referirse a un procedimiento de análisis "estándar", compuesto por pasos que son siempre los mismos para cualquier estudio de caso. Pero al mirar el corpus de investigación en esta área parece útil para identificar referencias comunes. Algunas indicaciones en este sentido pueden provenir, precisamente, de la relectura que propongo aquí.

\section{De las crónicas de piedra a la dimensión simbólica}

Todos estamos de acuerdo en reconocer en el espacio una "alta simbología". El espacio ha sido constantemente investido de significado y el hombre se ha inscrito en él con formas específicas de escritura, que se han construido con el tiempo: testigo de esto son las representaciones geográficas más antiguas, ricas en decoraciones y ricas en imágenes a menudo fantásticas, donde la experiencia y la imaginación se unieron. ${ }^{3}$ Por un lado, el hombre se inscribe "topológicamente" en el mundo, es decir se significa, por otro lado se entrega a "leer" en su identidad específica, es decir se comunica.

Un primer nodo problemático es la multiplicidad de las formas de escritura con su dominio y estratificación en el tiempo, que hacen de la ciudad un verdadero paisaje y palimpsesto semiótico (Pezzini 2013). En Notre Dame de Paris (1832) de Víctor Hugo, la famosa frase de Frollo "Ceci tuera cela. Le livre tuera l'edifice ", se refiere, en el tiempo de la novela, es decir 1482, a la aparición de la escritura verbal y del libro (recuerda que la Biblia de Gutenberg es de 1455), con respecto al lenguaje de la arquitectura, que está destinado a perder su dimensión de legibilidad compartida por la mayoría de las personas. En el capítulo "Paris à vol d'oiseau", leemos, al final de una descripción detallada: "No era solo una ciudad hermosa; era una ciudad homogénea (...), era una crónica de piedra". Aquí tenemos un ejemplo clásico de lectura urbana inscrita en un texto literario: París se observa desde la parte superior de su catedral, su identidad se reconoce a través de la aparición de sus monumentos que guían

2 Para una revisión sobre el tema del espacio y la narratividad Hammad 2001; Pezzini 2012. Sobre la concepción semióticamente constructivista del texto cf. Marrone 2010.

${ }^{3}$ Cf. Eco 2013. 
el ojo como una puntuación. Se trata de una lectura figurativa, basada en el reconocimiento de elementos conocidos, comprensible para todos. Una lectura que todavía encontramos hoy como uno de los rasgos definitorios del lugar, a diferencia del no lugar, según Augé (1992): un entorno en el que las personas pueden reconocer fácilmente los signos de un pasado compartido.

El uso del término écriture en Barthes, inspirada en la De la gramatología de Jacques Derrida (1967), es evidentemente más amplio que la dimensión lingüística: pero cuando él habla de los problemas que una semiología urbana debe enfrentar, su modelo es la lingüística. Insiste en lo que no debe hacerse: por ejemplo pensar que hay un léxico urbano con significado constante, y que esto puede coincidir con la identificación de funciones específicas correspondientes a cada forma espacial. A menudo, la función se opone al significado: Barthes recuerda a Kevin Lynch (1960), quien, siguiendo su investigación sobre la ciudad estadounidense moderna, afirma la legibilidad de la ciudad como un valor. Sin embargo, la percepción de los habitantes, sus mapas mentales de lugares y ciudades, a menudo, son muy distantes o incluso están en conflicto con los mapas llamados "objetivos". De hecho, la ciudad contemporánea no es el pueblo de Bororo analizado por Lévi-Strauss (1964), ejemplo de una correspondencia exacta entre organización espacial y cultural. El antropólogo, en una lectura que hoy llamaríamos plástica, reconoce en el plan circular del asentamiento los significados de una organización social dualista, en la que se estratifican las oposiciones entre centro/periferia; macho/hembra; sagrado/profano. La articulación espacial refleja, por lo tanto, la organización social de los Bororo, el sistema de parentesco, las posibilidades y prohibiciones de los intercambios matrimoniales entre clanes. Procedemos identificando categorías en el nivel de expresión a las que corresponden categorías en términos de contenido, en una forma de lectura que hoy definimos como semi-simbólica, y que también puede funcionar hoy, cuando estamos interesados en lugares fijos para siempre en un estado temporal dado, como los sitios arqueológicos, o lugares que se restan del devenir continuo que caracteriza el espacio habitado por el hombre. ${ }^{4}$

\section{Reescritura y resemantización}

En cambio, la ciudad contemporánea está expuesta a una continua reescritura y resemantización: "los significados se extinguen, los significantes permanecen", dice Barthes. "La búsqueda de significado es, por lo tanto, solo una etapa temporal. El papel del significado, cuando se trata de comprenderlo, es solo ofrecernos un testimonio en un escenario de distribución significativa". Por esta misma razón, Barthes sugiere multiplicar las lecturas de la ciudad, y en particular explorar su dimensión erótica, de la que poco se habla. Es decir, la ciudad como lugar de placeres de reunión, socialización, compras, comida,

\footnotetext{
${ }^{4}$ Cf. Manar Hammad 2015.
} 
juego etc. En última instancia, teniendo en cuenta que cada uno de nosotros viaja e incluye solo algunos fragmentos de la ciudad, que se pueden combinar entre sí indefinidamente, sin agotar su significado, la metáfora más efectiva es la que considera a la ciudad como un poema de vanguardia. Un poema que hace alarde del significante, en un juego de signos que finalmente se refieren a una estructura finalmente "vacía".

Umberto Eco también dedica un largo capítulo de la Struttura assente (1968) a la semiología de la arquitectura. Es cierto, el signo arquitectónico presenta una disimetría evidente entre la estabilidad de su significante, observable y descriptible, y la variabilidad del significado, que cambia de acuerdo con los diferentes códigos culturales que pueden relacionarse con él en el curso de la historia y sus diferentes interpretaciones. Pero Eco no se rinde, indicando una posible descripción basada en la distinción entre un nivel denotativo y uno connotativo. El nivel denotativo a menudo coincide con la función, el connotativo con los valores simbólicos que cada cultura atribuye a sus objetos. Y un largo párrafo sobre la historia del gótico, que modifica sus significados en función de los contextos en los que se encuentra, anuncia la expansión del formato semántico del código al más amplio y rizomático de la enciclopedia, que registra la evolución de los contenidos.

Se trata de una elección cercana a un enfoque semiótico de la cultura, que encontramos de la manera más explícita en Lotman (1987), para el cual también "la conciencia individual y colectiva (cultural) es espacial, se desarrolla en el espacio y razona con sus categorías ". Lotman habla, ya no de signo, sino de texto arquitectónico. A diferencia de Víctor Hugo (y muchos otros), no lamenta la homogeneidad de las ciudades antiguas "deformadas" por las vicisitudes históricas, sino que, por el contrario, las acepta plenamente como un dato específico de la textualidad urbana, que provoca reacciones dialógicas entre edificios y estilos de diferentes épocas, e innovaciones significativas. La aleatoriedad con la que esto sucede a menudo, por estratificaciones sucesivas, se opone una vez más al deseo de dominar el mundo de una manera racional y absoluta. Como en las utopías, pero también en las ciudades o sus partes diseñadas integralmente de acuerdo con un proyecto preciso, definidas para esto monológicas, expresivas, es decir, de un único punto de vista, de un solo logos. De esta manera, Lotman inserta en la lectura de la ciudad la cuestión de la enunciación, de la multiplicación de perspectivas, incluida dialógicamente en el proyecto y en el desarrollo de la ciudad.

\section{Enunciaciones peatonales y derivas urbanas}

Michel de Certeau (1980) compara la ciudad como una totalidad abstracta con la langue saussureana como sistema e institución, y la ciudad vivida, con la parole, practicada por las enunciaciones peatonales de sus habitantes. Pero 
el "sistema" en este caso no es un juego puramente combinatorio, tiene un sentido político-ideológico: como para Barthes, de alguna manera, "la lengua es fascista", en el sentido de que representa un conjunto de restricciones y predominaciones. De ahí la centralidad del caminar, a lo que De Certeau reconoce una forma de apropiación de la ciudad desde adentro, apropiación que está en tensión cuando no está en conflicto con respecto a la visión desde arriba, es decir, jerárquica y ordenada, de aquellos que gobiernan e institucionalizan la ciudad. Lecturas y escrituras al mismo tiempo, las enunciaciones peatonales se inscriben en el tejido urbano como una serie de tácticas, formas originales de vivir y usar la ciudad. "Desde el fondo", la ciudad se percibe como un laberinto, a menudo conocido a través de "bromas" personales, compuesto de caminos vividos, desconexiones y reconexiones originales y en tramos alternativos a los esperados por los ingenieros de tráfico y flujo. Desde un punto de vista metodológico, la referencia a la inversión de subjetividad y valores en el espacio y, en consecuencia, a los procesos de desemantización y re-semantización a los que está constantemente expuesto, abre el camino a la integración semiótica de las prácticas de investigación etnográfica. ${ }^{5}$

De Certeau ciertamente tiene una referencia a las prácticas de "deriva urbana" teorizadas por Guy Debord en los 1950, en el contexto del situacionismo. Una o más personas que se dejan llevar, por un período de tiempo más largo o más corto, renuncian a las razones para moverse y actuar que generalmente son sus habituales, trabajos y ocios propios, por déjate llevar por las tensiones del terreno y los encuentros que le corresponden. Con menos optimismo que De Certeau, las "derivas" destacaron la extrema pobreza de los circuitos habituales de la vida en la ciudad y quisieron empujar a los habitantes a alejarse para descubrir otros lugares. Se trata de dejarse llevar por las solicitudes del terreno y los encuentros que le corresponden, aunque la parte de la aleatoriedad se equilibra con el alivio psicogeográfico de las ciudades, con corrientes constantes, puntos fijos y vórtices que hacen que el acceso o la fuga sean muy incómodos de ciertas áreas.

También se tomarán como un programa poético: pienso en el proyecto literario de George Perec, su lenta y precisa fenomenología de Espèces d'espaces (1974), donde Perec describe las figuras de la ciudad (la calle, los edificios, los cafés etc.) con dosis necesarias de extrañamiento, en una propedéutica para saber percibir, saber observar, saber captar las características del espacio cotidiano y saber traducirlas en palabras.

\section{Traducciones y representaciones: el mapa y el cuento}

Traducir el lenguaje espacial a otros idiomas es una práctica constante. Pero si "El mapa no es el territorio" (Alfred Korbzyski), ¿qué es? El trabajo de

${ }^{5}$ Cf. por ejemplo Marsciani 2008. 
Louis Marin, interesado en el trabajo de transducción entre diferentes idiomas y tipos de escritura, encuentra una clave en la cuestión de la enunciación. Su lectura de la ciudad (1967) está mediada por la representación cartográfica, un texto en el que la imagen y el lenguaje verbal se entrelazan. Marin interroga la doble dimensión enunciativa, transitiva y autorreflexiva, inscrita en el mapa. Discurso sobre la ciudad, el mapa es a la vez retrato y diseño, el mapa no se limita a "describir" la ciudad, sino que la interpreta, la captura de cierta manera, la reconoce y programa una identidad.

El texto de la ciudad incluye la posibilidad el cuento: "El retrato de la ciudad, así como su perfil, o uno de sus posibles perfiles. La vista topográficaescribe Marin-es una reificación del cuento". Para su destinatario, representa un paradigma de caminos orientados o posibles, una descripción lista para convertirse en una historia. Y cada historia será, por lo tanto, la construcción de una configuración de lugares como la inscripción de un camino. La cuestión del punto de vista aquí se radicaliza, porque el mapa, típicamente, es un dispositivo semiótico que le permite a uno "salir" de la ciudad y, desde sus "puntos de vista", verlo como un todo y apropiarse cognitivamente e imaginativamente, ya que permiten muchos otros discursos sobre la ciudad, así como la necesidad de orientarse y apropiarse física y directamente.

Marin también usa el caminar y sus accidentes para describir también la forma en que avanza la investigación y la escritura. En "Rue Traversière" (1992), nos habla de esta calle parisina, que él atraviesa habitualmente, de final incierto y comienzo incierto que "no tiene otro sentido o dirección que eso o aquello, fragmentario, que el promeneur le otorga temporalmente". Lo asume como el emblema "itinerante" de sus viajes a través de textos y escritos, en el curso de los cuales busca diferentes respuestas a lo que las gramáticas latinas se refieren al lugar: ¿Aquí? Ubi? Quo? Unde?

\subsection{Los poderes de la narratividad}

Incluso Greimas habla de leer la ciudad. En su ensayo de 1976 "Pour une sémiotique topologique", la semiótica del espacio está completamente conectada con la teoría de la narratividad y con su estratificación en diferentes niveles de articulación. En los espacios cotidianos como en los de las narraciones, los caminos de los sujetos pueden describirse como programas narrativos, dotados de significado en relación con los espacios en los que se realizan. Se trata de considerar la ciudad "como un objeto-mensaje que es una cuestión de descifrar, tanto imaginando procedimientos previos a este mensaje destinados a producir la ciudad objeto, como parafraseando la forma en que el lector trata de decodificar el mensaje con todas sus connotaciones y todas sus presuposiciones. Tanto en un caso como en el otro, la ciudad puede considerarse como un texto, cuya gramática debe construirse, al menos parcialmente". 
Hasta ahora nos hemos centrado en leer el texto de la ciudad, que hemos visto progresivamente estructurado gracias a la matriz narrativa. Paul Ricoeur (1998) toma el cuento como un dispositivo teórico más general, vinculado no solo a la representación y el disfrute de la ciudad, sino también a su diseño. Ricoeur propone un estrecho paralelismo entre la construcción en el espacio y la narración, lo que para él significa sobre todo discursos entretejidos a lo largo del tiempo. La arquitectura sería para el espacio lo que la historia es para el tiempo, es decir, una operación de configuración. La sucesión en tres fases es la misma que se ilustra en Temps et récit (1983-1985): en la fase de prefiguración, la narración se inserta en la vida cotidiana y en la conversación, sin distanciarse aún para producir formas literarias. Luego sigue la fase de un tiempo verdadero construido, una vez dicho, que constituirá el segundo momento lógico, es decir, la configuración. Y finalmente termina con lo que, a nivel del leer y del releer, ha llamado refiguración. En analogía con esta sucesión, vivir es la presuposición de construir y el edificio asume la habitación, pero todo esto porque la última palabra se deja a una vida reflexiva, una vivienda que recupera la memoria del construir, y que sea libre de ofrecer diferentes interpretaciones.

\section{Para concluir, brevemente}

Desde esta rápida trayectoria a través de algunos textos fundamentales, siguiendo la metáfora de la escritura/lectura de la ciudad, me parece que emergen algunas constantes de algún interés para guiar también la investigación de hoy. Subrayo algunas de ellos:

- el reconocimiento de que el espacio urbano es un "objeto sincrético dinámico", muy difícil de transformar en un objeto de análisis "cerrado" y estable, si no fuera por fragmentos o por isotopías elegidas explícitamente;

- la oposición continua entre una visión "objetivante" y una visión "subjetiva" de la ciudad, podríamos decir también una visión "especialista" o "científica" y, viceversa, "vivida", "diaria". Esta polaridad también representa una constante en la historia urbana, de la cual surgen valores a veces en conflictos fuertes: por un lado, "visiones de alto" -arquitectónicas, urbanísticas, políticasautorizadas para decidir sobre los métodos de transformación de la ciudad, por otro lado, visiones que responden a otros tipos de valoraciones y también concepciones de lo que es la belleza y lo agradable de vivir en la ciudad.

Me parece que estas polaridades siguen estando presentes también en la investigación contemporánea sobre la ciudad, orientadas a dar cuenta de la doble dimensión de los "seres y las cosas" (y añadiría los discursos) que pueblan e interactúan en la ciudad, para mantener esta doble mirada comparativa entre la vista desde la "parte inferior" y la "parte superior", así como entre la ciudad representada y la ciudad vivida, los discursos de la ciudad y los discursos sobre la ciudad. 
Así, los momentos de "deriva" fenomenológica se alternan con momentos de construcción y reconstrucción metalingüística en busca de una forma semiótica más estructurada. Y, francamente, me parece que estas dos actitudes pueden unirse sin que una supere a la otra.

Las estrategias de análisis en relación con los lugares estudiados, en el contexto de un paradigma teórico-metodológico general compartido, cambian de acento, según los autores, en relación con sus objetivos teóricos y de acuerdo con los diferentes objetos de estudio. La investigación semiótica, en este sentido, se parece más a un organon que a un canon, como observa Paolo Fabbri. Es muy útil observar su forma de proceder, a través de los estudios de caso, que se multiplican, para tener la sensación de una ejemplaridad, como hemos tratado de hacer aquí.

\section{Referencias Bibliográficas}

AUGÉ, Marc. 1992. Non-Lieux, Seuil, Paris.

BARTHES, Roland. 1967, "Sémiologie e urbanisme", in L'aventure sémiologique. 1985: 261-271. Paris: Seuil.

CERTEAU, de, Michel. 1980. L'invention du quotidien. 1. Arts du faire. Paris: UGE. DEBORD, Guy. 1956. "Théorie de la dérive", Les Lèvres nues, No. 9, noviembre.

ECO, Umberto. 1968. 1983. La struttura assente. Milano: Bompiani.

ECO, Umberto. 2013. Storia delle terre e dei luoghi leggendari. Milano: Bompiani.

FABBRI, Paolo. 2017. L'efficacia semiotica. Risposte e repliche. Milano-Udine: Mimesis.

GREIMAS, Algirdas Julien. 1976. "Pour une sémiotique topologique", in Sémiotique et sciences sociales. Paris: Seuil.

HAMMAD, Manar. 2001. Lire l'espace, comprendre l'architecture. Paris: PUF.

HAMMAD, Manar. 2015. Semiotiser l'espace: Decrypter Architecture Et Archeologie. Essais Semiotiques. Paris: Geuther.

LÉVI-STRAUSS, Claude. 1964. Anthropologie structurale. Paris: Plon.

LYNCH, Kevin.1960. The Image of the City. Cambridge (MA): Harvard Un. Press.

LOTMAN, Jurij M. 1998. Il girotondo delle muse. Saggi sulla semiotica delle arti e della rappresentazione. Bergamo: Moretti\&Vitali. 
MARIN, Louis. 1992. Lectures Traversières. Paris, Seuil.

MARIN, Louis. 1994. De la représentation. 1994. Paris: Seuil.

MARRONE, Gianfranco \& PEZZINI, Isabella (eds.). 2006, Senso e Metropoli. Per una semiotica posturbana. Roma: Meltemi.

MARRONE, Gianfranco \& PEZZINI, Isabella (eds.).2008, Linguaggi della città. Senso e metropoli II. Modelli e proposte di analisi. Roma: Meltemi.

MARRONE, Gianfranco. 2010. Introduzione alla semiótica del testo. Roma-Bari: Laterza.

MARSCIANI, Francesco. 2007. Tracciati di etnosemiotica Milano: Franco Angeli.

PEZZINI, Isabella. 2012. "Spazio e narratività", in Lorusso \& Paolucci \&Violi (eds). Narratività. Problemi, analisi, prospettive. Bologna: Bononia University Press.

PEZZINI, Isabella y FINOCCHI, Riccardo (eds.). 2020. Dallo spazio alla città. Lettura e fondamenti di semiotica urbana, Milano-Udine: Mimesis.

PEZZINI, Isabella.2013-2014. “Nouveaux paysages sémiotique et changement de la forme urbaine", Degré 156-157. Espace, sémiotique, cognition, a cura di Isabel Marcos.

RICOEUR, Paul. 1998: 41-51. "Architecture et narrativité", Urbanisme 303, novdic. 


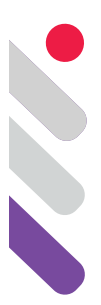

\title{
Presencia, identidad y afectividad en Los heraldos negros, de César Vallejo. Apuntes de hermenéutica semiótica
}

DOI: 10.24308/IASS-2019-8-028

\author{
Óscar Quezada Macchiavello \\ Universidad de Lima \\ oquezada@ulima.edu.pe
}

\section{Instancia de discurso}

Hay dos razones, o quizá indisposiciones, que me han provocado siempre cierta reticencia a emprender el análisis o aún el mero comentario de la obra de un poeta. La primera concierne a la objetiva dificultad que entraña involucrarse, adentrarse, compenetrarse, bucear en el caudal simbólico del texto poético. Este, por la complejidad del entramado de sus niveles y de sus figuras de composición (y de descomposición), es el que con más fuerza pone a prueba la consistencia de una elaboración teórica y la coherencia de sus respectivos procedimientos metodológicos.

La segunda concierne a la ingenua concepción instrumental del lenguaje como algo exterior a los actores individuales o sociales que, lamentablemente, predomina en la crítica literaria habitual. Frente a ella, la metodología semiótica entiende un fenómeno de lenguaje como acontecimiento que constituye al ser humano haciéndolo carne-cuerpo-sujeto de comunicación. Dicho en breve, si biológicamente somos de ADN, semióticamente somos de lenguaje. Y existir es hacer discurso de ese ser lenguaje. Así pues, cualquier discurso entraña en su entraña un proceso de significación asumido por una enunciación.

En consecuencia, la instancia de discurso, más aún si es empíricamente identificada con un poeta, no es un autómata que ejerce una mera capacidad codificadora sino una presencia humana, un cuerpo sensible que se expresa. El corte epistemológico de la semiótica se da, pues, en lo que la teoría funcionalista llama mensaje. Se entiende no solo que en un discurso hay tantos "mensajes" como operaciones que lo constituyen, no solo que los códigos son competencias de quienes se comunican, sino también que, precisamente porque son humanos, los sujetos modelados por la teoría son de lenguaje. Así 
pues, yendo al objeto aquí atendido, la significación de un poema es inmanente. No radica en el autor sino en la estructura de la obra. Es ella la que da valor al autor y no viceversa.

No es necesario, entonces, conocer al autor para captar el sentido de la obra. Cualquier cosa que el poeta diga sobre su poema, ya no es su poema, ya es "otro discurso". Blanco cita a Eco, quien resume de modo brutal esa tesis: "El autor debería desaparecer después de haber escrito su obra. Para allanarle el camino al texto" ${ }^{\prime 1}$. La vida contada es, eo ipso, una vida construida, radicalmente distinta de la vida vivida. Otra vez, tajante, Desiderio Blanco afirma: quien escribe su vida "inventa" su vida².

El enunciador poético es una entidad semántica construida por el poema (ergo, por el lenguaje puesto en acto, en discurso); solo existe en la medida en que profiere enunciados. Ningún enunciado se enuncia solo. Ante un enunciado como "Hay golpes en la vida tan fuertes... ¡Yo no sé!" es necesario postular una instancia que lo profiera, la cual no es el "yo" enunciado, que "no sabe", sino la del "yo" de la enunciación, que, sin decirse, "dice que no sabe". Insistimos, pues, en que el enunciado no se dice a sí mismo, exige una instancia que lo produzca. Esa es la instancia dual de enunciación: enunciador / enunciatario, la cual es identificada empíricamente por el par escritor/lector, lingüísticamente por las marcas "yo / tú", semióticamente por la instancia de discurso de la que forma parte y, fenomenológicamente, dentro de esa instancia, por el cuerpo propio y su "carne", núcleo sensorio-motor de la experiencia enunciante.

Voy a aprovechar, pues, las circunstancias que juegan a mi favor: el equipamiento conceptual de la semiótica, el hecho de no haber conocido personalmente a don César Vallejo o, más bien, el hecho de que don César Vallejo no me haya comentado "lo que quiso decir" en Los heraldos negros. ${ }^{3}$

\section{Título y epígrafe}

Este emblemático poema juega como carta de presentación, u obertura, de un poemario del mismo nombre. Consta de cuatro cuartetos más un verso final que repite el primero. Estrofas de versos alejandrinos, a excepción de la primera (en la que dos primeros versos son alejandrinos; y los dos siguientes, endecasílabos). En las estrofas regulares riman los versos pares; los impares están sueltos. En la primera estrofa riman el primero y el cuarto. El poema no

\footnotetext{
${ }^{1}$ (Eco 1985: 14) Poco antes, Blanco ha recordado a Lévi-Strauss, quien sostenía que "no iríamos muy lejos en el análisis de las obras de arte si nos atuviéramos a lo que sus autores han dicho o incluso a lo que han creído hacer". (Lévi-Strauss 1976: 596). (Blanco 2009:55).

2 (Blanco 2009: 57)

3 A partir de aquí: LHN. Texto del poema (Vallejo 1997: 143). "Luis Cernuda, exiliado en México, participaba en un recital poético. Después de leer su poema, un oyente levantó la mano y le preguntó: 'Señor Cernuda, ¿podría decirnos qué quiere decir con el poema?'. 'Con todo gusto', respondió Cernuda. Abrió la cuartilla y leyó de nuevo el poema. Y añadió: 'Eso es lo que quería decir'". (Blanco 2009: 62).
} 
guarda la forma perfecta: apela a la rima parcial y en una estrofa se permite otro metro y una rima diferente ${ }^{4}$.

A propósito de 'heraldo', Corominas identifica una genealogía de términos que remite al francés héraut y, antes, al fráncico. La palabra HERIALD, hipotética, no documentada en texto alguno ni en el lenguaje hablado es, no obstante, considerada de segura existencia. Significa 'funcionario del ejército'. Compuesto de HERI 'ejército' y WALDAN 'ser poderoso'. Hacia 1495 había sido castellanizado en la forma faraute, que significaba 'intérprete', 'mensajero de guerra" 5 .

Roles, ambos, de linaje semiótico: el primero desde la posición enunciataria, descifrador, dador de sentido; el segundo desde la posición enunciadora, emisario de un poderoso. Delegados ambos: uno del Hado, el otro del Imperio; en la figura de los 'heraldos' se encuentran, en estados puros o de mezcla, temas de Hermes y de Marte. El heraldo, en cuanto actor 'intérprete', convoca una pléyade de adivinos, augures y profetas. El heraldo, en tanto actor mensajero, convoca a emperadores, a reyes, a magos, a generales. En 'heraldos' conviven, pues, 'lecturas' y 'conflagraciones' (valga el quiasmo: lecturas de conflagraciones / conflagraciones de lecturas). Hermes, en particular, es el mensajero divino. Los heraldos negros, avatares de Hermes, traen mensaje del destino. El enunciador poeta toma posición en ese "hacer presente que lleva al conocimiento en la medida en que es capaz de prestar oído a un mensaje" 6 . De ahí que "lo hermenéutico no quiere decir primeramente interpretar, sino que, antes aún, significa el traer mensaje y noticia" ${ }^{\prime}$. Si en el mundo griego los poetas son mensajeros de los dioses, en el mundo que aquí exploramos los dioses ya no están, los ángeles tampoco, y al poeta solo le queda prestar oído a los 'heraldos negros' y ser mensajero de lo único "a la mano": el sufrimiento y la muerte.

Como epígrafe del poemario, Vallejo usa un leit motif tomado del Evangelio: Qui pótest cápere capiat, cuya traducción es: 'El que tenga oídos que escuche'; o bien, 'El que quiera entender, que entienda'8. Algunas figuras del

\footnotetext{
${ }^{4}$ Observaciones formales tomadas de Silva Santisteban, Ricardo (Vallejo 1997: 61). Identifica una vertiente negra de Vallejo proveniente "de un romanticismo afincado todavía en la tradición castellana modernista que intenta escandalizar al lector" (Vallejo 1997: 61).

${ }^{5}$ (Corominas 1976: 317). Informa, además, que del castellano faraute, el término pasó al francés faraud 'farolero'. En cuanto 'mensajero de luz', a las connotaciones herméticas añadiría las luciferinas. Esa observación es importante para nutrir la interpretación del imaginario discursivo de Los Heraldos Negros.
}

${ }^{6}$ (Heidegger, 1987: 110).

7 (Heidegger, 1987: 111).

8 Tanto en el Antiguo como en el Nuevo Testamento la Revelación es sometida a ocultación mistérica. "Ya desde los tiempos del salterio, cuando se anuncia que se va a publicar lo que está oculto desde la creación (Salmos 78,2), se abre la boca muy estrecha para ello en parábolas, para que, según se explica no sea que con sus oídos oigan y con su corazón entiendan (Isaías 6, 9-10) todos aquellos que aún no pueden o deben conocer el misterio" Pla, R., 2018: 92. El Mesías viene a hacer oír y a hacer entender en el supuesto de que, respecto al Misterio del Reino de Dios, "su 
Evangelio son recurrentes en LHN; podríamos decir que se trata de un poderoso intertexto, desacralizado por cierto, pero cuya aura sacra, numinosa, insiste y persiste a lo largo de varios poemas. Por lo pronto, sabida la etimología de "Evangelio", LHN serían un "Disangelio". Y los heraldos negros estarían en las antípodas de los ángeles blancos.

Precisamente, si de los 'heraldos' el enunciador poeta predica que son 'negros', entonces hace presente con el contracolor de todo color, asociado a las tinieblas arcaicas (o escatológicas), la indiferencia originaria, primordial y fatal. Todo enunciatario deviene presencia presenciando heraldos que son oscuros y se acercan en la oscuridad.

Si bien podemos imaginar que los 'heraldos' son 'negros', fuerza poética inmediata; también podemos ser más realistas e imaginar que los 'heraldos' están vestidos de negro, tienen puesta ropa negra. En el vaivén de un ser naturalmente negros a un cultural estar de negro vestidos, brota una pertinente escena práctica: el luto. Más aún por la ubicua y potente presencia de la muerte en el poemario. Tomemos nota.

Instalado bajo el mundo, lo negro expresa la pasividad absoluta, el estado de muerte consumado e invariante entre las dos noches blancas donde se operan, en sus costados, los pasajes de la noche al día y del día a la noche. El negro es pues color de duelo, no como el blanco, sino de una manera más abrumadora. El luto blanco tiene algo de mesiánico. Indica una ausencia destinada a colmarse, una vacancia provisional. Es el duelo de los reyes y los dioses que obligatoriamente han de renacer: el rey ha muerto, iviva el rey!, cuadra perfectamente a la corte de Francia, donde el duelo se llevaba de blanco. El luto negro es, podríamos decir, el duelo sin esperanza. Como un 'nada' sin posibilidades, como un 'nada' muerto después de la muerte del sol, como un silencio eterno, sin porvenir, sin la propia esperanza del porvenir, resuena interiormente el negro, escribe Kandinski. El duelo negro es la pérdida definitiva, la caída sin retorno en la nada: el Adán y la Eva del zoroastrismo, engañados por Ahrimán, se visten de negro cuando son expulsados del paraíso. Color de condenación, el negro se convierte también en el color de la renuncia a la vanidad de este mundo, de donde los abrigos negros constituyen una proclamación de fe en el cristianismo y en el islam: el manto negro de los mawlavi -los derviches giradores- representa la piedra tumbal. Cuando el iniciado se lo quita para emprender su danza giratoria-, aparece vestido con una ropa blanca que simboliza su renacimiento a lo divino, es decir, a la realidad verdadera: entretanto han sonado las trompetas del juicio. En Egipto, según Horapolo, una paloma negra es el hieroglifo de la mujer que quedaba viuda hasta su muerte. Esta paloma negra puede considerarse como el eros frustrado, la vida negada. Es sabida la fatalidad manifestada por el navío de velas negras desde la epopeya griega hasta la de Tristán?

entero ver y entender no depende solo de la agudeza del intelecto sino, ante todo, de la limpidez de la conciencia, para que esta reciba con sus aguas sosegadas el fruto de su semilla interior". Ibid.

9 (Chevalier y Gheerbrant 2003: 747) 
Esa extensa cita de Chevalier y Gheerbrant resume las estructuras figurativas, temáticas y pasionales, todas ellas potenciales, que Vallejo disemina en LHN, tomando posición del lado del luto negro, no del blanco, es decir de un duelo más abrumador, más total. De una pérdida definitiva, de una fatal condenación, de una caída sin retorno, de un vacío de esperanza, ante los que cualquier fe de renacimiento divino resulta ridícula. En suma, de un nihilismo lanzado al silencio eterno, sin porvenir, sumido en lo imposible de lo posible, en la nada absoluta e inapelable. En LHN resuena el 'negro' con todos esos valores agregados. No obstante, de él también emerge la ética de renuncia a la vanidad del mundo, caldo de cultivo para tomas de posición solidaria, semillas de comunismo.

Pues bien, ¿cómo se hace presente el poeta en su poema? ¿Cómo deviene presencia que presencia presencias? ¿Qué presencias presencia? ¿Cómo le afectan? ¿Cómo construye y deconstruye su identidad? Como primer poema, LHN concentra la tónica afectiva dominante en la integridad del poemario. Los 'golpes en la vida, tan fuertes', recurrentes, investidos por distintas configuraciones, son la presencia central, la cualidad sensible en la que la enunciación pone la mira intensa. Un sujeto pasional-cognitivo, 'yo', aparece como presencia próxima, captado por los 'golpes', sometido a ellos, los observa, los sufre. En cuanto cuerpo, ese sujeto es la superficie misma en la que los golpes han impactado. Catáfora al verso 8: amplificación a nosotros, esos 'golpes' equivalen a 'los heraldos negros que nos manda la Muerte', 'ella', no-persona en horizonte amenazante. La presencia de los 'golpes' se interpreta como aviso, advertencia o anuncio de aniquilación. Por lo tanto, 'la Muerte' ocupa, a su manera, por un lado, el horizonte de campo, en cuanto destinadora de los 'golpes-heraldos', cuyo destinatario es el sujeto pasional-cognitivo, carne de impresión que muda a la tercera persona en las figuras del 'rostro más fiero' y del 'lomo más fuerte'; por otro lado, el centro de campo, en cuanto presencia presente en los 'golpes-heraldos' que golpean y afectan al sujeto en posiciones sucesivas: yo, ellos, nosotros.

Postulamos la presencia de la relación [golpe / golpeado] como cualidad sensible central del discurso; esto es, como algo, que, por una parte, ocupa cierta posición relativa a la posición de lectura dando lugar a efectos espaciales de distancia y de duración; en concreto, a afectos abiertos a lo más cercano y a lo más reciente. Por otra parte, esa presencia de los 'golpes golpeando' es algo que afecta en lectura con intensidad tónica, fuerte; y de tempo acelerado (en cuanto intempestivos) o ralentizado (en tanto 'son pocos'). Así pues, la presencia es un valor trabajado, a la vez, por una valencia extensa (espacialidad/temporalidad) referida a las veces numerables y por una valencia intensa (tonicidad/tempo) referida a los golpes medibles ${ }^{10}$.

10 (Zilberberg 2006: 86-92) 


\section{Estrofa 1}

Una primera voz, presupuesta, desembraga: 'Hay golpes en la vida'. Cabe una observación, no tan al margen. Considerando que la ' $H$ ' es muda en español, la pronunciación de 'Hay' convoca a 'iAy!', exclamación de dolor que coloca al enunciador como paciente en acto de los 'golpes'. Esa 'otra lectura' no programada gramaticalmente, emerge como evento en el uso mismo de la expresión y de su coherencia con lo relatado. Ahí está. Latente.

La vida, espacio extensivo de las veces, muchas, débiles, valor de universo, deviene conteniente de los golpes, pocos, pero fuertes: valor de absoluto. El ejercicio de la vida, articulado por repeticiones, encarnadas de preferencia en inveteradas costumbres y en rituales cotidianos de supervivencia, es interrumpido "de vez en cuando" por eventos que sobrevienen y lo alteran. Definidas como "casos en los que se producen hechos", las veces dan forma al espacio-vida como lo que "llega a" un grado débil, átono, inacentuado, del sobrevenir. Como lo que, al transcurrir en el tiempo y en el espacio, da lugar a la enumeración y a la serialidad. El correlato de la vez, débil, átona, es el golpe, fuerte, acentuado. Lo fuerte, que define los 'golpes en la vida', es realmente fuerte, afecta toda carne de referencia.

'Yo no sé!'. Embrague de 'golpes', [ellos], a [yo]. Enunciación que, de golpe, hace golpe del enunciado. Su referente interno son los 'golpes' y, a su vez, es golpe (acento, exclamación). Resuena un lugar común del territorio socrático: Sólo sé que nada sé. O máximas como: el que no sabe y sabe que no sabe, sabe más que el que no sabe y no sabe que no sabe.

La voz pasional, presupuesta, afirma: 'hay golpes en la vida'. La voz cognitiva, puesta, manifestada por la primera persona, golpeada por la ignorancia, afirma su no saber. El enunciador paciente constata algo fuerte en la existencia, al mismo tiempo, ya como enunciador agente, se desentiende de ese algo, simulando ser un observador externo, trascendente. Yo solo constato en mí mismo que así es, no me pregunten por qué. Siento los golpes, no sé sus causas. Las dos voces del yo poético se unifican en el mismo drama, modalizado por padecer y no saber. Dos sujetos en uno (golpeado por los golpes y por la ignorancia acerca de su origen y sentido). Sabe que hay golpes, no por qué y menos aún con qué fin. Sabe porque los siente en su mi-carne y los hace ser en el enunciado.

El discurso va a dar vueltas expansivas en torno a la condensación del enunciado inicial: 'Hay golpes en la vida, tan fuertes'. Va a abrir nuevos horizontes, a diversificarlos en sus configuraciones. Va a insuflar fuerza en ellos, a imprimir una dirección de ascendencia tensiva: no solo existen, además redoblan y amplifican su intensidad, la que culmina con la tónica presencia de 'la Muerte', de la que son aviso. Ese trajín expansivo, que recurre al vector fórico del redoblamiento, refuerza la consternación en la que sumen los 'golpes'. Así, 
en el segundo verso, opera la semejanza, vía comparación: 'como', aplicada a la figura 'del odio de Dios'. Esta deviene parangón, imagen-fuente de los golpes cuyo destinatario-blanco es el "yo pasional". Un contundente inter discurso potencial, divulgado en la semiosfera cristiana, dice que Dios es fortísimo, todopoderoso. Si a esa fuerza exponencial, superlativa, que puede todo, se añade la pasión 'del odio', acentuamos el mencionado redoblamiento por amplificación. Ese 'odio de Dios' remite al arquetipo del patriarca autoritario que impone su ley. El "yo" poético, contestatario, responde así a un soterrado e institucional "yo" religioso; parafraseando: "de Dios siento odio, no amor". Los 'golpes en la vida' iconizan ese sentimiento repulsivo. Los 'golpes' dados por el 'odio de Dios' dejan un marcaje en el mí-carne enunciante. Una divinidad iracunda, colérica, golpea, pega. El enunciador pone al enunciatario ante los 'golpes', los desembraga, los objetiva, desde aquí los hace ser-ahí.

Ese mismo "yo-aquí", en el tercer y cuarto versos, presenta lo que sucede ante los golpes, ante su presencia ahí, ante su realidad. Ese ante coloca a los golpes antes de ese proceso icónico que asimila la temática del sufrimiento al agua que se va empozando. Pero la isotopía /física/, exteroceptiva, va a ser desplazada por la isotopía /psíquica/, interoceptiva: el efecto de ese afecto, tematizado ya, recae en la figura conteniente del "alma", donde parece que 'la resaca de todo lo sufrido se empozara'. El residuo de lo vivido-sufrido queda estancado cual creciente charco en el "alma". Late el potente arquetipo [psique:agua], mediación, en la antropología cristiana, entre [cuerpo:tierra] y [espíritu:fuego].

Los 'golpes', huellas en la isotopía /psíquica/, rigen sobre los 'golpes', meros impactos en la isotopía /física/. Su sola presencia da lugar a la imagen de lo que no fluye, de lo turbio que se acumula, de lo que queda grabado, de lo que pesa, del pesar cual creciente huella impregnada en la cavidad del sí-mismo. Culmina el cuarto verso con un nuevo embrague, reiterado testimonio del sujeto cognitivo-pasional, puesto más aquí: "iYo no sé!", cuya eficacia consiste en devaluar sus propios simulacros, recién enunciados, regidos por 'como si ante'.

\section{Estrofa 2}

En el quinto verso, los 'golpes', adquieren explícitamente valor de absoluto: 'son pocos', valencia concentrada, 'pero son', valencia tónica... recaen en las figuras somáticas del sujeto del padecer: 'rostro más fiero', 'lomo más fuerte'. Aunque la carne es agresiva, tensa, resistente, resulta sajada, quedan en ella 'zanjas oscuras'. Remisión a las heridas, a los sombríos resentimientos, a los sentimientos indescifrables, a los presentimientos de fosa, de tumba. El enunciador de LHN pone la acción de los 'golpes' en el centro del enunciado, pero también en el corazón de la enunciación exclamativa. Los 'golpes' son 
divisores, las 'veces' multiplicadoras; tanto en lo que respecta al relato del poema como en lo que concierne a su puesta en discurso. El ritmo discursivo oscila entre el estilo intensivo dado por la fuerza y unicidad de cada golpe, y el estilo extensivo manifestado en ese progresivo 'empozarse de lo sufrido', en esa acumulación de 'zanjas oscuras'. "Como el 'golpe' es 'seco' y 'súbito', su medida indudable fija al mismo tiempo la de la 'vez' como extensión"11. Formas imperativas "indican o recuerdan al usuario los matices que hay que respetar para conferir a la ejecución de los programas la prosodia que les conviene"12. El enunciador, en cuanto ususario, entiende que los golpes dividen la vida, la cortan, la tasajean, la matan, pero a la vez se extienden en ella como huellas de las que el poema hace memoria.

Recién en el verso 7 la modalidad factitiva reinante, típica de la dimensión pragmática, da paso a la probabilidad: 'Serán talvez'. 'Serán' opera como anáfora a los 'golpes' que, esta vez, se invisten ora como 'los potros de bárbaros atilas', reforzando la apertura de 'zanjas oscuras'; ora, octavo verso, como 'los heraldos negros que nos manda la Muerte'. La forma 'talvez' hace que estas figuras se deslicen, como probabilidad, a la dimensión cognitiva del discurso, esto es, a algo que el enunciador cree, pero no confirma. (Como si se tratase de un "tambaleo" cognitivo frente a la fuerza afectiva de los golpes).

En el verso 8 aparece un embrague a [nosotros], actante cognitivo, destinatario-blanco de los mensajes cifrados transmitidos por esos 'heraldos negros', míticos avatares de Hermes, actantes de control, delegados de 'la Muerte', destinadora-fuente que nos los 'manda'. (Notar la doble acepción de este último verbo: /envía/ y /ordena/, esta última, marca de jerarquía, índice de autoridad). Un saber potencial de la praxis enunciativa se agazapa en esas figuras: "se sabe" que donde pisaban las huestes de Atila no volvía a crecer vida. Pero el poeta habla de 'atilas' con minúscula, acoplando los 'golpes' a la cantidad, a la epidemia, a la proliferación, a la plaga. Por lo demás, dice 'bárbaros', actantes que, en profundidad vertiginosa, vienen desde un horizonte hacia un centro ocupado por el enunciador mismo, colocado en el lugar imaginario del civilizado, del cristiano. Entonces, se trata siempre de lo extraño, de lo extranjero, de lo invasor, del enemigo. "Se sabe", además, que la sequía y la carencia de frutos convierten en nómade al hombre...la tierra que pisa está maldita.

Se confrontan dos formas de vida (una sufriente, debilitada; la otra mensajera de muerte, fortalecida), dos líneas de congruencia 'vertical' entre planos 'horizontales' de oposiciones: [ "tierra fértil" vs "tierra estéril"; "verdor" vs "desierto"; "bendición" vs "maldición"; "sedentarismo cultivado" vs "nomadismo originario"; "ciudad" vs cábila; "seguridad" vs "errancia"]. El

${ }^{11}$ (Zilberberg 2006: 65)

12 (Zilberberg 2006: 66) 
Occidente cristiano promueve la forma de vida del cultivo-ciudad, introduce el concepto de "cultura", de "orden", de "tiempo". Desde ahí el poema enuncia un mundo amenazado. El Extremo Oriente, de donde provienen los 'bárbaros atilas', espacio exterior a la semiosfera presupuesta, es percibido desértico, regido por el nomadismo, por la precariedad e inestabilidad, con "órdenes" y "tiempos" de morfologías y sentidos distintos de los urbanos.

Por lo demás, cabe reiterar la ausencia de color y de luz hecha presente en los 'heraldos negros'. Los 'golpes' absorben nuestra energía vital, la debilitan, convirtiéndola de viviente en muriente, tal como algo negro absorbe la luz y no la devuelve. Delegados de 'la Muerte', los 'heraldos' son oscuros y dejan oscuridad a su paso, predican con 'golpes'. Los vivos murientes de LHN se contraponen a los muertos vivientes del Evangelio.

\section{Estrofa 3}

El verso 9 supone la modalización factitiva 'Son': se realiza lo regido por 'la Muerte'. Mediante la onomástica 'Cristos', el poeta engancha con el discurso evangélico. No hay un Cristo, que valdría como "él", objetivado, exterior, personaje de la historia sagrada. Más bien hay muchos y valen como actantes interiores, subjetivos, provenientes del alma, alojados en ella. Los 'golpes' son ahora las 'caídas hondas', de esos Cristos (anáfora a los 'pozos' de las 'resacas', a las 'zanjas oscuras', a las pisadas de los 'potros de bárbaros atilas'). Del alma-pozo, cavidad de todo lo sufrido, verso 4; al alma-morada de los Cristos (hondamente) caídos. Homología: el alma pozo es al alma morada lo que todo lo sufrido es a las caídas de "nuestros" Cristos. Se podría discutir, en una pertinencia gramatical, que el enunciado desembraga, objetiva, a "los" Cristos (no a "nuestros" Cristos). Replicaríamos que no los desembraga en una "historia sagrada" sino en "el alma" (del que habla). Y el que habla ha mencionado antes a "bárbaros atilas" (negándole la mayúscula al rey de los Hunos). El "yo" poético toma posición en el destinatario cristiano, "nosotros" de la "historia sagrada", semiosfera Occidental. Como vimos, los Hunos, "ellos en sus potros", oscuros heraldos arrasadores, vienen desde los bordes, destruyendo "la" vida. "Potros" acerca "golpe" a "galope". A pisada en el "alma tierra", alma corporal, paciente extensa de su brutal trotar. En el mundo hay "atilas", en la hondura del alma, alma aire, hay 'Cristos' caídos. Esas 'hondas caídas' no solo dan profundidad al alma, también asimilan la vida humana a la pasión de Cristo, en particular, al vía crucis: los golpes devienen latigazos, bofetadas, caídas...que son solo la superficie figurativa, corporal, de las penas tematizadas en el 'alma' espiritual. Los 'atilas' dibujan la dimensión horizontal del dolor; las 'caídas', su dimensión vertical. Espacialización en Cruz.

Verso 10: los 'Cristos del alma', sin perder presencia, dejan su lugar a 'alguna fe adorable que el Destino blasfema'. La praxis discursiva ha coagulado 
la constelación: fe, religión, Cristo, adoración. Generando coherencia: "Con los Cristos del alma cae también alguna fe adorable que el Destino blasfema...". Dos actantes entran a escena discursiva, aparecen por desembrague: la "fe adorable", "ella", tras la cual está el sujeto feligrés, devoto, ferviente creyente en una religión; y el Destino, "él", destinador-juez que, del lado de 'la Muerte', sanciona como disfórico el objeto adorado por aquel. Los 'golpes en la vida' coinciden con las blasfemias del Destino. La 'fe adorable' cae profanada por el insulto. 'Destino' y 'sentido' permutan su diferencia en el Mismo universo. Los 'golpes' y todas sus figuras, del lado del Destino, siguen el Sentido de un esquematismo ascendente que culminará en 'la Muerte'. El 'yo' poético, destinatario de los 'golpes', con sus Cristos, con su fe adorable, a partir de la acentuación de esos 'golpes', sigue el itinerario de un esquematismo descendente, su resistencia aminora hasta la honda extenuación.

Verso 11: 'Esos golpes sangrientos son las crepitaciones de algún pan que en la puerta del horno se nos quema', imagen quizá prosaica pero muy intensa pues entraña embrague a ese 'nosotros' destinatario de los 'heraldos negros' cuyo destinador es 'la Muerte', quien se consume y consuma en el centro del campo de presencia: los 'golpes', ahora 'sangrientos', se contagian de carne torturada. 'Son', se realizan, en cuanto 'crepitaciones de algún pan', figuras de un fuego impactando la masa de harina. Así como los galopes de los potros lo son los de una carne animal que horada la carne de la tierra, ahora se trata del fuego que hace vibrar 'algún pan'. La semiosfera cristiana, iterativa, presiona la lectura: el 'pan' es el cuerpo de Cristo, el 'vino' su sangre, el 'fuego' bautiza en Espíritu, no quema. El fuego del horno quema, el del espíritu libera, transforma.

Hay 'golpes sangrientos' que son como las 'crepitaciones de algún pan'. Herida. Sangre. Carne quemada. Sacrificio inútil. La figura retórica del 'pan que se quema en la puerta del horno' es la de la 'fe adorable', la del plan, el programa, el proyecto, la ilusión, el sueño, listo para realizarse y que, por una u otra razón, no se lleva a cabo. El hombre se esfuerza, propone; 'el odio de Dios' dispone. El pan es la fe, pero también es el plan de vida en el que se han ido sudores, insomnios, desvelos, preocupaciones. El 'pan quemado', parangón del objeto desprovisto de valor alimenticio, remite a las decepciones y fracasos. $Y$ 'quemado en la puerta del horno' significa que se nos malogró cuando no faltaba nada para bien lograrse. 'La resaca de todo lo sufrido' empozada en el alma, por anáfora a los versos 3 y 4 ; y lo vivido empozado como charco de culpa, en la mirada, por catáfora al verso 16; son efectos de la objetivación de los 'golpes', convocan ambos la figura del 'charco'. Las crepitaciones del pan que se quema en la puerta del horno, a su vez, convocan la figura del 'chasco'. 'Charco' es a resentimiento lo que 'chasco' es a frustración, a decepción. Circuito del pesar que deja sus huellas en [nosotros]. 


\section{Estrofa 4}

Si bien en la perspectiva sintáctica confirmamos un desembrague de 'nos' a 'él', semánticamente ha quedado fijada, consolidada, una identidad: \{"yo" = "él" . Quien dice: 'Y el hombre... ¡Pobre...pobre!', encarna al "yo", poetahombre, que toma distancia de "él", el hombre, y lo compadece modulando el adjetivo en exclamación ralentizada por los puntos suspensivos ${ }^{13}$. ¿Desde dónde se evidencia, en el verso 14, esta conmiseración del individuo 'último' por su propia especie así objetivada?: 'Vuelve los ojos, como cuando por sobre el hombro nos Ilama una palmada;.' [Él], pobre actor, vuelve los ojos, la mirada, al [yo] observador relator...el símil que sobreviene articula, por suma, la identidad ya señalada: $\{$ "yo + él = nosotros" $\}$. 'El' vuelve los ojos tal como lo hacemos 'nosotros', individuos de una pobre especie (receptores de los heraldos y del pan quemado, ambos negros). La figura, también prosaica, de la 'palmada sobre el hombro', atenúa sin duda la fuerza de 'los golpes', remite al abrazo de pésame o al gesto de consuelo...pero sólo para que el enunciatario se dé cuenta de que 'él' ya está sobrepasado, alienado, excitado, excedido por 'ellos': 'vuelve los ojos locos'. 'Y todo lo vivido' (repercusión anafórica al tercer verso: 'todo lo sufrido'), 'se empoza' (ídem al cuarto verso). Lo sufrido es lo vivido. Y 'se empoza, como charco de culpa, en la mirada'. El hombre ya no tiene recursos para desaguar la culpa empozada. Lo 'sufrido' que 'se empozara', de la primera estrofa, es, ahora, 'un charco de culpa'. Vimos ya que, entre ambos charcos, sobreviene el chasco. Lo sufrido, frustración de por medio, deviene culpa. El alma recipiente es, ahora, 'la mirada'. El alma de ese pobre ser se expresa en su mirada de ojos locos, revela la culpa atorada, atascada. La blasfemia del Destino es el veredicto del odio de Dios, de ese malvado juez que nos ha declarado ya desde siempre culpables. La locura, paroxística, se entrama con la culpa y, en horizonte, con la frustración. Evidencia (en la) videncia, mirada eternizada en un ahora fatal.

\section{Coda}

Poema de dominante 'objetiva', limita la construcción del efecto de 'intersubjetividad' al [tú] implícito, articulado bien sea desde el [yo] o bien desde el [nosotros], marcas que aparecen con seis embragues: tres a [nosotros] (versos 8, 12 y 14) y tres a [yo], semejante al apóstol Pedro, el enunciador niega tres veces saber algo (versos $1,4,17$ ). Si bien no hay lugar para un [tú] explícitamente enunciado, si lo hay para un [él] humano, demasiado humano (Nietzsche dixit). No obstante, los seis embragues mencionados crean y refuerzan la distancia con ese [él]. Sea como fuere, estén vestidas de [él] o de [nosotros],

\footnotetext{
${ }^{13}$ La 'pobreza' en LHN, se siente disfórica. Mientras que, en el lenguaje testamentario, al par riqueza/pobreza corresponde el par posesión/privación de atributos. En Mateo 5,3 Jesús dice: Bienaventurados los pobres de espiritu refiriéndose a aquellos que han alcanzado la conciencia pura del hombre espiritual. En el Salmo 49,3, se llama ricos a los hijos de Adán (hombres psíquicos) y se llama pobres a los hijos de hombre (hombres espirituales). (Pla 2018: 93).
} 
las figuras humanas ven modalmente menoscabado su poder al extremo de la impotencia; sacudidas por los poderosos 'golpes'. Estos, desplegados en una cadena de semejanzas, ocupan el centro del campo de discurso. A todo esto, el reino de las Mayúsculas acoge cuatro pobladores: del lado tónico, 'Dios', 'Destino' y 'Muerte'; del lado átono, los humanizados 'Cristos del alma' con sus 'hondas caídas'. Reveladora asimetría. Fin: repetición del primer verso. Más que clausurar un circuito, esa operación apunta a una apertura, a una repercusión interminable del acento afectivo puesto sobre el retumbar de los mortales 'golpes'.

\section{BIBLIOGRAFÍA}

BLANCO, Desiderio. 2009. Vigencia de la semiótica y otros ensayos. Lima. Fondo Editorial Universidad de Lima.

ECO, Umberto. 1985. Apostillas al Nombre de la Rosa. Barcelona. Lumen.

HEIDEGGER, Martin. 1987. De camino al habla. Barcelona. Ediciones del SerbalGuitard.

LANDOWSKI, Eric. 1993. La sociedad figurada. Ensayos de sociosemiótica I. México. Fondo de Cultura Económica.

LANDOWSKI, Eric. 2007. Presencias del otro. Ensayos de sociosemiótica II. Lima. Universidad de Lima.

LÉVI-STRAUSS, Claude. 1976. Mitológicas IV. El hombre desnudo. México. Siglo $\mathrm{XXI}$.

PLA, Roberto. 2018. El hombre, templo del Dios vivo. Barcelona. Sirio.

VALLEJO, César. 1997. Poesía Completa I. Lima. Pontificia Universidad Católica del Perú.

ZILBERBERG, Claude. 2006. Semiótica tensiva. Lima. Fondo Editorial Universidad de Lima. 


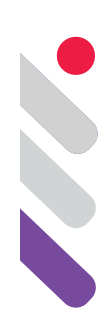

\section{Continuidades y rupturas en la narrativa de la historieta costumbrista}

DOI: 10.24308/IASS-2019-8-029

Oscar Steimberg

Universidad Nacional de las Artes, Argentina.

Universidad de Buenos Aires. steimbergoscar@gmail.com

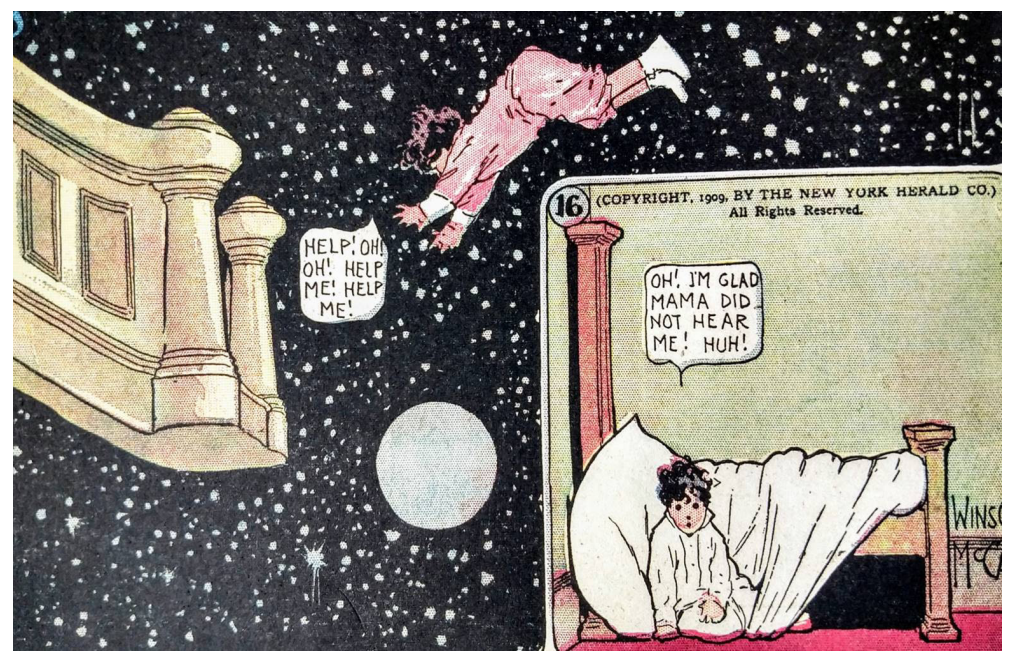

Figura 1: Winsor McCay, Little Nemo in Slumberland.

Se intentó recorrer aquí diferentes instancias de novedad y permanencia reconocibles en las trayectorias de las historietas con componente costumbrista, especialmente de diarios, con diferentes épocas de instalación en la memoria pública.

Y se trató de atender para eso a los efectos de los momentos de refundación de sus espacios de relato; al repertorio de conflictos y esperanzas que inevitablemente fue cambiando en las redefiniciones de sus cotidianeidades y en las reconstrucciones temáticas de los desempeños atribuidos a sus personajes. 


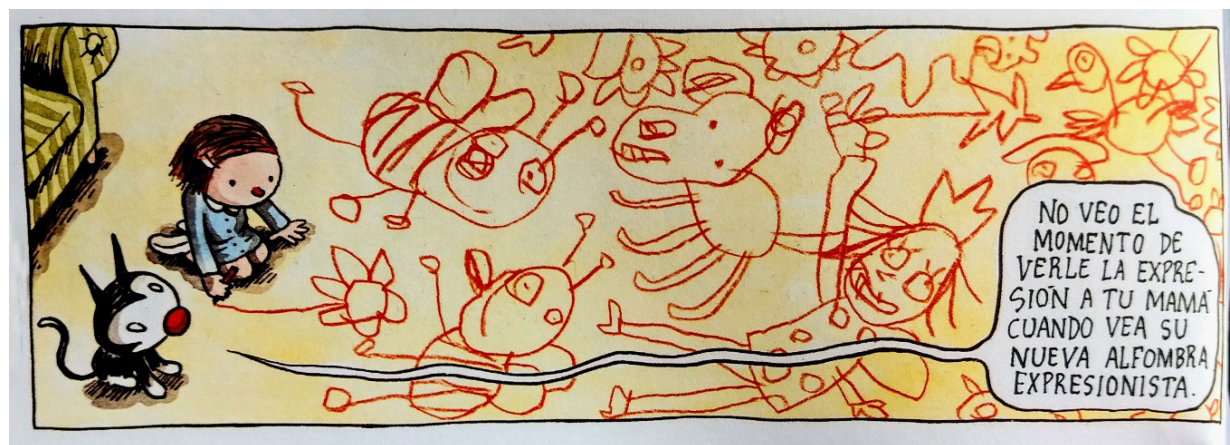

Figura 2: Liniers, Macanudo.

Esos personajes instalaban en las posibilidades de elaboración de la narración una previsibilidad cualitativamente distante de la que caracterizaría después a las tiras de etapas todavía recientes; aunque los cambios de moda y estilo sean de obligada referencia, incluso aquellos que parecen seguir reclamando el reconocimiento de la continuidad.

El pasaje del relato fuerte a la narración abierta incluye, en la historieta costumbrista continuada o convocada en la circulación contemporánea de la narración en imágenes, la implicación de una pluralidad de invitaciones de lectura, a partir de una hoy igualmente plural y lúdica posibilidad de interpretaciones de cierre. La nena y el gatito del "Macanudo" de Liniers son criaturas "de la casa", pero conocen la historia de los estilos artísticos, y los polemistas de la tira siguiente (los de "que empiece la discusión") aceptan que la discusión se exprese, complejamente, con símbolos abstractos...

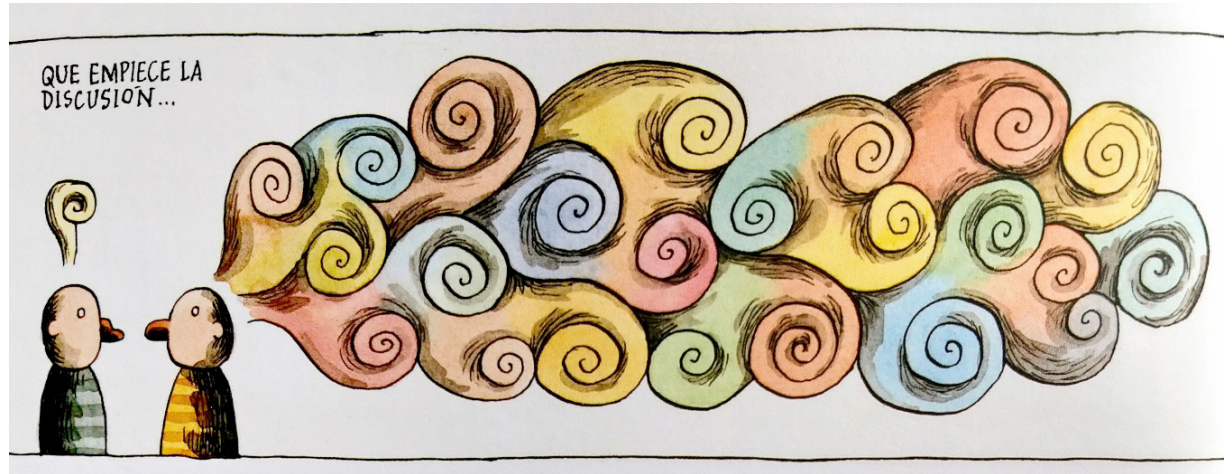

Figura 3: Liniers, Macanudo.

Y otras pluralidades, de acceso también inevitablemente complejo y diverso, se abren hoy junto a las de los sentidos generales de la narración; y pueden atender a fenómenos como el de la articulación entre géneros y estilos 
de autor, convocados como se sabe por el juego con la puesta en fase de nuevos hablares, dibujos, escritos de época. O desplegarse en nuevas secuencias visuales convertidas en pretexto para la proposición de nuevos juegos de diseño.

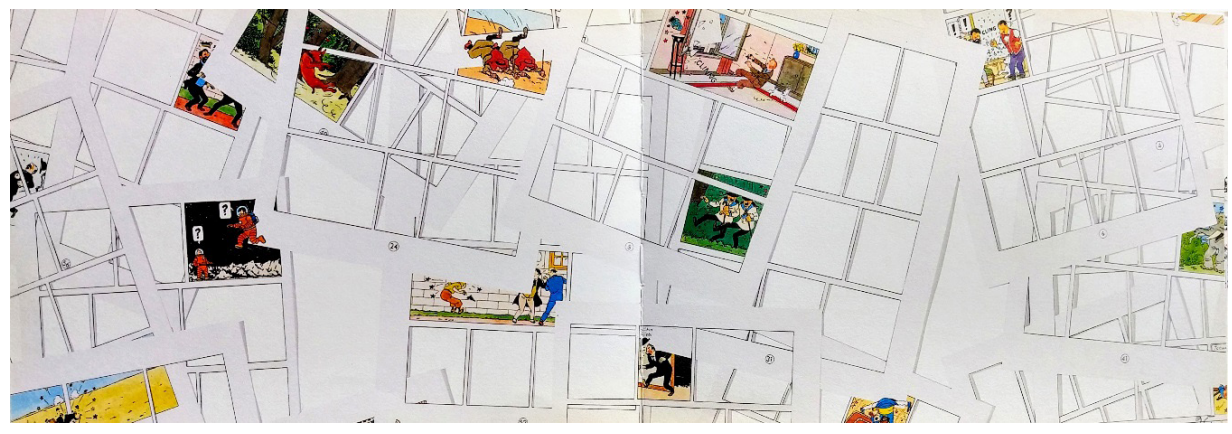

Figura 4: Martín Vitaliti, catálogo de exposición en Galería ABC, Madrid.

...que a veces incluso explotan.

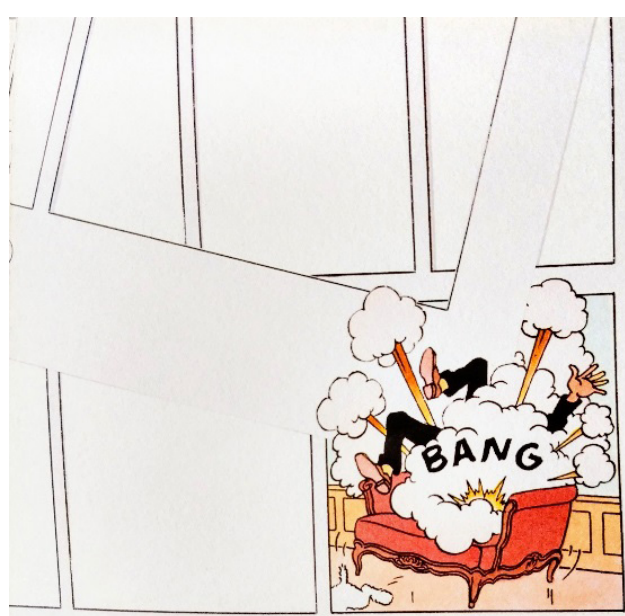

(61)
Figura 5: Martín Vitaliti, catálogo de exposición en Galería ABC, Madrid.

En las metahistorietas de Vitaliti al diseño de página le ocurren accidentes, estallidos, como a los superhéroes arrojados a la lectura.

Y en relación con la oposición entre relato fuerte y narración abierta, tomando como "fuerte" esa narrativa que convoca y reitera un modo estatuido de procesamiento de una problemática, ocurrió que los personajes de tira cómica actuaran a menudo en escenarios donde verse como entera confirmación de secuencias narrativas ya instaladas con reconocimientos de relato clásico. Las previsibilidades de la tira con relato fuerte tuvieron que ver con la reiteración de diálogos representativos de una absoluta cotidianeidad, como los que 
se desplegaban en aquellas tiras en que los personajes protagonizaban la reiteración de situaciones buscadas desde una perspectiva de gente común hasta el punto de que su conversación se mostrara hecha para desatender (o no entender) todo nuevo cambio del contexto.

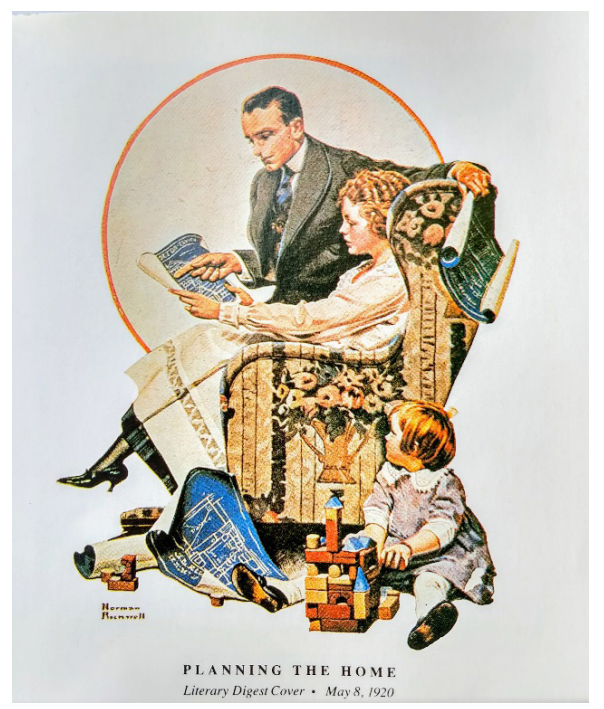

Figura 6: Norman Rockwell, Planning the Home.

Como es sabido, el relato fuerte y de confrontaciones previsibles, aun cuando se despliega en las narraciones de temas livianos y graciosos-con su previsibilidad temática, enunciativa y retórica en la organización del pasaje narrativo desde el planteo al combate y la resolución- se hizo cargo de las orientaciones argumentales de toda historieta de diarios hasta que se produjo la irrupción de una cotidianeidad opuesta: la de las sorpresas y autoironías de la narración contemporánea.

En el conjunto de los diarios de mayor circulación en Buenos Aires pueden encontrarse -no siempre en cada uno, sí en el conjunto- ejemplos de historietas que pueden considerarse parte de la sucesión histórica (más que centenaria) de la historieta leída en principio como simple, con fines de entretenimiento breve, aparentemente siempre olvidable, que formó parte central, desde el siglo XIX, de las secciones de entretenimientos y vida cotidiana de los diarios.

Pero ahí se registró también el cambio, aunque fuera en principio un cambio parcial. Para la narrativa histórica sería necesario poner el acento también en esa condición de parcialidad, o de no completud, del pasaje a la complejidad contemporánea. Para ese pasaje hay, por ejemplo, un límite temático: en etapas posteriores se complejiza el repertorio de problemas psicológicos convocados en la franja corta costumbrista, pero puede registrarse también el crecimiento, de más difícil previsibilidad, del tratamiento de cambiantes temáticas políticas, estéticas, sociológicas. 


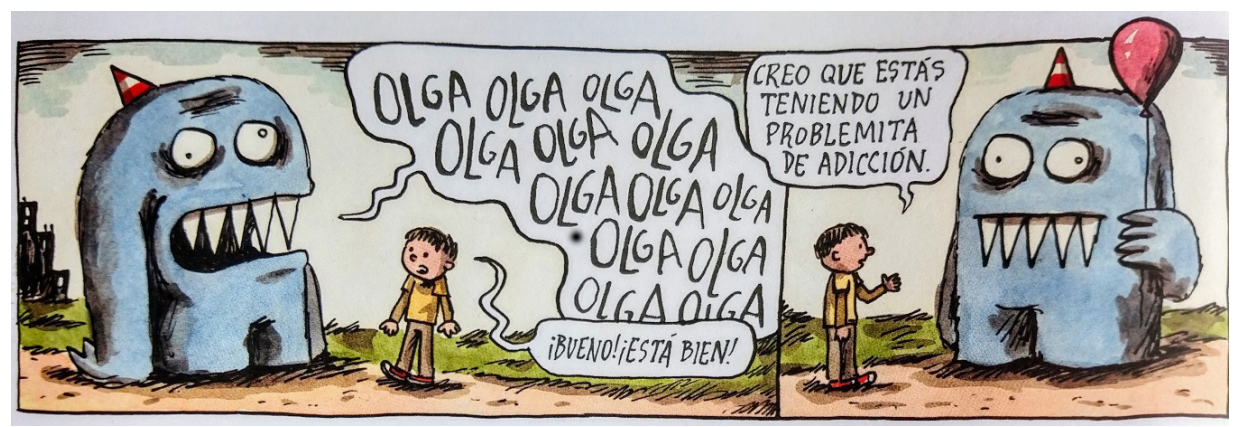

Figura 7: Liniers, Macanudo.

...Pero al crecimiento de la temática de los cambios psicológicos y sociológicos hay que añadir el de la convocación contemporánea de una discursividad que puede llegar a instancias político filosóficas. El niño o el hombre-niño que solía ser el protagonista y/o el lector supuesto de esa simple historia comenzó a reflexionar, en las tiras ahora contemporáneas, sobre aquellos temas que antes sólo podían asignarse a un pensamiento adulto.
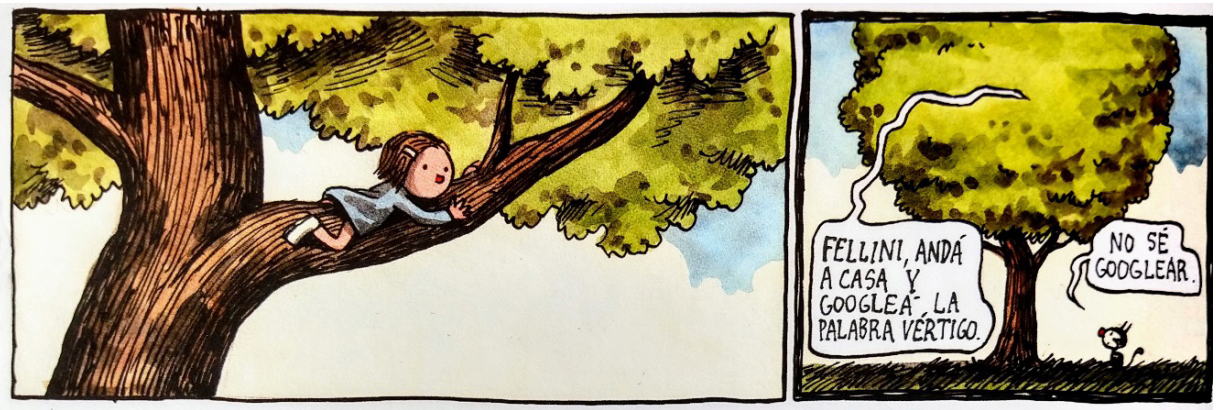

Figura 8: Liniers, Macanudo.

Unas veces las complejidades ahora infinitas de las tiras pueden ser asumidas directamente por niños y en otras son dichas por adultos y recibidas por niños con evidente capacidad de entendimiento en relación con todas las adulteces de la historieta contemporánea. Por ejemplo, en una de ellas un niño y una niña (tira de Erlich) se distancian secamente de los pensamientos de sus padres sobre el presente político; con una distancia enunciada como desde una adultez impiadosa. 


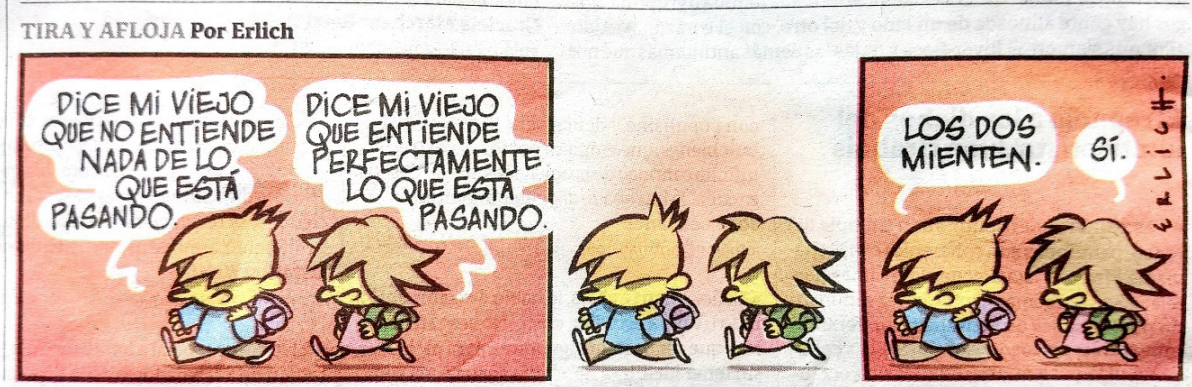

Figura 9: Erlich, Tira y afloja.

Pero también hay que señalar aquí que los cambios que se muestran como parte del procesamiento por parte de los niños de historieta del pensamiento o el comportamiento adulto pueden centrarse hoy en otro posible procesamiento por los niños del presente de esos cambios... si se atiende a despliegues de experiencias poético-visuales como las del Lukas de Rep cuando pone colores a una calificación de los días de la semana juzgada y descripta, literariamente, a partir de la adjudicación a cada día de colores usados en el momento como símbolos según tradiciones de pertenencia o fe con historias estilístico-poéticas, pero también por la política del día.

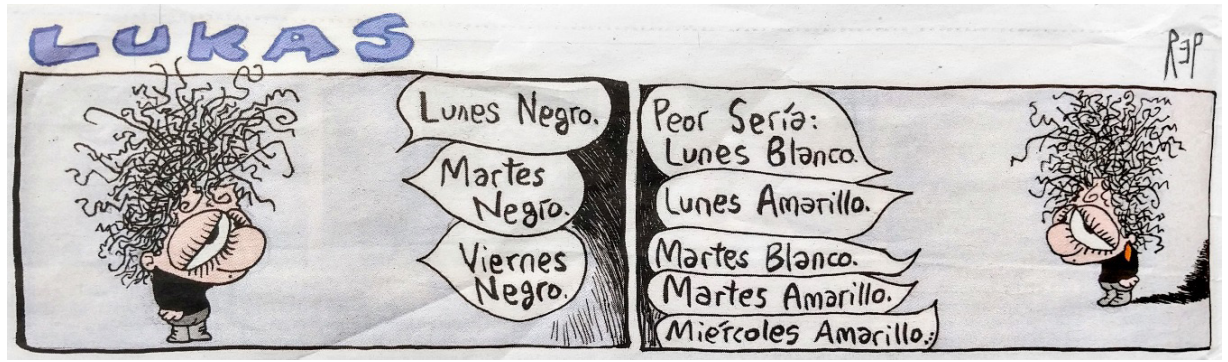

Figura 10: Rep, Lukas.

Y puede pensarse que la pluralización de los modos y sentidos del acceso a la comicidad y el humor de la tira costumbrista no se da en ella con todos los tipos de apuestas y maneras con los que se despliega en la historieta en su conjunto. Aunque los modos de su rehistorización sean no solo numerosos sino también crecientes. Numerosos y crecientes con la variedad de lo que crece como efecto de la condición cambiante de las búsquedas de sus procesadores. Pascal Lefevre' ${ }^{1}$, en un trabajo sobre historieta de los años '60, decía, confrontando con los que podían llegar a "reducir una obra a su contenido", que la primacía

\footnotetext{
${ }^{1}$ Pascal Lefevre, "Pour une aproche sensuelle de la bande dessinée", Neuvieme Art - Les cahiers du musée de la bande dessinée - N² 2, Paris, 1997.
} 
de ese modo de análisis, (combatido ya fundacionalmente por Susan Sontag en "Contra la interpretación"), privaba a la obra nada menos que de su efecto de sensualidad: ese que el lector puede sentir en "la forma de la historieta, el estilo gráfico, el ritmo de la página, la manera como se le cuenta la historia...". Se advertirá que el efecto de sensualidad mencionado por Lefevre no incluye sólo componentes de representación, sino también de diseño, construcción, interpretación..., componentes todos de amplias posibilidades lúdicas y de crecimiento incesante, entonces pero sobre todo después de aquellos '60. En una instancia al menos en parte novedosa de la historia de la historieta con componente costumbrista, en la que se había venido focalizando, por su inevitable componente parasociológico y parapolítico, como siempre previsible juego de mente, y solo ocultamente como diversión tan política como retórica, tan partidaria como lúdica. Como sabemos, la asunción de ese propósito artístico lúdico fue irrumpiendo, de entonces a hoy, como parte general del discurso del arte, incluyendo la palabra de artista. Así la del mismo Martín Vitaliti, citada por Rubén Varillas en el catálogo de la muestra organizada con motivo de la segunda edición del Premio de Dibujo Museo ABC, Madrid: “... la historieta, como concepto masotteano, revela todo lo que la lleva a cabo. Y todo eso está ahí, sobre la superficie..."2

Como se sabe, desde ese registro de aperturas el análisis de la historieta internalizó, como ocurrió en el resto de las artes desde las que se contribuyó a definir en sus inicios la posmodernidad, el señalamiento de novedades tanto a percibir como a comentar con prescindencia de su referencia a alguna lógica de su continuidad temporal. Con lo que es discurso crítico, tanto como la palabra de artista ahora también desplegada con habitualidad en la obra misma, pasó a incluir el reconocimiento de una nueva condición cambiante o provisoria, la del discurso que acompaña un hacer que pide seguir compartiéndose como proceso abierto y no como cierre en alguna completa asunción de género.

Medio siglo después de aquellas redefiniciones generales, de las prácticas de una metanarrativa visual impresa con primacías metaartísticas y, si cabe, metahistorietísticas, la palabra teórica y crítica insiste en enunciarse también desde las mismas obras que toman centralmente a la historieta no sólo como experiencia narrativa sino también como objeto con sentidos múltiples a descubrir y (¿para?) abandonar. O retomar después de la inspección de alguna nueva frontera de época.

\footnotetext{
2 citado en Rubén Varillas, "Martín Vitalitti y la viñeta como objeto artístico", catálogo de exposición, Galería ABC, Madrid, 2013
} 


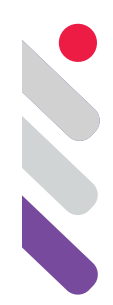

\section{Salomé y Judit: dos milenios de recurrencia discursiva}

DOI: $10.24308 /$ IASS-2019-8-030

Oscar Traversa

Universidad Nacional de las Artes - Área de Crítica de Artes oscarcesartraversa@gmail.com

Los nombres de Salomé y Judit, y en particular las narraciones en que se han incluido, serán el objeto de este trabajo que consiste en estudiarlas como casos del fenómeno que ha dado en designarse como de recurrencia semiótica ${ }^{1}$, fenómeno al que nos interesa acercarnos. Tal fenómeno consiste en la emergencia en el tiempo de diferentes variantes que reenvían a un espacio textual común propio de discursos precedentes en el tiempo; sea por semejanza con la totalidad, por fragmentación o por alusión. La recurrencia, en términos generales, puede manifestarse en una pluralidad de niveles de la organización textual, desde los componentes básicos de la lengua hasta los distintos modos de configuración de los enunciados, si se trata de la escritura, o bien a diferentes modos de figuración.

Nos remitiremos aquí a lo concerniente a las dimensiones narrativas $y$, en especial, a las recurrencias actanciales, tales productos son el resultado de procedimientos operatorios, que pueden ser similares o distintos, de los que dieron como resultado al original, es decir, objeto de operaciones transpositivas. Los casos que hemos escogidos fueron, en sus dos mil años de historia, frecuentados desde temprano por esos procedimientos.

Lo que nos proponemos con este trabajo no es de carácter explicativo o causal se limita a tratar con fines abductivos dos casos que responden a la definición que hemos propuesto limitada, por otra parte, a observaciones pragmáticas del decurso de los fenómenos discursivos en la larga duración

\footnotetext{
${ }^{1}$ Magariños de Morentín (1993) fue quién procuró dar forma a la noción de recurrencia desde la perspectiva de la semiótica, señala que la recurrencia circunscribe un campo fundamental de esa disciplina que considera de "constante presencia en los procesos discursivos". La diversidad del fenómeno como tal abarca un conjunto de procesos que dificultan su comprensión de lo que se indica por recurrencia. En el presente trabajo trataremos de precisar su alcance, al menos parcialmente, a partir del examen de dos casos.
} 
histórica. Por lo tanto, es solo una invitación a reflexionar en común acerca de la necesidad y pertinencia de la noción de recurrencia como recurso analítico de la de semiótica, para circunscribir posibles límites o expansiones de la producción de sentido, según diferentes procedimientos técnicos.

La invitación goza, por los casos elegidos de beneficios, tanto estéticos como analíticos, pues debemos recorrer distintas variantes, respecto de los textos originales, tales como: la ópera "Salomé" de Richard Strauss o la "Judit" de Arthur Jonegger, que incluyen variantes de la narración bíblica; las que ocuparán un lugar crucial en el análisis. Mientras que la "Salomé" de Julio Romero de Torres o la correspondiente a Judit de Artemisia Gentileschi, no ponen en juego los mismos procedimientos de fragmentación para sus imágenes, problematizando el papel de las diferentes materias y técnicas compositivas.

Se abre también, a partir de los casos elegidos, cuestiones tales como lo referente a las distancias entre las configuraciones de los personajes presentes en la pieza teatral de Mauricio Kartun que lleva por título "Salomé de chacra" y el film "Judit" de Daniel Mann protagonizada por Sofía Loren, en cuanto al papel de la remisión histórica en las potencialidades de producción de sentido respecto al presente: ¿indiferencia?, ¿gesto autoral potencialmente distintivo?, ¿conmoción e impacto religioso? Efectos, seguramente dispersos, solo localizables en reconocimiento, pero fruto de una particularidad en la instancia de producción.

Atentos a lo que venimos señalando deberíamos tratar de responder dos preguntas concadenadas, la primera: ¿cuál es la razón que justifica la elección de los casos de Salomé y Judit? y, la segunda ¿qué beneficios cognitivos se puede esperar de tratarlos y pretender justificar la posibilidad de sostener la pertinencia y necesidad de la noción de recurrencia?

En cuanto a la primera puede señalarse que faltos de antecedentes, más o menos organizados o directamente ausentes referidos a este tópico, se apeló a la notoriedad de las semejanzas, pero también a la no identidad de los transcursos, de los casos elegidos tales condiciones de identidad y diferencia validan la aplicación de criterios comparativos.

Por otra parte, a ambas se las puede suponer como contemporáneas o, al menos, incluidas en un mismo texto fechable; se trata de la biblia católica, no la llamada protestante, ni en los textos tradicionales judíos, excluida de estos últimos por imprecisiones de lugar y fecha de desarrollo del episodio. En cuanto

\footnotetext{
${ }^{2}$ Un estudio como el presente y los que le seguirán no persiguen propósitos eruditos acerca de los casos a los que recurre, cada uno de ellos ha sido objeto de extensas investigaciones propias de distintos dominios de la historia de las religiones, asimismo como las que corresponden a las diferentes artes. Este conjunto constituye las únicas referencias para indagar acerca de la noción de recurrencia semiótica pues constituyen el único modo de acceso. Ver: Traversa (2019) "Historia de los medios / Historia de las mediaciones"
} 
a Salomé está presente en los evangelios de Marcos y Mateo $^{3}$ que ocupan allí, en ambos, unas pocas líneas; la presencia de Judit ${ }^{4}$, en cambio, ocupa, dependiendo de la edición más de diez páginas, en el ámbito de los textos llamados sapienciales. No se puede adjudicar a una y otra una importancia teológicamente equivalente, como se verá Salomé está situada en una parte del texto sagrado que constituye pleno artículo de fe (se trata de un episodio periférico al que relata la estancia del hijo de dios en la tierra), mientras que el otro refiere a un contexto de un pasado no bien definido, reviste un carácter aleccionador, así suele justificarse su presencia.

Una cuestión crucial que han ligado a estos textos ha sido la inclusión de un episodio común, ambos dan cuenta de una degollación que ha servido, a todo lo largo de sus dos milenios de tránsito por la cadena semiótica de motivo (directa o indirectamente) infaltable en sus presentaciones, esta cercanía, más allá de sus diferencias ha sido incluso motivo de confusión entre ambos ${ }^{5}$. Esta cercanía en cuanto a la comparación juega un papel crucial, pues en el largo camino una y otra han ocupado todos los recursos discursivos empleados por nuestra especie para relacionarse: desde la oralidad hasta los procedimientos electrónicos, alojamientos mediáticos comunes, circunstancias y correspondencias distintas. Esto último apunta a responder la segunda pregunta, vinculada con el aporte cognitivo: la recurrencia nos está hablando -es posible- de ciertos límites de la capacidad de producción de procesos simbólicos de nuestra especie: el asunto queda en pie, las recurrencias formales son, sin embargo, sugerentes.

Para aquellos no conocedores de las historias a tratar reuniré su sustancia en pocas palabras. En cuanto al de Salomé, la acción se sitúa en una circunstancia festiva, el cumpleaños de un rey (Herodes), cuya mujer (Herodías) había sido la esposa de su hermano. Un severo predicador (Juan el Bautista) reprochaba públicamente la afrenta religiosa que significaba ese matrimonio, Herodías detestaba, por esa razón, a Juan el Bautista y deseaba eliminarlo. Aprovechó, veremos cómo, la circunstancia festiva para consumar su venganza. En la fiesta, su hija (Salomé, ese nombre es una adjudicación posterior) danza en homenaje a su padrastro, quien queda fascinado frente a la joven a quien le ofrece, con propósitos indisimulables, compensaciones cuantiosas. Salomé consulta con su madre y esta le señala que el mejor regalo será la cabeza del Bautista, a ejecutar de inmediato y presentar, sin más, a modo de manjar, sobre un plato el cruento resultado. A regañadientes - pues Herodes guardaba cierta admiración hacia la

\footnotetext{
${ }^{3}$ Uno y otro coinciden en las características del episodio y en la brevedad de su exposición, ninguno de los dos designa como Salomé a la hija de Herodías.

${ }^{4}$ Se trata de un texto narrativo extenso que se detiene en distintos momentos del episodio, salva no sin dificultades y forzamientos la presencia de relaciones sexuales entre Judit y Holofernes, justificadas por una llegada tardía al ágape de Judit junto a una prematura ebriedad de Holofernes.

${ }^{5}$ Fue Panofsky [1972] (1998) quien se detuvo en este aspecto: contrastando las versiones textuales originales y los productos pictóricos.
} 
víctima- ordena que se realice el horrible acto. En seguida la cabeza del Bautista es presentada ante los circunstantes.

Este final, si se quiere abierto, se modifica a partir de un texto de Oscar Wilde, de $1892^{6}$, que dará luego lugar a una ópera de Richard Strauss, en $1908^{7}$. Las modificaciones escénicas cruciales son dos: la inclusión de la danza (llamada "de los 7 velos") y además, por supuesto, la música que da lugar a un cambio de universo en la presencia de Salomé, ambos de enorme trascendencia, tanto para la lírica como para el teatro y sus múltiples prosecuciones en el cine.

La danza transgresiva -no solo por las características intrínsecas, finaliza en un desnudo, sino también por su dimensión en cuanto a la sustancia narrativa- que se suma a la mostración de la cabeza del Bautista y el beso de la escena final que estampa Salomé en los labios muertos de la víctima. Ambos componentes, danza y beso, propio del texto de Wilde, se muestran como fruto, al fin, ya no del deseo de su madre sino del suyo, vengando ahora, el rechazo de Juan de besarla, en un breve momento que ella solicitó verlo, violando la orden de prisión absoluta de su padrastro.

El caso Judit, al contrario, cuenta con una presentación Bíblica más extensa y detallada, la escena se sitúa en una ciudad pequeña que se ve amenazada por un tirano que deseaba apropiarse de toda la región, la presencia cercana de tropas, a esos propósitos, comandadas por un general impiadoso (Holofernes), siembran el espanto entre los habitantes. Al punto de proponer una rendición sin condiciones para salvar sus vidas y las de sus hijos; una mujer, viuda y de gran belleza (Judit), se niega a esa deshonrosa solución, atentatoria contra el don de dios que significaba la vida misma del conjunto y el lugar donde desplegarla. Ella arenga a sus conciudadanos, señalando que contaba con un plan que sería exitoso para enfrentar la peligrosa circunstancia. El afecto y fama de justa con la que contaba hizo que fuera aceptada su propuesta sin necesidad de revelarla. Esa misma noche parte, acompañada de una servidora y carga con sus mejores joyas y vestimentas hacia el campamento de Holofernes. A su llegada, fascinado por su belleza, le concede unos días de estancia en el lugar para establecer un

\footnotetext{
${ }^{6}$ Se trata de una pieza teatral en que se modifica un aspecto fundamental del relato bíblico, el rol de Salomé: de la adjudicada cualidad de dependencia materna, propia del relato bíblico, se pasa a un rol activo e independiente de la protagonista, que culmina con un acto criminal. Es Salomé quien se encarga de solicitar la cabeza de Juan el Bautista, en una suerte de venganza por el rechazo de este a sus solicitaciones de contacto corporal y súbito enamoramiento. La pieza teatral tuvo en sus orígenes diferentes inconvenientes para ser presentada, pues el esquema narrativo de Wilde se consideraba escandaloso e inmoral. El texto de referencia indispensable para contar con un panorama amplio del desenvolvimiento en el universo del arte de Salomé es Salomé de Mireille Dottin - Orsini (2012), al que se suman diversos autores de lectura igualmente indispensable.

7 La ópera, en un primer momento resistida, pero luego se hizo presente en los más importantes escenarios de Europa y en América, la naturaleza del texto escénico nunca dejó de ser un verdadero nodo de sus presentaciones, tanto para el lucimiento como para el fracaso. Lo cierto es que constituye hasta el presente una obra que da lugar a permanentes intentos de renovación, para nada ajenas a la naturaleza del libro.
} 
acuerdo de paz, junto a inocultables deseos de poseerla. Al poco de permanecer en el lugar es invitada a asistir a una fiesta que daría en su tienda. Judit acepta, pero argumenta que llegaría luego de cumplir con sus oraciones al Señor. Así lo hace y, al momento de llegar, Holofernes se hallaba ya ebrio y tendido en su cama. Sin perder un instante y ayudada por su servidora toma su espada y le secciona la cabeza. Acto seguido huyen del lugar llevándosela en una cesta; la que exhibirán a sus conciudadanos, instándolos a la resistencia armada. Luego la cabeza es exhibida en la puerta de la ciudad, los enemigos desconcertados por el extraño hecho son vencidos, siguiendo una convocatoria de Judit a presentar batalla. A posteriori del triunfo, la heroína vive en paz, en su ciudad hasta los 103 años.

Al igual que el texto de Salomé, el que corresponde a Judit es objeto de una modificación a mediados del siglo XIX, que altera en este caso, las motivaciones y el perfil de la protagonista. Corresponde a Friedrich Hebbel ${ }^{8}$ (guionista de Wagner en la tetralogía) se altera la motivación epopéyica adjudicada en el texto bíblico, agregando tonos propios de una frustrada condición individual (la obligada virginidad por enfermedad y muerte de su consorte). Holofernes posee a Judit, la decapitación entonces resultará de una conjugación de orígenes que reconfiguran su papel en el relato. Tal como en el caso de Salomé de allí en adelante los textos que la incluyan recorrerán otros caminos, tanto en el XIX como en el XX.

Estos dos textos han sido la base de un recorrido a través de dos mil años, pasando de su condición religiosa a verdaderos mitos artísticos literarios, no del mismo modo y con diferentes proyecciones tanto en el pasado cercano como en nuestro presente. Es cierto también que se han instalado en los medios como agentes activos de diferentes productos de gran consumo, la canción popular, por caso, despertando el interés público de manera ininterrumpida hasta nuestros días, pero siempre de manera antinómica: siguiendo una tradición que se arrastra desde momentos lejanos. El universo del arte ha sido el principal testigo de estos cambios, es posible encontrar buenos testimonios, en los más diversos productos (y productores), nos los han dado tanto Al Pacino como Chegenne, Honneguer y Monserrat Caballe, junto a tantos otros ${ }^{9}$.

\footnotetext{
${ }^{8}$ El texto de Hebbel es de 1840, precede al de Wilde en cincuenta años, disuelve la figura de Judit que el texto bíblico dejaba entrever: la plenitud de heroicidad de raíz epopéyica adjudicable a la protagonista. Surge en este texto una dimensión diferente: un sufrimiento singular a partir de una herida irreparable en el curso de su existencia, la que mezcla los impulsos que conducen a Judit a dar muerte a Holofernes, adecua, por decir breve, el personaje al "espíritu del tiempo".

${ }^{9}$ La diversidad de las presentaciones en el último tercio del siglo XIX y hasta nuestros días han sido tan diversas como numerosas para ambas figuras, en el ámbito poético ha sido señalado como un tópico excepcional, muy especialmente en lengua española, tanto en América como en España, lo mismo en las Artes Plásticas, el cine, teatro y televisión, no menos en la canción popular, es indudable que existe una dominancia de Salomé, tanto en lo numérico como en la diversidad. A esta cuestión, relacionada con la mediatización, nos dedicaremos en un próximo trabajo.
} 
Para intentar ordenar el campo y favorecer la discusión nos limitaremos a comentar los casos de Salomé y Judit en forma breve en cuatro aspectos: persistencia temporal, configuración narrativa, artificación y existencia mediática. En torno a la narrativa, debe consignarse que ella ha sido motivo de preocupación general y debate desde las primeras décadas del siglo $X X$, a su modo C. G. Jung, con sus arquetipos como repeticiones sistemáticas ya despertó, hace un siglo, las críticas de Freud desde el punto de vista psicoanalítico; las mías (con gran retraso y mucho menores méritos) no la comentaré en este trabajo ${ }^{10}$.

Por ahora nos limitamos a señalar que las manifestaciones discursivas repetidas -las que denominamos recurrencias- son muy diversas, en cuanto a las maneras de hacerse presentes, pueden manifestarse a través de la escritura o bien como imágenes o sonidos en sus múltiples configuraciones, con ausencia o presencia del cuerpo (teatro y cine, por ejemplo). Es de señalar que esos discursos revisten un carácter público y han vivido (y viven) integrados por los recursos técnicos a través de los cuales se relacionan el conjunto de los actores sociales, tanto en espacios restringidos como en lo colectivo y así lo han hecho en diferentes épocas; tales episodios de distintas maneras forman parte de los procesos de mediatización, fechable en sus episodios pero "sin tiempo" en cuanto momento o extensión, son formas emergenciales (es decir, no previsibles y no calculables en su duración y vigencia); cualificables como ajenas a procesos lineales, entonces.

¿Existe alguna razón que justifique preguntarse acerca de las recurrencias discursivas? Sí dado que, finalmente, forman parte de los más corrientes aspectos de nuestras vidas, suelen manifestarse en los usos comunes del hablar o del escribir, sea de manera puntual-los empleos del léxico es la forma más común-, encarnados en nombres que pueden sonarnos como francamente desconocidos mientras que para otros son absolutamente familiares. Las recurrencias adquieren muy distintas maneras de manifestarse, muchas veces nos hablan de la pertenencia a un mundo familiar y reconocible, otras dan prueba de nuestras marginalidades o ignorancia. De una u otra forma podríamos afirmar, sin equivocarnos, que habitamos un mundo de recurrencias, pero podríamos decir más aún: vivimos porque ellas existen y pasamos nuestras vidas gozando y sufriendo con ellas, para dar lugar a variantes que se incluirán también en ese ciclo. Pero, si solo algunas perviven, es posible pensar en un proceso selectivo, estereotipos o limitaciones de las que es no fácil trazar un esquema ordenador; pues como lo hemos señalado con nuestros dos casos la pervivencia de esas figuras requiere, momento a momento, correcciones que modifican aspectos y dejan otros rasgos identificatorios en pie, el nombre entre otros.

\footnotetext{
${ }^{10}$ Para consultar los principales lineamientos de sus puntos de vista puede consultarse Arquetipos e inconsciente colectivo, en especial las tres primeras partes.
} 
No basta, es evidente, esa respuesta pues todavía no hemos establecido ninguna distinción en un universo que, en apariencia, no tiene límites. Lo que nos interesa distinguir es la cualidad y el modo de inclusión de las recurrencias en nuestro despliegue temporal, dado que finalmente nos desenvolvemos en un mundo, sea este viejo o nuevo, que está construido a través de ellas. La pregunta acerca de la pertinencia y carácter de las recurrencias debe formularse en principio, si prestamos atención a los ejemplos que empleamos, al menos en dos modalidades de sus manifestaciones: por un lado, lo que podríamos, por un momento, denominar recurrencias constitutivas, las del universo biológico entre otros que nos concierne directamente y revisten un carácter universal, nos valemos de ellas tanto como las abejas y los elefantes.

Por otra parte, en oposición a las anteriores, otras recurrencias que podríamos -también de forma provisoria- llamarlas constituyentes. Son, en principio, limitadas a una especie, el Homo sapiens, las llamamos de ese modo porque suponen una dependencia de las anteriores. Dado que no existirían estas últimas de no estar encabalgadas en las primeras (el gestuario, la lengua, cualquier producto técnico fruto de la exteriorización de las actividades mentales, cuentan con un soporte biológico).

Las diferencias se manifiestan tanto en producción como en reconocimiento ${ }^{11}$, este último es preparatorio de una nueva instancia de producción (repetimos: de manera igual pero distinta). Las recurrencias remiten a las circularidades propias del lenguaje, pero siempre, a diferencia de la lengua estática, vista en acción, con desplazamientos singulares e imprevisibles propios de los dispositivos ${ }^{12}$ discursivos.

Las recurrencias en las que nos detendremos son las que hemos denominado como constituyentes, dentro de ese conjunto extremadamente amplio nos limitaremos a una zona de prácticas, aquellas que de muy distinta manera y cambiante con las épocas fue, en principio, agrupada no sin dificultades en los finales del siglo XVIII en el dominio del arte (el rincón de las singularidades).

Llegados a este punto el primer comentario que prometimos, el de la recurrencia temporal de nuestras dos figuras que, si bien ocupan espacios comunes, fueron incluso llevadas a la tela o la tabla por los mismos artistas (Caravaggio, entre otros). Sus recorridos por la imagen no instalan los mismos

\footnotetext{
${ }^{11}$ Empleamos los términos producción y reconocimiento en dirección al modo que lo hace Eliseo Verón, ver La semiosis social (1987), en especial páginas 125 a 130. Allí se podrá encontrar una exposición extensa referida a la constitución del proceso de producción de sentido.

${ }^{12}$ Entendemos como dispositivo a la puesta en obra, en todo discurso, de un ordenamiento que organiza su manifestación: una dimensión que da lugar a la organización de la sustancia y otra que lo hace con su soporte: por caso un poema puede ser leído de viva voz en presencia de un auditorio o bien emitido por radio, el vínculo entre las instancias, en cada uno de esos casos, no es el mismo; son, en consecuencia, materias a tener en cuenta en cualquier análisis (Traversa, 2001).
} 
conflictos. Mientras que una (Salomé) hasta la fractura del siglo XIX-XX, se estabiliza en la imagen de mujer fatal; Judit, por su parte, dado su origen textual en el universo de la virtud, tanto cívica (la heroína civil) débil mujer que se impone a la monstruosa fuerza del hombre, como sufriente, acuciada por su condición femenina. De aquí la primera tensión, que se hace presente: ¿acaso solo audacias o también astucias? ¿Sus triunfos son debidos al empleo avieso de su condición de bellas mujeres seductoras? ¿O sus finales fracasos son frutos, así mismo, de esa condición? Esta tensión no fue para nada menor en el curso de su desenvolvimiento discursivo.

Comentamos ahora aspectos de ambos relatos. En principio podemos observar que la pintura se hace eco de esta tensión, un límite transitorio donde se impone la adjudicación del carácter pecaminoso de sus actos (el desnudo de tono erótico patentiza esa posición) que volvería luego al camino virtuoso, hasta el presente. Leo en una biblia del 2017 “...el canto de la Virgen María, como el de Judit, celebra el triunfo de los débiles sobre los poderosos del mundo" (Mt 14: 1-12), antiguo objetivo de la catequesis.

Podemos observar en este tránsito las variedades posibles de las recurrencias; nos dan noticias de inestabilidades de lectura, por caso, más estables en Judit que en Salomé, cuando una contingencia textual que modifica su posición narrativa (de la joven bailarina dependiente de la voluntad perversa de los otros, se desliza al ejercicio independiente de su propia voluntad de ejercicio perverso) se torna en una constante, en la producción textual del presente.

Estos cambios se abren a una copiosa producción textual en el campo del espectáculo, contemporáneo en una evanescente Judit en ese terreno, promoviendo la pluralidad de lecturas acerca de Salomé. ¿Acaso la clausura de Judit en el universo del bien es defectuosa en el ejercicio del diálogo respecto de la huida, mal de los otros para ejercer la libertad propia? ¿Esa libertad, entonces, se salda con la muerte? No es necesario que tomemos partido, la cuestión aquí son las recurrencias y no la ética.

El acercamiento a Salomé y Judit, vistos en la larga duración, nos resguardan de adoptar -como ha ocurrido- la solución de la pervivencia y cambios de estas figuras por la hipóstasis de la presencia de las decapitaciones como motor exclusivo de las recurrencias, si se quiere exitosas (en cuanto a permanencia mediática) de ambas, fundadas en la consideración del traslado de la figura referida a la constitución del sujeto, homologándolas a la castración. Por el momento podríamos acercarnos a un necesario desdoblamiento articulado de atributos: por un lado los característicos que indican una identidad identificatoria no excluyente (el principio: para ser debe estar) y, por otra parte los vicariantes, los que a la inversa son susceptibles de estar ausentes o encontrarse modificados. Judit carga con la ejecutoria del acto de la decapitación, al contrario 
de Salomé que es el agente promotor, ambas propiedades son características, las motivaciones al parecer no lo son. En cambio, en las apariciones subsiguientes de Judit son casi inexistente las escenas narrativas que podrían desprenderse del relato de origen: la arenga heroica, las conversaciones con Holofernes (que reaparecen en Hebbel), la vejez digna y feliz (103 años), etc. Para el caso, todas son interesantes; en las elisiones en la pintura quedan reducidas a estereotipos femeninos de época, según los verosímiles que se corresponden con alguna variante que opera como atribución clave (sensualidad, belleza, candor, etc.).

Es necesario consignar dos tipos de relaciones con la configuraciones narrativas: las endógenas que comportan una alteración registrable de la fuente (el caso Oscar Wilde, en teatro y William Dieterle, en cine; en posiciones opuestas) y otras exógenas, por ambigüedad o desplazamiento (se verán en especial en plástica). Unas y otras producen campos de producción de sentido heterogéneos y alteraciones enunciativas polares, muy especialmente las pictóricas. Es así que, esta última figura, da en todo su trayecto en el tiempo un campo de tensiones que da lugar a prohibiciones y censuras, lo que indica funcionamientos transpositivos diferenciados de acuerdo a las relaciones entre el texto fuente y el de destino (discurso verbal a pintura, por ejemplo), lo que es esperable.

En cuanto a la artificación ${ }^{13}$, nos referimos a las adjudicaciones a campos de desenvolvimiento de los productos discursivos socialmente reconocidos (sea por la crítica o por pertenencias institucionales). Este proceso es de doble efecto pues valida las prácticas presentes o futuras, culminado el proceso, y valida las del pasado. Este efecto puede recaer tanto en el conjunto de una práctica o sobre un sector de obras o lugares de instalación, esto último corresponde a nuestro caso. Salomé durante un largo período perteneció (ambiguamente) al arte religioso. Plenamente hasta el siglo $\mathrm{XI}$, al menos, pues se incluía en el programa constructivo de las catedrales. En el renacimiento y el barroco se pone de manifiesto una activa carnalización de ambas figuras (momento consagratorio de la firma o la identificación de la fuente de producción: individuo o taller) y, además, la movilidad e individuación de las obras, con un retiro de los muros eclesiales. Para, finalmente, la triada Hebbel-FlaubertWilde ${ }^{14}$ da lugar, por vías completamente diferentes al mito artístico de Salomé

\footnotetext{
${ }^{13}$ La noción de artificación se refiere al cambio de estatuto de ciertos productos incluidos, por ejemplo, las categorías de uso cotidiano pasan a las de arte (piezas cerámicas, por ejemplo), se trata entonces de un proceso que conlleva la atribución de significado, el reconocimiento y la legitimación. Heinich y Shapiro (2012) identifican diez procesos constituyentes que dan lugar al consignado tránsito entre estados, los que incluyen tanto atributos correspondientes a los ejecutantes, como las relaciones institucionales y la constitución de públicos, sumado de manera esencial: el discurso de la crítica.

${ }^{14}$ La triada Hebbel - Flaubert - Wilde ocupan un lugar central en la artificación moderna de Judit y Salomé pero, por supuesto, no son las únicas, aportan al proceso un verdadero río textual que integra al periodismo, la poesía, el ensayo; lo que es cierto es que esos autores por efecto de su notoriedad han ocupado un lugar central, en cuanto autores que han legitimado a través de
} 
y Judit, deberíamos decir mejor de la reconfiguración del mito solo explicable si se atiende a la reconfiguración que impulsó la contradictoria dinámica entre iluminismo y romanticismo, a cuya sombra se acuñaron las primeras piezas de la individuación contemporánea. Los nombrados lo patentizan a través de los desplazamientos que operan en el relato, ligado a tres prácticas plenamente artísticas: la literatura, el teatro y, un paso más allá la música y la danza (y, luego, las técnicas desarrolladas en el siglo XX).

En cuanto a la mediatización $n^{15}$, cuestión esta, estrechamente ligada a la artificación, dado que requiere, al menos, de dos condiciones: la existencia de instituciones especializadas y recursos de difusión de su práctica (la prensa especializada y sus múltiples extensiones). Es así, entonces, que la plenitud del desenvolvimiento de las figuras de Judit y Salomé, en los distintos ámbitos artísticos se haga presente a partir de la primera mitad del siglo XIX. Pues la mediatización como tal es un proceso permanente que caracteriza a la especie, en consecuencia, las recurrencias constituyen un componente estructuralmente necesario de sus desempeños. La recurrencia semiótica, en el terreno del arte posee cualidades que singularizan a esta variedad; se hace necesario, si es así, describir sus particularidades que se sitúan en un nivel de integración (y complejidad constituyente) diferente a las que operan las correspondientes a otras variante discursivas (la conversación, el periodismo, la ciencia, etc.).

Lo señalado corresponde al despliegue de la semiosis social, lo que hace necesario asumir, hipotéticamente al menos, que el desfasaje entre producción y reconocimiento opera, y se hace presente en la sincronía, a través del trabajo transpositivo. Nos referimos a lo que compete en nuestro caso al pasaje de un texto escrito a una pieza teatral (estudio de las modificaciones de los, acaso, fenómenos intermediáticos de la escritura al teatro, por ejemplo); y, en la diacronía, lo que concierne a las recurrencias, es decir la emergencia de una cierta figura o procedimiento que ha cumplido un decurso particular en el tiempo histórico, en el mismo medio o en uno aun no frecuentado (Salomé o Judit, en el cine por caso).

De no tenerse en cuenta, este doble proceso se hace difícil pensar en los cambios discursivos sin atender a estas diferencias que recaen directamente en la producción de sentido, es decir que se trata de una forma pertinente

\footnotetext{
la tematización el lugar de esas figuras en el campo estético y, de manera recíproca, otorgaba legitimidad y densidad de sentido el trayecto cumplido por ellas (de lo religioso al universo de la pintura profana, por casos). Flaubert (1999) constituye un caso "no espectacular", pero crucial en la construcción e identificación de la figura de Salomé.

${ }^{15}$ Pensable como proceso ínsito en el desarrollo del Homo sapiens, la clase de fenómenos en que se hallan incluidos estos particulares no puede ser ajeno a la relación con su ámbito de desenvolvimiento, el propio del tráfico de la producción de sentido que conllevan las exteriorizaciones de la actividad mental y su presencia en el mundo; tal proceso incluye plenamente la dinámica entre permanencia y cambio, cuya principal característica es la recurrencia y sus necesarios procesos adaptativos.
} 
que concierne a las cualidades de los fenómenos siempre indisociables de articulación de la semiótica con la historia. Ligamen entonces que es imposible dejar de lado; pues la recurrencia semiótica es el presupuesto básico de los procesos de producción de sentido pues, sin ella, no hay cambios, es decir que no habría producción de sentido.

\section{Referencias}

DOTTIN-ORSINI, Mireille. [1996] 2012. Salomé. Paris: Editions Autrement (rééditions numérique FeniXX).

HEBBEL, Friedrich. Judith. [1849] 1952. Buenos Aires: Emecé Editores.

HEINICH, Natahalie y Roberta SHAPIRO. 2012. ¿Cuándo hay artificación? Revista Digial Contemporary Aesthtics, 4. https://es.scribd.com/document/361584051/ Cuando-Hay-Artificacion (consultado el 14/02/2020).

JUNG, Carl Gustav. 1994. Arquetipos e inconsciente colectivo. Barcelona: Paidós.

LA BIBLIA. EL NOMBRE DEL PUEBLO DE DIOS. 2017. Buenos Aires: Editorial Verbo Divina.

MAGARIÑOS DE MORENTÍN, Juan A. 1993. La recurrencia semiótica. Signa: revista de la asociación Española de Semiótica. 2. http://www.cervantesvirtual. com/obra-visor/signa-revista-de-la-asociacion-espanola-de-semiotica--15/html/ dcd92966-2dc6-11e2-b417-000475f5bda5_15.html\#l_20_ (consultado 14 de Febrero del 2020).

PANOFSKY, Erwin. [1972] 1998. Estudios sobre iconología. Madrid: Alianza Universidad.

TRAVERSA, Oscar. 2001. Aproximaciones a la noción de dispositivo. Signo y Seña 12, 231- 247.

TRAVERSA, Oscar. 2019. Historia de los medios / Historia de la mediatización: el papel de Eliseo Verón. Revista Lis. Facultad de Ciencias Sociales: UBA (en prensa).

VERÓN, Eliseo. 1987. La semiosis social. Barcelona: Gedisa, el mamífero parlante.

WILDE, Oscar. [1894] 1971. Salomé. London and Glasgow: Collins Classics. 


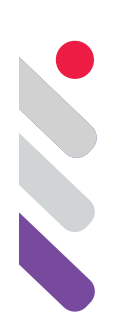

\title{
Los lugares de la memoria en un marco semiótico. La experiencia de SPEME
}

DOI: 10.24308/IASS-2019-8-031

\author{
Patrizia Violi \\ Università di Bologna \\ patrizia.violi@unibo.it
}

Los lugares de memoria en cuestión - museos, espacios, monumentos - incorporan las huellas de estos traumas, para recordarlos por supuesto, pero contribuyendo también a una reescritura y reinterpretación del pasado. El hecho de que el espacio nos cuente una historia, se inscriba dentro de las narraciones y los valores, no es una nueva adquisición para la semiótica; no obstante, nuestro proyecto se propone algo más ambicioso que reside en ir más allá del simple análisis y la descripción de los lugares de memoria. Trabajando en estos sitios nos hemos planteado ante todo el problema de su "activación": ¿cómo avivar lugares que, por su propia naturaleza, hablan de muerte y exterminio? ¿Cómo atraer nuevas generaciones, las cuales cada vez más lejanas a aquellas memorias? ¿Cómo implicar a nuevos sujetos extraños a los dramas de los que dichos lugares son testimonio? Por ejemplo, en lo que concierne a Europa, los migrantes de hoy, que poco o nada conocen de la historia europea del siglo pasado: ¿podrían reconocerse en esa historia de deportación y muerte releyéndola a la luz de sus propias historias?

Utilizar el término "patrimonio" (heritage) (Violi 2017) en el caso del trauma puede parecer forzado o paradójico, pero no es así: el trauma puede ser visto como un patrimonio en numerosos modos, tanto tangibles como intangibles, para utilizar la expresión misma acuñada por la Unesco, pensándola en términos de formas materiales y formas simbólicas. Cada vez más a menudo los lugares del trauma son hoy objeto de un turismo particular denominado black tourism (cfr. Lennon y Foley 2000), transformándose a su vez en lugares de inversión económica. Pero es en el patrimonio moral e histórico de estos lugares que pensamos cuando hablamos de heritage. En cualquier patrimonio, para mantener o aumentar su valor, debe invertirse en él sabiamente y así sacarle partido. Básicamente es esto lo que nuestro proyecto busca: los modos 
más adecuados y oportunos con el fin de hacer prosperar a la memoria que se relaciona con los traumas, memoria frágil y siempre en riesgo al olvido.

A lo largo de las reflexiones sobre los lugares de memoria y el complejo nexo del que estos gozan con transformaciones sociales de distinta índole, modificaciones de comportamientos y recuerdos, perspectivas memoriales colectivas, y también transformaciones más personales e íntimas de lo vivido, de los sentimientos de las modulaciones pasionales hacia el pasado, me he planteado una pregunta que se hace cada vez es más fundamental en el curso del proyecto, desplazando por tanto su eje y cuestionando los cimientos. La pregunta se resume así: ¿Puede la disciplina semiótica proponerse como herramienta para transformar la semiosis y los procesos de producción del sentido, y no solamente para entenderla, analizarla y describirla? Se habló mucho de prácticas en la investigación semiótica de los últimos años, pero nunca se intentó practicar la práctica.

Muy raramente de hecho, la teoría ha inspirado, guiado y sostenido una práctica innovadora, interrogándose sobre el nexo entre la teoría y acción para preguntarse como la descripción semiótica, considerada desde siempre la vocación primaria de la disciplina, puede transformar nuestras prácticas, acabando por incidir, en definitiva, sobre la semiosis en curso. Hasta donde yo conozco, hasta hoy sola en la práctica terapéutica de algunos expertos en semiótica se ha producido este corto-circuito: pienso por ejemplo en los trabajos de Ivan Darrault (Darrault-Harris y Klein 1993), donde la reflexión teórica ha abierto nuevos caminos hacia la propia práctica terapéutica, permitiendo así, al contrario, un nuevo desarrollo de la teoría.

En mi opinión, sería muy reduccionista definir estos resultados como simples "aplicaciones", porque se trata de otra cosa: a mi entender estamos aquí en presencia de la capacidad de la reflexión semiótica para incidir sobre la semiosis en curso, y el pensamiento sobre el sentido que produce otro sentido, que modifica y transforma los procesos de producción del sentido. Si el objeto de la semiótica es, a mi parecer, la semiosis de su devenir, no es en el fondo tan sorprendente que la teorización tome una nueva forma de semiosis, es decir, una práctica semiótica realizada. Estamos aquí en presencia de un aspecto performativo de la teoría semiótica, sobre la que se ha reflexionado en muy poca medida hasta ahora, limitándose a menudo a la actividad pura de descripción del objeto textual. Que está claro que es la misión primaria de la actividad del semiólogo, pero corre el riesgo de eclipsar el otro aspecto de la teoría, que también es siempre una transformación de la acción práctica.

Existen casos, y considero que nuestro proyecto está entre estos, en los que la práctica debe entenderse en un sentido más amplio, es decir; como capacidad de acción transformativa sobre la semiosis, así como sobre los procesos de producción del sentido. Nuestro proyecto se propone, de este 
modo, un doble trabajo de comprensión y análisis crítico, por un lado, y de invención trasformativa, por otro. Es un proyecto sobre los espacios, los espacios de memoria en particular.

Hace mucho tiempo que la semiótica empezó a estudiar el espacio. Primero fue Greimas, que en un artículo fundacional de 1976 puso las bases del análisis semiótico del espacio. El punto fundamental, como sabemos, es que el espacio significa siempre algo diferente de sí mismo; en otras palabras, el espacio es una semiótica que está constituida por un plano de la expresión y un plano de contenido. A partir de esto, muchísimas investigaciones se han realizado sobre distintos aspectos del espacio: arquitectura, edificios, y espacios de las ciudades. Me gustaría resaltar la doble investigación sobre Roma y São Paulo de Isabella Pezzini (Pezini 2016) y Ana Claudia de Oliveira (de Oliveira 2016), por la riqueza del trabajo y por el desafío que implicó un análisis tan vasto y complejo.

\section{Espacio y memoria}

El espacio tiene una relación particular y privilegiada con la memoria. Primero, porque todo espacio es una estratificación y un palimpsesto de los tiempos pasados. Cualquier ciudad tiene su propia historia registrada en su espacio, no solo en los monumentos, que son por excelencia objetos semióticos para transmitir memoria, sino también en todos sus edificios, calles, nuevas restructuraciones urbanísticas, etc. Segundo, todas las técnicas para recordar, las mnemotécnicas desarrolladas en el siglo decimoquinto y decimosexto están basadas en el espacio, en una imaginación espacial. Hoy, incluso los estudios de las neurociencias parecen decir algo sobre la relación espacio-memoria. Parece que el hipocampo coordina la codificación espacial y la memoria. Es decir, la memoria tiene una relación muy cercana con la codificación del espacio, a nivel neuronal.

En este panorama tan articulado, todos los lugares de memoria, como los museos, los sitios de memoria, los monumentos, tienen un rol particular. Los lugares de memoria son espacios dedicados específicamente a transmitir una memoria, cuyo significado, por lo tanto, es el objeto a recordar. Sin embargo, como vamos a ver, la situación es más compleja que esto. Como memoria y cultura son aspectos estrechamente correlacionados, el estudio de estos lugares tiene un papel fundamental en la semiótica de la cultura, en especial, la cultura de las sociedades del post-conflicto, se refiere a aquellas que han salido de dictaduras y guerras civiles que produjeron traumas y heridas profundas para el tejido social.

La memoria no solo consiste en una simple transmisión del pasado, sino que siempre es una construcción y una interpretación del mismo. Así, los lugares de la memoria siempre son lugares de mediaciones políticas, lugares de lucha 
de las memorias y de mediaciones políticas, donde diferentes actores sociales intentan proponer diferentes lecturas del pasado. Por ejemplo, la visión que el Estado y las instituciones oficiales quieren proponer puede ser muy diferente de lo que desean las personas sobrevivientes y los familiares de las víctimas, o de lo que quieren las organizaciones civiles y de derechos humanos. Es decir, los lugares de memoria son objetos semióticos privilegiados para comprender y analizar las formas de la organización cultural y de poder en una cultura del post-conflicto.

Pero esto es solamente un aspecto de la cuestión. Los lugares de memoria no son solamente formas de la representación de la memoria, estáticamente entendida. Por un lado, representan una forma en que una sociedad, o una parte de una sociedad, decide elegir como su auto-representación del conflicto pasado; por otro lado, tienen un papel activo para la construcción del futuro, la educación de las nuevas generaciones, la transmisión de una visión política y cultural. Hay, entonces, una función performativa de los lugares de la memoria, que no solamente transmiten un pasado, sino que construyen una forma del futuro. Si las memorias son siempre prácticas sociales que relacionan el pasado con el presente y lo proyectan en el futuro, los sitios de memoria tienen un vínculo más fuerte que otras formas de memorialización: esta es, su capacidad performativa de hacer algo, de activar acciones y prácticas sociales.

Este es el objetivo del proyecto internacional de intercambios europeo Marie Curie "SPEME - Questioning Traumatic Heritage: Spaces of Memory in Europe, Argentina, Colombia", que se propone investigar diferentes formas de la memorialización a través de los lugares de la memoria en diferentes países de América Latina y Europa. Estos países poseen memorias traumáticas muy diferentes por razones de historia, temporalidad, naturaleza de los eventos. La finalidad es comparar las diferencias y establecer posibles semejanzas transversales. Los países involucrados son cuatro: Italia y Holanda en Europa; y, Argentina y Colombia en América Latina. Historias y culturas muy diferentes, que exigen una investigación doble: en primer lugar, comprender en profundidad las características específicas de cada país; en segundo lugar, construir relaciones entre estas, algunas de ellas nuevas e imprevistas. Podemos decir que el proyecto se estructura entre las polaridades de la diferencia y la similitud: los dos ejes principales de la relación semiótica de significación. Queremos con esto construir nuevas formas de sentido, que puedan desarrollar inéditas lecturas e interpretaciones.

La feminista Niri Yuval-Davis (1997) empleó las expresiones inglesas rooting and shifiting, para describir la posibilidad de relaciones entre mujeres diferentes, como las palestinas y las israelitas. Conocer su propia historia y especificidad para lograr una comparación y diálogo con otras, es decir, interconexiones a través de las diferencias. 


\section{Las prácticas semióticas}

Pero no solamente queremos plantear una lectura transversal de situaciones diferentes, sino también ofrecer nuevas soluciones y formas creativas de intervención en estos lugares. Por esta razón, el proyecto no está compuesto solo por académicas/os, sino también por no académicos/as, directoras/directores de diferentes centros y museos de memoria en Italia, Holanda y Argentina. Como ya dije al principio, la semiótica en los últimos 20 años, por lo menos, ha estado trabajando muchísimo sobre la noción teórica del concepto de práctica, entendida como una modalidad de producción de sentido y semiosis. Pero muy raramente los académicos han trabajado realmente con las personas que ejecutan y practican las prácticas. SPEME quiere hacer precisamente esto: poner en el centro de su análisis la competencia material del "hacer", para disfrutar de competencias teóricas con el propósito de producir nuevas respuestas.

Tenemos tres partners directoras/directores de sitios y museos: Alejandra Naftal, directora de la ESMA, el centro de detención clandestina más importante en Buenos Aires, recientemente transformado en el Museo Ex ESMA; Marzia Luppi, directora de la Fundación Fossoli, en Carpi, cerca de Bologna, un lugar de memoria complejo, que incluye un excampo de tránsito nazi, un museo de la resistencia y un archivo; y Lars Ebert, director de H-401 en Amsterdam, un centro de arte y una casa museo de Gisèle van Waterschoot van der Gracht, una mujer que escondió judíos y personas de otras comunidades durante la guerra. Los tres lugares son muy diferentes, y esto es para nosotros un elemento muy positivo, por las razones anteriormente señaladas.

Los partners académicos son la Universidad de Bologna, con un grupo de semióticos y un grupo de arquitectos; la Universidad de Amsterdam, que tiene un centro especial de investigaciones sobre memoria y herencia; la Universidad de Buenos Aires, con su Centro de Estudios de Género y la Universidad Nacional de Colombia, Sede de Bogotá.

\section{Los lugares de memoria entre deixis y resemantización}

¿Qué son los lugares de memoria? Hemos dicho que el espacio siempre significa algo y remite a otros significados de sí mismo. Pero, tenemos que decir que el sentido del espacio cambia en el tiempo. Esto es particularmente importante en nuestro caso, porque los sitios de memoria con los cuales trabajamos son todos lugares que habían tenido otro sentido, incluso más allá de uno solo. Hablamos, en este caso, de resemantizaciones:

- ESMA: antes era el casino de los oficiales, y luego, fue convertido en un lugar secreto de detención clandestina. Actualmente es un museo.

- H 401 era la habitación personal de Gisèle, que la utilizó como refugio 
para esconder judíos y otras personas. Después se transformó en Casa Museo, que se convirtió a su vez en centro de arte.

- Fossoli también tiene una historia de transformaciones muy interesante. En un primer momento surgió como campo de tránsito nazi para prisioneros políticos; después, como un lugar de un experimento pedagógico muy innovativo: Nomadelfia, una comunidad de niños y niñas sin familia después de la guerra; y al final, se terminó convirtiendo en un campo para personas desplazadas del Noreste de Italia, anexado a Yugoslavia al final de la Guerra.

Es importante subrayar que, al cambiar de sentido, es decir al cambiar el plano del contenido, puede cambiar el plano de la expresión de una manera más o menos notable y pronunciada. Aquí encontramos un problema semiótico importante que es similar al de la restauración de los edificios y monumentos. ¿Qué conservar, y de qué manera? ¿Qué modificar? Claro que la opción depende del estado de conservación del lugar. En Castrum, la habitación de Gisèle estaba perfectamente conservada, mientras que en la ESMA todos los signos de la detención estaban borrados. Sin embargo, hay muchas opciones posibles y cada una afecta la significación global del lugar de manera diferente. Dos son las características principales de nuestros lugares:

1. Todos son espacios deícticos, es decir, espacios que tienen una conexión, una relación directa, de causa natural con los hechos que se produjeron exactamente en esos lugares. No tenemos el tiempo aquí de profundizar en este aspecto, pero este elemento convierte estos lugares en algo muy diferente a cualquier museo y afecta a la significación global de estos espacios.

2. Todos son espacios que tienen más de un solo sentido. Se trata de espacios de significación plural, espacios fluctuantes, de significación variable. El plan del contenido no está predeterminado, pero depende de la posición de los que lo interrogan. Pueden ser lugares de luto y de duelo; de formación y educación permanente para las jóvenes generaciones que no vivieron directamente el trauma; o, de movilización y actividad política. Podemos pensarlos como espacios de traducción de sentidos heterogéneos.

Aleida Assman (2002) dice algo muy similar en relación con Auschwitz, también un lugar de sentidos fluctuantes: es al mismo tiempo un museo, un sitio de trauma, un rastro del pasado, un espacio de duelo, y un cementerio. 
Para los que estuvieron internados en el campo, el lugar está lleno de sufrimiento, y proporciona la base concreta para su experiencia compartida. Para los sobrevivientes y sus hijos que llegan aquí para llorar a sus seres queridos que han muerto, el lugar es sobre todo un cementerio. Para los que no tienen ningún vínculo personal con los millones de víctimas, Auschwitz es principalmente un museo que presenta la escena del crimen a través de muestras y visitas guiadas. Para algunos grupos es una escena de santo martirio; mientras, los gobernantes y jefes de estado lo usan como plataforma donde pueden entregar sus confesiones públicas, admoniciones, declaraciones o aspiraciones. Para los historiadores, Auschwitz es un sitio arqueológico que conserva las huellas del pasado. El lugar es todo lo que se busca en él, lo que se conoce de él y se asocia con él. Las perspectivas son muchas y diversas. (Assmann 2002: 366-67, mi traducción).

Además, estos espacios se convierten cada vez con mayor frecuencia en lugares turísticos. Este es un aspecto importante, que añade una significación muy particular, la cual tenemos que considerar pensando en lo que podemos hacer en los lugares. La ESMA, por ejemplo, está ya incluida en las guías turísticas de Buenos Aires, aunque esto es un sentido complementario.

La significación variable de estos espacios y su carácter fluctuante depende de la posibilidad de leer, interpretar y vivir estos espacios de muchas maneras diferentes. $Y$ depende también de lo que nosotros hacemos de estos espacios y sobre ellos, por lo que los espacios actúan de maneras diferentes. Aquí está el carácter performativo de nuestro proyecto, un proyecto que no se propone solamente un análisis crítico de los sitios de memoria, sino también intervenir sobre ellos, inventar y construir prácticas nuevas y diferentes. Nuestro objetivo es actuar sobre los lugares, hacer algo con estos, utilizando las herramientas semióticas. Creemos que este aspecto es algo innovador en el campo semiótico.

Nuestra pregunta general es: ¿cómo pueden los espacios movilizar la memoria, construir una memoria viva, vinculada al presente y al futuro, y no solo al pasado? Por supuesto los espacios pueden movilizar la memoria, solo en la medida en que logran movilizar y comprometer a los visitantes; la visita de un sitio de memoria es performativa en sí misma, porque modifica la dimensión cognitiva, emocional, pasional y sensible del visitante. Pero, ¿de cuál visitante estamos hablando? Los visitantes no son una categoría homogénea: hay diferentes clases de visitantes. ¿Niños? ¿Nuevas generaciones que no conocen los traumas pasados? ¿Sobrevivientes? ¿Familiares de las víctimas? ¿Turistas extranjeros?

Entonces, tienen que ser pensadas diferentes formas de intervención. Por ejemplo, formación y educación para los jóvenes y los niños. En nuestro proyecto estamos trabajando mucho con las intervenciones artísticas de formas diferentes. El arte es un medio privilegiado para transmitir memoria. 
En Buenos Aires está el Parque de la Memoria, y en Amsterdam, nuestro partner $\mathrm{H}-401$ es un centro de memoria y de arte al mismo tiempo. En Bogotà el contra-monumento Fragmentos realizado por Doris Salcedo es quizá la obra más significativa existente a día de hoy para recordar la memoria de la terrible guerra colombiana. En cada uno de estos lugares el arte se declina en formas, modalidades y proyectos diferentes porque todos los partners de este proyecto tienen situaciones históricas muy diferentes. Una diferencia muy relevante en este sentido es la dimensión temporal, y la distancia o cercanía que nos separa de los hechos traumáticos.

Para Italia y Holanda se trata ahora de una temporalidad histórica: más de setenta años han pasado desde el final de la guerra, del nazismo y del fascismo. Los traumas de la dictadura militar en Argentina son más cercanos, y su memoria más viva, pero toda una generación nos separa de aquellos tiempos. La situación de Colombia es completamente diferente, la memoria es todavía una verdadera memoria del presente y no del pasado, al igual que el proceso de paz en Colombia no ha terminado en el conflicto armado: siguen las guerrillas del ELN, EPL y algunos disidentes de las FARC, los paramilitares están nuevamente activos y los narcotraficantes también están activos en muchas áreas periféricas del país. No existe todavía un Museo Nacional de la Memoria, ni tampoco una política pública y común sobre los sitios y espacios de memoria.

Muchas diferencias existen entonces entre los lugares objeto de nuestra investigación: diferencias en la temporalidad de los eventos, en los ritmos de la memoria, en la participación social y en la conciencia política; diversidad que precisa estrategias diferentes en el acto de afrontar la difícil tarea de hacer de la memoria como patrimonio traumático un bien común y compartido, capaz de generar nuevas energías para el futuro y no solamente para custodiar un pasado traumático.

\section{Bibliografia}

ASSMANN, Aleida. 2002. Ricordare. Forme e mutamenti della memoria culturale. Bologna: II Mulino. (texto original 1999. Erinnerungsraüme. Formen und Wandlungen des kulturellen Gedächtnisses, Müunchen: Oskar Beck

DARRAULT-HARRIS, Ivan, Jean Pierre, KLEIN. 1993. Pour une psychiatrie de l'ellipse. Paris: Puf.

DE OLIVEIRA, Ana Claudia. 2016. San Paolo in divenire tra identità, conflitti, riscritture. Roma: Edizioni Nuova Cultura.

GREIMAS, Algirdas. 1976. Pour une sémiotique topologique. In Sémiotique et sciences sociales. Paris: Seuil. 
LENNON, John, Malcom FOLEY (eds.). 2000. Dark Tourism. The attraction of Death and Disasters. London: Continuum.

PEZZINI, Isabella. 2016. Roma in divenire tra identità e conflitti. Roma: Edizioni Nuova Cultura.

VIOLI, Patrizia. 2017. Landscapes of Memory. Trauma, Space, History. Oxford: Peter Lang.

YUVAL-DAVIS, Niri. 1997. Gender and Nation. London: Sage. 


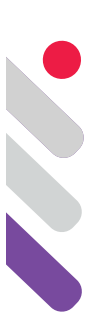

\section{From Buffy to a Discovery of Witches. Semiotic Considerations on Vampires, Witches, \& Preternatural phenomena in Literature and Television}

DOI: 10.24308/IASS-2019-8-032

Gloria Withalm

University of Applied Arts Vienna - Cultural Studies, Austria gloria.withalm@uni-ak.ac.at / gloria.withalm@gmx.net

\section{The texts - some common features of the texts and their characters}

Throughout the past some 25 years books, television shows and movies about preter natural beings, especially witches and vampires living in today's world, have peaked. The main ones I will focus on are:

Buffy the Vampire Slayer; Charlaine Harris's Sookie Stackhouse Novels plus the TV show True Blood; and, so far, four All Souls books by Deborah Harkness and the first season of A Discovery of Witches (as of early 2020, the shooting of the second season has just finished). In addition, I have included three more shows: The Vampire Diaries and its spin-offs The Originals and Legacies.

There are many more texts that deserve mentioning but are not analyzed in this article, like: Charmed (the very first primetime show about a group of contemporary witches); the Buffy spin-off Angel; Jim Butcher's book series The Dresden Files and the TV show; the Underworld film series; the Twilight saga, both the books and the films; The Magicians; the TV show Midnight, Texas, based on books by Charlaine Harris; and, of course, the Harry Potter saga seven books by J.K. Rowling and eight movies [cf. Withalm 2017].

As to the texts, I will take them as is and deal solely with the topics in question, neither discussing their aesthetic quality nor the moral of the characters.

\section{1. "I wanna be normal": 3 women -3 sets of abilities -3 paths of life}

All three main texts have female leading characters, presenting three different trajectories, multi-layered voyages to discover themselves. They are of 
different ages, live in different parts of the world, come from different social back grounds. And they are far more than "normal" women. All three are powerful and endowed with special talents. At first reluctant, they have to come to terms with their lives and learn to accept their powers. The texts accompany them in this process and depict their paths from bemoaning their fate to a matured self. In the end, they succeed in coping with their unusual abilities and handling their powers.

There is Buffy Summers (Sarah Michelle Gellar), the heroine of Buffy the Vampire Slayer. We watch her from sixteen to her early twenties. She's the youngest of the three, and the chosen Slayer, gifted with strength, special skills to fight, agility, and quick healing.

Both in Charlaine Harris's books and in True Blood, Sookie Stackhouse (Anna Paquin), a twenty-five-year old waitress at the local diner, is a telepath - a gift she considers rather a disability. Later it is revealed that she is also part fairy and therefore she can produce powerful balls of light with her hands that can even kill vampires.

In the All Souls books and in the TV show A Discovery of Witches, Diana Bishop (Teresa Palmer) is in her early thirties, a historian and tenured professor at Yale University. She is also the last descendant of two lines of powerful witches, but she tries to not use her magic and never mastered the craft.

Though the title quote of this section is taken from True Blood [TB 5.08], at one point all three say the same, practically verbatim, but - given their powers - being normal is unattainable.

Life doesn't get easier for any of the three when they meet vampires and fall in love with them. It's especially difficult for Buffy, who is supposed to kill every vampire.

At first, she has no clue that the mysterious Angel (David Boreanaz) is a vampire, but despite knowing better, he becomes her first vampire boyfriend (and first lover). Later in the series she starts a secret relationship with Spike (James Marsters).

Though in Sookie's world vampires have recently "come out of the coffin", they are still not widely accepted. So, her relationship to Bill Compton (Stephen Moyer) is bad-mouthed. Later, she starts to sleep with Eric Northman ${ }^{1}$ (Alexander Skarsgård).

In the case of Diana, any close, let alone intimate, relationship between witches and vampires is strictly forbidden by the Covenant, a set of strict rules drawn up in the Middle Ages by the Congregation (the ruling body of all creatures made up of three vampires, three witches, and three daemons). So, when she stumbles upon a bewitched manuscript and falls in love with Matthew

${ }^{1}$ In the book series she even becomes his wife according to vampire law/lore (SSN-09). 
Clairmont (Matthew Goode), a vampire and Oxford professor of bio chemistry, all hell breaks loose.

\section{2. “Daywalking?...the ultimate vampire dream?" [TB 3.11]: Out of the ground $\&$ into the sun}

A comparison of the vampires in the various TV shows can be based on their paths into the sun - "daywalking". Practically all vampires up until the late 2000s are nocturnal (not by choice): sunlight is fatal, but there are workarounds.

Spike is searching for the "Gem of Amara" [Buffy 4.03], an old talisman that counteracts all vampire vulnerabilities. For The Vampire Diaries guys, sunlight is lethal, unless they wear an enchanted piece of jewelry, for instance rings with lapis lazuli.

True Blood vampires have only one way to avoid burning, and even that just helps for a very short time: to drink the blood of a fairy, like both Bill [TB 3.07] and Eric [TB 4.04].

Within the Twilight universe, vampires avoid walking in direct sunlight, but only to keep their secret, because their pale skin starts to sparkle [Twilight 2009: 228]. This is a specific trait ridiculed in many Pinterest memes. And even Matthew - not at all affected by the sun - makes fun of this, when he reveals to the students at the Yale bio-chemistry lab that he is a vampire, but, "I do not, nor have I ever, sparkled!" [TBoL: 204]

\section{Vampires, Witches and more}

2.1. "He was not of an age, but for all time" [ADoW: 151] - Vampires, their bodies, their souls (?)

This title quote touches one characteristic: Though vampires aren't immortal, they live for a very, very long time. The oldest protagonists are thousands of years old.

Some vampire features appear in many texts: strength; fast movements (some can even fly); pale skin; low body temperature. Except for the Twilight and All Souls vampires, they have retractable fangs, and leave the characteristic double puncture marks on the necks of their victims. The fangs are out when the vampire is "angry, or horny, or hungry, or all three", as Sookie observes [SSN-03: 516]. In the case of Buffy and The Vampire Diaries, the extended fangs go together with extreme changes of the face. The vampires in Buffy show a protruding brow ridge and yellowish eyes, whereas in TVD the veins around the eyes become quite distinctly visible and the sclera is bloodshot.

For most of the 21st century species, large parts of the "classic" vampire lore are no longer valid. The last vampires affected by the burns of a cross are those in Buffy, and they are still without reflections, unlike Matthew or Bill, who 
explains that "we started most of the myths about ourselves many centuries ago." [TB 1.07]

Though some of the vampires are highly cultivated, sophisticated, and truly lovable characters, their nature as skillful killers, predators on the top of the food chain, is never denied. Many of them, like Angel, Bill, Stefan (Paul Wesley) in TVD, Matthew, sometimes even Spike or Stefan's brother Damon (Ian Somerhalder), are remorseful. They are on the verge of self-loathing, seek redemption, and rather hide their killings from their spouses. It certainly is this two-tiered message they convey - dangerous lethal predator and sexy remorseful lover - that constitutes their attraction as the "Good-Bad Boy".

\section{2. "Witch power is in your blood and it's in your bones." - Being a witch: corporeal manifestations and special abilities [ADoW 1.03]}

According to Matthew's research, the DNA shows how much genetic predisposition for magic a witch has. Diana's blood sample shows "nearly every genetic marker we've ever seen in a witch." Among them are mind-reading, telekinesis, and the markers for elemental magic, like earth, water, air, and even fire ${ }^{2}$, which is "very, very rare".

Flying is another aptitude no longer common among witches. Satu Järvinen, the witch who abducts Diana (and tortures her to find out about her powers), can fly. So can Diana when she has to rescue herself out of the oubliette (the underground dungeon in a medieval Auvergne castle). Some witches are able to at least levitate, for example Willow (Alyson Hannigan) and Tara (Amber Benson) during their dance at Tara's birthday [Buffy 5.06], or Marnie (Fiona Shaw) in True Blood [TB 4.07].

A corporeal feature shared by some witches are glowing hands when they work magic. In The Vampire Diaries some witches can absorb magic from someone/something on touch, with their hands emitting a reddish glow [TVD 6.10]. The hands of Dianatv start to glow in an orange-yellow hue whenever she does magic [ADoW 1.01, 1.02]. Throughout both the book series and the show, there is a strong connection between magic and electricity. ${ }^{3}$

Another characteristic of Diana is her shimmering, her chatoiement. Matthew observed it when he watched her for hours [ADoW: 28-29], and later he recalls, "Even when I was a young vampire, only the most powerful witches emitted these tiny pulses of light. It's rare to see it today." [ADoW: 96] Instead of having Diana float in the air during her dance at Sept-Tours [cf. ADoW: 267], in the show light is pouring from her body [ADoW 1.04]. When she is trained to timewalk, Diana starts to slightly shimmer right before she disappears for

\footnotetext{
2 Diana uses her witchfire as a deadly weapon against Juliette [ADoW: 509-510] and Benjamin [TBoL: 543].

3 In the book, the fingers of her hands start to shoot bluish electric sparks that can burn holes into carpets [cf. ADoW: 118, 193].
} 
the stillroom [ADoW 1.08]. With her timewalking to 1590s London, her glaem becomes even stronger [cf. SoN: 68, 308] and she has to cast a disguising spell to cover it up.

\section{The materiality of magical (sign) and communicative/ exchange processes}

\section{1. "All witches are taught to believe in signs." [TBOL: 565] - Semiotics and the} preter / supernatural

"Magic is a form of semiosis." - as Winfried Nöth states in the opening sentence of the chapter on MAGIC in his Handbook [1990: 188].

\subsection{1. "Signs and Bodies" - Some aspects of Ferruccio Rossi-Landi's semiotics}

Magic and spells are phenomena that can be discussed in terms of the materialistic semiotic theory developed by the Italian semiotician and philosopher Ferruccio Rossi-Landi.

45 years ago, Rossi-Landi presented the paper "Signs and Bodies" at the first Congress of the IASS, June 1974, in Milan [1979; 1992]. In this relatively short text, he proceeded from five propositions concerning the relation between signs and bodies:

\section{A, All signs are bodies; \\ $B$, Not all bodies are signs; C, All bodies can be signs. \\ And \\ D, Signs are not bodies; \\ E, All bodies are signs. [1992: 271]}

According to his main working hypothesis, the propositions $\mathrm{A}$ to $\mathrm{C}$ form "the basic model of materialistic semiotics" [1992: 272]. Hence, materialistic semiotics starts with bodies, and, by realizing that bodies can be signs or not, comes to consider signs as a subclass of bodies-in-general [1992: 272].

One concept in Rossi-Landian socio-semiotics, closely connected to the matter-sign relation, is that of Social Reproduction, "the sum total of all processes by means of which a community or society survives, grows bigger, or, at least, continues to exist." [1985: 175]

Viewed in its totality, there are several processes within social reproduction. The basic one, summarized in his Schema [1975: 65; 1985: $38]$, is the cycle of production - exchange - consumption, composed of "three indissolubly correlated moments" that social reproduction "always comprehends in a constitutive way" [1975: 65].

The moment of exchange, conceived in a twofold way, is at the very center. It is simultaneously both external material exchange, and sign exchange; the latter is in itself the reduplication of the entire cycle with, again, "three 
indissolubly correlated moments": sign production, sign exchange and sign consumption.

Analyzing magical processes in the light of these concepts reveals them as perfect examples of the sign-body duality: Magical sign processes are always simultaneously and in a constitutive way material and sign processes.

\subsection{2. "Names are important." [ADoW: 318] - Names \& runes \& sigils \& "symbols"}

With regard to the supernatural, "names are important", as Ysabeau, Matthew's mother, and the oldest vampire in the de Clermont family, explains to Diana. The "latte-loving" daemon Timothy J. Weston said exactly the same thing when giving Diana the third page cut from Ashmole 782, asking her that the name of his ancestor won't be forgotten [TBOL: 379].

A special use of names appears in The Originals [TO 1.14] when Elijah Mikaelson (David Gillies) gets a message from the witch Celeste, his 18th century lover. After she casts a spell, his whole body is covered with the names of all witches she had inhabited over the centuries.

Depending on the origin of a creature, different sign systems are preferred. Esther Mikaelson and her eldest daughter Freya were born in Norway in the 900s. Accordingly, they both use runes in their spells, for instance, to establish a magical connection.

Two more emblems that keep reappearing should be mentioned. One is Matthew's seal for the Order of the Knights of Lazarus with a fleur-de-lis and his insignia - a six-pointed star inside a crescent moon - in diagonal quadrants formed by a cross [ADoW 1.05; ADoW: 327]. The seal appears also on one of the pages missing from Ashmole 782 showing the chemical wedding [ADoW 1.07]. The other is the old ouroboros symbol. A silver ouroboros figures as de Clermont family emblem on standards etc. [cf. ADoW: 227, 279]. After Matthew has established his own scion, the new emblem, designed by his son Jack, combines the de Clermont ouroboros with a firedrake, Diana's familiar, both holding each other's tails in their mouths [TBOL: 465].

3.2. "Magic is desire made real." [ADoW: 180 \& ADoW 1.02] - Witches, magic and the world [ADoW: 180 \& ADoW 1.02]

Throughout the texts, the characters describe or give definitions of magic like the one cited in the title. 
3.2.1. "Magic's not just emotional and mental - it's physical, too." [ADoW: 451] - Magic and its effects

\subsubsection{1. "Letters [...] ran just under my skin." [TBOL: 520] - Corporeal effects of magic: Signs on a witch's body}

There are certain corporeal effects that appear only when a witch works magic. Actually, in two quite spectacular moments magic literally changes the witch's body. The second Willow touches dark art books, all words scroll up her chest and her face [Buffy 6.20].

When in the third volume of the All Souls Trilogy, The Book of Life, Diana inserts the lost pages of Ashmole 782, the written text enters her body for good [TBoL: 485]. In the show, this unique relation of the manuscript to Diana was already foreshadowed when she first called it up at the Bodleian [ADoW 1.01]. She touched the contours of the image, and the fast-moving spidery words float up her fingers. After clasping her hands on the illumination, the words re-enter the book, but the outlines of the upside-down vessel of the alchemical child are burned onto her palm. ${ }^{4}$ That could be interpreted as cataphoric again: as the vessel resembles a uterus, it could mean that the manuscript already knew that Diana will be able to carry the "alchemical child" - the synthesis of opposites.

\subsubsection{2. "The twisted red-and-white strand of time" [ADoW: 555] - Magic visualized}

When it comes to visualizing that magic is happening, double exposure seems to be the film makers' favorite choice. The Originals has well-defined modes. Often, the image wavers slightly, includes double exposure, and follows a distinct color palette. Most of "normal" magic appears in an orange-yellowish tint [TO 4.07], whereas magic related to an ancient evil spirit who inhabits some characters is shown in hues of blue [TO 4.13].

3.2.2. "Magic and witchcraft are but two paths that cross in the wood." [SON: 327] - Spell casting and/vs. magic

Even after she realizes that she's indeed a rare kind of witch, a weaver, Diana still thinks that "elemental magic and the craft are separate" [SoN: 579], which is pure nonsense according to her teacher. Magical power can take different forms; sometimes it is depicted as rippling airwaves, like Satu's (Malin Buska) beating on the tiny (Sámi) drum [ADoW 1.06 $]^{5}$.

\footnotetext{
${ }^{4}$ The show $A D o W$ alludes to this special connection again, when Matthew talks about it. In ADoW 1.03, he explains both her magic and why she could call up the manuscript with her need to do something. When Diana replies that it's not that simple, he concedes, "Well, no, of course not. There's something else, some kind of link between you and the book." And Diana knows too well what he means: she turns her hand and looks at the burn scar in her palm.

5 When I first saw the episode, I had the vague idea the tiny drum could be Sámi, given Satu's origin and the signs on top of the skin. Thankfully, Stephenie McGucken, an art historian who did extensive research on the All Souls Trilogy, wrote about the drum and quoted sources in one
} 
Casting spells is a combination of incantations and specific gestures. A flick of a hand, together with an incantation, can inflict pain, lift someone up in the air [ADoW 1.06], or even break a neck [TO 1.10]. To immobilize and overpower a vampire, Marnie gestures with both hands simultaneously [TB 4.06], and Vincent (Yusuf Gatewood) has unique gestures when working magic, like rubbing thumb and fingers together and blowing on them while chanting [TO 2.10].

\subsection{3. "The circle closed with a little snap." [StF: 73] - Forms and functions of magic circles}

There are many methods to draw a circle, for instance with salt, used from True Blood and The Vampire Diaries to All Souls. Salt has cleansing properties and, together with a spell, it creates a barrier to contain someone inside or hold them out. Holly - the other waitress at the diner - always carries a package of salt with her, a sort of Wicca emergency kit, which comes in handy if you need to keep someone at bay - like Lafayette (Nelsan Ellis), possessed by Marnie's vengeance seeking spirit, who tries to kill both Bill and Eric [TB 4.12].

Other methods are burning candles, or simply chalk, as Matthew discovers on the photograph of Diana's murdered parents [ADoW 1.04], proving that they were actually killed by witches, not by humans. Fire circles are also used quite often. Satu conjures a circle of flames twice - to kill someone [ADoW 1.01] and to confine Diana [ADoW 1.06]. For a violent ritual, the doppelgänger Elena (Nina Dobrev), the vampire Jenna (Sara Canning), and the werewolf Jules (Michaela McManus) are encircled in three fire rings which touch each other [TVD 2.21]. But fire can be used also in a positive way. When Diana is about to cast her forspell (the first spell of a weaver), all the witches gathered in a circle, one of them "murmured a spell and a curved line of fire traveled from witch to witch, binding the circle" [SoN: 362].

\subsection{4. "You trapped her in the house?" [TVD 2.11] - Shields, protective spells \& barriers}

Shields come in various forms and sizes. Sookie, for instance, considers her way of blocking out the minds of others as shielding [cf. SSN-07: 42]. Mostly, shields are quite large and erect a barrier. In Buffy [1.01], an ancient vampire is held by an invisible wall that quivers whenever he touches it. Likewise, the seal that keeps Elena in the house is invisible [TVD 2.11]: when she touches it, the flesh on her palm flattens as if pressing her hand against a pane of glass.

Another type of shield is made of light, like the barrier Diana conjured around her and Matthew when she feeds him her blood to save him [ADoW

of her articles on [cf. McGucken 2018]. Even though the drum in the show is only a tenth of the regular ones, the findings are compelling. 
1.08], or the protection spell around Marnie's shop [TB 4.11], made of "the power of the sun", deadly for vampires.

\section{3. "Get out of my head!" - Supernatural ways of seeing / reading / hearing / talking}

\subsection{1. "I can read every mind in there, except yours." [Twilight] - Mind reading} and silent speech

The most distinct telepath in these texts is Sookie. She hates to hear the constant thought chatter of everyone. That's one of the reasons she is drawn to vampires: she can't hear them. Bill's explanation is the lack of brain waves in vampires [TB 1.03]. Only after Bill has contracted HepV (a fatal vampire disease), and feels closer to humanity than ever before, can Sookie suddenly hear him [TB 7.10].

At one point, Buffy acquires telepathy too. When she tries it out on Angel, he tells her, "You can't get into my mind" [Buffy 3.18]. His explanation compares this phenomenon to another trait of vampires, "It's like the mirror. The thoughts are there, but they create no reflection in you."

Silent speech, on the other hand, is the active sending of communication to someone. Some times in a rather unfriendly way, such as when Diana's future ad ver sary, the witch Peter Knox does when he thrusts himself into her thoughts and she fights him, "Get the hell out of my head" [ADoW: 37].

\subsection{2. "White is the color of divination and prophecy." [TBOL: 146] - Precognition, Scrying \& Visions}

Various characters - not only witches, but also d(a)emons ${ }^{6}$ or vampires can have the second sight. Drusilla was a seer before Angel turned her. Unlike Matthew's mother Ysabeau, who had no more visions after she was made a vampire [cf. ADoW: 250], Drusilla (Juliet Landau) continued to have second sight, and can even induce visions in others, as she did with the imprisoned Giles (Anthony Stewart Head) [Buffy 2.22].

Usually, it's witches who have visions, and it often runs in the family. Diana's mother "was famous for her premonitions" [ADoW: 339], and in SeptTours Diana suddenly has her first visions (but they didn't make it into the show). Yet after Diana and Matthew come to Madison, NY, the Bishop house conveys a vision of the last embrace of her parents [ADoW 1.07], with blurred edges and a red/blue halo.

When witches are scrying, they use a crystal ball or a bowl of water, though any other liquid will do. Such is the case in True Blood, when Marnie sees herself dead in a pool of blood, with a gunshot wound in the forehead

\footnotetext{
6 In the All Souls Trilogy the third species besides witches and vampires is called daemons, whereas in other texts the creatures are usually spelled demons.
} 
[TB 4.11]. Diana's aunt Emily (Valarie Pettiford) is always scrying with a bowl of water. But, this time, she is shocked by what she sees. Two smoky specters come twirling out of the water bowl, ${ }^{7}$ the light-gray shape harassed by the dark one: Diana is in pain, tortured [ADoW 1.06].

\section{4. "Her witch's blood sings in her veins." [ADoW: 268] - Blood: myths, properties and effects}

This quote refers to a witch, but myths about blood are not confined to one species. Witches have an affinity to blood and often use it in their spells to link, locate and track [TO 2.22]. Blood seems to contain the essence of a being, like in True Blood, when Jesús was forced by his brujo (sorcerer) grandfather to kill a baby goat and "take the spirit inside" by licking the blood off the blade [TB 4.05].

Within the All Souls universe, all memories of humans and creatures alike are stored in someone's blood. When Matthew drinks from Gillian (Louise Brealey) [ADoW 1.05], he sees his suspicions confirmed that she tried to steal Diana's blood from his laboratory.

\subsection{1. "As your maker I command you!" [TB 2.02] - How vampires are sired/ made/reborn/...}

Whatever the action is called, in the end there should be a new vampire. Though blood is always involved, the process itself differs extremely. Sometimes, the exchange of blood can appear close to a seduction, as is the case with Darla (Julie Benz) and Angel back in Ireland in 1753, when she made him drink from a fresh cut on her breast [Buffy 2.21].

True Blood adds yet another step, but not even vampires know why: the maker has to be buried together with their new progeny to complete the transformation. When Eric turns Willa (Amelia Rose Blaire), he first digs up a place before he lays her down, bites her, so that her blood flows into the ground. Only then he pierces his neck to let her drink his blood [TB 6.04]. Both in the Sookie Stackhouse Novels and in True Blood, the maker has absolute power over their progeny, hence the quote in the chapter title that appears in several episodes. Because of this bond, a vampire can be mentally called by their maker and has to obey whatever asked to do.

A Discovery of Witches has an attempted siring after less than 15 minutes into the show [ADoW 1.01]. A young man and his friend leave the hospital after

\footnotetext{
7 It seems the visualization of Em's scrying is based on Diana's memory of an incident with her mother Rebecca, a powerful witch, and a bowl of water: "As she stared at the glassy surface, it became covered with a fog that twisted itself into tiny, ghostly shapes. I gasped with delight as they grew, filling the room with fantastic beings. Soon they were crawling up the drapes and clinging to the ceiling. I cried out for my mother's help, but she remained intent on the water." [ADoW: 6]
} 
their shift and one of them is run over by a car. (At that moment we don't know yet that Marcus (Edward Bluemel) is a vampire and Matthew's son.) Marcus tries to save/sire James who does wake up, drinks. In the end it didn't work and James dies. Within the storyline this is another failed siring, pointing at the fact that vampires are no longer able to create new progeny.

\subsection{2. "Drink!" - Feeding (on) a vampire \& healing}

One aspect of vampire blood that appears in all texts, is the healing property, as is shown at the beginning of the relationship between Sookie and Bill. After she was brutally attacked, Bill saves her life by giving Sookie his blood [TB 1.02].

Drinking from a human, on the other hand, is risky - that's why vampires often warn their lovers. All three women had to pay the price. With their vampire lovers close to death, the women all told them to drink, and were almost drained.

When Angel was shot by a poisoned arrow, and the only antidote is a Slayer's blood, Buffy orders him, "Drink me!" [Buffy 3.22]. When he refuses, she hits him until his "vamp face" comes out. He latches onto her neck and drinks, until he finally rolls off her and sees her lying unconscious.

After Sookie rescued the half-dead Bill, she cuts her arm to feed him. Acting on pure instinct, Bill bites her, drinks from her neck. He can't stop and Sookie ends up in a coma [TB 3.07].

Moments after she killed Juliette with witchfire, Diana tends the lethally injured Matthew. Inside her light barrier, she cuts her wrist and forces him to drink. But venous blood is not enough, so Diana offers her neck. Matthew drinks and sees images from their past weeks together. Only when he comes to the moment he said "I love you", he is able to stop [ADoW 1.08].

\subsection{3. "Blood sharing is kinda - personal." [TVD 4.02] - Exchanging Blood \& Sex}

Everyone knows that vampires drink blood from humans. Some humans, however, feel sexual pleasure when a vampire sucks their blood. And vice versa, some of the vampires get aroused when someone bites them and drinks their blood.

Even the Slayer and the ultimate vampire, Count Dracula, are not immune [Buffy 5.01]. When Dracula visits Buffy in her bedroom, she neither resists his touch, nor his bite. Buffy gasps when bit, but reading her expression, there's more to it than just pain. In the reciprocal scene, Dracula offers Buffy blood from his wrist, and when she latched onto the small cut, he very much liked it, at least according to the script: "Dracula's lids half-closed in ecstasy." [Noxon 2000] 
In the True Blood universe, vampire blood has specific benefits for humans: it increases the libido and induces erotic dreams about the vampire, such as the erotic dreams Sookie has about Eric after she had his blood [TB 2.09/2.10]. Later, when they have sex, Eric really likes Sookie to bite him, and take his blood, "because it makes me feel good" [SSN-09: 159] and they "will be one", as he explained [TB 4.08].

Elena tasted blood only after she turned, and it was Damon who offered his when she couldn't keep any other blood down. When she starts to suck on his punctured palm, Damon's face shows his arousal, fully immersed in the pleasure with half-closed eyes and breathing deeply while caressing her head (at that moment she is still his brother's girlfriend) [TVD 4.02].

\section{From calling names to segregation to genocide}

Human societies have a long history of fear and hatred of certain groups, fueled by ideologies which, according to Rossi-Landi [1978: 17; 1990: 19-20], range from ideas embedded in mythology and folklore to fraud or conscious deception; and false thinking leads to False Praxis.

Based on the opposition "us vs. them", the latter are marginalized, or even considered outside the own culture in the "extra-cultural space", as defined by the Tartu-Moscow school, and labeled by the majority population as different, according to various parameters: religion, ethnic origin, sexual orientation, skin color, or, as in my texts, for being not human.

Speech patterns and discourses based on prejudices are for instance discussed in Critical Discourse Analysis by scholars, like Teun Van Dijk or the Austrian sociolinguist Ruth Wodak.

\section{1. "Leech" vs. "Breather" - Prejudice, fear \& hatred among creatures}

Right after the opening title of $A$ Discovery of Witches, we hear Matthew's monolog about all creatures, "hiding in plain sight, [...] ill at ease, even with each other." These words set the tone not only for this show.

At one point in season 5, Sookie's brother Jason (Ryan Kwanten) and Eric exchange invectives for each other, like fanger, leech, or dead fuck vs. bloodbag, breather, or meatsack, respectively [TB 5.12]. It may sound lighthearted, but this banter between the two is preceded by Jason's vicious words, when he urges Sookie to "tell all these fucking fangers to go back to hell where they came from".

Calling names is quickly followed by denying the creatures their status as a person, using the epithet "that". Xander (Nicholas Brendon) does this with regard to Spike when he reproaches his ex-fiancée: "cos you had sex with that," 
[Buffy 6.18], or Gillian, who talks about Matthew and doesn't want Diana "to spend time with that" [ADoW 1.03].

As Matthew correctly pointed out, hatred is not restricted to humans vs. creatures. All species have prejudices towards others. There's witches vs. vampires, and centuries of hate and feuds between vampires and werewolves.

\section{2. "Blood is sacred" [TB 3.01] - For some, "bloodline" means more than just lineage or ancestry}

Speaking of a bloodline per se is nothing bad, unless this talk is aimed at keeping the bloodline pure. Some vampires have this tendency, but also some witches, as magic is considered to run in families. Searching medieval documents, Diana and her friends found that the pure bloodline myth was at the very beginning of the Covenant [cf. TBoL: 558]. Her Yale University friend Chris Roberts - in his own words "a black man from Alabama" [TBoL: 182] pointed out that "forced segregation - or the covenant if you want to be fancy about it - is often about concerns for racial purity." [TBoL: 187]

\section{3. "If we created them - we can uncreate them." - From segregation to genocide}

Segregation is only the first step. Together with fanaticism, it often leads to imprison ment, torture, and in the last instance, the extermination of the ousted group. In the All Souls universe, witches have even hunted down and killed a special group of their own, the weavers [cf. SoN: 323]. Whereas the Congregation vampires are ready to kill Diana and Matthew for their disobedience, the dreams of Peter Knox (Owen Teale) go far beyond this as he tells Diana with a smile, "If we created them, then we could un-create them." [ADoW 1.02] And in the TV show, Gillian tells Matthew that Knox is right, "The sooner your kind are wiped from the face of the Earth, the better." [ADoW 1.05]

How to overcome this hatred and segregation and killing?

One solution might be to overcome the boundaries between us and them, as proposed by Gloria Anzaldúa, who described herself as a new mestiza, with a "tolerance for contradictions, a tolerance for ambiguity." [Anzaldúa 1999: 101] According to Anzaldúa, another aspect is to be "a participant in the further evolution of humankind" [Anzaldúa 1999: 19].

In her book Borderlands she writes,

To survive the Borderlands You must live sin fronteras

Be a crossroads. [Anzaldúa 1999: 217] 
This crossroads metaphor appears verbatim in A Discovery of Witches, ${ }^{8}$ when the ghost of Bridget Bishop, her 17th century ancestor, told Diana that she is "a creature of the crossroads, neither here nor there." [ADoW: 490]

Diana was not afraid to challenge the obtrusive laws of segregation, and fight for her love. The forbidden couple succeeded, and their twins actually embody Anzaldúa's "further evolution", surmounting in their very selves the concocted cleft between the species. They are part vampire, part weaver-witch, "hybrids", just like Hope (Danielle Rose Russell) in The Originals and Legacies, who calls herself a "tribrid": witch and werewolf and vampire. As Hope was told by her mother,

"You are a Mikaelson witch with a werewolf mother and an Original father. You are the one that could finally unite all the factions." [TO 5.06]

As for Diana and Matthew's twins Rebecca and Philip, future books of Deborah Harkness will reveal their powers.

\section{References}

ADoW (1.00) $=$ Discovery of Witches, UK-BBC/SkyOne 2018 (season1.episode)

ADoW $=$ Harkness, Deborah (2011). A Discovery of Witches (= All Souls Trilogy 1). London: Headline

ANZALDÚA, Gloria (1987). Borderlands/La Frontera-The New Mestiza. San Francisco, CA: Spinsters/Aunt Lute Press, 2nd ed. 1999

Buffy (0.00) = Buffy the Vampire Slayer, US-WB/UPN 1997-2003 (season. episode)

McGUCKEN, Stephenie (2018). "Of Weavers, Drums, Markings, and Beginnings". The History of All Souls. Exploring the Art of the All Souls Trilogy. Web: https:// thearthistoryofallsouls.com/2018/10/24/of-weavers-drums-marking-andbeginnings/, visited 2019-08-14

NOXON, Marti (2000-08-23). Buffy vs. Dracula [script]. Web: http://www. buffyworld.com/buffy/scripts/079_scri.html, retrieved 2019-06-14

ROSSI-LANDI, Ferruccio (1978). Ideologia. Milano: ISEDI

\footnotetext{
8 The metaphor keeps re-appearing in Shadow of Night to characterize Diana's abilities once she and her teacher in 1590s London realize that she is a very special kind of witch, a weaver, who can both work magic and cast spells. "Magic and witchcraft are but two paths that cross in the wood. A weaver is able to stand at the crossroads with one foot placed on each path. She can occupy the place between, where the powers are the greatest." [SoN: 327] Diana is endowed with the power to "move between this world and the next", the power over "Life and death. You can be in both worlds." [SoN: 368]
} 
ROSSI-LANDI, Ferruccio (1979). "Signs and bodies". In: Chatman, Seymour, Umberto Eco \& Jean-Marie Klinkenberg (eds.). A Semiotic Landscape.

Proceedings of the First Congress of the International Association for Semiotic Studies, Milan, June 1974. The Hague: Mouton, 356-359

Rossi-Landi, Ferruccio (1985). Metodica filosofica e scienza dei segni. Nuovi saggi sul linguaggio e l'ideologia. Milano: Bompiani

Rossi-Landi, Ferruccio (1990). Marxism and Ideology. Oxford: Clarendon Press

Rossi-Landi, Ferruccio (1992). "Signs and bodies". In: Rossi-Landi, Ferruccio, Between Signs and Non-Signs. Ed. Susan Petrilli. Amsterdam: John Benjamins, 271-276

SoN = Harkness, Deborah (2012). Shadow of Night (= All Souls Trilogy 2). London: Headline 2013

SSN-03 = Harris, Charlaine (2003). Club Dead (= Sookie Stackhouse Novels. 3). New York: Ace Books

SSN-07 = Harris, Charlaine (2007). All Together Dead (= Sookie Stackhouse Novels. 7). New York: Ace Books

SSN-09 = Harris, Charlaine (2009). Dead and Gone (= Sookie Stackhouse Novels. 9). New York: Ace Books

StF = BUTCHER, Jim (2000). Storm Front. (= The Dresden Files. 1). New York: Roc Books 2009

TB (0.00) = True Blood, US-HBO 2008-2014 (season.episode)

TBoL = Harkness, Deborah (2014). The Book of Life (= All Souls Trilogy 3). London: Headline

TC $=$ Harkness, Deborah (2018). Time's Convert. London: Headline

TO $(0.00)=$ The Originals, US-The CW 2013-2018 (season.episode)

TVD (0.00) = The Vampire Diaries, US-The CW 2009-2017 (season.episode)

WITHALM, Gloria (2017). "Revelio! A (Socio-)Semiotic Reading of the Harry Potter Saga". In: BANKOV, Kristian (ed). New Semiotics. Between Tradition and Innovation. Proceedings of the 12th World Congress of Semiotics. Sofia: IASS Publications \& NBU Publishing House, 487-497 


\section{Índice general de las Actas}

\section{TOMO 1}

\section{TRAYECTORÍAS Y TEORÍAS}

COORDINADORES: MARÍA TERESA DALMASSO Y CLAUDIO GUERRI

LOS ARCHIVOS PERSONALES DE ELISEO VERÓN. Gastón Cingolani

DE LAS OPERACIONES SEMIÓTICAS A UNA SEMIÓTICA DE LAS OPERACIONES. María Elena Bitonte

LAS "SEMIOSIS SOCIALES" Y LAS TRANSFORMACIONES EN LOS PROCESOS COMUNICATIVOS. Gustavo Aprea

ELISEO VERÓN ENTRE DOS SEMIOSIS: DEL CUERPO SIGNIFICANTE AL CEREBRO DEL SAPIENS. Amparo Rocha Alonso

THE SEMIOTIC THEORY OF A.J. GREIMAS IN MAINSTREAM ORGANIZATION THEORY AND ORGANIZATION RESEARCH. Pertti Ahonen

ÉCOLE RUSSE ET ÉCOLE FRANCAISE DE SÉMIOTIQUE. VALEURS, FORMES DE VIE ET TRAJECTOIRES HISTORIQUES. Inna Merkoulova

TRAJECTÓRIAS DO LEITOR NO ESPAÇO TEXTUAL.

Maria Augusta Babo

DE LAS PASIONES EN LA ENUNCIACIÓN. TEORIZACIÓN E IMPLICANCIAS PARA EL ANÁLISIS SEMIÓTICO DE LOS DISCURSOS. Cristian Cardozo

ALIQUID PRO ALIQUO. ASOCIACIÓN, REPRESENTACIÓN Y SIGNIFICACIÓN. Fernando Rodríguez

DUALISM IN AL-FARABI'S WRITINGS AND LANGUAGES.

Driss Bouyahya

ALGUNAS OBSERVACIONES SOBRE EL GIRO LINGÜÍSTICO EN LA HISTORIA INTELECTUAL. Norma Fatala 
MASS-MEDIACIÓN: FORMATO Y DISPOSITIVO. Marcelino García

SOBRE LA VERDAD SEMIÓTICA Y PRESEMIÓTICA DE LA IMAGEN. Fernando Fraenza y Valentino Indorato

PROSPECTIVE AND SIGN IN ITS EVOLUTIONARY NATURE. Bianca Suárez Puerta

SEMIÓTICA DAS ORGANIZAÇÕES: ENTRE AS TESSITURAS TEXTUAIS E AS REDES DE SENTIDO. Elisangela Carlosso Machado Mortari

LA FILIGRANA MOMPOSINA: PRESERVACIÓN DE LA TRADICIÓN A TRAVÉS DEL APRENDIZAJE. Denis Senith Cabrera Anaya

SIGNS IN ACTION: OLD HERITAGE CRAFTS AND NEW

"SENSE KEEPERS". Nicolae-Sorin Drăgan

TRAYECTORIAS DE UN MODELO OPERATIVO: NONÁGONO SEMIÓTICO. Claudio F. Guerri

REORIENTANDO LA MÚSICA: UN ABORDAJE PEIRCEANO DE LA PERFORMANCE MUSICAL. Juan Pablo Llobet Vallejos y Pablo Stocco

APROPIACIÓN MATERIAL. TRAYECTORIAS, PROFANACIONES Y ESTRATEGIAS EN EL ARTE CONTEMPORÁNEO DE AMÉRICA LATINA. Guadalupe Ailén Álvarez

TRAYECTORIAS PERFORMÁTICAS DEL ARCHIVO EN LA ERA DIGITAL. \#VIVAS: TECNOLOGÍAS DIGITALES PARA LA CONSTRUCCIÓN DE MEMORIA COLECTIVA.

Guadalupe Ailén Álvarez, Maximiliano Cortés y Micaela Flavia Paz

GESTIONAR LA SOSTENIBILIDAD DE LAS ORGANIZACIONES COMO UNA TRAYECTORIA HACIA LA RESPONSABILIDAD SOCIAL.

Raquel Felisa Sastre

NONAGONO SEMIÓTICO DEL SIGNO GOBIERNO: UNA PROPUESTA PARA RECONOCER Y MINIMIZAR RELACIONES DE DOMINACIÓN. Juan Emilio Ortiz

¿"BOLUDA" O "BOLUDA DE MIERDA"? CONVERGENCIAS Y DIVERGENCIAS EN LAS TRAYECTORIAS DE DOS SIGNOS. Paula Elizabeth Fainstein 
ARCHIVOS QUE PERFORMAN. APROXIMACIONES SEMIÓTICAS A LAS PRÁCTICAS DE ARCHIVO. Claudio Guerri, Martín Acebal y Cristina Voto

THE TRAVELER'S GAZE: A SEMIOTIC ANALYSIS OF INSTAGRAM'S TRAVEL PHOTOGRAPHS. Fernanda Carvalho Ferrarezi

NEUROSEMIOSIS - TRANSITION FROM PHYSICAL TO MENTAL STATES. Karl Gfesser

PEIRCEAN SEMIOSIS AND THE ENGINEERING OF CONSENT AS PARALLEL TRAJECTORIES. Tony Jappy

SEMIÓTICA Y HERMENÉUTICA: REFLEXIONES METODOLÓGICAS EN BASE AL CONCEPTO DE SIGNO EQUÍVOCO. Roxana Cecilia Ynoub

SYNALETHISM AND UNLIMITED SEMIOSIS. Titus Lates

SEMIOTIC APPROACH TO IRONY. Evelyn Vargas

THE POWER OF IMAGINATION. NEW APPROACH TO CHARLES PEIRCE'S ABDUCTION. Reni Yankova 


\section{TOMO 2}

\section{ALTERIDADES, IDENTIDADES}

COORDINADORES: MARITA SOTO Y FEDERICO BAEZA

NO ES LO QUE PARECE. EDUARDA MANSILLA, VOCES FEMENINAS DESDE LA FRONTERA INTERIOR. Laura Sacchetti

LA MIRADA SEMIÓTICA AL DISCURSO SUFRAGISTA EN MÉXICO (1916-1923). Olga Nelly Estrada y Griselda Zárate

LOS AMORALES Y LAS "BUENAS COSTUMBRES": MEMORIA DISCURSIVA Y CLASIFICACIÓN DE LA DISIDENCIA SEXUAL EN LA DIPPBA. Paulina Bettendorff y Laura Bonilla

ENCYCLOPEDIC ANTHROPONYM AS THE SIGN OF CULTURE. Svetlana Bogdanova y Elena Ignatieva

THE CORSET AND THE HIJAB: ALTERNATIONS OF ABSENCE AND PRESENCE IN THE 19TH AND 20TH-CENTURY FASHION SYSTEM. Marilia Jardim

ENTRE ORILLAS. TRAYECTORIAS DISCURSIVAS DE LA IDENTIDAD GALLEGA EN LA ARGENTINA. Claudia López

LOS VARRIOS DE SAN DIEGO CALIFORNIA. RESISTENCIA CHICANA-CONCHERA. José Luis Valencia González

LA PREGUNTA POR EL CUERPO EN LA SEMIÓTICA CONTEMPORÁNEA: PERFORMATIVIDAD, VINCULACIÓN Y MEMORIA. Susana Temperley

INTERSUBJETIVIDAD, MULTIMODALIDAD Y ADQUISICIÓN DEL LENGUAJE. Fernando Gabriel Rodríguez

TRAJECTORIES OF POSSIBILITIES. SEMIOTICS OF THE UNPREDICTABLE FUTURE. Katarzyna Machtyl 
BETWEEN SEMEIOTICS AND SEMIOTICS: THE BODY AS A SIGNIFYING TEXT. Simona Stano

LA PRAXIS ENUNCIATIVA Y LO REAL: ARTICULACIONES INTERDISCIPLINARIAS PARA UN MODELO DE ANÁLISIS DEL DISCURSO. Marcos Javier Mondoñedo Murillo

LIBIDINAL INTELLIGENCE: CINEMA AND LITERATURE. Roseli Gimenes

SEMIOTIC STRATEGIES TO CREATE HERITAGE: LUXURY FASHION BRANDS IN THE AGE OF SOCIAL NETWORKS. Daria Arkhipova

LA ESCENOGRAFÍA DEL CUERPO EN EL DISEÑO DEL DESFILE DE MODA. Mihaela Radulescu de Barrio de Mendoza

TRAYECTORIAS DISCURSIVAS: LA ALIMENTACIÓN ENTRE CIENCIA Y COMUNICACIÓN. Simona Stano

A CIDADE COMO ESPAÇO DE COMUNICAÇÃO MERCADOLÓGICA: O POTENCIAL DE PRODUÇÃO DE SENTIDO DAS MARCAS A PARTIR DE INTERVENÇÕES PUBLICITÁRIAS NO CONTEXTO URBANO. Sergio Marilson Kulak y Rui Torres

\#YOSOYDIVERSO, MÁS QUE UN HASHTAG, UN LLAMADO A LA TOLERANCIA DESDE LA PERSPECTIVA DEL PLURALISMO CULTURAL EN LA VIRTUALIDAD.

Norberto Fabián Díaz Duarte y Antonia María Moreno Cano

BARRIOS EN FOCO: EL DISCURSO AUDIOVISUAL ENTRE LO TRANSLINGUISTICO Y LO TRANSDISCIPLINAR. Valeria Car, Alfredo Isasmendiz - Preti y Cinthia Naranjo DISCURSOS, PIQUETES Y ORDEN DEMOCRÁTICO. Liliana Pazo ANÁLISIS SEMIÓTICO DE LA REPRESENTACIÓN DE GÉNERO EN LA PELÍCULA PERSÉPOLIS. Lucía Leticia Anaya Avilés

LA PERSISTENCIA DEL AMOR ROMÁNTICO: ANÁLISIS DE SU REPRESENTACIÓN E INFLUENCIA EN LOS ROLES DE GÉNERO TRADICIONALES EN RUBY SPARKS Y LA LA LAND DESDE LAS FIGURAS DE EROS Y PSIQUE.

Itzel Mayelli Flores Urzua y José Honorio Cárdenas Vidaurri 


\section{TOMO 3}

\section{ESCRITURAS E HISTORIAS}

COORDINADORA: VANESA PAFUNDO

THE JEALOUS NARRATOR: ANALYSIS OF THE ENUNCIATION STRATEGIES IN ROBBE-GRILLET'S NOVEL LA JALOUSIE. Ludmila Lacková

UN NO- LUGAR COMÚN EN LA LITERATURA: LO INFINITO. Karina B. Lemes

LA TRAYECTORIA DE LA MIRADA SARAMAGUIANA. UN ANÁLISIS DEL DISCURSO SOBRE EL ARTE EN LOS CUADERNOS DE LANZAROTE, DE JOSÉ SARAMAGO. Marisa Leonor Piehl

ALGUNOS APUNTAMIENTOS DE JOSÉ SARAMAGO DESDE LA EMOCIÓN DE LOS SUCESOS DEL PROCESO REVOLUCIONARIO EN CURSO - PORTUGAL, 1974-1975. María Victoria Ferrara

FORMAS DE LA "AUTORÍA TRANSMEDIA" ACERCAMIENTOS SEMIÓTICOS. María Clara Lucifora

WHO IS THE DREAMER? TEXTUAL AND METHODOLOGICAL SEMIOTIC TRAJECTORIES IN TWIN PEAKS: THE RETURN. Giacomo Festi

ELENA SABE: LA EXHIBICIÓN DE UNA SOCIEDAD EN CRISIS. Karina Lemes

PROSA MESTIZA. CONFIGURACIONES DE LA FRONTERA EN TRES NOVELAS ARGENTINAS CONTEMPORÁNEAS. Froilán Fernández

MONSIEUR PAIN. NARRATIVA DE ORILLA.

Natalia Vanessa Aldana

HARRY POTTER: ANÁLISE DAS CAPAS DOS LIVROS.

Júlia Meister Barichello 
DO OBJETO LIVRO AO LIVRO-OBJETO LITERÁRIO:

UMA RESSEMANTIZAÇÃO SENSÍVEL. Marc Barreto Bogo

ENTRE O VERBAL, O GRÁFICO E O ESCULTÓRICO:

INTERSEMIOTICIDADE NA PUBLICAÇÃO TREE OF CODES. Marc Barreto Bogo

SALOMÉ: UN CASO DE RECURRENCIA DISCURSIVA. Oscar Traversa

EL HÉROE CONTEMPORÁNEO - NUEVAS TRAYECTORIAS

DE SIGNIFICADO ÉTICO. Rafael Zanlorenzi

REPRESENTATION AS A CATALYST FOR CULTURE CHANGE PROCESSES: THE SEMIOTICS OF CULTURE CHANGE.

Hamsini Shivakumar

CONTRAPUNTOS CRÍTICOS TERRITORIALES. ESCRITURA, RITMO, SONORIDAD. Carmen Guadalupe Melo

TRAVESÍAS Y ENCRUCIJADAS DEL ARCHIVO: DISCURSIVIDADES POÉTICAS Y TERRITORIALES. Carla Vanina Andruskevicz

IDENTIDAD Y FRONTERAS DENTRO DE LA OBRA: MEMORIAS DEL SUR - PRIMEROS RESULTADOS DE INDAGACIÓN.

María Leticia Scarpa

ESTRATEGIAS NARRATOLÓGICAS PARA EL ANÁLISIS DE MATERIAL AUTOBIOGRÁFICO: ¿A QUIÉN ESCRIBEN LOS QUE SE ESCRIBEN? Maité Delfina Lluch

A CONSTRUÇÃO DOS ATORES E SUA PROJEÇÃO NO ESPAÇO-TEMPO EM A CIDADE DORME, DE LUIZ RUFFATO. Marcela Ricardo y Vera Lucia Rodella Abriata

PASADOS EN TRÁNSITO: RELATAR DESDE EL OLVIDO. Sergio Rojas

SEMIÓTICA NARRATIVA E IMAGINARIO HUMANO: REFLEXIONES METODOLÓGICAS EN BASE A LOS APORTES DE GREIMAS Y PROPP. Maité Delfina Lluch, Miguel Adrián Romero y Roxana Ynoub

HACÉ MEMORIA, NO MONUMENTOS. HACIA LA CONSTRUCCIÓN DE ARTEFACTOS ESTÉTICO-SEMIÓTICOS (DES)EMPLAZADOS. Ariel Barbieri 
SEMIOTIC MULTIMODALITY AND THE PERCEPTION OF THE PAST. Jimena Biga

FOUR SPECIES OF SPANISH PATRIOTIC SONGS OF THE SPANISH WAR OF INDEPENDENCE 1808-1814. Aleksi Jari Ilmari Haukka

LA IDENTIDAD NACIONAL DEL PARTIDO COMUNISTA CHINO EN 1949: UNA APROXIMACIÓN A TRAVÉS DEL ANÁLISIS DE IMÁGENES. Ignacio Robba Toribio 


\section{TOMO 4}

\section{ARTES Y LENGUAJES}

COORDINADORES: MÓNICA KIRCHHEIMER Y GUSTAVO APREA

EL ESTUDIO DE LAS TRANSPOSICIONES DE LA LITERATURA AL CINE: LOS APORTES QUE DISTINTAS VERIENTES SEMIÓTICAS EFECTUARON AL CAMPO. María Rosa Del Coto

INTRODUCCIÓN FÍLMICO-LITERARIA DE VIAJES Y TRANSPOSICIÓN(ES). María Silvina Tatavitto

RETOMAS DEL CINE DE LOS 80: PROCEDIMIENTOS TRANSPOSITIVOS DE UN FENÓMENO PARTICULAR. José Tripodero

LA DESPEDIDA DE LOS AMANTES EN LA ESTACIÓN DE TREN. PERVIVENCIA Y MUTACIÓN DE FORMAS FÍLMICAS. Marina Locatelli

TEMPORALIDADES FICCIONALES - UNA EXPLORACIÓN DE LAS PARADOJAS TEMPORALES EN EL CINE DE FICCIÓN.

M. Laura Ragucci

POSIBLES PATHOSFORMELN EN LA HISTORIA DEL CINE. Mabel Tassara

CONFIGURACIONES DEL CINE REGIONAL EN LA PRENSA DE LA NORPATAGONIA DE LOS AÑOS OCHENTA. Ignacio Dobree

TUNCHES, PISHTACOS Y JARJACHAS: FORMAS ENUNCIATIVAS DEL MIEDO EN EL CINE REGIONAL ANDINO PERUANO. Miguel Ángel Torres Vitolas

LE CINÉMA ET SON DOUBLE OU LE PRINCIPE DE L'ASYNCHRONISME REVISITÉ. Ivan Capeller

WHAT'S IN THE NAME LIVE CINEMA? Marga van Mechelen 
TRÂNSITO E COMPLEXIDADES SENSORIAIS EM IMAGENS COMTEMPORÂNEAS. Lívia Machado

OPERACIONES DE LUDICIDAD Y AUTORREFERENCIA EN DOS CASOS DE ANIMACIÓN DIGITAL CONTEMPORÁNEA.

Maria Alejandra Alonso

SI SOLO SI: LA DISCAPACIDAD EN LA FICCIÓN TELEVISIVA ARGENTINA. Carolina Casali

CASI UNA SERIE. APUNTES TRASNOCHADOS SOBRE REALISMO Y CINE EN DOS MINISERIES MISIONERAS. Mauro Figueredo

TÉLÉVISION ET JUSTICE : UNE TRAJECTOIRE MÉDIATIQUE CONTROVERSÉE? Yannick Lebtahi

FORMAS DE VIDA MIGRATORIAS: ARTE E INTIMIDAD. Jaime Cordero

LO LÚDICO, LO SOCIAL Y LO POLÍTICO EN DOS CASOS DE ANIMACIÓN CONTEMPORÁNEA. Mónica Kirchheimer

SNUFF 2.0: SOBRE LOS VIDEOS DE VIOLENCIA Y MUERTE EN REDES SOCIALES. Julián Tonelli

DISPOSITIVOS Y ENUNCIACIÓN EN LA POSTFOTOGRAFÍA: ALGUNAS TRAYECTORIAS DE LA IMAGEN FOTOGRÁFICA DIGITAL EN REDES SOCIALES. Mariano Zelcer

LA AUTOPOIESIS DEL ACONTECER ARTÍSTICO QUE EMERGE A TRAVÉS DEL DIÁLOGO ENTRE DIFERENTES DIMENSIONES DE LA CORPORALIDAD. Daniela Lieban

TRASUNTO \#1: POESÍA EN TRÁNSITO. Valentina Paillaleve

LECTURAS DEL BIOARTE EN CLAVE SEMIÓTICA: AVANCES DE INVESTIGACIÓN. Lucía Stubrin

LA INTIMIDAD COMO APUESTA POLÍTICA EN RECORDAR 30 AÑOS PARA VIVIR 65 MINUTOS, DE MARINA OTERO. Luciana Estevez

DANZA EN PRIMERA PERSONA. EL GIRO AUTOBIOGRÁFICO EN LAS OBRAS DEL UNDER PORTEÑO. María José Rubin

HISTORIA, MONTAJE, ARCHIVO: PARA UNA PERFORMATIVIDAD DE LA MEMORIA. Cecilia Tosoratti 
INNOVACIONES DISCURSIVAS Y NUEVAS ESTÉTICAS DE LA HISTORIETA ARGENTINA CONTEMPORÁNEA.

Andrea Acosta Camargo, Laura Amarilla y Gaspar Buono

PIERRE DUPRAS, BÉDÉISTE CARICATURISTE ENGAGÉ.

Mila Falardeau

TRAYECTORIAS DE LA ABYECCIÓN EN EL ARTE POSMODERNO. Amparo Latorre Romero

UN NO LUGAR PARA LA FOTOGRAFIA: SOBRE LA SERIE ARCHIVO UTOPIA- EL PROYECTO BRASILIA. Vanesa Magnetto

EL GESTO MUSICAL Y LA COGNICIÓN CORPOREIZADA:

ARTICULADORES DEL SENTIDO EN LA DISCURSIVIDAD MUSICAL. Federico Buján

THE BODY AS MEDIUM: THE SUBVERSIVE SELF-PORTRAITSOF FRANCESCA WOODMAN. Patrícia Fonseca Fanaya

LA CONSTRUCCIÓN DEL TANGO COMO GÉNERO MUSICAL EN LOS MEDIOS MASIVOS. Jimena Jauregui

CUERPOS Y PALABRAS EN EL RITMO: LA ESCENA DE LA VOZ EN EL RAP FREESTYLE. Amparo Rocha Alonso

PROCEDIMENTOS RETÓRICOS E SEMIÓTICOS NA CANÇÃO RETRATO EM BRANCO E PRETO, DE CHICO BUARQUE E TOM JOBIM. Robson Costa Bessa y Alfredo Werney Lima Torres

MÚSICA Y PRODUCCIÓN DE SENTIDO EN EL CINE DE WOODY ALLEN. LA PRESENCIA DE OBRAS MUSICALES REPRESENTATIVAS DE UN DETERMINADO MOMENTO COMO REENVÍO A MANIFESTACIONES CULTURALES DEL PASADO. Carolina Inés Rochi

LA CADENA SIGNIFICANTE DE LOS CUERPOS EN LOS BOMARZOS ARGENTINOS. Jerónimo Brignone

VILLA-LOBOS: SYMBOLICAL AND SEMIOTICAL. Cleisson Melo 


\section{TOMO 5}

\section{COMUNICACIÓN MEDIÁTICA, PUBLICIDAD Y DIGITALIDADES}

COORDINADORES: MABEL TASSARA Y ROLANDO MARTÍNEZ MENDOZA

LA IMPORTANCIA DE LOS ESTUDIOS SEMIÓTICOS EN EL DISEÑO DE INTERFACES INTERACTIVAS. Francisco V. C. Ficarra

THE READING CONTRACT FOR THE CUSTOMIZATION ALGORITHM. Gustavo Markier

THE LAWS OF SEMIOTICS AND DIGITALIZATION OF CULTURE: THE BIRTH OF THE NEW MEANINGS. Marina Merkulova

MEMÓRIA E ESQUECIMENTO: AMBIVALÊNCIAS DO DIGITAL ENTRE A WIKILEAKS E O FACEBOOK. Francisco Rui Cádima

ZONAS DE CONTACTO Y LAS NUEVAS FORMAS DE CIRCULACIÓN: TRAYECTORIAS DISCURSIVAS Y PARTICIPACIÓN EN LÍNEA. Eduardo Ruedell y Viviane Borelli

SEMIÓTICA DAS INTERAÇÕES NO AUDIOVISUAL: PRODUÇÃO DE SENTIDOS NO CLIPE INTERATIVO "SATURN BARZ".

Bárbara Heliadora Cavalcante Fontenelle y Murilo Scoz

ARI FOLMAN'S PROMISES OF TECHNOLOGICAL MEDIATION IN THE CONGRESS. Cassia Cassitas

A TRANSMÍDIA COMO SEMIOSFERA PARA A CONSTRUÇÃO ESTÉTICA. Gisele Frederico

CONFIGURACIONES DISCURSIVAS DE LA CRÍTICA CINEMATOGRÁFICA EN YOUTUBE. Laura Andrea Iribarren

FOLKLORE DIGITAL, PROSUMIDORES Y CREEPYPASTA. Sandra Sánchez 
SEMIÓTICA NARRATIVA EN EL DISCURSO PUBLICITARIO CONTEMPORÁNEO: ANÁLISIS DE LA LANDING PAGE DE "MANANTIALES" DEL GRUPO EDISUR. Belén Angelelli y Natalia Desirée Vaccaro

SMARTHPHONES Y AURICULARES PARA INSCRIBIR LA CIUDAD COMO ESCENOGRAFÍA. Mónica Berman

REFLECTIONS ABOUT NEW PERCEPTIONS ON SPACE AND TIME: THE USE OF MOBILE PHONE IN THE METRO DE SANTIAGO, CHILE. Catalina Largo González

SEMIÓTICA APLICADA: CAMPANHA PUBLICITÁRIA JOURNEY, COM ANGELINA JOLIE, SOB O ESPECTRO DA TEORIA PEIRCEANA.

Carolina Boari Caraciola

MODALIDADES DE INSERCIÓN DE EMERGENTES CULTURALES EN LA COMUNICACIÓN DE LAS MARCAS. Claudio Centocchi

LA CONSTRUCCIÓN DEL DESTINATARIO EN LA MARCA PAÍS ARGENTINA. Daniela Fiorini y Paula Socolovsky

SEMIÓTICA APLICADA: ANÁLISE DE PEÇAS DA MARCA GATORADE À LUZ DA TEORIA PEIRCEANA. Gabriel Moni de Souza, Heder SeitiOno y Maria Clotilde Perez

TRAJECTORIES AND MEANINGS IN SPECIALTY COFFEE PACKAGING: A SEMIOTIC EXPLORATION OF THE BRAZILIAN MARKET. Maria Collier de Mendonça, Flavia Cardoso y Richard Perassi

ESTRATEGIAS, TRANSACCIONES Y SÍMBOLOS EN LA PUBLICIDAD ELECTORAL AUDIOVISUAL. María Ernestina Morales

RACISMO Y CLASISMO EN LA PUBLICIDAD MEXICANA. Carl Winston Jones

ADVERFILMS Y FENÓMENOS DE RETOMA: UNA APROXIMACIÓN SOCIOSEMIÓTICA A LA DISCURSIVIDAD PUBLICITARIA EN PLATAFORMAS INTERACTIVAS. Lorena Steinberg 


\section{TOMO 6}

\section{ESPACIALIDADES Y RITUALIZACIONES}

COORDINADOR: JOSÉ LUIS CAIVANO

POETIC SYMBOLS OF UNLIMITED TIME. Richard Trim

FUNDAMENTOS SEMIÓTICOS, ONTOLÓGICOS Y COGNITIVOS PARA UNA TEORÍA SEMIÓTICA DEL ESPACIO GEOGRÁFICO: APORTES DE UNA TESIS DOCTORAL. Emilas Darlene Carmen Lebus

SIGNIFICACIONES Y ACCIÓN SEMIOTÉCNICA EN LOS PROCESOS PRODUCTIVOS AGRARIOS DEL NORDESTE SANTAFESINO EN EL ESCENARIO DEL NORTE GRANDE ARGENTINO. TENDENCIAS Y CONTEXTOS DE SENTIDO. Emilas Darlene Carmen Lebus

DISCURSO JURÍDICO DE LA PLANEACIÓN DEL TERRITORIO EN COLOMBIA. ANÁLISIS SEMIO-DISCURSIVO: ESTUDIO DE CASO. Lucila Reyes Sarmiento y Camilo Alejandro Rodríguez Flechas

APUESTA ANALITICO TRANSDISCIPLINARIA FRENTE A LA HIBRIDACIÓN DE LAS AMENAZAS EN LA FRONTERA COLOMBOECUATORIANA EN CLAVE PROSPECTIVA. María Fernanda Noboa González

EL SUELO ES LAVA: REPRESENTACIÓN DE LOS FENÓMENOS VOLCÁNICOS EN RELATOS AUDIOVISUALES. Ignacio Dobrée y Ailén Spera

"SANTANDER AYER Y HOY, MEMORIAS DEL PATRIMONIO", UNA EXPERIENCIA CROSSMEDIA DEL ENTORNO FÍSICO AL DIGITAL. Norberto Fabián Díaz Duarte y Carolina Raigosa Díaz

EL ACTO DE LA REPRESENTACIÓN VISUAL MUSEAL COMO PUENTE ENTRE EL CONOCIMIENTO SOCIOLÓGICO Y EL SOPORTE SEMIÓTICO. Sebastián Chávez Hernández

APROXIMACIÓN AL CAMPO DE INTERTEXTOS EN LA OBRA DE TOMÁS SARACENO. María Rosa More 
LAS CULTURAS DE LOS PIXADORES Y DE LOS ESCRITORES DE GRAFFITI. Marco Tulio Pedroza Amarillas

MAPAS, CIDADES, MUROS: IMPRESSÕES DO/NO ESPAÇO. Kati Caetano y Adriana Tulio Baggio

CULTURAL LANDSCAPE AS METAPHOR. Olga Lavrenova

A SEMIOTIC JOURNEY THROUGH THE CONCEPT OF TRAJECTORY IN LATOUR'S THEORY. Giacomo Festi

TRANSCULTURALIDAD E IDENTIDAD EN LA MESOAMÉRICA CONTEMPORÁNEA. Horacio Mendizábal García

A SEMIOTIC AND GEOGRAPHICAL APPROACH TO MONUMENTS AN ANALYSIS OF THE MULTIPLE MEANINGS OF MONUMENTS IN TALLINN, ESTONIA. Federico Bellentani

SPACE, POWER AND INTER-SEMIOTIC TRANSLATION: THE SYMBOLISM OF ROME AND THE FASCIST REGIME. Pierluigi Cervelli

LA ITINERANCIA PÚBLICA Y EFIMERA COMO MODELO DE REPRESENTACION POPULAR Y POTENCIADORA EN LA PERFORMANCE CULTURAL Y POLITICA DE LOS FESTEJOS DEL BICENTENARIO. Daniela Lieban

LA SEMIÓTICA DE LOS HIMNOS PATRIOS Y SU INCIDENCIA EN LA CONFIGURACIÓN DE LA MENTALIDAD COLECTIVA. Julio César Rivera Dávalos

LA NOSTALGIA DEL SEXO FELIZ O REFLEXIONES SOBRE LA NOCHE DE LA NOSTALGIA EN URUGUAY. Claudia Mera Rodríguez

LA SANTIDAD COMO UNA FORMA DE VIDA Y LA FIGURA DE SANTA GIANNA BERETTA MOLLA. Jenny Ponzo

JAMES THE APOSTLE ICON: TRAJECTORIES IN HISPANIC LITERATURE (12TH-16TH CENTURIES). Lidia Raquel Miranda

SEMIOTIC INTERPRETATIONS OF THE SQUARE AND THE CIRCLE IN RELIGIOUS CULTURAL HERITAGE. Hee Sook Lee-Niinoja

SEMIOTICS AND AESTHETICS AS A DISCOURSE ON ARCHITECTURE CASE STUDY: MINIMALISM IN ARCHITECTURE. Dragana Vasilski 
INTER-SEMIOTIC APPROACH TO TEXTS-IMAGES OF FOOD SEALER ZIPPER BAGS. Hee Sook Lee-Niinioja

THE ESTHESIC TRANSFORMATION OF THE BUBBLE TEA: FROM EAST TO WEST. Rafael G. Lenzi

AT THE CROSSROAD OF BIOSIMULATION AND DESIGN: NOVEL CODES IN BI-MODAL REPRESENTATION OF BLOOD FLOW. Dolores A. Steinman y David A. Steinman 


\section{TOMO 7}

\section{PALABRAS PÚBLICAS}

COORDINADORES: MARIA ALEJANDRA ALONSO Y SERGIO RAMOS

LLORANDO EN EL COLÓN. RETOMAS DISCURSIVAS DEL G-20 EN LOS INTERNET MEMES. Nicolás Canedo, Verónica Urbanitsch y Daniel Sierra

SEMIÓTICA Y NARRATIVAS POLÍTICAS: PERSUASIÓN Y PROPAGANDA EN LA CONFIGURACIÓN DISCURSIVA DE LA IDENTIDAD DE ACTORES POLÍTICOS DEL CHACO A TRAVÉS DE LOS MEDIOS DE COMUNICACIÓN DE MASAS. Natalia Virgina Colombo y Romina Gisel Gayoso

LA DIMENSIÓN POLÉMICO/ANTAGÓNICA DEL DISCURSO PERONISTA. LA POLÉMICA PERÓN/LANUSSE. Hugo José Amable

VERIDICÇÃO E DISCURSO: INFORMAÇÃO E DESINFORMAÇÃO NO "JOGO DA VERDADE" DAS AGÊNCIAS DE CHECAGEM DE FATOS (FACT-CHECKING). Simone Bueno da Silva y Valdenise Leziér Martyniuk

¿GOLPE O IMPEACHMENT? LA POLARIZACION MEDIA DE LAS REVISTAS VEJA Y CARTA CAPITAL. Hélen Rodrigues Simões

JORNAIS REGIONAIS E A CONSTRUÇÃO DE VÍNCULOS COM SEUS LEITORES. Fabiana Sparremberger y Viviane Borelli

LA REVISTA TÍA VICENTA COMO EXPERIENCIA SEMIÓTICA CRÍTICA QUE DESVELA UNA REALIDAD POLÍTICA Y SOCIAL. María Lourdes Gasillón

EL ENCIERRO COMO ESPACIO NARRADO. Valeria Vivas Arce

LA SEMIÓTICA DEL ESPACIO POLÍTICO: UN ESTUDIO DE CASO EN AMÉRICA HISPANA TARDO-COLONIAL. Carmen Susana Cantera

AÇÃO COLETIVA E GERAÇÃO DE SENTIDO: OS DESAFIOS DE GESTÃO DE UM ESPAÇO PÚBLICO EM CRISE. Karin Vecchiatti 
TERRITORIOS EDUCATIVOS: LA LECTURA Y LA ESCRITURA EN LOS UMBRALES. Carla Vanina Andruskevicz

MANIOBRAS Y OPERACIONES SEMIÓTICAS EN LOS UMBRALES DE LA ALFABETIZACIÓN INICIAL. REFLEXIONES ACERCA DE PRÁCTICAS Y RELATOS EN LA FRONTERA. Raquel Alarcón y Froilán Fernández

APROXIMACIÓN DESDE LA SEMIÓTICA VISUAL EN EL DISEÑO DE MATERIALES DIDÁCTICOS PARA SORDOS. Lucero Fabiola García Franco

JÓVENES QUE CUENTAN: ANÁLISIS DE RELATOS AUDIOVISUALES DE ESTUDIANTES DE SECUNDARIOS. Corina Ilardo

EL GÉNERO AUDIOVISUAL ESCOLAR. CONTINUIDADES EN EL ANÁLISIS DE PRODUCCIONES PERIFÉRICAS Y PROPUESTA TEÓRICOMETODOLÓGICA. Diego Agustín Moreiras

COMPARATIVE ANALYSIS OF THE STATE OF AFFAIRS IN THE FIELD OF ART SEMIOTICS: SEMIOTICS OF VISUAL, AUDIOVISUAL AND PERFORMANCE LANGUAGES BETWEEN THE NATIONAL UNIVERSITY OF CORDOBA, ARGENTINA AND THE INSTITUTE OF ROMANCE LANGUAGES AND CULTURES, UNIVERSITY OF POTSDAM, GERMANY. Fabiola C. de la Precilla

ALFABETIZACIÓN SEMIÓTICA EN LA UNIVERSIDAD: DEVENIRES DE LA ENSEÑANZA DE LA SEMIÓTICA EN LAS CARRERAS DE LETRAS DE LA FACULTAD DE HUMANIDADES DE LA UNNE. Natalia Virginia Colombo

ENSEÑANZA DE LA SEMIÓTICA APLICADA A LA PLANIFICACIÓN DE PROYECTOS DE COMUNICACIÓN. EL DEVENIR DE UNA TRAYECTORIA ESPECÍFICA DE LA SEMIÓTICA ARGENTINA. Maria Alejandra Alonso, Rolando Martínez Mendoza y Sergio Ramos

DE QUÉ SIRVIÓ LA SEMIÓTICA. SEMIÓTICA APLICADA A LA PLANIFICACIÓN DE PROYECTOS DE COMUNICACIÓN EN UN ENTORNO VIRTUAL DE ENSEÑANZA Y APRENDIZAJE. Maria Alejandra Alonso y Sergio Ramos

LA HETEROGENEIDAD EN LA COMUNICACIÓN CIENTÍFICA. UN ANÁLISIS DISCURSIVO DESDE LA SEMIÓTICA DE LA CULTURA. Carina Itzel Gálvez García 


\section{TOMO 8}

\section{CONFERENCIAS PLENARIAS}

COORDINADORES: OSCAR STEIMBERG, OSCAR TRAVERSA Y

GASTÓN CINGOLANI

PAOLO FABBRI (1939-...). Tiziana Migliore

(traducción al español Claudio Guerri)

METALOGUES MEET INTERVIEW: IT TAKES THREE TO TANGO. Myrdene Anderson

MATRICES IDEOLÓGICAS Y COMPONENTE RETÓRICO EN LA DISCURSIVIDAD POLIITICA: LAS EMOCIONES EN MAURICIO MACRI Y CRISTINA FERNÁNDEZ DE KIRCHNER, AGOSTO DE 2019. Elvira Narvaja de Arnoux

A GRADUALIST PERSPECTIVE FOR A SEMIOTIC APPROACH TO VISUAL IMAGES. José Luis Caivano

TRAYECTORIA Y CONTINUIDAD DE LA TEORÍA TEXTUAL DE UMBERTO ECO EN LAS NUEVAS NARRATIVAS Y SUS ESTRATEGIAS TEXTUALES. Alfredo Tenoch Cid Jurado

LUIS PRIETO. LA RECUPERACIÓN DE UNA TEORÍA MUY PERTINENTE. María Teresa Dalmasso

EPISTEMOLOGÍA PARA UNA SEMIÓTICA DEL ESPACIO: CÉSAR JANNELLO. Lucrecia Escudero Chauvel

CURSOS SEMIÓTICOS: CAMINOS Y TRAYECTORIAS ANTRÓPICAS. Jacques Fontanille

APPLYING PEIRCE. FROM THE THREE CATEGORIES TO THE SEMIOTIC NONAGON. Claudio F. Guerri

TRAJECTOIRES DE LA SÉMIO-LINGUISTIQUE. Anne Hénault

A NON-ANTHROPOCENTRIC SEMIOTICS OF THE WRITING IN THE ERA OF THE POSTHUMAN LITERACY. Sung do Kim 
¿POR QUÉ HAY SENTIDO Y NO MÁS BIEN NADA? EXPERIENCIA, COGNICIÓN, SENTIDO. Jean-Marie Klinkenberg

PRESENTACIÓN DEL PROYECTO SEMIÓTICO: ACTUALIDAD DE RENÉ THOM. Isabel Marcos

THE SEMIOTIC METHOD. Tiziana Migliore

TRAJECTORIES OF MEANING IN SPACE AND VALUE SYSTEMS. Pierre Pellegrino

TRANSDISCIPLINARY TRAJECTORIES: THE AUDACITY OF DESIGN AND THE RESILENCE OF SIGNS. Farouk Y. Seif

READING TRAJECTORIES AND SEMIOSIS, GRAPHIC DESIGN AND IDEOLOGY. Evripides Zantides

SEMIÓTICA DE UN PROCESO UTÓPICO Y OTRO DISTÓPICO EN AMÉRICA LATINA: DOS SENDEROS ANTITÉTICOS HACIA LA AUTENTICIDAD. Fernando Andacht

TERRITORIOS ARTÍSTICOS EN DISPUTA. LA OBRA DE EDUARDO KAC. Pampa Arán

SEMIOSIS OF THE BODY IN ARAB SEXOLOGICAL LITERATURE. Mohamed Bernoussi

TRAYECTORIA DE LA SEMIÓTICA DE LAS MEDIATIZACIONES HACIA LAS PLATAFORMAS MEDIÁTICAS. José Luis Fernández

LE WEB 2.0 : UNE NOUVELLE TRAJECTOIRE POUR LA SÉMIOLOGIE AUDIOVISUELLE? François Jost

VECINDADES DIGITALES. HACIA QUÉ OBJETOS APUNTAN LOS ÍNDICES. María del Valle Ledesma

ROSTROS GIGANTES: TAMAÑO VERSUS PROPORCIÓN EN LA SEMIÓTICA DEL PODER. Massimo Leone

SEMIOSIS DE LAS ARTES PERFORMATIVAS: A PARTIR DEL CUERPO DE LAS ENVOLTURAS. Rocco Mangieri

DEL ESPACIO A LA CIUDAD. TRAYECTORIAS SEMIÓTICAS. Isabella Pezzini 
PRESENCIA, IDENTIDAD Y AFECTIVIDAD EN LOS HERALDOS NEGROS, DE CÉSAR VALLEJO. APUNTES DE HERMENÉUTICA SEMIÓTICA.

Óscar Quezada Macchiavello

CONTINUIDADES Y RUPTURAS EN LA NARRATIVA DE LA HISTORIETA COSTUMBRISTA. Oscar Steimberg

SALOMÉ Y JUDIT: DOS MILENIOS DE RECURRENCIA DISCURSIVA. Oscar Traversa

LOS LUGARES DE LA MEMORIA EN UN MARCO SEMIÓTICO. LA EXPERIENCIA DE SPEME. Patrizia Violi

FROM BUFFY TO A DISCOVERY OF WITHCHES. SEMIOTIC CONSIDRATIONS ON VAMPIRES, WITCHES, AND PRETERNATURAL PHENOMENA IN LITERATURE AND TELVISION. Gloria Withalm 

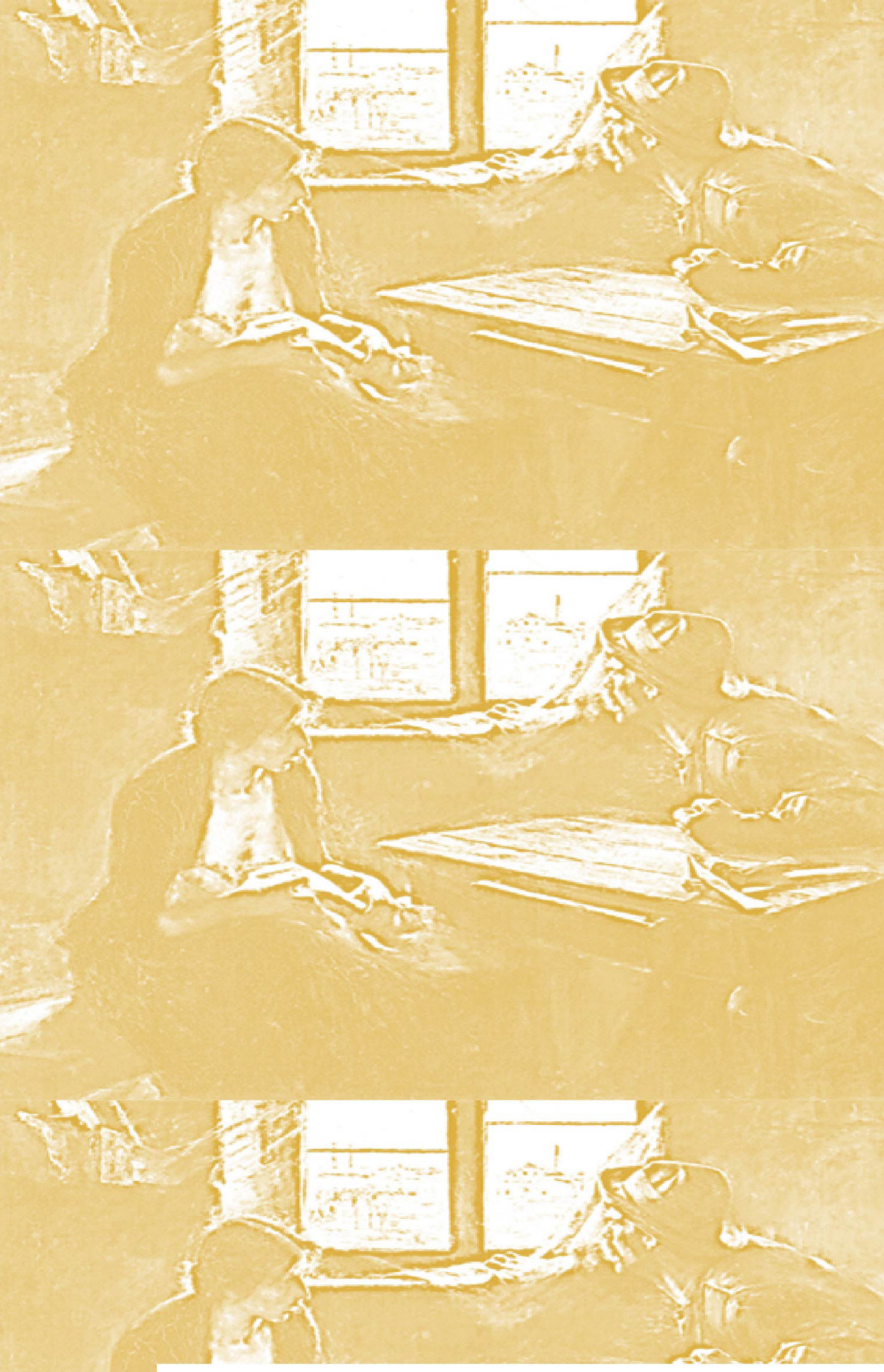

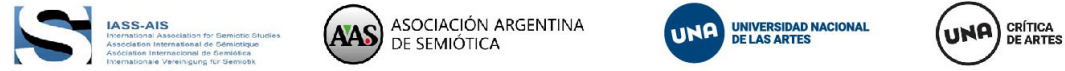

